\title{
A RESPONSABILIDADE PROFISSIONAL E A REPARAÇÃO DE DANOS
}

\begin{abstract}
Dissertação apresentada à Comissão Julgadora da Faculdade de Direito da Universidade de São Paulo, como exigência parcial para obtenção do título de Mestre em Direito Civil, sob a orientação da Professora Titular Doutora Giselda Maria Fernandes Novaes Hironaka.
\end{abstract}

Universidade de São Paulo

Faculdade de Direito

São Paulo, 2011 


\section{BANCA EXAMINADORA:}

1. Orientadora: Giselda Maria Fernandes Novaes Hironaka

2. Segundo(a) Examinador(a):

3. Terceiro(a) Examinador(a): 
Às minhas avós Maria e Sohemes, onde quer que estejam; aos meus pais, Vitor e Vânia; à minha irmã Verônika; e ao meu noivo Wilton. 


\section{AGRADECIMENTOS}

Gostaria de registrar meus agradecimentos a todos aqueles que contribuíram de alguma maneira para a consecução e o enriquecimento deste trabalho:

- à minha querida orientadora, Profa. Dra. Giselda Maria Fernandes Novaes Hironaka, pelos conselhos e atenção dispensados, pela generosidade e pela confiança, minha eterna gratidão;

- aos estimados professores Dr. Nestor Duarte e Dr. José Fernando Simão, pelos importantes e pertinentes apontamentos formulados no processo de qualificação da dissertação e que foram essenciais para o aperfeiçoamento deste trabalho;

- aos respeitáveis professores Dr. Álvaro Villaça Azevedo, Dr. Rui Geraldo Camargo Viana, Dr. Carlos Alberto Dabus Maluf e Dr. José Luiz Gavião de Almeida, cujos ensinamentos na graduação e na pós-graduação foram - e continuam sendo - muito importantes para minha formação;

- à Faculdade de Direito da Universidade de São Paulo, pelo sentimento de acolhimento desde o primeiro contato, antes mesmo de que ali ingressasse na condição de discente. 


\section{RESUMO}

O trabalho tem por escopo a análise da responsabilidade civil profissional orientada para a extração das características que lhe são peculiares, bem como da reparação do dano dela decorrente, em suas diversas modalidades. Aborda três categorias profissionais: os médicos e demais profissionais da área de saúde; os advogados, tabeliães e profissionais conexos, e engenheiros, arquitetos e empreiteiros. A escolha do tema se justifica em razão do propósito de conferir uma unidade à matéria, quase sempre estudada de maneira desconexa no que tange a cada tipo de profissional. Na presente dissertação, o assunto é tratado de modo a propiciar a reunião de todas as atividades profissionais, já que estas são interligadas por características bastante semelhantes. A abordagem proposta permite não somente a discussão da responsabilidade subjetiva, mas também da imprevisibilidade atinente à atividade do profissional liberal, o que justifica o fato de sua obrigação ser, em regra, de meio. Em síntese, são abordados os seguintes assuntos: elementos essenciais da responsabilidade civil; o dano, em suas diversas modalidades, com ênfase na possibilidade de cumulação dos danos morais com os estéticos, e a perda de uma chance; a responsabilidade civil contratual pertinente à matéria. No tocante à atividade médica, entre outros assuntos, são estudados a responsabilidade do cirurgião plástico, do anestesista e do chefe de equipe, o ônus da prova - em especial a teoria da perda de uma chance -, e a responsabilidade de hospitais, dentistas, farmacêuticos e enfermeiros. No que concerne à atuação do advogado e profissionais conexos, discutem-se a responsabilidade por atos de desídia, a perda de uma chance, as ofensas irrogadas em juízo e o dever de sigilo, bem como a responsabilidade dos tabeliães, notários e registradores, que exercem função pública mediante delegação. Por fim, no que alude aos engenheiros, arquitetos e empreiteiros, realça-se a responsabilidade oriunda do contrato de construção, nas modalidades empreitada e administração, bem como a responsabilidade por solidez e segurança constante do art. 618 do CC, e a responsabilidade do incorporador imobiliário. A pesquisa utiliza-se de dois métodos: o dialético, que se consubstancia na análise e discussão das posições antagônicas sobre os temas controversos; e a análise jurisprudencial, cujo propósito é abstrair dos diversos acórdãos os argumentos utilizados para sustentar sua orientação. Ampara-se, ainda, em doutrinadores pátrios como Alvino Lima, Wilson Melo da Silva, José de Aguiar Dias e Agostinho Alvim e nos estrangeiros Robert Joseph Pothier, René Demogue, René Savatier e irmãos Mazeaud - Henri, Léon e Jean.

Palavras-chave: Responsabilidade civil; profissionais; danos; obrigação de resultados; obrigação de meios; responsabilidade subjetiva. 


\begin{abstract}
The research aims at the analysis of professional liability oriented for the extraction of features that are peculiar as well as compensation for damage resulting from it, in its diverse forms. It will be addressed three professional categories: physicians and other health professionals, lawyers, notaries and related professionals, and engineers, architects and contractors. The theme is justified on grounds of giving a unity to the field, often studied in a manner unconnected with each type of professional. In this dissertation, the subject is treated in order to facilitate the meeting of all professional activities, since they are linked by very similar characteristics. The proposed approach not only allows discussion of subjective responsibility, but also regards the activity of the unpredictability of the liberal professional, which explains why their obligations are, as a rule, of means. In summary, the following issues are addressed: the essential elements of liability; the damage, in their different ways, with emphasis on the possibility of overlapping material damage to the aesthetic, and the loss of a chance; the contractual liability concerning this matter; in regarding the medical activity, among other themes, are studied the responsibility of the plastic surgeon, the anesthesiologist and the chief of staff, the burden of proof - especially the theory of the loss of a chance -, and the responsibility of hospitals, dentists, pharmacists and nurses; with respect to the role of attorney and related professionals, it discusses the responsibility for acts of sloth, the loss of a chance, offenses given in court and the duty of confidentiality, as well as the liability of notaries, who carry out public service through delegation; finally, with regard to engineers, architects and contractors, it's highlighted the liability arising out of the building contract, in two genres: empreitada and administration, as well as the responsibility for security and stability constant of Art. $618 \mathrm{CC}$, and the real estate developer's responsibility. The dissertation makes use of two methods: the first is the dialectic, which is embodied in the analysis and discussion of opposing viewpoints on controversial issues, and the second relates to the analysis of case law, in order to abstract from the various judgments of the arguments used to maintain its orientation. It's also sustained by national scholars as Alvino Lima, Wilson Melo da Silva, José de Aguiar Dias e Agostinho Alvim and by foreign scholars as Robert Joseph Pothier, René Demogue, René Savatier and Mazeaud brothers - Henri, Léon and Jean.
\end{abstract}

Keywords: Liability; professionals; damages; obligation of results; obligation of means; subjective responsibility. 


\section{RIASSUNTO}

La ricerca si propone di analizzare la responsabilità professionale per determinare le caratteristiche che gli sono peculiari, e anche un risarcimento per i danni da essi derivanti, nelle sue diverse forme. Sono affrontati tre categorie professionali: medici e altri professionisti sanitari, avvocati, notai e professionisti collegati, e degli ingegneri, architetti e imprenditori. La scelta del soggetto è giustificato nella necessità di dare una unità al campo, spesso studiate in maniera non collegati con ogni tipo di professionista. In questa tesi, l'argomento è trattato in modo da facilitare l'incontro di tutte le attività professionali, in quanto essi sono legati da caratteristiche molto simili. L'approccio proposto non solo permette la discussione di responsabilità soggettiva, ma riguarda anche l'imprevedibilità della attività del professionista, che spiega perché gli obblighi sono, di regola, di mezzi. In sintesi, i seguenti aspetti saranno affrontati: gli elementi essenziali della responsabilità; il danno, in modi diversi, evidenziando la possibilità di cumulo dei danni non patrimoniale, e la perdita di chance; la responsabilità contrattuale dei professionisti; per quanto riguarda l'attività medica, tra l'altro, si studiano le responsabilità del chirurgo plastico, l'anestesista e il capo della equipe medica, l'onere della prova - in particolare la teoria della perdita di chance -, e la responsabilità degli ospedali, dentisti, farmacisti e infermieri; per quanto riguarda il ruolo di avvocato e professioni affini, si discute la responsabilità per gli atti di pigrizia, la perdita di una possibilità, dei reati in tribunale e il dovere di riservatezza, anche la responsabilità dei notai, che svolgere un servizio pubblico attraverso la delegazione; infine, per quanto riguarda gli ingegneri, architetti e imprenditori, si voglia sottolineare la responsabilità derivanti dal contratto di costruzione, in queste due modalità: empreitada e amministrazione, nonché la responsabilità per la sicurezza e la solidità trattati dall'art. 618 cc, e la responsabilità dello sviluppatore immobiliare. La tesi si avvale di due metodi: il primo è la dialettica, che è incorporata nel analisi e discussione di opposti punti di vista su questioni controverse, e il secondo riguarda l'analisi della giurisprudenza, al fine di estrarre dalle sentenze dei vari argomenti utilizzati per mantenere il suo orientamento. Si sostiene, anche, negli studiosi brasiliani come Alvino Lima, Wilson Melo da Silva, José de Aguiar Dias e Agostinho Alvim e negli studiosi stranieri come Robert Joseph Pothier, René Demogue, René Savatier e fratelli Mazeaud - Henri, Léon e Jean.

Parole-chiave: Responsabilità civile; professionisti; danni; obblighi di fine; obblighi di mezzi; responsabilità soggettiva. 


\section{SUMÁRIO}

INTRODUÇÃO

1. ELEMENTOS ESSENCIAIS DA RESPONSABILIDADE CIVIL

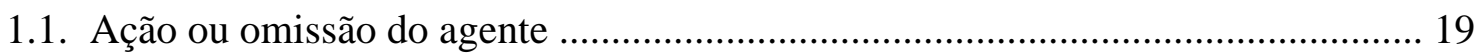

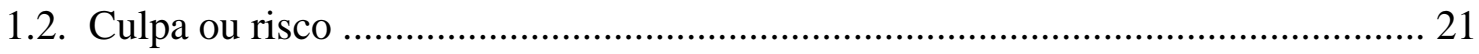

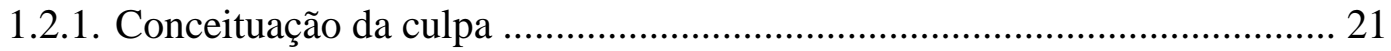

1.2.2. Modalidades de culpa em sentido estrito ................................................. 25

1.2.3. A evolução do conceito de culpa e o desenvolvimento da

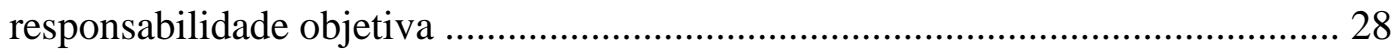

1.2.4. O risco e a responsabilidade civil objetiva ........................................... 31

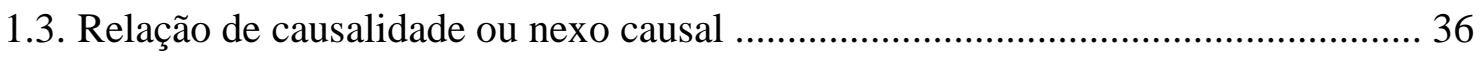

1.3.1. Teoria da Equivalência das Condições ..................................................... 38

1.3.2. Teoria da Causalidade Adequada ............................................................. 40

1.3.3. Teoria da Causalidade Direta ou Imediata .............................................. 42

1.3.4. A teoria adotada pelo Código Civil brasileiro ........................................... 45

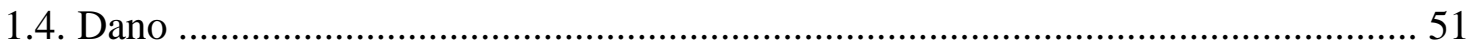

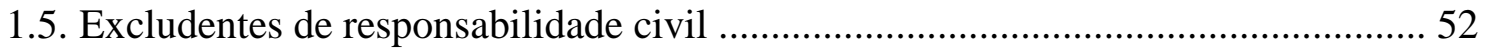

1.5.1. Legítima defesa, exercício regular de um direito e estado de

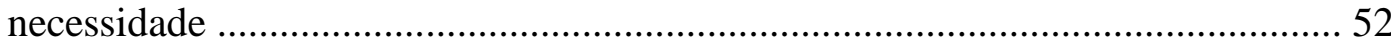

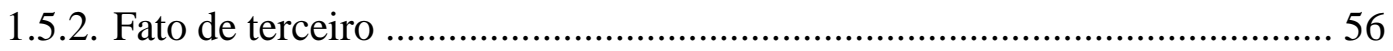

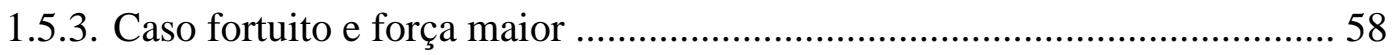

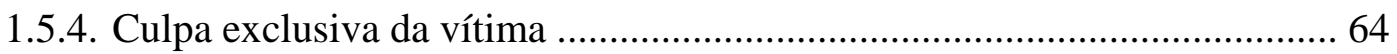

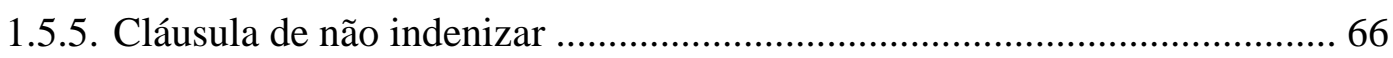


2.1. O conceito de dano

2.2. O dano ressarcível

2.3. Formas de ressarcimento: natural (ou específica) e indenização

pecuniária 78

2.4. O conceito de dano patrimonial 79

2.5. Damnum emergens (dano emergente) e lucrum cessans (lucro cessante) 81

2.6. O conceito de dano moral 87

2.7. A evolução dos danos morais e sua indenização no Direito brasileiro 92

2.8. Fundamentos jurídicos da reparação do dano moral 98

2.9. Critérios para a compensação do dano moral 106

2.10. O conceito de dano estético 113

2.11. A avaliação do dano estético 123

2.12. A possibilidade de cumulação dos danos estéticos e morais 126

2.13. O conceito de perda de uma chance 130

2.14. Parâmetros para a indenização da perda de uma chance

\section{RESPONSABILIDADE CIVIL CONTRATUAL POR ATO PRÓPRIO E POR ATO DE TERCEIRO}

3.1. A responsabilidade civil contratual em oposição à responsabilidade extracontratual 146

3.2. Obrigações de meio e de resultado

3.3. A responsabilidade do profissional autônomo

3.4. A responsabilidade por fato de terceiro 158

3.4.1. Algumas considerações sobre a responsabilidade por ato de terceiro no Código Civil de 1916 
3.4.3. A responsabilidade do empregador ou comitente por atos de seus empregados, serviçais e prepostos

3.4.4. O profissional empregado ou preposto

3.5. Responsabilidade do profissional que atua como servidor público 169

3.6. Aplicação do Código de Defesa do Consumidor sobre a matéria 172

\section{A RESPONSABILIDADE CIVIL DOS MÉDICOS, DENTISTAS,} FARMACÊUTICOS E OUTROS PROFISSIONAIS DA ÁREA DA SAÚDE 180

4.1. Notas introdutórias 180

4.2. A responsabilidade subjetiva contratual e a obrigação de meio do médico 182

4.3. Os deveres do médico 183

4.3.1. Do dever de aconselhar e informar 184

4.3.2. Obtenção do consentimento esclarecido do paciente 185

4.3.3. Dever de cuidados com o paciente 188

4.3.4. Dever de sigilo 190

4.4. O erro profissional, o erro de diagnóstico e o erro médico 191

4.5. A responsabilidade civil do cirurgião plástico 194

4.6. Outras obrigações de resultado relacionadas à atividade médica 199

4.7. A obrigação do anestesista e a responsabilidade civil da equipe médica 200

4.8. A responsabilidade médica pelos aparelhos e equipamentos utilizados 202

4.9. Do ônus da prova 204

4.9.1. A inversão do ônus da prova 204

4.9.2. Teoria da carga dinâmica do ônus da prova 205

4.9.3. A perda de uma chance 205

4.9.4. Teoria da res ipsa loquitur 209

4.9.5. Teoria da faute virtuelle 210 
4.10. A responsabilidade dos hospitais e outros estabelecimentos semelhantes

4.11. Responsabilidade civil das operadoras de planos de saúde 214

4.12. Responsabilidade civil dos dentistas 216

4.13. Responsabilidade civil dos farmacêuticos

4.14. Responsabilidade civil dos enfermeiros e demais profissionais com atuação conexa

\section{RESPONSABILIDADE CIVIL DOS ADVOGADOS, TABELIÃES E} PROFISSIONAIS CONEXOS

5.1. A responsabilidade contratual e subjetiva do advogado 223

5.2. A obrigação de meio do advogado 225

5.3. A responsabilidade por atos de desídia no patrocínio da causa do cliente 226

5.3.1. Omissão de providências necessárias 228

5.3.2. A omissão de informações 229

5.3.3. A perda de prazo processual 230

5.4. A perda de uma chance na responsabilidade do advogado 234

5.5. A responsabilidade sobre as ofensas irrogadas em juízo e pela litigância de má-fé 242

5.6. A responsabilidade por violação do dever de sigilo.

5.7. A responsabilidade civil dos mandatários

5.8. A responsabilidade civil dos tabeliães, notários e registradores

5.8.1. Responsabilidade contratual e extracontratual dos tabeliães, notários e registradores

5.8.2. Da obrigação assumida pelo tabelião, notário e registrador 251

5.8.3. Deveres do tabelião, notário e registrador 251

5.8.4. Responsabilidade objetiva do Estado pelos atos dos tabeliães 253

5.8.5. A responsabilidade individual dos tabeliães 255 


\section{RESPONSABILIDADE CIVIL DE ENGENHEIROS, ARQUITETOS E}

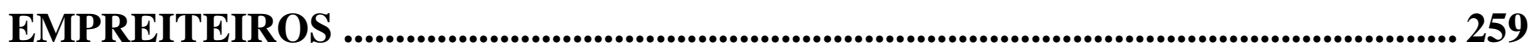

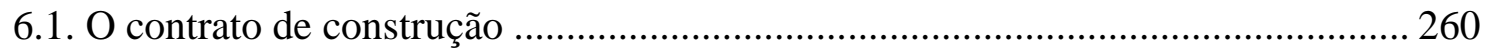

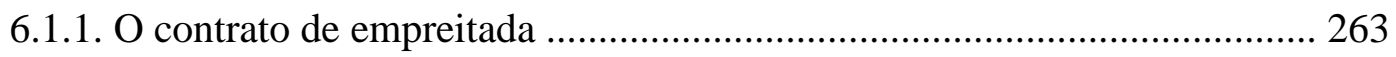

6.1.1.1. A empreitada por preço global e por medição ............................ 264

6.1.1.2. A empreitada de lavor ou de material ...................................... 266

6.1.2. O contrato de construção por administração .......................................... 267

6.1.3. O contrato de incorporação imobiliária ................................................ 269

6.2. Contratos de projeto e fiscalização de obra ..................................................... 270

6. 3. Obrigações e responsabilidades do empreiteiro e do dono da obra ........................ 272

6.4. Aplicação da teoria dos vícios redibitórios aos contratos de construção ............. 273

6.5. A responsabilidade dos construtores prevista no art. 618 do $\mathrm{CC}$......................... 275

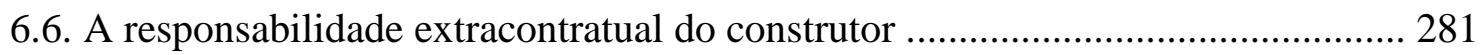

6.7. A responsabilidade do incorporador imobiliário. ............................................. 284

6.7.1. O patrimônio de afetação .................................................................. 285

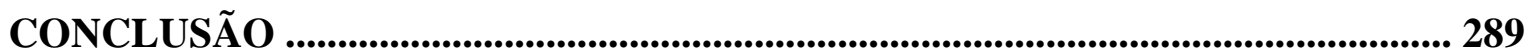

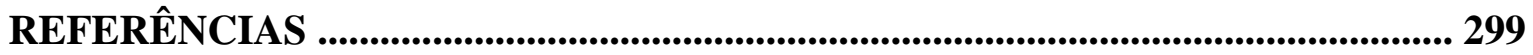




\section{INTRODUÇÃO}

Os trabalhos recentes sobre responsabilidade civil em rigor inserem-se em uma das três tendências da responsabilidade civil, consagradas por Fernando Noronha: a expansão dos danos suscetíveis de reparação, a objetivação da responsabilidade e sua coletivização ${ }^{1}$. Silmara Juny Chinelato acrescenta uma quarta tendência, a do alargamento do rol dos titulares ativos e passivos da responsabilidade civil ${ }^{2}$.

A presente dissertação, contudo, trilha caminho diverso, ao trazer à lume um tema clássico, que é o da responsabilidade civil profissional. Como não poderia deixar de ser, matérias contemporâneas são discutidas, a exemplo dos danos estéticos e a perda de uma chance; no entanto, afasta-se de apreciação a tendência da objetivação da responsabilidade, tendo em vista que a responsabilidade profissional é a seara por excelência da culpa ${ }^{3}$. O mesmo se dá no que alude à tendência da coletivização, por não constituírem foco de análise assuntos como seguridade social, seguro obrigatório e seguro de responsabilidade civil. Por fim, a quarta tendência, isto é, o alargamento do rol dos titulares, não é sequer objeto de comentário.

Por que dar, então, esse encaminhamento? Já não existem inúmeros trabalhos sobre a responsabilidade do advogado, do médico e do engenheiro? É possível que ainda haja algo de novo a ser discutido?

Sustenta-se aqui que, se não existem novidades, é possível conceder uma nova abordagem à matéria, em especial no que tange a questões que a doutrina e a jurisprudência tomam como verdade absoluta, sem indagações mais aprofundadas. É o que sucede, v.g., com a obrigação do cirurgião-plástico, considerada taxativamente de resultado, quando esse cirurgião se encontra submetido à mesma álea dos demais profissionais da saúde. $\mathrm{O}$ art. 618 do $\mathrm{CC}$, que trata da responsabilidade pela solidez e segurança da obra, da mesma forma, demanda uma análise mais atenta dos doutrinadores, em razão da influência do Código de Defesa do Consumidor sobre os contratos de

1 NORONHA, Fernando. Desenvolvimentos contemporâneos da responsabilidade civil. Revista dos Tribunais, São Paulo, ano 88, v. 761, mar. 1999. p. 35.

${ }^{2}$ CHINELATO, Silmara Juny. Tendências da responsabilidade civil no direito contemporâneo: reflexos no Código de 2002. In: DELGADO, Mário Luiz; ALVES, Jones Figueiredo (Coord.). Questões controvertidas responsabilidade civil. São Paulo: Método, 2006. v. I, p. 583-606.

${ }^{3}$ Como reconhecido pelo CDC, art. $14, \S 4^{\circ}$. 
construção. Esses são somente alguns exemplos das matérias que geraram interesse e que são examinadas no decorrer deste trabalho.

Opta-se, assim, por trazer para a discussão tema tradicional da responsabilidade civil em vez de temas contemporâneos, e por fazer uma releitura dos autores clássicos, como Alvino Lima, Wilson Melo da Silva, José de Aguiar Dias e Agostinho Alvim. Os autores estrangeiros não são olvidados e são sempre discutidos nas questões mais relevantes, para que se torne mais fácil compreender os institutos do direito brasileiro e não para que se faça um estudo de direito comparado, pois este não é o objetivo do trabalho. Aliás, basta uma rápida leitura das obras clássicas de Robert Joseph Pothier, de René Demogue, de René Savatier e dos irmãos Mazeaud - Henri, Léon e Jean - para que se compreenda que as teorias jurídicas, quando inspiradas e bem fundamentadas, não envelhecem com o tempo, tornando-se embasamento essencial para o desenvolvimento da doutrina que as sucedem. É o que se observa, v.g., com a clássica divisão entre obrigação de meio e de resultado, fundamental para o desenvolvimento do presente estudo.

Não será difícil notar a influência da Orientadora, Profa. Dra. Giselda Maria Fernandes Novaes Hironaka, nos assuntos tratados nesta dissertação, já que a doutrinadora transitou com maestria por diversos temas da responsabilidade civil, por vezes, com notável ousadia, ao buscar a instituição de uma responsabilidade pressuposta para certas situações, e, em outras ocasiões, com sensibilidade, ao demonstrar que a culpa ainda deve ser fundamento de algumas espécies de responsabilidade civil.

Cumpre justificar, igualmente, a escolha de um tema tão amplo, que abrange as três principais profissões liberais: médicos, advogados e engenheiros. O bom senso, decerto, indicaria a opção por apenas uma dessas categorias, uma vez que já são, per se, bastante abrangentes. A primeira razão para tal empreitada, em princípio, pouco aconselhável, resulta da admiração pela obra de José de Aguiar Dias, intitulada Da responsabilidade civil, na qual o autor dedica o Capítulo II à responsabilidade profissional tripartida, da maneira como aqui adotada. Em um segundo momento, a ideia do trabalho surgiu do respeito pelas obras dos escritores argentinos, como Jorge Mosset Iturraspe, Carlos Alberto Ghersi, Félix A. Trigo Represas e Marcelo J. López Mesa, todos com tratados dedicados à responsabilidade profissional, iniciativa que não se observa com frequência no Brasil. Por fim, a terceira razão que influenciou na escolha do tema foi o entendimento de que a matéria, quando estudada reiteradamente de maneira fragmentada, perde muito de sua coesão. De fato, sobre a análise do assunto se observam duas tendências: o estudo de um 
único tipo de profissional - em regra, o advogado ou o médico -, ou a inserção da matéria na esfera da responsabilidade contratual, juntamente com os contratos bancários e de transporte, entre outros, como se a responsabilidade decorrente de atividade profissional não tivesse qualquer particularidade com relação aos demais contratos. Entende-se, assim, que a matéria deve ser tratada de maneira independente das demais hipóteses de responsabilidade contratual, mas que, ao mesmo tempo, propicie a reunião de todas as atividades profissionais, já que estas são permeadas por características bastante semelhantes, a despeito de suas peculiaridades.

Tendo esses aspectos em vista, estrutura-se a abordagem da matéria em seis Capítulos.

O Capítulo 1 destina-se aos elementos essenciais da responsabilidade civil: a ação ou omissão do agente, a culpa ou risco e o nexo causal ${ }^{4}$. No que tange à culpa, são particularmente observadas suas modalidades, e a evolução de seu conceito até o desenvolvimento do conceito de risco e da responsabilidade objetiva. Com relação ao nexo causal, trata-se das três principais teorias que procuram explicá-lo: a teoria da equivalência das condições, a teoria da causalidade adequada, e a teoria da causalidade direta ou imediata. Por fim, são analisadas as excludentes de responsabilidade civil: a legítima defesa, o exercício regular de um direito, o estado de necessidade, o fato de terceiros, o caso fortuito e a força maior, e a culpa exclusiva da vítima. Também não se negligencia a análise da cláusula de não indenizar.

O Capítulo 2 dedica-se à análise do dano, por meio de ponderações sobre o seu conceito, os limites do dano ressarcível, as formas de ressarcimento e suas modalidades: dano patrimonial, subdividido em dano emergente e lucro cessante, e o dano moral, considerado em lato e stricto sensu. No que alude a essa modalidade de dano, são tecidos comentários sobre evolução doutrinária e jurisprudencial, os fundamentos jurídicos de reparação, assim como os critérios para compensação. Ao final, examinam-se o dano estético e a possibilidade de sua cumulação com os danos morais em sentido estrito, bem como a teoria da perda de uma chance.

O Capítulo 3 é alusivo à responsabilidade civil contratual por ato próprio e por ato de terceiro, compreendendo o estudo de temas pertinentes à responsabilidade contratual, como a cláusula penal, a análise das obrigações de meio e de resultado, e a

\footnotetext{
${ }^{4} \mathrm{O}$ dano constitui tema especial do Capítulo 2, tendo em vista a maneira pormenorizada como é tratado o assunto.
} 
responsabilidade do profissional em diversas situações: como autônomo, como empregado ou preposto e como servidor público. O estudo desenvolvido dá ensejo, igualmente, ao exame da responsabilidade por fato de terceiro, em particular no que tange à responsabilidade do empregador ou comitente por atos de seus empregados, serviçais e prepostos (art. 932, inc. III, do CC). O Capítulo é finalizado com considerações sobre a aplicação do Código de Defesa do Consumidor à responsabilidade profissional.

Depois dos três primeiros Capítulos, passa-se ao estudo da responsabilidade de profissionais individualmente considerados.

O Capítulo 4 discute acerca da responsabilidade civil dos médicos, dentistas, farmacêuticos e outros profissionais da área da saúde, com ênfase na responsabilidade subjetiva contratual e na obrigação que, na maior parte das vezes, é de meio. Em seguida, são discutidos os principais deveres do médico: de aconselhar e informar, de obtenção de consentimento esclarecido do paciente, de cuidados e de sigilo. Diferenciam-se os erros profissional, de diagnóstico e o propriamente médico. Em razão das peculiaridades que lhe são inerentes, a responsabilidade do cirurgião plástico será individualizada, o mesmo ocorrendo com o anestesista, quando então se trata, igualmente, da tormentosa questão da equipe médica. O ônus da prova tem especial destaque, com o exame de sua inversão propiciada pelo Código de Defesa do Consumidor, da teoria da carga dinâmica do ônus da prova, da perda de uma chance, da teoria da res ipsa loquitur e da teoria da faute virtuelle. Segue-se, no Capítulo, a abordagem da responsabilidade dos hospitais, planos de saúde, dentistas, farmacêuticos e enfermeiros.

O Capítulo 5 aborda a responsabilidade de advogados, tabeliães e profissionais conexos, no qual é ressaltada a responsabilidade contratual e subjetiva desses profissionais, bem como sua obrigação que, em regra, é de meio. Em seguida, examinam-se as hipóteses de responsabilidade por atos de desídia no patrocínio da causa do cliente, o que pode ocorrer em consequência da omissão de providências necessárias, de informações, da perda de prazo processual, entre outros. A perda de uma chance na atividade advocatícia é bem desenvolvida, por se tratar de área de maior aplicação da teoria. Não se olvida de analisar a responsabilidade do advogado sobre as ofensas irrogadas em juízo, e sobre a manutenção do dever de sigilo. Fazem-se breves comentários sobre a responsabilidade do mandatário, e, em seguida, o estudo se reporta aos tabeliães, notários e oficiais de registro, que exercem função pública mediante delegação, fazendo que sua responsabilidade detenha algumas particularidades em relação aos demais diplomados no curso de Direito. 
O Capítulo 6 é consagrado à responsabilidade civil de engenheiros, arquitetos e empreiteiros, com realce ao contrato de construção, nas modalidades construção por empreitada e construção por administração. Analisam-se: a empreitada por preço global e por medição, a empreitada simplesmente de lavor e de lavor e material, o contrato de incorporação imobiliária, e os contratos de projeto e fiscalização de obra. Contempla-se, igualmente, o estudo das obrigações e responsabilidades do empreiteiro e do dono da obra, a análise da teoria dos vícios redibitórios e o art. 618 do $\mathrm{CC}$, bem como a influência do Código de Defesa do Consumidor sobre esses contratos. Observa-se, igualmente, a responsabilidade extracontratual do construtor, por danos gerados a vizinhos e terceiros, e a responsabilidade do incorporador imobiliário, mencionando-se de forma breve a possibilidade de constituição de patrimônio de afetação.

A Conclusão retoma e sintetiza os principais entendimentos firmados no tocante aos aspectos mais controversos abordados neste trabalho. 


\section{ELEMENTOS ESSENCIAIS DA RESPONSABILIDADE CIVIL}

Este trabalho inicia-se com a análise dos elementos essenciais da responsabilidade civil - também conhecidos como pressupostos da responsabilidade civil -, em razão da relevância dos assuntos aqui tratados para as discussões a serem desenvolvidas.

Para a consecução do referido objetivo, é incontornável a análise do disposto no art. 186 do Código Civil (CC), que, como asseveram Pablo Stolze Gagliano e Rodolfo Pamplona Filho, é a norma que consagra o princípio do neminem laedere, ou seja, aquele que gera prejuízo a outrem tem o dever de indenizá-lo 5 . O artigo em comento possui a seguinte redação:

\footnotetext{
“Art. 186. Aquele que, por ação ou omissão voluntária, negligência ou imprudência, violar direito e causar dano a outrem, ainda que exclusivamente moral, comete ato ilícito".
}

Com o dispositivo legal pré-citado, que já constava do art. 159 do CC de 1916, ainda que com algumas alterações ${ }^{6}$, a doutrina destacou a existência de quatro elementos essenciais para a configuração da responsabilidade civil: ação ou omissão do agente, culpa ou risco, nexo causal e dano.

Procede-se, a seguir, ao estudo de cada um desses elementos de maneira detalhada. Ao final, são analisadas as excludentes de responsabilidade civil, uma vez que estão intrinsecamente relacionadas com o nexo de causalidade.

\footnotetext{
${ }^{5}$ GAGLIANO, Pablo Stolze; PAMPLONA FILHO, Rodolfo. Novo curso de Direito Civil - responsabilidade civil. 4. ed. São Paulo: Saraiva, 2006. v. III, p. 23. Na mesma toada, Sílvio Rodrigues preleciona que o referido artigo é o registro na legislação brasileira do "princípio geral de direito, informador de toda a teoria da responsabilidade, encontradiço no ordenamento jurídico de todos os povos civilizados e sem o qual a vida social é quase inconcebível" (Direito Civil - responsabilidade civil. 19. ed. São Paulo: Saraiva, 2002. v. 4, p. 13).

${ }^{6}$ Consoante artigo em comento: “[...] Aquele que, por ação ou omissão voluntária, negligência ou imprudência, violar direito, ou causar prejuízo a outrem, fica obrigado a reparar o dano. A verificação da culpa e a avaliação da responsabilidade regulam-se pelo disposto neste Código, arts. 1.518 a 1.532 e 1.537 a 1.553". É de se observar que o art. 186 do Código Civil vigente exige a violação de direito e, cumulativamente, a ocorrência de dano a outrem, enquanto o art. 159 do Código de 1916 demanda apenas a existência de violação de dano ou, alternativamente, a presença de prejuízo.
} 


\subsection{Ação ou omissão do agente}

A ação ou a omissão do agente refere-se à sua conduta, que pode ser positiva ou negativa. O que caracteriza tal conduta é a voluntariedade, decorrente da liberdade de atuação do indivíduo imputável, ou seja, portador do discernimento necessário para compreender o ato que está sendo desempenhado. A conduta representa, portanto, circunstância passível de ser controlada ou dominada pela vontade humana ${ }^{7}$.

A voluntariedade, contudo, não pode ser confundida com a intenção de causar dano. Ela se refere, em verdade, à intenção de cometimento do ato, ou consciência acerca do modo pelo qual o agente se conduziu, sem necessariamente haver o propósito de gerar prejuízo a quem quer que seja ${ }^{8}$. Conforme explicado com mais profundidade logo adiante, havendo o firme direcionamento para a prática de ilícito, configura-se o dolo; caso contrário, tem-se a culpa em sentido estrito.

É também tradicional na doutrina a caracterização da conduta que gera responsabilidade como antijurídica ou ilícita. Esse posicionamento, no entanto, deve ser abandonado, eis que existe a possibilidade de haver responsabilidade civil sem ilicitude, quando autorizado por dispositivo legal ${ }^{9}$. Ao destacar com vigor tal assertiva, é imperioso trazer à lume o posicionamento de Giselda Maria Fernandes Novaes Hironaka, in verbis:

"Estrutura-se, paulatinamente, um sistema de responsabilidade civil que já não se sustenta mais pelos tradicionais pilares da antijuridicidade, da culpabilidade e do nexo de causalidade, apenas.

Organiza-se, já, um sistema que não recusa - como outrora se

\footnotetext{
${ }^{7}$ GONÇALVES, Carlos Roberto. Responsabilidade civil. 7. ed. São Paulo: Saraiva, 2002. p. 36.

${ }^{8}$ GAGLIANO, Pablo Stolze; PAMPLONA FILHO, Rodolfo. Novo curso de Direito Civil - responsabilidade civil, p. 28: "[...] a voluntariedade, que é pedra de toque da noção de conduta humana ou ação voluntária, primeiro elemento da responsabilidade civil, não traduz necessariamente a intenção de causar o dano, mas sim, e tão-somente, a consciência daquilo que se está fazendo. E tal ocorre não apenas quando estamos diante de uma situação de responsabilidade subjetiva (calcada na noção de culpa), mas também de responsabilidade objetiva (calcada na idéia de risco), porque em ambas as hipóteses o agente causador do dano deve agir voluntariamente, ou seja, de acordo com a sua livre capacidade de autodeterminação. Nessa consciência, entenda-se o conhecimento dos atos materiais que se está praticando, não se exigindo, necessariamente, a consciência subjetiva da ilicitude do ato".

${ }^{9}$ Sílvio Rodrigues salienta que: "Seria preferível que o preceito não usasse a expressão violar direito, e seguisse, desse modo, mais de perto, a regra do art. 1.382 do Código Civil francês, onde o legislador brasileiro certamente se inspirou. Isso porque há hipóteses em que a lei ordena a reparação do prejuízo experimentado pela vítima ainda quando o comportamento da pessoa obrigada a repará-lo não envolve a violação da lei, como no caso de acidente do trabalho" (Direito Civil - responsabilidade civil, v. 4, p. 13). O art. 1.382 do Diploma francês aludido pelo autor tem a seguinte redação: "Tout fait quelconque de l'homme, qui cause à autrui un dommage, oblige celui par la faute duquel il est arrivé, à le réparer". (Tradução livre: "Qualquer ato humano que cause a outrem um dano, obriga aquele por cuja culpa esse se sucedeu, a reparálo".)
} 
recusava, por ser absolutamente inaceitável - a existência de um dano injusto, por isso indenizável, decorrente de conduta lícita. Apresenta-se, nos dias de hoje, um sistema de responsabilidade que já não se estarrece com a ocorrência de responsabilidade independentemente de culpa de quem quer que seja" ${ }^{\prime 10}$.

Conforme mencionado no início deste subitem, a conduta pode tomar forma positiva ou negativa. No primeiro caso, há uma ação propriamente dita, o que aconteceria, v.g., no caso de atropelamento de um pedestre por agente conduzindo automóvel; já na segunda hipótese, tem-se uma abstenção, que, para configurar-se, requer a existência prévia do dever jurídico de praticar determinado ato. Ademais, nessa última hipótese, é necessária a demonstração de que, com a prática do referido dever, o dano poderia ter sido evitado $^{11}$. Seria caso de omissão, em um atropelamento, a falta de prestação de socorro à vítima pelo condutor do automóvel, de modo a lhe agravar o estado de saúde. O atropelamento, por certo, é uma conduta positiva, mas a falta de prestação de socorro constitui uma omissão.

Esclareça-se, por fim, que nem sempre a responsabilidade civil é decorrente de ato próprio, podendo, ao contrário, resultar de ato de terceiro, conforme preceitua o art. 932 do $\mathrm{CC}^{12}$; de fato do animal, consoante disposto no art. 936 do mesmo Diploma

\footnotetext{
${ }^{10}$ HIRONAKA, Giselda Maria Fernandes Novaes. Responsabilidade pressuposta. Belo Horizonte: Del Rey, 2005b. p. 2. Acerca do assunto, Sílvio Neves Baptista ressalta que, no ordenamento pátrio, admite-se que a responsabilidade derive de um fato lícito, ou seja, o dano pode derivar de violação permitida. Segundo o autor, "o dano lícito é o dano tolerado, ou 'não-antijurídico', como prefere A. De Cupis. Mas, a despeito de ser fato tolerado, a lei impõe o dever de reparação por parte de quem se utiliza desse poder de lesão do interesse alheio. [...] Nessa categoria de fato danoso, a lei admite situações especialíssimas em que o interesse predominante de um venha sobrepor-se ao interesse de outro, impondo a este o dever de 'suportar' a ofensa ou negando-lhe a finalidade de defesa quando do ataque do ofensor. Em contrapartida, o direito oferece ao prejudicado o poder de pleitear indenização pela ofensa tolerada, exigindo o dever de reparação da pessoa que viola o interesse do outro, embora o dano resulte de um fato permitido pelo ordenamento jurídico. Não é propriamente uma sanção, porém, uma mera 'compensação' ao titular pelo interesse sacrificado, donde a obrigação de indenizar surge em virtude de lesão do interesse de outrem autorizada por lei" (Teoria geral do dano de acordo com o novo Código Civil brasileiro. São Paulo: Atlas, 2003. p. 56). O autor cita como exemplo de dano lícito a hipótese do art. 188, inc. II, e art. 929, ambos do Código Civil, a qual é estudada neste trabalho no item 1.5.1. Erik Frederico Gramstrup fornece, igualmente, como exemplo, o art. 938 do Código Civil, que responsabiliza o dono do prédio pelas coisas que dele caírem ou forem lançadas (Responsabilidade objetiva na cláusula geral codificada e nos microssistemas. In: DELGADO, Mário Luiz; ALVES, Jones Figueiredo (Coord.). Questões controvertidas - responsabilidade civil, v. I, p. 129).

${ }^{11}$ GONÇALVES, Carlos Roberto. Responsabilidade civil, p. 37.

${ }^{12}$ A norma em tela determina: "[...] São também responsáveis pela reparação civil: I - os pais, pelos filhos menores que estiverem sob sua autoridade e em sua companhia;

II - o tutor e o curador, pelos pupilos e curatelados, que se acharem nas mesmas condições;
} 
$\operatorname{legal}^{13}$, e, ainda, de fato da coisa, de acordo com o dispositivo subsequente ${ }^{14}$. A responsabilidade por ato de terceiro é objeto de análise adiante, no Capítulo 3, tendo em vista a relevância da matéria para o tema desta dissertação, em especial no que tange à atuação de prepostos e empregados dos profissionais liberais. O art. 937, por sua vez, é revisitado por ocasião do estudo da responsabilidade de engenheiros, arquitetos e empreiteiros ${ }^{15}$.

\subsection{Culpa ${ }^{16}$ ou risco}

O lugar do segundo elemento - ou pressuposto - constitutivo da responsabilidade civil é ocupado neste estudo pela culpa ou pelo risco. A culpa fundamenta a responsabilidade subjetiva, ao passo que o risco o faz com relação à objetiva. Cada uma das hipóteses será analisada de maneira pormenorizada.

\subsubsection{Conceituação da culpa}

A culpa, tradicionalmente, comportou duas espécies de definição. A primeira delas refere-se à concepção moral da culpabilidade, mediante a qual deve ser considerado culpado aquele que tenha tido a possibilidade de prever que, se houvesse se conduzido de maneira diversa, poderia ter evitado o dano. A segunda diz respeito à concepção social, identificando a culpa com o erro de conduta ${ }^{17}$. Trata-se, na verdade, de mera modificação de perspectiva que recai ora sobre o agente, ora sobre a ação ou omissão.

A despeito dessa diferenciação observada originariamente, a doutrina denota ter incorporado elementos de ambas as concepções para a formação do conceito de culpa.

III - o empregador ou comitente, por seus empregados, serviçais e prepostos, no exercício do trabalho que lhes competir, ou em razão dele;

IV - os donos de hotéis, hospedarias, casas ou estabelecimentos onde se albergue por dinheiro, mesmo para fins de educação, pelos seus hóspedes, moradores e educandos;

$\mathrm{V}$ - os que gratuitamente houverem participado nos produtos do crime, até a concorrente quantia”.

13 “Art. 936. O dono, ou detentor, do animal ressarcirá o dano por este causado, se não provar culpa da vítima ou força maior," Essa norma carece de interesse para o presente estudo, motivo pelo qual não será retomada.

14 “Art. 937. O dono de edifício ou construção responde pelos danos que resultarem de sua ruína, se esta provier de falta de reparos, cuja necessidade fosse manifesta."

${ }^{15}$ Ver Capítulo 6.

${ }^{16}$ Pablo Stolze Gagliano e Rodolfo Pamplona Filho entendem que a culpa não é elemento essencial da responsabilidade civil, tendo em vista que esta também pode ser objetiva (Novo curso de Direito Civil responsabilidade civil, p. 25). O posicionamento de ambos os autores é compreensível, mas não se sustenta, tendo em vista a possibilidade de colocação do risco juntamente com a culpa como pressuposto de responsabilidade civil, o que foi feito neste capítulo.

${ }^{17}$ RODRIGUES, Sílvio. Direito Civil - responsabilidade civil, v. 4, p. 145. 
Verifique-se, nesse sentido, de acordo com Alvino Lima, que:

“[...] culpa é um erro de conduta, moralmente imputável ao agente e que não seria cometido por uma pessoa avisada, em iguais circunstâncias de fato". 18

Com efeito, na preleção transcrita, observam-se elementos tanto da concepção moral ("moralmente imputável") como da social ("erro de conduta").

Da mesma maneira, Henri, Léon e Jean Mazeaud sustentam ser a culpa um erro de conduta (erreur de conduite), acrescentando, contudo, que:

“[...] l'auteur du dommage n'a pas agi, sachant qu'il causerait ce dommage ou qu'il violerait le contrat; mais, s'il s'était conduit prudemment et diligemment, le dommage ne se serait pas réalisé", 19 .

Com esteio nas definições trazidas à lume e em tantas outras semelhantes tradicionalmente apresentadas pela doutrina, observa-se que a culpa tem dois traços constitutivos: a voluntariedade ${ }^{20}$ e a evitabilidade da conduta ${ }^{21}$. A voluntariedade consiste na capacidade de livre determinação de vontade e discernimento, de modo a ser possível a imputação do resultado à consciência do agente. A evitabilidade da conduta diz respeito à possibilidade de atuação diversa por parte do agente.

O erro de conduta, imbuído de ambos os caracteres retromencionados, pode ser analisado de maneira abstrata, quando se obtém a culpa in abstracto, ou de maneira concreta, quando se verifica a ocorrência da chamada culpa in concreto $^{22}$. A aferição da culpa em abstrato decorre da comparação de uma conduta com outra, oriunda de

\footnotetext{
${ }^{18}$ LIMA, Alvino. Culpa e risco. 2. ed. São Paulo: Revista dos Tribunais, 1998. p. 69.

${ }^{19}$ MAZEAUD, Henri; MAZEAUD, Léon; MAZEAUD, Jean. Leçons de droit civil - obligations - théorie générale. Atualizada por François Chabas. 9. ed. Paris: Montchrestien, 1998b. t. II, v. I, p. 457. (Tradução livre: "[...] o autor do dano não agiu sabendo que causaria este dano ou que violaria o contrato; mas, se ele tivesse se conduzido prudente e diligentemente, o dano não teria se realizado".)

${ }^{20}$ DINIZ, Maria Helena. Curso de Direito Civil brasileiro: responsabilidade civil. 17. ed. São Paulo: Saraiva, 2003. v. 7, p. 96-97. Verifique-se, igualmente, ITURRASPE, Jorge Mosset. Responsabilidad por daños parte general. Buenos Aires: Rubinzal-Culzoni, 1998a. t. I, p. 121.

${ }^{21}$ KÜHN, Maria Leonor de Souza. Responsabilidade civil - a natureza jurídica da relação médico-paciente. Barueri: Manole, 2002. p. 35.

${ }^{22}$ GOMES, Luiz Roldão de Freitas. Elementos de responsabilidade civil. Rio de Janeiro/São Paulo: Renovar, 2000. p. 61.
} 
determinado padrão ideal. Faz-se, assim, o cotejo da conduta do agente com a de um homem padrão, o bonus pater familias, de modo que, se, em determinado evento, o dano pudesse ser evitado pelo referido homem standard, o ofensor será demandado a indenizar a vítima. Há culpa, então, ao não se comportar o indivíduo de acordo com a conduta do "bom pai de família", colocado nas mesmas circunstâncias de tempo, lugar e ação. Se, no entanto, sua conduta é condizente com a de um homem médio, nas mesmas condições fáticas, não haverá o dever de ressarcir o dano ${ }^{23}$. A aferição da culpa em concreto, todavia, resulta simplesmente da análise do comportamento habitual do causador do dano ${ }^{24}$.

No campo da responsabilidade extracontratual, inclina-se a doutrina abertamente para a aferição em abstrato, a qual, contudo, não deve ser tomada de maneira absoluta, como bem pontua Alvino Lima. Para o doutrinador, não se devem afastar da averiguação as circunstâncias de meio, classe social, usos, costumes e hábitos sociais, já que o tipo abstrato de comparação não pode ser o de um homem imaginário. Dessa maneira, elementos concretos devem ser levados em consideração, colocando-se o tipo abstrato efetivamente nas mesmas condições em que se encontra o autor do dano ${ }^{25}$.

Já no tocante à esfera da responsabilidade contratual, Luiz Roldão de Freitas Gomes assinala ser habitual a aplicação da culpa em concreto, tendo em vista que já houve anuência do contratante para que se realizasse a negociação, de maneira que não se pode exigir que este aja com diligência superior à que sempre demonstrou ${ }^{26}$. Tal consideração deve ser analisada diante do caso concreto, uma vez que nem sempre há escolha da pessoa com a qual se firma o contrato, o que ocorre como regra, v.g., no transporte público de passageiros.

Um breve estudo da jurisprudência dos tribunais brasileiros, por sua vez, evidencia que a culpa na responsabilidade contratual também vem sendo aferida in abstracto, enquanto a culpa na esfera extracontratual pode vir a ser avaliada in concreto $^{27}$.

\footnotetext{
${ }^{23}$ RODRIGUES, Sílvio. Direito Civil - responsabilidade civil, v. 4, p. 146.

${ }^{24}$ Os Mazeaud e François Chabas entendem que a aferição da culpa em concreto consiste no exame do estado da alma do agente, de modo a se verificar se ele possui alguma reprovação de sua própria consciência (MAZEAUD, Henri; MAZEAUD, Léon; MAZEAUD, Jean. Leçons de droit civil - obligations - théorie générale, p. 457). Não é esse, contudo, o sentido que aqui se pretende conferir à culpa em concreto, cuja verificação, segundo nosso entender, resume-se à análise da conduta do ofensor no que tange à sua atuação habitual e prévia ao evento danoso.

${ }^{25}$ LIMA, Alvino. Culpa e risco, p. 60.

${ }^{26}$ GOMES, Luiz Roldão de Freitas. Elementos de responsabilidade civil, p. 61.

27 Verifique-se, nesse sentido, a aferição da culpa em abstrato no seguinte julgado concernente à responsabilidade civil contratual (contrato de mandato): $1^{\circ}$ TACSP. 2 ${ }^{\mathrm{a}}$ Câmara - B. Apelação n. 879.318-0. Rel. Cerqueira Leite. j. 10. 11.04. v.u. (Ementa: "Responsabilidade civil - Banco - Notas promissórias
} 
De qualquer modo, a reiteração da determinação de comparação da conduta do ofensor com a do bonus pater familias denota que a apuração da culpa em abstrato é a regra no Direito brasileiro ${ }^{28}$, o que se mostra, efetivamente, como o procedimento mais salutar.

Cabe salientar, em acréscimo, que a culpa lato sensu engloba a culpa stricto sensu e o dolo. Na culpa em sentido estrito, conforme salientado, há a violação de um dever que o agente podia conhecer e observar, segundo os padrões de comportamento do homem médio, ao passo que, no dolo, observam-se o completo conhecimento do ato ilícito e a perfeita intenção de cometê-lo. Assim, enquanto a culpa stricto sensu consiste

entregues para cobrança mediante endosso-mandato - Extravio dos títulos - Falta de diligência do bancomandatário caracterizada - Inexigibilidade de transferir à cliente-endossante o manejo da ação de anulação e substituição dos títulos - Responsabilidade do mandatário que decorre da culpa in abstracto - Juntada ao processo de parte dos títulos, no curso da demanda, que não exime e apenas evidencia a negligência no desempenho da incumbência - Indenização igual ao valor integral dos títulos e mais reembolso de taxas de serviço e despesas debitadas na conta-corrente da cliente. Recurso e agravo retido desprovidos"). Em sentido contrário, estabelecendo a culpa in concreto em matéria de responsabilidade contratual (contrato de trabalho), mencione-se o acórdão proveniente do TRT 3ㄹ R. $6^{\mathrm{a}}$ T. RO 01349-2004-037-03-00-0. Rel. Sebastião Geraldo de Oliveira. j. 06.09.05. v.u. (Ementa: "Culpa. Acidente do trabalho. Desvio de função. Incapacidade parcial e temporária. A constatação de culpa resulta de um processo comparativo do comportamento do empregador que acarretou o infortúnio com a conduta esperada de uma empresa que zela adequadamente pela segurança e saúde do trabalhador. É importante assinalar que a conduta exigida do empregador vai além daquela esperada do homem médio nos atos da vida civil (bonus pater familias), uma vez que a empresa tem o dever legal de adotar as medidas preventivas cabíveis para afastar os riscos inerentes ao trabalho, aplicando os conhecimentos técnicos até então disponíveis para eliminar as possibilidades de acidentes ou doenças operacionais. Neste sentido, a empresa que desvia o empregado para função para a qual não está habilitado, não lhe fornecendo treinamento específico, responde culposamente pelo acidente de trabalho ocorrido nestas circunstâncias, ainda que se constate não haver seqüela definitiva, porquanto no campo de responsabilidade civil basta demonstrar a incapacidade, ainda que parcial e temporária, para a profissão que o acidentado exercia no momento do infortúnio, para fazer jus à indenização". Note-se, por outro lado, a culpa in concreto sendo utilizada em responsabilidade extracontratual na seguinte decisão: TJSP. 31 a Câmara de Direito Privado. Apelação n. 992.08.063992-4. Rel. Adilson de Araujo. j. 15.12.09. v.u. (Ementa: "Responsabilidade civil. Trânsito. Atropelamento de criança com dois anos de idade. Conversão anterior de ingresso na via não permitida. Circunstância não determinante do atropelamento. Circunstâncias denotativas da falta de previsibilidade do evento. Sentença de improcedência do pedido indenizatório. Avaliação da responsabilidade civil pela culpa in concreto. Necessidade. Recurso improvido. Embora o motorista tenha realizado momentos antes manobra de conversão para ingresso na rua em que se deu o atropelamento, não constitui causa determinante de sua ocorrência. Por essa razão, à falta de outros elementos indicativos da previsibilidade do evento, não se cogita de responsabilização civil do motorista atropelante e seus empregadores, sobretudo por não militar, no caso, presunção de culpa. Necessária a avaliação da conduta sob a ótica aceita na doutrina pela culpa in concreto".

${ }^{28}$ Maria Helena Diniz tece importantes comentários sobre a matéria, transcritos a seguir: "Em nosso direito, segundo Agostinho Alvim, a culpa é, em regra, apreciada abstratamente, pois nosso Código Civil, ao dizer nos arts. 582 e 629 que sua apreciação é in concreto, não visa propriamente apreciá-la concretamente, mas sim encarecer a responsabilidade do agente. O homem normal cuida razoavelmente de sua pessoa e de suas coisas e respeita os interesses alheios, por isso a doutrina, principalmente no campo extracontratual, vem aceitando a tese da medição da culpa in abstracto, entendendo que a cada indivíduo será lícito exigir que os demais sejam medianamente diligentes e prudentes, para que não esteja exposto ao risco de sofrer danos perfeitamente evitáveis. Por prevalecer o critério da culpa in abstracto, dever-se-á aferir o comportamento do agente pelo padrão admitido, dando-se a flexibilidade à apreciação do órgão judicante" (Curso de Direito Civil brasileiro: responsabilidade civil, v. 7, p. 43-44). 
simplesmente na falta de diligência, o dolo manifesta-se como violação deliberada do dever jurídico ${ }^{29}$. A culpa em sentido amplo admite ambas as modalidades.

A culpa em sentido estrito, por sua vez, admite diversas classificações, abordadas a seguir, de modo sucinto.

\subsubsection{Modalidades de culpa em sentido estrito}

A culpa comporta diversas classificações. A primeira, e mais importante delas, é a que a divide em negligência, imprudência e imperícia ${ }^{30}$.

A negligência consiste na omissão de tomada das precauções necessárias ao executar uma ação, isto é, na omissão pertinente ao cumprimento de um dever. É exemplo emblemático o caso do advogado que aceita o patrocínio de uma causa e não verifica o prazo prescricional ou decadencial da pretensão do cliente, incorrendo em uma atuação negligente.

A imprudência, por sua vez, diz respeito a uma conduta comissiva, de realização de uma ação da qual o agente deveria abster-se, ou, então, que foi feita de maneira impensada ou precipitada, demonstrando pouco interesse pelo direito alheio. É ilustrativa dessa situação a hipótese em que um médico, sem analisar com cautela o quadro clínico do paciente, realiza uma cirurgia, quando, em verdade, a doença da vítima poderia ter sido tratada com segurança e sem sequelas com a administração de um medicamento ou a combinação de tratamentos menos invasivos.

Por fim, a imperícia pode ser definida como a incapacidade técnica para o exercício da atividade desenvolvida pelo ofensor. Muitas vezes é entendida como a verdadeira culpa profissional. Trata-se, do caso, hipoteticamente considerado, do engenheiro projetista que calcula mal o peso da água que ocupará uma piscina na cobertura de um prédio de apartamentos e gera rachaduras nas unidades autônomas que se localizam abaixo dela ${ }^{31}$.

A culpa também pode ser classificada em exclusiva, quando existente somente na conduta do ofensor, ou concorrente, quando resulta da atuação conjunta do ofensor e da

\footnotetext{
${ }^{29}$ GONÇALVES, Carlos Roberto. Responsabilidade civil, p. 10.

${ }^{30}$ José de Aguiar Dias assinala que essas modalidades de culpa se relacionam entre si, o que significa dizer que, frequentemente, as condutas são revestidas de duas ou mais das espécies (Da responsabilidade civil. 3. ed. Rio de Janeiro: Forense, 1954. t. I/II, p. 140).

${ }^{31}$ GONÇALVES, Carlos Roberto, op. cit., p. 10.
} 
vítima. É possível, igualmente, a ocorrência de culpa exclusiva da vítima ${ }^{32}$, que se trata de uma excludente da responsabilidade civil, como se verá adiante ${ }^{33}$.

Admite-se também a classificação entre culpa in vigilando, in custodiendo, in eligendo, in comittendo e in omittendo. Assinale-se, porém, que nem sempre uma categoria exclui a outra, ou seja, a culpa pode integrar mais de uma das espécies ora mencionadas.

A culpa in vigilando resulta da falta de vigilância ou fiscalização da conduta de terceiro sobre o qual se tem responsabilidade. Como exemplo, tradicionalmente se menciona a culpa do pai pelos atos dos filhos, mas não se deve olvidar que, a partir da vigência do Código Civil de 2002, esta se trata de hipótese de responsabilidade objetiva.

A culpa in custodiendo é uma subespécie da culpa in vigilando e se aplica à guarda de animais e coisas, ou seja, decorre da falta de cuidado na guarda destes. De acordo com o disposto no Código Civil hodierno, os casos dessa espécie de culpa também se tornaram hipóteses de responsabilidade objetiva.

A culpa in eligendo, por sua vez, advém da má escolha de representante ou de preposto efetuada pelo responsável pelo dano ${ }^{34}$. Trata-se do caso do proprietário que escolhe um construtor manifestamente desqualificado para realizar uma obra, o que o leva a responder pelos danos por este ocasionados ${ }^{35}$.

A culpa in comittendo é a resultante de um ato positivo, ao passo que a culpa in omittendo relaciona-se à abstenção culposa. Nessa classificação se verifica, na verdade, mera transposição, para o âmbito da culpa, da divisão entre conduta comissiva e omissiva.

A culpa também pode ser dividida em culpa grave ou lata, culpa leve e culpa levíssima. A culpa grave é a que mais se aproxima do dolo - segundo o brocardo culpa lata dolo aequiparatur - porque a violação do dever é tão grave que quase faz crer que o autor do dano atuou de modo proposital. Diz respeito à imprudência, negligência ou imperícia grosseira ${ }^{36}$. A culpa leve consubstancia-se na falta de cuidado médio que um homem normal observa em sua conduta, sendo o caso de falta possível de ser evitada com

\footnotetext{
${ }^{32}$ Quando a vítima concorre para a produção do dano, há divisão proporcional da indenização, a ser determinada pelo magistrado, conforme disposto no art. 945 do CC. No âmbito dos direitos do consumidor, porém, somente a culpa exclusiva da vítima ilide o dever de indenizar (Lei n. 8.078/1990, art. 12, § 3º).

${ }^{33}$ Verifique-se o item 1.5.4 deste capítulo.

${ }^{34}$ VENOSA, Silvio de Salvo. Responsabilidade civil. 3. ed. São Paulo: Atlas, 2003c. v. 4, p. 26.

${ }^{35}$ Essa hipótese de responsabilização do proprietário será estudada com pormenores no Capítulo 6, intitulado Responsabilidade Civil de Engenheiros, Arquitetos e Empreiteiros.

${ }^{36}$ RODRIGUES, Sílvio. Direito Civil - responsabilidade civil, v. 4, p. 148.
} 
atenção ordinária. Já a culpa levíssima relaciona-se à pequena falta cometida que, para ser evitada, exige a máxima diligência ${ }^{37}$.

Em rigor, considera-se que qualquer espécie de culpa fundamenta o dever de indenizar, motivo pelo qual a doutrina costumava não encontrar mais utilidade prática na referida diferenciação. A verdade, porém, é que, ao menos no que tange à apuração dos danos morais, os tribunais raramente afastam a avaliação do grau da culpabilidade ${ }^{38}$.

Carlos Celso Orcesi da Costa vai além dessa assertiva, sustentando que a mencionada graduação influencia, ainda que de modo indireto, na imputação e avaliação do dano de maneira geral, uma vez que o magistrado, encontrando-se diante de culpa substancial, sente-se mais seguro, do ponto de vista psicológico, para condenar o causador do dano ${ }^{39}$.

A despeito dos argumentos trazidos pelo doutrinador, o entendimento aqui esposado segue em sentido diverso, isto é, propugna-se que a indenização deve ser medida tão somente pela extensão do dano, inclusive no que tange aos danos morais.

É, no entanto, imperioso salientar que o art. 944, parágrafo único, do $\mathrm{CC}^{40}$ altera a abordagem categórica da questão, na medida em que determina que se diminua a indenização em caso de excessiva desproporção entre a gravidade da culpa e o dano. Diverge-se, neste estudo, do disposto pela norma em comento; no entanto, é necessário reconhecer que esta introduz alteração de posicionamento legislativo que deverá

${ }^{37}$ GONÇALVES, Carlos Roberto. Responsabilidade civil, p. 32.

${ }^{38} \mathrm{O}$ assunto será tratado com mais profundidade no próximo Capítulo, itens 2.6 e seguintes, que versam sobre o tema de danos morais.

${ }^{39}$ COSTA, Carlos Celso Orcesi da. Código Civil na visão do advogado - responsabilidade civil. São Paulo: Revista dos Tribunais, 2005. v. 3, p. 123-126. Ao defender seu ponto de vista, o doutrinador assevera que: “[...] a graduação da culpa tem sim influência na imputação e na avaliação do dano, donde o interesse de seu estudo sob a visão prática do advogado. Como recusar, no direito, a consideração comum de que uma criança que derrama sem querer um copo de leite na mesa é sancionada de modo diferente daquela que o faz de propósito? [...] Entretanto a doutrina conclui que a graduação da culpa não tem influência na imputação ou na avaliação do dano. Chega a ser curiosa a monocórdia repetição da doutrina, data venia, como se ninguém realmente pensasse a respeito. [...] Dessarte, embora a falta de uma construção dogmática que distinga essa circunstância, ela está presente no espírito de todos e na realidade concreta da vida. De início, no que se refere à imputação, porque o juiz tem diante de si elementos de convicção mais claros e definidos. [...] Porém ainda que assim não fosse para a finalidade da imputação, seguramente a graduação da culpa, o fator subjetivo, o animus nocendi, tem sim radical influência no momento da fixação da indenização. Sem dúvida o juiz terá diante de si muito maior conforto para aplicação da pena cabível. Trata-se de um fator psicológico, que conduz o juiz a uma segurança na difícil tarefa de aplicar a indenização cabível".

${ }^{40} \mathrm{O}$ mencionado artigo, apenas para conferência, segue aqui transcrito:

"Art. 944. A indenização mede-se pela extensão do dano.

Parágrafo único. Se houver excessiva desproporção entre a gravidade da culpa e o dano, poderá o juiz reduzir, eqüitativamente, a indenização.”. 
influenciar os tribunais. Conclui-se, pois, que a distinção entre culpa e dolo passa a ter uma relevância outrora desconsiderada pela doutrina.

O dispositivo legal em comento, decerto, deve ter sua aplicação restringida em algumas situações. Primeiro, somente poderá ser aplicado aos casos de responsabilidade subjetiva, eis que, na objetiva, não se faz sequer necessária a presença de culpa ${ }^{41}$. Também, deve ser utilizado em caráter restrito, tal como recomendado pelo Enunciado n. 46 da I Jornada de Direito Civil de 2002, promovida pelo Conselho da Justiça Federal (CJF), com a redação dada pelo Enunciado n. 380 da IV Jornada, realizada em $2006^{42}$ :

“Art. 944. A possibilidade de redução do montante da indenização em face do grau de culpa do agente, estabelecida no parágrafo único do art. 944 do novo Código Civil, deve ser interpretada restritivamente, por representar uma exceção ao princípio da reparação integral do dano".

\subsubsection{A evolução do conceito de culpa e o desenvolvimento da responsabilidade objetiva}

As profundas mudanças ocorridas na sociedade, tais como a revolução industrial, o progresso científico e a explosão demográfica das grandes cidades, demonstraram a insuficiência da culpa como fundamento do dever de indenizar. De fato, o desenvolvimento de diversos instrumentos mecânicos, em variados campos da vida humana, levou ao aumento de acidentes de trabalho, no qual a culpa se mostrou particularmente inadequada na medida em que os danos eram gerados, em sua maior parte,

\footnotetext{
${ }^{41}$ Verifique-se a obra de Alexandre Guedes A. Assunção et al., na qual Regina Beatriz Tavares da Silva assim se manifesta: "O parágrafo único deste artigo adota a teoria da gradação da culpa, a influenciar o quantum indenizatório, mas somente possibilita sua diminuição diante de desproporção entre a gravidade da culpa e o dano. Esse parágrafo é inaplicável nas hipóteses de responsabilidade objetiva, em que não há apuração da culpa e, portanto, descabe a diminuição da indenização consoante o critério aqui estabelecido. Desse modo esse parágrafo é aplicável exclusivamente à responsabilidade civil subjetiva" (SILVA, Regina Beatriz Tavares da. In: ASSUNÇÃO, Alexandre Guedes A. et al. Código Civil comentado. 6. ed. São Paulo: Saraiva, 2008. p. 912). Observa-se, entretanto, que o entendimento doutrinário sobre o assunto não é pacífico, tendo em vista que o Enunciado n. 46 da I Jornada de Direito Civil, promovido pelo Conselho da Justiça Federal, teve justamente sua redação alterada para a retirada da expressão que constava da parte final: "não se aplicando às hipóteses de responsabilidade objetiva".

${ }^{42}$ Daqui por diante, as Jornadas em comento serão designadas tão somente Jornadas de Direito Civil. O aludido Enunciado n. 380 possui a seguinte redação: "380 - Atribui-se nova redação ao Enunciado n. 46 da I Jornada de Direito Civil, com a supressão da parte final: não se aplicando às hipóteses de responsabilidade objetiva". A despeito dessa alteração, sustenta-se, neste estudo, ser inadmissível que a análise do grau de culpa influencie o valor da indenização decorrente de hipótese de responsabilidade objetiva.
} 
pelo despreparo dos trabalhadores e inexperiência no manejo das máquinas ${ }^{43}$. Tratava-se, assim, de situação de difícil comprovação da culpa dos empregadores. Do mesmo modo, proliferaram-se os acidentes de trânsito, em consequência do surgimento e da popularização de diversos veículos, e os decorrentes de transporte público, especialmente trens, cada vez mais necessários nas novas metrópoles.

Assim surgia a necessidade da concessão de flexibilidade ao conceito de culpa, de modo a ampliar a abrangência de danos indenizáveis, bem como intensificar a proteção da vítima do ato danoso.

A culpa, contudo, não foi substituída de pronto e inteiramente pela ideia de risco. Antes disso, foi perdendo parte de seu conteúdo ao ser confundida com meros erros, bem como identificada em condutas perfeitamente escusáveis.

No período moderno, a culpa encontrou forte abrigo no Código Civil francês e, posteriormente, no Código Civil brasileiro de 1916, que pouco espaço concedeu a qualquer outro tipo de responsabilidade. Infere-se, assim, que o século XIX e o início do século XX se caracterizaram pelo domínio da culpa como fundamento do dever de indenizar. Essa situação, no entanto, não se manteve ad infinitum.

Em um primeiro momento, os tribunais começaram a admitir a prova da culpa com menos rigor, extraindo-a, por vezes, das próprias circunstâncias em que se dava o evento danoso e dos antecedentes pessoais dos participantes ${ }^{44}$.

Com o passar do tempo, evoluíram para a admissão da ideia de abuso de direito como ato ilícito, bem como da culpa presumida, que permitia a inversão do ônus da prova. Em se aplicando a referida presunção, o causador do dano, até prova em contrário, é reputado como culpado, cabendo-lhe provar situação diversa.

As hipóteses de responsabilidade contratual foram ampliadas, posteriormente, para então ser admitida a responsabilidade independente de culpa em determinados $\operatorname{casos}^{45}$, e,

\footnotetext{
${ }^{43}$ HIRONAKA, Giselda Maria Fernandes Novaes. Responsabilidade pressuposta. Evolução de fundamentos e de paradigmas da responsabilidade civil na contemporaneidade. In: DELGADO, Mário Luiz; ALVES, Jones Figueiredo (Coord.). Questões controvertidas - responsabilidade civil, v. I, p. 212.

${ }^{44}$ CAVALIERI FILHO, Sérgio. Programa de responsabilidade civil. 4. ed. São Paulo: Malheiros, 2003. p. 145.

${ }^{45}$ RODRIGUES, Sílvio. Direito Civil - responsabilidade civil, v. 4, p. 152-153. No mesmo sentido, Carlos Roberto Gonçalves (Responsabilidade civil, p. 478-479) e Alvino Lima (Culpa e risco, p. 40/70).
} 
em seguida, foi adotada uma cláusula geral de responsabilidade objetiva, como a que consta do art. 927, parágrafo único, do CC vigente ${ }^{46}$.

No período em que a ideia de responsabilidade evoluía, mas ainda não se aceitava a teoria da responsabilidade objetiva, a jurisprudência majoritária imputava responsabilidade a autores de danos cujo comportamento era irrepreensível. Esse momento histórico ficou conhecido com a fase do "pó da culpa"

Outro fator importante para o desprestígio da culpa foi a interpretação extensiva, ou releitura, que a jurisprudência concedeu ao primeiro parágrafo do art. 1.384 do CC francês de 1804, assim redigido:

“On est responsable non seulement du dommage que l'on cause par son propre fait, mais encore de celui qui est causé par le fait des personnes dont on doit répondre, ou des choses que l'on a sous sa garde" ${ }^{, 48}$.

É de se observar que o artigo empregou o termo fait, que pode ser traduzido como "fato" e não faute ${ }^{49}$, passível de tradução pelo termo "culpa", de modo que o dispositivo francês acabou por dar margem à aplicação da teoria do risco, ao contrário do que ocorreu

46 O parágrafo em comento dispõe que: "Parágrafo único. Haverá obrigação de reparar o dano, independentemente de culpa, nos casos especificados em lei, ou quando a atividade normalmente desenvolvida pelo autor do dano implicar, por sua natureza, risco para os direitos de outrem".

${ }^{47}$ HIRONAKA, Giselda Maria Fernandes Novaes. Responsabilidade pressuposta, p. 150. Em outra obra, a autora se manifesta da seguinte maneira: "A culpa, fundamento da responsabilidade subjetiva responsabilidade por culpa provada -, foi, paulatinamente, perdendo o seu feitio ancestral, processo que se acelerou muito no início do século XIX, anteriormente ao início do fenômeno de objetivação de certos episódios danosos, quando então os magistrados consideraram como culpa -, em alguns casos, e buscando fazer justiça - ocorrências moralmente insignificantes, muitas vezes tomando por culpa o que era um erro vulgar e, por vezes, mesmo desculpável. Foi a fase jurisprudencial conhecida como pó da culpa, que tinha, por um lado, o bom lastro de atender ao reclamo justo da vítima, em face do dano sofrido, mas que, por outro lado, não tinha o lastro do bom direito, especialmente pela falta de critério para julgar e imputar responsabilidade, confundindo comportamentos moral e socialmente irrepreensíveis com negligência, principalmente" (HIRONAKA, Giselda Maria Fernandes Novaes. Responsabilidade civil e contemporaneidade: retrato e moldura. Revista EPD - Escola Paulista de Direito, São Paulo, ano I, n. I, maio/ago. 2005a. p. 210-211).

${ }^{48}$ Tradução livre: "É-se responsável não somente pelo dano que se causou por fato próprio, mas também pelo causado por fato das pessoas pelas quais se deve responder, ou pelas coisas que estão sob sua guarda".

${ }^{49}$ Não se pode olvidar, entretanto, que o próprio termo faute é mais genérico do que o termo culpa. Faute tem como primeiro significado "manquement contre le devoir, contre la loi" (falta em contrariedade ao dever, à lei), o que não necessariamente significa culpa. Ademais, pode significar também "manquement, imperfection en quelque ouvrage" (erro, imperfeição em qualquer obra), que também se afasta consideravelmente do conceito de culpa da maneira pela qual é entendida no direito brasileiro (a definição mencionada foi extraída do Dicoplus. Disponível em: <www.dicoplus.org/definition/faute>. Acesso em: 15 abr. 2010). 
com o art. 159 do CC brasileiro de 1916, que mencionava de maneira expressa o termo "culpa".

De qualquer modo, a norma francesa fez surgir um princípio diverso do da culpa no caso da responsabilidade pelo fato de terceiro e das coisas, motivo pelo qual os defensores da teoria do risco vislumbraram nesse dispositivo a consagração inconfundível da responsabilidade independentemente de culpa.

\subsubsection{O risco e a responsabilidade civil objetiva}

A responsabilidade objetiva configura-se com a mera existência do dano e do nexo causal, não havendo necessidade da comprovação de culpa na conduta do agente. Exige-se, porém, a presença do risco, o qual, em sentido não jurídico, pode ser entendido como o perigo ou a probabilidade de dano ${ }^{50}$. De acordo com a teoria aplicada, todavia, o termo poderá adquirir concepções diferentes.

Em um primeiro momento na evolução da objetivação da responsabilidade, predominou a teoria do risco proveito ${ }^{51}$. A modalidade proveito se caracteriza pelo fato do risco gerar determinado benefício ao responsável, de modo que aquele que lucra pondo em risco bens patrimoniais ou extrapatrimoniais de terceiros deve ser onerado com pagamento de indenização ${ }^{52}$. Atribui-se, assim, responsabilidade àquele que tira proveito ou vantagem de uma atividade e causa dano a terceiro, em clara alusão ao brocardo ubi emolumentum, ibi onus ${ }^{53}$. A tese, porém, estava mais relacionada à atividade empresarial, não podendo ser facilmente encaixada em situações nas quais os ofensores eram simplesmente causadores de acidentes ${ }^{54}$.

O Direito Civil, em consequência, caminhou em direção ao desenvolvimento da teoria do risco criado. Nessa vertente da teoria do risco, entende-se que o dever de reparar o dano advém de uma atividade normalmente desenvolvida pelo agente, que gera risco a direitos ou interesses alheios, abrangendo toda e qualquer atividade mesmo que não esteja

\footnotetext{
${ }^{50}$ CAVALIERI FILHO, Sérgio. Programa de responsabilidade civil, p. 146.

${ }^{51}$ COSTA, Carlos Celso Orcesi da. Código Civil na visão do advogado - responsabilidade civil, v. 3, p. 155.

${ }^{52}$ LOPEZ, Teresa Ancona. Princípio da precaução e evolução da responsabilidade civil. São Paulo: Quartier Latin, 2010. p. 44-45.

${ }^{53}$ GONÇALVES, Carlos Roberto. Responsabilidade civil, p. 22. A frase em latim pode ser traduzida como "onde há lucro, há despesa", ou então como "não há proveito sem custo".

${ }^{54}$ CAVALIERI FILHO, Sérgio, op. cit., p. 147: "Se o proveito tem o sentido de lucro, vantagem econômica, a responsabilidade fundada no risco-proveito ficará restrita aos comerciantes e industriais, não sendo aplicável aos casos em que a coisa causadora do dano não é a fonte de ganho".
} 
relacionada com o proveito econômico do causador do risco ${ }^{55}$. Na referida teoria, portanto, o enfoque não jaz sobre a obtenção de proveito ou vantagem, mas sim na atividade, considerada potencialmente danosa ${ }^{56}$.

Ocorre que a teoria em comento é muito ampla, sendo até mesmo mais abrangente do que a de risco proveito, tendo em vista que toda atividade gera determinado risco ${ }^{57}$. A despeito de sua excessiva generalização, a teoria do risco criado veio a ser consagrada no Código Civil de 2002, no parágrafo único do art. $927^{58}$, com algumas restrições, conforme pode ser observado logo adiante ${ }^{59}$.

A doutrina também menciona outra espécie de risco: o administrativo, pertinente à União, aos Estados, aos Municípios e ao Distrito Federal, além de outras pessoas jurídicas de direito público. Para a configuração de sua responsabilidade, basta o fato do serviço e que o Estado cause um dano em sua atividade ${ }^{60}$.

Mencione-se, por fim, a existência da teoria do risco integral, da qual resulta o entendimento de que qualquer fato obriga o ofensor a reparar o dano ${ }^{61}$. Em regra, a culpa exclusiva da vítima, o fato de terceiro e o caso fortuito ou a força maior não rompem o nexo de causalidade e, portanto, não eximem o responsável do dever de indenizar.

Afirma-se com frequência que a responsabilidade por danos ambientais é hipótese de aplicação da teoria do risco integral, bem como a responsabilidade da administração pública, posicionamento que não se coaduna com o entendimento propugnado neste

${ }^{55}$ LOPEZ, Teresa Ancona. Princípio da precaução e evolução da responsabilidade civil, p. 45.

${ }^{56}$ COSTA, Carlos Celso Orcesi da. Código Civil na visão do advogado - responsabilidade civil, v. 3, p. 155.

${ }^{57}$ Ibidem, p. 156: "Tudo é risco criado, daí que sob esse prisma inclusive a vítima assume um certo risco quando abre um refrigerante ou come alimento pleno de conservantes. [...] A idéia e a nomenclatura são imprecisas pela já apontada razão de que todos os riscos são criados pelos agentes. Quer dizer, inexiste risco 'não-criado', basta estar vivo".

${ }^{58}$ A teoria do risco-proveito remanesce como fundamento da responsabilidade objetiva do empregado pelos atos do empregador, constante do art. 932, inc. III c/c art. 933, do CC.

${ }^{59}$ Esse é o pensamento da maior parte da doutrina, admitindo-se posicionamentos em sentido contrário. Erik Frederico Gramstrup, partilhando do entendimento propugnado no presente estudo, manifesta-se da seguinte maneira: "Foi acolhida pelo Código a teoria do risco-criado. Isso significa que o fundamento ético da hipótese mais geral de responsabilidade objetiva em nosso direito não é o ganho que o agente retira da atividade perigosa (como seria na teoria do risco-proveito). A prova disso é que o pressuposto é uma 'atividade', expressão que aparece sem nenhuma qualificação especial, a não ser o da periculosidade. Não se exigiu que seja lucrativa, nem ao menos remunerada" (Responsabilidade objetiva na cláusula geral codificada e nos microssistemas. In: DELGADO, Mário Luiz; ALVES, Jones Figueiredo (Coord.). Questões controvertidas - responsabilidade civil, v. I, p. 130). Em sentido contrário, Giselda Maria Fernandes Novaes Hironaka, que sustenta ter sido acolhida a teoria do risco-proveito (Responsabilidade pressuposta. Evolução de fundamentos e de paradigmas da responsabilidade civil na contemporaneidade. In: DELGADO, Mário Luiz; ALVES, Jones Figueiredo (Coord.), op. cit., p. 202). De fato, a teoria do risco-proveito encontra guarida no $\mathrm{CC}$, mas não na cláusula geral de responsabilidade objetiva, e sim no dispositivo pertinente à responsabilidade por fato de terceiro do empregador ou comitente, conforme esclarecido na nota acima.

${ }^{60}$ SIMÃO, José Fernando. Responsabilidade civil do incapaz. São Paulo: Atlas, 2008. p. 68.

${ }^{61}$ ASSUNÇÃO, Alexandre Guedes A. et al. Código Civil comentado, p. 883. 
estudo. De fato, na hipótese de se entender que o risco integral não admite excludentes do dever de indenizar ou do nexo de causalidade, certamente não será o caso de identificá-lo na responsabilidade na esfera do meio ambiente, tendo em vista que a lei específica sobre o tema (Lei n. 6.938/1981) prevê algumas excludentes. A responsabilidade por danos nucleares é agravada, mas também pode ser exonerada em caso de culpa exclusiva da vítima e fortuito externo (Lei n. 6.453/1977, arts. $6^{\underline{o}}$ e $8^{\underline{o}}$ ). O mesmo se diga da responsabilidade por risco administrativo, que também admite excludentes.

Conclui-se, pois, que a teoria do risco integral não se aplica no Direito brasileiro, ao menos na hipótese de se entender que esta não admite qualquer tipo de exoneração de responsabilidade $^{62}$. Tal observação corrobora a importância dos estudos desenvolvidos por Giselda Maria Fernandes Novaes Hironaka, que advoga pelo desenvolvimento de uma responsabilidade pressuposta que não admita quaisquer excludentes de responsabilidade ${ }^{63}$.

Independentemente da teoria que se adote, o fato é que o Código Civil de 1916 restringiu a aplicação da responsabilidade objetiva a poucos dispositivos legais, como é o caso do art. $1.528^{64}$, que imputava ao dono do edifício ou construção a responsabilidade pelos danos decorrentes da ruína deste(a), bem como o art. $1.529^{65}$, que responsabilizava objetivamente o habitante de uma casa ou parte dela, pelas coisas que dela caíssem ou fossem atiradas em lugar indevido.

Legislações contemporâneas e posteriores ao Código em comento adotaram, no entanto, essa espécie de responsabilidade, como o Decreto n. 2.681, de 7 de dezembro de 1912. Essa lei trata da responsabilidade das estradas de ferro pelos danos aos proprietários marginais, independentemente de culpa, sendo pioneira nessa diretriz ${ }^{66}$. Mencione-se, igualmente, a Lei n. 5.316, de 14 de setembro de 1967, pertinente à reparação dos danos

62 GRAMSTRUP, Erik Frederico. Responsabilidade objetiva na cláusula geral codificada e nos microssistemas. In: DELGADO, Mário Luiz; ALVES, Jones Figueiredo (Coord.). Questões controvertidas responsabilidade civil, v. I, p. 133.

${ }^{63}$ HIRONAKA, Giselda Maria Fernandes Novaes. Responsabilidade pressuposta. Evolução de fundamentos e de paradigmas da responsabilidade civil na contemporaneidade. In: DELGADO, Mário Luiz; ALVES, Jones Figueiredo (Coord.), op. cit., p. 221.

${ }^{64} \mathrm{O}$ dispositivo legal em comento dispunha que: “[...] O dono do edifício ou construção responde pelos danos que resultarem de sua ruína, se esta provier de falta de reparos, cuja necessidade fosse manifesta". Tal redação foi mantida no art. 937, do Código Civil de 2002.

65 Apenas para conferência pelo leitor, reproduz-se o texto do em comento: "[...] Aquele que habitar uma casa ou parte dela, responde pelo dano proveniente das coisas que dela caírem ou forem lançadas em lugar indevido". O art. 938 do CC atual manteve praticamente a mesma redação da norma anterior, substituindo o termo "casa" por "prédio".

${ }^{66}$ À mencionada lei se seguiram diversas outras, como o Decreto n. 15.673, de 7 de setembro de 1922. 
advindos dos acidentes de trabalho ${ }^{67}$, que são cobertos por seguro pago pelo empregador. No caso de lesão decorrente da relação empregatícia, o órgão previdenciário paga uma indenização tarifada ao empregado, sem que haja a necessidade de comprovação de culpa de uma das partes.

Não se olvidem, igualmente, da Lei n. 6.194, de 19 de dezembro de 1974, com suas diversas modificações posteriores ${ }^{68}$, que institui o seguro obrigatório de responsabilidade civil para os proprietários de automóveis (DPVAT); da Lei n. 6.453, de 17 de outubro de 1977, que trata da responsabilidade civil por danos nucleares e a responsabilidade criminal por atos relacionados com atividades nucleares ${ }^{69}$; da Lei n. 6.938, de 13 de julho de 1981, que dispõe acerca dos danos causados ao meio ambiente e estabelece, em seu art. 14, $\S 1^{\underline{o}}$, a responsabilidade objetiva do poluidor; dos dispositivos constantes da Constituição Federal de 1988, como, por exemplo, o art. 37, $\S 6^{\underline{o}}$, que estendeu a responsabilidade objetiva do Estado $^{70}$ às pessoas jurídicas de direito privado, prestadoras de serviços públicos; e, por fim, da Lei n. 8.078, de 11 de setembro de 1990 (o chamado Código de Defesa do Consumidor - CDC), que tornou a responsabilidade objetiva regra para todas as relações de consumo. Em tempos mais recentes, verifica-se o emprego da responsabilidade objetiva na Lei n. 10.671, de 15 de maio de 2003 (o chamado "Estatuto do Torcedor"), e na Lei n. 11.105, de 24 de março de 2005, regulamentada pelo Decreto n. 5.591, de 22 de novembro de 2005 (Lei de Biossegurança) ${ }^{71}$.

Ressalte-se, por fim, que a teoria do risco foi definitivamente adotada pelo Código Civil de 2002 com caráter mais genérico para os "casos especificados em lei, ou quando a

\footnotetext{
${ }^{67}$ Os acidentes de trabalho foram regulados por diversas leis anteriores a essa: Decreto n. 3.724 , de 15 de janeiro de 1919; Decreto n. 24.637, de 10 de julho de 1934; e Decreto-lei n. 7.036, de 10 de novembro de 1944. Trata-se, aqui, apenas da Lei n. 5.316/1967, regulamentada pelo Decreto n. 61.784, de 28 de novembro de 1967, em virtude da criação de um seguro coletivo. A matéria foi, posteriormente, objeto do art. $7^{\circ}$, inc. XXVIII, da Constituição Federal, e da Lei n. 8.213, de 24 de julho de 1991, regulamentada pelo Decreto n. 2.172, de 5 de março de 1997. Nesta última norma, foi adotada a teoria do risco integral, não havendo, como salientado anteriormente, exclusão do nexo causal, nem mesmo em hipótese de culpa exclusiva da vítima, fato de terceiro, caso fortuito ou força maior. A indenização é tarifada, exceto se o empregado tiver atuado com dolo ou culpa, quando poderá, então, ser integral.

${ }^{68}$ De acordo com a legislação em análise, a vítima é ressarcida, de maneira tarifada, independentemente de culpa do motorista causador do dano. Mesmo nos casos em que o veículo provocador do acidente esteja com o seguro vencido, ou quando não tenha sido possível sua identificação, será concedida indenização. A lei determina que qualquer seguradora participante do convênio, administrado pela Federação Nacional das Empresas de Seguros Privados e Capitalização, efetue o pagamento ao beneficiário, recuperando dos demais participantes do grupo a parte da indenização que tenha excedido sua cota.

69 Sobre a matéria, verifique-se a obra de Carlos Alberto Bittar (Responsabilidade civil nas atividades nucleares. São Paulo: Revista dos Tribunais, 1985).

${ }^{70}$ A responsabilidade civil do Estado passou a ser objetiva a partir da Constituição Federal de 1946.

${ }^{71} \mathrm{O}$ rol de leis supramencionado é apenas exemplificativo, não sendo intenção da pesquisadora apresentar a listagem completa de todas as normas brasileiras que contribuíram para a aceitação do risco como pressuposto da responsabilidade civil.
} 
atividade normalmente desenvolvida pelo autor do dano implicar, por sua natureza, risco para os direitos de outrem", conforme dicção do parágrafo único do art. 927.

A referida norma, contudo, vem gerando intensas discussões da doutrina, que encontram dificuldades em determinar qual é o risco a que se reporta o mencionado artigo. $\mathrm{Na}$ verdade, o Código Civil criou um conceito jurídico indeterminado, de modo a ampliar os poderes do magistrado também no que tange a esse ponto.

A despeito das intensas discussões, têm-se algumas indicações acerca do alcance do dispositivo legal. O uso do advérbio "normalmente", v.g., indica que somente será considerada como atividade de risco aquela que mesmo quando exercida com regularidade seja potencialmente nociva ou danosa. Conforme salienta Sérgio Cavalieri Filho, "aqui não se tem em conta a conduta individual, isolada, mas sim a atividade como conduta reiterada, habitualmente exercida, organizada de forma profissional ou empresarial para realizar fins econômicos",72.

A segunda parte do dispositivo legal, isto é, "implicar, por sua natureza, risco para os direitos de outrem”, demonstra o emprego da noção de risco inerente, ou seja, aquele que é peculiar e intrínseco a determinados serviços pela sua própria natureza e modo de funcionamento $^{73}$. Frise-se, contudo, que é a atividade de produção que deve ser normalmente perigosa, não o produto dela resultante ${ }^{74}$.

Convém salientar, ainda, que a atividade que enseja indenização não necessita ser ilícita, sendo exigível apenas que o seu exercício habitual tenha a capacidade potencialmente de produção de dano ${ }^{75}$. De fato, como mencionado no início deste Capítulo, mesmo no tocante a uma atividade legal e regulamentada, não se admite a produção indiscriminada de danos ${ }^{76}$.

Verifique-se, em acréscimo, que, além do parágrafo único do art. 927, a responsabilidade objetiva também está presente em outros dispositivos legais do Código

\footnotetext{
${ }^{72}$ CAVALIERI FILHO, Sérgio. Programa de responsabilidade civil, p. 171. É também nesse sentido que parece ter se encaminhado o Enunciado n. 38, da I Jornada de Direito Civil (apesar de certa obscuridade em sua redação), in verbis: "Art. 927. A responsabilidade fundada no risco da atividade, como prevista na segunda parte do parágrafo único do art. 927 do novo Código Civil, configura-se quando a atividade normalmente desenvolvida pelo autor do dano causar a pessoa determinada um ônus maior do que aos demais membros da coletividade".

${ }^{73}$ CAVALIERI FILHO, Sérgio, op. cit., p. 172.

${ }^{74}$ SIMÃO, José Fernando. Vícios do produto no novo Código Civil e no Código de Defesa do Consumidor. São Paulo: Atlas, 2003. p. 167-168.

${ }^{75}$ ASSUNÇÃO, Alexandre Guedes A. et al. Código Civil comentado, p. 884.

76 GAGLIANO, Pablo Stolze; PAMPLONA FILHO, Rodolfo. Novo curso de Direito Civil responsabilidade civil, p. 139.
} 
Civil, como, por exemplo, as já citadas hipóteses de responsabilidade civil por fato de terceiro (arts. 932 e 933), do animal (art. 936) e da coisa (arts. 937 e 938), além daquela constante do art. $928^{77}$, que trata da responsabilidade do incapaz ${ }^{78}$.

Por fim, é importante mencionar a divisão efetuada por Álvaro Villaça Azevedo entre responsabilidade objetiva pura e impura ${ }^{79}$. A primeira modalidade enseja ressarcimento mesmo que não haja culpa de qualquer pessoa envolvida no evento danoso, uma vez que a indenização decorre do ato lícito ou de simples fato jurídico, sempre que houver determinação legal nesse sentido. São hipóteses dessa espécie o $§ 1^{\underline{0}}$ do art. 14 da já mencionada Lei n. 6.938/1981, que dispõe acerca dos danos causados ao meio ambiente, bem como o art. 4 da Lei n. 6.453/1977, que trata dos prejuízos oriundos de atividades nucleares. A responsabilidade objetiva impura é, por sua vez, resultante de culpa de outrem, vinculado juridicamente ao responsável. Nessa hipótese, ainda que o responsável pelo ressarcimento do dano não tenha atuado com culpa, é mister que o causador do dano tenha se conduzido de modo culposo. Admite-se, em regra, nessa seara, o direito de regresso do responsável em face do causador do dano ${ }^{80}$, o que não se cogita no caso da responsabilidade objetiva pura. É impura, segundo o referido doutrinador ${ }^{81}$, a responsabilidade por fato de terceiro.

\subsection{Relação de causalidade ou nexo causal}

O nexo causal é o elemento de ligação entre a conduta do ofensor e o dano suportado pela vítima. Consiste no vínculo que deve existir entre o fato e o dano para que o autor desse ato seja responsabilizado pelo prejuízo.

Trata-se de árdua tarefa a de determinar o critério a ser utilizado para se chegar à conclusão de que, dentre tantas circunstâncias, uma específica foi a que ocasionou o

\footnotetext{
77 “Art. 928. O incapaz responde pelos prejuízos que causar, se as pessoas por ele responsáveis não tiverem a obrigação de fazê-lo ou não dispuserem de meios suficientes."

${ }^{78} \mathrm{O}$ abuso de direito, constante do art. 187 do CC ("[...] Também comete ato ilícito o titular de um direito que, ao exercê-lo, excede manifestamente os limites impostos pelo seu fim econômico ou social, pela boa-fé ou pelos bons costumes"), também é importante matéria regida pela responsabilidade objetiva, conforme corroborado pelo Enunciado n. 37, da I Jornada de Direito Civil: "A responsabilidade civil decorrente do abuso do direito independe de culpa, e fundamenta-se somente no critério objetivo-finalístico". O assunto será abordado de maneira sucinta, adiante, neste Capítulo.

${ }^{79}$ AZEVEDO, Álvaro Villaça. Teoria geral das obrigações - responsabilidade civil. 10. ed. São Paulo: Atlas, 2004. p. 284.

${ }^{80}$ Inadmite-se o direito de regresso, nos termos do art. 934 do CC, quando o causador do dano é descendente, absoluta ou relativamente incapaz, do responsável pela reparação.

${ }^{81}$ AZEVEDO, Álvaro Villaça, op. cit.
} 
dano $^{82}$. Nesse ponto, cumpre diferenciar as causas das meras condições. Causas são os fatores determinantes para a ocorrência do dano, enquanto as condições são todas as ocorrências que se encontram na origem de um dano, mas que não são consideradas efetivamente como causa deste ${ }^{83}$. Deve-se, assim, selecionar, entre todas as condições, aquela que deu causa ao dano.

Pode haver, no entanto, mais de uma causa para determinado incidente, motivando a discussão sobre as chamadas concausas.

As concausas podem ser simultâneas ou sucessivas. No caso de simultaneidade, isto é, ocorrendo todas as causas ao mesmo tempo, entende-se que o dano, apesar de único, deriva de um concurso delas. Nas concausas sucessivas, por sua vez, há uma reação em cadeia, isto é, uma circunstância gera outra e assim sucessivamente. Nessa seara, as concausas preexistentes não têm o condão de ilidir o nexo causal, na medida em que são antecedentes ao próprio desencadeamento da causalidade. É o que ocorre, v.g., com condições preexistentes de saúde da vítima, que não são consideradas para estabelecimento do nexo ${ }^{84}$. As causas supervenientes, que se observam quando um ou mais eventos posteriores ao que gerou o dano são a ele acrescentados, geram discussões mais acirradas. De fato, nessa hipótese é que surge o problema de determinar se o fato posterior interrompe o nexo causal, e quando o faz, liberando o primeiro ofensor com relação ao segundo dano. Só há rompimento do nexo se a condição superveniente não for uma sequela do curso causal desenvolvido pela conduta do suposto ofensor.

Várias teorias foram desenvolvidas, com a finalidade de trazer elementos aptos a solucionar os problemas ora enunciados. Na oportunidade, estudar-se-ão três delas ${ }^{85}$ : teoria de equivalência das condições ${ }^{86}$, teoria da causalidade adequada e teoria da causalidade direta ou imediata ${ }^{87}$.

\footnotetext{
${ }^{82}$ ALVIM, Agostinho. Da inexecução das obrigações e suas consequiências. 3. ed. Rio de Janeiro/São Paulo: Jurídica e Universitária, 1965. p. 327.

${ }^{83}$ NORONHA, Fernando. Direito das obrigações: fundamentos do direito das obrigações - introdução à responsabilidade civil. São Paulo: Saraiva, 2003. v. 1, p. 588.

${ }^{84}$ As condições preexistentes de saúde da vítima podem exercer influência no caso de responsabilidade médica, como será discutido no Capítulo 4.

${ }^{85}$ Saliente-se que existem muitas outras teorias além das pré-relacionadas. Tendo em vista a impossibilidade de discussão do tema em comento com mais profundidade neste Capítulo, que há de ser considerado meramente introdutório, a pesquisadora optou pela análise das três mais relevantes, do ponto de vista do Direito brasileiro.

${ }^{86}$ Também chamada de teoria da equivalência dos antecedentes causais ou teoria da conditio sine qua non.

${ }^{87}$ A teoria em comento é igualmente denominada teoria da causa próxima, teoria da interrupção do nexo causal, ou, ainda, teoria do dano direto e imediato.
} 
Pretende-se, ao final, determinar qual foi o arcabouço teórico adotado pela legislação pátria vigente.

\subsubsection{Teoria da Equivalência das Condições}

De acordo com a teoria da conditio sine qua non, desenvolvida pelo penalista alemão Maximiliano von Buri $^{88}$, em 1860, todos os eventos que concorreram para a ocorrência de dano são considerados causa deste. Não se faz, portanto, uma diferenciação entre as condutas que antecederam ao dano, isto é, não se distinguem causas de condições.

Causa é, dessa maneira, toda condição da qual dependeu a realização do efeito, independentemente de sua maior ou menor proximidade ou relevância. Havendo pluralidade de causas, portanto, todas devem ser consideradas essenciais na produção do dano. É de tal característica que advém a nomenclatura "teoria da equivalência das condições", já que há uma equivalência entre os fatores causais ${ }^{89}$.

Evidencia-se, portanto, que, em princípio, a aplicação da teoria da equivalência não geraria grandes dificuldades ao julgador, bastando a esse enumerar todas as condições que precederam a ocorrência da conduta danosa para estabelecimento do nexo de causalidade. Seu inconveniente mais evidente, entretanto, é que essa enumeração levaria exageradamente longe o dever de indenizar.

A teoria em comento foi adotada pelo Código Penal (CP) brasileiro, que no art. 13 dispõe:

"Art. 13. O resultado, de que depende a existência do crime, somente é imputável a quem lhe deu causa. Considera-se causa a ação ou omissão sem a qual o resultado não teria ocorrido".

A despeito do emprego da teoria pelo Código Penal ${ }^{90}$, esta é muito ampla para aplicação no Direito Privado. De fato, conforme tal raciocínio, causa seria tudo aquilo que,

\footnotetext{
${ }^{88}$ ITURRASPE, Jorge Mosset. Responsabilidad por daños - parte general, t. I, p. 212.

${ }^{89}$ GOMES, Luiz Roldão de Freitas. Elementos de responsabilidade civil, p. 70.

${ }^{90}$ Conforme assinala Fernando Noronha, no âmbito penal a teoria pode ser convenientemente aplicada em razão da existência de dois filtros que restringem o número de eventos que podem ser considerados: "por um lado, não é qualquer evento danoso que interessa, já que o imprescindível tipo legal é integrado pelo próprio 'resultado, de que depende a existência do crime', e, por outro lado, só têm relevo os fatos danosos que, como regra geral, sejam resultantes de condutas dolosas, isto é, preordenadas à realização de determinados resultados" (Direito das obrigações: fundamentos do direito das obrigações - introdução à responsabilidade
} 
se não existisse preliminarmente, teria evitado a ocorrência do dano, o que não pode subsistir tendo em vista as dificuldades de aplicação prática.

Para ilustrar o entendimento esposado por este estudo, traz-se à lume exemplo citado por Pablo Stolze Gagliano e Rodolfo Pamplona Filho, qual seja, o do indivíduo que se serve de uma arma para matar seu inimigo ${ }^{91}$. Nesse caso, de acordo com a teoria da equivalência de condições, dever-se-ia considerar como causa do ilícito não somente o disparo, como também, sucessivamente, a aquisição da arma de fogo, sua confecção, a compra de ferro e pólvora pela indústria que a fabricou, entre outros, em uma cadeia causal que pode prosseguir ad infinitum ${ }^{92}$.

Os doutrinadores pré-citados assinalam, ainda, que a teoria vem sendo utilizada pelos próprios penalistas com a limitação das causas à necessária previsibilidade, isto é, só ingressam no nexo causal os agentes que atuaram com dolo ou culpa para a ocorrência do dano. Nesse caso, o fabricante da arma seria excluído, pois, ao confeccioná-la, não tinha por intenção, e nem mesmo poderia imaginar, que o adquirente fosse cometer um crime ${ }^{93}$.

Verifica-se, contudo, que no âmbito da responsabilidade civil a limitação da causa à atuação culposa ou dolosa do agente poderia ser aplicada somente no que tange à responsabilidade subjetiva, tendo em vista que nessa esfera se admite, e, em verdade, exige-se, a apuração da culpa. No tocante, porém, à responsabilidade objetiva, não é possível a aplicação da teoria da equivalência das condições de modo algum, razão pela qual esta se mostra inadequada ${ }^{94}$.

civil, p. 590). Acrescenta, ademais, que: "Na infração penal, os fatores causais em princípio não passam de meios que o agente preordena com vista aos efeitos queridos, isto é, à consumação do crime, como é muito bem enfatizado nos quadros da chamada teoria finalista da ação, que vê a ação humana como uma atividade instrumental, dirigida à obtenção de determinados resultados: sempre que o resultado ainda é atribuível à vontade do agente, os elementos subjetivo-interiores do comportamento dele são incindíveis dos elementos objetivo-exteriores. Somente nos crimes culposos, sempre excepcionais (Cód. Penal, art. 18, parágrafo único), a teoria da equivalência das condições poderia suscitar alguns problemas, mas mesmo quanto a eles a tipicidade legal sempre serviria de filtro da punibilidade do agente" (Direito das obrigações: fundamentos do direito das obrigações - introdução à responsabilidade civil, p. 590).

91 GAGLiAnO, Pablo Stolze; PAMPLONA FILHO, Rodolfo. Novo curso de Direito Civil responsabilidade civil, p. 87.

92 Carlos Roberto Gonçalves recorre ao mesmo exemplo para chegar a conclusões idênticas (Responsabilidade civil, p. 522).

93 GAGLIANO, Pablo Stolze; PAMPLONA FILHO, Rodolfo, op. cit., p. 88. No mesmo sentido, Gisela Sampaio da Cruz (O problema do nexo causal na responsabilidade civil. Rio de Janeiro: Renovar, 2005. nota 73, p. 41). Fernando Noronha assinala que, mesmo no âmbito penal, a teoria da equivalência das condições está ultrapassada (op. cit., p. 591).

${ }^{94}$ CRUZ, Gisela Sampaio da, op. cit., p. 48-49: "A grande oposição que se faz à Teoria da Equivalência dos Antecedentes Causais, todavia, diz respeito ao seu excessivo apego à causalidade natural. Com efeito, ao lado da causalidade natural (física e psíquica), há de se levar em conta os limites objetivos traçados pelo sistema jurídico, sob pena de se chegar a resultados contraditórios. Do contrário, o nexo causal estaria afastado na 
Prossegue-se, assim, com a análise de outras teorias nas quais se procede à distinção entre condição e causa.

\subsubsection{Teoria da Causalidade Adequada}

A segunda teoria a ser abordada é a teoria da causalidade adequada, criada por Ludwig von Bar, e posteriormente desenvolvida por Johannes von Kries ${ }^{95}$. Nesta, considera-se causa somente o antecedente apto in abstracto a gerar o dano. Trata-se, portanto, de entender como causa somente a conduta que é perfeitamente adequada ou idônea para a ocorrência do evento danoso. Se determinada condição depender de outra circunstância, chamada de acidental, não será considerada causa ${ }^{96}$.

Nessa vertente, observa-se a adequação da causa em relação à possibilidade e à probabilidade de certo resultado acontecer, levando-se em consideração o que empiricamente sucede com mais frequência. A análise tem, assim, caráter abstrato, relacionando-se à vivência comum. É necessário que se faça um prognóstico póstumo a fim de determinar, entre todas as causas, qual era a mais adequada para produzir o resultado final. Esse prognóstico é póstumo porque o magistrado se coloca no momento da realização da conduta, antes da concretização do resultado, com a finalidade de determinar a probabilidade de que esse aconteça ${ }^{97}$.

De acordo com Luiz Roldão de Freitas Gomes:

"Trata-se de remontar no tempo para se interrogar,
retrospectivamente, se seria objetivamente possível pensar que

responsabilidade civil por omissão, pois não impedir um fato danoso que se tem o dever jurídico de evitar, sob o prisma naturalístico, jamais equivaleria a produzi-lo". Acrescenta, ainda, in verbis, que: "A doutrina tentou adaptar os postulados dessa teoria aos ditames da justiça, limitando seu sentido e alcance, por meio de certas distinções conceituais, classificando as concausas em juridicamente relevantes e irrelevantes, ou as condições em positivas, negativas e indiferentes. Assim, seriam excluídas da cadeia causal, não sendo levadas em conta na apreciação dos antecedentes, as causas juridicamente irrelevantes e as condições negativas e indiferentes. Na prática, contudo, o problema persistiu, pois em determinadas situações é muito difícil verificar quais das concausas são juridicamente irrelevantes" (ibidem, loc. cit.).

${ }^{95}$ ALVIM, Agostinho. Da inexecução das obrigações e suas conseqüências, p. 329.

${ }^{96}$ GONÇALVES, Carlos Roberto. Responsabilidade civil, p. 522.

${ }^{97}$ Fernando Noronha discorre sobre a teoria da causalidade adequada da seguinte maneira, ipsis litteris: "Para tal teoria, um fato é causa de um dano quando este seja consequiência normalmente previsível daquele. E para sabermos se ele deve ser considerado conseqüência normalmente previsível, devemos nos colocar no momento anterior àquele em que o fato aconteceu e tentar prognosticar, de acordo com as regras da experiência comum, se era possível antever que o dano viesse a ocorrer. Quando a resposta for afirmativa, teremos um dano indenizável. Os danos não indenizáveis serão aqueles que só se produziram devido a circunstâncias extraordinárias, a situações improváveis que não seriam consideradas por um julgador prudente, ponderando as regras de experiência, comum e técnica (cf. art. 335 do Cód. Proc. Civil)" (Direito das obrigações: fundamentos do direito das obrigações - introdução à responsabilidade civil, p. 476). 
determinado fato provocaria normalmente o efeito nocivo. Se a resposta a este cálculo de probabilidades é afirmativa, se o fato aparece como a causa essencial, há causalidade adequada" ${ }^{98}$.

Agostinho Alvim apresenta interessante exemplo para esclarecer a diferença existente entre a aplicação da teoria da equivalência das condições e a da causalidade adequada. Suponha-se que "A" deu uma pancada leve no crânio de "B", a qual seria incapaz de gerar dano em um indivíduo de constituição normal. No entanto, "B" tinha uma fraqueza particular dos ossos do crânio, o que fez que a pancada lhe provocasse uma fratura da qual resultou a morte. De acordo com a teoria da equivalência das condições, “A” seria responsabilizado pela morte de "B", pois todas as condições são igualmente consideradas; no entanto, segundo a teoria da causalidade adequada, não haveria responsabilidade porque a conduta de "A" não é causa adequada a produzir aquele dano em um homem normal ${ }^{99}$.

A causalidade adequada admite duas formulações: a positiva e a negativa. $\mathrm{Na}$ primeira, o fato deve ser considerado causa adequada somente quando favoreceu a produção de evento posterior; já na corrente negativa, a causalidade só é excluída quando as consequências são indiferentes, estranhas ou extraordinárias ao fato. A causa adequada, de acordo com essa segunda concepção, é toda aquela que não for indiferente ao surgimento do dano. Nota-se, portanto, que a formulação negativa é bem mais ampla que a positiva. Segundo Fernando Noronha, a corrente negativa é preferível à positiva não apenas em razão de dilatar o âmbito da causalidade, mas também porque ressalta a razão da subsistência do nexo causal mesmo quando outras circunstâncias tenham contribuído para o evento danoso ${ }^{100}$.

A teoria é objeto de críticas porque o conceito de causa adequada não é preciso, admitindo diversas interpretações - o que terminaria por conferir excessivo arbítrio ao julgador na avaliação do caso concreto ${ }^{101}$.

\footnotetext{
${ }^{98}$ GOMES, Luiz Roldão de Freitas. Elementos de responsabilidade civil, p. 73.

${ }^{99}$ ALVIM, Agostinho. Da inexecução das obrigações e suas conseqüências, p. 330.

100 NORONHA, Fernando. O nexo de causalidade na responsabilidade civil. Revista dos Tribunais, São Paulo, v. 92, n. 816, out. 2003, p. 734.

101 GAGLIANO, Pablo Stolze; PAMPLONA FILHO, Rodolfo. Novo curso de Direito Civil responsabilidade civil, p. 90: "Se a teoria anterior peca por excesso, admitindo uma ilimitada investigação da cadeia causal, esta outra, a despeito de mais restrita, apresenta o inconveniente de admitir um acentuado grau de discricionariedade do julgador, a quem incumbe avaliar, no plano abstrato, e segundo o curso normal das
} 
Ocorre que, na verdade, quase todas as teorias que distinguem as concausas dependem, para sua aplicação, do maior ou menor arbítrio do magistrado. Convém salientar que o próprio Código Civil de 2002, em diversos dispositivos, concedeu poderes discricionários aos julgadores. Tendo tal fato em vista, a crítica mencionada no parágrafo anterior resta enfraquecida, já que se trata de característica da própria legislação conceder poderes ao juiz, nada impedindo que este tivesse também a faculdade de determinar qual é a causa adequada para a produção do dano.

Entende-se, pois, que o maior problema da teoria em comento é a falta de desenvolvimento da matéria no que tange à interrupção do nexo causal ${ }^{102}$, defeito do qual não padece a teoria da causalidade direta e imediata, analisada a seguir.

\subsubsection{Teoria da Causalidade Direta ou Imediata}

A teoria da causalidade direta ou imediata foi estudada com mais profundidade, no Brasil, por Agostinho Alvim ${ }^{103}$, que sustenta ter sido esta a teoria adotada pelo Código Civil de 1916 , em seu art. $1.060^{104}$, norma essa que veio a ser praticamente repetida no art. 403 do Código Civil hodierno. O autor debruçou-se no estudo da matéria particularmente com a finalidade de determinar o alcance da expressão "direto e imediato" utilizada pelo dispositivo legal.

A aplicação da teoria da causalidade direta e imediata consiste na identificação da causa somente como o evento necessário para a consecução do dano, o qual seria, em conclusão, uma consequência direta e imediata do referido evento ${ }^{105}$. A expressão "direto e

coisas, se o fato ocorrido no caso concreto pode ser considerado, realmente, causa do resultado danoso". No mesmo sentido, Gisela Sampaio da Cruz (O problema do nexo causal na responsabilidade civil, p. 83). Jorge Mosset Iturraspe relata que, também na Argentina, vários doutrinadores criticam o excessivo arbítrio concedido ao juiz pela teoria da causalidade adequada, a despeito do fato de que a corrente majoritária se inclina pela adoção desta pelo art. 906 do CC argentino (Responsabilidad por daños - parte general, t. I, p. 220). O artigo em comento possui a seguinte redação: “Art. 906. En ningún caso son imputables las consecuencias remotas, que no tienen con el hecho ilícito nexo adecuado de causalidad” (Tradução livre: "Em nenhuma hipótese são imputáveis as consequências remotas, que não têm com o ato ilícito nexo adequado de causalidade").

${ }^{102} \mathrm{Se}$, por exemplo, há mais de uma causa adequada e essas causas são sucessivas, a teoria não formulou resposta no que tange à determinação de quem deve reparar o dano.

${ }_{103}$ ALVIM, Agostinho. Da inexecução das obrigações e suas conseqüências, p. 330-355.

${ }^{104} \mathrm{O}$ artigo em referência possui a seguinte redação: “[...] Ainda que a inexecução resulte de dolo do devedor, as perdas e danos só incluem os prejuízos efetivos e os lucros cessantes por efeito dela direto e imediato".

105 A teoria da causalidade direta ou imediata comportou diversas subteorias que não são estudadas no presente Capítulo, em decorrência de seu já mencionado caráter meramente introdutório. No entanto, cumpre salientar que a necessariedade da causa é somente uma das diversas escolas da teoria que surgiram na Itália, tendo sido, igualmente, a defendida por Robert Joseph Pothier - conhecido tão somente como Pothier - na 
imediato" constitui-se, portanto, em um defeito de linguagem do Código ${ }^{106}$, que não representa o espírito da lei, motivo pelo qual os termos devem ser interpretados como o nexo causal necessário ${ }^{107}$.

Segundo essa teoria deve-se analisar a necessariedade da circunstância, ou seja, deve haver a certeza de que, sem ela, o dano não teria sido produzido, de modo que se excluem prejuízos ulteriores, oriundos de novas causas, sempre que estas não sejam efeito imediato e direto da conduta do ofensor.

Somente são consideradas, assim, as causas que se ligam ao dano de maneira mais necessária do que com relação a outras condições ${ }^{108}$. Saliente-se, contudo, que nem sempre a causa direta e imediata é mais próxima. A necessariedade não se relaciona com a distância temporal ${ }^{109}$.

Também faz parte dessa teoria a concepção de que, ocorrendo a interrupção do nexo causal original por causa superveniente independente da cadeia de acontecimentos, não haverá responsabilização do primeiro agente, mas tão somente a daquele que gerou a interrupção do nexo por meio de outra conduta. Considera-se fato independente a culpa exclusiva da vítima ou de terceiro, ou, ainda, o caso fortuito e a força maior ${ }^{110}$.

Para esclarecer o que poderia configurar a interrupção do nexo causal, utiliza-se um simples exemplo: José e João têm uma discussão que resulta em lesões corporais graves para o primeiro deles. José é, então, colocado em uma ambulância para que seja encaminhado a um hospital. Ocorre que, em consequência de um acidente de trânsito provocado por Alfredo, a ambulância sofre uma capotagem, o que resulta no falecimento de José. Em tal situação, houve rompimento do nexo causal entre o dano final e o primeiro

interpretação do art. 1.151 do CC francês (Oeuvres completes de Pothier: traité des obligations. Paris: Langlois. 1844. v. 2, p. 262), bem como considerada a mais pertinente por Agostinho Alvim (Da inexecução das obrigações e suas conseqüências, p. 338), de modo que acabou por influenciar outros doutrinadores pátrios.

${ }^{106}$ NORONHA, Fernando. O nexo de causalidade na responsabilidade civil. Revista dos Tribunais, v. 92, n. 816, p. 735: "Vejamos mais um exemplo simples, demonstrativo da necessidade de dar ao art. 403 um sentido diverso do literal. Se um profissional tem um veículo que é absolutamente necessário para o seu trabalho e se ele é danificado num acidente, o aluguel de outro veículo, que ele tiver de fazer para continuar trabalhando, não é efeito direto e imediato do acidente, mas ninguém duvidará da necessidade de ser incluído entre os danos (no caso, emergentes) suscetíveis de ressarcimento".

${ }^{107}$ ALVIM, Agostinho, op. cit., p. 341/351: "Códigos posteriores reportam-se à necessariedade, que não é uma evolução da idéia de dano direto e imediato, mas a mesma idéia, diversamente exprimida, apenas com maior precisão, tanto assim, que todos se apóiam em Robert Joseph Pothier, cuja regra e exemplos repetem". Em seguida, assinala que: "Finalmente, essa é a interpretação que se deve dar ao art. 1.060 do nosso Código, fiel tradução do art. 1.151 do Cód. Napoleão".

${ }^{108}$ CRUZ, Gisela Sampaio da. O problema do nexo causal na responsabilidade civil, p. 102.

${ }^{109}$ ALVIM, Agostinho, op. cit., p. 346.

${ }^{110}$ Ibidem, p. 352-353. 
acontecimento, qual seja, a lesão corporal grave. O único responsabilizado pelo ressarcimento do dano será, portanto, Alfredo, e não mais João.

Essa teoria, da mesma forma que as demais, também não escapou incólume das críticas da doutrina. Segundo Fernando Noronha ${ }^{111}$, a equiparação da expressão "efeito direto e imediato" a "efeito necessário" é questionável, mesmo levando-se em consideração que ela já estava presente nos ensinamentos de Robert Joseph Pothier ${ }^{112}$; ademais, entende que a exigência da necessariedade da causa reduz excessivamente a obrigação de indenizar. A esse respeito, o doutrinador tece os seguintes comentários:

"Nos termos em que A. ALviM formulou a teoria da causalidade necessária, seria possível dizer que a causa do dano é a condição necessária e suficiente dele: é condição necessária, porque sem ele não teria havido dano ("ele a ela se filia", nas palavras de ALVIM); é condição suficiente, porque sozinha era idônea para produzir o resultado ("por não existir outra que explique o mesmo dano", com "exclusividade", no dizer do Mestre). Todavia, exigir que um fato seja condição não só necessária como também suficiente de um dano, para que juridicamente possa ser considerado sua causa, parece excessivo. É que dificilmente encontraremos uma condição à qual o dano possa com exclusividade ser atribuído". ${ }^{113}$

De fato, as críticas formuladas por Fernando Noronha não são desarrazoadas. Entende-se, contudo, que não é necessária a escolha de uma única causa, uma vez que a teoria em comento, a despeito da interpretação realizada pelo autor, não exclui a existência de causas concorrentes. Eventual rigor da teoria, ainda, pode ser amenizado pelo magistrado na análise do caso concreto. O que importa é que os estudos desenvolvidos por Agostinho Alvim ${ }^{114}$ trouxeram critérios mais seguros para o estabelecimento do nexo de causalidade, bem como de quando este se interrompe.

Por fim, é oportuno ressaltar que a interrupção do nexo de causalidade que aqui se menciona não tem qualquer relação com a ressarcibilidade do dano reflexo ou em

\footnotetext{
${ }^{111}$ NORONHA, Fernando. Direito das obrigações: fundamentos do direito das obrigações - introdução à responsabilidade civil, p. 597/598.

${ }^{112}$ POTHIER, Robert Joseph. Oeuvres completes de Pothier: traité des obligations, v. 2, p. 262-263.

${ }^{113}$ Ibidem, p. 597/598.

${ }^{114}$ ALVIM, Agostinho. Da inexecução das obrigações e suas conseqüências.
} 
ricochete, que será abordado com mais profundidade no próximo capítulo. Apenas para que fique clara a diferença entre as duas hipóteses, devem ser feitas algumas observações sobre essa espécie de dano.

No dano reflexo, está-se diante de um único evento danoso que gera dois tipos de vítima: uma direta e imediata e outra em ricochete. É o que ocorre, v.g., na hipótese de homicídio de vítima que provia alimentos a terceiros. A vítima direta, sem dúvida, é o assassinado, mas os terceiros também são considerados vítimas, pois deixarão de receber os alimentos que eram pagos pelo falecido. Em situações semelhantes, admite-se a concessão de indenização aos terceiros.

Já no caso da interrupção do nexo de causalidade abordada pela teoria da causalidade direta e imediata, há dois eventos danosos consecutivos, em que a independência do segundo faz gerar o rompimento do nexo de causalidade entre a primeira ocorrência e o dano final. Evidencia-se, portanto, que a aplicação da teoria da causalidade direta e imediata não impede o ressarcimento de danos reflexos.

\subsubsection{A teoria adotada pelo Código Civil brasileiro}

O nexo de causalidade é abordado no art. 403 do CC de $2002^{115}$, a teor do reproduzido a seguir:

"Art. 403. Ainda que a inexecução resulte de dolo do devedor, as perdas e danos só incluem os prejuízos efetivos e os lucros cessantes por efeito dela direto e imediato, sem prejuízo do disposto na lei processual".

Em face de a legislação não ser autoexplicativa, coube à doutrina analisar qual seria o embasamento teórico adotado pelo Código Civil brasileiro.

Saliente-se que, como ocorre frequentemente com os assuntos que oferecem certa complexidade, não há consenso entre os autores pátrios acerca da teoria adotada pelo Diploma legal em comento. Os doutrinadores dividem-se, basicamente, em duas correntes:

\footnotetext{
${ }^{115}$ Conforme salientado, o Código Civil de 1916 continha a mesma disposição em seu art. 1.060, salvo no que tange à expressão "sem prejuízo do disposto na lei processual", que foi acrescida no Código de 2002.
} 
a que entende ter sido adotada a teoria da causalidade adequada e a que advoga pela teoria do dano direto e imediato (ou causalidade direta e imediata).

No rol daqueles que defendem a tese da causalidade adequada, observam-se, em caráter exemplificativo, Luiz Roldão de Freitas Gomes ${ }^{116}$, Silvio de Salvo Venosa ${ }^{117}$, Flávio Tartuce ${ }^{118}$ e Fernando Noronha ${ }^{119}$. Destaque-se, dentre esses, o jurista Fernando Noronha, que, justificando com mais argumentos seu posicionamento, sustenta que a aludida teoria comporta a interpretação mais pertinente do art. 403 do CC, sendo flexível o suficiente para explicar por que danos indiretos também são ressarcíveis a despeito da redação desse dispositivo. Seu entendimento encontraria sustentáculo também no art. 335 do Código de Processo Civil (CPC), o qual, embora disponha apenas sobre a apreciação de prova pelo magistrado, que deverá aplicar "as regras de experiência comum subministradas pela observação do que ordinariamente acontece", consagra o brocardo id quod plerumque accidit $^{120}$.

É oportuno salientar, entretanto, que a teoria da causalidade direta e imediata também admite a indenização de danos indiretos ou em ricochete, como esclarecido há

116 GOMES, Luiz Roldão de Freitas. Elementos de responsabilidade civil, p. 75-76: “A orientação predominante, pelo menos em certos países, é o da causa adequada, em que aquela será apenas a condição adequada à produção do dano. Deve como tal ser considerada, em princípio, toda e qualquer condição do prejuízo. Mas uma condição deixará de ser a causa adequada, tornando-se pois juridicamente indiferente, desde que seja irrelevante para a produção do dano segundo as regras da experiência, dada sua natureza e atenta as circunstâncias conhecidas do agente, ou suscetíveis de serem conhecidas por uma pessoa normal no momento da prática da ação". Arremata seu entendimento da seguinte maneira: "Parece compatibilizar-se, na verdade, mais esta orientação com o Direito brasileiro, a partir das regras inscritas nos arts. 159, 1.069 e seu parágrafo único, 1.060 e 956 do Código Civil, como pondera o Prof. Antunes Varela: é a que melhor se coaduna com o pensamento ético-jurídico latente nas disposições reguladoras da responsabilidade fundada na culpa do ofensor". Os artigos mencionados pelo autor referem-se ao Código Civil de 1916. Surpreendentemente, o art. 1.069 da referida legislação não possui parágrafo único. Ademais, os dispositivos citados pelo autor, com exceção do art. 1.060, não parecem ter qualquer relação com o tema do nexo da causalidade.

${ }^{117}$ VENOSA, Silvio de Salvo. Responsabilidade civil, p. 39-40.

118 TARTUCE, Flávio. Direito Civil - direito das obrigações e responsabilidade civil. 5. ed. São Paulo: Método, 2010. v. 2, p. 368: "Em nosso parecer o Código Civil de 2002 adotou, em melhor sentido, a teoria da causalidade adequada, eis que a indenização deve ser adequada aos fatos que a cercam. Essa conclusão pode ser retirada dos arts. 944 e 945 do CC, já comentados. Nesse sentido, o Enunciado 47 da I Jornada de Direito Civil prevê que o último dispositivo não exclui a teoria da causalidade adequada. É imperioso dizer que a adoção desta teoria não afasta a investigação dos fatores que excluem ou obstam o nexo de causalidade".

${ }^{119}$ NORONHA, Fernando. Direito das obrigações: fundamentos do direito das obrigações - introdução à responsabilidade civil.

${ }^{120}$ Ibidem, p. 609-610. A expressão id quod plerumque accidit pode ser traduzida como "aquilo que ocorre com mais frequência" ou o "caso mais provável” (MORWOOD, James (Ed.). Oxford Latin Minidictionary. Oxford: Oxford University Press, 1995; QUEIROZ, O. A. Pereira de. Dicionário Latim-Português. 5. ed. São Paulo: Lep, 1958). 
pouco. A interpretação do doutrinador ao art. 335 do referido Diploma legal ${ }^{121}$ denota ser exagerada e pouco condizente com seu propósito original, que é o de ser aplicada, na esfera probatória processual, somente em caso de ausência de normas jurídicas particulares.

$\mathrm{Na}$ corrente oposta, posicionando-se a favor da adoção da tese da causalidade direta e imediata, além, obviamente, de Agostinho Alvim ${ }^{122}$, verificam-se, também a título exemplificativo, Carlos Roberto Gonçalves ${ }^{123}$, Gisela Sampaio da Cruz ${ }^{124}$, Arnaldo Rizzardo $^{125}$, Maria Helena Diniz ${ }^{126}$, bem como Pablo Stolze Gagliano e Rodolfo Pamplona Filho ${ }^{127}$. Estes últimos sustentam seu posicionamento nos próprios termos empregados pelo mencionado art. 403, isto é, "efeito dela direto e imediato"128. Ressaltam, ademais, que é esta a teoria empregada pela jurisprudência, ainda que, muitas vezes, esteja sendo invocada a da causalidade $\operatorname{direta}^{129}$.

A despeito da argúcia na defesa do ponto de vista eleito, a verdade é que os doutrinadores pré-citados estão equivocados no tocante a essa matéria, uma vez que os termos ínsitos no dispositivo legal são interpretados, pela própria teoria que advogam, com significado diverso daquele considerado o óbvio. De fato, conforme salientado, a expressão "efeito direto e imediato" é entendida como "efeito necessário".

${ }^{121}$ O dispositivo legal do Código de Processo Civil tem a seguinte redação: "Em falta de normas jurídicas particulares, o juiz aplicará as regras de experiência comum subministradas pela observação do que ordinariamente acontece e ainda as regras de experiência técnica, ressalvado, quanto a esta, o exame pericial".

${ }^{122}$ ALVIM, Agostinho. Da inexecução das obrigações e suas conseqüências, p. 354. O autor, em seu trabalho, fazia referência ao Código Civil de 1916. No entanto, tendo em vista que não houve alteração substancial entre os dispositivos da legislação de 1916 e a atual, pode-se valer dos mesmos ensinamentos.

123 GONÇALVES, Carlos Roberto. Responsabilidade civil, p. 523-526: “Ao legislador, portanto, quando adotou a teoria do dano direto e imediato, repugnou-lhe sujeitar o autor do dano a todas as nefastas conseqüências do seu ato, quando já não ligadas a ele diretamente".

${ }^{124}$ CRUZ, Gisela Sampaio da. O problema do nexo causal na responsabilidade civil, p. 107-110: "A Teoria do Dano Direto e Imediato mostra-se, como se vê, mais apta a enfrentar o problema da causalidade múltipla do que a maioria das teorias expostas anteriormente que quase sempre conduzem o julgador a soluções injustas. É a teoria adotada no Brasil segundo grande parte da doutrina, não obstante a jurisprudência ainda vacile, invocando sem precisão científica outras teorias [...]. A Teoria do Dano Direto e Imediato não tem, como reconhece o próprio Agostinho Alvim, o condão de resolver todas as dificuldades práticas que o tema suscita, mas é a que de modo mais simples traduz a expressão "dano direto e imediato", disposta no art. 403 do Código Civil. Além disso, o cerne desta teoria está relacionado à idéia de interrupção do nexo causal que é tão útil para se aferir, no caso concreto, quem deve responder pelo dano que já vem sendo adotada pelos defensores mais modernos da Teoria da Causalidade Adequada".

${ }^{125}$ RIZZARDO, Arnaldo. Responsabilidade civil. Rio de Janeiro: Forense, 2005. p. 76.

${ }^{126}$ DINIZ, Maria Helena. Curso de Direito Civil brasileiro: responsabilidade civil, p. 107.

127 GAGLIANO, Pablo Stolze; PAMPLONA FILHO, Rodolfo. Novo curso de Direito Civil responsabilidade civil, p. 93.

${ }^{128}$ Ibidem, loc. cit.

${ }^{129}$ Ibidem, p. 94. Gisela Sampaio da Cruz faz a mesma observação acerca do engano conceitual observado na jurisprudência (O problema do nexo causal na responsabilidade civil, p. 83/84). 
No tocante aos equívocos observados na jurisprudência, deve-se considerar que, de fato, com relação à matéria, esta vem se mostrando bastante vacilante. Notase a invocação tanto da teoria da causalidade adequada ${ }^{130}$ como da teoria do dano direto e

${ }^{130}$ A título de demonstração, verifiquem-se: STJ. 2. T. REsp 669258/RJ. Rel. Min. Humberto Martins. j. 27.02.2007. v.u. DJe 25.03.2009. “ADMINISTRATIVO, CIVIL E PROCESSO CIVIL RESPONSABILIDADE CIVIL DO ESTADO - ATO COMISSIVO - ACIDENTE AUTOMOBILÍSTICO CAUSADO POR DETENTO QUE, NA HORA DO EVENTO, DEVERIA ESTAR RECLUSO EM PRISÃO-ALBERGUE - AGENTES ESTATAIS QUE POSSIBILITAVAM, REITERADAMENTE, QUE O CONDENADO DORMISSE FORA DA PRISÃO - INAPLICABILIDADE DA SÚMULA 07/STJ VALORAÇÃO JURÍDICA DOS FATOS - ART. 160 DO CC/16 - ART. 403 DO CC/02 - FUNDAMENTO INFRACONSTITUCIONAL - TEORIA DOS DANOS DEPENDENTES DE SITUAÇÃO PRODUZIDA PELO ESTADO DIRETAMENTE PROPICIATÓRIA - DOUTRINA - DISSÍDIO JURISPRUDENCIAL NÃO CONFIGURADO. 1. A moldura fática estabelecida na instância ordinária dá conta de que o acidente dano - ocorreu diretamente por culpa do condutor do veículo, que deveria estar, naquele momento, recluso, porque cumpria prisão-albergue, em progressão de pena privativa de liberdade; e só não estava recolhido ao sistema prisional em razão de agentes estatais possibilitarem, quotidianamente, que o causador do dano dormisse fora. 2. Saber se o ato do agente policial que permitiu, propositadamente, a saída do causador do dano da custódia estatal, por si só, é apto a estabelecer ou não a correlação lógica entre o alegado ato e o sobredito dano é questão que diz respeito à qualificação jurídica dos fatos já assentados na instância ordinária, não revolvimento da matéria fática. Não incidência do enunciado n. 07 da Súmula do STJ. 3. A questão federal está em saber se, para configuração do nexo causal no âmbito do fato do serviço, basta a atuação estatal correlacionada, ainda que mediata, ao dano, somada à ausência das excludentes do nexo culpa exclusiva da vítima, caso fortuito ou força maior. 4. Análise da doutrina de Celso Antonio Bandeira de Mello (in Curso de Direito Administrativo; Malheiros, 21ํㅡㄹ ed.; 0. 971-4) dos danos dependentes de situação produzida pelo Estado diretamente propiciatória, o que faz surgir a responsabilidade objetiva do Estado por ato comissivo. 5. Ainda que se possa afirmar que existe, nesses casos, a possibilidade de configuração de um nexo causal indireto, é importante ter em mente que, mesmo diante da situação fática criada pelo Estado, ou seja, impor-se ao condenado que durmisse (sic) fora do local a ele destinado pelo sistema penitenciário, o acidente automobilístico realmente está fora do risco criado, não guardando a lesão sofrida pela vítima, em local distante do 'prédio onde sedia a fonte do risco', nexo lógico com o fato do serviço. 6. Inexiste, in caso, nexo causal, porque a causa não é idônea para o dano produzido. Correta, portanto, a tese do acórdão recorrido, que pode ser assim resumida: "Análise essencial do nexo de causalidade. A lei brasileira (antiga e atual) adotou a teoria da causalidade adequada. Assim, somente o fato idôneo ou adequado para produzir o dano é de ser levado em consideração para o estabelecimento de responsabilidade. Inteligência do art. 1.060, hoje do art. 403 do Código Civil". 7. Alínea "c". Dissídio jurisprudencial não configurado. Existe similitude fática apenas com um acórdão paradigma, mas que traz fundamentação eminentemente constitucional (Constituição Federal de 1967) para a resolução da controvérsia. Recurso especial parcialmente conhecido e, na parte conhecida, improvido”. No mesmo sentido, STJ. 4- T. REsp 326.971-AL. Rel. Min. Ruy Rosado de Aguiar. j. 11.06.02. v.u. No âmbito dos Tribunais Estaduais, observem-se: TJSP. 26-a Câm. de Direito Privado. Apelação com revisão n. 990.10.195605-5. Rel. Carlos Alberto Garbi. j. 08.06.10. v.u, o qual possui a seguinte ementa: “Acidente de veículo. Ação de reparação de danos causados por acidente de trânsito julgada procedente. Automóvel que saiu do estacionamento de supermercado para realizar conversão à esquerda, onde havia um caminhão irregularmente estacionado, e atingiu motociclista que trafegava na rua. Culpa da motorista do automóvel. Aplicação da teoria da causalidade adequada. Tinha a motorista do automóvel melhores condições de evitar o dano. Cabia à apelante, em respeito ao dever de cuidado, reduzir a velocidade e efetuar a conversão com cautela, de modo a não interceptar a trajetória do motociclista. Determina o Código de Trânsito Brasileiro que o condutor que for ingressar numa via, procedente de um lote lindeiro a essa via, deverá dar preferência aos veículos e pedestres que por ela estejam transitando (art. 36). Sentença mantida. Recurso não provido"; e TJSP. 35ª Câm. de Direito Privado. Apelação no 990.09.3655594. Rel. Artur Marques. j. 05.04.10. v.u., o qual possui a seguinte ementa: "CIVIL - ACIDENTE DE TRÂNSITO - RESPONSABILIDADE DO EMPREGADOR EM RELAÇÃO AOS DANOS CAUSADOS PELO EMPREGADO - CULPA DO CONDUTOR CARACTERIZADA - CULPA CONCORRENTE DO PEDESTRE AFASTADA - TEORIA DA CAUSALIDADE ADEQUADA - INDENIZAÇÃO BEM ARBITRADA - CORREÇÃO MONETÁRIA DA INDENIZAÇÃO POR DANO MORAL - DATA DO ARBITRAMENTO - SÚMULA № 362, STJ - DECAIMENTO PREPONDERANTE DA ACIONADA SÚMULA № 326, STJ - RECURSOS IMPROVIDOS. A causa adequada para a ocorrência do acidente não 
imediato $^{131}$, aparentemente, com igual frequência, além de não serem raros os casos em

foi a conduta da pedestre, mas a ação imprudente do condutor profissional que, impaciente, não aguardou o prosseguimento natural do fluxo de trânsito, preferindo ingressar marcha-ré para se adiantar aos demais veículos. Cumpre ressalvar que o açodamento se revelou desnecessário porque, como apurado, o ponto final distava poucos metros do local”. No mesmo sentido, TJSP. 37ํㅡㄹ Câm. de Direito Privado. Apelação n⿳o 7370541-0. Rel. Tasso Duarte de Mello. j. 7.10.09. v.u.; TJRJ. 2a Câm. Civ. Ap. Civ. 1528/97. Rel. Sérgio Cavalieri Filho. j. 29.04.97. v.u. DORJ 28.06.1997; TJRJ. 17ª Câm. Civ. Ap. Civ. 2009.001.32119. Rel. Maria Inês da Penha Gaspar. j. 15.07.09. v.u. DJRJ 23.07.09; TJRJ. 10ª Câm. Civ. Ap. Civ. 2002.001.22269. Rel. Bernardo Moreira Garcez Neto. j. 12.11.02. v.u. DORJ 27.02.03; TJMG. 15ª Câm. Civ. Ap. Civ. 1.0040.05.019366-5/001. Rel. Bitencourt Marcondes. j. 18.10.07. v.m. DJMG 06.11.07; e TJRS. 9ª Câm. Civ. Ap. Civ. 70007090798. Rel. Luís Augusto Coelho Braga. j. 19.11.03. v.u.

${ }^{131}$ Nessa toada, é de se observar: STF. 1. T. RE 130.764-1-PR. Rel. Min. Moreira Alves. j. 12.05.1992. v.u. DJU 07.08.1992, publicado na RT 688/230, com a seguinte ementa: "Responsabilidade civil do Estado. Dano decorrente de assalto por quadrilha de que fazia parte preso foragido vários meses antes. A responsabilidade do Estado, embora objetiva por força do disposto no art. 107 da EC 1/69 (e, atualmente no $\S 6^{0}$ do art. 37 da Carta Magna), não dispensa, obviamente, o requisito, também objetivo, do nexo de causalidade entre a ação ou omissão atribuída a seus agentes e o dano causado a terceiros. Em nosso sistema jurídico, como resulta do disposto no art. 1.600 do CC, a teoria adotada quanto ao nexo de causalidade e a teoria do dano direto e imediato, também denominada teoria da interrupção do nexo causal. Não obstante aquele dispositivo da codificação civil diga respeito à impropriamente denominada responsabilidade contratual, aplica-se a ele também à responsabilidade extracontratual, inclusive a objetiva, até por ser aquela que, sem quaisquer considerações de ordem subjetiva, afasta os inconvenientes das outras duas teorias existentes: a da equivalência das condições e a da causalidade adequada. No caso, em face dos fatos tidos como certos pelo acórdão recorrido, e com base nos quais reconheceu ele o nexo de causalidade indispensável para o reconhecimento da responsabilidade objetiva constitucional, é inequívoco que o nexo de causalidade inexiste e, portanto, não pode haver a incidência da responsabilidade prevista no art. 107 da EC 1/69, a que corresponde o $\S 6^{\circ}$ do art. 37 da atual Constituição. Com efeito, o dano decorrente do assalto por uma quadrilha de que participava um dos evadidos da prisão não foi o efeito necessário da omissão da autoridade pública que o acórdão recorrido teve como causa da fuga dele, mas resultou de concausas, como a formação da quadrilha, e o assalto ocorrido cerca de 21 meses após a evasão. Recurso extraordinário conhecido e provido. [...]. Essa teoria [do dano direto e imediato], como bem demonstra Agostinho Alvim (Da Inexecução das Obrigações, 5ª ed., n. 226, p. 370, ed. Saraiva, São Paulo, 1980), só admite o nexo de causalidade quando o dano é efeito necessário de uma causa, o que abarca o dano direto e imediato sempre, e, por vezes, o dano indireto e remoto, quando, para a produção deste, não haja concausa sucessiva. Daí, dizer Agostinho Alvim: 'Os danos indiretos ou remotos não se excluem, só por isso; em regra, não são indenizáveis, porque deixam de ser efeito necessário, pelo aparecimento de concausas. Suposto não existam estas, aqueles danos são indenizáveis". Utilizando a lição de Moreira Alves, verifiquem-se: STF. 2. T. RE 369.820-6-RS. Rel. Min. Carlos Velloso. j. 04.11.2003. v.u. DJU 27.02.2004. Publicado na RT 825/172; STJ. 1. T. REsp 719738/RS. Rel. Min. Teori Albino Zavascki. J. 16.09.2008. v.u. DJe 22.09.2008; STJ. 1. T. REsp 858511/DF. Rel. Min. Luiz Fux. J. 19.08.2008. v.u. DJe 15.09.2008; STJ. 3. T. REsp 594.962/RJ. Rel. Min. Antônio de Pádua Ribeiro. j. 09.11.2004. v.u. DJU 17.12.2004. no âmbito estadual, ressalta-se: TJSP. $1^{\underline{a}}$ Câm. de Direito Privado. Apelação no 994.04.073525-7. Rel. Luiz Antonio de Godoy. j. 02.03.10. v.u., cuja ementa é assim redigida: "RESPONSABILIDADE CIVIL - Venda de imóvel inexistente pelo réu ao genitor da autora verificada - Ocorrência de morte deste, por força de queda de avião que alugou, na tentativa de localização de referido bem - Adoção tanto pelo Código Civil de 1916 quanto pelo de 2002 da teoria do dano direto e imediato - Impossibilidade de sujeitar o autor do dano a todas as nefastas conseqüências do seu ato, quando já não ligadas a ele diretamente - Necessidade de existência de uma relação de causa e efeito direta e imediata entre o fato e o dano - Ocorrência de fato (venda de imóvel inexistente) que não foi apta a produzir o dano (morte do genitor da autora) - Nexo causal inexistente - Honorários advocatícios - Ocorrência de plena observância dos comandos pertinentes da lei processual - Redução ou majoração indevidas - Recursos desprovidos"; e TJRJ. 10 $0^{\mathrm{a}}$ Câm. Civ. Ap. Civ. 000058/98. Rel. Des. João Nicolau Spyrides. j. 23.03.1999. v.u. DORJ 30.09.99. Publicado na RDPriv 03/296, com a ementa a seguir transcrita: "Pedido dos três primeiros julgado parcialmente procedente e improcedência do pedido do quarto autor. Paciente que chega morto no posto de Assistência Médica. Embora recomendada, não foi realizada autópsia. Não obstante, o médico que preenche a declaração de óbito, constando ter examinado o corpo, lança como causa mortis o enfarte agudo do miocárdio e cardiopatia hipertensiva sendo acrescentado tabagismo na certidão de óbito, irregularmente quando deveria constar na declaração 'causa indeterminada' ou 'morte súbita' tornando inevitável a autópsia. Histórico médico apontando numerosos fatores de risco do paciente - hipertensão 
que são confundidas ou tomadas como sinônimo ${ }^{132}$.

De qualquer modo, nem sempre é salutar tentar enquadrar o caso concreto em

determinada teoria jurídica. O magistrado deve utilizar o critério que entender mais

grave, hipertrofia do ventrículo esquerdo, doença coronariana, personalidade estressada, vida sedentária, além de inúmeras recomendações não atendidas para reduzir e parar com o hábito do fumo ou ainda de observar medicação recomendada para hipertensão. Inexistência de anotação relativa a enfisema que tem maior incidência entre fumantes. Teoria da interrupção do nexo causal, adotada pela sistemática de nosso Código Civil - art. 1.060. Omissão e equívocos da sentença - Prova produzida fora dos autos. Interpretação errônea e oposta a afirmação de trabalho médico invocado. Inocorrência de atividade ilícita da R. Inexistência de propaganda enganosa. Licitude da atividade e controle da publicidade pelo Estado. Inexistência de qualquer modalidade ou nível de culpa atribuível a atividade da empresa R. Inexistência manifesta de nexo causal. Pareceres dos mestres da medicina e de comunicações. Procedência do apelo da empresa. Improcedência do apelo do pai. Reforma de sentença. Improcedência do pedido". No mesmo sentido, TJSP. 35 Câm. de Direito Privado. Ap. 992.09.084159-9. Rel. Clóvis Castelo. j. 26.10.09. v.u; TJSP. 8 $8^{\mathrm{a}}$ Câm. de Direito Privado. Ap. 379.458-4/4-00. Rel. Ribeiro da Silva. j. 30.09.09. v.u.; TJSP. 32a Câm. de Direito Privado. Ap. 1136264-0/0. Rel. Kioitsi Chicuta. j. 30.07.09. v.u.;TJSP. 7ª Câm. de Direito Público. Ap. 990.10.166119-5. Rel. Guerrieri Rezende. j. 14.06.10. v.u.; e TJMS. 5ª T. Cível. Ap. Civ. 2006.021397-3/0000-00. Rel. Sideni Sonani Pimentel. j. 08.01.09. v.u. DJe-MS 04.02.09.

${ }^{132}$ A fim de demonstrar os equívocos, analisem-se: STJ. 4. T. REsp. 325.622/RJ. Rel. Min. Carlos Fernando Mathias (juiz federal conv. do TRF-1 ${ }^{a}$ Reg.). j. 28.10.2008. v.u. DJE 10.11.2008. Publicado na Revista de Direito Privado 36/320. O acórdão possui a seguinte ementa: "Civil. Recurso especial. Responsabilidade civil. Acidente de trânsito. Danos materiais e morais. Empresa de estacionamento que permite a retirada de veículo pelo filho da proprietária do mesmo, sem a apresentação do comprovante de estacionamento. Acidente de trânsito ocorrido horas mais tarde em cidade diversa. Nexo de causalidade. Inexistência. 1. À luz do comando normativo inserto no art. 1.060 do CC/1916, reproduzido no art. 403 do vigente Codex, sobre nexo causal em matéria de responsabilidade civil - contratual ou extracontratual, objetiva ou subjetiva vigora no direito brasileiro, o princípio da causalidade adequada, também denominado princípio do dano direto e imediato. 2. Segundo referido princípio ninguém pode ser responsabilizado por aquilo a que não tiver dado causa (art. 159 do CC/1916 e art. 927 do CC/2002) e somente se considera causa o evento que produziu direta e concretamente o resultado danoso (art. 1.060 do CC/1916 e 403 do CC/2002). E. A imputação de responsabilidade civil, portanto, supõe a presença de dois elementos de fato, quais: a conduta do agente e o resultado danoso; e de um elemento lógico-normativo, o nexo causal (que é lógico, porque consiste num elo referencial, numa relação pertencialidade, entre os elementos de fato; e é normativo, porque tem contornos e limites impostos pelo sistema de direito, segundo o qual a responsabilidade civil só se estabelece em relação aos efeitos diretos e imediatos causados pela conduta do agente. 4. In casu, revela-se inequívoca a ausência de nexo causal entre o ato praticado pela ora recorrida (entrega de veículo ao filho da autora e seus acompanhantes sem a apresentação do respectivo comprovante de estacionamento) e o dano ocorrido (decorrente do acidente envolvendo o referido veículo horas mais tarde), razão pela qual, não há que se falar em responsabilidade daquela pelos danos materiais e morais advindos do evento danoso. 5. Recurso especial a que se nega provimento" (sem grifo no original); e TRF da 4⿳⺈ ${ }^{\mathrm{a}}$ Região. 3. T. AgIn 1999.04.01.006506-0/RS. Rel. Juíza Vivian Josete Pantaleão Caminha. j. 30.11.2000. v.u. DJU 10.01.2001. Publicado na RT 792/435. Consta a seguinte passagem do texto do acórdão: "Dessume-se da manifestação da Suprema Corte que, em matéria de responsabilidade civil, adota-se a teoria da causalidade adequada, a qual define "causa" como "aquele fato a que o dano se liga com força de necessidade"; ou seja, o fato que, se não existisse, não correria o dano" (Apenas para conferência, a ementa do acórdão possui a seguinte redação: "A responsabilidade civil do Estado, fundada no risco da atividade administrativa, a pressupõe a concorrência do dano injusto sofrido pela vítima, a conduta omissiva ou comissiva do agente e o nexo de causalidade entre o dano e a ação. Tais elementos não se presumem, pois, para a configuração da responsabilidade objetiva, embora seja irrelevante o animus do agente, é indispensável que se demonstre a relação de causalidade entre o dano e a conduta. Assim, não há responsabilidade do Estado no caso em que profissional da área de enfermagem, aproveitandose de sua facilidade em obter remédios, torna-se deles dependente, em razão de sua má utilização, ou seja, fazer uso de doses excessivas e por tempo prolongado, pois, embora seja exigível do Estado a fiscalização da comercialização de produtos químicos e farmacêuticos, é faticamente impossível controlar o uso que deles fazem as pessoas"). 
conveniente para obter uma decisão equânime. Se, nesse propósito, algumas teorias são invocadas de maneira pouco precisa, é questão de pouca importância ${ }^{133}$.

Em razão do assinalado, não é fácil adotar um posicionamento em um sentido ou em outro, em especial porque a maior parte da doutrina e da jurisprudência não apresenta argumentos suficientes para a defesa da escolha realizada. Entende-se, neste estudo, que a teoria em mais consonância com a redação do art. 403 do CC é a da causalidade direta e imediata. Isso porque seu desenvolvimento doutrinário adequou-a com mais pertinência para resolução dos casos concretos. A análise de sua gênese, ainda, permite constatar que o dispositivo legal em comento se inspirou no art. 1.151 do CC napoleônico ${ }^{134}$. O artigo citado foi extensivamente estudado por Robert Joseph Pothier ${ }^{135}$, que acabou por desenvolver a teoria da causalidade direta e imediata, e influenciou diversos estudiosos ao redor do mundo ${ }^{136}$. Se essa foi a teoria que a doutrina francesa entendeu ser mais adequada à interpretação do art. 1.151 do CC, é natural que se espose entendimento de que esta também é a teoria eleita pelo legislador brasileiro. Por fim, a necessariedade ínsita à teoria do dano direto e imediato, na modalidade consagrada, traz maior precisão para estabelecimento do nexo causal do que a causa adequada, o que decerto colabora para a preferência esposada neste estudo.

\subsection{Dano}

O elemento dano é de excepcional importância para o presente trabalho, o que justifica o fato de o próximo Capítulo ser dedicado exclusivamente a esse pressuposto e suas diversas modalidades. A matéria não será, portanto, abordada neste primeiro momento.

\footnotetext{
${ }^{133}$ No mesmo sentido, Anderson Schreiber assinala que os Tribunais se preocupam menos com a técnica e mais com os resultados finais, com o objetivo de obter a solução mais justa para o caso analisado (Novos paradigmas da responsabilidade civil - da erosão dos filtros da reparação à diluição dos danos. 2. ed. São Paulo: Atlas, 2009. p. 242).

${ }^{134} \mathrm{O}$ artigo em comento é assim redigido: "Dans le cas même où l'inexécution de la convention résulte du dol du débiteur, les dommages et intérêts ne doivent comprendre à l'égard de la perte éprouvée par le créancier et du gain dont il a été privé, que ce qui est une suite immédiate et directe de l'inexécution de la convention". (Tradução livre: "Mesmo no caso em que a inexecução da convenção resulte do dolo do devedor, as perdas e danos devem compreender, com relação à perda sofrida pelo credor e o ganho do qual ele foi privado, somente o que é efeito imediato e direto da inexecução da convenção".)

${ }_{135}^{135}$ POTHIER, Robert Joseph. Oeuvres completes de Pothier: traité des obligations, v. 2, p. 262-263.

${ }^{136}$ NORONHA, Fernando. Direito das obrigações: fundamentos do direito das obrigações - introdução à responsabilidade civil, p. 593.
} 


\subsection{Excludentes de responsabilidade civil}

$\mathrm{O}$ assunto que ora se analisa constitui matéria de defesa importante em demandas indenizatórias, motivo pelo qual não poderia deixar de constar do presente capítulo, ainda que de maneira sucinta. Com efeito, é comum que sejam chamadas em juízo pessoas que apenas aparentemente geraram dano. A análise técnica posterior da questão resulta na demonstração de que a causa foi outra - que não a indicada na exordial -, ou, então, alguma circunstância impediu que o suposto responsável cumprisse com sua obrigação.

As excludentes de responsabilidade civil podem ser definidas como as circunstâncias que atingem um ou mais pressupostos da responsabilidade civil. A presença de uma ou mais delas, portanto, extingue o dever de ressarcir em decorrência da própria extinção da relação de causalidade ${ }^{137}$.

Há grande variação, entre os diversos autores, sobre quais sejam, de fato, as excludentes. Sem se alongar em tal discussão, serão abordadas as seguintes: legítima defesa; exercício regular de um direito; estado de necessidade; fato de terceiro; caso fortuito e força maior; e culpa exclusiva da vítima. Ao final, será tratada a cláusula de não indenizar ${ }^{138}$.

\subsubsection{Legítima defesa, exercício regular de um direito e estado de necessidade}

As excludentes legítima defesa, exercício regular de um direito e estado de necessidade dizem respeito a atos lesivos que não são considerados ilícitos, não implicando propriamente o rompimento do nexo de causalidade, mas sim a exclusão do dever de indenizar.

As hipóteses em comento serão discutidas pari passu, uma vez que encontram fundamento no mesmo dispositivo legal, qual seja, o art. 188 do CC, a seguir transcrito:

\footnotetext{
“Art. 188. Não constituem atos ilícitos:

I - os praticados em legítima defesa ou no exercício regular de um direito reconhecido;

II - a deterioração ou destruição da coisa alheia, ou a lesão a pessoa, a fim de remover perigo iminente.
}

\footnotetext{
${ }^{137}$ CAVALIERI FILHO, Sérgio. Programa de responsabilidade civil, p. 83: "Causas de exclusão do nexo causal são, pois, casos de impossibilidade superveniente do cumprimento da obrigação não imputáveis ao devedor ou agente".

${ }^{138}$ As matérias abordadas abrangem excludentes do dever de indenizar e também excludentes do nexo de causalidade (caso fortuito e força maior, culpa exclusiva da vítima e fato de terceiro). A cláusula de não indenizar é uma excludente convencional da responsabilidade civil (HIRONAKA, Giselda Maria Fernandes Novaes. Direito Civil: estudos. Belo Horizonte: Del Rey, 2000. p. 296).
} 
Parágrafo único. No caso do inciso II, o ato será legítimo somente quando as circunstâncias o tornarem absolutamente necessário, não excedendo os limites do indispensável para a remoção do perigo".

Atua em legítima defesa o indivíduo que se depara com situação de injusta agressão atual ou iminente, a qual é dirigida a si ou a outrem, lesão essa que não é obrigado a suportar. Em outras palavras, e nos termos do art. 25 do CP, conduz-se em legítima defesa aquele que, "usando moderadamente dos meios necessários, repele injusta agressão, atual ou iminente, a direito seu ou de outrem".

São requisitos da legítima defesa: a ocorrência de mal injusto e grave, agressão de iniciativa do ofensor, dano atual ou iminente e reação proporcional à agressão.

Não sendo comprovada a necessidade da defesa, haverá a responsabilização do agente, o mesmo ocorrendo em caso de cometimento de excessos. Da mesma forma, ainda que atuando em legítima defesa, será condenado a indenizar se o ato gerar a lesão de direito de terceiro inocente, sendo-lhe facultada a via de regresso em face do agressor que ocasionou a situação, conforme disposto no art. 930, parágrafo único, do $\mathrm{CC}^{139}$. A legítima defesa somente é aplicável, portanto, em relação à pessoa que efetivamente iria gerar dano à vítima ${ }^{140}$.

Em caso de legítima defesa putativa, isto é, quando o agente pensa se encontrar em situação de perigo, mas esta não existe no plano fático, não será eximido do dever de indenizar, já que a putatividade é somente excludente da culpabilidade penal - também chamada dirimente - , remanescendo o caráter de ilícito civil ${ }^{141}$.

O exercício regular de um direito - também designado "das próprias funções" refere-se ao exercício normal de um direito reconhecido ou à prática de um ato legal, como, por exemplo, a inclusão do nome do devedor em uma relação de inadimplentes oriunda de uma instituição privada como a Centralizadora de Serviços Bancários S/A

\footnotetext{
${ }^{139} \mathrm{O}$ dispositivo legal mencionado assim preceitua: "No caso do inciso II do art. 188, se o perigo ocorrer por culpa de terceiro, contra este terá o autor do dano ação regressiva para haver a importância que tiver ressarcido ao lesado. Parágrafo único. A mesma ação competirá contra aquele em defesa de quem se causou o dano (art. 188, inciso I)".

${ }^{140}$ AGUIAR DIAS, José de. Da responsabilidade civil, t. II, p. 662.

${ }^{141}$ GONÇALVES, Carlos Roberto. Responsabilidade civil, p. 715. Também Flávio Tartuce (Direito Civil Direito das obrigações e responsabilidade civil, v. 2, p. 557).
} 
$\left(\right.$ Serasa) ${ }^{142}$ ou perante o Serviço de Proteção ao Crédito (SPC). De fato, nessa hipótese, uma vez que a pessoa inadimplente tenha sido notificada acerca de seu débito, é lícita a inclusão de seu nome no rol de devedores. Também não é indevida a publicação da lista dos condôminos inadimplentes de determinado edifício, desde que seja feita no momento da prestação de contas que deve ser enviada a todos os moradores.

Ressalte-se que valem as mesmas observações retromencionadas a fim de que a vítima responda pelos excessos cometidos no exercício regular de seu direito, que, nesse caso, recebem o nome de abuso de direito ${ }^{143}$.

A teoria do abuso de direito se desenvolveu na França, depois do caso de Clement Bayard. Trata-se de demanda com origem no desentendimento entre dois vizinhos, um deles construtor de dirigíveis e o outro interessado em fazer que aquele adquirisse seu terreno. O segundo vizinho ergueu grandes pilastras de madeira com pontas de ferro para dificultar a aterrissagem dos dirigíveis ${ }^{144}$. Vê-se, no caso em comento, que o proprietário agia dentro de seu direito, mas o exercia de maneira abusiva, prejudicando terceiro. Entendeu-se, portanto, que o abuso de direito caracterizava ato ilícito, apto a gerar consequências decorrentes de sua prática.

Pode-se inferir, pautando-se nesse exemplo, que o agente atua com abuso de direito quando, mesmo se conduzindo de acordo com o disposto em lei, não atenta para a finalidade social de seu direito, causando prejuízo a terceiro ${ }^{145}$.

A matéria em comento foi, por fim, positivada no Direito brasileiro, no art. 187 do $\mathrm{CC}^{146}$, norma essa que, por sua redação, adotou o critério objetivo-finalístico, de maneira

\footnotetext{
${ }^{142}$ A sigla permaneceu com as letras iniciais do nome original: Serviço de Assessoria S/A, mas o gênero passou de masculino para feminino.

${ }^{143}$ Gustavo René Nicolau assinala que o abuso de direito se refere a um ato lícito no antecedente e ilícito no consequente porque o agente ultrapassa sua esfera legítima de atuação (Efetiva aplicação da teoria do risco no Código Civil de 2002. In: DELGADO, Mário Luiz; ALVES, Jones Figueiredo (Coord.). Questões controvertidas - responsabilidade civil, v. I, p. 234).

${ }^{144}$ RODRIGUES, Sílvio. Direito Civil - responsabilidade civil, v. 4, p. 45.

145 Ibidem, p. 46: "O abuso de direito ocorre quando o agente, atuando dentro das prerrogativas que o ordenamento jurídico lhe concede, deixa de considerar a finalidade social do direito subjetivo e, ao utilizá-lo desconsideradamente, causa dano a outrem". Em acréscimo, salienta que: "Aquele que exorbita no exercício de seu direito, causando prejuízo a outrem, pratica ato ilícito, ficando obrigado a reparar. Ele não viola os limites objetivos da lei, mas, embora lhes obedeça, desvia-se dos fins sociais a que esta se destina, do espírito que a norteia".

${ }^{146} \mathrm{O}$ artigo em comento assim dispõe: "Também comete ato ilícito o titular de um direito que, ao exercê-lo, excede manifestamente os limites impostos pelo seu fim econômico ou social, pela boa-fé ou pelos bons costumes".
} 
que não se exige a comprovação de culpa para a configuração do abuso de direito ${ }^{147}$.

O estado de necessidade verifica-se quando o agente provoca a lesão a direito de terceiro, com valor igual ou inferior àquele que pretende resguardar, para afastar perigo iminente, diante de circunstâncias que não dão margem a outro tipo de conduta. Aquela conduta, portanto, é o único meio de se evitar outro dano, ou, ao menos, o agente supõe que assim o seja ${ }^{148}$. Em resumo, conduz-se de modo a retirar um direito seu ou de outrem de situação de perigo iminente, ou seja, concreto.

Sobre essa excludente do dever de indenizar, Sílvio Rodrigues assinala que:

"A destruição ou deterioração de coisa alheia ordinariamente constitui ato ilícito, porque a ninguém é dado fazê-lo. Todavia a lei, excepcionalmente, entende ser lícito o procedimento de quem deteriora ou destrói coisa alheia, se o faz para evitar mal maior, contanto que as circunstâncias tornem o ato absolutamente necessário e não exceda os limites do indispensável para a remoção do perigo" 149 .

Conforme disposto no parágrafo único do art. 188 pré-citado, o agente deve atuar nos estritos limites trazidos pela necessidade, sendo responsável pelos excessos eventualmente cometidos.

É oportuno salientar que o estado de necessidade exclui a ilicitude, mas não afasta o dever de indenizar se o proprietário da coisa destruída não for o responsável pelo perigo, consoante preceitua o art. 929 do $\mathrm{CC}^{150}$. Trata-se de uma incongruência legal, uma vez que, inexistindo ilicitude, seria de se esperar que o dono da coisa destruída não pudesse pleitear indenização daquele que agiu em estado de necessidade. Adverte-se, no entanto, acerca do fato de que o agente tem a seu favor o direito de regresso em face do verdadeiro causador da situação perigosa ${ }^{151}$.

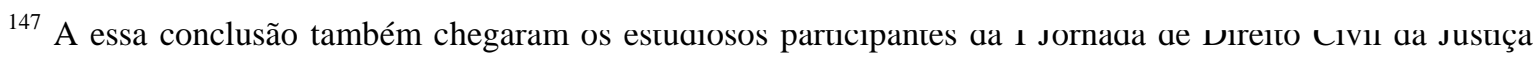
Federal, na qual foi redigido e aprovado o Enunciado n. 37, in verbis: "Art. 187: a responsabilidade civil decorrente do abuso de direito independe de culpa e fundamenta-se somente no critério objetivo-finalístico". ${ }^{148}$ SILVA, Wilson Melo da. Da responsabilidade civil automobilística. São Paulo: Saraiva, 1974. p. 81-82.

${ }^{149}$ RODRIGUES, Sílvio. Direito civil - responsabilidade civil, v. 4, p. 26.

${ }^{150} \mathrm{O}$ artigo em comento determina que: "Se a pessoa lesada, ou o dono da coisa, no caso do inc. II do art. 188, não forem culpados do perigo, assistir-lhes-à direito à indenização do prejuízo que sofreram".

${ }^{151}$ Segundo Carlos Roberto Gonçalves, não se trata propriamente de uma espécie de excludente porque se o agente gerar dano deverá indenizar (Responsabilidade civil, p. 707). De fato, há que se concordar com o
} 
No que tange ao direito de regresso, recorre-se ao exemplo a seguir, bastante ilustrativo da situação abrangida pelo dispositivo legal em comento. Um motorista, dirigindo com cautela seu veículo, para não atropelar um pedestre desatencioso que atravessou a rua sem observar os dois lados, projeta seu automóvel sobre um carro estacionado em conformidade com as leis de trânsito. Ainda que o ato do motorista tenha sido louvável, ele gerou dano a um veículo estacionado regularmente, motivo pelo qual deverá indenizar seu proprietário, que não atuou de maneira culposa. Se, na mesma situação hipotética, o proprietário do carro danificado o tivesse estacionado em local proibido, conduzindo-se culposamente, não teria direito de obter indenização perante o autor do dano $^{152}$.

As hipóteses ora mencionadas - de exclusão do dever de indenizar - abrangem também os casos de estrito cumprimento do dever legal ou de exercício regular das próprias funções, em que o indivíduo tem uma incumbência legal ou administrativa de atuar. É o caso do bombeiro, v.g., que tem o dever de apagar o incêndio. Segundo Flávio Tartuce, nessa situação, caso haja necessidade de danificar algum bem privado, não se configurará o dever de indenizar, de modo que não se aplica o disposto no art. 929, por se tratar de hipótese enquadrada no art. 188, inc. I, e não no II $^{153}$. Carlos Roberto Gonçalves, no entanto, sustenta que a vítima poderá obter ressarcimento perante o Estado, mas o ente público não terá direito de regresso em face do funcionário uma vez que o agente não atuou com culpa ${ }^{154}$. O posicionamento de Flávio Tartuce denota ser mais acertado e condizente com o ordenamento jurídico.

\subsubsection{Fato de terceiro}

O fato de terceiro ocorre quando a conduta, passiva ou omissiva, de outrem interfere na relação de causalidade estabelecida entre o agente e a vítima. A posição de terceiro é ocupada por qualquer pessoa que não seja a vítima ou o causador do dano, que

autor. Não obstante tal fato, a abordagem da matéria ainda é pertinente ao estudo das excludentes de responsabilidade civil e o integra tradicionalmente. Na mesma esteira, Sílvio Neves Baptista: "O ato de salvar o direito próprio ou alheio é considerado causa de exclusão de ilicitude - trata-se portanto de excludente de responsabilidade civil, como os autores em geral classificam, pois não livra o agente de indenizar os danos materiais causados à vítima" (Teoria geral do dano de acordo com o novo Código Civil brasileiro, p. 130).

${ }^{152}$ SILVA, Wilson Melo da. Da responsabilidade civil automobilística, p. 87.

153 TARTUCE, Flávio. Direito Civil - Direito das obrigações e responsabilidade civil, v. 2, p. 564.

${ }^{154}$ GONÇALVES, Carlos Roberto. Responsabilidade civil, p. 714. 
não tenha relação aparente com estes. A atuação do terceiro, portanto, deve constituir uma causa totalmente estranha ao devedor ${ }^{155}$.

O demandado se torna mero agente intermediário do dano, motivo pelo qual não se aplica a regra de que quem deve indenizar é o autor direto da ofensa, situação em que poderia ingressar com ação de regresso em face do real causador do dano.

Com efeito, se o fato de terceiro for causa exclusiva do prejuízo, desaparece o liame jurídico $^{156}$. Não é sempre, porém, que leva ao rompimento do nexo causal. Veja-se, nesse sentido, a dicção do art. 735 , do CC:

"A responsabilidade contratual do transportador por acidente com o passageiro não é elidida por culpa de terceiro, contra o qual tem ação regressiva" 157 .

A jurisprudência majoritária, contudo, não aplica o mencionado dispositivo legal em todas as situações, sustentando que, havendo arremesso de objeto por terceiro para o interior de um veículo de transporte coletivo, há de se configurar excludente de responsabilidade. A empresa de transporte rodoviário (ou ferroviário) não tem, assim, dever de indenizar passageiro que venha a sofrer lesões em virtude do incidente ${ }^{158}$.

O roubo de talonário de cheques durante o transporte por empresa contratada por instituição financeira não é, por sua vez, considerado fato de terceiro apto a excluir o dever de indenizar ${ }^{159}$. Isso demonstra que o eventual rompimento do nexo causal é analisado caso a caso.

Em face das questões ora assinaladas, conclui-se que o fato de terceiro, para eximir o responsável da indenização, deve ter característica de inevitabilidade, de maneira que

\footnotetext{
155 AGUIAR DIAS, José de. Da responsabilidade civil, t. II, p. 663.

${ }^{156}$ GONÇALVES, Carlos Roberto. Responsabilidade civil, p. 722.

${ }^{157}$ Esta já era a orientação adotada pela jurisprudência, consolidada na Súmula n. 187 do STF, com redação semelhante à do art. 735 do CC. Deve-se observar, contudo, que a obrigação do transportador é de resultado, ou seja, somente se considera adimplida quando há a consecução do objetivo final. A cláusula de incolumidade dos passageiros, ademais, é ínsita ao contrato de transporte de pessoas. A empresa de transporte, portanto, não poderia se eximir em razão de fato de terceiro.

${ }^{158}$ Nesse sentido, verifique-se: STJ. 3 ${ }^{\underline{a}}$ Turma. REsp 231137/RS. Rel. Min. Castro Filho. j. 29.10.03. v.u. DJ 17.11.03 p. 317 . RSTJ vol. 178 p. 249 . RT v. 823 p. 158.

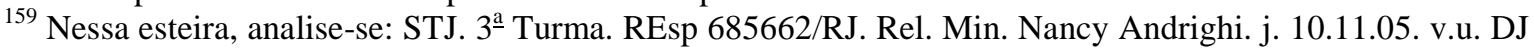
05.12 .05 , p. 323 .
} 
possa ser assemelhado ao caso fortuito ${ }^{160}$. Essa particularidade induz a que se confundam as situações de caso fortuito e força maior com as de fato de terceiro, o que se observa em particular na jurisprudência. Com efeito, o disparo de arma de fogo, ou mesmo o assalto, ocorrido dentro de ônibus (ou trem), v.g., ora é aclamado como fato de terceiro, ora como caso fortuito ou força maior. O resultado prático, contudo, é sempre o mesmo: em qualquer uma das opções, a empresa de transporte rodoviário (ou ferroviário) é eximida de responsabilidade ${ }^{161}$.

De qualquer modo, para fins doutrinários, é possível vislumbrar uma sutil diferença entre fato de terceiro e caso fortuito ou força maior: no fato de terceiro, a exoneração de responsabilidade terá lugar se for identificada a pessoa cuja participação deu origem ao dano; no caso fortuito ou força maior, por sua vez, o dano provirá de um fato necessário, cujos efeitos não poderiam ser evitados ou impedidos, como se verá a seguir.

\subsubsection{Caso fortuito e força maior}

A diferença entre caso fortuito e força maior somente remanesce importante no campo doutrinário, tendo em vista que o Código Civil, como já fazia a legislação pretérita, igualou os dois tipos ${ }^{162}$ em seu art. 393, que exime o devedor de responder "pelos prejuízos resultantes de caso fortuito ou força maior, se expressamente não se houver por eles responsabilizado". Em complementação, o parágrafo único da norma citada trata novamente os dois termos como sinônimos, dispondo que "O caso fortuito ou de força maior verifica-se no fato necessário, cujos efeitos não era possível evitar ou impedir”. Equiparação similar se observa no Código Civil francês, cujo art. 1.148 possui a seguinte redação:

"Il n'y a lieu à aucun dommages et intérêts lorsque, par suite d'une force majeure ou d'un cas fortuit, le débiteur a été empêché de

\footnotetext{
${ }^{160}$ RODRIGUES, Sílvio. Direito Civil - responsabilidade civil, v. 4, p. 173: "Portanto, concluindo quanto a esta parte, poder-se-ia dizer que o fato de terceiro, para excluir integralmente a responsabilidade do agente causador direto do dano, há que se vestir de características semelhantes às do caso fortuito, sendo imprevisível e irresistível. Nessa hipótese, não havendo relação de causalidade, não há responsabilidade pela reparação". No mesmo sentido, José de Aguiar Dias (Da responsabilidade civil, t. II, p. 671). Observe-se, porém, que a imprevisibilidade não é essencial para a configuração do caso fortuito e para a força maior. Sobre o assunto, veja-se o item subsequente do presente estudo.

161 Sobre o assunto, analisem-se: STJ. 4 ${ }^{\mathrm{a}}$ Turma. REsp 262682/MG. Rel. Min. Barros Monteiro. j. 03.08.04. v.u. DJ 20.06.05 p. 289; STJ. $4^{\mathrm{a}}$ Turma. REsp 142186/SP. Rel. Min. Hélio Quaglia Barbosa. j. 27.02.07. v.u. DJ 19.03.07 p. 353. RSTJ vol. 207 p. 331; e STJ. 4ª Turma. AgRg no REsp 960578/SP. Rel. Min. Hélio Quaglia Barbosa.j. 18.09.07. v.u. DJ 08.10.07 p. 315.

${ }^{162}$ SILVA, Wilson Melo da. Da responsabilidade civil automobilística, p. 60.
} 
donner ou de faire ce à quoi il était obligé, ou a fait ce qui lui était interdit"163.

A mesma equiparação também pode ser notada na jurisprudência ${ }^{164}$. Vários são, portanto, os elementos que levam ao descrédito da diferenciação entre caso fortuito e força maior.

De qualquer maneira, alguns comentários sobre as possíveis diferenças existentes entre os dois tipos serão tecidos adiante. Por ora, tratar-se-á das características similares existentes entre as duas hipóteses.

Podemos observar, preliminarmente, a existência de dois elementos fundamentais: o subjetivo, que consiste na ausência de culpa - isto é, o devedor não concorreu para o incidente -, e o objetivo, representado pela inevitabilidade do evento ${ }^{165}$.

Não se deve confundir a inevitabilidade, enquanto característica do evento que não pode ser afastado, com a imprevisibilidade, caracterizadora do evento que não pode ser previsto, em particular porque este último elemento não é essencial ${ }^{166}$. É o caso de um terremoto, causa clássica de força maior, que em alguns casos pode ser previsto, não podendo, contudo, ser evitado. A inevitabilidade, portanto, deve estar relacionada com a necessariedade do incidente.

\footnotetext{
${ }^{163}$ Tradução livre: "Não há lugar para quaisquer perdas e danos quando, em decorrência de uma força maior ou de um caso fortuito, o devedor foi impedido de dar ou de fazer aquilo a que estava obrigado ou fez algo de que deveria se abster".

${ }_{164}$ Nesse sentido, apenas a título de exemplo, verifiquem-se os seguintes acórdãos provenientes do STJ: 4. T. REsp 663356/SP. Rel. Min. Luis Felipe Salomão. j. 19.08.10. v.u.; 4. T. AgRg no Ag 1152301/MG. Rel. Min. Raul Araújo. j. 15.06.10. v.u.; 3. T. REsp 819568/SP. Rel Min. Nancy Andrighi. j. 20.05.10. v.u.; e 2. T. REsp. 710078/SP. Rel. Min. Mauro Campbell Marques. j. 23.03.10. v.u.

${ }^{165}$ AGUIAR DIAS, José de. Da responsabilidade civil, t. II, p. 674. Agostinho Alvim, na mesma linha de pensamento, assinala que a aparente semelhança dos termos caso fortuito e força maior deriva justamente de seu caráter comum, qual seja, a inevitabilidade do evento, além do fato de serem tradicionalmente utilizados em conjunto, como no art. 1.148 do CC francês e no art. 1.226 do CC italiano de 1865 (Da inexecução das obrigações e suas consequiências, p. 314-315).

${ }^{166}$ Pablo Stolze Gagliano e Rodolfo Pamplona Filho entendem que a inevitabilidade caracteriza a força maior, enquanto a imprevisibilidade marca o caso fortuito (Novo curso de Direito Civil - responsabilidade civil, p. 111). Pelo exposto, evidencia-se a discordância de pensamento deste estudo no que tange a tal observação. De fato, sustenta-se aqui que ambas as hipóteses devem ter por elemento essencial a inevitabilidade, caso contrário, não haveria rompimento do nexo causal. Ressalte-se que também partilham do entendimento dos doutrinadores pré-citados os seguintes autores: Sérgio Cavalieri Filho (Programa de responsabilidade civil, p. 85) e Flávio Tartuce (Direito Civil - Direito das obrigações e responsabilidade civil, v. 2, p. 373).
} 
O evento que autoriza a aplicação da excludente, em ambos os casos, deve ser superveniente ao momento em que se firmou o contrato ou se estabeleceu a relação entre $\operatorname{as~partes}^{167}$.

Por óbvio, faz-se necessário, igualmente, que o fato caracterizador do caso fortuito ou força maior seja a razão fundamental do inadimplemento, de modo a tornar impossível o cumprimento da obrigação. Por esse motivo, crises financeiras dificilmente são aceitas na qualidade de tais excludentes, já que, a despeito delas, ainda é possível cumprir a obrigação.

Como se pode inferir da redação do art. 393, referido anteriormente, a excludente de caso fortuito e força maior pode ser afastada mediante convenção entre as partes, ou seja, pode ser estabelecido que, mesmo em caso de ocorrência de tais eventos, haverá o cumprimento da obrigação. Uma cláusula de assunção convencional, tal qual mencionada, somente será válida na esfera da responsabilidade contratual e em contratos paritários, ou seja, nos quais as partes estejam em condição de equivalência ${ }^{168}$. Ademais, o objeto do pacto deve ser determinado, de maneira que sejam estabelecidas pelos contratantes as hipóteses em que se assume a responsabilidade por caso fortuito e força maior ${ }^{169}$.

No que tange à diferença entre os dois termos ${ }^{170}$, a teoria tradicional, que se coaduna com o propugnado neste estudo, assinala que caso fortuito é o impedimento proveniente de atos humanos, ou seja, acontecimentos ligados ao próprio homem. É ilustrativo desse tipo de evento o defeito em uma máquina que impede a produção de um bem de consumo ou a ocorrência de uma greve. Força maior, por sua vez, seria o acontecimento externo à figura humana, isto é, decorrente da atuação de elementos naturais extraordinários, como os terremotos.

Nessa linha de pensamento, tem-se Agostinho Alvim, que vê no caso fortuito "um

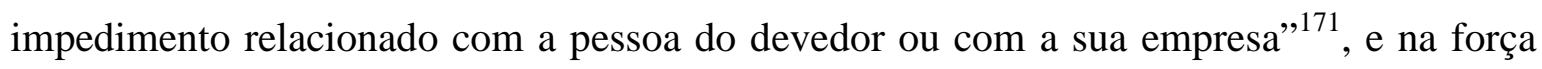
maior "um fato externo que não se liga à pessoa ou à empresa por nenhum laço de conexidade" ${ }^{, 172}$ Ocorre que o doutrinador utiliza os dois conceitos para dar tratamento

\footnotetext{
${ }^{167}$ GONÇALVES, Carlos Roberto. Responsabilidade civil, p. 737.

${ }^{168}$ TARTUCE, Flávio. Direito Civil - Direito das obrigações e responsabilidade civil, v. 2, p. 567.

${ }^{169}$ ITURRASPE, Jorge Mosset. Responsabilidad por daños - parte general, t. I, p. 245-246.

${ }^{170}$ Neste momento, sustenta-se existir uma diferença, ainda que de interesse meramente doutrinário, entre caso fortuito e força maior. É, no entanto, imperioso considerar que José de Aguiar Dias esposa entendimento contrário à diferenciação, tratando os termos como sinônimos (Da responsabilidade civil, t. II, p. 673).

${ }^{171}$ ALVIM, Agostinho. Da inexecução das obrigações e suas conseqüências, p. 315.

${ }^{172}$ Ibidem, p. 316.
} 
diverso ao devedor, de acordo com o fundamento de sua responsabilidade. Se for a culpa, o devedor seria eximido do dever de indenizar tanto por ocorrência de caso fortuito como de força maior. Se a fundamentação for o risco, somente a força maior elidiria a responsabilidade do ofensor. No que tange à responsabilidade objetiva, o autor entende que somente há exoneração em caso de culpa exclusiva da vítima, ordens de autoridades - o chamado fait $d u$ Prince -, fenômenos naturais e outras hipóteses de força externa invencível $^{173}$.

A despeito do entendimento esposado pelo doutrinador, a divisão de caso fortuito e força maior para fins de exclusão da responsabilidade em apenas uma das hipóteses não se sustenta em virtude da própria situação de equivalência trazida pela lei ${ }^{174}$.

Outra corrente, capitaneada por Álvaro Villaça Azevedo, advoga que caso fortuito é o acontecimento provindo da natureza, sem que haja intervenção da vontade humana, o que se verifica, v.g., com a inundação de um rio. A força maior, por sua vez, seria o fato de terceiro ou do credor, isto é, consistiria na atuação humana, não provinda do devedor, que impossibilita o cumprimento obrigacional ${ }^{175}$.

É notório, pois, que tais definições são praticamente opostas às trazidas por Agostinho Alvim, ou seja, o que um dos autores considera caso fortuito é força maior para o outro, e vice-versa.

Corrente mais moderna utiliza a expressão caso fortuito para se reportar a obstáculo de origem acidental e imprevista, enquanto o termo força maior é empregado em caso de obstáculo insuperável da natureza, que, no entanto, não precisaria ser imprevisível. A imprevisibilidade seria, assim, característica típica do caso fortuito, ao passo que a inevitabilidade o seria da força maior ${ }^{176}$. Ainda que essa vertente conte com diversos adeptos, não é a adotada neste trabalho, tendo em vista o entendimento esposado, de que a

\footnotetext{
173 ALVIM, Agostinho. Da inexecução das obrigações e suas conseqüências, p. 315-316.

174 José Fernando Simão reforça que tanto o caso fortuito como a força maior possuem as mesmas consequências (Vícios do produto no novo Código Civil e no Código de Defesa do Consumidor, p. 181).

${ }_{175}$ AZEVEDO, Álvaro Villaça. Teoria geral das obrigações - responsabilidade civil, p. 273-274.

${ }^{176}$ Flávio Tartuce identifica o caso fortuito com o "evento totalmente imprevisível decorrente de ato humano ou de evento natural", ao passo que a força maior seria o "evento previsível, mas inevitável ou irresistível, decorrente de uma ou outra causa" (Direito Civil - Direito das obrigações e responsabilidade civil, v. 2, p. 373). Na mesma toada, verifique-se Sérgio Cavalieri Filho: "estaremos diante do caso fortuito quando se tratar de evento imprevisível e, por isso, inevitável, se o evento for inevitável, ainda que previsível, por se tratar de fato superior às forças do agente, como normalmente são os fatos da Natureza, como as tempestades, enchentes, etc., estaremos em face da força maior, como o próprio nome o diz. É o Act of God, no dizer dos ingleses, em relação ao qual o agente nada pode fazer para evitá-lo, ainda que previsível”. Por fim, o autor conclui: "a imprevisibilidade, portanto, é o elemento indispensável para a caracterização do caso fortuito, enquanto a inevitabilidade o é da força maior" (Programa de responsabilidade civil, p. 85).
} 
imprevisibilidade não é essencial para a caracterização da força maior ou do caso fortuito. É oportuno ressaltar, nesse sentido, que o parágrafo único do art. 393 do CC não determina que o caso fortuito ou a força maior sejam imprevisíveis, mas tão somente inevitáveis ${ }^{177}$.

Note-se, ademais, que, além da divisão entre caso fortuito e força maior, Sérgio Cavalieri Filho propõe outra classificação, a ser aplicada na seara das relações de consumo: a de fortuito externo e fortuito interno. $\mathrm{O}$ fortuito interno seria aquele inerente à atividade do agente, como, por exemplo, a imprecisão de funcionamento em uma máquina que gera um produto defeituoso. Nessa situação, não há rompimento do nexo causal. Já o fortuito externo diz respeito a evento completamente estranho à atividade do agente, como, por exemplo, uma guerra ou os fenômenos da natureza ${ }^{178}$.

Todo acidente ocorrido no interior de uma empresa, desde que sob o controle de atuação do empresário, não deve, portanto, exonerá-lo de responsabilidade, ainda que ele não tenha qualquer participação no fato danoso. Somente poderá eximir-se, em conclusão, se o fato ocorrer no exterior da empresa e tiver se constituído na única causa do dano. Nessa hipótese, o incidente escapa ao controle do empresário porque não poderia ser por ele controlado.

É importante ressaltar que, em qualquer hipótese, o ônus da prova do caso fortuito ou força maior é do devedor inadimplente ${ }^{179}$. Ao credor cabe somente provar a infração, motivo pelo qual cumpre ao devedor demonstrar que não atuou com culpa, ou seja, trazer aos autos fatos que juridicamente excluam sua culpabilidade.

Saliente-se, igualmente, que nem sempre uma mesma situação é considerada caso fortuito ou força maior. De fato, tal apreciação depende do caso concreto e da espécie de contrato que se esteja lidando.

O roubo de carga, v.g., é considerado pelo Superior Tribunal de Justiça (STJ) suficiente para excluir a responsabilidade da transportadora ${ }^{180}$. O roubo ocorrido em estacionamento de supermercados e outros estabelecimentos comerciais, no entanto, não exime de responsabilidade o proprietário destes, uma vez que se entende ser seu dever

\footnotetext{
177 MALUF, Carlos Alberto Dabus. Do caso fortuito e da força maior excludentes de culpabilidade no Código Civil de 2002. In: DELGADO, Mário Luiz; ALVES, Jones Figueiredo (Coord.). Questões controvertidas - responsabilidade civil, v. I, p. 42.

${ }^{178}$ CAVALIERI FILHO, Sérgio. Programa de responsabilidade civil, p. 298. No mesmo diapasão, Carlos Roberto Gonçalves (Responsabilidade civil, p. 739).

${ }^{179}$ MALUF, Carlos Alberto Dabus, op. cit., p. 59.

180 Nesse sentido, os acórdãos: $3^{\text {a }}$ Turma. AgRg no REsp 753404/SC. Rel. Min. Paulo Furtado (Desembargador convocado do TJ/BA). j. 01.10.09. v.u. Dje 19.10.09; e 3ª Turma. REsp 904733/MG. Rel. Min. Nancy Andrighi. j. 09.08.07. v.u. DJ 27.08.07 p. 249.
} 
zelar pela segurança do local utilizado pelos consumidores ${ }^{181}$. Adota-se o mesmo posicionamento para assaltos e furtos ocorridos em agências bancárias, uma vez que a segurança é prestação essencial à sua atividade ${ }^{182}$. Da mesma forma, problemas técnicos que geram atraso de voos de companhias de transporte aéreo, bem como extravios de bagagem, não são considerados hipóteses de caso fortuito ${ }^{183}$.

No que tange às enchentes, Flávio Tartuce sustenta que, na cidade de São Paulo, estas não constituem caso fortuito (ou força maior) porque

\begin{abstract}
“[...] não se enquadram como eventos imprevisíveis (caso fortuito).
Pelo contrário, são totalmente previsíveis. Também não constituem força maior, pois é possível evitar as enchentes por meio de obras de melhoria. Em reforço, o Poder Público deve fiscalizar a limpeza da cidade, não cabendo o argumento de inevitabilidade por tal razão. Entendemos, portanto, que a enchente não afasta o dever de indenizar da Municipalidade em São Paulo, Capital, realidade que vivenciamos, e sobre a qual há legitimidade para opinar. Para as demais localidades, cabe análise caso a caso"184.
\end{abstract}

A despeito do que afirma o doutrinador, entende-se que, mesmo em São Paulo, as enchentes devem ser analisadas no caso concreto, tendo em vista que algumas situações de danos advindos destas podem ser evitadas, outras não.

\footnotetext{
${ }^{181}$ Verifique-se: STJ. 3aㅡㄹ Turma. REsp 582047/RS. Rel. Min. Massami Uyeda, j. 17.02.09. v.u. Dje 04.08.09. Em sentido contrário, analise-se a seguinte ementa, também proveniente do STJ: "Direito civil. Assalto à mão armada no interior de hotel. Hipótese em que, durante a noite, os recepcionistas do estabelecimento foram rendidos pelos criminosos, que invadiram o quarto do autor e lhe roubaram jóias que portava consigo, para venda em feira de artesanato. Caso fortuito configurado. De acordo com as regras do Código Civil de 1916, a responsabilidade do hotel por roubo à mão armada no interior do estabelecimento somente se considera caso fique comprovado que agiu com culpa, facilitando a ação dos criminosos ou omitindo-se de impedi-la. Comprovado que os recepcionistas do hotel agiram de maneira correta, procurando barrar a entrada dos criminosos, e que a chave mestra dos quartos somente foi entregue aos assaltantes mediante ameaça de morte com arma de fogo, resta caracterizado caso fortuito. Na hipótese, o hóspede portava quantidade considerável de jóias, que expunha para venda em público em feira livre. Desempenhava, portanto, atividade de risco, que não declarou ao hotel no check in. Também não se utilizou do cofre conferido pelo estabelecimento para guarda de objetos de valor. Recurso especial não conhecido" (3를 Turma. REsp 841090/DF. Rel. Min. Nancy Andrighi. j. 24.10.06. v.u. DJ 12.02.07 p. 261. RSTJ vol. 210 p. 273).

182 Anotem-se: STJ. 4 ${ }^{\mathrm{a}}$ Turma. REsp 503208/SP. Rel. Min. Aldir Passarinho Junior. j. 26.05.08. v.u. Dje 23.06.08; e STJ. 4⿳亠丷厂 Turma. REsp 750418/RS. Rel. Min. Aldir Passarinho Junior. j. 12.09.06. v.u. DJ 16.10.06 p. 378. RNDJ vol. 85 p. 89.

${ }_{183}$ Para conferência: STJ. $4^{\text {a }}$ Turma. REsp 612817/MA. Rel. Min. Hélio Quaglia Barbosa. j. 20.09.07. v.u. DJ 08.10.07 p. 287. RT vol. 869 p. 188; e STJ. 3 ${ }^{\text {a }}$ Turma. AgRg no Ag 442484/RJ. Rel. Humberto Gomes de Barros. j. 25.09.06. v.u. DJ 09.10.06 p. 284.

${ }^{184}$ TARTUCE, Flávio. Direito Civil - Direito das obrigações e responsabilidade civil, v. 2, p. 2.
} 


\subsubsection{Culpa exclusiva da vítima ${ }^{185}$}

A culpa exclusiva da vítima constitui mais uma hipótese de rompimento do nexo de causalidade e importa no afastamento do dever de indenizar. Consiste no fato de a própria vítima gerar o dano que foi a ela impingido, o que pode ocorrer, v.g., quando inadvertidamente toma uma medicação em desconformidade com a bula e com a prescrição médica. Exige-se que a atuação da vítima seja decisiva e causa única do evento $^{186}$.

Na hipótese em comento, o agente participa de modo acidental do evento danoso, isto é, constitui-se como mero instrumento do dano, que decorre exclusivamente do comportamento da vítima.

Deve-se observar a ausência de reprovabilidade da conduta do demandado, bem como a imprevisibilidade da atuação da vítima. É o que ocorre com os surfistas ferroviários, isto é, aquelas pessoas que ficam de pé na superior externa do trem, tentando se equilibrar, como se estivessem sobre uma prancha de surfe. Nesse caso, o STJ já entendeu que não se pode exigir físcalização da companhia ferroviária, pois essa seria impraticável. É indubitável, ainda, que a pessoa, ao se arriscar em cima de uma composição ferroviária, deve assumir a consequência de seus atos ${ }^{187}$.

Observa-se que a intensidade da participação da vítima no evento atinge grau máximo quando esta busca intencionalmente o dano ou quando se conduz em uma situação de risco, ou, ao menos, não a evita, tendo consciência que há alta probabilidade de ocorrência de dano. Também pode se configurar a culpa da vítima em caso de omissão no tocante a procedimentos de segurança que visam evitar possíveis danos. Em todas essas circunstâncias, a culpa do ofendido prevalecerá em relação à conduta do suposto ofensor.

$\mathrm{Na}$ hipótese de culpa concorrente, a responsabilidade do causador do dano se atenua, com a consequente redução da indenização. É o que ocorre, v.g., com a vítima que

\footnotetext{
185 Destaque-se que Sérgio Cavalieri Filho contesta o emprego de tal nomenclatura, sustentando que a expressão correta seria "fato exclusivo da vítima", tendo em vista que não se trata de análise de culpa desta. Ademais, parte da doutrina prefere não falar em culpa para que a excludente também possa ser utilizada em casos de responsabilidade objetiva (Programa de responsabilidade civil, p. 84). O presente estudo não partilha desse entendimento, motivo pelo qual adota a expressão tradicionalmente empregada pela doutrina (culpa exclusiva da vítima), mesmo porque o próprio Código de Defesa do Consumidor (CDC), que, como é cediço, consagrou a responsabilidade objetiva, utiliza em ser art. $12, \S 3^{\circ}$, a expressão - repetida no art. 14, $\S$ $3^{\text {o }}$ - "culpa exclusiva do consumidor ou de terceiro".

${ }^{186}$ AGUIAR DIAS, José de. Da responsabilidade civil, t. II, p. 678.

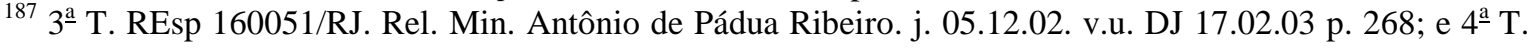
REsp 261027/RJ. Rel. Min. Barros Monteiro. j. 19.04.01. v.u. DJ 13.08.2001 p. 164.
} 
cai dentro de um bueiro que estava aberto, à noite, e próximo de uma rodovia, porque estava embriagada. Por um lado, o Estado deve responder, na modalidade objetiva, eis que deixou o bueiro aberto indevidamente; por outro, a vítima também colaborou para seu próprio infortúnio, pois o fato de estar embriagada foi uma das razões para que caísse. A indenização há de ser mitigada ${ }^{188}$.

O mesmo ocorre no caso do passageiro pingente, aquele que vai pendurado na composição ferroviária. Em hipóteses semelhantes, o STJ entende haver responsabilidade da companhia de transporte ferroviário pela preservação da integridade física do passageiro, responsabilidade essa, contudo, atenuada porque a vítima também se sujeitou a ser transportada como pingente, quando poderia esperar que a próxima composição chegasse mais vazia ${ }^{189}$.

Essa ponderação acerca da indenização do dano em caso de concorrência da culpa da vítima ficará a cargo do magistrado, a quem caberá a atenta verificação do caso concreto. Verifica-se, ordinariamente, a divisão da indenização pela metade; no entanto, poderá variar de acordo com o grau de culpabilidade das partes. Deve-se avaliar se é possível a especificação matemática da contribuição da culpa da vítima para o efeito danoso. Se for possível determinar a proporção de sua participação, caberá ao juiz estabelecê-la. Se não houver prova suficiente para avaliar tal proporção, somente restará ao magistrado a solução da divisão equânime ${ }^{190}$.

A regra exposta encontra fundamentação normativa no art. 945 do $\mathrm{CC}^{191}$, mas não é aplicada na seara de direitos do consumidor, em razão do disposto no art. $12, \S 3^{\text {o }}$, da Lei n. 8.078/1990. De fato, a referida norma somente exclui a responsabilidade do fornecedor pelo ressarcimento da integralidade do dano no caso de culpa exclusiva da vítima e não em caso de culpa concorrente. Entende-se que, neste último caso, deve haver a indenização

\footnotetext{
${ }^{188}$ O caso relatado foi objeto do acórdão AgRg no REsp 901897/RN, proveniente da $1^{\mathfrak{a}}$ Turma do STJ (Rel. Min. Luiz Fux. j. 25.11.08. v.u. Dje 17.12.08).

$1893^{\mathrm{a}}$ T. REsp 226348/SP. Rel. Min. Castro Filho. j. 19.09.06. v.u. DJ 23.10.06 p. 294; e 4⿳⺈ ${ }^{\mathrm{a}}$ T. EDcl no Ag 877541/RJ. Rel. Min. Hélio Quaglia Barbosa. j. 13.11.07. v.u., do qual se transcreve pequeno excerto: "Entende-se que é dever da empresa de transporte conduzir o passageiro até seu destino final, garantindo sua integridade física, bem como assegurar todas as medidas cabíveis para tal intento. Por outro lado, inegável o reconhecimento do risco provocado pelo próprio passageiro que viajava como pingente. Não há que se falar, sequer, em culpa exclusiva da vítima, pois, em casos como os dos autos, a jurisprudência desta Corte tem posicionamento remansoso quanto à configuração de culpa concorrente".

${ }^{190}$ RODRIGUES, Sílvio. Direito Civil - responsabilidade civil, v. 4, p. 168.

${ }^{191}$ Apenas para conferência, reproduz-se o dispositivo em tela: "Art. 945. Se a vítima tiver concorrido culposamente para o evento danoso, a sua indenização será fixada tendo-se em conta a gravidade de sua culpa em confronto com a do autor do dano".
} 
integral $^{192}$. Em igual sentido orientou-se o art. 17 do já mencionado Decreto n. $2.681 / 1912^{193}$.

\subsubsection{Cláusula de não indenizar}

José de Aguiar Dias, em obra clássica sobre a cláusula exonerativa de responsabilidade, relaciona quatro matérias de direito obrigacional e responsabilidade como "fórmulas de equilíbrio entre as exigências da reparação e as da conservação da atividade responsabilizada": a cláusula penal, a cláusula de limitação da responsabilidade, a cláusula de irresponsabilidade, e o seguro de responsabilidade civil. De fato, a multiplicação dos sinistros deixa o julgador em uma posição delicada: ou deixam-se muitas vítimas sem reparação, ou empobrecem-se muitos devedores ${ }^{194}$.

No que tange à primeira delas, a ser novamente abordada no Capítulo 3 deste trabalho, sustenta que a cláusula penal, que estabelece o montante da indenização em caso de não cumprimento da obrigação, suprime a incerteza da liquidação do dano, de maneira a evitar o risco de serem arbitradas verbas superiores às naturalmente derivadas do inadimplemento ${ }^{195}$. Assemelha-se à cláusula de limitação da responsabilidade, com a diferença de que a cláusula penal é invocada pelo credor, enquanto a limitativa de responsabilidade o é pelo devedor ${ }^{196}$. As cláusulas limitativas, de fato, são estipulações pelas quais se determina antecipadamente a soma que o devedor pagará ao credor, no caso de ser declarado responsável pelo dano ${ }^{197}$. O seguro de responsabilidade, por fim, traz para a relação estabelecida entre as partes um terceiro, a seguradora, para a qual será transferida a obrigação de pagar a indenização no lugar do verdadeiro responsável, o segurado, que poderá, assim, manter íntegro seu patrimônio.

\footnotetext{
192 GAGLiANO, Pablo Stolze; PAMPLONA FILHO, Rodolfo. Novo curso de Direito Civil responsabilidade civil, p. 95.

${ }^{193}$ A norma em comento possui a seguinte redação: "Art. 17 - As estradas de ferro responderão pelos desastres que nas suas linhas sucederem aos viajantes e de que resulte a morte, ferimento ou lesão corpórea. A culpa será sempre presumida, só se admitindo em contrário alguma das seguintes provas:

$1^{\underline{a}}$ - Caso fortuito ou força maior;

$2^{2}$ - Culpa do viajante, não concorrendo culpa da estrada".

${ }^{194}$ AGUIAR DIAS, José de. Cláusula de não-indenizar: chamada cláusula de irresponsabilidade. 3. ed. Rio de Janeiro/São Paulo: Forense, 1976. p. 20.

${ }^{195}$ Ibidem, p. 21.

${ }^{196}$ Ibidem, p. 129.

${ }^{197}$ Ibidem, p. 125.
} 
O princípio da autonomia da vontade é a principal fundamentação das cláusulas de exclusão e limitativas de responsabilidade contratual de maneira geral ${ }^{198}$, por isso, não é de agrado da integralidade da doutrina, que, frequentemente, sustenta a incompatibilidade da cláusula de não indenizar com o direito privado em sua concepção contemporânea ${ }^{199}$.

No presente momento, tratar-se-á apenas da modalidade que importa em exclusão do dever de indenizar, já que a matéria estudada é sobre excludentes de responsabilidade civil e não da limitação de indenizar.

A cláusula de não indenizar, também chamada de cláusula exonerativa de responsabilidade ${ }^{200}$, consiste na convenção que exclui o dever de indenizar, modificando o resultado da ocorrência de dano, e transferindo os riscos do negócio de um contratante para o outro. Estabelece-se, com isso, que determinada parte não será responsável por certos danos.

Lapidar é a definição de José de Aguiar Dias:

“A cláusula ou convenção de irresponsabilidade consiste na estipulação prévia por declaração unilateral, ou não, pela qual a parte que viria a obrigar-se civilmente perante outra afasta, de acordo com esta, a aplicação da lei comum ao seu caso. Visa anular, modificar ou restringir as consequências normais de um fato da responsabilidade do beneficiário da estipulação"201 .

Em outras palavras, pode-se dizer que a cláusula exonerativa de responsabilidade é o pacto acessório que, antecipadamente, afasta a obrigação indenizatória atribuída ao

\footnotetext{
198 Observa-se a existência de cláusulas de supressão total de responsabilidade, cláusulas limitativas da responsabilidade ou de responsabilidade atenuada, bem como cláusulas de responsabilidade atenuada temporariamente. Será abordada apenas da primeira modalidade.

${ }^{199}$ Pablo Stolze Gagliano e Rodolfo Pamplona Filho assim se manifestam a respeito do tema, in verbis:

"Em verdade, essa cláusula não nos agrada muito.

No Direito Civil ensinado e difundido na primeira metade do século XX, imbuído de ideais individualistas e egoísticos, essa convenção teria lugar mais apropriado.

Não nos dias de hoje, em que vivemos um re-pensar do Direito Privado, mais vocacionado aos superiores princípios constitucionais, e influenciado por valores de solidarismo social" (Novo curso de Direito Civil responsabilidade civil, p. 119).

${ }^{200}$ Também é possível encontrar referência às expressões "cláusula de irresponsabilidade" e "cláusula de exclusão de responsabilidade".

${ }^{201}$ AGUIAR DIAS, José de. Da responsabilidade civil, t. II, p. 653-654.
} 
devedor em decorrência do inadimplemento de suas obrigações. O que se exclui, portanto, não é o cumprimento da obrigação, mas sua sanção habitual ${ }^{202}$.

A atuação da cláusula se dá no plano da obrigação de indenizar, em fase posterior à verificação dos elementos da responsabilidade civil. Em consequência disso, não é, tecnicamente, causa excludente de responsabilidade porque esta obsta o preenchimento dos requisitos da responsabilidade civil, ao passo que a convenção em comento afasta o surgimento da obrigação reparatória.

A aplicação da cláusula, de qualquer modo, não é irrestrita, sendo aplicável somente na esfera contratual, eis que a responsabilidade extracontratual tem fulcro em princípios de ordem pública inspirados pelo escopo de proteção do bem comum contra atos ilícitos. Ademais, na responsabilidade aquiliana inexiste negócio jurídico anterior que vincule as partes, de maneira que não há que se cogitar na matéria em comento ${ }^{203}$.

Saliente-se, ainda, que a cláusula se sujeita a alguns requisitos, conforme enunciados a seguir:

- não pode afastar obrigações essenciais do contrato ${ }^{204}$;

- não deve contrariar a ordem pública ${ }^{205}$ e os bons costumes, motivo pelo qual somente pode versar sobre direitos individuais disponíveis ${ }^{206}$;

${ }^{202}$ MALUF, Carlos Alberto Dabus. Do caso fortuito e da força maior excludentes de culpabilidade no Código Civil de 2002. In: DELGADO, Mário Luiz; ALVES, Jones Figueiredo (Coord.). Questões controvertidas - responsabilidade civil, v. I, p. 60.

${ }^{203}$ Há, contudo, posicionamento em contrário: Wilson Melo da Silva (Da responsabilidade civil automobilística, p. 32); José de Aguiar Dias (Cláusula de não-indenizar: chamada cláusula de irresponsabilidade, p. 57).

${ }^{204}$ GONÇALVES, Carlos Roberto. Responsabilidade civil, p. 746-747.

${ }^{205}$ Entende-se como ordem pública o conjunto de princípios fundamentais do ordenamento jurídico cuja salvaguarda tem em vista, sobretudo, a tutela de interesses coletivos. O mesmo preceito se observa no art. 1.229 do Código Civil italiano, com a seguinte redação: "Clausole di esonero da responsabilità. É nullo qualsiasi patto che esclude o limita preventivamente la responsabilità del debitore per dolo o per colpa grave $(1490,1579,1681,1694,1713,1784,1838,1900)$.

É nullo (1421 e seguenti) altresi qualsiasi patto preventivo di esonero o di limitazione di responsabilità per i casi in cui il fato del debitore o dei suoi ausiliari (1580) costituisca violazione di obblighi derivanti da norme di ordine pubblico (prel. 31)". (Tradução livre: "Art. 1.229. Cláusulas de exoneração de responsabilidade. É nulo qualquer pacto que exclui ou limita preventivamente a responsabilidade do devedor por dolo ou por culpa grave $(1490,1579,1681,1694,1713,1784,1838,1900)$. É nulo (1421 e seguintes) qualquer outro pacto preventivo de exoneração ou limitação da responsabilidade para os casos em que o fato do devedor ou de seus auxiliares (1580) constitua violação de obrigações derivadas de normas de ordem pública (prel. 31))". ${ }^{206}$ AGUIAR DIAS, José de. Da responsabilidade civil, t. II, p. 654. 
- somente pode ser aplicada na hipótese de ausência de dolo ou culpa inescusável $(\text { grave })^{207}$;

- pressupõe a igualdade dos contratantes, o que faz que não possa ser utilizada em caso de vulnerabilidade jurídica de uma das partes;

- deve haver bilateralidade do consentimento, razão pela qual não é admissível em contratos de adesão.

Além dos requisitos elencados, à cláusula somente pode ser conferida validade se esta possibilitar a manutenção do equilíbrio contratual econômico, o que deverá ser apurado no caso concreto.

Em algumas hipóteses, a legislação afasta expressamente a validade da cláusula. É o que ocorre, v.g., no art. 25 da Lei n. 8.078/1990 (CDC) ${ }^{208}$, reforçado pelo disposto no art. 51 , inc. I, do mesmo Diploma legal ${ }^{209}$, que acaba por não conferir validade a essa cláusula nos contratos de consumo, na medida em que veda disposição que exonere ou atenue a responsabilidade civil do fornecedor. Com efeito, trata-se de contrato que não pressupõe a igualdade entre as partes, razão pela qual a cláusula não pode ser estipulada.

${ }^{207}$ RODRIGUES, Sílvio. Direito Civil - responsabilidade civil, v. 4, p. 181. Agostinho Alvim admite a validade da cláusula em caso de culpa grave ou lata porque a lei vigente repeliu a graduação da culpa. ( $D a$ inexecução das obrigações e suas conseqüências, p. 321). José de Aguiar Dias também sustenta que a culpa grave não se assimila ao dolo, aduzindo que: "a gravidade da culpa é, pois, incapaz de equipará-la ao dolo. O valor que lhe pode ser reconhecido é o de prova ou indício de má-fé. Sendo tal a gravidade da falta que representa procedimento por demais aberrante do que se poderia esperar, em face da obrigação, servirá de elemento de convicção para estabelecer que o agente procedeu de má-fé e nada mais do que isso" (Cláusula de não-indenizar: chamada cláusula de irresponsabilidade, p. 99). No presente trabalho, contudo, não se partilha de tal entendimento, adotando-se posicionamento alinhado com a parte majoritária da doutrina.

${ }^{208} \mathrm{O}$ dispositivo legal em comento tem a seguinte redação:

“Art. 25. É vedada a estipulação contratual de cláusula que impossibilite, exonere ou atenue a obrigação de indenizar prevista nesta e nas seções anteriores.

$\S 1^{\underline{o}}$ - Havendo mais de um responsável pela causação do dano, todos responderão solidariamente pela reparação prevista nesta e nas seções anteriores.

$\S 2^{\mathrm{o}}$ - Sendo o dano causado por componente ou peça incorporada ao produto ou serviço, são responsáveis solidários seu fabricante, construtor ou importador e o que realizou a incorporação".

${ }^{209} \mathrm{O}$ artigo, no inciso mencionado, determina que:

“Art. 51. São nulas de pleno direito, entre outras, as cláusulas contratuais relativas ao fornecimento de produtos e serviços que:

I - impossibilitem, exonerem ou atenuem a responsabilidade do fornecedor por vícios de qualquer natureza dos produtos e serviços ou impliquem renúncia ou disposição de direitos. Nas relações de consumo entre o fornecedor e o consumidor pessoa jurídica, a indenização poderá ser limitada, em situações justificáveis”. 
$\mathrm{Na}$ mesma esteira, dispõe o art. 734 do $\mathrm{CC}$, que a cláusula exonerativa de responsabilidade também não se aplica aos contratos de transporte de pessoas ${ }^{210}$. Nesse caso, não se trata somente de desigualdade entre as partes - visto se tratar também de contrato de consumo -, mas também da vedação contida no item "a" retromencionado. Ao contrato de transporte é ínsita a cláusula de segurança e preservação da incolumidade do passageiro. Sendo assim, se fosse afastada a indenização por danos dessa natureza, estarse-ia liberando o transportador de obrigação essencial do contrato.

Do mesmo modo, não se admite a cláusula exonerativa em contratos de estacionamento, nos quais em regra se coloca, indevidamente, placa informando a não responsabilidade por furto ou roubo de bens. Esse posicionamento é reforçado pelo disposto na Súmula 130 do STJ, cuja redação é a seguinte: "A empresa responde perante o cliente, pela reparação de dano ou furto de veículo ocorridos em seu estacionamento". Ressalte-se que, mesmo se inexistisse a Súmula, trata-se de caso evidente de contrato de consumo, sendo, portanto, aplicável o art. 25 do CDC.

Pelos mesmos motivos, a cláusula de não indenizar também não pode ser invocada em caso de furtos em hotéis e similares, assim como aposta em contratos de guarda, como os de depósito ${ }^{211}$.

\footnotetext{
${ }^{210}$ A matéria já era objeto da Súmula n. 161, do STF: "Em contrato de transporte é inoperante a cláusula de não indenizar". O Decreto n. 20.704/1931 (Convenção de Varsóvia) não admite a cláusula exoneratória de responsabilidade, mas possibilita a limitação convencional da indenização em algumas hipóteses. Também relacionado com a matéria, verifique-se o art. 12 do Decreto-lei 2.681, de 7 de dezembro de 1912, com a seguinte redação: "A cláusula de não-garantia das mercadorias bem como a prévia determinação do máximo de indenização a pagar, nos casos de perda ou avaria, não poderão ser estabelecidas pelas estradas de ferro senão de modo facultativo e correspondendo a uma diminuição da tarifa. Serão nulas quaisquer outras cláusulas diminuindo a responsabilidade das estradas de ferro estabelecida na presente lei".

${ }^{211}$ TARTUCE, Flávio. Direito Civil - Direito das obrigações e responsabilidade civil, v. 2, p. 569-570. O autor assegura que a cláusula não tem validade reconhecida em contratos de seguro, mesmo quando há negativa de pagamento de indenização com justificativa de suposta informação incorreta fornecida pelo segurado.
} 


\section{O DANO}

Este Capítulo destina-se à análise do dano em seus diversos aspectos, motivo pelo qual serão objetos de estudo: o conceito de dano, a caracterização do dano ressarcível, as formas de ressarcimento, bem como as modalidades de dano, quais sejam, patrimonial, moral, estético e perda de uma chance.

Cumpre salientar, de início, o entendimento de que o dano estético não constitui uma categoria autônoma, mas sim uma espécie de dano moral lato sensu, o que não impede sua cumulação com o dano moral stricto sensu. A perda de uma chance, por outro lado, diz respeito, em regra, a uma espécie de dano material, especificamente dano emergente $^{212}$, como será esclarecido nos tópicos que se seguem.

\subsection{O conceito de dano}

O complexo estudo do pleno significado que o termo "dano" pode obter escapa ao propósito do presente trabalho. É necessário, não obstante, que fique estabelecido um ponto de partida para o desenvolvimento do tema escolhido. Para esse fim, vislumbrar-se-á o dano como a subtração a um bem jurídico que, como tal, encontra proteção no ordenamento jurídico. Dessa perspectiva, o dano pode ser material, quando atinge bens apreciáveis em dinheiro, ou moral, se resultante de lesão a bens não apreciáveis em pecúnia, ou seja, que não podem ser valorados monetariamente ${ }^{213}$.

\footnotetext{
${ }^{212}$ Entende-se que não é salutar a criação de um "terceiro gênero de dano" sempre que o doutrinador deparar com uma situação que se apresente peculiar em relação às modalidades clássicas. Isso levaria, ao final, à perda da sistematização da matéria. Verifique-se, v.g., que João Antônio Álvaro Dias sustenta ser o dano corporal tertium genus, em razão de nele identificar elementos de dano patrimonial, e extrapatrimonial (Dano corporal - quadro epistemológico e aspectos ressarcitórios. Coimbra: Almedina, 2004. p. 205). Ora, está-se, então, diante de um panorama problemático: uns defendem que o dano estético é um terceiro gênero, outros o fazem com relação ao dano corporal, há ainda aqueles que sustentam que a perda de uma chance configura outra espécie de dano, e assim em diante. Antônio Junqueira de Azevedo sugere ainda a existência de outro tipo de dano - o dos danos sociais -, que se opõe aos danos individuais (divididos em patrimoniais e morais), ensejando verba autônoma a ser revertida à vítima, a despeito de seu caráter social (Por uma nova categoria de dano na responsabilidade civil: o dano social. In: ___ . Novos estudos e pareceres de direito privado. São Paulo: Saraiva, 2009. p. 377-384, É evidente que nem todos estão com a razão; portanto, é mais prudente manter a divisão já centenária entre danos patrimoniais e extrapatrimoniais, procedendo às subdivisões que se fizerem necessárias.

${ }^{213}$ LALOU, Henri. La responsabilité civile: principes élémentaires et applications pratiques. 2. ed. Paris: Dalloz, 1932. p. 81; FISCHER, Hans Albrecht. Der Schaden Nach den Bürgerlichen Gesetzbuche. Trad.
} 
Explica Teresa Ancona Lopez que, do ponto de vista etimológico, o termo dano advém de demere, que pode ser entendido como tirar, apoucar, diminuir. Assim, de acordo com a autora, "a ideia de dano surge das modificações do estado de bem-estar da pessoa, que vem em seguida à diminuição ou perda de qualquer dos seus bens originários ou derivados extrapatrimoniais ou patrimoniais" ${ }^{214}$.

O conceito de dano, em verdade, sofreu muitas alterações ao passar do tempo, eis que, de início, somente incluía os danos de natureza patrimonial. Tal processo se deu também no Direito brasileiro, bastando lembrar que muitos eram os estudiosos defensores de que o Código Civil de 1916 somente dava abrigo ao dano material. Nos dias atuais, conforme disserta Anderson Schreiber, está-se diante de um processo de ampliação da possibilidade de reparação, no qual se denota o desprestígio da culpa e do nexo causal em detrimento do dano, em particular aqueles de natureza existencial ${ }^{215}$. Esse tema será tratado adiante, nos itens 2.6 e seguintes. Por ora, dedicar-se-á à análise do conceito de dano, em suas características mais amplas.

Encontra consenso entre os diversos doutrinadores a assertiva de que o dano é elemento necessário à configuração da responsabilidade civil. José de Aguiar Dias registra que, para a unanimidade dos autores, não pode haver responsabilidade sem a existência de um dano ${ }^{216}$. Para este estudo, no entanto, não é suficiente entender o dano apenas como pressuposto da responsabilidade civil, mas sim como elemento necessário para a configuração dessa responsabilidade, razão pela qual serão analisados outros aspectos deste.

Carlos Alberto Bittar define o dano como "lesão ou redução patrimonial, sofrida pelo ofendido, em seu conjunto de valores protegidos no Direito, seja quanto à sua própria

port. de Ferrer Correia. A reparação dos danos no Direito Civil. São Paulo: Acadêmica, 1938. p. 81; e SALAZAR, Alcino de Paula. Reparação do dano moral. Rio de Janeiro: Borsoi, 1943. p. 125-126.

${ }^{214}$ LOPEZ, Teresa Ancona. $O$ dano estético - responsabilidade civil. 2. ed. São Paulo: Revista dos Tribunais, 1999. p. 20.

${ }^{215}$ SCHREIBER, Anderson. Novos paradigmas da responsabilidade civil - da erosão dos filtros da reparação à diluição dos danos, p. 81-83.

216 AGUIAR DIAS, José de. Da responsabilidade civil, t. II, p. 702. Nesse mesmo sentido, Carlos Roberto Gonçalves: "O dano é pressuposto inafastável da responsabilidade civil. Não há responsabilidade onde não existe prejuízo" (Comentários ao Código Civil - parte especial do Direito das obrigações (arts. 927 a 965). São Paulo: Saraiva, 2003. v. 11, p. 319). Também Sílvio Rodrigues: "O ato ilícito só repercute na órbita do direito se causar prejuízo a alguém" (Direito Civil - responsabilidade civil, v. 4, p. 18). Ainda tratando desse tema, Maria Celina Bodin de Moraes lembra que, apesar de muitas teorias pretenderem conceituar o dano como o pressuposto inafastável para a configuração da responsabilidade civil, uma vez que não havendo dano, não há o que indenizar, o dano moral não é propriamente indenizável, mas sim compensável (Danos à pessoa humana - uma leitura civil-constitucional dos danos morais. Rio de Janeiro/São Paulo: Renovar, 2003. p. 144-145). 
pessoa - moral ou fisicamente - seja quanto a seus bens ou a seus direitos". Acrescenta que o dano se identifica com a perda, ainda que parcial, "de elementos, ou de expressão, componente de sua estrutura de bens psíquicos, físicos, morais ou materiais”"217. A definição apresentada pelo autor é bastante interessante na medida em que relaciona o dano com a invasão injusta da esfera jurídica do lesado, atingindo-se elementos tanto de seu complexo pecuniário como de seu complexo moral e pessoal.

Para Luiz Roldão Freitas Gomes, dano é toda lesão nos interesses de outrem, tutelados pela ordem jurídica, quer tais interesses sejam de ordem patrimonial, quer sejam de caráter não patrimonial ${ }^{218}$. Anderson Schreiber ressalta como vantagem dessa definição o fato de que ela possibilita o destaque do interesse lesado e não as consequências econômicas e morais. O dano moral, segundo o autor, é uma cláusula geral que permite ao magistrado determinar se o interesse lesado em questão merece proteção ${ }^{219}$. Essa visão do dano é a adotada para o prosseguimento do presente trabalho e a que se propugna que deveria ser considerada definição padrão de dano, de acordo com a concepção da responsabilidade civil atual.

A despeito das respeitáveis opiniões em sentido contrário, diverge-se dos doutrinadores que consideram o patrimônio apenas como o conjunto do acervo material ${ }^{220}$.

${ }^{217}$ BITTAR, Carlos Alberto. Responsabilidade civil - teoria e prática. Rio de Janeiro: Forense, 1989. p. 8.

${ }^{218}$ GOMES, Luiz Roldão de Freitas. Elementos de responsabilidade civil, p. 76. Maria Helena Diniz, na mesma toada, também menciona o fato de o dano ser pressuposto indispensável da responsabilidade civil, contratual ou extracontratual, podendo ser dividido, não de acordo com a índole dos direitos subjetivos afetados, mas sim conforme os efeitos da lesão jurídica provocada (Curso de Direito Civil brasileiro: responsabilidade civil p. 58). Por fim, a autora o conceitua como "a lesão (diminuição ou destruição) que, devido a um certo evento, sofre uma pessoa, contra a sua vontade, em qualquer bem ou interesse jurídico, patrimonial ou moral" (ibidem, p. 61). Severo também segue na mesma linha, conceituando-o como a lesão de interesses juridicamente protegidos, devendo o dano atingir um interesse legítimo e pessoal (SEVERO, Sérgio. Os danos extrapatrimoniais. São Paulo: Saraiva, 1996. p. 224). Wilson Melo da Silva, após citar várias definições de dano dadas por diversos doutrinadores, conceitua o dano como diminuição ou subtração de um bem jurídico, sendo este amplamente considerado como o conjunto de haveres, patrimônio, honra e outros aspectos morais ( $O$ dano moral e sua reparação. 3. ed. Rio de Janeiro: Forense, 1999. p. 324). Acrescenta que se definir o dano apenas como diminuição do patrimônio, considerando este como o conjunto dos direitos de valor econômico, seria, na linguagem de G. Formica (Dizionario pratico del diritto privato, de Scialoja, v. II. Milano. p. 542, palavra "Danno". In: SILVA, Wilson Melo da, op. cit., p. 324) e de conformidade com a tradução que faz Agostinho Alvim dessa parte, "não só exprimir um conceito de dano que não corresponde ao popular e comum, mas ainda resolver a priori, com uma definição, o gravíssimo problema da ressarcibilidade do dano não-patrimonial ou moral" (Da inexecução das obrigações e suas conseqüências, p. 171). Destaca-se, ainda, Sílvio Neves Baptista como um dos que partilham desse entendimento. $\mathrm{O}$ autor adverte que o dano constitui "um fato violador do dever jurídico (dano ilícito), ou do interesse juridicamente tutelado, ainda que a violação do interesse de alguém seja autorizada pelo próprio ordenamento, como ocorre no dano lícito" (Teoria geral do dano de acordo com o novo Código Civil brasileiro, p. 45).

${ }^{219}$ SCHREIBER, Anderson. Novos paradigmas da responsabilidade civil - da erosão dos filtros da reparação à diluição dos danos, p. 138.

${ }^{220}$ Agostinho Alvim, por exemplo, faz divisão entre dano em sentido amplo e em sentido estrito. O primeiro se identificaria com a lesão de qualquer bem jurídico, aí se incluindo o dano moral; já o segundo seria a lesão 
Este estudo advoga que o patrimônio do indivíduo abrange todos os aspectos de sua existência, em particular o âmbito moral. Tal opinião se fundamenta, principalmente, na proteção da dignidade da pessoa humana, garantida pela Constituição Federal brasileira e na tendência atual da responsabilidade civil em priorizar os danos extrapatrimoniais em detrimento dos patrimoniais. Em razão do exposto, reforçar-se-á, no presente trabalho, o conceito de dano enquanto prejuízo patrimonial e moral, em seu sentido amplo.

Com o intuito de oferecer um estudo mais completo da matéria, passar-se-á, a seguir, à análise dos pressupostos do dano indenizável ou ressarcível.

\subsection{O dano ressarcível}

Apresentado seu conceito, faz-se necessário esclarecer que nem todo dano é ressarcível, ou passível de reparação ${ }^{221}$. Para que haja indenização do dano, exigem-se alguns requisitos.

Em primeiro lugar, é necessária a diminuição ou a destruição de um bem jurídico, patrimonial ou moral, pertencente a uma pessoa, pois a noção de dano pressupõe a existência da vítima ${ }^{222}$.

do patrimônio, este considerado como o conjunto das relações jurídicas de uma pessoa, apreciáveis em dinheiro. Esse doutrinador apresenta, assim, um conceito puramente material do patrimônio, ainda que considere a possibilidade de o dano ser moral, se visto em seu sentido amplo (Da inexecução das obrigações e suas conseqüencias, p. 172).

${ }^{221}$ Já que se mencionou a palavra ressarcível, convém diferenciar os termos ressarcimento, reparação e indenização, os quais são utilizados, em rigor, como sinônimos, mas que, ao menos teoricamente, dizem respeito a hipóteses jurídicas diferentes. Carlos Roberto Gonçalves sustenta que: "Ressarcimento é o pagamento de todo prejuízo material sofrido, abrangendo o dano emergente e os lucros cessantes, o principal e os acréscimos que lhe adviriam com o tempo e com o emprego da coisa. Reparação é a compensação pelo dano moral, a fim de minorar a dor sofrida pela vítima. E a indenização é reservada para a compensação do dano decorrente de ato ilícito do Estado, lesivo do particular, como ocorre nas desapropriações. A Constituição Federal, contudo, usou-a como gênero, do qual o ressarcimento e a reparação são espécies, ao assegurar, no art. 5ำ V e X, indenização por dano material e moral" (Comentários ao Código Civil - parte especial do direito das obrigações (arts. 927 a 965), p. 279). Sílvio Rodrigues assevera que indenizar significa ressarcir o prejuízo, nos termos do art. 402 do CC, referindo-se a qualquer tipo de dano (Direito Civil responsabilidade civil, v. 4, p. 29). Prefere-se, aqui, utilizar as expressões pré-citadas nas acepções indicadas pela Constituição Federal, reservando o termo ressarcimento para os danos materiais e reparação para os danos morais que, a bem da verdade, não podem ser ressarcidos, mas apenas compensados (vide TARTUCE, Flávio. Direito civil - direito das obrigações e responsabilidade civil, v. 2, p. 384). No que tange à indenização, trata-se de palavra que já está efetivamente consagrada no campo da responsabilidade civil, configurando-se muito artificial caso fosse empregado para as hipóteses de desapropriação. Ressalte-se, ademais, consoante lembra José Fernando Simão, indenizar é tornar indene, ou seja, "repor aquilo que foi tirado, diminuído" (Vícios do produto no novo Código Civil e no Código de Defesa do Consumidor, p. 159).

${ }^{222}$ DINIZ, Maria Helena. Curso de Direito Civil brasileiro: responsabilidade civil, p. 62. 
O dano deve, ainda, ser certo no tocante à sua existência, o que não significa que o deva ser também com relação à sua atualidade ${ }^{223}$. O dano certo é o dano real ou decorrente de efetiva probabilidade de incidência futura ${ }^{224}$. Este pode ser atual, quando corresponde àquilo que foi efetivamente perdıo; ou tuturo, 1sto e, potencial, desde que seja consequência necessária, certa, inevitável e previsível da ação ${ }^{225}$.

De acordo com René Savatier, o dano incerto é aquele cuja existência mesma não se encontra estabelecida ${ }^{226}$. O autor explica, ainda, que se trata de dano eventual, cuja realização é incerta, que se contrapõe ao dano atual, e não o dano futuro ${ }^{227}$. No que tange à determinação do dano, o autor em comento assinala que o dano indeterminado também pode ser indenizado, devendo o magistrado fazer uma determinação provisória e sujeita a revisão ou revisões periódicas ${ }^{228}$.

O dano poderá ser direto ou indireto em relação ao fato gerador. Será direto se for resultante do fato lesivo, atingindo a vítima no contexto de uma relação causal, e indireto se consistir em uma consequência da perda mediatamente sofrida pelo lesado, representando repercussão ou efeito da causa em outros bens que não os diretamente atingidos pelo fato lesivo. Trata-se do chamado dano por ricochete ${ }^{229}$.

Caio Mário da Silva Pereira afirma que o dano reflexo ou em ricochete ocorre quando o agente sofre as consequências de dano causado à vítima principal. Não seria, portanto, o caso de responsabilidade indireta, decorrente de fato de terceiro. Acrescenta que, nessa espécie de dano, haverá duas vítimas e duas ações, fundadas em um só fato danoso, podendo ele ser moral ou pecuniário ${ }^{230}$. No tocante à sua ressarcibilidade, conclui que "é reparável o dano reflexo ou em ricochete, dês ${ }^{231}$ que seja certa a repercussão do

\footnotetext{
${ }^{223}$ Carlos Roberto Gonçalves afirma que o dano ressarcível deve ser certo e atual, mas em seguida pondera que um dano futuro pode ser indenizado, desde que não seja meramente hipotético ou eventual (Comentários ao Código Civil - parte especial do direito das obrigações (arts. 927 a 965), p 277, e Responsabilidade civil, p. 530). Na mesma esteira, Silvio de Salvo Venosa (Responsabilidade civil, p. 28).

${ }^{224}$ SEVERO, Sérgio. Os danos extrapatrimoniais, p. 224.

${ }^{225}$ DINIZ, Maria Helena. Curso de Direito Civil brasileiro: responsabilidade civil, p. 62.

${ }^{226}$ SAVATIER, René. Traité de la responsabilité civile en Droit français, Paris, 1939. t. II, p. 97: "Le dommage matériel doit être considére comme certain toutes les fois que le responsable a lesé un droit patrimonial determiné et établi". (Tradução livre: "O dano material deve ser considerado certo todas as vezes em que o responsável lesou um direito patrimonial determinado e estabelecido".)

${ }^{227}$ Ibidem, p. 98: "le prétendu prejudice futur n'est que la manifestation future d'un prejudice parfaitement présent". (Tradução livre: "o pretendido prejuízo futuro é [não deixa de ser] a manifestação futura de um prejuízo perfeitamente presente".)

${ }^{228}$ SAVATIER, René, op. cit., p. 100.

${ }^{229}$ DINIZ, Maria Helena, op. cit., p. 63/67.

${ }^{230}$ PEREIRA, Caio Mário da Silva. Responsabilidade civil. 9. ed. Rio de Janeiro: Forense, 1999. p. 41-42.

${ }^{231}$ A palavra em comento realmente é grafada desta maneira pelo autor. Trata-se de uma forma reduzida, arcaica, de "desde", porém em desuso.
} 
dano principal, por atingir a pessoa que lhe sofra a repercussão, e esta seja devidamente comprovada"232. Exemplo já clássico de dano em ricochete indenizável é o dano moral provocado aos parentes mais próximos da vítima em caso de homicídio desta.

Além dos três principais requisitos retromencionados, Maria Helena Diniz acrescenta os seguintes:

- a subsistência do dano no momento da reclamação do lesado;

- a legitimidade, no sentido de que a vítima deverá ser titular do direito atingido - os titulares podem ser os lesados ou seus beneficiários ${ }^{233}$; e

- a ausência de causas excludentes de responsabilidade - caso fortuito, força maior e culpa exclusiva da vítima ${ }^{234}$.

Deve-se, no entanto, analisar com cuidado tal assertiva - no que tange ao primeiro item -, já que é possível um dano moral, v.g., não mais subsistir no instante da reclamação, mesmo que tenha ocorrido em momento pretérito, sendo ainda indenizável. Verifique-se a hipótese de inserção indevida do nome da vítima em rol de devedores. Mesmo que a ação seja proposta após a retirada do nome da referida lista, ainda será o caso de concessão de indenização. No tocante aos demais requisitos apresentados pela autora pré-citada, esses estão relacionados com outros pressupostos da responsabilidade civil, que não propriamente o dano.

Carlos Alberto Bittar apresenta os requisitos de maneira diferente, sustentando que é ressarcível:

- o dano atual - e não remoto -, aceitando também o dano futuro ou a perda de oportunidade, desde que consequências certas e previsíveis da ação violadora;

- o dano certo - definido ou determinável;

- o dano pessoal, mas também admissível aquele ocasionado a pessoas da família; e

- o dano direto, igualmente sendo possível acolher-se o dano derivado ou reflexo ${ }^{235}$.

\footnotetext{
232 PEREIRA, Caio Mário da Silva. Responsabilidade civil, p. 43.

${ }^{233}$ Nesse sentido, verifique-se, por exemplo, o art. 12, parágrafo único, e o art. 20, parágrafo único, ambos do CC.

${ }^{234}$ DINIZ, Maria Helena. Curso de Direito Civil brasileiro: responsabilidade civil, p. 64.

${ }^{235}$ BITTAR, Carlos Alberto. Responsabilidade civil - teoria e prática, p. 8.
} 
Trata-se de uma eficiente síntese da matéria.

Anderson Schreiber apresenta outra proposta de análise da reparabilidade ou ressarcibilidade dos danos, a qual, por ser verdadeira inovadora, é digna de menção. Seu método de aferição do dano passa por quatro etapas. A primeira delas consiste no exame abstrato do mérito da tutela do interesse lesado, isto é, faz-se mister verificar se o interesse deve efetivamente ser tutelado. Se não for o caso, não há dano em sentido jurídico, ainda que a vítima possa ter sofrido prejuízo em sentido vulgar, como ocorre, v.g., quando parte do produto de roubo do ladrão é subtraído por seu comparsa. A segunda etapa consiste no exame do mérito de tutela do interesse lesivo, eis que podem existir razões que justifiquem a conduta do ofensor. É o que acontece com o direito à imagem e o direito à liberdade de expressão: o direito à imagem ampara a vítima, ao passo que a liberdade de expressão o faz com relação ao ofensor. Isso não se verificará, contudo, se a conduta lesiva for expressamente proibida, quando, então, a questão já estará resolvida. Não sendo a conduta do ofensor vedada pelo ordenamento, passa-se à terceira etapa, na qual deve o magistrado apurar se há uma regra legal de prevalência entre os interesses conflitantes. Um exemplo de regra semelhante é a do art. 20 do $\mathrm{CC}$, que estabelece a prevalência do interesse à administração da justiça em relação ao interesse à própria imagem. Se a regra de prevalência é inferior hierarquicamente aos interesses protegidos - estes podem estar previstos constitucionalmente, ao passo que a regra de prevalência consta de legislação federal, v.g. -, ainda é possível discutir sua validade, ou mesmo adequação; caso contrário, a área de atuação legítima já está definida. Na maior parte das vezes, porém, a prevalência não pode ser definida porque a norma simplesmente declara que um direito é inviolável. Ao se deparar com tal situação, segundo Anderson Schreiber, o julgador não deve entender que esse direito prevalece sobre todos os outros porque não se admitem direitos absolutos; deverá, ao contrário, ponderar os interesses. A quarta etapa somente será necessária, portanto, em caso de inexistência de regra de prevalência. Nesta última, o Poder Judiciário deverá decidir qual interesse vai predominar; para isso, analisa o caso concreto e faz a pergunta: "O grau de realização do interesse lesivo justifica o grau de afetação do interesse lesado?”. Pautado nesse questionamento, vai determinar a área de atuação legítima de cada parte a fim de chegar ao dano ressarcível ${ }^{236}$. O interesse da formulação do autor é evidente, pois esta fornece diretrizes mais concretas para a definição do que seja efetivamente o dano que merece ressarcimento.

${ }^{236}$ SCHREIBER, Anderson. Novos paradigmas da responsabilidade civil - da erosão dos filtros da reparação à diluição dos danos, p. 160-164. 
Os danos indenizáveis são, em rigor, divididos em danos patrimoniais e danos morais. Apesar da diferenciação na nomenclatura, ambos os danos são violações ao patrimônio, considerado universalidade jurídica intangível, constituída pelo conjunto de bens de uma pessoa, incluindo os de natureza moral. Ao se falar em dano patrimonial, está se fazendo referência, tão somente, aos bens cuja violação implica perda pecuniária.

A divisão entre essas duas espécies de danos, portanto, não decorre da natureza do bem lesado, mas do efeito da lesão, ou seja, do caráter de sua repercussão sobre o lesado. Dessa maneira, tanto é possível ocorrer dano patrimonial em consequência de lesão a um bem não patrimonial, como dano moral em resultado de ofensa a bem material ${ }^{237}$.

\subsection{Formas de ressarcimento: natural (ou específica) e indenização pecuniária}

Ainda no que tange ao dano, convém tratar da clássica bipartição entre ressarcimento de forma natural (ou específica) e indenização pecuniária.

O primeiro modelo corresponde melhor ao fim de restaurar, tendo em vista que, por um lado, ao menos aparentemente, tem maior probabilidade de recolocação da vítima no statu quo ante ${ }^{238}$. Porém, a indenização pecuniária também é legítima porque o dano patrimonial sempre acarreta perda econômica do patrimônio e este consiste em um conceito aritmético $^{239}$.

Com relação aos danos morais, não há o que se discutir, já que a reparação natural é impossível. No que tange a tais danos, aliás, o que se tem é a compensação, como restará cristalino nos itens 2.6 e seguintes. Não se olvide, porém, a possibilidade de retratação pública, que não devolve o ofendido ao estado anterior ao dano, mas lhe oferece uma reparação de natureza não patrimonial.

A reparação natural pode ser empregada tanto nas obrigações de dar coisa certa ou incerta, quanto nas de fazer ou não fazer, desde que não sejam personalíssimas ${ }^{240}$. Considerando-se os danos exclusivamente materiais, estar-se-ia diante da reparação

\footnotetext{
${ }^{237}$ AGUIAR DIAS, José de. Da responsabilidade civil, t. II, p. 721.

${ }^{238}$ Por vezes, a expressão é utilizada como status quo ante; no entanto, tal escolha não tem razão de ser uma vez que na expressão latina completa in statu quo ante, a palavra status não aparece no nominativo, mas no ablativo "statu". Somente seria correto utilizar status se a palavra fosse sujeito; contudo, deve-se empregar "statu" porque é um adjunto adverbial que corresponde, grosso modo, ao ablativo latino (SERGE, Damião; CASTRO, Ludovico M. Gomes de; MULLER, Reinaldo. Ars Latina - Curso prático da língua latina. 32. ed. Petrópolis: Vozes, 1999. p. 100).

${ }^{239}$ AGUIAR DIAS, José de, op. cit., p. 717.

${ }^{240}$ BAPTISTA, Sílvio Neves. Teoria geral do dano de acordo com o novo Código Civil brasileiro, p. 136.
} 
natural, v.g., se no caso de furto de um objeto, o dano fosse reparado mediante a devolução da coisa furtada. Seria possível, também, a dação de objeto idêntico, mas essa hipótese geraria incontáveis problemas, eis que o objeto furtado já havia sido utilizado e era marcado pelo uso, ao passo que o fornecido pelo ofensor é novo. Nesse caso, haveria a seguinte opção: ou se repele completamente a reparação natural, impossibilitando a dação de objeto novo em substituição ao usado, ou se admite a reparação natural, gerando a obrigação para a vítima de devolver o valor da diferença entre os dois bens ao ofensor. Vêse, portanto, que se trata de possibilidade de difícil ocorrência, motivo pelo qual, na maior parte das vezes, opta-se pelo caminho da indenização pecuniária. Ademais, se houve destruição do objeto, e este é único - no sentido de insubstituível por falta de outro semelhante ${ }^{241}-$, só é cabível a via indenizatória.

\subsection{O conceito de dano patrimonial}

No tocante à natureza do bem violado, o dano é, tradicionalmente, dividido em material e moral. Nos dias atuais, no entanto, mencionam-se também outras modalidades, como o dano estético e a perda de uma chance. Entende-se, todavia, que, em verdade, as duas modalidades citadas não são propriamente outras espécies de dano, conforme restarão esclarecidos nos itens 2.10 e seguintes. Por ora, tratar-se-á do dano material.

Para tanto, convém iniciar o estudo pela definição do que seja patrimônio, o qual, segundo José de Aguiar Dias, comporta duas acepções: a primeira delas o identifica com um complexo de direito, formado por direitos apreciáveis monetariamente, com acréscimo do passivo patrimonial. Em uma segunda vertente, seria um conjunto de bens econômicos $^{242}$. Consoante salientado neste estudo, diverge-se da assertiva de que o patrimônio seja apenas o conjunto do acervo material; no entanto, ao se reportar a dano patrimonial, estar-se-á, necessariamente, tratando do patrimônio com outra conotação, decerto de caráter econômico, o que não ocorreu ao se definir dano.

O dano material consiste, pois, na lesão concreta que afeta um interesse relativo ao patrimônio econômico da vítima, referindo-se à perda ou à deterioração dos bens materiais que lhe pertencem, sendo suscetível de avaliação pecuniária e de indenização pelo

\footnotetext{
${ }^{241}$ No que tange à unicidade do objeto, essa consideração pode variar de acordo com o possuidor deste. De fato, para determinada pessoa, aquele objeto, tão comum para um observador externo, pode possuir alguma peculiaridade que o torna único e, portanto, insubstituível.

${ }^{242}$ AGUIAR DIAS, José de. Da responsabilidade civil, t. II, p. 708.
} 
responsável. Ou seja, de acordo com aqueles que veem o patrimônio somente como o conjunto de bens materiais, o dano material seria aquele que apenas afeta o patrimônio do ofendido ou repercute no patrimônio do lesado. Segundo a concepção aqui defendida, seria mais adequado dizer que o dano material implica prejuízo no patrimônio econômico da vítima, mas não em sua esfera moral.

O dano em comento pode ser medido pela diferença entre o valor atual do patrimônio da vítima e aquele que ela teria, no mesmo momento, se não houvesse a lesão. Traz-se, nesse sentido, novamente à lume os ensinamentos de José de Aguiar Dias, que assim se manifesta:

"O dano [patrimonial] se estabelece mediante o confronto entre o patrimônio realmente existente após o dano e o que possivelmente existiria, se o dano não se tivesse produzido: o dano é expresso pela diferença negativa encontrada nessa operação"243.

O critério diferencial pode não ser necessário, contudo, se for possível a reparação natural, isto é, a restauração da situação alterada pela lesão, que poderá consistir na entrega da própria coisa objeto de furto, por exemplo.

Infere-se que há a possibilidade de se identificar o dano patrimonial com o dano suscetível de avaliação pecuniária, aquele possível de ser reparado por reposição em dinheiro $^{244}$, ou mesmo por um objeto - no caso da reparação natural -, uma vez que se confere ao conceito de patrimônio uma amplitude maior do que à do aspecto material.

Não obstante o fato de se qualificar o dano patrimonial de modo diferente do tradicionalmente exposto pela doutrina - uma vez estabelecido que o patrimônio se compõe de valores materiais e morais -, entende-se que esse dano realmente deve ser mensurado por critério diferencial, promovendo-se o levantamento da perda econômica trazida pelo evento danoso, sendo considerados o dano emergente e os lucros cessantes, analisados a seguir.

\footnotetext{
243 AGUIAR DIAS, José de. Da responsabilidade civil, t. II, p. 709.
}

${ }^{244}$ VENOSA, Silvio de Salvo. Responsabilidade civil, p. 30. 


\subsection{Damnum emergens (dano emergente) e lucrum cessans (lucro cessante)}

O dano patrimonial abrange o dano emergente, mas também o lucro cessante. Este último é, em rigor, identificado com a perda da chance ou oportunidade ${ }^{245}$, engano que se intentará corrigir ao longo deste item e daquele destinado ao estudo específico da perda de uma chance.

Por ora, é mister ter em mente que o dano emergente (damnum emergens) se refere um dano positivo, representado pela concreta diminuição da fortuna ${ }^{246}$ do lesado - o que o lesado efetivamente perdeu -, enquanto o lucro cessante (lucrum cessans) diz respeito a um dano negativo, consistente no fato de a vítima ter deixado de auferir um benefício - o aumento que seu patrimônio teria, mas deixou de ter, em razão do evento danoso ${ }^{247}$. Há, portanto, uma frustração do lucro ${ }^{248}$.

Em linhas gerais, os lucros cessantes correspondem ao afastamento de uma vantagem esperada ou na imposição de uma perda que poderia ser evitada, enquanto o dano emergente é representado pelo déficit no patrimônio do credor, a concreta redução por este sofrida em sua riqueza ${ }^{249}$.

Agostinho Alvim consigna, sobre o assunto em pauta, que:

“[...] lucro cessante não é somente aquele que se estancou, como, por exemplo, o que alguém normalmente obtinha, em sua profissão, e não mais poderá obter, em virtude de ato ilícito ou de inexecução de obrigação por parte de outrem.

Lucro cessante é isso: mas também aquele que o credor não obterá, ainda que não viesse obtendo antes.

Por isso, os Códigos e os autores, geralmente, referem-se ao ganho de que o credor ficou privado (cf. Cód. Francês, art. 1.127 etc.).

\footnotetext{
${ }^{245}$ DINIZ, Maria Helena. Curso de Direito Civil brasileiro: responsabilidade civil, p. 64-65. Também Carlos Roberto Gonçalves (Comentáriso ao Código Civil - parte especial do direito das obrigações (arts. 927 a 965), p. 629-631).

${ }^{246} \mathrm{O}$ termo fortuna é aqui utilizado na sua concepção de riqueza e não de sorte.

${ }^{247}$ DINIZ, Maria Helena, op. cit., p. 66. Também Carlos Roberto Gonçalves, op. cit., e Washington de Barros Monteiro (Curso de Direito Civil - direito das obrigações. 19. ed. São Paulo: Saraiva, 1984. v. 4, p. 333).

${ }^{248}$ TARTUCE, Flávio. Direito Civil - direito das obrigações e responsabilidade civil, v. 2, p. 385.

${ }^{249}$ MONTEIRO, Washington de Barros, op. cit., v. 5, p. 334.
} 
Com relação ao dano emergente, ponderamos que ele diz respeito não somente a uma diminuição do ativo, como também a um aumento do passivo" 250 .

É também interessante a preleção de Silvio de Salvo Venosa, segundo o qual os lucros cessantes são uma projeção contábil que nem sempre se mostram de fácil avaliação, havendo, de qualquer maneira, de se considerar o que o lesado teria auferido em caso de não ocorrência do dano ${ }^{251}$.

José de Aguiar Dias, no mesmo compasso, assinala que, enquanto os danos positivos ou emergentes possuem base firme, dada sua relação com fatos passados, o lucro cessante se liga a elementos flutuantes, em face da incerteza que sempre domina a quem opere com dados imaginários. Segundo o autor, com segurança, só se podem considerar os resultados que determinam os lucros. O critério acertado estaria em condicionar o lucro cessante a uma probabilidade objetiva, resultante do desenvolvimento normal dos acontecimentos, ligado às circunstâncias peculiares ao caso concreto ${ }^{252}$.

Em que pese o pensamento do autor, não se enxerga tal fluidez na consideração dos lucros cessantes ${ }^{253}$ e se pretende mostrar a pouca caracterização probabilística destes mediante um exemplo prático, bastante utilizado pelos doutrinadores quando abordam a matéria. Suponha-se que um taxista tenha seu veículo abalroado por outro motorista, sofrendo pequenos danos físicos, como torção em um dos pulsos, sendo o automóvel danificado em alguns pontos. Os gastos derivados dos cuidados médicos e hospitalares e da reforma do carro são danos emergentes. Vislumbram-se também lucros cessantes porque o

\footnotetext{
${ }^{250}$ ALVIM, Agostinho. Da inexecução das obrigações e suas conseqüências, p. 174.

${ }^{251}$ VENOSA, Silvio de Salvo. Responsabilidade civil, p. 30: "O lucro cessante traduz-se na dicção legal, o que a vítima razoavelmente deixou de lucrar. Trata-se de uma projeção contábil nem sempre muito fácil de ser avaliada. Nesta hipótese, deve ser considerado o que a vítima teria recebido se não tivesse ocorrido o dano. O termo razoavelmente posto na lei lembra, mais uma vez, que a indenização não pode converter-se em um instrumento de lucro. Assim, no exemplo do veículo sinistrado, temos que calcular quanto seu proprietário deixou de receber com os dias em que não pôde utilizá-lo. Se o automóvel pertencia a um taxista, evidente que o lucro cessante será calculado de forma diversa do que para o proprietário de um veículo utilizado exclusivamente para lazer. Em ambas as hipóteses, porém, haverá prejuízo nesse nível a ser indenizado. O detentor de automóvel particular, por exemplo, pode ter sido obrigado a alugar um veículo no período para manter suas atividades habituais".

${ }^{252}$ AGUIAR DIAS, José de. Da responsabilidade civil, t. II, p. 713: "Para autorizadamente, se computar o lucro cessante, a mera possibilidade não basta, mas também não se exige a certeza absoluta. $\mathrm{O}$ critério acertado está em condicionar o lucro cessante a uma probabilidade objetiva resultante do desenvolvimento normal dos acontecimentos conjugados às circunstâncias peculiares ao caso concreto".

${ }^{253}$ Para Carlos Roberto Gonçalves, somente é indenizável o lucro que se tem certeza que teria sido usufruído se não houvesse ocorrido o evento causador do dano (Responsabilidade civil, p. 530).
} 
taxista remanesceu sem trabalhar durante dez dias. Para cálculo do valor devido ao lesado, é verdadeiramente necessário o cálculo de probabilidades? Está-se, de fato, diante de tão grande fluidez? Com efeito, denota tratar-se de realizar o cálculo da média de faturamento diário do taxista e multiplicar pelos dias não trabalhados. Não há necessidade de elucubrações.

É diferente do que ocorre, por exemplo, quando um advogado deixa de interpor um recurso. Nesse caso, será necessário estudar as probabilidades que o cliente teria de ver seu recurso provido no Tribunal competente, e estabelecer a indenização devida com base nessa porcentagem. Nesse último caso, já não se trata de lucros cessantes, mas sim de perda da chance, na qual não há certeza acerca do prejuízo ocorrido. Nos lucros cessantes, caso se lide com probabilidades, estas se encontram em seu grau máximo, não havendo que se falar em incerteza. A perda de uma chance, por sua vez, não constitui uma espécie de lucro cessante, mas sim de um dano emergente. Isso porque, nesse caso, não há o ressarcimento de um lucro que eventualmente poderia se verificar, mas sim o dano atual e certo decorrente da frustração da oportunidade e não propriamente do lucro ${ }^{254}$.

Questão interessante, para a qual se faz mister dedicar alguns parágrafos, é a dos alimentos indenizatórios, previstos no art. 948 do CC, em específico no que tange ao cumprimento da sentença dos quais decorrem, o qual deve se seguir nos termos do art. 475-Q do CPC.

Analisa-se primeiramente o art. 948 do CC, que determina, ipsis litteris:

“Art. 948. No caso de homicídio, a indenização consiste, sem excluir outras reparações:

I - no pagamento das despesas com o tratamento da vítima, seu funeral e o luto da família;

II - na prestação de alimentos às pessoas a quem o morto os devia, levando-se em conta a duração provável da vida da vítima". (sem grifo no original)

Ressalte-se, preliminarmente, que a prestação de alimentos aos dependentes do falecido é hipótese inegável de lucros cessantes, motivo pelo qual é tratada nesse

${ }^{254}$ SCHREIBER, Anderson. Novos paradigmas da responsabilidade civil - da erosão dos filtros da reparação à diluição dos danos, p. 200. O assunto em comento será estudado com mais profundidade no item 2.13. 
momento. O valor desses alimentos é determinado mediante diversos critérios objetivos desenvolvidos pela jurisprudência, variando de acordo com características pessoais do falecido $^{255}$.

O Código de Processo Civil, após as alterações incluídas pela Lei n. 11.232/2005, admite certa elasticidade no que concerne ao montante dos referidos alimentos, o que se observa da norma transcrita, in verbis:

“Art. 475-Q. Quando a indenização por ato ilícito incluir prestação de alimentos, o juiz, quanto a esta parte, poderá ordenar ao devedor constituição de capital, cuja renda assegure o pagamento do valor mensal da pensão.

$\S 1^{\underline{0}}$ Este capital, representado por imóveis, títulos da dívida pública ou aplicações financeiras em banco oficial, será inalienável e impenhorável enquanto durar a obrigação do devedor.

$\S 2^{0} \mathrm{O}$ juiz poderá substituir a constituição do capital pela inclusão do beneficiário da prestação em folha de pagamento de entidade de direito público ou de empresa de direito privado de notória capacidade econômica, ou, a requerimento do devedor, por fiança bancária ou garantia real, em valor a ser arbitrado de imediato pelo juiz.

§ $3^{\circ}$ Se sobrevier modificação nas condições econômicas, poderá a parte requerer, conforme as circunstâncias, redução ou aumento da prestação.

$\S 4^{\mathrm{o}}$ Os alimentos podem ser fixados tomando por base o saláriomínimo.

$\S 5^{0}$ Cessada a obrigação de prestar alimentos, o juiz mandará liberar o capital, cessar o desconto em folha ou cancelar as garantias prestadas".

\footnotetext{
${ }^{255}$ Convém salientar que mesmo o falecimento de menor de idade enseja indenização por lucros cessantes, conforme entendimento jurisprudencial consolidado na Súmula n. 491 do STF ("É indenizável o acidente que cause a morte de filho menor, ainda que não exerça trabalho remunerado”).
} 
Em conformidade com o disposto no $\S 3^{\underline{0}}$ ora reproduzido, os alimentos indenizatórios inicialmente fixados podem ser alterados em caso de ocorrência de modificações nas condições econômicas. Infelizmente, a norma não esclareceu com relação a quem dizem respeito tais condições: se à vítima, se ao causador do dano, ou se a ambos. Flávio Tartuce sustenta que tais alimentos devem seguir a mesma regra dos oriundos do direito de família, sendo aplicável o art. 1.699 do $\mathrm{CC}^{256}$. Nessa esteira, seria possível a diminuição ou o aumento do montante em comento tanto na hipótese de alteração da situação do credor, quanto na do réu devedor. O autor assegura, ainda, ser possível a exoneração total, quando, v.g., a viúva se casa novamente, sendo possível, assim, a aplicação analógica do art. 1.708, caput, do $\mathrm{CC}^{257}$.

A despeito do entendimento do doutrinador, verificam-se diferenças entre os alimentos decorrentes do direito de família e os de natureza indenizatória, eis que os primeiros se submetem ao binômio "possibilidade-necessidade" 258 , enquanto os segundos consoante posição defendida pelo presente estudo - devem corresponder à extensão do dano sofrido pela vítima e não à possibilidade econômica do ofensor ${ }^{259}$.

De qualquer maneira, demonstrou-se, em linhas anteriores, que os alimentos indenizatórios admitem variação no que tange ao seu montante, o que poderia denotar incoerência com relação à assertiva pretérita deste trabalho de que, ao contrário do que sustenta José de Aguiar Dias ${ }^{260}$, não há, verdadeiramente, fluidez na consideração dos lucros cessantes. $\mathrm{O}$ aparente equívoco é afastado quando se observa que, mesmo no caso desses alimentos, não se está diante de mera probabilidade de dano, sendo desnecessária qualquer análise probabilística. De fato, é evidente que os dependentes do falecido sofreram, com sua morte, um prejuízo material, que pode ser apurado objetivamente pelo

\footnotetext{
${ }^{256} \mathrm{O}$ referido dispositivo legal tem a seguinte redação: "Se, fixados os alimentos, sobrevier mudança na situação financeira de quem os supre, ou na de quem os recebe, poderá o interessado reclamar ao juiz, conforme as circunstâncias, exoneração, redução ou majoração do encargo".

${ }^{257}$ TARTUCE, Flávio. Direito Civil - direito das obrigações e responsabilidade civil, v. 2, p. 395. Sua formulação teórica é arrematada da seguinte maneira: "Em suma, o que se percebe é que os alimentos indenizatórios passam a ser sujeitos às regras relativas às alterações das circunstâncias. Em certo ponto, pode-se até dizer que a cláusula rebus sic stantibus, sempre invocada para a ação de alimentos do Direito de Família, passa a incidir para os alimentos decorrentes de atos ilícitos" (ibidem, v. 2, p. 396). O art. 1.708, caput, determina que, "com o casamento, a união estável ou o concubinato do credor, cessa o dever de prestar alimentos".

${ }^{258}$ Esse binômio está expresso no $\S 1^{\circ}$ do art. 1.694, quando se determina que: "os alimentos devem ser fixados na proporção das necessidades do reclamante e dos recursos da pessoa obrigada". No entanto, alguns já falam no trinômio proporcionalidade-necessidade-possibilidade, como Maria Berenice Dias (Manual de direito das famílias. 3. ed. São Paulo: Revista dos Tribunais, 2006. p. 432-433).

${ }^{259}$ Este assunto será discutido, com outro viés, no item 2.9, alusivo aos critérios de avaliação dos danos morais.

${ }^{260}$ AGUIAR DIAS, José de. Da responsabilidade civil, t. II.
} 
cálculo do montante com que este contribuía para as despesas domésticas. Os valores concedidos à vítima somente se alteram porque as circunstâncias mudam com o passar do tempo, atingindo diretamente a extensão do dano. Verifica-se que as demandas econômicas de uma criança de cinco anos são, em rigor, diferentes daquelas de um jovem de quinze anos, o que, de acordo com o Diploma Processual, deve se refletir sobre o valor da indenização.

Os lucros cessantes, ademais, como ressaltam Pablo Stolze Gagliano e Rodolfo Pamplona Filho, devem ser fortemente comprovados, a fim de que sejam afastadas pretensões de litigantes inescrupulosos, que busquem o recebimento de quantias $\operatorname{absurdas}^{261}$. Isso demonstra que, nos Tribunais, meras conjecturas sobre lucros cessantes não serão indenizadas.

É interessante ainda mencionar entendimento de Sérgio Severo, qual seja, o de que ambos os conceitos - dano emergente e lucros cessantes - se aplicam à esfera dos danos patrimoniais e extrapatrimoniais ${ }^{262}$. Propugna-se que tal assertiva é inadmissível, pois como dividir o dano moral em dano emergente e lucro cessante se o dano moral nem ao menos pode ser indenizado, na acepção própria da palavra - tornar-se indene -, mas tão somente compensado?

Por fim, acerca da expressão utilizada com frequência, e já consagrada no Direito brasileiro, perdas e danos, Agostinho Alvim observa que esta é incorreta, uma vez que os termos perdas e danos são sinônimos, que designam somente o dano emergente. A expressão francesa (dommages et intérêts) seria mais conveniente, por designar o dano emergente (diminuição) e o lucro cessante (privação de aumento) ${ }^{263}$.

261 GAGliANO, Pablo Stolze; PAMPLONA FILHO, Rodolfo. Novo curso de Direito Civil responsabilidade civil, p. 42: "Claro está que o dano emergente e os lucros cessantes devem ser devidamente comprovados na ação indenizatória ajuizada contra o agente causador do dano, sendo de bom alvitre exortar os magistrados a impedirem que vítimas menos escrupulosas, incentivadoras da famigerada 'indústria da indenização', tenham êxito em pleitos absurdos, sem base real, formulados com o nítido propósito, não de buscar ressarcimento, mas de obter lucro abusivo e escorchante".

${ }^{262}$ SEVERO, Sérgio. Os danos extrapatrimoniais, p. 224. No mesmo sentido, Sílvio Neves Baptista (Teoria geral do dano de acordo com o novo Código Civil brasileiro, p. 87). Para corroborar seu entendimento, o autor fornece o exemplo do erro médico do qual se origina incapacidade para o trabalho. Nesta hipótese, sustenta que o dano moral a ser reparado não consiste somente na ofensa corporal, mas também na privação dos ganhos da atividade laboral. Ocorre que, no caso, o doutrinador se equivoca porque está tomando típico dano material por extrapatrimonial, o que não se justifica.

${ }^{263}$ ALVIM, Agostinho. Da inexecução das obrigações e suas conseqüências, p. 175. 


\section{6. $O$ conceito de dano moral}

São muitas as definições de dano moral que podem ser encontradas na doutrina pátria e estrangeira. Para que se possam extrair os principais pontos de caracterização do instituto, serão compiladas as mais importantes. É oportuno ressaltar que o dano moral, neste item, será analisado em sua concepção ampla, e não em seu sentido estrito. A diferença entre ambas as espécies será explicada posteriormente.

Henri Lalou define o dano moral como o atentado aos direitos extrapatrimoniais: os direitos políticos, os direitos inerentes à personalidade - direito à vida, liberdade, honra - e os direitos de família ${ }^{264}$. No que tange a esse ponto, o posicionamento deste estudo coaduna-se com o esposado pelo autor, na medida em que se sustenta que a lesão aos direitos da personalidade é o grande elemento identificador dos danos morais.

René Savatier entende que o dano moral pode se travestir de um sofrimento psíquico, o chamado pretium doloris, ou então, com bastante frequência, ser uma dor moral de origem diversa, como a lesão à reputação, à autoridade legítima, ao seu pudor e ao seu amor próprio estético ${ }^{265}$. A definição de René Savatier é muito importante para este trabalho, pois prenuncia a divisão que se pretende fazer entre dano moral em sentido amplo e dano moral em sentido estrito, o pretium doloris mencionado pelo autor.

Jaime Santos Briz, por sua vez, define os danos não patrimoniais como aqueles cuja valoração em dinheiro não tem a mesma base de equivalência que caracteriza os patrimoniais, por afetarem elementos ou interesses de difícil valoração pecuniária ${ }^{266}$.

Teresa Ancona Lopez, vislumbrando a questão por outro ângulo, pondera que o dano é sempre consequência de uma lesão a um direito, seja ele patrimonial ou não, e que a pessoa deve servir de medida do dano em vez do patrimônio, pois aquela tanto pode ser

\footnotetext{
${ }^{264}$ LALOU, Henri. La responsabilité civile: principes élémentaires et applications pratiques, p. 219-220. No mesmo sentido, Carlos Alberto Bittar (Responsabilidade civil - teoria e prática, p. 16-17). Esse autor caracteriza o dano moral como o dano relativo a elementos do complexo valorativo intrínseco do indivíduo, em suas projeções na sociedade. Segundo ele, são morais os danos aos atributos valorativos da pessoa, enquanto ser integrado socialmente, ou seja, os danos aos elementos que a individualizam como ente, como a honra, a reputação e as manifestações do intelecto.

${ }^{265}$ SAVATIER, René. Traité de la responsabilité civile en Droit français, p. 101. Da mesma forma, Henri Mazeaud e Léon Mazeaud utilizam-se do termo prejudice moral para caracterizar os danos que não se referem de maneira alguma ao patrimônio e causam, com frequência, uma dor moral à vítima, como a lesão corporal, o atentado à honra, reputação, liberdade pessoal, vida e a violação de domicílio (Traité théorique et pratique de la responsabilité civile delictuelle et contractuelle. 3. ed. Paris: Librarie du Recueil Sirey, 1938a. t. I, p. 361).

${ }^{266}$ BRIZ, Jaime Santos. La responsabilidad civil - derecho sustantivo y derecho procesal. 3. ed. Madrid: Montecorvo, 1981. p. 140-141. Com entendimento semelhante, também Wilson Melo da Silva ( $O$ dano moral e sua reparação, p. 1).
} 
lesada no que é quanto no que tem. Uma causa moral pode determinar um grave prejuízo econômico, da mesma forma que uma causa material pode determinar um prejuízo moral $^{267}$. Há ainda lesões que acarretam conjuntamente prejuízos morais e materiais, como em rigor é o caso do dano estético, sobre o qual se tecerá comentários no item 2.10.

Apresentado um panorama sintético do entendimento que se faz acerca dos danos morais, ressaltar-se-ão alguns pontos relevantes para o posterior desenvolvimento do trabalho, sempre considerando que a ordem constitucional protege os indivíduos de qualquer ofensa - ou ameaça de ofensa - à sua personalidade, sendo o dano moral a concretização dessa ofensa.

De início, ressalta-se posicionamento favorável a que as definições de dano moral levando em conta apenas os elementos "dor" e "sofrimento",268 devem ser substituídas por aquelas que efetivamente reconhecem elementos mais definidos, como, por exemplo, a lesão a direitos da personalidade, para a caracterização desse dano. Na verdade, a dor é meramente a sintomatologia do dano moral, não sendo essencial para sua caracterização ${ }^{269}$.

Em face da assertiva ora expressa, listam-se as seguintes características próprias desse tipo de dano:

1. O dano moral é, em geral, considerado uma lesão de direito não patrimonial, quando se entende o patrimônio como o conjunto de bens materiais da pessoa, mas pode ser identificado, como aqui se faz, com uma lesão psicofísica, capaz de atingir o patrimônio moral do indivíduo.

2. O dano moral sempre envolve abalo aos direitos da personalidade ou direitos fundamentais, que são direitos da personalidade ínsitos na Constituição Federal. No viés constitucional da matéria, muito se disserta acerca de um direito geral de personalidade, do qual decorrem inúmeros outros direitos. Verifique-se o Enunciado 274, da IV Jornada de Direito Civil:

"Enunciado 274: Os direitos da personalidade, regulados de maneira não exaustiva pelo Código Civil, são expressões da cláusula geral de tutela da pessoa humana, contida no art. $1^{\underline{0}}$, III, da

\footnotetext{
${ }^{267}$ LOPEZ, Teresa Ancona. $O$ dano estético - responsabilidade civil, p. 22.

${ }^{268}$ São exemplos de definições nesse sentido as apresentadas por José de Aguiar Dias (Da responsabilidade civil, t. II, p. 721); Wilson Melo da Silva (O dano moral e sua reparação, p. 355) e Yussef Said Cahali (Dano moral. 2. ed. São Paulo: Revista dos Tribunais, 2000. p. 19).

${ }^{269}$ SCHREIBER, Anderson. Novos paradigmas da responsabilidade civil - da erosão dos filtros da reparação à diluição dos danos, p. 129.
} 
Constituição (princípio da dignidade humana). Em caso de colisão entre eles, como nenhum pode sobrelevar os demais, deve-se aplicar a técnica da ponderação".

3. O dano moral, ao contrário do material, não é homogêneo e pode se apresentar em uma multiplicidade de formas, exigindo também variedade nos meios de reparação ${ }^{270}$. De fato, há várias espécies de dano moral, tantas quantas puderem decorrer da cláusula geral de tutela da pessoa humana, enquanto o dano material admite uma única divisão, entre danos emergentes e lucros cessantes, sempre derivando de interesse que causa prejuízo economicamente apreciável $^{271}$.

4. Ainda que o elemento "dor", em suas modalidades física ou emocional, esteja presente na maior parte dos casos em que se verifica o dano moral, em verdade este se trata de puro reflexo ou consequência da lesão. Anderson Schreiber ressalta ser possível a ocorrência de dano moral sem o tão mencionado sofrimento, fornecendo o exemplo do indivíduo que tem sua imagem utilizada em um contexto publicitário. A referida vítima pode até nem sofrer psicologicamente com a exposição de suas feições, mas, pelo simples fato de não ter autorizado a exibição, esta configura uma lesão concreta ao direito de imagem e, por decorrência, um dano moral ${ }^{272}$.

5. Por fim, o dano moral suscita prejuízo que não pode ser avaliado economicamente por critérios matemáticos - dano emergente e lucros cessantes, por exemplo -, devendo ser estimado mediante outros critérios, que oscilam bastante, dependendo da natureza jurídica atribuída à indenização dos danos morais.

As características retromencionadas são atinentes ao dano moral causado à pessoa física tão somente, e não podem ser expandidas para o âmbito da reparação de danos morais causados à pessoa jurídica. De fato, as pessoas jurídicas não têm direitos fundamentais ou direitos da personalidade, que são próprios da pessoa humana. Entende-se

\footnotetext{
${ }^{270}$ AGUIAR DIAS, José de. Da responsabilidade civil, t. II, p. 721. Roxana Cardoso Brasileiro Borges ressalta que os direitos da personalidade não são numerus clausus (Direitos de personalidade e dignidade: da responsabilidade civil para a responsabilidade constitucional. In: DELGADO, Mário Luiz; ALVES, Jones Figueiredo (Coord.). Questões controvertidas - responsabilidade civil, v. I, p. 561). Sendo assim, decerto também não o podem ser os danos morais.

${ }^{271}$ MELO, Diogo L. Machado de. A função punitiva da reparação dos danos morais (e a destinação de parte da indenização para entidades de fins sociais - artigo 883, parágrafo único, do Código Civil). In: DELGADO, Mário Luiz; ALVES, Jones Figueiredo (Coord.), op. cit., p. 97.

${ }^{272}$ SCHREIBER, Anderson. Novos paradigmas da responsabilidade civil - da erosão dos filtros da reparação à diluição dos danos, p. 198.
} 
que quem poderia se enquadrar nos critérios ora apresentados são os representantes legais da pessoa jurídica, mas não ela própria. Frise-se que a pessoa jurídica não é titular nem mesmo da tão aclamada honra objetiva, tratando-se, tal consideração, de mero estratagema para garantir o ressarcimento de danos materiais de difícil reparação (por dificuldade de comprovação). No que tange ao direito à imagem, este possui uma concepção diferente da observada na pessoa física. De fato, nesta última, a imagem é um atributo constitucional, que pode até mesmo visar à preservação da integridade psíquica de seu titular. No tocante à pessoa jurídica, está relacionada aos prejuízos financeiros oriundos da mácula à sua reputação perante o mercado.

Convém ressaltar, entretanto, que o entendimento aqui esposado é minoritário, tendo em vista o disposto pelo art. 52 do $\mathrm{CC}^{273}$, bem como pela Súmula n. 227 do STJ, que consolidou, na jurisprudência, a existência e possibilidade de reparação de danos morais da pessoa jurídica.

A despeito desse fato, posicionamento contrário, e semelhante ao aqui defendido, vem sendo sustentado por doutrina abalizada. Pietro Perlingieri é um dos integrantes da corrente em foco; ao estudar a questão do ponto de vista do Direito Constitucional, assim se manifesta o doutrinador:

"Para as pessoas jurídicas o recurso à cláusula geral da tutela dos 'direitos invioláveis' do homem constituiria uma referência totalmente injustificada, expressão de uma mistificante interpretação extensiva fundada em um silogismo: a pessoa física é sujeito que tem tutela, a pessoa jurídica é sujeito, ergo, à pessoa jurídica deve-se aplicar a mesma tutela. Daqui uma concepção dogmática e unitária da subjetividade como fato neutro. $\mathrm{O}$ valor do sujeito pessoa física é, todavia, diverso daquele do sujeito pessoa jurídica. [...] É necessário adquirir consciência da identidade apenas aparente de problemáticas como, por exemplo, o segredo, a privacidade e a informação. Estes aspectos assumem valor existencial unicamente para a pessoa humana; nas pessoas jurídicas, exprimem interesses diversos, o mais das vezes de natureza patrimonial. $\mathrm{O}$ sigilo industrial, o sigilo bancário, etc.

273 A norma em comento possui a seguinte redação: "Aplica-se às pessoas jurídicas, no que couber, a proteção dos direitos da personalidade". 
podem também ser em parte garantidos pelo ordenamento, mas não com base na cláusula geral de tutela da pessoa humana. Deve ser recusada, por exemplo, a tentativa de justificar o sigilo bancário com a tutela da privacidade. Esta exprime um valor existencial (o respeito da intimidade da vida privada da pessoa física); aquele, um interesse patrimonial do banco e/ou do cliente" 274 .

No mesmo sentido preleciona Gustavo Tepedino, que concede interpretação diferenciada ao art. 52 do $\mathrm{CC}$, ao sustentar que este, ao contrário do entendimento esposado pela maioria dos doutrinadores, reconhece que somente as pessoas físicas possuem direitos de personalidade. Para o autor, a norma apenas admite que a proteção cabível a tais direitos, em algumas hipóteses, seja estendida para a proteção da pessoa jurídica $^{275}$.

Nessa esteira, verificam-se as lições de Maria Celina Bodin de Moraes e Heloisa Helena Barbosa, as quais, juntamente com Gustavo Tepedino, abordam outra questão problemática ínsita no mesmo tema: os danos morais das pessoas jurídicas que não possuem fins lucrativos. Nessa hipótese, segundo os doutrinadores, em caso de lesão à honra, não se estaria diante de danos materiais, mas sim de outra categoria, a dos danos institucionais $^{276}$, que atingem a pessoa jurídica em sua credibilidade ou reputação ${ }^{277}$, mas não são danos morais.

\footnotetext{
${ }^{274}$ PERLINGIERI, Pietro. Perfis do Direito Civil: introdução ao Direito Civil Constitucional. 3. ed. Renovar: Rio de Janeiro, 2007. p. 157-158.

${ }^{275}$ TEPEDINO, Gustavo. A tutela da personalidade no ordenamento civil-constitucional brasileiro. In: (Coord.). Temas de Direito Civil. 3. ed. Rio de Janeiro: Renovar, 2004. p. 55-56. Em acréscimo, o autor disserta que: "As lesões atinentes às pessoas jurídicas, quando não atingem, diretamente, as pessoas dos sócios ou acionistas, repercutem exclusivamente no desenvolvimento de suas atividades econômicas, estando a merecer, por isso mesmo, técnicas de reparação específicas e eficazes, não se confundindo, contudo, com os bens jurídicos traduzidos na personalidade humana (a lesão à reputação de uma empresa comercial atinge - mediata ou imediatamente - os seus resultados econômicos, em nada se assemelhando, por isso mesmo, a chamada honra objetiva, com os direitos da personalidade)".

${ }^{276}$ Esta é uma das poucas hipóteses em que seria possível aceitar a existência de outro tipo de dano, uma vez que é difícil de ser enquadrado em qualquer uma das duas modalidades. A matéria, no entanto, ainda foi objeto de poucos estudos e exige mais reflexão. Inclina-se aqui pelo entendimento de que os referidos danos institucionais sejam mesmo danos materiais, pois prejudicam o escopo ou finalidade das mencionadas pessoas jurídicas, ainda que sem fins lucrativos.

${ }^{277}$ MORAES, Maria Celina Bodin de. Danos à pessoa humana - uma leitura civil-constitucional dos danos morais, p. 191-192: "A propósito, não se pode deixar de assinalar a enorme incongruência da jurisprudência nacional, seguida pela doutrina majoritária, no sentido, de um lado, de insistir que o dano moral deve ser definido como dor, vexame, tristeza e humilhação e, de outro, de defender a ideia de que as pessoas jurídicas são passíveis de sofrer dano moral. Das duas, uma: ou bem não mais se sustenta aquela definição - e outra, mais ampla, faz-se necessária -, ou bem a pessoa jurídica, pela sua própria natureza, não tem legitimidade
} 
Por fim, faz-se necessário mencionar, sobre o tema, a existência do Enunciado 286, aprovado na IV Jornada de Direito Civil, que possui a seguinte redação: "Os direitos da personalidade são direitos inerentes e essenciais à pessoa humana, decorrentes de sua dignidade, não sendo as pessoas jurídicas titulares de tais direitos”. Observa-se que, a despeito do entendimento majoritário propalando que a pessoa jurídica pode ser objeto de dano moral, há forte corrente doutrinária em sentido contrário, com a qual este estudo se coaduna.

\subsection{A evolução dos danos morais e sua indenização no Direito brasileiro}

Neste momento, far-se-á, de maneira resumida, uma digressão histórica demonstrativa da evolutiva aceitação da doutrina de reparação dos danos morais no Brasil.

Em fase legislativa anterior à codificação, surgiu o primeiro marco dessa evolução, que foi o Decreto n. 2.681, de 7 de junho de 1912. A norma em comento regulou a responsabilidade civil das estradas de ferro em moldes pouco convencionais para a época.

$\mathrm{O}$ art. 21 do referido Decreto determinou que:

"No caso de lesão corpórea ou deformidade, à vista da natureza da mesma e de outras circunstâncias, especialmente a invalidade para o trabalho ou profissão habitual, além das despesas com o tratamento e os lucros cessantes, deverá pelo juiz ser arbitrada uma indenização conveniente". (sem grifo no original)

Esse dispositivo, ao estabelecer a concessão de uma indenização suplementar às despesas materiais, deu ensejo à entrada da reparação do dano moral no ordenamento jurídico brasileiro.

Alguns anos depois, viria a ser promulgado o Código Civil de 1916. Nos trabalhos de sua elaboração, o problema do dano moral não suscitou debates e, portanto, não houve disposição expressa sobre a matéria. Isso resultou na grande disputa doutrinária acerca da aceitação, ou não, da reparação dos danos morais por aquele Diploma legal. Ademais, no

para tal tipo de compensação"; e TEPEDINO, Gustavo; BARBOSA, Heloisa Helena; MORAES, Maria Celina Bodin de. Código Civil interpretado conforme a Constituição da República. 2. ed. Rio de Janeiro/São Paulo/Recife: Renovar, 2007. v. 1, p. 134-138. 
interior da corrente favorável à aceitação, discutia-se se a indenização a esses danos poderia ser concedida a título genérico ou só para os casos específicos previstos ${ }^{278}$.

A doutrina e a jurisprudência pátrias se dividiram em primeiro lugar entre os que aceitavam e os que não aceitavam a reparação dos danos morais de forma genérica. Em um segundo momento, os partidários da reparação se dividiram entre os que entendiam que o Código de 1916 abrigava a indenização dos danos morais e aqueles que sustentavam que essa legislação não a autorizava. Por fim, entre os defensores da reparação em face da legislação brasileira, havia quem a aceitasse de forma generalizante, ou seja, para qualquer caso, e quem a admitisse somente nas hipóteses previstas pelo Código. A corrente que admitia a reparação dos danos morais em face do ordenamento pátrio era, de longe, a mais numerosa, antes mesmo da promulgação da Constituição Federal de 1988.

Muitos dos partidários da reparação dos danos morais utilizavam-se do art. 76 do CC como fundamento, sustentando que se tratava de um dispositivo generalizante da aceitação do dano moral, porque dispunha que tanto o interesse econômico como o moral davam ensejo à propositura de ação, ou sua contestação ${ }^{279}$. Esse entendimento, no entanto, não era absoluto. Muitos viam apenas caráter processual nessa norma, entre eles Eduardo Espínola e Sá Pereira ${ }^{280}$.

Alcino de Paula Salazar apoiava a reparação dos danos morais em face da legislação brasileira, mas sem fundamentar seu entendimento no referido artigo, no qual via apenas natureza processual. Sustentou que o dano moral era cabível de maneira geral, somente não o sendo na indenização decorrente de homicídio, porque o art. 1.537 discriminava todas as verbas, não dando ensejo à condenação em danos morais nessa hipótese. O art. 1.538, por sua vez, não traria obstáculos à indenização de danos morais, mesmo não se configurando caso de deformidade, em face da imposição de multa ao ofensor, além da condenação no pagamento das despesas de tratamento e dos lucros cessantes $^{281}$.

\footnotetext{
${ }^{278}$ SALAZAR, Alcino de Paula. Reparação do dano moral, p. 69.

${ }^{279}$ GOMES, Luiz Roldão de Freitas. Elementos de responsabilidade civil, p. 91.

${ }^{280}$ ESPÍNOLA, Eduardo. Manual P. de Lacerda; PEREIRA, Sá. Decisões e julgados. In: SALAZAR, Alcino de Paula, op. cit., p. 155-6.

${ }^{281}$ SALAZAR, Alcino de Paula, op. cit., p. 163-165. O autor assim conclui suas ponderações: “[...] o nosso direito admite a tese da ressarcibilidade do dano moral, embora não a tenha acolhido explicitamente, com reserva apenas à hipótese de homicídio, prevista no artigo 1.537 do Código Civil, não se devendo entender como casos excepcionais de aplicação do princípio os que vêm relacionados no mesmo Código na parte relativa à liquidação das obrigações decorrentes de atos ilícitos. Nem a rigor podem ser conceituados todos
} 
Yussef Said Cahali defendia o conteúdo mais amplo do art. 76 retromencionado, posicionando-se ao lado de Clovis Bevilácqua. Ademais, sustentava que os referidos artigos do Código não constituiriam exceção à regra, mas visavam disciplinar a forma de liquidação dos diversos danos, prestando-se a confirmar que na lei civil estava presente a ideia da reparabilidade do dano moral ${ }^{282}$. Yussef Said Cahali pondera, porém, que, no âmbito da jurisprudência, o entendimento da questão era diferente. No caso de homicídio, durante muito tempo, não se indenizaram os danos morais causados aos familiares da vítima. Além disso, o entendimento acerca do art. 76 era mesmo restrito, no sentido de ser considerado meramente processual. Também predominavam decisões somente indenizando os reflexos patrimoniais dos danos morais ${ }^{283}$.

Esse quadro foi gradativamente mudando, com a ampliação do conceito de dano indenizável, para compreender também os danos patrimoniais indiretos e outros tipos de danos que escondiam, sob diversas denominações, sua natureza moral ${ }^{284}$.

Passou-se, assim, a induzir, das hipóteses casuísticas e controvertidas do Código Civil e de outras leis esparsas, um princípio geral da reparabilidade do dano moral que encontrava fundamento, não no discutido art. 76 , mas sim no art. $159^{285}$, que não fazia nenhuma distinção no tocante à reparação dos danos morais e dos danos materiais ${ }^{286}$.

Acrescente-se a tudo o quanto foi dito que não constituiria obstáculo à aplicação desse princípio geral a falta de parâmetros legais para a liquidação do dano moral, uma vez que, para os casos não previstos pelo legislador, havia o art. $1.553^{287}$ do Diploma em comento, que determinava a indenização por arbitramento.

Conforme salientado, o art. 1.537 do CC de 1916 era o que menos dava ensejo à reparação do dano moral, por precisar exatamente as verbas indenizatórias a serem concedidas; contudo, a evolução jurisprudencial e doutrinária nessa matéria foi muito

estes casos como de dano moral em vista dos reflexos patrimoniais que normalmente decorrem de alguns deles" (SALAZAR, Alcino de Paula. Reparação do dano moral, p. 168).

${ }^{282}$ CAHALI, Yussef Said. Dano moral, p. 46-47.

${ }^{283}$ Ibidem, p. 48-50.

${ }^{284}$ Ibidem, p. 51.

285 "Art. 159. Aquele que, por ação ou omissão voluntária, negligencia, ou imprudência, violar direito, ou causar prejuízo a outrem, fica obrigado a reparar o dano".

${ }^{286}$ CAHALI, Yussef Said, op. cit., p. 53. No mesmo sentido, também José de Aguiar Dias (Da responsabilidade civil, t. II, p. 748) e Silvio de Salvo Venosa (Responsabilidade civil, p. 514).

${ }^{287} \mathrm{O}$ artigo em comento dispunha que: "Nos casos não previstos neste Capítulo, se fixará por arbitramento a indenização". 
grande, tendo sido a questão discutida no seio do problema prático da indenização a ser conferida ao dano decorrente de morte de filho menor de idade ${ }^{288}$.

Carlos Roberto Gonçalves assinala que a evolução da questão se deu em três fases. Na primeira, o dano era considerado irreparável porque seria meramente moral, já que o menor não contribui - ou, ao menos, não deveria contribuir - para a renda familiar. De fato, o Código determinava que, nesses casos, a indenização consistiria no pagamento das despesas de tratamento da vítima, seu funeral, e o luto da família, bem como na prestação de alimentos às pessoas a quem o de cujus as devia. Como o menor não deve prestação alimentícia a seus pais, a morte deste só ensejaria o pedido de reembolso das despesas de tratamento, funeral e luto. De fato, em situações como essa, sabe-se que o caráter do dano sofrido pelos pais é eminentemente moral. A segunda fase é representada pela relativa ressarcibilidade, em função de seus reflexos patrimoniais imediatos, no caso de menor que trabalhasse. Na terceira fase, atinge-se a ampla reparabilidade, com a indenização do dano moral e do dano patrimonial remoto, representado pela expectativa de ganho econômico futuro $^{289}$. A questão ficou consolidada com a Súmula n. 491 do $\operatorname{STF}^{290}$.

Consolidou-se, assim, de forma oblíqua, a possibilidade de reparação dos danos morais oriundos do homicídio, o que tanto se relutou em aceitar.

Outra norma importante para o estudo do dano moral no Brasil é o Código Brasileiro de Telecomunicações (Lei Federal n. 4.117, de 27 de agosto de 1962) ${ }^{291}$, que estabeleceu parâmetros para a reparação dos danos morais, tratando desses danos e da possibilidade de sua reparação em expresso texto de lei. Essa Lei, que visa reparar os danos morais oriundos de crimes contra a honra praticados pelos meios de comunicação social, estabeleceu limites para o montante da indenização, que poderia variar entre 5 e 100 vezes o maior salário mínimo vigente no País, de acordo com o art. 84 e seus parágrafos. Esse valor poderia ser dobrado, se fosse comprovada a reincidência ou se o ilícito fosse praticado no interesse de grupos econômicos ou visando a objetivos antinacionais. Os

\footnotetext{
${ }^{288}$ RODRIGUES, Sílvio. Direito Civil - responsabilidade civil, v. 4, p. 193.

${ }^{289}$ GONÇALVES, Carlos Roberto. Responsabilidade civil, p. 555.

${ }^{290}$ A Súmula possui a seguinte redação: "É indenizável o acidente que cause a morte do filho menor, ainda que não exerça trabalho remunerado".

${ }^{291}$ A Lei n. 5.250, de 9 de fevereiro de 1967, denominada Lei de Imprensa, também estabeleceu indenização tarifada para as indenizações decorrentes de situações nela previstas.
} 
limites rígidos trazidos pela Lei não foram ampliados para os demais casos de danos morais, em virtude de ter se considerado mais conveniente o arbítrio judicial ${ }^{292}$.

Seguindo a trajetória das leis retromencionadas, a jurisprudência foi se tornando mais flexível, mas não totalmente segura, até que a Constituição Federal de 1988 dissipou todas as possíveis dúvidas, garantindo o ressarcimento de prejuízos materiais e morais em seu art. $5^{\mathrm{o}}$, incs. V e X, ao assegurar o direito de resposta e a inviolabilidade da imagem, da intimidade e da honra da pessoa.

Após a Constituição, surgiram importantes leis garantindo a indenização dos danos puramente morais, como o Código de Defesa do Consumidor (CDC - Lei n. 8.078, de 11 de setembro de 1990), no art. 6º , incs. VI e VII, e o Estatuto da Criança e do Adolescente (ECA - Lei n. 8.069, de 13 de julho de 1990), art. $17^{293}$.

Por fim, entrou em vigor o atual Código Civil (Lei n. 10.406, de 10 de janeiro de 2002), que não contribuiu com muitas inovações para o ordenamento do ponto de vista da responsabilidade civil, mas consolidou definitivamente a possibilidade de reparação dos danos morais. A norma genérica de reparação dos danos morais que faltava no antigo Código foi finalmente inserida no art. $186^{294}$ do Código vigente, que reproduz o antigo art. 159, corolário da indenização civil, com o acréscimo da expressão "exclusivamente moral”, trazendo para a lei civil o que já havia sido consagrado pela Constituição Federal de 1988.

Outro artigo que também se correlaciona ao art. 186, é o $927^{295}$, que se trata de norma ainda mais genérica e ampla do que o primeiro e dispõe apenas acerca da reparação

\footnotetext{
292 SILVA, Wilson Melo da. O dano moral e sua reparação, p. 469. Além disso, ao se estipular previamente o valor da indenização, permite-se que o ofensor possa calcular que o proveito obtido com o dano será maior do que o valor do ressarcimento, de modo que resolva cometê-lo mesmo assim.

293 A redação dos artigos supracitados é a seguinte:

CDC - "Art. 6º São direitos básicos do consumidor: [...]

VI - a efetiva prevenção e reparação de danos patrimoniais e morais, individuais, coletivos e difusos;

VII - o acesso aos órgãos judiciários e administrativos, com vistas à prevenção ou reparação de danos patrimoniais e morais, individuais, coletivos ou difusos, assegurada a proteção jurídica, administrativa e técnica aos necessitados [...]".

ECA - "Art. 17. O direito ao respeito consiste na inviolabilidade da integridade física, psíquica e moral da criança e do adolescente, abrangendo a preservação da imagem, da identidade, da autonomia, dos valores, ideias e crenças, dos espaços e objetos pessoais".

294 “Art. 186. Aquele que, por ação ou omissão voluntária, negligência ou imprudência, violar direito e causar dano a outrem, ainda que exclusivamente moral, comete ato ilícito".

295 “Art. 927. Aquele que, por ato ilícito (arts. 186 e 187), causar dano a outrem, fica obrigado a repará-lo.

Parágrafo único. Haverá obrigação de reparar o dano, independentemente de culpa, nos casos especificados em lei, ou quando a atividade normalmente desenvolvida pelo autor do dano implicar, por sua natureza, risco para os direitos de outrem".
} 
do dano causado a outrem por ato ilícito. A inovação do dispositivo consta do parágrafo único, que trata das hipóteses de reparação independente de culpa ${ }^{296}$.

Os arts. 944 e $945^{297}$, sem correspondência no antigo Código, procuram criar parâmetros para a reparação dos danos, o que é particularmente importante no que concerne aos danos morais. Em suma, determinam que o dano seja reparado de acordo com sua extensão, ressalvados os casos em que haja excessiva desproporção entre o grau de culpa e o dano, quando o juiz pode reduzir o valor da indenização ${ }^{298}$. Tendo também a vítima agido com culpa - a chamada culpa concorrente -, o grau de sua participação no evento danoso influenciará na indenização do dano. Com exceção do disposto no parágrafo único do art. 944, esses critérios há muito já vinham sendo utilizados pela jurisprudência, mas não constavam de nenhum texto legal ${ }^{299}$.

O antigo art. 1.537, correspondente ao atual art. $948^{300}$, que tratava da indenização por homicídio, foi corrigido para que nenhuma verba fosse excluída da indenização. $\mathrm{O}$ Código mais uma vez apenas reforçou a evolução previamente conquistada pela jurisprudência, relatada anteriormente.

Os arts. 949 e $950^{301}$, por sua vez, correspondem aos arts. 1.538 e 1.539 do Código de 1916. Ambos se referem aos danos decorrentes de ofensa ou lesão à saúde. A mudança

${ }^{296}$ GONÇALVES, Carlos Roberto. Comentários ao Código Civil - parte especial do direito das obrigações (arts. 927 a 965), p. 313.

${ }^{297}$ Estes artigos têm a seguinte redação:

"Art. 944. A indenização mede-se pela extensão do dano.

Parágrafo único. Se houver excessiva desproporção entre a gravidade da culpa e o dano poderá o juiz reduzir, equitativamente, a indenização".

“Art. 945. Se a vítima tiver concorrido culposamente para o evento danoso, a sua indenização será fixada tendo-se em conta a gravidade de sua culpa em confronto com a do autor do dano".

${ }^{298}$ José de Aguiar Dias, já na terceira edição de sua obra, defendia posicionamento de que a equidade deveria ser aplicada para redução da indenização de acordo com as posses do ofensor. Defendia, igualmente, que deveria ser possível a revisão da condenação em caso de alteração das condições econômico-financeiras das partes após a prolatação de sentença (Da responsabilidade civil, t. II, p. 771 et seq.). A despeito do que consta do Código e do que preconizam diversos doutrinadores, este estudo diverge da tese de diminuição da indenização do dano com apoio na equidade, em face do princípio da reparação integral do dano.

${ }^{299}$ GONÇALVES, Carlos Roberto, op. cit., p. 519-524.

300 “Art. 948. No caso de homicídio, a indenização consiste, sem excluir outras reparações:

I - no pagamento das despesas com o tratamento da vítima, seu funeral e o luto da família;

II - na prestação de alimentos às pessoas a quem o morto os devia, levando-se em conta a duração provável da vida da vítima".

301 Está-se incluindo a redação dos artigos apenas para fazer referência neste momento, mas eles serão estudados posteriormente já que se relacionam de forma mais próxima com o objeto deste trabalho:

“Art. 949. No caso de lesão ou outra ofensa à saúde, o ofensor indenizará o ofendido das despesas do tratamento e dos lucros cessantes até o fim da convalescença, além de algum outro prejuízo que o ofendido prove haver sofrido".

"Art. 950. Se da ofensa resultar defeito pelo qual o ofendido não possa exercer o seu ofício ou profissão, ou se lhe diminua a capacidade de trabalho, a indenização, além das despesas do tratamento e lucros cessantes 
de um Código para o outro foi bastante nítida, sendo a redação atual bem mais abrangente do que a do Código anterior.

Vê-se que as mudanças trazidas pelo atual Código Civil são pouco significativas, pelo menos no que tange ao estudo do dano moral e da responsabilidade civil, em consequência da atualização do antigo Código conquistada pela própria jurisprudência, durante os anos em que vigorou.

\subsection{Fundamentos jurídicos da reparação do dano moral}

De modo geral, são ressaltados dois fundamentos para a reparação dos danos morais $^{302}$ : a satisfação compensatória e a pena privada ${ }^{303}$.

Na doutrina da satisfação compensatória, a prestação é feita de acordo com o dano sofrido, destinando-se a compensar a vítima pelo menoscabo suportado, funcionando como um lenitivo. A prestação é feita tendo em vista a extensão da lesão e se destina a compensá-la, à semelhança do que ocorre na reparação do dano patrimonial ${ }^{304}$, guardadas as devidas diferenças entre os dois tipos de dano.

Já na da pena privada, sustenta-se que a reparação por equivalência é artificial, uma vez que o que a vítima realmente quer, e o que lhe é concedido, é o reconhecimento de seu direito mediante a punição do ofensor ${ }^{305}$. Trata-se de simples afirmação da existência da tutela jurídica. Essa é, atualmente, a corrente menos numerosa.

A função punitiva também pode estar revestida da chamada teoria do desestímulo função pedagógica ou deterrence -, segundo a qual se deve inserir no âmbito da indenização quantia suficiente a desestimular o ofensor a não persistir no comportamento lesivo. Trata-se, portanto, de um efeito preventivo de danos morais ${ }^{306}$.

até o fim da convalescença, incluirá pensão correspondente à importância do trabalho para que se inabilitou, ou da depreciação que ele sofreu.

Parágrafo único. O prejudicado, se preferir, poderá exigir que a indenização seja arbitrada e paga de uma só vez".

${ }^{302}$ Esses fundamentos geralmente se confundem com os próprios da responsabilidade civil, conforme será possível verificar no transcorrer do texto.

${ }^{303}$ A doutrina da pena privada inclui também a do desestímulo.

${ }^{304}$ SALAZAR, Alcino de Paula. Reparação do dano moral, p. 141-143.

${ }^{305}$ Ibidem, p. 141-142.

${ }^{306}$ Teresa Ancona Lopez, apesar de defender o efeito preventivo como função da responsabilidade civil, afirma que esta se encontra desgastada em decorrência da generalização dos seguros de responsabilidade e assinala que: "É necessário que se ponha em prática o princípio de prevenção como instrumento anterior ao dano, e não como consequência desse (função automática da indenização), quando o seguro já 'reparou' os prejuízos sofridos. Aliás, seguro é o oposto do princípio da prevenção" (Princípio da precaução e evolução 
Acerca da função da reparação dos danos morais, Agostinho Alvim ressalta que, por um lado, se esta for caracterizada como pena, nada impediria que o valor da indenização fosse previamente taxado; por outro lado, se fosse entendida como reparação, a prévia fixação não se configuraria justa, nem realizável, em razão da infinita variedade de casos em que poderia surgir ${ }^{307}$. É interessante ressaltar, todavia, que tal observação jamais é levada em conta pelos defensores da natureza punitiva da indenização dos danos extrapatrimoniais.

A despeito das duas correntes antagônicas ora explicitadas, o posicionamento adotado pela maioria dos autores é o da natureza mista do instituto, ou seja, segundo eles, a indenização dos danos morais teria, até ao mesmo tempo, natureza compensatória e aflitiva $^{308}$. O mesmo se observa, quase sem exceções, na jurisprudência ${ }^{309}$.

Yussef Said Cahali, v.g., defende a natureza mista da reparação, a despeito de considerar que o caráter de pena concedido aos danos morais era o que fazia que alguns doutrinadores se opusessem à possibilidade de reparação de tais danos, sob a fundamentação de que a pena é incompatível com o direito privado ${ }^{310}$.

René Savatier também defende o caráter compensatório e penal, acrescentando que em regra este último caráter é levado em conta pela jurisprudência. $\mathrm{O}$ autor vê o caráter precipuamente penal quando se consideram como critérios para avaliação do montante da condenação a culpabilidade do agente e os seus recursos financeiros. Segundo ele, seria a necessidade de imposição de uma pena que levaria os juízes a avaliarem o quantum indenizatório de acordo com esses critérios ${ }^{311}$. Essa correlação é de grande propriedade. De

da responsabilidade civil, p. 78-79). No mesmo diapasão, André Tunc (La responsabilité civile. 2. ed. Paris: Economica, 1989. p. 139) salienta que a responsabilidade civil como instrumento de prevenção parece sofrer de duas fraquezas fundamentais: em primeiro lugar, ela não implica uma relação necessária entre o grau de desvio e a sanção. Uma política de prevenção, ao contrário, exigiria que a sanção fosse sempre mensurada pelo grau de culpa. Em segundo lugar, os efeitos da prevenção são reduzidos a muito pouco em decorrência da generalização do seguro de responsabilidade (ao menos na França, local onde são desenvolvidos o estudo do autor).

${ }^{307}$ ALVIM, Agostinho. Da inexecução das obrigações e suas conseqüências, p. 238-239.

${ }^{308}$ Nessa esteira: SALAZAR, Alcino de Paula, Reparação do dano moral, p. 146; GONÇALVES, Carlos Roberto. Responsabilidade civil, p. 566-568.

${ }^{309}$ A título de amostragem, verifiquem-se: STJ. 4. T. REsp 866220/BA. Rel. Min. Luis Felipe Salomão. j. 17.08.10. Dje 13.09.10. v.u.; e STJ. 1. T. REsp. 1047986/RN. Rel. Min. Luiz Fux. j. 03.03.09. Dje 26.03.09.

${ }^{310}$ CAHALI, Yussef Said. Dano moral, p. 39, nos seguintes termos: "Nessas condições, tem-se portanto que o fundamento ontológico da reparação dos danos morais não difere substancialmente, quando muito em grau, do fundamento jurídico do ressarcimento dos danos patrimoniais, permanecendo ínsito em ambos os caracteres sancionatório e aflitivo, utilizados pelo direito moderno".

311 SAVATIER, René. Traité de la responsabilité civile en Droit français, p. 103, nos seguintes termos: "Mais c'est cette idée de peine privée qui explique que la réparation du dommage moral soit, d'autre part, particulièremente influencée par la degré de culpabilité de l'agent et par l'entendue de sés ressources. C'est aussi l'idée de la necessite d'une punition qui pousse les tribunaux à frapper de dommages-intérêts l'auteur 
fato, os critérios da culpabilidade do lesante e da condição econômica das partes só se justificam com a aplicação da função punitiva e jamais com a meramente compensatória, pois ocorre o deslocamento de foco da vítima para o ofensor ${ }^{312}$.

Poder-se-ia continuar longamente apresentando a lista de autores que defendem o duplo caráter da reparação dos danos morais, o que, contudo, extrapolaria o propósito do presente trabalho. O fato é que, não obstante o posicionamento majoritário da doutrina, entende-se que o fundamento para a aludida reparação é somente o compensatório, uma vez que não deveria ser função do Direito Civil impor sanção de caráter penal ${ }^{313}$. Denota, ainda, ser bastante paradoxal a adoção simultânea de ambos os critérios, uma vez que a quantia a mais a ser concedida para a vítima, a título de pena, acabaria por "enriquecê-la", na medida em que lhe é dado mais do que o necessário para compensá-la. Entende-se, também, equivocada a diminuição do valor indenizatório em decorrência da baixa culpabilidade do ofensor, a despeito do previsto pelo art. 944, parágrafo único, do CC, uma que se preconiza a doutrina de reparação integral do dano.

As assertivas apresentadas, contudo, não implicam a desconsideração da necessidade de proteção da dignidade humana também do ofensor. Ao contrário, pois aquele que causa danos também deve ser protegido pelo ordenamento jurídico, não sendo justo que seja desprovido de todos os seus bens em decorrência de um equívoco mínimo que eventualmente possa ter tomado grandes proporções. No entanto, além do art. $1^{\underline{o}}$ da Lei n. 8.009, de 29 de março de 1990, que tornou impenhorável o bem de família, o Direito Processual possui meios eficientes de manutenção da dignidade do indivíduo em casos

d'un prejudice matériel, leur paraîtrait sans sanction civile suffisante". (Tradução livre: "Mas é esta ideia de pena privada que explica que a reparação do dano moral seja, de outra parte, particularmente influenciada pelo grau de culpabilidade do agente e pela extensão de seu patrimônio. É também a ideia de necessidade de uma punição que compele os tribunais de infligir de perdas e danos o autor de um prejuízo material, quando lhes pareça sem sanção civil suficiente [o ato danoso]".)

312 Assim também se posicionam Geneviève Viney e Basil Markesinis ao constatarem que o ideal de compensação do dano é o principal argumento para a reparação dos danos morais tanto na França quanto na Inglaterra, mas que, no entanto, a ideia de pena privada não seria completamente afastada, uma vez que serviria para mitigar a regra de reparação integral, com o intuito de se poder fazer variar a condenação em função da gravidade da falta constatada (La réparation du dommage corporel - essai de comparaison des droits anglais et français. Paris: Economica, 1985. p. 54).

${ }^{313}$ Em sentido contrário, verifique-se Antônio Junqueira de Azevedo, que enumera diversos dispositivos legais, sustentando serem de natureza punitiva no CC (Por uma nova categoria de dano na responsabilidade civil: o dano social. In: Novos estudos e pareceres de direito privado, p. 379-389). A despeito do entendimento esposado pelo autor, entende-se que os exemplos mencionados têm função indenizatória e não punitiva. É o caso, v.g., do art. 940 do CC, cuja redação determina àquele que demanda por dívida já paga a obrigação de pagá-la em dobro ao demandado. O doutrinador vê nesse preceito uma punição ao demandante, mas a lógica é invertida: o que busca a lei é indenizar a violação da honra do credor que, mesmo estando com todas as suas obrigações em dia, se vê réu em um procedimento judicial. O dispositivo legal apenas facilita a prova do dano, estabelecendo previamente o valor da indenização. 
semelhantes, resguardando salários e proventos semelhantes e até mesmo aplicações financeiras em poupança, conforme se observa do art. 649 do CPC, transcrito a seguir, ipsis litteris:

“Art. 649 - São absolutamente impenhoráveis:

I - os bens inalienáveis e os declarados, por ato voluntário, não sujeitos à execução;

II - os móveis, pertences e utilidades domésticas que guarnecem a residência do executado, salvo os de elevado valor ou que ultrapassem as necessidades comuns correspondentes a um médio padrão de vida;

III - os vestuários, bem como os pertences de uso pessoal do executado, salvo se de elevado valor;

IV - os vencimentos, subsídios, soldos, salários, remunerações, proventos de aposentadoria, pensões, pecúlios e montepios; as quantias recebidas por liberalidade de terceiro e destinadas ao sustento do devedor e sua família, os ganhos de trabalhador autônomo e os honorários de profissional liberal, observado o disposto no $\S 3^{\circ}$ deste artigo;

V - os livros, as máquinas, as ferramentas, os utensílios, os instrumentos ou outros bens móveis necessários ou úteis ao exercício de qualquer profissão;

VI - o seguro de vida;

VII - os materiais necessários para obras em andamento, salvo se essas forem penhoradas;

VIII - a pequena propriedade rural, assim definida em lei, desde que trabalhada pela família;

IX - os recursos públicos recebidos por instituições privadas para aplicação compulsória em educação, saúde ou assistência social;

X - até o limite de 40 (quarenta) salários mínimos, a quantia depositada em caderneta de poupança. 
XI - os recursos públicos do fundo partidário recebidos, nos termos da lei, por partido político".

Posicionam-se de acordo com o aqui esposado, ou seja, preconizando a natureza exclusivamente reparatória do dano moral, entre outros, Wilson Melo da Silva ${ }^{314}$, Philippe Le Tourneau ${ }^{315}$, Anderson Schreiber ${ }^{316}$ e Maria Celina Bodin de Moraes ${ }^{317}$.

No que tange ao pensamento de Maria Celina Bodin de Moraes, este deve ser analisado com mais pormenores. A autora, preliminarmente, sustenta que a inexistência de critérios seguros, ou legais, tem feito a jurisprudência afirmar a existência de um caráter punitivo, a ser sempre considerado na reparação como forma de dissuasão de algumas condutas e também como meio de aumentar o valor das indenizações pagas sob aquele título. Lembra que essa tendência tem também influenciado a doutrina, sendo hoje corrente minoritária a que nega completamente o caráter punitivo da reparação do dano moral, apesar desse critério não ter sido adotado pelo legislador ordinário - pelo menos por enquanto, em decorrência do projeto de alteração do Código, que será comentado adiante. Acrescenta que, em sistemas como o do Brasil, reconhecer a existência de um caráter

\footnotetext{
${ }^{314}$ Wilson Melo da Silva afirma que a indenização pelos danos morais não tem verdadeiramente o caráter de pena privada. Sustenta que para que haja pena é necessário um texto legal expresso que a comine, e um delito que a justifique; todavia, para a existência do dano, não são necessários tais requisitos. O delito, no dano, é apenas o fato gerador. No juízo cível se busca ressarcir a consequência do delito e não o delito mesmo. Além disso, o delito pressupõe a culpa e visa à punição da culpabilidade do agente, algo que não acontece com o dano. Segundo o autor, "mira-se, na responsabilidade civil, a pessoa do ofendido e não a do ofensor; a extensão do prejuízo, para graduação do quantum reparador, e não a culpa do autor" ( $O$ dano moral e sua reparação, p. 572).

${ }^{315}$ Le Tourneau Philippe também se inclina na direção da natureza satisfativa, ao afirmar que se a concepção de pena privada do dano moral, na qual este teria o escopo de sancionar um dever moral, não tendo assim caráter indenizatório, mas sim exemplar, fosse exata, a ação de indenização de danos morais não passaria nem aos credores nem aos herdeiros da vítima. Além disso, não poderia ser exercida, em caso de morte de um familiar, por só um deles, à exclusão dos outros, bem como não poderia ser cumulada com a ação contra a companhia de seguros e nem ser exercida contra o Estado porque, contra este, a ideia de pena privada não faz sentido. Afasta, assim, completamente a natureza aflitiva, afirmando que a função da reparação do dano moral é a de compensar (La responsabilité civile. 2. ed. Paris: Dalloz, 1976, p. 172-173).

${ }^{316}$ SCHREIBER, Anderson. Novos paradigmas da responsabilidade civil - da erosão dos filtros da reparação à diluição dos danos, p. 191 e 205-206. O autor esclarece que a jurisprudência brasileira confunde compensatory damages e punitive damages, que são arbitrados separadamente nos Estados Unidos, salientando que: "a incorporação dos punitive damages pela prática judicial brasileira traz, ainda, consideráveis inconsistências face ao princípio da proibição do enriquecimento sem causa - já que a quantia paga a título de punição vem, inexplicavelmente, atribuída à vítima -, além de ferir frontalmente a dicotomia entre ilícito civil e ilícito penal, aplicando penas sem balizamento legal, sem as garantias processuais próprias e sem a necessária tipificação prévia das condutas reprováveis. Por fim, a indenização punitiva não raro se mostra ineficaz em seu próprio intuito, uma vez que na responsabilidade civil, nem sempre o responsável é o culpado e nem sempre o culpado será punido (porque ele pode ter feito um seguro)" (ibidem, p. 206).

${ }^{317}$ MORAES, Maria Celina Bodin de. Danos à pessoa humana - uma leitura civil-constitucional dos danos morais.
} 
punitivo representaria uma importante exceção ao princípio da equivalência entre dano e reparação ${ }^{318}$.

De fato, são bastante pertinentes as observações apresentadas pela autora, em particular quando ela nota que, ao se tentar cumprir funções de natureza antagônica punitiva e compensatória -, obtém-se um resultado bastante conflituoso, no sentido de que se deve punir a ofensa, mas não a ponto de enriquecer a vítima. É, no entanto, bastante evidente que a vítima sairá "enriquecida”, na medida em que estará recebendo necessariamente mais do que a compensação do dano exigiria. Conforme assinalado, partilha-se integralmente desse entendimento.

Maria Celina Bodin de Moraes faz também outra importante colocação, no que se refere ao sistema norte-americano, de onde os chamados "danos punitivos" (punitive damages) foram importados, no qual, segundo a autora, não há nenhuma preocupação com o enriquecimento da vítima, que seria, na verdade, até mesmo pressuposto. Além disso, as questões relacionadas às indenizações desses danos, em lugar de serem reguladas no âmbito de critérios e de parâmetros estritamente jurídicos, têm sido absorvidas pela lógica de mercado ${ }^{319}$, fato esse totalmente incompatível com o sistema brasileiro de indenização.

A doutrinadora faz uma relevante advertência com relação ao uso do critério punitivo, nos seguintes termos:

$$
\begin{aligned}
& \text { “[...] ao se adotar sem restrições o caráter punitivo, deixando-o ao } \\
& \text { arbítrio unicamente do juiz, corre-se o risco de violar o } \\
& \text { multissecular princípio da legalidade, segundo o qual nullum } \\
& \text { crimem, nulla poena sine lege; além disso, em sede civil, não se } \\
& \text { colocam à disposição do ofensor as garantias substanciais e } \\
& \text { processuais como, por exemplo, a maior acuidade quanto ao ônus } \\
& \text { da prova - tradicionalmente previstas ao imputado no juízo } \\
& \text { criminal” } 320
\end{aligned}
$$

Maria Celina Bodin de Moraes pondera que esse critério pode ser aplicado quando for imperioso dar uma resposta à sociedade, no caso de a conduta ofensora ser

\footnotetext{
${ }^{318}$ MORAES, Maria Celina Bodin de. Danos à pessoa humana - uma leitura civil-constitucional dos danos morais, p. 28-29.

${ }^{319}$ Ibidem, p. 33/233.

${ }^{320}$ Ibidem, p. 260.
} 
particularmente ultrajante em relação à consciência social. De qualquer modo, seria necessária a manifestação do legislador, tanto para delinear os contornos do instituto quanto para estabelecer garantias processuais correlativas, exigíveis sempre que se trate de juízo de punição ${ }^{321}$.

A autora apregoa, ainda, que o critério punitivo também poderia ser utilizado em situações potencialmente causadoras de lesões a um grande número de pessoas, em casos de direitos difusos. Nessa hipótese, o valor excedente da indenização, a ser pago a título de punição, não deveria ser destinado à vítima singularmente considerada, mas, de acordo com o sistema brasileiro, e em obediência às previsões da Lei n. 7.347/1985, serviria para beneficiar um número maior de pessoas, mediante o depósito das condenações em fundos já especificados ${ }^{322}$.

A despeito de sustentar posição divergente da teoria do desestímulo, por se entender que não é função da responsabilidade civil, muito menos da condenação em danos morais, punir comportamentos, mesmo que perniciosos, este estudo vislumbra no pensamento da autora grande perspicácia, podendo ser de conveniente aplicação, em casos específicos a serem determinados pelo magistrado, particularmente quando o agente obtém lucro com a conduta ilícita, inclusive depois de ter reparado o dano.

Acerca de que danos não representam somente um menoscabo ao indivíduo, mas também um malefício à sociedade como um todo, convém lembrar o conceito de dano social desenvolvido por Antônio Junqueira de Azevedo, sustentando que, quando um ato é doloso ou gravemente culposo, ele não é somente lesivo ao indivíduo, mas atinge toda a sociedade $^{323}$. Acrescenta, ainda, que o art. 944 do CC não impede a fixação, pelo

\footnotetext{
${ }^{321}$ Diogo L. Machado de Melo sustenta que, aplicando-se o disposto no art. 883, parágrafo único, do CC, é possível reverter a indenização para terceiros em qualquer hipótese, sem necessidade de norma expressa (A função punitiva da reparação dos danos morais (e a destinação de parte da indenização para entidades de fins sociais - artigo 883, parágrafo único, do Código Civil). In: DELGADO, Mário Luiz; ALVES, Jones Figueiredo (Coord.). Questões controvertidas - responsabilidade civil, v. I, p. 121). O artigo do Código Civil possui a seguinte redação:

"Art. 883. Não terá direito à repetição aquele que deu alguma coisa para obter fim ilícito, imoral, ou proibido por lei.

Parágrafo único. No caso deste artigo, o que se deu reverterá em favor de estabelecimento local de beneficência, a critério do juiz".

Não se partilha, contudo, desse entendimento, tendo em vista que o art. 883 está inserido nas disposições pertinentes ao pagamento indevido, e somente nessa seara pode ser aplicado. Posiciona-se, assim, pela necessidade de legislação específica para que a indenização oriunda de dano à vítima seja revertida em favor de terceiros.

${ }^{322}$ MELO, Diogo L. Machado de, op. cit., p. 263.

${ }^{323}$ AZEVEDO, Antônio Junqueira de. Por uma nova categoria de dano na responsabilidade civil: o dano social. In: ___ Novos estudos e pareceres de direito privado, p. 382: "Portanto, a nossa tese é bem clara: a responsabilidade civil deve impor indenização por danos individuais e por danos sociais. Os danos
} 
magistrado, de uma verba autônoma para a reparação do dano social. Até aqui, seu posicionamento assemelha-se ao de Maria Celina Bodin de Moraes. O autor em comento conclui seu trabalho afirmando que o valor acrescido em razão desse dano deve ser destinado à vítima, o que é manifesta incoerência. Ou o dano é social, e sua reparação deve ser revertida à sociedade, preferencialmente pela constituição de um fundo, ou o dano é individual, sendo destinado à vítima em decorrência da função punitiva atribuída à responsabilidade civil, com a qual não se coaduna. Com efeito, entende-se que, diante de um comportamento indesejável, o Estado deve impor uma multa administrativa ao ofensor - e não uma indenização -, cujo produto reverterá para toda a sociedade, e não em prol de somente um indivíduo. Por fim, resta lembrar a existência do Projeto de Lei n. 276/2007, no qual se pretende alterar quase duas centenas de artigos do Código Civil de 2002. Entre tais modificações, está previsto o acréscimo de novo parágrafo ao art. $944^{324}$, justamente para inserir a natureza punitiva na reparação do dano moral. Esse parágrafo $2^{\circ}$ teria a seguinte redação: "A reparação do dano moral deve constituir-se em compensação ao lesado e adequado desestímulo ao lesante". Caso tal alteração realmente se proceda, o critério punitivo ficará consolidado na legislação ordinária, o que, de acordo com o preconizado neste estudo, seria um grande equívoco, uma vez que se perderia de vista a vítima, figura principal da reparação civil. O critério seria, portanto, falho.

Considerar-se a pena privada, ainda que parcialmente, fundamento da indenização de danos, quaisquer que sejam eles, é inadmissível, a despeito do que venha prever a legislação. A indenização visa à recomposição de determinada situação jurídica a seu estado anterior, quando ainda não havia ocorrido o dano. Quando isso não é possível, como no caso dos danos morais, um valor, em dinheiro, é atribuído à vítima, para que ela, usufruindo outras situações prazerosas que a pecúnia pode proporcionar, consiga superar, de forma menos dolorida, o dano sofrido.

\footnotetext{
individuais são os patrimoniais, avaliáveis em dinheiro - danos emergentes e lucros cessantes - e os morais -, caracterizados por exclusão e arbitrados como compensação para a dor, para lesões de direito de personalidade e para danos patrimoniais de quantificação precisa impossível. Os danos sociais, por sua vez, são lesões à sociedade, no seu nível de vida, tanto por rebaixamento de seu patrimônio moral principalmente a respeito da segurança - quanto por diminuição de sua qualidade de vida. Os danos sociais são causa, pois, de indenização punitiva por dolo ou culpa grave, especialmente, repetimos, se atos que reduzem as condições coletivas de segurança, e de indenização dissuasória, se atos em geral da pessoa jurídica, que trazem uma diminuição do índice de qualidade de vida da população".

${ }^{324}$ A redação atual do dispositivo é a seguinte:

"Art. 944. A indenização mede-se pela extensão do dano.

Parágrafo único. Se houver excessiva desproporção entre a gravidade da culpa e o dano, poderá o juiz reduzir, eqüitativamente, a indenização".
} 
Se, todavia, a condenação em dinheiro funciona como uma pena para o responsável, isto também não interessa ao Direito Civil, que, ao conceder indenização, visa ao benefício da vítima, e não ao prejuízo do réu. É claro que, toda vez que alguém é condenado a ressarcir um dano, esse ressarcimento constituirá uma sanção à conduta lesiva realizada, mas isso não deve influenciar a fundamentação da indenização civil. A punição da figura do ofensor só deve ser vislumbrada no âmbito penal.

A questão da natureza da reparação do dano moral está estreitamente relacionada com a problemática dos critérios a serem utilizados para mensurá-lo. Entende-se que, no âmbito civil, não se deve considerar o grau de culpa ou dolo, mas sim a extensão do dano provocado. Da mesma maneira, a condição econômica das partes também não deve ser avaliada, uma vez que denota o caráter aflitivo da condenação. Essa questão será aprofundada a seguir.

\subsection{Critérios para a compensação do dano moral}

Mesmo com o advento do Código Civil de 2002, a questão da formulação de critérios para a compensação do dano moral remanesceu sem disposição legal, uma vez que o referido estatuto civil nada dispõe sobre o assunto. O juiz continuará com a incumbência de, no exame do caso concreto, conceder ou não a indenização, graduando-a de acordo com o sofrimento experimentado pela vítima ${ }^{325}$.

Muitos são os que criticam o excessivo arbítrio concedido ao magistrado, o que, contudo, não resultou no fortalecimento da aplicação de critérios de $\operatorname{tarifação~}^{326}$, mediante os quais o valor da indenização do dano moral é pré-fixado, de acordo com a hipótese em que se encaixe o caso concreto. Seria, dessa forma, concedida determinada quantia para os casos de homicídio, outra para os de lesões corporais deformantes, e assim por diante. A impopularidade da tarifação advém de seus próprios inconvenientes. O principal deles é a possibilidade do lesante, sabendo antecipadamente o valor da condenação, avaliar as consequências da lesão, o que lhe conferiria a possibilidade de optar em cometê-la se assim fosse auferir mais do que o que iria perder com o pagamento do valor taxado para o ato

\footnotetext{
${ }^{325}$ RODRIGUES, Sílvio. Direito Civil - responsabilidade civil, v. 4, p. 192.

${ }^{326}$ Apesar do desprestígio da doutrina favorável à tarifação, o Projeto de Lei n. 150/1999, de autoria do Senador Antônio Carlos Valadares, pretende reintroduzir a tarifação no ordenamento pátrio. Após o encaminhamento da proposta à Câmara dos Deputados, o projeto foi arquivado.
} 
ilícito ${ }^{327}$. Além disso, o valor tarifado pode ser inadequado ao caso concreto: em algumas ocasiões, não seria suficiente para compensar o dano; em outras, seria desproporcionalmente elevado. Ressalte-se, ainda, que há inúmeros casos particulares que não seriam abarcados pela norma, em decorrência de sua completa ausência de adaptação aos modelos legais.

De qualquer maneira, predominou no sistema brasileiro o critério do arbitramento pelo juiz, a senso do art. 1.553 do CC de 1916 e do art. 946 do CC de $2002^{328}$.

$\mathrm{Na}$ falta de disposição legal, os Tribunais começaram a se servir de outros expedientes para a aferição do montante indenizatório.

Durante muito tempo, utilizaram-se, por analogia, os critérios estabelecidos pelo Código Brasileiro de Telecomunicações (Lei n. 4.117/1962) e pela Lei de Imprensa (Lei n. 5.250/1967). Ainda que a tarifação oriunda destas leis não possa mais subsistir em razão do disposto no art. 5ํㅜㄹ inc. V, da Constituição Federal de 1988, muitos doutrinadores sustentam que algumas de suas recomendações podem ser utilizadas, em particular os critérios constantes do art. 53 da Lei de Imprensa: consideração da situação econômica do lesado, da intensidade do sofrimento suportado pela vítima, da gravidade, natureza e repercussão da ofensa, do grau de culpa e da situação econômica do ofensor, bem como das circunstâncias que envolveram os fatos ${ }^{329}$. Ainda que por analogia pudessem ser aplicados os critérios arrolados, eles não são os mais adequados, por desconsiderarem o aspecto principal da indenização, que é a extensão do dano.

Silvio de Salvo Venosa arrola como critérios a serem utilizados as condições pessoais do lesado, o sofrimento por ele suportado, as circunstâncias traumáticas da conduta do ofensor - o que não deixa de ser avaliação da culpabilidade -, as sequelas que

${ }^{327}$ GONÇALVES, Carlos Roberto. Responsabilidade civil, p. 569. Da mesma forma, se opõe à tarifação, Silvio de Salvo Venosa: "Sempre que se tarifa o valor de um dano, corre-se o risco de o próprio legislador conceder um salvo-conduto ao ofensor para transgredir a norma” (Responsabilidade civil, p. 210). Assim também se posiciona Maria Celina Bodin de Moraes, in verbis: "Cada perda e cada dano deverão ser avaliados separadamente, valorizados em relação à pessoa da vítima (pessoalmente, quase se poderia dizer), de modo que de nada servirá produzir uma tabela, por assim dizer fixa, do que hoje se procura chamar de "preço da dor". Claro está que, considerando todas as circunstâncias do caso concreto, tampouco será possível afastar-se demais de algum valor médio, que será resultado da repetição de valores atribuídos a casos semelhantes, controlados pela instância superior" (Danos à pessoa humana - uma leitura civilconstitucional dos danos morais, p. 310).

${ }^{328}$ A redação destes artigos, apenas para efeitos de comparação, é a seguinte:

“Art. 1.553. Nos casos não previstos neste Capítulo, se fixará por arbitramento a indenização".

"Art. 946. Se a obrigação for indeterminada, e não houver na lei ou no contrato disposição fixando a indenização devida pelo inadimplente, apurar-se-á o valor das perdas e danos na forma que a lei processual determinar".

${ }^{329}$ GONÇALVES, Carlos Roberto, op. cit., p. 570. 
afetam a vítima e também sua idade. O autor confere especial importância ao fator idade, afirmando que, por um lado, conceder uma indenização muito vultosa a quem já tem idade avançada poderia beneficiar mais seus herdeiros do que ela mesma, o que não seria a finalidade da indenização; e, por outro, atribuir indenização ínfima a um jovem, bastante traumatizado, também não seria correto ${ }^{330}$.

Entende-se que a idade da vítima deve ser levada em consideração na medida em que seja necessária para determinar a extensão do dano sofrido. O fator idade pode, assim, gerar uma diferenciação no caso da lesão deformante, que, de modo geral, será mais penosa para uma pessoa jovem do que para uma pessoa mais velha, consideradas ambas em igualdade de condições. Não se pode, todavia, concordar com a assertiva de que sempre uma pessoa mais velha deva receber indenização menor do que uma jovem, porque isto acabaria por beneficiar seus herdeiros. A responsabilidade civil deve medir a extensão do dano para conceder à vítima uma indenização integral, tendo em vista o princípio da dignidade humana. Não cabe ao Direito questionar o que será feito da quantia recebida. Mesmo em vida, a pessoa lesada poderá transferir tudo que recebeu a uma terceira pessoa. Não há que se questionar o destino a ser dado à indenização.

Wilson Melo da Silva ressalta, por sua vez, a preponderância do papel do juiz ${ }^{331}$, apresentando como principal critério a análise do padrão do homem médio:

"Para a fixação, em dinheiro, do quantum da indenização, o julgador haveria de atentar para o tipo médio do homem sensível da classe.

E, tipo médio do homem sensível de cada classe, seria o daquele cidadão ideal que estivesse a igual distância do estóico ou do homem de coração seco de que fala Ripert, e do homem de sensibilidade extremada e doentia. E isto porque, se certo é que existem os indiferentes, não menos verdade é, também, que o tipo usual do exagerado, do extremamente sensível, é bastante encontradiço.

E como, de um modo comum, há escalões na sensibilidade dos grupos (o intelectual ou o artista tem uma sensibilidade bem

\footnotetext{
${ }^{330}$ VENOSA, Silvio de Salvo. Responsabilidade civil, p. 207-211.

${ }^{331}$ SILVA, Wilson Melo da. O dano moral e sua reparação, p. 630.
} 
diversa da do homem da rua), é mister estabelecer-se uma diferenciação para tal fim, dos grupos sociais.

A gravidade do dano moral proveniente da injúria, por exemplo, variaria de conformidade com o grupo social do ofendido e do ofensor" 332 .

Wilson Melo da Silva salienta, ainda, que outro fator a ser relevado é o comportamento do lesante no momento da execução do ato lesivo. Também seria necessário analisar a maior ou menor parcela de culpa ou dolo do agente para determinar a graduação do montante do ressarcimento a ser outorgado, bem como o comportamento da própria vítima, verificando-se de que maneira o evento a afetou e suas repercussões na sociedade ${ }^{333}$.

Esta última observação do doutrinador é de causar estranheza, já que, em um momento, posiciona-se em prol da natureza da reparação dos danos morais como simplesmente compensatória e, em outro, adota o critério da avaliação da culpa do ofensor, claramente de origem punitiva e que em nada se coaduna com a sua posição inicial. De qualquer maneira, a ideia de avaliação do sentimento do chamado "homem médio" há de ser considerada.

Maria Helena Diniz, partidária, como muitos, da natureza mista da reparação dos danos morais, alonga-se bastante no tocante à questão dos critérios a serem observados para a indenização desses danos e apresenta o seguinte rol de elementos importantes na avaliação da quantia a ser arbitrada, aqui transcrito em face de seu caráter sintético de todos os argumentos em regra mencionados pela doutrina:

“a) evitar indenização simbólica e enriquecimento sem justa causa, ilícito ou injusto da vítima. A indenização não poderá ter valor superior ao dano, nem deverá subordinar-se à situação de penúria do lesado; nem poderá conceder a uma vítima rica uma indenização inferior ao prejuízo sofrido, alegando que sua fortuna permitiria suportar o excedente do menoscabo;

\footnotetext{
${ }^{332}$ SILVA, Wilson Melo da. $O$ dano moral e sua reparação, p. 663.

${ }^{333}$ Ibidem, p. 667.
} 
b) não aceitar tarifação, porque esta requer despersonalização e desumanização, e evitar porcentagem do dano patrimonial;

c) diferenciar o montante indenizatório segundo a gravidade, a extensão e a natureza da lesão;

d) verificar a repercussão pública provocada pelo fato lesivo e as circunstâncias fáticas;

e) atentar às peculiaridades do caso e ao caráter anti-social da conduta lesiva;

f) averiguar não só os benefícios obtidos pelo lesante com o ilícito, mas também sua atitude ulterior e situação econômica;

g) apurar o real valor do prejuízo sofrido pela vítima;

h) levar em conta o contexto econômico do país. No Brasil não haverá lugar para fixação de indenização de grande porte, como as vistas nos Estados Unidos;

i) verificar a intensidade ou o grau de culpa do lesante $(\mathrm{CC}$, art. 944, parágrafo único);

j) basear-se em prova firme e convincente do dano;

k) analisar a pessoa do lesado, considerando a intensidade de seu sofrimento, seus princípios religiosos, sua posição social ou política, sua condição profissional e seu grau de educação e cultura;

1) procurar a harmonização das reparações em casos semelhantes;

m) aplicar o critério do justum ante as circunstâncias particulares do caso sub judice (LICC, art. $5^{\circ}$ ), buscando sempre, com cautela e prudência objetiva, a eqüidade". 334

Propugna-se que, dentre os critérios apresentados pela autora pré-citada, os que de fato devem ser utilizados, de acordo com a concepção meramente compensatória, são os ínsitos nos itens "c", "d", "g" e "k". Os três primeiros são relacionados diretamente com a avaliação da extensão do dano, e o último atinente às condições pessoais do lesado, que

${ }^{334}$ DINIZ, Maria Helena. Curso de Direito Civil brasileiro: responsabilidade civil, p. 96. 
devem ser levadas em conta ao se determinar a extensão mencionada. No que tange ao item "k", contudo, os princípios religiosos extrapolam o que deve se entender por condição pessoal da vítima, razão pela qual devem ser desconsiderados na avaliação do dano. Ademais, considerações desse tipo podem resultar no tratamento diferenciado de pessoas pertencentes a religiões diversas, o que configuraria descriminação. Considerações como a do item “f”, por sua vez, são inadmissíveis, em particular no que concerne à verificação de conduta anterior do lesante. De fato, tal assertiva não encontra abrigo nem na legislação, nem na teoria clássica da responsabilidade civil. Os antecedentes podem ser de utilidade para o Direito Penal, mas nunca para o Direito Privado.

Maria Celina Bodin de Moraes critica a escolha dos critérios da culpa do agente e sua capacidade econômica, eis que estão imbuídos de caráter punitivo. A consideração da culpabilidade e da gravidade da conduta lesiva, consistente na necessidade de o agente pagar mais se agiu com dolo ou com maior culpa, contraria a doutrina clássica de reparação dos danos, expressa, principalmente, pelos arts. 1.059 e 1.060 do CC de $1916^{335}$. Pondera, no entanto, que, em decorrência da redação do art. 944, parágrafo único, do CC de 2002, os preceitos tradicionais devem ser amenizados para reduzir a indenização em caso de culpa levíssima, mas não majorar no caso de maior culpa ou dolo, uma vez que a norma utiliza expressamente o termo "reduzir" e não "ponderar" 336 . Com relação ao critério do nível socioeconômico do ofensor, a autora afirma que ele tem conotação ainda mais punitiva que o anterior. Este em rigor é conjugado com outro, o do aporte econômico da vítima, o qual, segundo ela, gera mais controvérsia, por mostrar claro equívoco ao considerar que o indenizável no dano moral é o sofrimento ${ }^{337}$. Conforme assinalado, é a violação de direitos da personalidade a efetivamente punida. Em razão disso, o critério em comento não faria sentido.

\footnotetext{
${ }^{335}$ Os referidos dispositivos têm a seguinte redação:

“Art. 1.059. Salvo as exceções previstas neste Código, de modo expresso, as perdas e danos devidos ao credor abrangem, além do que ele efetivamente perdeu, o que razoavelmente deixou de lucrar.

Parágrafo único. O devedor, porém, que não pagou no tempo e forma devidos, só responde pelos lucros, que foram ou podiam ser previstos na data da obrigação".

"Art. 1.060. Ainda que a inexecução resulte de dolo do devedor, as perdas e danos só incluem os prejuízos efetivos e os lucros cessantes por efeito dela direto e imediato".

${ }^{336}$ MORAES, Maria Celina Bodin de. Danos à pessoa humana - uma leitura civil-constitucional dos danos morais, p. 296-297.

${ }^{337}$ Ibidem, p. 298-300. A autora acrescenta que o argumento mais utilizado para justificar a adoção desse critério, o enriquecimento sem causa, configuraria um simples pretexto, na medida em que a sentença do juiz é razão suficiente para afastar o enriquecimento justificado. De fato, se esse enriquecimento servir para "abrandar os efeitos nefastos de lesão à dignidade humana, é mais do que justificado, é devido" (ibidem, p. 302). Afasta, assim, a sua utilização.
} 
A autora se posiciona, assim, em prol da adoção, como critérios válidos, da extensão do dano e das condições pessoais da vítima, não importando se a conduta ofensiva foi mais grave ou menos grave porque "se o objetivo é reparar o dano moral sofrido injustamente, não há como se ater a qualquer conceito de dano causado"338. E, tecendo argumentos sob a ótica da dignidade humana, conclui, ipsis litteris, que:

“[...] ficam desde logo excluídos quaisquer critérios que tenham como parâmetro as condições econômicas ou o nível social da vítima, não se coadunando com a noção de dignidade, extrapatrimonial na sua essência, quaisquer fatores patrimoniais para o juízo de reparação.

No entanto, e por outro lado, as condições pessoais da vítima, desde que se revelem aspecto de seu patrimônio moral, deverão ser cuidadosamente sopesadas, para que a reparação possa alcançar sob a égide do princípio de isonomia substancial, a singularidade de quem sofreu o dano" 339 .

Considera-se de perfeição irretocável o entendimento da ilustre doutrinadora porque em nenhum momento a figura da vítima é afastada em detrimento de outros critérios. De fato, sustenta-se aqui que a indenização deve sempre se concentrar nas condições pessoais da vítima, para a verificação da extensão do dano produzido, e não na conduta ou nas condições econômicas do ofensor. As condições do ofensor poderiam ser consideradas, em caráter eventual, se elas produzissem diretamente o agravamento do dano. De fato, em algumas hipóteses, o porte financeiro do ofensor pode tornar a ofensa mais profunda. É o que aconteceria, v.g., na divulgação de notícia inverídica sobre determinada celebridade em um jornal de bairro e em um jornal de renome e de distribuição nacional. $\mathrm{O}$ dano provocado por este último decerto seria mais extenso.

Em conclusão a tudo quanto até aqui exposto, ressalta-se que a extensão do dano é, de fato, o critério mais importante para a avaliação do dano moral. As características pessoais da vítima são essenciais justamente para a melhor avaliação dessa extensão do

\footnotetext{
${ }^{338}$ MORAES, Maria Celina Bodin de. Danos à pessoa humana - uma leitura civil-constitucional dos danos morais, p. 304.

${ }^{339}$ Ibidem, p. 306-307.
} 
dano. Um mesmo evento pode ter consequências muito diferentes, de acordo com o indivíduo por ele atingido.

Não se pode, no entanto, concordar com o critério do grau de culpa do lesante para a avaliação do quantum do dano, uma vez que se diverge da corrente que atribui ao dano moral função punitiva, exclusiva ou associada com a função compensatória. Propugna-se que a indenização do dano moral visa unicamente compensar a vítima pela dor sofrida e não punir aquele que causou o sofrimento, pois isso é função do direito penal.

É de extrema relevância salientar que à pessoa humana cabe a proteção mais ampla, concedida de acordo com suas condições pessoais, de acordo com as diretrizes da reparação integral, que possui a finalidade de recompor a ofensa sofrida pela vítima em seus direitos da personalidade mediante a reparação integral do dano. Para que isso se concretize, é essencial a atuação do magistrado. Este, procurando reduzir o nível de subjetivismo do arbitramento do dano moral, deverá justificar sua decisão com detalhes, em particular no tocante à determinação da verba indenizatória, à exceção de se tratar de casos em que naturalmente deve se presumir o dano moral, como na hipótese, v.g., da perda de um familiar.

\subsection{O conceito de dano estético}

Este item terá como preocupação central apresentar um panorama conciso do dano estético, com suas definições e principais características. Essa modalidade de dano decorre de uma multiplicidade de circunstâncias, entre elas as intervenções médicas, particularmente aquelas de caráter estético, motivo pelo qual a matéria deve, necessariamente, ser examinada neste trabalho.

Aproveitar-se-á, ademais, o ensejo para fortalecer a diferença existente entre os danos estéticos e os danos morais em sentido estrito, o que já foi objeto de discussão, en passant, no presente estudo.

Em linhas gerais, defende-se que o dano moral em seu sentido amplo é um gênero que admite diversas espécies, entre elas o dano moral em sentido estrito, ou pretium doloris, e o dano estético. O dano estético é, de fato, espécie de dano moral, quando este último é considerado em sentido amplo, mas não se confunde com o dano moral stricto sensu. Os autores que apregoam a ocorrência do bis in idem no caso de cumulação de 
verbas para ambos os danos não atentam para esse aspecto da questão e, além disso, advogam tese contrária à esposada pelo STJ, na Súmula n. $387^{340}$.

Uma corrente doutrinária hodierna preconiza que os danos estéticos são outra espécie de dano, a ser considerada ao lado dos danos morais e materiais; dessa maneira, tratar-se-ia de uma terceira modalidade, verdadeiro exemplo de uma das novas tendências da responsabilidade civil: a ampliação dos danos reparáveis ${ }^{341}$. Diverge-se desse posicionamento, uma vez que o dano estético é decorrente de lesão a direito da personalidade, assim como os demais danos morais.

Convém salientar, ademais, que aos danos estéticos, muitas vezes, são conferidos aspectos de ordem moral e patrimonial ${ }^{342}$, como se esse aspecto fosse uma particularidade dessa modalidade de dano. É evidente que o dano estético pode ter um caráter patrimonial, no entanto, não se trata de característica que lhe é própria, pois a lesão a interesses extrapatrimoniais pode gerar danos patrimoniais sem que isso represente a criação de um terceiro tipo de dano. Verifique-se, v.g., que a violação à honra pode gerar abalo de crédito, que tem, evidentemente, consequências patrimoniais. Essa característica, portanto, não é suficiente para apreender o conceito do dano.

Posto isso, passa-se à análise dos ensinamentos de alguns doutrinadores a fim de que seja possível chegar a um conceito adequado aos propósitos do presente trabalho.

José de Aguiar Dias define o dano estético como a deformidade, isto é, a lesão aparente, irreparável, indelével e permanente ${ }^{343}$. Saliente-se o excessivo rigor dessa

\footnotetext{
${ }^{340}$ A Súmula n. 387 foi publicada em $1^{\circ}$ de setembro de 2009, e possui a seguinte redação: "É lícita a cumulação das indenizações de dano estético e dano moral".

${ }^{341}$ TARTUCE, Flávio. Direito Civil - direito das obrigações e responsabilidade civil, v. 2, p. 420.

${ }^{342}$ AGUIAR DIAS, José de. Da responsabilidade civil, t. II, p. 310-311.

${ }^{343}$ Ibidem, p. 334. Na mesma esteira, Yussef Said Cahali (Dano moral, p. 189-195). O autor, ao tratar especificamente sobre o dano estético, não apresenta propriamente uma definição para o referido instituto jurídico, mas o relaciona diretamente com o aleijão ou a deformidade permanente, considerando a questão na seara penal. Sendo a definição do primeiro de verificação simples - pois a falta de um órgão ou membro é evidente -, parte para o estudo das principais características da deformidade permanente, conceituando-a, em termos gerais, como a alteração da forma física visível ou aparente, geradora de um prejuízo estético capaz de causar desgosto ou desagrado, irreparável pelos meios terapêuticos comuns ou ordinários. Ainda da perspectiva do direito penal, ressalta a necessidade de que o dano seja aparente e até mesmo visível a distância porque é esse aspecto que configurará o dano estético, pelas consequências morais que dela resultam para o sujeito, em sua relação na sociedade. Observa, porém, que, sendo visível a lesão, o simples fato de poder ser mascarada, de qualquer modo, não exclui a caracterização do dano. Por fim, conclui que a definição da deformidade permanente é tão importante para a existência do dano estético que ambas chegam a se confundir.
} 
preleção, que se insere melhor no âmbito penal, no qual, para condenação do ofensor, exige-se uma gravidade maior da lesão ${ }^{344}$.

Sérgio Severo, por sua vez, conceitua o dano estético ou prix de la beauté como aquele consistente em uma variação da imagem corporal, que se verifica quando a ofensa provoca um desequilíbrio na harmonia da aparência do indivíduo. Acrescenta que a verificação do dano estético comporta variações de acordo com as características individuais do ofendido. Uma cicatriz para um boxeador, v.g., pode nada representar, ao passo que uma cicatriz para uma atriz pode implicar um dano patrimonial e também extrapatrimonial $^{345}$.

Luiz Antônio Rizzato Nunes relaciona o dano estético com uma modificação física permanente que altere o aspecto externo do lesado, mais do que com os conceitos de beleza ou feiura. É indubitável que, havendo uma modificação para melhor, esta não ensejará dano estético ${ }^{346}$. O autor, ao relacionar o dano estético com o dano moral, afirma que ambos são independentes, podendo um existir sem o outro, uma vez que o dano moral pode ter origem em fatos diversos do dano estético em $\mathrm{si}^{347}$. Advoga-se que o aspecto mais importante para a sua caracterização é justamente a modificação do equilíbrio da aparência do indivíduo, desde que seja para pior, não se relacionando necessariamente com a dor psicológica ou o grande sofrimento, que ensejarão verba autônoma a outro título.

Pelo descrito até este momento, para a configuração do dano estético, destaca-se a necessidade de uma deformidade ou, ao menos, de uma alteração estética e um segundo aspecto, que é a permanência ou irreparabilidade do dano. Acerca desse ponto, reitera-se assertiva de Yussef Said Cahali ao esclarecer que não deixa de ser deformidade aquela que permite a dissimulação, uma vez que ninguém pode ser obrigado a utilizar artifícios como

\footnotetext{
${ }^{344}$ Quando se faz alusão a âmbito penal, está-se considerando o tipo penal do art. 129 do CP, ou seja, o tipo de lesão corporal, particularmente a lesão corporal gravíssima que se configura, dentre outras hipóteses, quando a lesão provocada na vítima acarretar deformidade permanente.

${ }^{345}$ SEVERO, Sérgio. Os danos extrapatrimoniais, p. 151. Orlando Soares também apresenta uma definição do dano estético, identificando-o com as lesões fisionômicas ou corporais suportadas pela vítima, em consequência de acidente profissional de transporte, de agressão física ou de ato cirúrgico que resultam em deformidade. Acrescenta que este se insere na categoria do dano moral (Responsabilidade civil no Direito brasileiro - teoria, prática forense e jurisprudência. Rio de Janeiro: Forense, 1996. p. 87). A definição apresentada, entretanto, é insuficiente por não diferenciar as lesões de acordo com a sua gravidade ou permanência. Por consequência, não se pode ter pleno entendimento do tipo de lesão que o autor pretende alcançar com a definição concebida.

${ }^{346} \mathrm{~A}$ afirmativa somente é válida se a melhora surgiu do próprio ato, não decorrendo de outras intervenções cirúrgicas ou tratamentos.

${ }^{347}$ NUNES, Luiz Antônio Rizzato; CALDEIRA, Mirella D'Angelo. $O$ dano moral e sua interpretação jurisprudencial. São Paulo: Saraiva, 1999. p. 8-9.
} 
um olho de vidro, por exemplo. ${ }^{348} \mathrm{O}$ dano deve ser de difícil ou longínqua reparabilidade, não necessariamente devendo ser definitivo. Basta que não haja meio de corrigi-lo no presente momento ou em um futuro próximo.

O autor pré-citado assinala a necessidade de conceder flexibilidade ao conceito de deformidade aparente no campo da responsabilidade civil, o que permitiria maior elasticidade na identificação do dano estético decorrente de deformidade porque é possível fazer variar o quantum indenizatório em função da gravidade da lesão deformante. Da mesma forma, amplia-se o conceito de aparência, para nela também incluir partes mais reservadas do corpo, procurando-se valorar a dor e o sofrimento íntimo daqueles que foram lesados em sua integridade corporal, considerando-se também o prejuízo que possam ter sofrido em suas funções sociais ${ }^{349}$.

A matéria é tratada com pormenores por Teresa Ancona Lopez, em monografia destinada especificamente ao estudo do dano estético, a qual o identifica com a "lesão à beleza física, ou seja, à harmonia das formas externas de alguém" ${ }^{350}$, sempre ponderando a mudança suportada pelo indivíduo em relação ao que ele era antes da lesão, porque o conceito de beleza é bastante relativo. Ato contínuo, define o dano estético como:

“[...] qualquer modificação duradoura ou permanente na aparência externa de uma pessoa, modificação esta que lhe acarreta um 'enfeamento' e lhe causa humilhações e desgostos, dando origem portanto a uma dor moral" ${ }^{\prime 351}$.

É possível notar que a definição apresentada é mais ampla do que a de outros autores, uma vez que considera dano estético qualquer transformação na aparência e não só aquilo capaz de causar desprezo a quem vê a lesão. A autora ressalta que não pode ser diretamente aplicada a conceituação do direito penal, consoante já exposto aqui. Para o Direito Civil, bastaria mera cicatriz para a caracterização do dano. Isso, no entanto, não afasta a necessidade da permanência ou efeito prolongado do dano, porque, caso contrário, configuraria dano material, facilmente superável, apto a ser resolvido em perdas e danos. A modificação permanente há de ser na aparência externa da pessoa, em qualquer parte do

\footnotetext{
${ }^{348}$ CAHALI, Yussef Said. Dano moral, p. 209.

${ }^{349}$ Ibidem, p. 214 -215.

${ }^{350}$ LOPEZ, Teresa Ancona. $O$ dano estético - responsabilidade civil, p. 37.

${ }^{351}$ Ibidem, p. 38. No que tange à expressão "dor moral”, saliente-se o entendimento, exposto linhas adiante, de que o abalo psicológico não é necessário para a configuração do dano estético.
} 
corpo, desde que possa ser vista, não importa em qual ocasião. São incluídas também as deficiências só verificáveis quando a pessoa assume uma atitude dinâmica, como a fala, o andar claudicante, entre outros ${ }^{352}$.

Teresa Ancona Lopez conclui a análise do assunto afirmando que o dano estético implica dano moral, porque, com a lesão, advém um sofrimento que tem por causa ofensa à integridade física ${ }^{353}$. Diverge-se desse posicionamento por não se considerar necessária a presença de um "sofrimento" para que haja o dano estético, tendo em vista que este decorre do abalo na aparência do indivíduo, independentemente do aspecto psicológico. De qualquer modo, as considerações da doutrinadora são relevantes para o desenvolvimento do presente estudo já que permitem divisar com clareza o dano estético do moral em sentido estrito. Não se pode olvidar de mencionar, contudo, que a cumulação de danos estéticos com danos morais em sentido estrito encontra alguns opositores ${ }^{354}$.

Na mesma linha da autora pré-citada, Wilson Melo da Silva, ao estudar a natureza do dano estético, advoga que qualquer deformidade, ainda que pequena, e que acarrete piora na aparência da vítima, deverá ser considerada dano estético. Para ele, não é necessária a constante visibilidade da lesão. Esse fato só seria causa de uma menor ou maior indenização ${ }^{355}$. O autor, assim, em vez de relacionar dano estético com uma grande deformação, em verdade, o faz com uma transformação na aparência do lesado ${ }^{356}$. Considera-se essa posição mais coerente com a seara do direito civil, na qual o menor dano é passível de ressarcimento, uma vez que se mede a indenização de acordo com sua extensão.

\footnotetext{
${ }^{352}$ LOPEZ, Teresa Ancona. O dano estético - responsabilidade civil, p. 43.

${ }^{353}$ Ibidem, p. 44-45. A autora resume a questão da seguinte maneira: "o dano estético é sempre um dano moral e, na maioria das vezes, concomitantemente, também dano material, mas se dele somente advierem prejuízos de ordem econômica pode-se, quando muito, falar em ofensa passageira à estética pessoal ou em dano estético transitório, pois, para nós, para que exista tal tipo de lesão é necessária, pelo menos, a existência de um sofrimento moral" (ibidem, p. 40).

${ }^{354}$ Carlos Roberto Gonçalves, v.g., faz uma relação muito estreita entre a deformidade e o dano estético, afirmando que, nesse dano, o que se indeniza é o dano moral decorrente da deformidade física. Para o autor, não se trata de uma terceira espécie de dano, mas somente de um aspecto do moral. Lembra que há situações em que este pode acarretar prejuízo patrimonial à vítima, além do já característico dano moral, hipóteses em que se admitiria a cumulação dos danos patrimonial e estético, este entendido como aspecto do dano moral. Por considerar o dano estético meramente um "aspecto" do moral, Carlos Roberto Gonçalves, assim como Silvio de Salvo Venosa, é contrário à cumulação dessas duas espécies de danos, sob o argumento de que haveria bis in idem, ou seja, seriam concedidas duas verbas indenizatórias para reparar um mesmo dano (GONÇALVES, Carlos Roberto. Responsabilidade civil, p. 691, e também Comentários ao Código Civil parte especial do direito das obrigações (arts. 927 a 965), p. 540-541). Conforme evidenciado, diverge-se dessa tese, pois o dano estético é muito mais do que um aspecto do moral, a menos que esse seja considerado em seu sentido amplo. Nesse caso, o dano estético faria parte do gênero moral, enquanto subespécie dele, mas sempre distinto do dano moral em seu sentido estrito.

${ }^{355}$ SILVA, Wilson Melo da. O dano moral e sua reparação, p. 498-500.

${ }^{356}$ Ibidem, p. 503-504.
} 
Outro aspecto levantado por Wilson Melo da Silva é de suma relevância, isto é, a lesão que pode ser corrigida mediante cirurgia plástica. $\mathrm{O}$ autor pondera, com muita propriedade, que ninguém pode ser obrigado a se submeter a qualquer operação, ainda que seja para corrigir um dano estético ${ }^{357}$. Se a vítima não quiser se submeter à cirurgia de correção, o dano estético não pode se transformar em material, ou seja, continua sendo estético e, como tal, deve ser indenizado.

Concorda-se novamente com o ilustre doutrinador. De fato, a vítima, assim como qualquer outra pessoa, não pode ser forçada a se submeter a intervenção cirúrgica, caso contrário, estar-se-ia violando um direito de personalidade do indivíduo, o direito à integridade física, resguardado de modo expresso pelo art. 15 do CC $^{358}$. Para qualquer intervenção cirúrgica deve-se ter a anuência do interessado, ou de quem o represente, exceto se o caso for de estado de necessidade. A pessoa também pode se opor a tratamento doloroso ou perigoso, à secção de qualquer parte do corpo, até mesmo as renováveis. Faculta-se, da mesma maneira, a rejeição de intervenção ou aplicação de técnicas médicas ou dentárias, salvo se houver questão relevante de interesse público ${ }^{359}$.

Wilson Melo da Silva, contudo, em sede de seu trabalho sobre responsabilidade civil automobilística, entende ser possível a aplicação da compensatio lucri cum damno na seara dos danos estéticos, afirmação com a qual aqui se diverge. A compensatio lucri cum damno se verifica quando, em decorrência de uma única e mesma causa, o lesado, ao mesmo tempo em que sofre um dano, aufere também certos benefícios. Na esfera dos danos estéticos, o autor propõe a seguinte hipótese: uma mulher de aparência excessivamente desagradável - e, segundo o autor, com poucas chances de casamento sofre um acidente automobilístico. Em razão do infortúnio, se submete a uma cirurgia plástica e se torna muito mais bonita do que antes, disso lhe advindo diversas oportunidades, como, por exemplo, pretendentes. Assim, segundo ele, não haveria dano

\footnotetext{
${ }^{357}$ SILVA, Wilson Melo da. O dano moral e sua reparação, p. 512-513. Yussef Said Cahali também se posiciona da mesma maneira, asseverando que a recusa do ofendido em submeter-se à cirurgia não resulta em perda do direito à indenização, sendo opção da vítima "submeter-se ou não a uma operação cirúrgica, opção legítima que tangencia o próprio direito da personalidade, a sua recusa, preferindo conviver com a deformidade ainda que humilhante e constrangedora, resolve-se na condenação do agente pelo dano estético tornado definitivo" (Dano moral, p. 223-224).

${ }^{358} \mathrm{O}$ referido artigo possui a seguinte redação: "Ninguém pode ser constrangido a submeter-se, com risco de vida, a tratamento médico, ou a intervenção cirúrgica". Convém salientar que o dispositivo legal em comento sofre diversas críticas, em consequência da menção "com risco de vida", tendo em vista que a recusa pode se dar sempre, mesmo que não haja perigo no tratamento ou na intervenção.

${ }^{359}$ BITTAR, Carlos Alberto. Os direitos da personalidade. 5. ed. Rio de Janeiro: Forense, 2001. p. 74-75.
} 
extrapatrimonial a ser indenizado ${ }^{360}$. No entanto, o estudioso incorre em engano evidente na medida em que não leva em consideração que a vítima, além de ter passado pelo trauma do acidente, ainda se submeteu a uma cirurgia que, tudo indica, não tinha interesse antes do acidente. Ademais, não se pode simplesmente supor que todas as mulheres buscam incessantemente a beleza e o matrimônio, ou estão dispostas a sofrer intervenções cirúrgicas para os obterem.

Dentre os autores estrangeiros, destaca-se o entendimento de Philippe Le Tourneau, que estabelece uma importante diferença entre o prix de la douleur (preço da dor) e o prix de la beauté (preço da beleza). O primeiro teria a função de compensar o dano moral causado pelo sofrimento infligido à vítima. De acordo com o autor, é o mais conhecido dos danos morais ocasionados por um atentado corporal, devendo ser apreciado tendo em conta tanto a dor física como o ressentimento psicológico de que a vítima possa ser acometida. Em termos gerais, seria o dano moral stricto sensu. O segundo, também conhecido como pretium pulchritudinis ${ }^{361}$, viria compensar o prejuízo estético que resulte de atentado à harmonia física da vítima ${ }^{362}$. O prejuízo estético seria uma variedade menos grave da perda da integridade corporal $^{363}$. Sua importante observação mostra com muita clareza não só a natureza jurídica do dano estético, como também a conveniência da concessão de duas indenizações apartadas, uma para a perturbação psíquica e outra para a perda da beleza.

Com esteio na exposição dos diversos pontos de vista sobre a matéria, podem-se traçar, em linhas gerais, os aspectos relevantes para a configuração do dano estético, de acordo com o que se entende que ele verdadeiramente seja.

O principal a ser ressaltado é que o dano estético pertence à categoria do dano moral lato sensu e, como tal, decorre da lesão a um direito da personalidade, qual seja, o direito à integridade física ${ }^{364}$.

Ademais, é resultante da lesão à forma física externa do indivíduo, de modo a provocar uma alteração morfológica desfavorável à sua aparência, podendo ser maior ou menor, o que se irá, de acordo com a gradação, refletir na avaliação do dano.

\footnotetext{
${ }^{360}$ SILVA, Wilson Melo da. Da responsabilidade civil automobilística, p. 320.

${ }^{361}$ A expressão pretium pulchritudinis também pode ser traduzida como "preço da beleza".

${ }^{362}$ LE TOURNEAU, Philippe. La responsabilité civile, p. 186.

${ }^{363}$ BITTAR, Carlos Alberto. Os direitos da personalidade, p. 186.

${ }^{364}$ LOPEZ, Teresa Ancona. $O$ dano estético - responsabilidade civil, p. 49: "O dano estético é a lesão a um direito da personalidade - o direito à integridade física, especialmente na sua aparência externa. Como todo direito da personalidade, qualquer dano que o seu titular possa sofrer vai ter consequiências materiais, e, principalmente, morais".
} 
Outro aspecto importante a ser lembrado é a necessidade de sua permanência. No caso de o dano ser passageiro, ou poder ser remediado de alguma maneira, não será possível se configurar como uma lesão estética. Deve-se ter em conta, por sua vez, que ninguém pode ser submetido a intervenção cirúrgica contra a própria vontade, sob pena de violação do direito de personalidade, qual seja, o direito à integridade física, conforme se ressaltou há pouco. Se houver a negativa, independentemente da existência de tratamento, deverá ser concedida a indenização a título do referido dano.

Acerca da diferenciação existente entre o dano moral stricto sensu e o dano estético, convém fazer mais algumas observações, com escopo de corroborar o posicionamento aqui esposado.

Rubens Limongi França ${ }^{365}$ apresenta uma classificação tripartida dos direitos da personalidade, levando em conta os aspectos físicos, intelectuais e morais, que é feita da seguinte maneira:

- direito à integridade física;

- direito à integridade intelectual; e

- direito à integridade moral.

A integridade física incluiria, basicamente, o direito à vida e aos alimentos, ao próprio corpo, ao corpo alheio e às partes separadas do corpo, vivo ou morto - nos três casos. A integridade intelectual abrangeria o direito à liberdade de pensamento e o direito pessoal de autor científico, autor artístico e inventor. Por fim, o direito à integridade moral seria composto pelo direito de liberdade civil, política e religiosa; pelo direito à honra, à honorificência ${ }^{366}$, ao recato, ao segredo pessoal, doméstico e profissional, à imagem e à identidade pessoal, familiar e social. ${ }^{367}$

Ao direcionar a questão para o aspecto específico do tema a que se propõe discorrer neste estudo, observa-se, na classificação de Rubens Limongi França, a existência de um direito "ao aspecto físico da estética humana", e de um direito "ao aspecto moral da estética humana". O primeiro deles é incluído no direito à integridade física, como

\footnotetext{
365 LIMONGI FRANÇA, Rubens. Direitos da personalidade - coordenadas fundamentais. Direitos da Personalidade e Responsabilidade Civil. Revista do Advogado, n. 38, dez. 1992. p. 9.

366 A honorificência pode ser definida como aquilo que causa distinção ao indivíduo, v.g., o título de professor honoris causa concedido por Universidades.

${ }^{367}$ LIMONGI FRANÇA, Rubens, op. cit., loc. cit.
} 
subdivisão do direito à vida, ao passo que o segundo pertence à categoria do direito à integridade moral $^{368}$.

Dessa divisão, evidencia-se a diferença conceitual existente entre o dano estético, enquanto dano físico objetivo, e o moral gerado pelo dano estético, este sim verdadeiro dano moral, considerado em seu sentido estrito. O dano estético seria resultante da lesão a direito ao aspecto físico da estética humana, ao passo que o dano moral stricto sensu decorrente da lesão estética seria consequência do desrespeito a direito ao aspecto moral da estética humana. Observa-se, assim, a possibilidade de violação de dois aspectos da forma humana: o físico e o moral.

Sendo os direitos da personalidade critério para a classificação dos diversos tipos de danos morais, resta cristalina a diferença entre as duas espécies de danos discutidos. Em face dessa diferença, torna-se conveniente que sejam individualizados, apurados separadamente e, assim, cumulados. Afasta-se, com isso, qualquer possibilidade de bis in idem na cumulação, pois não se trataria de concessão de verba distinta a danos de igual natureza, passíveis de serem confundidos. O dano estético e o dano moral em sentido estrito são facilmente distinguíveis, uma vez que um resulta da lesão ao direito à integridade física e o outro da lesão ao direito à integridade moral.

Carlos Alberto Bittar ${ }^{369}$, por sua vez, distribui os direitos da personalidade de maneira diferente, dividindo-os em:

- direitos físicos;

- direitos psíquicos; e

- direitos morais.

Os primeiros - direitos físicos - seriam relativos a componentes materiais da estrutura humana, como a integridade corporal, com suas subdivisões. Os psíquicos seriam aqueles atinentes a elementos internos à personalidade, como a integridade psíquica, que, no entender do autor, compreende a liberdade, a intimidade e o sigilo. Os direitos morais seriam aqueles concernentes a atributos valorativos da pessoa na sociedade, representados pelo patrimônio moral que compreenderia a identidade, a honra e as manifestações do

${ }^{368}$ LIMONGI FRANÇA, Rubens. Direitos da personalidade - coordenadas fundamentais. Direitos da Personalidade e Responsabilidade Civil. Revista do Advogado, n. 38, p. 10-11.

${ }^{369}$ BITTAR, Carlos Alberto. Os direitos da personalidade, p. 17. 
intelecto. Carlos Alberto Bittar observa que os direitos físicos e psíquicos estão relacionados com a pessoa em si mesma, ao passo que os direitos morais aludem à sua posição perante a sociedade, ou seja, sua projeção na coletividade ${ }^{370}$.

Essa classificação também corrobora o posicionamento apregoado neste estudo porque o autor distingue a integridade física, na qual se inclui o direito à integridade estética, do patrimônio moral, cuja lesão dá ensejo ao dano moral em sentido estrito ${ }^{371}$.

De fato, Carlos Alberto Bittar conceitua o direito à integridade física como o direito "pelo qual se protege a incolumidade do corpo e da mente". Consistiria, assim, em "manter-se a higidez física e a lucidez mental do ser, opondo-se a qualquer atentado que venha a atingi-las, como direito oponível a todos"372. Esse direito visaria preservar os dotes naturais e os adquiridos pela pessoa, em níveis físico e mental ${ }^{373}$. $\mathrm{O}$ autor pondera que o atentado à integridade física pode atingir a imagem ou a honra da pessoa, de acordo com a essencialidade da imagem para aquele indivíduo, em particular para o exercício de sua atividade $^{374}$, denotando que o direito à integridade física pode alcançar maior amplitude do que só a questão corporal.

O doutrinador relaciona o direito à integridade psíquica com aquele que protege os elementos integrantes do psiquismo humano, atinentes ao princípio da dignidade do $\operatorname{ser}^{375}$. Entende-se que a violação desse direito resultará no surgimento do dano moral em sentido estrito, que se caracteriza pela perturbação psíquica gerada na vítima.

Constata-se, novamente, a dualidade existente entre o dano estético - lesão aos direitos físicos (especificamente à integridade física) -, e o dano moral stricto sensu -

\footnotetext{
${ }^{370}$ BITTAR, Carlos Alberto. Os direitos da personalidade, p. 17.

${ }^{371}$ Ibidem, p. 64-65.

372 Ibidem, p. 72.

${ }^{373}$ Teresa Ancona Lopez, posicionando-se em igual sentido, sustenta que os direitos sobre a integridade física seriam os direitos que o homem exerce sobre sua vida, seu próprio corpo vivo ou morto ou sobre suas partes separadamente, em sua dimensão física. Fariam parte dessa integridade a saúde física e a aparência estética. É em razão disso que afirma ser o dano estético uma ofensa a um direito da personalidade, assim como qualquer dano moral o é ( $O$ dano estético - responsabilidade civil, p. 46).

${ }^{374}$ BITTAR, Carlos Alberto, op. cit., p. 77. Esse posicionamento está de acordo com sua concepção de direito à imagem, na qual esse direito seria mais relacionado com o aspecto moral do que físico, aludindo à honra, à reputação, ao decoro e à intimidade (ibidem, p. 65 e p. 90). Conforme salientado, Rubens Limongi França prefere inseri-los no direito à integridade física (Direitos da personalidade - coordenadas fundamentais. Direitos da Personalidade e Responsabilidade Civil. Revista do Advogado, n. 38, p. 9).

375 BITTAR, Carlos Alberto, op. cit., p. 115. Na verdade, o direito à existência digna não justifica somente o direito à integridade psíquica, mas também o direito à integridade física, uma vez que serve de cláusula geral para garantir numerosos direitos da personalidade, instituindo um direito à saúde, que corresponderia ao bemestar psicofísico e social (MORAES, Maria Celina Bodin de. Danos à pessoa humana - uma leitura civilconstitucional dos danos morais, p. 94). De qualquer maneira, permanece válida a diferenciação entre os direitos físicos e psíquicos apresentada por Carlos Alberto Bittar, op. cit.
} 
lesão aos direitos psíquicos, na terminologia de Carlos Alberto Bittar (ou à integridade moral, na de Rubens Limongi França). Em razão disso, é possível sustentar a cumulação de verbas indenizatórias a título de ambos os danos, conforme disposto na Súmula n. 387 do STJ, sem a necessidade de se considerar o dano estético uma terceira espécie de dano.

\subsection{A avaliação do dano estético}

A questão dos critérios para a compensação do dano moral já foi apresentada no item 2.9 - o que se fará nesse momento é apenas direcionar o enfoque do estudo para a avaliação do dano estético, providência necessária em razão de suas peculiaridades em relação às outras espécies de danos morais.

Deve ficar claro, preliminarmente, que, não obstante a referida mudança de enfoque, continua-se propugnando pela extensão do dano como critério mais importante para a avaliação, rejeitando qualquer consideração alusiva ao grau de culpa do ofensor, por não se admitir a função punitiva do dano moral, conforme asseverado. Entende-se que somente os elementos atinentes às condições pessoais da vítima e à dimensão do dano devem ser considerados para o estabelecimento da indenização em concreto ${ }^{376}$, enquadrando-se aqui a análise das ocupações da vítima, intensidade da lesão, localização da deformidade, seu caráter estático ou dinâmico ${ }^{377}$, suscetibilidade ou não de ser corrigida $^{378}$, idade do ofendido, entre outros de natureza semelhante ${ }^{379}$.

Não é assim, porém, que se posiciona a maior parte da doutrina.

Teresa Ancona Lopez, v.g., lista como critérios importantes a gravidade objetiva do dano - extensão material do dano no caso particular - e as circunstâncias particulares do ofendido, não podendo as últimas se sobressair à primeira porque, segundo a autora, é a extensão do dano que dá a medida da indenização ${ }^{380}$.

Com esse entendimento, a doutrinadora relaciona os seguintes parâmetros:

\footnotetext{
${ }^{376}$ MORAES, Maria Celina Bodin de. Danos à pessoa humana - uma leitura civil-constitucional dos danos morais, p. 332. A autora, ao tratar genericamente da reparação de danos morais, ressalta a importância da análise das condições pessoais da vítima e da dimensão do dano, rechaçando os critérios próprios do juízo de punição, representados pela análise das condições econômicas do ofensor e a gravidade da culpa. Acrescenta que tampouco são relevantes os seguintes critérios: "proporcionalidade entre a vantagem de quem praticou o ato lesivo e o prejuízo causado a terceiro; a utilidade (interesse) para quem o praticou ou a mera intenção de prejudicar o outro" (ibidem, p. 333).

377 O caráter dinâmico se evidencia quando a vítima se movimenta, como ocorre com o andar claudicante.

${ }^{378}$ Não se olvide, porém, a impossibilidade de imposição de intervenção cirúrgica corretiva.

${ }^{379}$ DIAS, João Antônio Álvaro. Dano corporal - quadro epistemológico e aspectos ressarcitórios, p. 377.

${ }^{380}$ LOPEZ, Teresa Ancona. O dano estético - responsabilidade civil, p. 101-103.
} 
- o grau de culpa do ofensor;

- a extensão do dano objetivamente considerado;

- as circunstâncias particulares do ofendido - sexo, idade, condições sociais, beleza, situação familiar;

- a perda das chances de vida e dos prazeres da vida social ou da vida íntima;

- a igualdade de tratamento dos sexos;

- as condições do ofensor, sempre ressaltando que a responsabilidade civil não foi criada para enriquecer a vítima, mas sim compensar o dano, não se esquecendo, todavia, que o valor da indenização deve ser de monta suficiente para desencorajar o lesante da prática de outros atos ilícitos ${ }^{381}$.

A autora, como se pode observar, apresenta alguns critérios divergentes dos preconizados por este estudo por se relacionarem com a consideração da natureza punitiva do dano moral, como os parâmetros de grau de culpa do ofensor e as condições sociais do ofendido $^{382}$ e do ofensor. Considera-se também que não é função da indenização desencorajar o lesante da prática de novos atos ilícitos. Além disso, não seria possível deixar de enriquecer a vítima, se for concedida verba suplementar para que seja cumprida a aludida função de reprovação ${ }^{383}$.

\footnotetext{
${ }^{381}$ LOPEZ, Teresa Ancona. O dano estético - responsabilidade civil, p. 109.

${ }^{382}$ Maria Celina Bodin de Moraes critica severamente esse critério por considerar que ele apresenta mais iniquidades do que soluções para a determinação do quantum indenizatório dos danos morais, entendimento esse que é adotado na íntegra pelo presente estudo. De fato, a autora aduz que: "Tanto a suposição de que pessoas de classes diferentes 'sofrem' em valores (quantias) diferentes quanto a de que todas as pessoas têm os mesmos sentimentos (donde concluir que não é cabível especificar-se, em relação ao caso concreto, a indenização) decorrem da errônea suposição de que é o 'sentimento' o que deve ser avaliado. Daí, aliás, o engano profundo em que recaem todas as decisões que se arrogam conjecturar sobre os sentimentos dos outros e acabam julgando apenas com base na aparência, isto é, com base nas condições econômicas da vítima e do ofensor" (Danos à pessoa humana - uma leitura civil-constitucional dos danos morais, p. 300). A doutrinadora conclui a abordagem da questão nos seguintes termos: "Se a vítima vive em más condições econômicas, isto não significa que ela estará fadada a apresentar para sempre tais condições. Pior, o argumento mais utilizado para justificar a adoção do critério da condição econômica da vítima - o que diz tratar-se de evitar enriquecimento sem causa - parece configurar um mero pretexto. Ora, a sentença de um juiz, arbitrando o dano moral, é razão jurídica mais do que suficiente para impedir que se fale, tecnicamente, de enriquecimento injustificado. O enriquecimento, se estiver servindo para abrandar os efeitos nefastos de lesão à dignidade humana, é mais do que justificado: é devido" (ibidem, p. 301-302).

${ }^{383}$ Yussef Said Cahali (Dano moral, p. 261-265), em entendimento bastante semelhante ao de Teresa Ancona Lopez, aponta alguns fatos e circunstâncias, em casos de dano à integridade física e psíquica, que deveriam informar o convencimento judicial. São elas: 1. a natureza da lesão e a extensão do dano, critério considerado fundamental por este estudo, e, de certo modo, único; 2. as condições pessoais do ofendido, de suma importância para a avaliação da extensão do dano e, principalmente, para a avaliação do dano estético; 3 . as
} 
René Savatier, por sua vez, concentra-se mais nas condições da vítima, asseverando que o dano corporal deve ser apreciado tendo-se em vista a idade da vítima, as suas capacidades intelectuais e físicas de ganho, de seu sexo - particularmente importante na consideração do dano estético -, de seus hábitos anteriores e de sua condição social ${ }^{384}$. Destaca-se mais uma vez a crítica já feita ao critério da condição social da vítima, do qual se diverge; no que tange aos demais pressupostos, decorrentes da avaliação das características específicas da vítima, estes são de suma importância para a avaliação do dano estético.

Roberto Brebbia coloca a questão da mesma forma, sustentando que outros fatores como idade, sexo, profissão e condição social têm importância singular para determinar a magnitude do agravo moral produzido pela lesão estética. Entende que a gravidade do dano patrimonial não será igual em uma mulher e um homem, em um adolescente e um ancião, em uma mulher solteira e uma casada, em uma pessoa que tenha constante vida social e outra que viva isolada de qualquer contato. Acrescenta, ainda, que a perda de "chance matrimonial" como consequência de uma lesão estética configura verdadeiro dano extrapatrimonial constituído pelo sofrimento moral que causa à vítima a incerteza de se poder realizar esse ato "transcendental", base da instituição familiar ${ }^{385}$. O que o autor preconiza, em termos gerais, é que o valor da indenização deve variar de acordo com as condições pessoais do ofendido. Com efeito, as aludidas condições são o principal critério para determinar a extensão do dano. No tocante à diferença do dano sofrido por uma mulher solteira e uma casada, esta consiste, evidentemente, em um absurdo e somente poderia ser concebida em uma sociedade muito diferente da brasileira. Da mesma forma, com relação à aclamada "perda de chance matrimonial", considera-se de bom alvitre ignorá-la, pois se trata de preceito bastante em desuso, o que acaba por torná-lo critério sem qualquer serventia.

Por fim, em adição às conclusões apresentadas neste estudo, acerca da importância da avaliação da extensão do dano e condições pessoais do lesado, resta acrescentar que, no

condições pessoais do responsável, não no sentido de buscar uma função punitiva do dano moral, mas para que não se arbitre valor em quantia muito aquém das condições econômicas do responsável - diverge-se desse critério, conforme consignado; 4 . a equidade, a cautela e a prudência, para que a indenização não leve o ofensor à ruína e o ofendido ao enriquecimento ilícito; 5. a gravidade da culpa, critério esse de caráter punitivo, com o qual não se concorda; 6. e o arbitramento em função da natureza e finalidade da indenização, que, da mesma forma, tem caráter punitivo, mas também aspecto pedagógico, aspecto esse que também não se admite.

${ }^{384}$ SAVATIER, René. Traité de la responsabilité civile en Droit français, p. 104.

${ }^{385}$ BREBBIA, Roberto H. El daño moral - doctrina, legislación, jurisprudencia, precedida de una teoría jurídica del daño. 2. ed. Buenos Aires: Orbir, 1967. p. 293. 
caso da reparação do estético, torna-se ainda mais importante a consideração das características físicas e profissionais da vítima, pois isso será essencial para a avaliação de sua extensão. Na hipótese de se configurar o dano estético uma piora ou abalo negativo na aparência do indivíduo, sendo ele portador de maior beleza, decerto, sofrerá mais do que outro, não tão belo, com uma mesma cicatriz, por exemplo, o que não significa que o dano provocado à pessoa menos favorecida do ponto de vista estético deva ser afastado ou desmerecido. O que ocorre é que, tratando-se o lesado de, v.g., uma modelo fotográfica, que aufere renda com sua aparência, o dano estético adquire também caráter de dano material, devendo ser ressarcido de acordo com o que foi perdido pela vítima e o que ela deixou de ganhar - dano emergente e lucros cessantes.

\subsection{A possibilidade de cumulação dos danos estéticos e morais}

Afirmou-se que o dano estético e o dano moral stricto sensu ensejam verbas separadas. Foram fornecidos alguns argumentos para essa assertiva, como a diferença de natureza jurídica das duas espécies e a existência de vários tipos de danos morais, decorrentes da diversidade de categorias em que podem ser divididos os aspectos do direito da personalidade. Como restou demonstrado, o dano estético decorre da lesão de direitos físicos (ou da integridade física), ao passo que o dano moral em sentido estrito advém da lesão de direitos morais (ou da integridade moral) ${ }^{386}$.

Jamais se negou que inexiste, em um primeiro momento, oposição entre danos morais e danos estéticos; ao contrário, o segundo estaria subsumido no primeiro, se este fosse considerado em seu sentido amplo. O dano estético é, assim, espécie de dano moral $^{387}$.

Ocorre que se pode utilizar a expressão "dano moral" em distintos sentidos. Ao afirmar que o dano estético é tipo de dano moral, a ela se atribuiu a significação do gênero no qual se incluem inúmeras espécies, entre elas, o dano estético e o dano moral em sentido estrito. Daí a verificação de que a expressão "danos morais" tanto pode significar

\footnotetext{
${ }^{386}$ Na nomenclatura empregada por Carlos Alberto Bittar, é usada a expressão "direitos psíquicos” porque esses direitos são relativos a elementos intrínsecos da personalidade, ao passo que os morais seriam concernentes a atributos valorativos da pessoa na sociedade (Os direitos da personalidade, p. 17).

${ }^{387}$ LOPEZ, Teresa Ancona. $O$ dano estético - responsabilidade civil, p. 125: "Sem dúvida, dano estético (lesão permanente) é dano moral. É o que desde a $1^{\underline{a}}$ edição deste livro temos afirmado e continuamos afirmando, pois se trata de ofensa a bens inestimáveis. É dano à pessoa".
} 
gênero quanto espécie. Em face desse aspecto, qualificou-se a expressão, definindo que dano moral em sentido amplo denota gênero e dano moral stricto sensu, espécie.

Evidencia-se, pois, que o dano estético não está incluído no dano moral stricto sensu, o que permite conceber a cumulação de verbas indenizatórias separadas para cada uma dessas espécies.

Cumpre ressaltar, ainda, que o dano deformante à integridade física não é igual a qualquer outro tipo de dano moral, porque, além de gerar uma transformação física - dano moral objetivo -, pode gerar outro dano de natureza extrapatrimonial, que é o "dano moral à imagem social” ${ }^{, 388}$. Em linhas gerais, frequentemente, há nessa espécie de dano um acréscimo de sofrimento decorrente de a vítima ter de enfrentar o ambiente social com uma aparência desagradável ${ }^{389}$, o que configuraria mais uma razão para a referida cumulação. Se o dano estético vier desacompanhado dessa perturbação psíquica, não será, então, o caso de cumulação de verbas, mas tão somente de indenização do dano estético.

A cumulação dos danos em comento encontra fundamento no art. $5^{\circ}$, inc. $\mathrm{V}$, da Constituição Federal, in verbis:

"Art. 5. Todos são iguais perante a lei, sem distinção de qualquer natureza, garantindo-se aos brasileiros e aos estrangeiros residentes no País a inviolabilidade do direito à vida, à liberdade, à igualdade, à segurança e à propriedade, nos termos seguintes: [...]

$\mathrm{V}$ - é assegurado o direito de resposta proporcional ao agravo, além da indenização por dano material, moral ou à imagem". (sem grifo no original)

De fato, a norma pré-citada previu a reparação para três tipos de danos patrimoniais e extrapatrimoniais ${ }^{390}$ : materiais, morais lato sensu e à imagem. Trata-se de dispositivo de grande interesse porque cria precedente para a consideração de inúmeros danos, de natureza extrapatrimonial, que poderão ser cumulados, de acordo com o caso concreto.

\footnotetext{
${ }^{388}$ LOPEZ, Teresa Ancona. $O$ dano estético - responsabilidade civil, p. 125.

389 Ibidem, loc. cit.: "Em suma, há no dano estético um plus negativo, que é essa humilhação diuturna e perene que sente sua vítima ao ter que enfrentar o ambiente social e do qual ela não pode fugir”.

${ }^{390}$ Entende-se que o dispositivo constitucional em referência não coloca o dano à imagem à margem dos danos morais em sentido amplo, mas tão somente o diferencia do dano moral stricto sensu.
} 
Com base no exposto, pode-se sustentar que o artigo constitucional em tela funciona como fundamento legal para a pretendida cumulação.

O dano à imagem decorre da violação do direito à imagem que é, evidentemente, um direito da personalidade. Carlos Alberto Bittar define-o como o:

\begin{abstract}
"[...] direito que a pessoa tem sobre a sua forma plástica e respectivos componentes distintos (rosto, olhos, perfil, busto) que a individualizam no seio da coletividade. Incide, pois, sobre a conformação física da pessoa, compreendendo esse direito um conjunto de caracteres que a identifica no meio social. Por outras palavras, é o vínculo que une a pessoa à sua expressão externa, tomada no conjunto, ou em partes significativas (como a boca, os olhos, as pernas, enquanto individualizadoras da pessoa)".
\end{abstract}

Essa definição de direito à imagem, contudo, somente diz respeito à imagemretrato. Convém salientar, contudo, que esse direito também abrange a imagem-atributo, isto é, aquela que se relaciona à reputação e ao bom nome da vítima ${ }^{391}$.

No que tange ao dano à imagem previsto constitucionalmente, Teresa Ancona Lopez afirma que este não é o dano à imagem na acepção própria do termo, como a proibição de reprodução de imagem se não autorizada, mas sim da imagem em seu valor ético-social, tendo como conteúdo a vida de relação ${ }^{392}$.

Em razão desse entendimento, a doutrinadora é partidária da cumulação sustentada neste estudo, conforme consignado a seguir:

\begin{abstract}
"Dessa forma, não só é possível, mas principalmente justa, a cumulação do dano estético com o dano moral por serem dois tipos diferentes de danos morais à pessoa, ou seja, atingem bens jurídicos diferentes. O dano estético (dano físico) é dano moral objetivo que ofende um dos direitos da personalidade, o direito à integridade física. Não precisa ser provado, é o damnum in re ipsa. $O$ sofrimento e a dor integram esse tipo de dano. O dano moral é o
\end{abstract}

\footnotetext{
391 DRAY, Guilherme Machado. Direitos de personalidade - anotações ao Código Civil e ao Código do Trabalho. Coimbra: Almedina, 2006. p. 50.

${ }^{392}$ LOPEZ, Teresa Ancona. O dano estético - responsabilidade civil, p. 126.
} 
dano à imagem social, à nova dificuldade na vida de relação, o complexo de inferioridade na convivência humana.

Sem dúvida, há no dano estético a destruição da integridade do corpo, e com isso a modificação para pior da antiga aparência física (imagem) da sua vítima. O sofrimento é duplo e por isso pede indenização dupla"393.

Na mesma linha, posiciona-se Luiz Roldão de Freitas Gomes, ao asseverar, ipsis litteris, que:

"[...] o inc. V, do art. 5 ${ }^{\circ}$, da $\mathrm{CF}$, ao assegurar o direito de resposta, proporcional ao agravo, além da indenização por dano material, moral ou à imagem, abre ensejo a cogitar-se da reparação do último, independentemente das demais lesões, compreendida a aparência, como direito resguardado, na imagem da pessoa"394.

Apresentada a fundamentação legal da referida cumulação, resta trazer à lume mais um argumento para o posicionamento aqui preconizado, que seria uma possível analogia com a Súmula n. 37 do STJ.

A questão da cumulação entre dano material e dano moral trata-se, atualmente, de matéria superada em face da redação da aludida Súmula - que dispõe serem "cumuláveis as indenizações por dano material e dano moral oriundos do mesmo fato".

O principal fundamento apresentado pela doutrina para a defesa da aludida cumulação é que a indenização do dano material tem caráter ressarcitório, ao passo que a indenização do dano moral tem caráter reparatório - ou compensatório ${ }^{395}$. É claro que esse fundamento não pode ser totalmente empregado na cumulação aqui pretendida, uma vez que diz respeito a espécies de danos morais, cuja indenização terá sempre o mesmo caráter, o de compensação - ou até de aflição, como entende a maioria da doutrina, da qual se diverge.

\footnotetext{
${ }^{393}$ LOPEZ, Teresa Ancona. O dano estético - responsabilidade civil, p. 126-127.

${ }^{394}$ GOMES, Luiz Roldão de Freitas. Elementos de responsabilidade civil, p. 99-100.

${ }^{395}$ BITTAR, Carlos Alberto. Os direitos da personalidade, p. 90.
} 
A importância da Súmula n. 37 se deve à sua relevância histórica na autorização de cumulação de verbas indenizatórias e à sua aplicação analógica aos casos de cumulação de danos morais e estéticos ${ }^{396}$. De fato, denota ser bastante lógica a referida analogia. De acordo com a redação apresentada, podem ser cumuladas duas espécies de danos diferentes, oriundos de um mesmo fato: danos materiais e danos morais. Demonstrou-se que há várias espécies de danos morais, dentre elas, o dano estético e o dano moral stricto sensu, que possuem diferenças profundas entre si, sendo o dano estético um dano moral objetivo $^{397}$, conquanto é passível de verificação visual, e o dano moral em sentido estrito um dano moral subjetivo, que não pode ser constatado. Entende-se, desse modo, que nada obstaria que a Súmula n. 37 do STJ servisse também de fundamento para a cumulação de espécies de danos morais. Sustenta-se, pois, que a aludida Súmula funcionaria como uma cláusula que permitiria a livre cumulação de indenizações, sempre que fosse possível a identificação de danos autônomos, não importando sua natureza, se moral ou material.

De qualquer maneira, a questão foi consolidada na já mencionada Súmula n. 387 que, expressamente, estabeleceu ser lícita a cumulação das indenizações oriundas de danos estéticos e morais.

Por fim, cumpre salientar a importância de que seja avaliado pelo juiz, ao julgar o caso concreto, se é possível diferenciar as diversas espécies de dano, independentemente de serem elas de dano material ou moral. No caso de haver possibilidade de serem diferenciados, cada um deles deverá ser indenizado com verba autônoma, a fim de que seja atendido o princípio da reparação integral da lesão causada à vítima.

\subsection{O conceito de perda de uma chance}

Cumpre esclarecer, de início, que a perda de uma chance ainda se trata de matéria de difícil aceitação na doutrina e jurisprudência brasileiras, em razão da aleatoriedade que

\footnotetext{
${ }^{396}$ LOPEZ, Teresa Ancona. O dano estético - responsabilidade civil, p. 126. Acerca da mencionada Súmula n. 37, Flávio Tartuce afirma que esta merece uma releitura, já que desde o ano 2000 o STJ admite a cumulação de danos materiais, morais e estéticos (Direito Civil - direito das obrigações e responsabilidade civil, v. 2, p. 382).

${ }^{397}$ Aqui não se está utilizando a diferença que parte da doutrina faz entre dano moral subjetivo e dano moral objetivo, no sentido de que o primeiro necessitaria de prova e o segundo seria in re ipsa, ou seja, não dependeria de prova, como ocorre, v.g., no abalo de crédito decorrente da colocação, de modo indevido, do nome da vítima em rol de devedores perante empresas de proteção ao crédito. Nesse caso, o dano presumido é justamente o objetivo. A despeito dessa observação, Flávio Tartuce equipara os danos estéticos ao dano moral objetivo na concepção descrita nesta nota (op. cit., p. 418).
} 
lhe é inerente. Dessa álea ${ }^{398}$ advém a desconfiança, pouco justificada, no tocante à aplicação do instituto. Some-se a isso, igualmente, a dificuldade em estabelecer um valor à oportunidade perdida, como se discutirá linhas a seguir.

Assinalou-se anteriormente que apenas os danos certos são passíveis de indenização, o que significa que, em tese, somente um dano real pode dar origem a esta e não um dano hipotético resultante de conjunturas mais ou menos eventuais sobre o futuro $^{399}$.

Ocorre que ao direito não é estranho o estudo de probabilidades e presunções ${ }^{400}$. Com efeito, foi por meio da evolução destas últimas que se desenhou e se desenvolveu a responsabilidade objetiva, percurso esse que foi minuciosamente descrito por Alvino Lima, em sua clássica obra ${ }^{401}$.

Como bem ressalta Alain Bénabent, "Le droit ne se contente pas de connâitre les faits ${ }^{402}$, isto é, o direito não se contenta em simplesmente conhecer os fatos. Com efeito, o direito se orienta fundado nos fatos e, de acordo com tal conhecimento, continua ampliando seus campos de atuação procurando, muitas vezes, prever a realização de eventos futuros $^{403}$.

O cotidiano forense, por sua vez, mostra que não é incomum que um juiz tenha de fazer um prognóstico, para o qual deverá se servir de probabilidades, seja para determinar como seria o presente, conforme o que se desenvolvia no passado, ou então o que seria do futuro, de acordo com o que se passava no presente ${ }^{404}$. Essa lógica de prognóstico é frequentemente utilizada para a avaliação de lucros cessantes e também para a determinação da reparação da incapacidade laborativa.

\footnotetext{
398 Segundo Teresa Ancona Lopez, álea "é um acontecimento totalmente inevitável para o qual não há, geralmente, possibilidade de previsão" (Princípio da precaução e evolução da responsabilidade civil, p. 24). ${ }_{399}$ Assim se posicionam: VENOSA, Silvio de Salvo. Responsabilidade civil, p. 28-199; GONÇALVES, Carlos Roberto. Responsabilidade civil, p. 530; e DINIZ, Maria Helena. Curso de Direito Civil brasileiro: responsabilidade civil, p. 62.

${ }_{400}$ Acerca dos estudos das presunções, vide a obra de Giselda Maria Fernandes Novaes Hironaka, na qual a autora apresenta o desenvolvimento histórico das presunções e disserta acerca de sua necessidade no campo da responsabilidade civil (Responsabilidade pressuposta, p. 253 et seq.).

${ }^{401}$ LIMA, Alvino. Culpa e risco.

${ }^{402}$ BÉNABENT, Alain. La chance et le droit. Paris: Librairie Générale de Droit et de Jurisprudence, 1973. p. 178.

${ }^{403}$ Rafael Peteffi da Silva afirma que a incerteza integra as soluções jurídicas porque ao Direito cabe tratar de "complexos e probabilísticos conflitos dos fenômenos sociais" (Responsabilidade civil pela perda de uma chance. 2. ed. São Paulo: Atlas, 2009. p. 9).

${ }^{404}$ BÉNABENT, Alain, op. cit., p. 179.
} 
Reitere-se, porém, a assertiva feita no item 2.5 , isto é, a perda de uma chance não se confunde com os lucros cessantes, eis que a perda de uma chance se trata de modalidade de dano emergente, consistente na própria frustração da oportunidade ${ }^{405}$. Com relação a esse aspecto, Sérgio Savi adverte:

"No caso de lucros cessantes, o autor deverá fazer prova não do lucro cessante em si considerado, mas dos pressupostos e requisitos necessários para a verificação deste lucro. Já nas hipóteses de perda de uma chance, se permanecerá sempre no campo do desconhecido, pois, em tais casos, o dano final é, por definição, indemonstrável, mesmo sob o aspecto dos pressupostos de natureza constitutiva"406.

Resta esclarecido, portanto, que a perda da chance não pode ser ressarcida como lucro cessante, uma vez que esta, na avaliação de sua ocorrência e quantificação, exige a análise de estatísticas e probabilidades. Em verdade, somente passou a se admitir o ressarcimento da perda de uma chance porque o fato do percurso do raciocínio probabilístico conduziu os tribunais a reparar prejuízos cujo coeficiente de incerteza é bem mais elevado.

A teoria da perda de uma chance foi construída pela doutrina francesa, inicialmente, no campo da responsabilidade médica, tendo se consagrado, segundo Miguel Kfouri Neto, em uma decisão da Corte de Cassação datada de 1965, que condenou um médico a reparar a perda da chance de cura ou sobrevivência de seu paciente ${ }^{407}$.

A noção, entretanto, não ficou restrita à seara da responsabilidade médica, expandindo-se de modo a ser utilizada sempre que o prejuízo sofrido pelo ofendido era decorrente das consequências aleatórias de um evento, do qual ele não pôde participar. De fato, Sérgio Savi relata que o primeiro caso de perda de uma chance que se verificou nos

\footnotetext{
${ }^{405}$ SAVI, Sérgio. Responsabilidade civil por perda de uma chance. São Paulo: Atlas, 2006. p. 11: "ao considerar o dano da perda de uma chance como um dano emergente, consistente na perda da chance de vitória e não na perda da vitória, eliminam-se as dúvidas acerca da certeza do dano e da existência do nexo causal entre o ato danoso do ofensor e o dano".

${ }^{406}$ Ibidem, p. 18.

${ }^{407}$ KFOURI NETO, Miguel. Responsabilidade civil do médico. 7. ed. São Paulo: Revista dos Tribunais, 2010. p. 67-68. Rafael Peteffi da Silva, ao contrário de Miguel Kfouri Neto, afirma que o primeiro caso de aplicação da teoria da perda de uma chance na França data de 17 de julho de 1889 e diz respeito a um oficial ministerial que atuou de maneira a extinguir todas as chances de êxito do feito promovido pela vítima. No âmbito da Common Law, o autor relata que o caso pioneiro data de 1911 (Chaplin v. Hicks), referindo-se à perda da oportunidade - de uma entre cinquenta candidatas - de participar da fase final de um concurso de beleza (Responsabilidade civil pela perda de uma chance, p. 10-11).
} 
tribunais italianos nem sequer se relacionava com responsabilidade profissional, mas aludia à perda da oportunidade de participar de um processo seletivo. De acordo com o autor, uma empresa estava realizando um processo de seleção de candidatos para o cargo de motorista. Alguns desses candidatos fizeram exames médicos, mas foram injustificadamente impedidos de realizar as provas subsequentes, necessárias para a conclusão do processo de admissão. Os candidatos prejudicados levaram a demanda a juízo e, em primeiro grau, a empresa foi condenada a permitir que fizessem os demais exames. Se passassem, deveriam ser contratados. A demandada ainda deveria ressarci-los dos prejuízos decorrentes do atraso sofrido no mencionado processo seletivo. A decisão, contudo, foi revertida no Tribunal de Roma, no qual se entendeu que o dano decorrente da perda de uma chance não seria passível de indenização. Ao final, a Corte de Cassação reformou novamente a decisão, de modo a confirmar a sentença de primeiro grau, vislumbrando valor econômico na oportunidade perdida ${ }^{408}$.

Com base no exposto, depreende-se que a perda de uma chance consiste no desaparecimento de um evento favorável que não se tem certeza se efetivamente aconteceria $^{409}$. A indenização pela perda da chance não é, assim, do ganho deixado de ter ou do prejuízo impedido de ser evitado, mas da oportunidade perdida pela vítima, de maneira que o prejuízo deverá ser apreciado segundo a probabilidade que esta tinha de se concretizar $^{410}$. Nesse caso, portanto, chance deve ser compreendida como oportunidade.

Antônio Jeová Santos define perda de uma chance como a "frustração de uma oportunidade em que seria obtido um benefício, caso não houvesse o corte abrupto em decorrência de um ato ilícito". O autor assinala que a chance frustrada não corresponde ao benefício aguardado, mas tão somente à simples probabilidade de que esse benefício pudesse surgir se não houvesse uma interrupção do modo de vida da vítima ${ }^{411}$.

Fernando Noronha, por sua vez, identifica a perda de uma chance em situação "em que está em curso um processo que propicia a uma pessoa a oportunidade de vir a obter no

\footnotetext{
${ }^{408}$ SAVI, Sérgio. Responsabilidade civil por perda de uma chance, p. 25 . O caso em comento foi julgado em 19 de novembro de 1983.

${ }^{409}$ REPRESAS, Félix A. Trigo; MESA, Marcelo J, López. Tratado de la responsabilidad civil. Buenos Aires: La Ley, 2005. t. I, p. 466: "El sujeito que tenía posibilidades a favor y contra de obtener una ganancia ve frustradas sus posibilidades de oportunidad o ganancia por el hecho de un tercero que le impide la participación en la definición de essas possibilidades" (Tradução livre: "O sujeito que tinha possibilidades favoráveis e negativas de obter lucro vê frustradas suas possibilidades de chance ou lucro por ato de um terceiro que lhe impede de participar na definição dessas possibilidades").

${ }^{410}$ DINIZ, Maria Helena. Curso de Direito Civil brasileiro: responsabilidade civil, p. 66-67.

${ }^{411}$ SANTOS, Antônio Jeová. Dano moral indenizável. 4. ed. São Paulo: Revista dos Tribunais, 2003. p. 106.
} 
futuro algo benéfico"412. No âmbito da responsabilidade civil, esse processo seria interrompido por fato antijurídico que causou a destruição da oportunidade. A chance perdida, como aduz o doutrinador, pode se caracterizar pela perda de oportunidade de obtenção de uma vantagem ou pela frustração da oportunidade de evitar um dano ${ }^{413}$. Na segunda hipótese, haveria um dano presente, uma vez que este já se concretizou.

Para a aferição do valor do dano, independentemente do fato apontado, ambos os casos exigem a análise de elementos que se projetam para um momento futuro em relação ao da produção do dano. A determinação da verossimilhança da vantagem pretendida, no primeiro caso, depende do grau de probabilidade que havia em concretizá-la posteriormente, da mesma forma que a avaliação do prejuízo ocorrido no segundo caso depende do cálculo do grau da probabilidade de ser evitado ${ }^{414}$. Em qualquer uma das duas hipóteses, a chance perdida constitui um dano real que será passível de indenização quando for viável calcular o grau de probabilidade de concretização da chance esperada ou de cessação do prejuízo. Mesmo que se refira a eventos futuros, o dano decorrente da perda de uma chance é, portanto, dano certo ${ }^{415}$.

De acordo com Alain Bénabent, a noção de perda da chance destina-se a preencher o vazio existente entre o indenizável integralmente e o não indenizável, amenizando a diferença entre o dano certo e o incerto. Ao mesmo tempo, cria uma solução intermediária para a reparação de dano cuja existência ou extensão dependiam de evento aleatório do qual a vítima foi impedida de concorrer ${ }^{416}$. Diverge-se aqui, em parte, do autor pré-citado, primeiro, porque não há fundamentação jurídica para a criação de um terceiro gênero entre o dano certo e o incerto. Com efeito, ou o dano é certo, ensejando indenização, ou então é incerto, não sendo reparável. O fato de um dano não ser indenizável integralmente, por sua vez, não afasta sua condição de certeza. Félix A. Trigo Represas e Marcelo J. López Mesa observam justamente esse aspecto, declarando que: "la certidumbre del daño aparece

\footnotetext{
${ }^{412}$ NORONHA, Fernando. Direito das obrigações: fundamentos do direito das obrigações - introdução à responsabilidade civil, p. 665.

${ }^{413}$ Ibidem, p. 665.

${ }^{414}$ Ibidem, loc. cit.

${ }^{415}$ REPRESAS, Félix A. Trigo; MESA, Marcelo J. López. Tratado de la responsabilidad civil, t. I, p. 469.

416 BÉNABENT, Alain. Droit civil - les obligations. 9. ed. Paris: Montchrestien, 2003. p. 456. Com entendimento semelhante, ressalta Miguel Kfouri Neto que "de maneira geral, a perda de uma chance repousa sobre uma possibilidade e uma certeza: é verossímil que a chance poderia se concretizar, é certo que a vantagem esperada está perdida - e disso resulta um dano indenizável. Noutras palavras: há incerteza no prejuízo - e certeza na probabilidade" (Responsabilidade civil do médico, p. 70).
} 
esfumada o borrosa, aunque se halla presente, pues de otro modo no se trataria de un daño indemnizable, ${ }^{, 417}$.

Se confrontada com o teor da legislação brasileira, a tese apresentada por Alain Bénabent é particularmente problemática. $\mathrm{O}$ art. 186 do $\mathrm{CC}$ pátrio exige que o dano seja certo para que seja indenizado ${ }^{418}$. Se, portanto, se entender que a perda da chance não é dano certo, esta não poderá ser reparada. Danos certos, por sua vez, podem ser indenizados de modo parcial, a senso do já mencionado art. 944, parágrafo único, do Diploma legal em comento, que determina a redução do montante da indenização em caso de evidente desproporção entre a extensão do prejuízo e a culpabilidade do ofensor.

Sustenta-se, ainda, que a perda da chance de auferir benefício ou evitar evento desfavorável constitui um prejuízo específico e é independente do prejuízo final. Ainda que não seja possível a avaliação de um dano patrimonial, o que deverá ocorrer na maior parte dos casos, haverá, ao menos, um dano moral - stricto sensu - em razão da oportunidade perdida $^{419}$.

Com efeito, na perda da chance há dois tipos de danos envolvidos: o dano da perda da oportunidade, que é certo, pois a chance foi perdida definitivamente, e o dano final correspondente a todo o prejuízo decorrente da não realização da chance. Trata-se, neste último caso, de dano incerto, porque é possível que a chance perdida jamais fosse se concretizar; no entanto, a própria chance de realizar um ganho, ou evitar uma perda, constitui um dano, apto a justificar a reparação ${ }^{420}$.

François Terré reafirma, na mesma linha do entendimento preconizado por este estudo, que, se o sucesso da chance perdida não é certo, há indubitável certeza na perda. Não se trata, pois, de conceder à vítima a vantagem que a superveniência de um acidente a privou irremediavelmente da possibilidade de usufruir, mas sim de se considerar que a chance perdida valia alguma coisa, da qual a vítima foi privada ${ }^{421}$.

A teoria da perda da chance pode ser aplicada em diversas situações. Alain Bénabent menciona alguns exemplos de sua utilização: o proprietário de um cavalo

\footnotetext{
${ }^{417}$ REPRESAS, Félix A. Trigo; MESA, Marcelo J. López. Tratado de la responsabilidad civil, t. I, p. 465. Tradução livre: "a certeza do dano aparece esfumaçada e tremida, ainda que se faça presente, pois de outro modo não se trataria de um dano indenizável".

${ }^{418} \mathrm{O}$ mencionado artigo tem a seguinte redação: "Aquele que, por ação ou omissão voluntária, negligência ou imprudência, violar direito e causar dano a outrem, ainda que exclusivamente moral, comete ato ilícito".

${ }^{419}$ SAVI, Sérgio. Responsabilidade civil por perda de uma chance, p. 53.

${ }^{420}$ REPRESAS, Félix A. Trigo. Responsabilidad civil del abogado. Buenos Aires: Hammurabi, 1991. p. 175.

${ }^{421}$ TERRÉ, François. Droit Civil - les obligations. 8. ed. Paris: Dalloz, 2002. p. 679-681.
} 
impedido de correr em razão de um acidente, o candidato a um concurso impedido de comparecer na data de um dos exames, o litigante frustrado de ver o prosseguimento de seu processo por negligência de seu advogado e o apostador privado das chances de ganhar por culpa do jóquei. Quando a chance perdida for suficientemente séria, sua perda constituirá um prejuízo reparável ${ }^{422}$.

A seriedade da chance pode ser avaliada em exemplos trazidos pela jurisprudência. Verifique-se o famoso caso do "Show do Milhão". A vítima participou do referido programa, transmitido pelo Sistema Brasileiro de Televisão (SBT), no qual, conforme o participante vai acertando as questões que lhe são perguntadas, aufere valores mais elevados. A questão final, chamada "pergunta do milhão", vale R\$ 1.000.000,00 (um milhão de reais) em barras de ouro. No caso em tela, a participante acertou todas as questões até chegar à última, que, por estar deliberadamente mal formulada, não possuía resposta $^{423}$. A participante, então, optou por não respondê-la e preservar a quantia que já havia ganhado ( $\mathrm{R} \$ 500.000,00$ - quinhentos mil reais). Mais tarde, considerou que, em razão do incidente, deixou de ganhar $\mathrm{R} \$ 500.000,00$ (quinhentos mil reais), ingressando com ação judicial para que a empresa de televisão fosse condenada ao pagamento de danos materiais com valor equivalente ao prêmio máximo, não recebido, bem como danos morais decorrentes da frustração do sonho. Em primeira instância, o pedido foi acolhido em sua integralidade no que tange aos danos materiais. A decisão foi objeto de apelação pela demandada, tendo sido o recurso improvido. A recorrente, então, interpôs Recurso Especial $^{424}$. Nele, alegou não ser cabível a condenação no valor do prêmio máximo, já que a própria participante havia decidido não responder à questão, não tendo se configurado nenhum tipo de dano. Sustentou ainda que, mesmo na hipótese de ser a questão passível de resposta, haveria mera possibilidade de acerto, motivo pelo qual ou a ação deveria ser julgada improcedente ou, então, o valor da indenização deveria ser reduzido para o montante de $\mathrm{R} \$ 125.000,00$, correspondente à probabilidade de $25 \%$ de acerto da pergunta, já que esta comportava quatro opções.

\footnotetext{
${ }^{422}$ BÉNABENT, Alain. Droit Civil - les obligations, p. 456-457.

${ }^{423}$ A questão formulada foi a seguinte: "A Constituição reconhece direito aos índios de quanto do território brasileiro? $1-22 \% ; 2-02 \% ; 3-04 \% ; 4-10 \%$ ". A resposta para a questão foi retirada da Enciclopédia Barsa e não se encontra descrita na Constituição Federal, tendo em vista que seu art. 231 não prevê qualquer percentual de terras reservadas aos índios. Conforme ressalta Sérgio Savi, não há dúvida de que a resposta se referia a um percentual de terras que seria reconhecido como pertencente aos indígenas constitucionalmente. Como a Constituição nada prevê, mesmo porque a própria União ainda não conseguiu fazer um levantamento preciso dessa área, com efeito, a questão não era passível de resposta (Responsabilidade civil por perda de uma chance, p. 77).

${ }^{424}$ STJ. 4. T. REsp. 788.459-BA. Rel. Min. Fernando Gonçalves. j. 8.11.95. v.u.
} 
O STJ entendeu que não havia certeza de que a demandante teria acertado a questão se esta tivesse sido redigida de modo correto, mesmo diante de seu desempenho irretocável até aquele momento. De fato, teriam de ser considerados diversos fatores, como a dificuldade progressiva das perguntas, que já havia feito diversos participantes errarem a última questão, e aspectos emocionais. Decidiu-se, assim, o que se segue:

"Destarte, não há como concluir, mesmo na esfera da probabilidade, que o normal andamento dos fatos conduziria ao acerto da questão. Falta assim, pressuposto essencial à condenação da recorrente no pagamento da integralidade do valor que ganharia a recorrida caso obtivesse êxito na pergunta final, qual seja, a certeza - ou a probabilidade objetiva - do acréscimo patrimonial apto a qualificar o lucro cessante.

Não obstante, é de se ter em conta que a recorrida, ao se deparar com questão mal formulada, que não comportava resposta efetivamente correta, justamente no momento em que poderia sagrar-se milionária, foi alvo de conduta ensejadora de evidente dano.

Resta, em consequência, evidente a perda de oportunidade pela recorrida, seja ao cotejo da resposta apontada pela recorrente como correta com aquela ministrada pela Constituição Federal que não aponta qualquer percentual de terras reservadas aos indígenas, seja porque o eventual avanço na descoberta das verdadeiras condições do programa e sua regulamentação, reclama investigação probatória e análise de cláusulas regulamentares, hipóteses vedadas pelas súmulas 5 e 7 do Superior Tribunal de Justiça [...].

A quantia sugerida pela recorrente $(\mathrm{R} \$ 125.000,00$ - cento e vinte e cinco mil reais - equivalente a um quarto do valor em comento, por ser uma 'probabilidade matemática' de acerto de uma questão de múltipla escolha com quatro itens) reflete as reais possibilidades de êxito da recorrida". 
O caso em tela evidencia que seria essencial recorrer à teoria da perda de uma chance para a concessão da indenização, tendo em vista que a demandante, em verdade, não deixou de ganhar o prêmio máximo, mas sim perdeu a chance de concorrer ao prêmio máximo. Não se está, portanto, diante de lucros cessantes, mas de danos emergentes, decorrentes da perda da oportunidade. A despeito da perfeita aplicação da teoria em comento na decisão estudada, talvez fosse o caso de conceder ressarcimento um pouco mais elevado à litigante, tendo em vista que a chance de acerto de $25 \%$ é a probabilidade de uma pessoa qualquer acertar a questão. A participante, no entanto, não era uma pessoa qualquer, genericamente considerada: havia acertado todas as questões até aquele momento, demonstrando conhecimento superior ao normal, o que aumenta a chance de que também acertasse a última ${ }^{425}$.

A seriedade das chances deve, pois, ser avaliada no caso concreto. Acerca desse assunto, assinale-se que Sérgio Savi advoga que a perda de uma chance somente deve ser indenizada quando tiver ao menos $50 \%$ de chance de se realizar ${ }^{426}$. Diverge-se desse entendimento e, ainda, considera-se não ser salutar estabelecer uma porcentagem mínima prévia para o ressarcimento do dano decorrente da perda de uma chance. Verifique-se, ademais, que o posicionamento do autor propicia injustiças, tendo em vista que, seguindo seu raciocínio, no caso aqui relatado, a demandante não faria jus a nenhuma indenização. Decerto, situação semelhante se verificaria em outras demandas.

É de se ressaltar, todavia, que a teoria deve ser utilizada com prudência, a fim de evitar a banalização do instituto, e até mesmo sua descaracterização. Como bem assinala Sílvia Vassilieff:

“[...] a possibilidade de aplicação da teoria da perte d'une chance passa pela delimitação e restrição de seu alcance. A viabilidade de sua aplicação depende de sua aproximação com o lucro cessante ${ }^{427}$, com a perda da probabilidade de êxito, com a razoabilidade, com a expectativa real, com a probabilidade bastante realizável, com a plausibilidade da pretensão. Sua viabilidade depende também do

\footnotetext{
${ }^{425}$ Rafael Peteffi da Silva também partilha desse entendimento (Responsabilidade civil pela perda de uma chance, p. 203).

${ }^{426}$ SAVI, Sérgio. Responsabilidade civil por perda de uma chance, p. 82.

${ }^{427}$ No que tange a esse ponto, conforme ressaltado, o entendimento do presente estudo não se coaduna com o da autora em comento.
} 
seu afastamento da mera hipótese, da mera expectativa, da ínfima possibilidade" ${ }^{, 428}$.

A despeito do exposto, é necessário esclarecer que a indenização por perda de uma chance não é aceita com unanimidade pela doutrina.

Rui Stoco, um dos mais ferozes opositores, se não o maior deles, ao discorrer acerca da responsabilidade civil do advogado, sustenta ser inadmissível que o juiz natural da causa seja substituído com o escopo de perscrutar o íntimo de sua convicção, fazendo um "juízo de valor a destempo" sobre como teria sido julgada a causa se chegasse a termo. Para o autor, a concessão de indenização em hipóteses semelhantes implicaria aceitar que a chance de ver a ação julgada conduziria, inevitavelmente, a uma decisão favorável, além de consagrar a possibilidade de reparação de um dano não comprovado e que não se sabe se ocorreria ${ }^{429}$.

Não obstante o entendimento expresso pelo respeitável doutrinador, com a indenização da perda da chance não se procura atingir o benefício que poderia ser auferido, mas sim a chance de auferi-lo. Preconiza-se, além disso, que a concessão de reparação parcial - objeto de abordagem no próximo item -, possui o condão de solucionar as justas inquietações da corrente contrária à indenização da perda da chance. Decerto, não é coerente que se conceda, a título de perda da chance, o mesmo montante que seria obtido com a concretização completa da chance, porque não se tem absoluta certeza de que esta seria efetivamente favorável. O que se pode fazer é avaliar a probabilidade de a decisão ser julgada de modo positivo ao credor da obrigação e estimar o valor da indenização de acordo com essa avaliação.

Pautado em outros argumentos, Flávio Tartuce reluta em aceitar a indenização da perda de uma chance por considerá-la dano meramente eventual, ou seja, incerto. O autor

\footnotetext{
${ }^{428}$ VASSILIEFF, Sílvia. Responsabilidade civil do advogado. Belo Horizonte: Del Rey, 2006. p. 69.

${ }^{429}$ STOCO, Rui. Tratado de responsabilidade civil. 6. ed. São Paulo: Revista dos Tribunais, 2004. p. 490: "Ademais de se caracterizar em verdadeira futurologia empírica, mais grave ainda é admitir que alguém possa ser responsabilizado por um resultado que não ocorreu e, portanto, por um dano hipotético e, em ultima ratio, não verificado ou demonstrado e sem concreção. Por fim, a maior heresia será admitir que o profissional, em uma obrigação contratual de meios, seja responsabilizado pelo resultado. Seria, data venia, a suma contraditio".
} 
sustenta que o art. 186 do CC de 2002, ao contrário do art. 159, seu correspondente no Código Civil revogado, exige a certeza do dano para que este possa ser indenizado ${ }^{430}$.

De fato, já se reportou a essa questão ao comentar o pensamento de Alain Bénabent. A redação do art. 186 é bastante incisiva e não deixa margem para dúvida acerca da necessidade de certeza sobre o dano indenizável. Enquanto o antigo art. $159^{431}$ faz alusão a "violar direito, ou causar prejuízo a outrem", o art. 186 menciona "violar direito e causar dano a outrem". Entende-se, no entanto, que essa mudança não impede a concessão de indenização a título de perda da chance, já que, conforme salientado, esta configura dano certo, e não eventual. A análise da probabilidade refere-se unicamente ao montante da indenização já que a perda da oportunidade é sempre certa; o que se deve definir é quanto ela "vale".

É indubitável que, por vezes, torna-se difícil determinar se o prejuízo invocado é certo ou simplesmente eventual. Entende-se, no entanto, que o reconhecimento da reparação dessa espécie de dano é imprescindível para que prejuízos decorrentes de alguns tipos de obrigação sejam indenizados. Conforme será exposto adiante, especialmente no Capítulo 4, quando a responsabilidade de determinado tipo de atividade é avaliada de modo subjetivo e decorre de obrigação de meio, como a responsabilidade do profissional liberal, o nexo causal pode ser difícil de ser demonstrado pela vítima, fazendo-se necessário recorrer à teoria da perda da chance para que o lesado possa ser devidamente indenizado.

No tocante ao nexo causal, cumpre salientar que este, muitas vezes, deve ser tomado em padrões pouco tradicionais a fim de propiciar a reparação dos danos decorrentes da frustração da oportunidade. Sobre essa questão, Rafael Peteffi da Silva salienta que várias teorias tentam explicar a natureza jurídica da perda de uma chance, as quais podem se dividir em três grandes vertentes: a primeira preconiza que se deve adotar uma causalidade alternativa ou parcial em qualquer caso; a segunda advoga que a causalidade alternativa seja utilizada somente nos casos de responsabilidade médica; e a terceira sustenta não ser necessário alterar os padrões tradicionais de causalidade,

430 TARTUCE, Flávio. Questões controvertidas quanto à reparação por danos morais. Aspectos doutrinários e visão jurisprudencial. Disponível em: <www.flaviotartuce.adv.br>. Acesso em: 15 set. 2005. O mesmo pensamento é mantido em Direito Civil, v. 2, p. 420 et seq.

${ }^{431} \mathrm{O}$ art. 159 determinava que: "Aquele que, por ação ou omissão voluntária, negligência, ou imprudência, violar direito, ou causar prejuízo a outrem, fica obrigado a reparar o dano”. 
considerando a perda de uma chance sempre um dano autônomo ${ }^{432}$. O autor, por sua vez, apregoa que a necessidade de flexibilização do nexo causal deverá ser avaliada de acordo com o caso concreto, esclarecendo, contudo, que a perda da chance somente se verifica quando não está presente a conditio sine qua non entre a conduta do ofensor e a vantagem pretendida pela vítima, isto é, não se tem certeza de que a conduta do ofensor foi responsável por gerar a perda da vantagem pretendida:

"Em todos os casos típicos de responsabilidade pela perda de uma chance existe um prejuízo sofrido pela vítima bastante fácil de identificar: a perda da vantagem esperada pela vítima, também denominada de dano final. Esse dano final pode ser a perda do processo judicial, para o litigante; a perda da vida, para o paciente; ou a perda do concurso vestibular, para o estudante. Entretanto, a perda definitiva da vantagem esperada não pode ser indenizada tendo em vista que a conduta do réu, nos casos de perda de uma chance, nunca se caracteriza como uma condição sine qua non".

Domenico Chindemi, do mesmo modo, ao tratar da responsabilidade médica, sustenta que a teoria da perda da chance, nessa seara, deve ser utilizada para a avaliação, em termos percentuais, do prejuízo sofrido em relação ao nexo causal probabilístico entre a conduta do médico e o agravamento das condições de saúde ou mesmo morte do paciente. Dessa maneira, ainda que não se possa afirmar que o evento não teria acontecido sem a intervenção falha do profissional, se for possível afirmar que o paciente perdeu, em decorrência da conduta do ofensor, a chance de sobrevivência ou de cura que estatisticamente possuía, haverá o dever de indenizar. O ressarcimento será, todavia, reduzido percentualmente às chances reconhecidas ao paciente ${ }^{433}$. Está-se diante, em conclusão, da substituição do critério de certeza do nexo causal pelo da probabilidade razoável do agravamento da possibilidade (diminuição das chances de sobreviver).

Partilha-se do entendimento esposado pelos autores, de modo a reconhecer que, em alguns casos concretos, em especial relacionados à responsabilidade decorrente de atividade médica ${ }^{434}$, será necessário analisar o nexo de causalidade com menor rigor.

\footnotetext{
${ }^{432}$ SILVA, Rafael Peteffi da. Responsabilidade civil pela perda de uma chance, p. 49.

${ }^{433}$ CHINDEMI, Domenico. Il danno da perdita di chance. Milano: Giuffrè, 2007. p. 125-127.

${ }^{434}$ A matéria será estudada no Capítulo 4.
} 


\subsection{Parâmetros para a indenização da perda de uma chance}

Conforme salientado há pouco, nem toda perda de oportunidade enseja reparação, mas tão somente aquela que é séria e real, o que deverá ser analisado com prudência pelo magistrado. Se a chance perdida era ínfima, não há dano. Se, contudo, a probabilidade de sua concretização era substancial, sua perda constitui, em regra, um prejuízo patrimonial $^{435}$.

Yves Chartier afirma que a determinação do valor de uma chance perdida não necessariamente há de ser feita pelo mero arbitramento, já que o montante da indenização pode ser o resultado de um estudo das possibilidades matemáticas por um técnico. Se não for o caso de prova pericial, os magistrados deverão, então, tomar conhecimento, de maneira detalhada, dos elementos integrantes do prejuízo para os quais concedem indenização. De acordo com o entendimento do autor, o cotejo das somas concedidas permitiria maior harmonia na reparação advinda dessa espécie de dano ${ }^{436}$.

Decerto há situações mais fáceis de serem avaliadas do que outras. Regina Beatriz Tavares da Silva relata o caso do corredor brasileiro Vanderlei Cordeiro de Lima, que foi abordado por pessoa mentalmente perturbada enquanto participava de uma competição esportiva nos jogos olímpicos de 2004. O atleta estava em primeiro lugar, com 28 segundos de vantagem em relação ao segundo colocado, faltando percorrer apenas um sétimo da prova, quando se deu o malfadado incidente. Após ser empurrado, Vanderlei Cordeiro caiu e somente conseguiu voltar a correr após 8 segundos. Em seguida, foi ultrapassado por dois competidores e acabou ocupando o terceiro lugar ${ }^{437}$.

Trata-se de hipótese bem característica de perda de chance, em específico, da chance de obtenção de vitória, que não seria inviável de ser avaliada por meio de critérios objetivos. O montante da indenização poderia, v.g., ser auferido pela análise da velocidade da vítima e de seus dois adversários no momento da interrupção da corrida, da variação desta durante o percurso e, principalmente, no trecho final, bem como das condições físicas de cada um deles, entre outras variantes.

\footnotetext{
${ }^{435}$ DIAS, João Antônio Álvaro. Dano corporal - quadro epistemológico e aspectos ressarcitórios, p. 254: “A possibilidade perdida configura-se assim como um bem patrimonial, uma entidade económica e juridicamente avaliável, cuja perda produz um dano actual e ressarcível".

${ }^{436}$ CHARTIER, Yves. La responsabilité de l'avocat. Paris: Dalloz, 1981. p. 62.

${ }^{437}$ SILVA, Regina Beatriz Tavares da. Perda de uma chance. Disponível em: <www.flaviotartuce.adv.br>. Acesso em: 15 set. 2005.
} 
Não é, todavia, esse tipo de indenização que tem prevalecido na perda da chance, mas sim o da concessão de verba a título de reparação de danos morais ${ }^{438}$. Nessa esteira, considerando a perda da chance em seu aspecto apenas moral, consigna Antônio Jeová Santos, que ela deverá ser quantificada considerando-se:

- a situação da vítima, se a chance invocada como perdida tivesse se realizado;

- a chance em si mesma, a ser valorada em função do interesse prejudicado, do grau de probabilidade de sua produção e do caráter reversível ou irreversível do prejuízo que provoque sua frustração;

- o montante indenizatório que adviria da realização da chance. Acrescenta, ainda, que os juízes devem conceder indenização em valor menor do que a concedida em caso de certeza do dano final, ponderando, do mesmo modo, que, a despeito de ser parcial, essa indenização não deverá ser irrisória ${ }^{439}$.

Em face de todos os critérios apontados por Antônio Jeová Santos, pressupõe-se que este, apesar de identificar o dano aqui discutido como hipótese de dano moral, entende que a perda da chance deve ser avaliada por critérios objetivos pautados em dados probabilísticos - o que transcende ao simples arbitramento por meio do qual são calculados, em rigor, os danos extrapatrimoniais; isso não quer dizer que, em alguns casos, a perda de uma chance não possa configurar apenas dano moral ${ }^{440}$. Fora dessas hipóteses excepcionais, porém, é mais adequado proceder ao cálculo probabilístico. Ainda que o

\footnotetext{
${ }^{438}$ Verifiquem-se as ementas dos seguintes acórdãos: Apelação Cível n. 70007261795. Quinta Câmara Cível do Tribunal de Justiça do Rio Grande do Sul. Relator: Leo Lima. j. 27.11.03: "RESPONSABILIDADE CIVIL. ENSINO PARTICULAR. DANO MORAL E MATERIAL. REPROVAÇÃO DE ALUNA. Comprovada a irregularidade na reprovação da aluna, à qual não foi oportunizada adequada recuperação terapêutica, com perda da chance de ser aprovada e rompimento de seu equilíbrio psicológico, impõe-se seja indenizado o dano moral sofrido. A frustração dos pais, porém, não constitui dor passível de reparação, nas circunstâncias. Dano moral afastado. Apelo provido em parte"; Apelação Cível n. 71000588822. Primeira Turma Recursal Cível do Juizado Especial Cível de Porto Alegre. Relator: João Pedro Cavalli Junior. j. 28.10.04: "DANO MORAL. BANCO. ERRO DE ATRIBUIÇÃO DE PAGAMENTO PELO CAIXA. VESTIBULAR. PERDA DE CHANCE. Frustrada a participação do autor em concurso vestibular de universidade pública por defeito do serviço do banco arrecadador do valor da inscrição, que creditou o valor a terceiro, e demonstrada a viabilidade de aprovação, caracteriza-se perda de chance que configura dano moral indenizável. Recurso provido. Unânime".

${ }^{439}$ SANTOS, Antônio Jeová. Dano moral indenizável, p. 107-108.

${ }^{440}$ Domenico Chindemi sustenta que a perda de uma chance, quando configura uma alteração do estado de bem-estar de uma pessoa pode ser reconhecida como dano à saúde, enquanto que se projetar reflexos negativos sobre a atividade quotidiana e sobre aspectos dinâmicos da vida de relação do prejudicado pode ser reconhecida como dano biológico; se se tratar de fato ilícito decorrente de causa diversa, pode ser entendida como dano existencial. Assim, de acordo com o autor, há dano extrapatrimonial quando a chance não tem repercussões sobre a capacidade da vítima de produzir rendimentos (Il danno da perdita di chance, p. 102$103)$.
} 
arbitramento seja procedimento mais fácil e até mesmo menos oneroso para as partes, é prudente que a indenização seja determinada após a realização de prova pericial, exceto se não houver nenhum tipo de critério objetivo que possa ser extraído do caso concreto.

De qualquer modo, conforme mencionado, para abranger o grau de probabilidade alusiva à oportunidade perdida, a indenização deverá, em regra, ser parcial ${ }^{441}$. A vítima não poderá obter a totalidade da vantagem esperada, mas somente uma porcentagem proporcional à probabilidade de sua concretização. A reparação da perda da chance deve ser mensurada em correspondência com a oportunidade perdida e, em rigor, não poderá ser igual à vantagem que teria sido gerada pela plena realização da chance, como relatado exaustivamente pela doutrina pátria e estrangeira e conforme se verificou no caso do "Show do Milhão", referido páginas anteriores. O que ocorre é que, como o montante da indenização é aferido mediante análise de probabilidade, e dificilmente se chegará ao índice de $100 \%$ de possibilidade de concretização da chance perdida, a indenização raramente será integral ${ }^{442}$.

No caso da atuação do advogado, v.g., ainda que a perda em juízo por omissão imputável a ele represente um dano certo, a indenização não pode consistir na soma reclamada na demanda, já que, por depender, em alguma medida, de circunstâncias alheias ao causídico, não se pode ter a certeza de que a sentença teria reconhecido a totalidade do pedido; em razão disso, o ressarcimento deve consistir na perda da chance. Do mesmo modo, se o profissional deixou prescrever uma ação, deverá indenizar o cliente pelas custas judiciais despendidas (se previamente pagas) e pela chance de triunfar que possuía a ação prescrita, o que vai depender de análise da matéria objeto da ação.

Deve-se salientar, entretanto, que há casos em que a realização da chance é tão certa, que não há óbice à concessão de indenização integral, como é o caso do julgado transcrito a seguir, ipsis litteris:

“Apelação cível. Responsabilidade civil. Ação de indenização por danos materiais e morais. Sindicato. Não inclusão do nome da autora em demanda trabalhista. $\mathrm{O}$ demandado deve ser responsabilizado pelos prejuízos originados da perda da chance

\footnotetext{
${ }^{441}$ CHINDEMI, Domenico. Il danno da perdita di chance, p. 128.

${ }^{442}$ Verifique-se que essa indenização parcial não implica a violação do princípio da reparação integral; na verdade, a indenização concedida está reparando na íntegra a chance perdida, que é efetivamente o que deve ser objeto de ressarcimento, e não o prejuízo final (SILVA, Rafael Peteffi da. Responsabilidade civil pela perda de uma chance, p. 453).
} 
experimentada pela autora, ao deixar de ter seu nome incluído e não ter sua pretensão examinada e acolhida no Juízo trabalhista, como ocorrido com seus colegas de trabalho. Dano material fixado com paradigma em outro funcionário. Possibilidade. Fixação de indenização por dano moral. O dano moral deve ser fixado, considerando a necessidade de punir o ofensor e evitar que repita seu comportamento, devendo se levar em conta o caráter punitivo da medida, a condição social e econômica do lesado e a repercussão do dano. Apelo provido" 443 .

De fato, demandas de natureza trabalhista têm grande chance de serem exitosas em virtude de sua legislação específica, ao menos tempo, minuciosa e restritiva. No caso em tela, bastava verificar se a cliente possuía todos os requisitos necessários para a propositura da ação e, eventualmente, deixar a cargo de um perito o cálculo do valor que seria por ela auferido em caso de propositura da demanda.

O exemplo pré-citado demonstra que a perda da chance é essencial para o estudo da responsabilidade profissional, que com frequência gera danos difíceis de serem precisados. É claro que não há restrição de campo de utilização para a teoria da perda da chance, a qual pode ser aplicada sempre que determinada ordem lógica de acontecimentos é interrompida em razão da conduta do ofensor; porém, tradicionalmente, ela tem seu emprego no âmbito da responsabilidade profissional. As particularidades de cada caso serão estudadas nos capítulos específicos.

${ }_{443}$ Apelação Cível no 70009254566 , Sexta Câmara Cível do Tribunal de Justiça do Rio Grande do Sul, Relator: Ney Wiedemann Neto, julgado em 6 de abril de 2005. 


\section{RESPONSABILIDADE CIVIL CONTRATUAL POR ATO PRÓPRIO E POR ATO DE TERCEIRO}

No presente Capítulo tratar-se-á da responsabilidade civil contratual, típica da atividade dos profissionais liberais, ainda que, em algumas hipóteses, seja possível a configuração da responsabilidade extracontratual, como será esclarecido adiante. Em seguida, serão analisadas as obrigações de meio e de resultado. Além disso, far-se-ão considerações sobre a responsabilidade do profissional que atua por conta própria, bem como daquele que é empregado ou atua na condição de preposto e do que é servidor público. Serão tecidos comentários, igualmente, sobre a responsabilidade por ato de terceiro, em específico na hipótese prevista no art. 932, inc. III, do CC. Por fim, será abordada a possibilidade de aplicação do Código de Defesa do Consumidor à matéria, bem como as consequências dessa aplicação, como a inversão do ônus da prova, o prazo prescricional aplicável à demanda indenizatória e a responsabilidade das pessoas jurídicas que prestam serviços com atuação de profissionais liberais.

\subsection{A responsabilidade civil contratual em oposição à responsabilidade extracontratual}

Faz-se necessário, antes de tudo, apresentar a clássica divisão entre responsabilidade civil contratual e extracontratual ${ }^{444}$, a qual também recebe o nome de negocial ou extranegocial ${ }^{445}$.

A responsabilidade contratual se assenta na autonomia da vontade e obedece às normas gerais contratuais, decorrendo do descumprimento de uma norma inserida em um negócio jurídico ${ }^{446}$. A responsabilidade extracontratual ou aquiliana, por sua vez, independe da vontade das partes, surgindo do acaso, da ocorrência de um evento entre pessoas que não possuíam prévio vínculo jurídico ${ }^{447}$ e do descumprimento de uma norma

\footnotetext{
${ }^{444}$ Também se admitem os termos aquiliana e delitual para a designação dessa espécie de responsabilidade. ${ }^{445}$ BAPTISTA, Silvio Neves. Teoria geral do dano, p. 112-113.

${ }^{446}$ MAJO, Adolfo di. La responsabilità contrattuale. Torino: G. Giappichelli, 2007. p. 11.

${ }^{447}$ AGUIAR DIAS, José de. Da responsabilidade civil, t. II, p. 147.
} 
legal. A responsabilidade negocial se difere, assim, da delitual em razão de pressupor uma relação jurídica anterior que vincula vítima e ofensor ${ }^{448}$.

Os ensinamentos de André Tunc, transcritos a seguir, corroboram essa assertiva:

“L'objet de la responsabilité délictuelle est d'obliger une personne à compenser un dommage qu'elle a illégalement causé à une autre en dehors de toute relation contractuelle. La plupart du temps, l'auteur du dommage et sa victime sont étrangers l'un à l'autre. Comme on l'a dit, le droit de la responsabilité civile délictuelle assure la coexistence de citoyens libres et l'harmonisation de leur liberté.

Le droit des contrats, en revanche, régit les droits et les obligations de personnes don't l'une au moins a promis à l'autre de faire ou donner quelque chose ou de s'abstenir de faire quelque chose. Les parties sont liées l'une à l'egard de l'autre, et elles ont accepté de se lier. Souvent, le dommage souffert par le demandeur resulte du seul fait qu'il n'a pas reçu la prestation promise. Il est clair qu'il n'aurait pas d'action si un contrat n'avait été conclu" ${ }^{\text {"49 }}$.

Também à guisa de diferenciação, ressalte-se que a capacidade jurídica das partes é avaliada de forma mais restrita na responsabilidade contratual, tendo em vista que a convenção exige contratantes capazes ${ }^{450}$ no momento da conclusão do negócio jurídico, sob pena de nulidade, enquanto, em sede de responsabilidade extracontratual, mesmo o incapaz pode ser condenado a indenizar os prejuízos causados, desde que as pessoas por

\footnotetext{
${ }^{448}$ GOMES, Luiz Roldão de Freitas. Elementos de responsabilidade civil, p. 29.

${ }^{449}$ TUNC, André. La responsabilité civile, p. 32. Em tradução livre, o texto transcrito pode ser lido da seguinte maneira:

"O objeto da obrigação delitual é de obrigar uma pessoa a reparar um dano que ela ilegalmente causou a outra fora de qualquer relação contratual. Na maior parte do tempo, o autor do dano e sua vítima são estranhos um ao outro. Como havia sido dito, o direito da responsabilidade civil delitual assegura a coexistência de cidadãos livres e a harmonização de sua liberdade.

"O direito dos contratos, por sua vez, rege os direitos e as obrigações de pessoas, nas quais ao menos uma prometeu à outra fazer ou dar qualquer coisa ou se abster de fazer qualquer coisa. As partes são ligadas uma em relação à outra, e elas aceitaram se relacionar. Com frequência, o dano sofrido pelo autor resulta do simples fato de ele não ter recebido a prestação prometida. Está claro que ele não teria fundamento para a ação se um contrato não tivesse sido concluído".

${ }_{450}$ Admite-se que sejam absoluta ou relativamente incapazes, desde que estejam, respectivamente, representados ou assistidos.
} 
ele responsáveis não tenham condição de fazê-lo, ou não disponham de meios suficientes para tanto $^{451}$.

A despeito das inúmeras críticas formuladas à divisão da responsabilidade nessas duas vertentes $^{452}$, o Código Civil manteve a diferença, tratando da contratual nos arts. 389 e seguintes, e da aquiliana nos arts. 186 a 188.

Conforme asseverado, a natureza jurídica predominante da responsabilidade profissional é contratual, motivo pelo qual é de interesse prevalente o estudo dessa modalidade. Sendo assim, passar-se-á à sua análise.

O contrato constitui-se de um acordo de vontades que tem por escopo a criação, modificação ou extinção de direitos. Por meio desse instrumento, as partes se vinculam ao que contrataram de uma maneira tal que, havendo o descumprimento de qualquer das cláusulas estabelecidas, surge a responsabilidade contratual.

O descumprimento pode ser caracterizado como mora ${ }^{453}$ ou como inadimplemento absoluto. A mora se verifica não somente no caso do pagamento realizado a destempo, isto é, fora do prazo estabelecido, mas também quando este é procedido em local ou forma distintos do convencionado ${ }^{454}$. Nessa hipótese, ainda há utilidade, para o credor, no cumprimento correto da obrigação. No segundo caso, ou seja, quando se verifica o inadimplemento absoluto, ela já se tornou imprestável ${ }^{455}$, como ocorre, v.g., com o vestido de noiva que é entregue pelo ateliê de costura depois de realizada a cerimônia de casamento.

Na hipótese de simples mora, a qual pode ser purgada, podem ser cominados juros moratórios ao devedor, o que decorre da análise do art. 395 do $\mathrm{CC}^{456}$. Convém salientar

451 GONÇALVES, Carlos Roberto. Responsabilidade civil, p. 28; SILVA, Wilson Melo da. Da responsabilidade civil automobilística, p. 21.

${ }^{452}$ Dissertando acerca da existência da tese da dualidade das responsabilidades e a da unidade (a primeira é chamada dualista ou clássica, e a segunda, monista), CARVAL, Suzanne. La construction de la responsabilité civile. Paris: Presses Universitaires de France, 2001. p. 125. Ainda tratando do mesmo assunto, Adolfo di Majo (La responsabilità contrattuale, p. 12). A tese monista confere os mesmos efeitos aos dois tipos de responsabilidade.

${ }^{453}$ A mora se divide em ex re e ex persona. No primeiro caso, decorre da própria lei e não depende de provocação do credor, sendo aplicável a regra dies interpellat pro homine, isto é, o termo interpela em lugar do credor. É o que ocorre, v.g., com as obrigações positivas, líquidas e vencidas. Já na segunda hipótese, como não há determinação certa do termo da obrigação, é necessária a realização de interpelação judicial ou extrajudicial.

${ }^{454}$ AZEVEDO, Álvaro Villaça. Teoria geral das obrigações - responsabilidade civil, p. 214.

${ }^{455}$ DINIZ, Maria Helena. Curso de Direito Civil brasileiro - responsabilidade civil, p. 234.

${ }^{456} \mathrm{O}$ referido artigo possui a seguinte redação:

“[...] Responde o devedor pelos prejuízos a que sua mora der causa, mais juros, atualização dos valores monetários segundo índices oficiais regularmente estabelecidos, e honorários de advogado. 
que os juros podem ser moratórios ou compensatórios. Os juros compensatórios são devidos em consequência do uso do capital alheio, ao passo que os moratórios advêm do inadimplemento contratual $^{457}$. Ambos podem ser estipulados pelas partes, ou então, em caso de omissão no instrumento, será utilizada a taxa prevista em lei, isto é, aplicar-se-á o disposto pelo art. 406 do $\mathrm{CC}^{458}$.

Os juros moratórios, que podem ser convencionais ou legais, possuem natureza jurídica indenizatória de lucros cessantes com relação ao credor que deixou de usufruir dos frutos da prestação, isto é, de seus rendimentos, durante certo período de tempo. Consistem, assim, na indenização pelo retardamento da execução do débito ${ }^{459}$. A despeito da possibilidade de cominação de juros, não havendo interesse no recebimento da prestação, configura-se o inadimplemento absoluto, de modo que o credor poderá rejeitar o objeto da prestação e pleitear a indenização dos prejuízos.

A existência de um contrato possibilita, ademais, que seja estabelecida a chamada cláusula penal, que consiste na obrigação acessória por meio da qual o devedor se compromete ao pagamento de uma pena de natureza pecuniária ou não, em caso de descumprimento da convenção, fixando previamente o valor das perdas e danos ${ }^{460}$. Como se depreende da definição apresentada, a pena não precisa necessariamente ser uma soma em dinheiro, sendo admitido também o cumprimento de uma obrigação de dar um objeto, ou de prestar um serviço. De qualquer maneira, não deixa de ser uma multa, destinada a evitar as consequências da mora e do inadimplemento, sendo uma forma de predeterminar os prejuízos ${ }^{461}$, bem como de facilitar o ônus da prova do credor, para o qual bastará provar a ocorrência de mora ou inadimplemento ${ }^{462}$.

A cláusula em comento pode ser compensatória ou moratória. Será compensatória quando se verificar o total inadimplemento da obrigação, isto é, quando a prestação não for

\footnotetext{
Parágrafo único. Se a prestação, devido à mora, se tornar inútil ao credor, este poderá enjeitá-la, e exigir a satisfação das perdas e danos".

${ }^{457}$ AZEVEDO, Álvaro Villaça. Teoria geral das obrigações - responsabilidade civil, p. 235.

${ }^{458} \mathrm{O}$ artigo em comento determina que os juros moratórios sejam estabelecidos de acordo com "a taxa que estiver em vigor para a mora do pagamento de impostos devidos à Fazenda Nacional", o que gera bastante controvérsia da doutrina, pois há que se determinar quais são os juros devidos à Fazenda Nacional. Parte da doutrina entende ser aplicável o Sistema Especial de Liquidação e Custódia (Selic), enquanto outros apregoam que deve ser aplicada a taxa prevista no art. 161, $\S 1^{\circ}$, do Código Tributário nacional, ou seja, $1 \%$ ao mês, posição que se coaduna com a preconizada neste trabalho.

${ }^{459}$ DINIZ, Maria Helena. Curso de Direito Civil brasileiro - responsabilidade civil, p. 248.

${ }^{460}$ Ibidem, p. 261. No mesmo sentido, Álvaro Villaça Azevedo (op. cit., p. 257).

${ }^{461}$ SIMÃO, José Fernando. Vícios do produto no novo Código Civil e no Código de Defesa do Consumidor, p. 157.

${ }^{462}$ AZEVEDO, Álvaro Villaça, op. cit., p. 259.
} 
mais útil ao credor, tendo por finalidade servir de base de cálculo para a indenização. Será moratória se convencionada para aplicação em caso de simples mora, quando, então, visa garantir o cumprimento de determinada cláusula ou desencorajar o atraso. Se o credor, contudo, entender que o valor previsto na cláusula não é suficiente para repará-lo devidamente, poderá pleitear indenização superior, desde que comprove os prejuízos $\operatorname{suportados}^{463}$. O valor da cláusula, em sua modalidade compensatória, encontra limitação no montante da obrigação, não podendo lhe ser superior, nos termos do art. 912 do CC. Poderá também ser reduzida, em caso de cumprimento parcial da obrigação (art. 913 do CC). O montante estipulado na cláusula penal moratória encontra limitação na legislação vigente, como, por exemplo, no art. 52, $\S 1^{\circ}$, do $\mathrm{CDC}^{464}$, que limita a multa a $2 \%$ do valor total da prestação sempre que se verificar relação de consumo ${ }^{465}$.

Por fim, convém frisar que a diferença, de fato, relevante entre os dois tipos de responsabilidade diz respeito ao ônus probatório. Na responsabilidade contratual, basta ao credor demonstrar que não houve o adimplemento da obrigação, cabendo ao devedor comprovar a existência de excludentes do dever de indenizar a fim de se eximir de sua responsabilidade $^{466}$. O ônus se transfere, assim, ao devedor. Na responsabilidade

${ }^{463}$ RODRIGUES, Silvio. Direito Civil - parte geral: das obrigações. 28. ed. São Paulo: Saraiva, 2000. v. 2, p. $84 / 88$.

${ }^{464} \mathrm{O}$ parágrafo em comento possui a seguinte redação: "§ $1^{\circ}$. As multas de mora decorrentes do inadimplemento de obrigações no seu termo não poderão ser superiores a $2 \%$ (dois por cento) do valor da prestação".

${ }_{465}$ Outros exemplos de redução se encontram no art. 12, § 3º da Lei n. 4.591/1964 ("O condômino que não pagar a sua contribuição no prazo fixado na Convenção fica sujeito ao juro moratório de $1 \%$ ao mês, e multa de até $20 \%$ sobre o débito, que será atualizado, se o estipular a Convenção, com a aplicação dos índices de correção monetária levantados pelo Conselho Nacional de Economia, no caso da mora por período igual ou superior a seis meses"); no art. 11, alínea "f”, do Decreto-lei n. 58/1937, que trata sobre loteamentos e compra e venda de terrenos em prestações ("Do compromisso de compra e venda a que se refere esta lei, contratado por instrumento público ou particular, constarão sempre as seguintes especificações: [...] f) cláusula penal não superior a $10 \%$ do débito, e só exigível no caso de intervenção judicial"); e no art. $1^{\circ}$ do Decreto n. 22.626/1933, a chamada Lei de Usura, com disposições já revogadas, mas cuja menção faz sentido por motivos históricos (“Art. $1^{\circ}$. É vedado, e será punido nos termos desta lei, estipular em quaisquer contratos taxas de juros superiores ao dobro da taxa legal (Código Civil, art. 1062). § 1ํ. Essas taxas não excederão de $10 \%$ ao ano se os contratos forem garantidos com hipotecas urbanas, nem de $8 \%$ ao ano se as garantias forem de hipotecas rurais ou de penhores agrícolas. $\S 2^{\underline{0}}$. Não excederão igualmente de $6 \%$ ao ano os juros das obrigações expressa e declaradamente contraídas para financiamento de trabalhos expressa e declaradamente contraídas para financiamento de trabalhos agrícolas, ou para compra de maquinismos e de utensílios destinados a agricultura, qualquer que seja a modalidade da dívida, desde que tenham garantia real; $\S 3^{\circ}$. A taxa de juros deve ser estipulada em escritura pública ou escrito particular, e não o sendo, entenderse-á que as partes acordaram nos juros de $6 \%$ ao ano, a contar da data da propositura da respectiva ação ou do protesto cambial").

${ }^{466}$ CARDOSO, Alaércio. Responsabilidade civil e penal dos médicos nos casos de transplantes. Belo Horizonte: Del Rey, 2002. p. 271. No mesmo sentido, tratando da legislação italiana, Giovanna Visintini assevera que: "Come è noto, l'art. 1218 dispone che il debitore è responsabile se non prova che l'inadempimento è stato determinato da 'impossibilitá della prestazione derivante da causa a lui non imputabile'. La stessa espressione che implica, a carico del debitore, l'onere della prova della causa non imputabile, si legge negli artt. 408, 409, 412 cod. nav. in tema di trasporto maritimo di personne e nell'art. 
extracontratual, a vítima deve demonstrar que o agente agiu com culpa, ou, então, que se está diante de hipótese de responsabilidade objetiva ${ }^{467}$. José de Aguiar Dias assevera que a responsabilidade contratual frequentemente se baseia em um dever de resultado ${ }^{468}$, que enseja a presunção de culpa. Ver-se-á, porém, que não é o caso da responsabilidade profissional.

A distinção ora procedida depende da conjugação com outra: a de obrigações de meio e de resultado, analisada a seguir, uma vez que esta também exerce influência sobre o ônus da prova a cargo do credor e do devedor.

\subsection{Obrigações de meio e de resultado}

A doutrina aponta a origem da diferenciação entre obrigações de meio e de resultado como de titularidade de René Demogue ${ }^{469}$, formulada incidentalmente em

1.588 cod. civ. in tema di locazione" (La responsabilitá contrattuale. Napoli: Eugenio Jovene. 1979). (Tradução livre: "Como se nota, o art. 1.218 dispõe que o devedor é responsável se não prova que o inadimplemento foi determinado pela 'impossibilidade da prestação em decorrência de causa que não lhe imputável'. A mesma expressão que implica, a cargo do devedor, ônus da prova da causa não imputável se lê nos arts. 408, 409, 412 do cód. naval em tema de transporte marítimo de pessoas e no art. 1.588 do cód. civil em tema de locação".)

${ }^{467}$ AGUIAR JR., Ruy Rosado de. Responsabilidade civil do médico. Revista dos Tribunais, São Paulo, ano 84, v. 718, ago. 1995. p. 35.

${ }^{468}$ AGUIAR DIAS, José de. Da responsabilidade civil, t. II, p. 152.

469 DEMOGUE, René. Traité des obligations en général. Paris: Librairie Arthur Rousseau, 1925. parag. 1237, t. V, p. 538-7: “L'obligation qui peut peser sur un débiteur n'est pas toujours de même nature. Ce peutêtre une obligation de résultat ou une obligation de moyen. Une personne a reçu le mandate de faire un acte unilatéral, ou elle s'est chargée de transporter un colis, de construire un bâtiment. Ces résultats ne sont pas atteints. Ce deux points constatés: obligation et inexécution, le créancier a gain de cause, à moins que le débiteur ne prouve avoir été dans l'impossibilité d'exécuter par cas fortuit ou force majeure. Au lieu de promettre un résultat, on peut être obligé légalement ou conventionnellement de prendre certaines mesures qui normalement sont de nature à amener un résultat. Ainsi un banquier au lieu de prendre des titres en dépot aux guichets (obligation de résultat quant à leur conservation) loue un coffre-fort. Il s'engage à prendre les précautions d'usage pour l'admission dans la salle des coffres, l'ouverture. Si des titres étaint volés, je devrais prouver que le banquier a manqué une de ses obligations: laissant une personne ouvrir un coffre sans s'être assuré de son identité, car la banque ne m'a pas promis un résultat: à savoir que je retroverai mes titres, elle m'a promis de surveiller l'acèss à mon coffre-fort. Si elle a laissé pénétrer un tiers près de mon coffre, elle pourra d'ailleurs prouver qu'il y a eu cas fortuit ou force majeure. Des émeutiers peuvent avoir usé de menaces, elle peut s'être trompée sur l'identité du visiteur du coffre. (Tradução livre: “A obrigação que pode pesar sobre um devedor não é sempre da mesma natureza. Esta pode ser uma obrigação de resultado ou uma obrigação de meio. Uma pessoa recebeu o mandato de fazer um ato unilateral, ou está encarregada de transportar um pacote, de construir um prédio. Esses resultados não são alcançados. Constatados este dois pontos: obrigação e inexecução, o credor ganha a causa, a menos que o devedor prove estar na impossibilidade de executar em razão de caso fortuito ou força maior. Ao contrário de prometer um resultado, podemos estar obrigados legal ou convencionalmente a tomar certas medidas que em regra são de natureza a alcançar um resultado. Assim um banqueiro, em vez de colocar os títulos em depósito no balcão (obrigação de resultado quanto à sua conservação), aluga um cofre-forte. Ele se compromete a tomar as precauções de uso para admissão na sala dos cofres, a abertura. Se os títulos tivessem sido roubados, eu deveria provar que o banqueiro faltou com uma de suas obrigações: deixando uma pessoa abrir um cofre sem estar assegurada de sua identidade, porque o banco não me prometeu um resultado: sabendo que eu retomaria os meus títulos, ele me prometeu vigiar o acesso ao meu cofre-forte. Se ela deixou penetrar um terceiro perto 
matéria de obrigações contratuais e delituais, mas a matéria também foi objeto de estudo aprofundado por outros autores franceses, como os irmãos Mazeaud.

Distinguir obrigações de meio das de resultado tem por escopo determinar a natureza da culpa contratual em caso de inadimplemento. Nas obrigações de meio, para que seja considerado adimplente, basta ao devedor que atue de maneira diligente em prol dos objetivos da obrigação, isto é, basta que se comporte como o bonus pater familias. Essas obrigações não estão, pois, comprometidas com a finalidade pretendida pelo credor, de modo que não ensejam dever de indenizar em decorrência da não consecução do resultado. Nas obrigações de resultado, o adimplemento impõe que o fim seja alcançado, fazendo que o devedor deva provar a ocorrência do resultado pretendido ou a ausência de culpa pela frustração da obrigação.

Sobre o assunto, disserta com precisão José de Aguiar Dias:

"A fórmula é de Demogue, que considera obrigação de meios as que encerram a promessa do emprego de certa diligência reputada, em princípio, como capaz de proporcionar um dado resultado, não, porém, a promessa desse resultado. A obrigação de meios implica, pois, em dever de atenção e diligência, visando a um fim que, todavia, não entra necessária e imperativamente nesse dever, podendo deixar de verificar-se, não obstante desempenhados satisfatoriamente os deveres do devedor. Isto é, na obrigação de meios, faz-se a abstração do resultado, embora não se compreenda um contrato sem resultado, para só considerar a diligência e atenção com que se perseguiu esse resultado; na obrigação de resultado, abstrai-se, ao contrário, dos meios: o que ao devedor toca é a prestação final, não obstante ser claro que dificilmente se poderá obter o resultado se não foram empregados os meios necessários" ${ }^{470}$.

Retomam-se os irmãos Mazeaud, a fim de salientar que esses autores apresentam uma terminologia diferente para tratar do mesmo assunto. Afirmam que a obrigação

do meu cofre, ela poderá também provar que houve caso fortuito ou força maior. Os invasores podem ter usado de ameaças, ela pode ter se enganado sobre a identidade do visitante do cofre").

${ }^{470}$ AGUIAR DIAS, José de. Da responsabilidade civil, t. II, p. 307-308. 
determinada, a que se atribui a nomenclatura de resultado, configura-se quando o devedor deve cumprir um fato determinado, ou seja, deve cumprir uma obrigação precisa. Nas obrigações gerais de prudência e diligência, aquelas a que se chamou de meio, o devedor obriga-se a ser diligente, devendo conduzir-se de maneira prudente na tentativa de obtenção do resultado desejado. Não tem o dever, portanto, de atingir o escopo combinado $^{471}$.

Nessa mesma esteira tem-se o posicionamento de Álvaro Villaça Azevedo, ressaltando que, pela obrigação de meio, o devedor se obriga a fornecer os meios necessários para a realização de um fim, sem, contudo, responsabilizar-se pelo resultado, somente devendo empenhar-se e convergir seus esforços em prol da obtenção deste. $\mathrm{Na}$ hipótese de se tratar de obrigação de resultado, o devedor deverá realizar plenamente o escopo pretendido, a fim de que sua obrigação seja considerada adimplida. Enquanto o resultado não sobrevier, a obrigação não se exaure ${ }^{472}$.

A despeito das obrigações, em regra, serem de resultado ${ }^{473}$, a do profissional é, na maior parte dos casos, considerada de meio. Os advogados e médicos, v.g., deverão utilizar seus conhecimentos técnicos para que os objetivos pretendidos sejam alcançados. No entanto, nem o advogado pode garantir o sucesso da demanda de seu cliente, nem pode o médico assegurar a cura ao seu paciente ${ }^{474}$. O primeiro não tem o dever de ganhar a causa de seu cliente, mas sim o de prestar atendimento jurídico atento e diligente; da mesma forma, não tem o segundo o dever de curar o paciente, mas sim de lhe prestar cuidados conscienciosos, procurando obter seu consentimento prévio e esclarecido ${ }^{475}$.

De fato, o advogado, em especial quando atuando na área contenciosa, não pode garantir o resultado da demanda porque este não depende somente dele, mas sim do posicionamento do magistrado, das declarações das testemunhas em audiência, das conclusões do perito, entre outras tantas variáveis. Se, todavia, é contratado para a elaboração de um contrato, a conclusão da obrigação depende somente de sua conduta, motivo pelo qual não se trata mais de uma obrigação de meios, mas sim de resultado.

\footnotetext{
${ }^{471}$ MAZEAUD, Henri; MAZEAUD, Léon; MAZEAUD, Jean. Leçons de Droit Civil - obligations - théorie générale, t. II, p. 13.

472 AZEVEDO, Álvaro Villaça. Teoria Geral das Obrigações - responsabilidade civil, p. 54.

${ }^{473}$ REPRESAS, Félix A. Trigo; MESA, Marcelo J. López. Tratado de la responsabilidad civil, t. I, p. 737.

${ }^{474}$ Para mencionar um exemplo que não se refira às já tradicionais responsabilidades de médicos e advogados, verifique-se, v.g., a obrigação do agente de propaganda ou publicidade, que se compromete a realizar sua atividade com zelo e criatividade, mas não garante o aumento de clientela da empresa contratante.

${ }^{475}$ DINIZ, Maria Helena. Curso de Direito Civil - responsabilidade civil, p. 265.
} 
Ressalte-se, pois, que nada impede que um mesmo devedor tenha obrigações de natureza diversa, ora de meio, ora de resultado.

O mesmo se diga sobre o médico, que, na atividade quotidiana, depende da colaboração do paciente para obter a cura ou sobrevivência deste e, além disso, labora em área científica pouco exata, na qual os tratamentos não têm resultado totalmente previsível. Muitas vezes, o resultado varia de acordo com o organismo daqueles que são a eles submetidos ${ }^{476}$. No caso dos patologistas clínicos, que realizam análises laboratoriais, as quais não apresentam riscos, observa-se que os tratamentos não dependem da atuação de terceiros e demandam apenas precisão técnica, sendo, portanto, de responsabilidade desses profissionais oferecer resultado compatível com o serviço contratado ${ }^{477}$.

É, no entanto, consenso entre os doutrinadores que a responsabilidade no contrato de empreitada se caracteriza como de resultado, sendo necessária, para adimplemento da obrigação do empreiteiro, a entrega da obra, em conformidade com as indicações do contratante. Isso não significa que a obrigação do engenheiro e do arquiteto seja sempre de resultado, ou que estes devam garantir uma data precisa para o término do trabalho. Isso porque lidam também com diversas variáveis que independem de seu lavor: mudanças climáticas, atraso na entrega dos materiais necessários para a conclusão da construção, entre outros ${ }^{478}$.

Vê-se, portanto, que a obrigação de meios decorre de situações que a álea inerente ao negócio jurídico não permite que o devedor garanta o resultado objetivado pelo credor $^{479}$. É justamente o que concluíram os Mazeaud, que propõem um método de identificação das obrigações de meio e de resultado que consiste na verificação de existência de um elemento aleatório no fim perseguido pelo contrato. Em caso positivo, isto é, havendo álea, estar-se-á diante de uma obrigação apenas de meio, porque, em rigor, o devedor não se propõe a obter um resultado que somente eventualmente possa ser obtido. Quando, ao contrário, a realização do resultado não é aleatória, e depende somente de sua

\footnotetext{
${ }^{476}$ Sobre o assunto, são pertinentes os comentários de CARVAL, Suzanne. La construction de la responsabilité civile, p. 120: “[...] le médecin ne s'oblige pas à guerir le malade: il n'en a pas le moyen, et ici chaque médecin doit se rappeler la belle formule du grand Ambroise Paré quando il disait: 'Je le pansai, Dieu le guérit". (Tradução livre: “[...] o médico não se obriga a curar o doente: ele não possui os meios para tanto, e aqui cada médico deve se lembrar da bela fórmula do grande Ambroise Paré quando ele dizia: 'eu cuido de suas feridas, Deus o cura"”.)

${ }^{477}$ KÜHN, Maria Leonor de Souza. Responsabilidade civil - a natureza jurídica da relação médico-paciente, p. 66.

${ }^{478}$ Para o estudo aprofundado da matéria, verifique-se o Capítulo 6.

${ }^{479}$ REPRESAS, Félix A. Trigo; MESA, Marcelo J. López. Tratado de la responsabilidad civil, t. II, p. 739.
} 
atuação $^{480}$, pode-se supor que o devedor prometeu cumprir aquele feito determinado. A natureza aleatória ou não da realização do fim a atingir permite, então, descobrir a vontade tácita dos contratantes $^{481}$. A análise da aleatoriedade da obrigação demonstra o equívoco de se considerar a obrigação do cirurgião plástico de resultado, uma vez que este se sujeita, como qualquer médico, à álea inerente à atividade médica ${ }^{482}$.

A distinção das obrigações da maneira ora estudada tem grande aplicabilidade no plano da prova, já que o credor de uma obrigação de resultado deve, simplesmente, provar que o resultado não foi atingido. A realização de tal resultado é encargo do devedor e pressuposto para que possa dela liberar-se $\mathrm{s}^{483}$. O credor de uma obrigação de meio deve, no entanto, comprovar que o dano que lhe foi impingido advém da atuação negligente do profissional $^{484}$, o que pode ser uma tarefa árdua.

Paulo Luiz Netto Lôbo, percebendo tal inconveniente, propõe a superação da divisão entre a responsabilidade decorrente de obrigação de meio e a resultante de obrigação de fim, para que se privilegie o consumidor ${ }^{485}$. Essa medida pode, no entanto, tornar-se excessivamente rigorosa e inviabilizar a atuação do profissional, o que se discutirá no item 3.6, ao tratar da aplicação do Código de Defesa do Consumidor às obrigações do profissional liberal, bem como da possibilidade de inversão do ônus da prova.

De acordo com os Mazeaud, a classificação em comento engloba todas as obrigações, sejam elas contratuais ou extracontratuais. Seria, v.g., uma obrigação de prudência e diligência extracontratual a de se conduzir com prudência em todas as

\footnotetext{
480 Neste caso também há certa margem de aleatoriedade, mas essa se encontra em grau mínimo (REPRESAS, Félix A. Trigo; MESA, Marcelo J. López. Tratado de la responsabilidad civil, t. II, p. 739). É evidente que diversos fatores podem impedir o cumprimento da obrigação de resultado. Esses fatores deverão configurar, no entanto, excludentes do dever de indenizar para que o devedor possa se eximir de sua obrigação.

${ }^{481}$ MAZEAUD, Henri; MAZEAUD, Léon; MAZEAUD, Jean. Leçons de Droit Civil - obligations - théorie générale, p. 15.

${ }_{482}$ Para a análise aprofundada da matéria, verifique-se o Capítulo 4.

483 HIRONAKA, Giselda Maria Fernandes Novaes; MORAES, Renato Duarte Franco de. Direito das obrigações. São Paulo: Revista dos Tribunais, 2008. v. 2, p. 53.

${ }^{484}$ Ruy Rosado de Aguiar Jr. ressalta que, tanto na responsabilidade contratual quanto na aquiliana derivada de uma obrigação de meios, o paciente deve demonstrar que o médico atuou com culpa (Responsabilidade civil do médico. Revista dos Tribunais, v. 84, n. 718, p. 35). A afirmação, decerto, pode ser estendida para outros casos de responsabilidade profissional.

${ }^{485}$ LÔBO, Paulo Luiz Netto. Responsabilidade civil do advogado. Revista de Direito Privado, São Paulo, n. 10, abr.-jun. 2002. p. 216.
} 
circunstâncias. Seria determinada a que pesa sobre o guardião de coisa ou animal, os quais, em hipótese alguma, podem lhe escapar ao controle ${ }^{486}$.

Com posição contrária, Luiz Roldão de Freitas Gomes assinala que a distinção entre obrigação de meio e de resultado não é própria para a matéria contratual, pois, em seu domínio, o devedor nada desejou e a vítima se enquadra na condição de credora de modo involuntário. Não há, assim, como se pretender a existência de compromisso de um deles em relação ao outro, eis que não houve vontade na origem da relação jurídica ${ }^{487}$.

Em que pese o abalizado entendimento dos Mazeaud, adota-se aqui o posicionamento de Luiz Roldão de Freitas Gomes, tendo em vista que, na esfera extracontratual, é mais difícil definir uma obrigação de meio ou de resultado. É indubitável que aquele que exerce vigilância sobre um animal está adstrito ao seu dever por uma obrigação comparável à de resultado, mas essa aproximação não encerra grande utilidade, pois não se poderá falar em inadimplemento. Os exemplos fornecidos pelos irmãos Mazeaud denotam ser mais aptos a distinguir a responsabilidade subjetiva da objetiva, esta última refutada com veemência por esses autores.

Por fim, uma vez mencionada a responsabilidade objetiva, convém salientar que a obrigação de resultado não deve ser com ela confundida, já que, nesta última, ainda que o credor não precise demonstrar a culpa do devedor, este poderá discutir tal aspecto em sua defesa, demonstrando que fez tudo que estava a seu alcance para a obtenção do resultado proveitoso $^{488}$.

No que tange à responsabilidade objetiva, não se admite a discussão da culpa, nem mesmo como matéria de defesa. A diferença apontada pode ser observada na ementa transcrita a seguir, recentemente publicada, da lavra da Ministra Nancy Andrighi:

"Recurso especial. Responsabilidade civil. Erro médico. Art. 14 do CDC. Cirurgia Plástica. Obrigação de resultado. Caso fortuito.

\footnotetext{
${ }^{486}$ MAZEAUD, Henri; MAZEAUD, Léon; MAZEAUD, Jean. Leçons de Droit Civil - obligations - théorie générale, p. 14.

${ }_{487}$ GOMES, Luiz Roldão de Freitas. Elementos de responsabilidade civil, p. 348.

488 CAVALIERI FILHO, Sérgio. Programa de responsabilidade civil, p. 379: "Entendo, todavia, que a obrigação de resultado em alguns casos apenas inverte o ônus da prova quanto à culpa; a responsabilidade continua sendo subjetiva, mas com culpa presumida. O Código do Consumidor não criou para os profissionais liberais nenhum regime especial, privilegiado, limitando-se a afirmar que a apuração de sua responsabilidade continuaria a ser feita de acordo com o sistema tradicional, baseado na culpa. Logo, continuam a ser-lhes aplicáveis [aos médicos] as regras de responsabilidade subjetiva com culpa provada nos casos em que assumem obrigação de meio; e as regras da responsabilidade subjetiva com culpa presumida nos casos em que assumem obrigação de resultado".
} 
Excludente de responsabilidade.

[...] 2. Nas obrigações de resultado, a responsabilidade do profissional da medicina permanece subjetiva. Cumpre ao médico, contudo, demonstrar que os eventos danosos decorreram de fatores externos e alheios à sua atuação durante a cirurgia"489.

\subsection{A responsabilidade do profissional autônomo}

Conforme exposto neste trabalho, a relação dos profissionais liberais com as pessoas às quais prestam serviço é precipuamente de meio e contratual, seja o contrato dela decorrente escrito ou verbal, gratuito ou oneroso. É possível, no entanto, que se verifique responsabilidade extracontratual quando, por exemplo, a atuação do profissional gerar danos a terceiros, que não o seu cliente ${ }^{490}$, ou então quando atuar como curador especial para o requerido citado por edital ou hora certa. Da mesma forma, o médico pode vir a ser compelido a fazer um atendimento emergencial para indivíduo desmaiado em via pública. Nesse caso, constata-se que não houve tempo hábil para formação de um contrato, nem mesmo a possibilidade de estabelecimento de um negócio jurídico, tendo em vista que a vítima não está em condições de manifestar sua vontade.

O profissional liberal, na acepção estrita do termo ${ }^{491}$, é aquele que trabalha por conta própria, em caráter autônomo, e que exerce sua atividade com plena liberdade, escolhendo os clientes que irá atender, determinando o valor da prestação de seu serviço, e outras condições do contrato a ser firmado com o credor $^{492}$.

Não se trata, portanto, do trabalhador empregado ou que atua como preposto, e muito menos daquele que ocupa função pública. A despeito de tal fato, far-se-ão, a seguir, breves comentários sobre esses profissionais, o que requer a abordagem, também, da responsabilidade por ato de terceiro.

O profissional que ora se estuda firma obrigação intuito personae com o cliente, e responde subjetivamente em face de eventuais danos, mesmo quando diante de uma

\footnotetext{
${ }^{489}$ STJ. $3^{\text {a }}$ T. REsp. 1180815. j. 26.08.10. v.u. A responsabilidade do cirurgião plástico será analisada no próximo Capítulo, quando então se exporá o entendimento que versa sobre obrigação de meio, ainda que possa haver inversão do ônus da prova.

${ }^{490}$ VASSILIEFF, Silvia. Responsabilidade civil do advogado, p. 100.

${ }^{491}$ Para os fins deste trabalho, considera-se profissional liberal aquele que possui um título universitário e desempenha atividade intelectual.

${ }^{492}$ REPRESAS, Félix A. Trigo; MESA, Marcelo J. López. Tratado de la responsabilidad civil, t. II, p. 275.
} 
relação consumerista, a senso do disposto no art. $14, \S 4^{\underline{0}}$, do CDC. A questão da aplicabilidade da referida legislação à atuação do profissional liberal será discutida no item 3.6 .

O contrato a ser firmado com o cliente comporta diversas variações, mas, na maioria das vezes, verifica-se que se trata de contrato inominado, ou sui generis, com fortes elementos da modalidade de prestação de serviço ${ }^{493}$, mediante o qual uma das partes se obriga a prestar um serviço e a outra a pagar-lhe, pelo referido trabalho, um preço em dinheiro.

Segundo Orlando Gomes, o contrato de prestação de serviços stricto sensu é aquele no qual "uma pessoa se obriga a prestar um serviço a outra, eventualmente, em troca de determinada remuneração, executando-os com independência técnica e sem subordinação hierárquica"494. Não se observa subordinação na prestação de serviço porque estes são realizados por trabalhador autônomo, que têm conhecimentos técnicos especiais por meio dos quais se orienta, decidindo qual o melhor procedimento a ser tomado por conta própria. Não segue, portanto, recomendações do contratante no que tange à maneira pela qual irá desenvolver seu trabalho ${ }^{495}$.

Nada obsta que o profissional contrate outros profissionais para que lhe prestem serviço. Se configurado vínculo empregatício, serão considerados empregados, sendo-lhes aplicadas as normas da CLT; contudo, no caso de existir somente relação de direito civil, marcada, em regra, pela eventualidade, haverá preposição. Em ambos os casos, o profissional contratante responderá por fato dos empregados e prepostos, como analisado a seguir.

\subsection{A responsabilidade por fato de terceiro}

Ressaltou-se, no decorrer do Capítulo 2, que o dano somente pode ensejar dever indenizatório àquele que o pratica ${ }^{496}$. De fato, a responsabilidade por ato próprio é a forma

\footnotetext{
${ }^{493}$ CARVAL, Suzanne. La construction de la responsabilité civile, p. 116. Convém mencionar que, no âmbito da responsabilidade civil do advogado, o contrato de mandato também é bastante relevante, na medida em que um dos contratantes se obriga a praticar atos jurídicos em nome do outro. Mesmo nesse caso, contudo, não há descaracterização do contrato de prestação de serviço, mas sim a configuração de um contrato inominado com características de prestação de serviço e mandato.

${ }^{494}$ GOMES, Orlando. Contratos. 21. ed. Rio de Janeiro: Forense, 2000a. p. 292.

${ }^{495}$ ITURRASPE, Jorge Mosset. Responsabilidad por daños - el incumplimiento contractual. Buenos Aires: Rubinzal-Culzoni, 1998b. t. II, p. 270.

${ }^{496}$ AGUIAR DIAS, José de. Da responsabilidade civil, t. II, p. 520.
} 
mais óbvia de imputação de responsabilidade, resultando exclusivamente da atuação pessoal do causador do dano. Ocorre que, em algumas hipóteses, às quais se dá o nome de responsabilidade complexa, esta pode resultar de ato cometido por terceiro, ou por dano causado por coisa ou animal sobre o qual se tinha dever de guarda.

A responsabilidade por ato de terceiro, que se verifica sempre que o responsável responde pelas consequências jurídicas da conduta de outrem, é de suma importância para o presente estudo, tendo em vista que os profissionais muitas vezes se veem em situação de serem compelidos a indenizar danos provocados por seus empregados e prepostos. Sendo assim, é incontornável que se proceda, ao menos, a uma breve análise da matéria.

Pode-se dizer que quando a lei estabelece a responsabilidade de um agente por atos de outrem, está presumindo que, de algum modo, o verdadeiro causador do dano não tem discernimento para compreendê-lo, não exerce a atividade em nome próprio, não possui meios para pagar pelo prejuízo ou então não aufere vantagem com a atividade que ele próprio desenvolve $\mathrm{e}^{497}$. Observe-se, portanto, a necessidade de que haja entre o responsável e o autor do ato ilícito um vínculo jurídico ${ }^{498}$, o que se verifica nas hipóteses previstas no art. 932 do CC, as quais, ressalte-se, não esgotam todos os casos de responsabilidade por ato de terceiro $^{499}$.

De acordo com o mencionado dispositivo legal, os pais são responsáveis pelos filhos menores que estiverem sob sua autoridade e em sua companhia (inc. I), assim como o tutor e o curador o são pelos pupilos e curatelados que se encontrarem nas mesmas condições da hipótese anterior (inc. II). São também responsáveis o empregador ou comitente por seus empregados e prepostos, no exercício de seu trabalho ou em razão dele (inc. III); os donos de hotéis, hospedarias, casas ou estabelecimentos nos quais se albergue mediante remuneração, mesmo para fins educacionais, pelos hóspedes, moradores e educandos (inc. IV); e, por fim, os que gratuitamente houverem participado nos produtos do crime, até a quantia em que concorreram (inc. V).

A responsabilidade por ato de terceiro - também denominada por ato de outrem ou por representação, in casu, voluntária - enseja solidariedade entre as pessoas retromencionadas (art. 942, parágrafo único, do CC), o que não afasta o direito de regresso do responsável em face do causador do dano, com algumas exceções. De acordo com o art.

\footnotetext{
${ }^{497}$ RIZZARDO, Arnaldo. Responsabilidade civil, p. 107.

498 GAGLIANO, Pablo Stolze; PAMPLONA FILHO, Rodolfo. Novo Curso de Direito Civil responsabilidade civil, p. 147.

${ }^{499}$ Verifique-se, v.g., a responsabilidade da locadora de veículos pelos danos provocados pelo locatário.
} 
934 do CC, o responsável tem direito regressivo contra o causador do dano, salvo se este for seu descendente, absoluta ou relativamente incapaz. Nos demais casos, portanto, seria plenamente cabível a ação de regresso.

Há que se fazer, contudo, mais uma ressalva. O art. 462, § $1^{\circ}$, da Consolidação das Leis do Trabalho (CLT) ${ }^{500}$ determina que o desconto salarial dos prejuízos causados pelo empregado somente será lícito se essa possibilidade for acordada previamente ou se o agente agiu com dolo. A despeito de a norma proibir apenas o desconto do salário, e não propriamente a responsabilização do empregado, a jurisprudência se orientou no sentido de que o empregador não pode mover ação regressiva em face do empregado quando este atuou com mera culpa ou quando não houve acordo prévio sobre a referida responsabilização ${ }^{501}$.

Em razão das mencionadas excludentes, a ação regressiva fica restrita aos empregadores e comitentes, em relação a empregados e prepostos que atuaram com dolo ou culpa grave (que ao dolo se equipara); aos tutores e curadores, em relação aos tutelados e curatelados que puderem pagar a indenização sem se privar do necessário à sua subsistência; bem como às empresas hoteleiras, hospitais e instituições de ensino em relação aos hóspedes, pacientes e educandos.

Convém lembrar, ainda, que certa corrente doutrinária entende ser imprópria a terminologia responsabilidade por ato de terceiro (ou de outrem). Alega que esta não deixa de ser responsabilidade por ato próprio, na medida em que, de acordo com o disposto em lei, aqueles que devem responder sempre terão contribuído para a ocorrência do ato danoso, atuando, muitas vezes, de modo negligente, ainda que por omissão ${ }^{502}$. No caso do

\footnotetext{
${ }^{500}$ A norma é assim redigida:

“Art. 462. Ao empregador é vetado efetuar qualquer desconto nos salários do empregado, salvo quando este resultar de adiantamentos, de dispositivos de Lei ou de contrato coletivo.

$\S 1^{\circ} \stackrel{\circ}{ }$. Em caso de dano causado pelo empregado, o desconto será lícito, desde que esta possibilidade tenha sido acordada ou na ocorrência de dolo do empregado".

${ }^{501}$ TJSP. 10ª Câmara Cível. Ap. Cível 378.979-4/4. Rel. Maurício Vidigal. j. 25.08.09. v.u.; TJSP. 34ํㅗㄹ Câmara Cível. Ap. 1.187.750.00/1. Rel. Emanuel Oliveira. j. 02.02.09. v.u.; e TJSP. 2ª Câmara Cível. Ap. 61.415-4/5. Rel. Lino Machado. j. 17.02.98. v.u. No mesmo sentido, manifestam-se Pablo Stolze Gagliano e Rodolfo Pamplona Filho (Novo curso de Direito Civil - responsabilidade civil, p. 162).

${ }^{502}$ De acordo com José de Aguiar Dias, esta é a tese adotada pelos subjetivistas, que não podiam aceitar o caráter objetivo de tal imputação. Sobre o assunto, assim se manifesta: "Para os partidários da doutrina objetiva, pois, o fato de reconhecerem os seus adversários que existe, ao lado da responsabilidade por fato próprio, uma responsabilidade por fato de outrem, significa a aceitação de casos de responsabilidade sem culpa. Postos em frente desse argumento, os subjetivistas alegam que se trata de um domínio de exceção, o que, do seu ponto de vista, não deixa de ter justificativa. Aliás, adiantam, na realidade a responsabilidade por fato de outrem é responsabilidade por fato próprio, porque as pessoas que respondem a esse título terão sempre contribuído para o fato danoso. Assim se chega a considerar um tanto abusivo falar de fato de outrem em relação aos pais, por exemplo, porque têm acentuada influência na produção do dano. Sem dúvida, este
} 
empregador, v.g., este seria pessoalmente responsável pela má escolha ou mau treinamento de seu empregado, de modo que, em verdade, não estaria propriamente respondendo por um terceiro, mas sim por suas próprias falhas.

Defende-se, aqui, a posição de que a indignação é injustificada e a argumentação, exagerada. É certo que o desenvolvimento da teoria da responsabilização por ato de terceiro repousa em uma mudança de perspectiva no estudo da matéria, que consiste no deslocamento de enfoque da pessoa do causador do dano para a vítima, o que faz que se procure mecanismos para que esta seja, tanto quanto possível, indenizada. Isso não quer dizer, no entanto, que o empregador, os pais, tutores e curadores possam, sempre, supervisionar e controlar seus empregados, filhos, tutelados e curatelados. Há casos em que os responsáveis nada poderiam ter feito para evitar o dano, motivo pelo qual a responsabilidade por ato de terceiro não encontra fundamento, nem mesmo remotamente, na teoria da culpa, mas sim na do risco.

\subsubsection{Algumas considerações sobre a responsabilidade por ato de terceiro no Código}

\section{Civil de 1916}

$\mathrm{O}$ art. 932 do CC de 2002 tem redação quase idêntica à do art. 1.521 do CC de 1916, o que não quer dizer, entretanto, que a matéria tenha permanecido inalterada na transição da legislação.

O mencionado dispositivo do Diploma civil revogado dava uma falsa sensação de responsabilidade objetiva, já que não mencionava a necessidade da comprovação de culpa por parte do responsável. Ocorre que o art. 1.523 funcionava como entrave para a objetivação, ao dispor que a responsabilidade das pessoas arroladas no art. 1.521, com exceção daquelas que participaram gratuitamente no produto de um crime, dependia da prova de uma das modalidades de culpa em sua conduta ${ }^{503}$.

Essa postura, considerada, já na época, conservadora, não permaneceu incólume por muito tempo, tendo sido lentamente flexibilizada pela jurisprudência, que passou a

não tem como causa derradeira o fato do pai (vigilância insuficiente, defeito de educação, etc.), porque a causa imediata é o ato do filho, mas aquele não deixa por isso de ser causa eficiente do prejuízo" ( $D a$ responsabilidade civil, t. II, p. 520-521). A mencionada corrente doutrinária é lembrada também por José Fernando Simão (Responsabilidade civil do incapaz. São Paulo: Atlas, 2008. p. 50).

${ }^{503} \mathrm{O}$ art. 1.523 do Código revogado possui a seguinte redação: “[...] Excetuadas as do art. 1.521, V, só serão responsáveis as pessoas enumeradas nesse e no art. 1.522, provando-se que elas concorreram para o dano por culpa, ou negligência de sua parte". 
adotar a tese da presunção juris tantum, isto é, relativa, da responsabilidade de pais, tutores, curadores e demais responsáveis ${ }^{504}$. Sendo assim, cabia ao responsável, e não à vítima, o ônus probatório ${ }^{505}$.

Saliente-se que, independentemente do posicionamento jurisprudencial, no que diz respeito aos pais, o Código de Menores (Decreto n. 17.943-A, de 12 de outubro de 1927) alterou a regra do art. 1.523, estabelecendo a presunção de culpa dos progenitores pelos atos ilícitos praticados por seus filhos, mesmo que o menor não estivesse sob o poder ou em companhia deles. O teor do art. $68, \S 4^{\circ}$, do referido Diploma era conforme reproduzido a seguir: "São responsáveis pela reparação civil do dano causado pelo menor os pais ou a pessoa a quem incumbia legalmente a sua vigilância, salvo se provarem que não houve de sua parte culpa ou negligência"506.

No que tange à responsabilidade do empregador, esta foi efetivamente delineada pela jurisprudência, consolidando-se na Súmula n. 341 do STF, conforme redação a seguir: "É presumida a culpa do patrão ou comitente pelo ato culposo do empregado ou preposto".

Anote-se, porém, que, surpreendentemente, a responsabilidade do farmacêutico por ato de seu preposto já era objetiva no CC de 1916 por força do disposto no art. 1.546 - "O farmacêutico responde solidariamente pelos erros e enganos de seu preposto" -, que nada mencionava sobre culpa.

O Código Civil de 2002 abandonou, então, em definitivo as presunções, elegendo, conforme expresso no art. 933, a responsabilidade objetiva como regra geral para as hipóteses de responsabilidade por fato de terceiro previstas no art. 932, fundadas sobre um dever objetivo de guarda e vigilância legalmente imposto aos responsáveis outrora enumerados.

\subsubsection{A abordagem da matéria no Código Civil de 2002}

$\mathrm{O}$ art. 933 é expresso no sentido de que as pessoas mencionadas no art. 932 respondem, mesmo que não tenham atuado de maneira culposa, pelos atos praticados pelos terceiros ali relacionados. Ocorre que não se pode fazer uma exegese simplista desse dispositivo, sob pena de se perder o espírito do instituto.

\footnotetext{
${ }^{504}$ AGUIAR DIAS, José de. Da responsabilidade civil, t. II, p. 522.

${ }^{505}$ GOMES, Luiz Roldão de Freitas. Elementos de responsabilidade civil, p. 109.

${ }^{506}$ SIMÃO, José Fernando. Responsabilidade civil do incapaz, p. 61.
} 
De fato, a responsabilidade por ato de terceiro constitui-se de duas relações, não sendo ambas regidas pelo mesmo fundamento jurídico. A primeira delas, formada entre o verdadeiro causador do dano e a vítima, é precipuamente regida pela responsabilidade subjetiva, ou seja, deve ser provada a culpa do ofensor. O ato praticado pelo terceiro há de ter sido perpetrado de tal maneira que, se praticado por qualquer outro agente, este seria considerado culpável ${ }^{507}$. Somente sobre a segunda relação, estabelecida entre este último e o responsável, há de ser aplicada a responsabilidade objetiva. Observe-se, assim, que há um verdadeiro concurso de responsabilidade subjetiva e objetiva, ao que Carlos Celso Orcesi da Costa confere inspirada nomenclatura de responsabilidade em duplo estágio ${ }^{508}$. De acordo com tal organização da matéria, o primeiro estágio é ocupado pelo fato em si mesmo, visto pela perspectiva do dano, regendo-se a responsabilidade pela imputação de culpa. O segundo estágio, por sua vez, é ocupado pela responsabilidade por representação, solidária ou derivada, a qual depende do resultado culposo do evento ocorrido no primeiro estágio, mas é objetiva ${ }^{509}$.

É mister ressaltar, todavia, que a primeira escala pode ser também ocupada pela responsabilidade objetiva, caso se trate, v.g., de atividade que possa ser incluída no parágrafo único do art. 927. No primeiro estágio, portanto, verifica-se a atuação humana. Se há culpa ou risco - de acordo com previsão legal -, o vínculo ao segundo estágio é imediato.

Tendo em vista que o propósito do presente trabalho é a análise da responsabilidade profissional, e não a do relevante tema da responsabilidade por ato de terceiro, furtar-se-á ao exame de cada uma das espécies ínsitas no art. 932 do CC. Passa-se, desse modo, ao estudo da responsabilidade do empregador ou do comitente, que é a que interessa mais diretamente ao objeto de estudo desta dissertação.

\footnotetext{
${ }^{507}$ Acerca do assunto, mencione-se a observação de Sérgio Cavalieri Filho (Programa de responsabilidade civil, p. 189): “[...] quando falamos em situação que em tese configuraria a culpa não estamos querendo dizer que serão necessários todos os elementos do ilícito culposo, inclusive a imputabilidade, como sustentava Orlando Gomes (Obrigações, $2^{\text {a }}$. ed., Forense, p. 348), mesmo porque esta nunca se fará presente no ato praticado pelo absolutamente incapaz. O que pretendemos dizer é que o ato deve ser tal que, se praticado por alguém imputável, configuraria a violação de um dever; a culpa estaria caracterizada se o ato ilícito fosse praticado por alguém imputável".

${ }^{508}$ COSTA, Carlos Celso Orcesi da. Código Civil na visão do advogado - responsabilidade civil, v. 3, p. 300-301.

${ }^{509}$ CAVALIERI FILHO, Sérgio, op. cit., p. 188: "Não se olvide, entretanto, que objetiva é a responsabilidade dos pais, tutor, curador e empregador, e não das pessoas pelas quais são responsáveis. Em qualquer dessas hipóteses, será preciso a prova de uma situação que, em tese, em condições normais, configure a culpa do filho menor, do pupilo, do curatelado, como também do empregado (se for o caso de responsabilidade subjetiva). [...] De onde se conclui que na responsabilidade pelo fato de outrem há, na realidade, o concurso de duas responsabilidades, a do comitente ou patrão e a do preposto".
} 


\subsubsection{A responsabilidade do empregador ou comitente por atos de seus empregados, serviçais $^{510}$ e prepostos}

A responsabilidade dos empregadores e comitentes por atos de seus empregados e prepostos sofreu várias modificações, antes mesmo da vigência do Código Civil hodierno, como se infere dos comentários tecidos.

De acordo com a sistemática prevista no Código Civil de 1916, a responsabilidade do empregador era subjetiva por culpa in eligendo ${ }^{511}$, tendo a jurisprudência criado uma presunção relativa de culpa do responsável, mediante a aplicação, nesse caso específico, da teoria da substituição, na qual o empregado seria o longa manus de seu empregador, uma vez que se encarrega das atividades que não podem ser materialmente executadas por ele ${ }^{512}$. A Súmula n. 341 do STF, pré-transcrita, consagrou essa presunção e, de acordo com muitos doutrinadores, foi além, estabelecendo uma presunção absoluta (juris et jure), isto é, que não admite prova em contrário.

José de Aguiar Dias ponderou, com extrema lucidez, que "em poucos terrenos se mostra com tanta intensidade a insuficiência da idéia subjetiva dentro da qual o direito moderno força a discussão, dificultando a solução moderna",513.

Seja como for, a partir da entrada em vigor do Código Civil de 2002, o fundamento dessa responsabilidade deslocou-se da presunção de culpa para a teoria do riscoproveito $^{514}$. De acordo com esta última teoria, o empregador deve responder pelos atos de seu empregado porque, ao contratá-lo para desenvolver atividade em seu benefício, cria o risco de que este cause dano a alguém. O nexo de causalidade entre a atuação do empregado e a responsabilidade do empregador independe de qualquer consideração acerca da culpa deste último, ou do fato de o primeiro ter excedido as ordens recebidas, ou ter atuado com excesso ou abuso de poder. Trata-se, em verdade, da hipótese mais importante de responsabilidade por ato de terceiro, por ser a mais ampla e fornecer segurança às relações jurídicas.

Justifica-se, assim, que sejam estudados os termos utilizados no inciso em discussão.

\footnotetext{
${ }^{510} \mathrm{O}$ termo é aqui utilizado somente em respeito à redação do inc. III do art. 932 do CC, mas, como salientado adiante, é despiciendo e denota relação de subserviência que não se justifica.

511 Segundo José Fernando Simão, pode decorrer também de culpa in instruendo e culpa in vigilando (Responsabilidade civil do incapaz, p. 54).

${ }^{512}$ CAVALIERI FILHO, Sérgio. Programa de responsabilidade civil, p. 196.

${ }^{513}$ AGUIAR DIAS, José de. Da responsabilidade civil, t. II, p. 537.

${ }^{514}$ SIMÃO, José Fernando, op. cit., p. 70.
} 
Verifica-se, preliminarmente, que a mencionada norma abrange dois tipos de relação, a empregatícia e a de preposição, que possuem características diversas.

O empregado é o trabalhador que presta serviço nos moldes previstos pela legislação trabalhista ${ }^{515}$ : com subordinação hierárquica, habitualidade e mediante remuneração ${ }^{516}$.

No que tange ao preposto, este é a pessoa que presta serviço cumprindo ordens de natureza diversa, com ou sem remuneração, de modo temporário ou permanente ${ }^{517}$. Sua atuação pode estar relacionada com diversos contratos como o de mandato, de agência ou de representação comercial ${ }^{518}$. De qualquer modo, o vínculo de comissão formal não se faz necessário para a configuração dessa responsabilidade.

Sobre o assunto, assevera Alvino Lima que o direcionamento do comitente em relação aos atos do preposto não possui caráter técnico, mas sim de organização econômica, verificando-se uma relação de:

"[...] dependência ou sujeição do preposto ao comitente, decorrente da autoridade deste, ou seja, o direito de dar ordens e instruções sobre o modo de cumprir as funções que são atribuídas ao preposto, assim como o direito de fiscalizar e até de intervir no respectivo trabalho" ${ }^{, 519}$.

O conceito de preposição foi bastante ampliado pela jurisprudência ${ }^{520}$, de modo a permitir a responsabilização da locadora de veículos pelo dano causado pelo locatário, conforme se verifica da Súmula n. 492 do STF, que dispõe: "A empresa locadora de veículos responde, civil e solidariamente, com o locatário, pelos danos por este causados a

\footnotetext{
${ }^{515} \mathrm{O}$ art. $3^{\mathrm{o}}$ da CLT, tratando da matéria, dispõe:

“[...] Considera-se empregado toda pessoa física que prestar serviços de natureza não eventual a empregador, sob a dependência deste e mediante salário.

Parágrafo único - Não haverá distinções relativas à espécie de emprego e à condição de trabalhador, nem entre o trabalho intelectual, técnico e manual".

${ }^{516}$ GOMES, Luiz Roldão de Freitas. Elementos de responsabilidade civil, p. 117.

${ }^{517}$ AGUIAR DIAS, José de. Da responsabilidade civil, t. II, p. 525. O referido autor assinala que, enquanto a relação de preposição envolve a subordinação voluntária, a relação entre pais e filhos e curadores e tutores com seus curatelados e tutelados é de subordinação legal. Ainda que o termo "subordinação" seja de aplicação duvidosa tendo em vista os princípios hodiernos de parentalidade responsável, a diferenciação feita pelo respeitável jurista é de grande aplicabilidade didática.

518 GAGLIANO, Pablo Stolze; PAMPLONA FILHO, Rodolfo. Novo Curso de Direito Civil responsabilidade civil, p. 159.

${ }^{519}$ LIMA, Alvino. A responsabilidade civil pelo fato de outrem. Rio de Janeiro: Forense, 1973. p. 54.

${ }^{520}$ RIZZARDO, Arnaldo. Responsabilidade civil, p. 119.
} 
terceiro, no uso do carro locado"521. Ocorre que, nesse caso, não há, em verdade, relação de preposição; a Súmula simplesmente consagrou a responsabilidade objetiva do locador de veículos, criando outra espécie de responsabilidade por ato de terceiro. No que tange à responsabilidade do proprietário do veículo em caso de dano provocado pelo comodatário, a questão é mais controvertida, já que o contrato de comodato não consta do rol autorizador do art. 932, e nem há súmula estabelecida sobre o assunto.

Convém salientar, ademais, o fato de remanescer a responsabilidade do comitente mesmo quando o preposto atuar com abuso de função, sempre que se verificar que o ato foi praticado, segundo Alvino Lima, “obedecendo e visando à sua missão, e situando-se dentro das finalidades das funções que lhe foram confiadas" ${ }^{\prime 22}$.

No que tange ao termo "serviçal", este provavelmente foi utilizado para designar o empregado que desenvolve trabalho doméstico, mas se trata de vocábulo obsoleto e perfeitamente dispensável ${ }^{523}$.

Com relação à figura do empregador ou comitente, é mister ressaltar que esta não é necessariamente ocupada por uma pessoa física ou empresário individual, mas também por pessoas jurídicas.

Assinala-se, com frequência, que o requisito essencial e diferenciador dessa hipótese de responsabilidade por ato de terceiro é a subordinação hierárquica ou a dependência, manifestada pelo poder de direção e vigilância do empregador ou preponente. Essa afirmação, contudo, não deixa de ser rechaçada pela doutrina que aduz, com propriedade, que o vínculo de subordinação, em uma situação de preposição, pode ou não existir. O que importaria, então, seria a atuação em nome do comitente ${ }^{524}$.

Observe-se, ainda, que a redação do artigo sofreu alteração na mudança dos Códigos, substituindo-se a expressão "por ocasião dele" para "ou em razão dele", com claro intuito de se ampliar a abrangência do instituto, para que este alcançasse também situações indiretamente relacionadas ao trabalho. O exercício da função será apreciado de acordo com a normalidade, ou seja, as incumbências normais da ocupação exercida pelo agente causador do dano. Haverá responsabilidade do empregador sempre que se constatar

\footnotetext{
${ }^{521}$ CAVALIERI FILHO, Sérgio. Programa de responsabilidade civil, p. 198.

${ }^{522}$ LIMA, Alvino. A responsabilidade civil pelo fato de outrem, p. 69.

${ }^{523}$ GAGLIANO, Pablo Stolze; PAMPLONA FILHO, Rodolfo. Novo Curso de Direito Civil, p. 161.

${ }^{524}$ CAVALIERI FILHO, Sérgio, op. cit., p. 198.
} 
que o trabalho possibilitou ou facilitou a prática do dano ${ }^{525}$. De fato, a responsabilidade do empregador é tão ampla que se encontra na jurisprudência condenação de empresa no pagamento de danos morais decorrentes de declarações feitas por seu diretor em entrevista $^{526}$.

Verificando-se a existência dos elementos ora aludidos, o nexo de causalidade é automático, não dependendo de quaisquer outras considerações que não a existência de relação empregatícia ou de preposição. Mesmo no caso de desvio ou abuso de atribuições, o patrão responde, prevalecendo a teoria da aparência da função, já que o terceiro não possui informações necessárias para aferir tal condição. Se a vítima, contudo, sabia do desvio ou abuso, o empregador não responderá.

Além dessa hipótese, o empregador se exonera de sua responsabilidade em caso de força maior, caso fortuito, ou se o ato praticado pelo empregado ocorreu fora do exercício das atribuições do empregado ou preposto. Também não haverá responsabilidade se o ato cometido pelo empregado for completamente diverso de suas funções ou se foi praticado em seu próprio interesse, e não no do empregador. Trata-se, como se percebe, de exceções de difícil ocorrência.

\subsubsection{O profissional empregado ou preposto}

É usual que o profissional, no desempenho de seu ofício, conte com a ajuda de outros profissionais que lhe prestem serviço, os quais atuam como seus empregados ou prepostos, dependendo do vínculo jurídico que possuírem entre si.

Conforme mencionado há pouco, uma vez verificada a prestação de serviço, haverá relação de preposição, aplicando-se as regras ínsitas nos arts. 593 a 609 do CC. Se, todavia, houver relação empregatícia, será aplicada a CLT.

\footnotetext{
${ }^{525}$ STJ. $3^{\text {a }}$ T. REsp 623040/MG. Rel. Min. Humberto Gomes de Barros. j. 16.11.2006. DJ 04.12.2006, p. 296, v.u.: "Responsabilidade civil. Furto praticado em decorrência de informações obtidas pelo preposto por ocasião do seu trabalho. Responsabilidade solidária do empregador. [...] Responde o preponente, se o preposto, ao executar serviços de dedetização, penetra residência aproveitando-se para conhecer os locais de acesso e fuga, para - no dia seguinte - furtar vários bens. A expressão 'por ocasião dele' (art. 1.521, III, do Código Beviláqua) [Código Civil de 1916] pode alcançar situações em que a prática do ilícito pelo empregado ocorre fora do local de serviço ou da jornada de trabalho. Se o ilícito foi facilitado pelo acesso do preposto à residência, em função de serviços executados, há relação causal entre a função exercida e os danos. Deve o empregador, portanto, responder pelos atos do empregado".

${ }^{526}$ TJRS. 10 ${ }^{\mathrm{a}}$ Câmara Cível. Ag. Inst. 70016401499. Rel. Luiz Ary Vessini de Lima. j. 23.08.2006. v.u.
} 
Convém salientar que o contrato de prestação de serviço tem utilização de caráter subsidiário, ou residual, em virtude da amplitude das relações trabalhistas. De fato, em regra estar-se-ia diante de uma relação de emprego, e não de prestação de serviço ${ }^{527}$. A condição de prestador de serviço somente se evidencia diante da ausência de continuidade e dependência na relação de trabalho ${ }^{528}$.

Também é possível se verificar o vínculo de preposição quando há um profissional que comanda uma equipe formada por outros profissionais, como é o caso do chefe da equipe médica, ao qual se submetem os assistentes, o enfermeiro, o instrumentador, entre outros $^{529}$. Nesse caso, haverá responsabilidade solidária do médico quando tiver participado da escolha dos assistentes, conforme restará evidenciado no Capítulo subsequente ${ }^{530}$.

Não é, no entanto, pelo fato do profissional trabalhar na condição de empregado ou preposto que deixará de ser responsabilizado pessoalmente pelos danos causados de maneira culposa ${ }^{531}$. A diferença que se observa é que, havendo subordinação técnica, típica do vínculo empregatício e da preposição, o empregador ou preponente poderá ser responsabilizado no lugar dos empregados e prepostos, se o credor assim desejar.

Nesse caso, estar-se-á na seara da responsabilidade por ato de terceiro, estudada há pouco. Não é demasiado dizer que, também por aplicação do art. 932, inc. III, do CC, o

${ }^{527}$ PODESTÁ, Fábio Henrique. Apontamentos sobre o contrato de prestação de serviços. Revista EPD, São Paulo, ano I, n. I, maio/ago. 2005. p. 138. No mesmo sentido, Caio Mário da Silva Pereira (Instituições de Direito Civil - contratos, declaração unilateral de vontade, responsabilidade civil. 11. ed. Rio de Janeiro: Forense, 2003. v. III, p. 377).

${ }^{528}$ PEREIRA, Caio Mário da Silva, op. cit., p. 378. Jorge Mosset Iturraspe assinala que a relação de trabalho tem como requisitos: a subordinação, a exclusividade, a profissionalismo e a estabilidade relativa ou durabilidade, ainda que possa existir, em situações excepcionais, contrato de trabalho sem exclusividade, quando o trabalhador labora em mais de um lugar ao mesmo tempo, como frequentemente acontece com profissionais da saúde (Responsabilidad por daños - el incumplimiento contractual, t. II, p. 268).

${ }_{529}$ Como será possível verificar no próximo Capítulo, o chefe da equipe médica responde objetivamente pela culpa da equipe, se esta foi escolhida por ele (STJ. 4 ${ }^{\mathrm{a}}$ T. REsp. 605435/RJ. Rel. Min. João Otávio de Noronha. j. 22.09.09. v.u.; STJ. 4 ${ }^{\mathrm{a}}$ T. REsp. 200831/RJ. Rel. Min. Barros Monteiro. J. 08.05.01. v.u.). Sobre a matéria, Ruy Rosado de Aguiar Jr. (Responsabilidade civil do médico. Revista dos Tribunais, v. 84, n. 718, p. 43) assinala que a responsabilidade pela equipe cirúrgica é do chefe que a formou, tanto pelos atos dos outros médicos, na condição de assistentes, como pelos auxiliares de enfermagem, a menos que se trate de atos comuns e banais, pelos quais responde o hospital. Com relação ao anestesista, na maior parte das vezes, entende-se como um profissional destacado dos demais, com responsabilidade individualizada. Contudo, quando indicado diretamente pelo médico-cirurgião, como profissional de confiança, não será possível afastar a responsabilidade do chefe da equipe (RIZZARDO, Arnaldo. Responsabilidade civil, p. 336).

${ }^{530}$ RIZZARDO, Arnaldo, op. cit., p. 335. O autor esclarece que o médico responde solidariamente pelo médico substituto que tenha indicado, bem como pelos enfermeiros, assistentes e atendentes, desde que os tenha escolhido. Se os auxiliares são escolhidos pelo hospital, a ele lhe será imputada a responsabilidade pela atuação desses profissionais.

531 Nesse sentido, verifique-se o art. 18 da Lei n. 8.906/1994 (Estatuto da Advocacia e da Ordem dos Advogados do Brasil - EAOAB): “[...] A relação de emprego, na qualidade de advogado, não retira a isenção técnica nem reduz a independência profissional inerentes à advocacia". 
profissional responderá pelos atos não somente dos profissionais contratados, mas também pelos atos de seus secretários e assistentes, bem como pelos de seus estagiários.

Por fim, convém salientar que o estágio, de acordo com a Lei n. 11.788, de 25 de setembro de $2008^{532}$, não gera vínculo trabalhista entre o estagiário e o profissional, desde que se enquadre nos requisitos previstos na legislação ${ }^{533}$. O vínculo gerado entre o profissional e o estagiário que trabalha sob sua supervisão é, no entanto, de preposição, fazendo que seja igualmente submetida aos preceitos pertinentes à responsabilidade por fato de terceiro.

\subsection{Responsabilidade do profissional que atua como servidor público}

Observa-se que, quando se trata de profissional que presta serviço para pessoa jurídica de direito público na condição de servidor público, isto é, de modo não eventual, sob vínculo de dependência econômica com o Poder Público, e tendo ingressado no cargo mediante concurso público ou sendo nomeado em comissão ${ }^{534}$, a prestação de serviço possui uma característica particular: a função pública ${ }^{535}$, a despeito de existirem servidores públicos que não estão submetidos ao regime estatutário, mas sim vinculados por contratos de trabalho submetidos às normas da CLT ${ }^{536}$.

A exegese gramatical da lei evidencia que o Estado deveria responder objetivamente pelos atos de tais agentes, com fundamento na teoria do risco administrativo, ínsita no art. $37, \S 6^{\circ}$, da $\mathrm{CF}^{537}$, bem como no art. 43 do $\mathrm{CC}^{538}$. Com efeito,

\footnotetext{
$532 \mathrm{O}$ art. $1^{\text {o }}$ da referida lei define o que vem a ser estágio: “[...] Estágio é ato educativo escolar supervisionado, desenvolvido no ambiente de trabalho, que visa à preparação para o trabalho produtivo de educandos que estejam freqüentando o ensino regular em instituições de educação superior, de educação profissional, de ensino médio, da educação especial e dos anos finais do ensino fundamental, na modalidade profissional da educação de jovens e adultos". [...] $§ 2^{0} \mathrm{O}$ estágio visa ao aprendizado de competências próprias da atividade profissional e à contextualização curricular objetivando o desenvolvimento do educando para a vida cidadã e para o trabalho".

${ }^{533}$ Conforme art. $3^{\mathrm{o}}$ da norma em comento.

${ }^{534}$ ARAÚJO, Edmir Netto de. Curso de Direito Administrativo. 3. ed. São Paulo: Saraiva, 2007. p. 256.

535 PEREIRA, Caio Mário da Silva. Instituições de Direito Civil - contratos, declaração unilateral de vontade, responsabilidade civil, p. 378.

${ }^{536} \mathrm{O}$ conceito de servidor público compreende duas principais categorias de agente público: os servidores estatutários, que se submetem a um estatuto, do qual decorrem direitos e obrigações; e os empregados públicos, que são contratados sob o regime da CLT (ARAÚJO, Edmir Netto de, op. cit., p. 267-273).

${ }_{537}$ O parágrafo em comento possui a seguinte redação: “§ 6‥ As pessoas jurídicas de direito público e as de direito privado prestadoras de serviços públicos responderão pelos danos que seus agentes, nessa qualidade, causarem a terceiros, assegurado o direito de regresso contra o responsável, nos casos de dolo ou culpa".

${ }^{538}$ Conforme dicção do dispositivo: “Art. 43. As pessoas jurídicas de direito público interno são civilmente responsáveis por atos dos seus agentes que nessa qualidade causem danos a terceiros, ressalvado direito regressivo contra os causadores do dano, se houver, por parte destes, culpa ou dolo".
} 
os dispositivos em comento não exigem que o servidor atue culposamente para que haja a responsabilização do órgão público; apenas estabelecem que, caso tenham atuado com dolo ou culpa, poderão ser condenados a ressarcir os prejuízos causados ao Estado em ação regressiva.

Ocorre que, como poucas vezes a exegese gramatical é a mais adequada, observa-se que a doutrina é manifestamente favorável ao entendimento de que somente haverá responsabilidade das pessoas jurídicas de direito público quando se verificar erro profissional $^{539}$. Verifique-se, nesse sentido, tratando da responsabilidade do médico, o entendimento de Miguel Kfouri Neto ${ }^{540}$, bem como de Ana Cláudia Vergamini Luna e Rita de Cássia Gimenes Arcas. As doutrinadoras sustentam que o Estado responde objetivamente somente por ato próprio decorrente de prestação de atendimento médico, como, por exemplo, pela falta de vagas para internação do paciente; no entanto, para a responsabilização por ato do médico, é necessária a ocorrência de faute du service. Exigese, assim, segundo ambas as autoras, a comprovação da falha dos agentes estatais na prestação do serviço de natureza médica ${ }^{541}$.

Ruy Rosado de Aguiar Jr. partilha do mesmo pensamento, ao aduzir que, no caso de prestação de serviços médicos, é melhor que o Estado somente seja responsabilizado pela culpa no serviço. E justifica: "não parece razoável impor ao Estado o dever de indenizar dano produzido por serviço público cuja ação, sem nenhuma falha, tenha sido

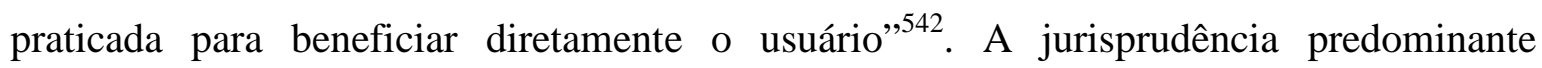
caminha no mesmo sentido, com poucas decisões em contrário, nas quais o Estado é condenado, independentemente da culpa do profissional ${ }^{543}$.

\footnotetext{
${ }^{539}$ Silvio de Salvo Venosa esposa entendimento em sentido contrário, sustentando que o Estado responde de forma objetiva, independentemente de culpa do profissional (Direito Civil - responsabilidade civil. 3. ed. São Paulo: Atlas, 2003a. t. IV, p. 96).

${ }^{540}$ KFOURI NETO, Miguel. A responsabilidade civil dos hospitais, p. 123.

${ }^{541}$ LUNA, Ana Cláudia Vergamini; ARCAS, Rita de Cássia Gimenes. Responsabilidade civil do Estado e a atividade médica. In: HIRONAKA, Giselda Maria Fernandes Novaes; FALAVIGNA, Maria Clara Osuna Diaz (Coord.). Ensaios sobre responsabilidade civil na pós-modernidade. Porto Alegre: Magister, 2007. p. 29.

${ }^{542}$ AGUIAR JR., Ruy Rosado de. Responsabilidade civil do médico. Revista dos Tribunais, v. 84, n. 718, p. 46.

${ }^{543}$ TJRS. 5a Câmara Cível. Ap. 70025517665. Rel. Jorge Luiz Lopes do Canto. j. 12.11.08. v.u.; TJRJ. 1 ${ }^{\mathrm{a}}$ Câmara Cível. Ap. 0071173-43.2004.8.19.0001. Rel. Fábio Dutra. j. 19.10.10. v.u.; TJSP. 7ª Câmara Cível. Ap. 990.10.181727-6. Rel. Coimbra Schmidt. j. 28.06.10. v.u. Em sentido contrário, determinando a responsabilidade objetiva do Estado, com fundamento no risco administrativo, sem discussão da culpa do médico, verifique-se TJRJ. 7ª Câmara Cível. Ap. 0044374-84.2009.8.19.0001. Rel. José Geraldo Antônio. j. 13.10.10. Do mesmo modo: TJSP. 5ª Câmara de Direito Público. Ap. 994.03.041129-5. Rel. Xavier de Aquino. j. 25.10.10. v.u., decisão em que o hospital foi responsabilidade objetivamente e a responsabilidade do médico excluída. Em virtude do interesse da decisão, segue transcrita a ementa (dividida em duas partes):
} 
As considerações aqui formuladas se aplicam também ao advogado que atua como agente público, inclusive por meio de convênio eventualmente celebrado entre a Procuradoria do Estado e a Ordem dos Advogados ${ }^{544}$, bem como outros profissionais liberais.

O entendimento predominante, com efeito, é o mais acertado, pois não se pode admitir que, diante de uma mesma situação fática, a vítima não seja indenizada quando atendida por um profissional autônomo, mas poderia o ser se o profissional atuasse na condição de servidor público. Verifique-se que a situação será diferente se os danos forem causados em razão das más condições em que são mantidos os estabelecimentos públicos; nesse caso, estar-se-á diante de responsabilidade direta do Estado, e não decorrente de atos de seus agentes, que devem atuar de acordo com as possibilidades oferecidas pela pessoa jurídica de direito público competente.

Caso não seja exigida a comprovação de culpa do profissional, a vítima poderá demandar diretamente o Estado, bastando para isso que demonstre a relação de causalidade entre a atuação do órgão público e o dano por ela experimentado. Seguindo-se, porém, a doutrina majoritária, será necessária, em acréscimo, a indicação da atuação culposa do agente público. Da mesma forma, caso deseje demandar diretamente o profissional, deverá demonstrar a ocorrência de culpa. Por fim, ainda é possível que a ação de reparação do

"DIREITO CONSTITUCIONAL, ADMINISTRATIVO E CIVIL - AÇÃO ORDINÁRIA INDENIZAÇÃO - UNIDADE DE SAÚDE MUNICIPAL - PACIENTE MENOR - CRISE CONVULSIVA EPILÉTICA - APLICAÇÃO DE INJEÇÃO NA ARTÉRIA RADIAL DO PULSO ESQUERDO AMPUTAÇÃO DA MÃO - RESPONSABILIDADE CIVIL EXTRACONTRATUAL - PREFEITURA EXISTÊNCIA - MODALIDADE OBJETIVA - O Município responde objetivamente pelos danos que seu agente, o médico, causou, nessa condição, ao autor, conforme o art. 37, § $6^{\circ}$, da Constituição Federal. Basta haver a ação (injeção na artéria radial do pulso), o nexo causal (aplicação da injeção no pulso esquerdo) e o dano (amputação do membro) - Pensão mensal devida proporcional à redução do patrimônio físico - Juros moratórios fluem a partir do evento danoso (Súmula 54 do STJ e art. 962 do Código Civil de 1916) - Danos morais e estéticos devidos - Honorários advocatícios reduzidos para $10 \%$ (dez por cento) do valor da condenação"; "MÉDICO - DOLO OU CULPA - INEXISTÊNCIA - RESPONSABILIDADE EXCLUSÃO - Correndo iminente risco de morte a criança, não se encontrando a sua veia e inexistindo os outros indispensáveis e mínimos meios na Unidade de Saúde, não haverá outra conduta a ser praticada pelo médico, senão tentar salvar o menor, mesmo pondo em risco a sua mão. O profissional João Pedro Jungers Mello Júnior, portanto, não atuou com dolo nem culpa. Pelo contrário, foi diligente, dentro das condições precárias de trabalho, valendo-se de seus conhecimentos técnicos para salvar a vida do paciente e tentar, em seguida, preservar a sua mão esquerda. Excluída a culpa ou o dolo, inexiste responsabilidade civil - Dá-se provimento ao recurso de João Pedro Jungers Mello Júnior e dá-se parcial provimento ao recurso voluntário da Prefeitura bem como ao reexame necessário, julgando-se prejudicada a Medida Cautelar $\mathrm{n}^{\mathrm{o}}$ 994.08.091033-1, em que se buscava antecipação dos efeitos da tutela aqui concedida". Também com responsabilização da Municipalidade, mas não a dos médicos que atuaram no tratamento do paciente: TJSP. 9aㅡ Câmara de Direito Público. Ap. 994.08.179861-3. Rel. Sérgio Gomes. j. 27.01.10. v.m. (O voto vencido, do Desembargador Oswaldo Luiz Falu, foi no sentido de responsabilização também dos médicos, tendo reconhecido atuação negligente dos profissionais.)

${ }^{544}$ TJSP. $13^{\mathrm{a}}$ Câmara Cível. Ap. 990.10.304030-9. Rel. Ivan Sartori. j. 15.09.10. v.u. 
dano seja proposta, ao mesmo tempo, em face do funcionário e da pessoa jurídica, em litisconsórcio facultativo ${ }^{545}$.

\subsection{Aplicação do Código de Defesa do Consumidor sobre a matéria}

A responsabilidade civil dos profissionais liberais, por expressa disposição do Código de Defesa do Consumidor, é subjetiva, de modo que sobre eles não recairá presunção de culpa em razão de resultado insatisfatório de seus serviços. Quanto a isso, não se discute. A dificuldade, contudo, é determinar se, tendo em vista o disposto no art. $14, \S 4^{\circ}$, do referido Diploma, a relação do profissional liberal com seus clientes é de consumo ou não ${ }^{546}$. A principal consequência dessa indagação é a possibilidade de inversão do ônus da prova, conforme disposto no art. $6^{-}$, inc. VIII, desse estatuto legal ${ }^{547}$.

Diversos autores tratam sobre a matéria, ora no âmbito da responsabilidade do médico, ora na do advogado, mas em regra não se aborda a questão do ponto de vista unificado da responsabilidade do profissional. Essa análise, no entanto, se faz de rigor, tendo em vista que a solução dada ao médico deverá ser a mesma para o advogado e os demais profissionais liberais.

No que tange à aplicação do Código de Defesa do Consumidor, não resta dúvida de que não é possível afastá-lo da relação estabelecida pelos clientes com o profissional liberal, já que estes se encaixam, respectivamente, no conceito de consumidor e fornecedor constantes dos arts. $2^{\mathrm{o}}$ e $3^{\mathrm{o}^{548}}$ do referido Código. Ademais, o próprio fato de a legislação incluir expressamente o profissional liberal, mesmo isentando-o da responsabilidade

\footnotetext{
${ }^{545}$ DI PIETRO, Maria Sylvia Zanella. Direito Administrativo. 21. ed. São Paulo: Atlas, 2008. p. 627.

${ }^{546}$ GOMES, Luiz Roldão de Freitas. Elementos de responsabilidade civil, p. 216.

${ }^{547} \mathrm{O}$ artigo 6o $6^{\circ}$, inc. VIII, do CDC, determina: “[...] São direitos básicos do consumidor: [...] VIII - a facilitação da defesa de seus direitos, inclusive com a inversão do ônus da prova, a seu favor, no processo civil, quando, a critério do juiz, for verossímil a alegação ou quando for ele hipossuficiente, segundo as regras ordinárias de experiências".

${ }^{548} \mathrm{O}$ art. $2^{\circ}$ dispõe: “[...] Consumidor é toda pessoa física ou jurídica que adquire ou utiliza produto ou serviço como destinatário final.". O art. 3oㅡ, por sua vez, preceitua: "[...] Fornecedor é toda pessoa física ou jurídica, pública ou privada, nacional ou estrangeira, bem como os entes despersonalizados, que desenvolvem atividades de produção, montagem, criação, construção, transformação, importação, exportação, distribuição ou comercialização de produtos ou prestação de serviços.". O $\S 1^{\mathrm{o}}$ do referido artigo reza: "Produto é qualquer bem, móvel ou imóvel, material ou imaterial.". Por fim, o § $2^{\circ}$ diz: "Serviço é qualquer atividade fornecida no mercado de consumo, mediante remuneração, inclusive as de natureza bancária, financeira, de crédito e securitária, salvo as decorrentes das relações de caráter trabalhista.".
} 
objetiva, é demonstrativo de que o legislador buscou abranger também essas obrigações ${ }^{549}$. $\mathrm{Na}$ jurisprudência, esse entendimento já é pacífico ${ }^{550}$.

Miguel Kfouri Neto, uma das poucas vozes dissonantes sobre o assunto, defende a inaplicabilidade do Código de Defesa do Consumidor às atividades médicas, mesmo quando realizadas nos estabelecimentos hospitalares. $\mathrm{O}$ autor tece os seguintes comentários:

\begin{abstract}
"Nunca é ocioso repetir: os serviços hospitalares, não puramente médicos, estão mesmo sujeitos ao regramento do CDC. Todavia, considerada a natureza peculiaríssima do serviço prestado, o CDC não se presta a disciplinar a intervenção pessoal do médico. Invariavelmente, a atuação do profissional da medicina está adstrita a fatores imponderáveis, que podem escapar ao controle do médico mais preparado e que disponha de equipamentos de última geração. Por isso, a inversão sistemática do ônus da prova, a pretexto desse desconhecimento científico por parte do paciente, a par de consagrar um truísmo, implicará sempre, a condenação antecipada do profissional, haja ou não culpa. Exatamente por isso, o Código de Defesa do Consumidor excepcionou os profissionais liberais da responsabilidade sem culpa (art. $14, \S 4^{\mathrm{o}}$ ).

[...] Em suma, à luz do ordenamento vigente, torna-se impossível a inversão do ônus da prova, em desfavor do médico - seja a que pretexto for, máxime pela invocação das normas consumeristas em ações decorrentes de má prática, fundadas na culpa do profissional" ${ }^{, 551}$.
\end{abstract}

Em que pesem seus argumentos, pelas razões apontadas, o posicionamento aqui adotado é o de aplicação das normas consumeristas, não havendo de serem excluídas do

\footnotetext{
${ }^{549}$ GRINOVER, Ada Pellegrini et al. Código Brasileiro de Defesa do Consumidor comentado pelos autores do anteprojeto. 7. ed. Rio de Janeiro: Forense, 2001. p. 176; RIZZARDO, Arnaldo. Responsabilidade civil, p. 337.

$5502^{\mathrm{o}}$ Tribunal de Alçada Civil de São Paulo, Ap. c/ Ver. 685.670-00/4, 1르 Câmara, Relator Juiz Linneu de Carvalho, j. em 27.11.01. v.u.

${ }^{551}$ KFOURI NETO, Miguel. Responsabilidade civil dos hospitais, p. 58/69.
} 
âmbito do Código de Defesa do Consumidor as atividades médicas, como se fossem dissociadas de todas as demais atividades profissionais.

Deve-se passar, assim, à análise da possibilidade de inversão do ônus da prova, bem como da aplicação do prazo prescricional contido no art. 27 do CDC.

No que tange ao primeiro aspecto, José Geraldo Brito Filomeno, em clássica obra sobre direito do consumidor, advoga pela aplicação do princípio da inversão do ônus da prova em contratos firmados por profissionais liberais ${ }^{552}$, assim como Silvio de Salvo Venosa $^{553}$, Sílvia Vassilieff ${ }^{554}$, Sérgio Cavalieri ${ }^{555}$, entre outros. A jurisprudência caminha no mesmo sentido ${ }^{556}$ e, de fato, a corrente majoritária está com razão.

Uma vez definida a aplicabilidade do Código de Defesa do Consumidor aos contratos firmados pelos profissionais liberais, é evidente a necessidade de todas as suas normas serem por ele observadas, tendo em vista que a legislação apenas previu que a eles não fosse imputada a responsabilidade objetiva. Sendo assim, será possível a inversão do ônus da prova, nos termos do art. $6^{\circ}$, inc. VIII, quando for verificada a verossimilhança da alegação, ou a hipossuficiência do contratante. Por decorrência, a inversão não é automática, e deverá ser justificada em decisão fundamentada pelo magistrado, a qual comportará, naturalmente, recurso de agravo de instrumento pelo prejudicado. Se aplicada da maneira correta, a inversão do ônus da prova se justifica e não representa ônus excessivo aos profissionais.

Pelos mesmos motivos, há de ser aplicado à matéria em comento o disposto no art. 27 do CDC, de modo que o prazo prescricional do contratante para demandar a reparação de danos perpetrados pelo profissional liberal será de cinco anos - contados a partir do conhecimento do dano e de sua autoria. O prazo de três, conforme consta do art. 206, inc. $\mathrm{V}$, do $\mathrm{CC}$, somente será aplicável às pretensões de reparação civil que não sejam provenientes de relação de consumo ${ }^{557}$.

\footnotetext{
${ }^{552}$ FILOMENO, José Geraldo Brito et al. Código Brasileiro de Defesa do Consumidor comentado pelos autores do anteprojeto. 7. ed. Rio de Janeiro: Forense, 2001. p. 176.

${ }_{553}^{5}$ VENOSA, Silvio de Salvo. Direito Civil - responsabilidade civil, p. 92-93.

${ }^{554}$ VASSILIEFF, Sílvia. A responsabilidade civil profissional do médico no Direito Civil e no Direito do Consumidor. In: TARTUCE, Flávio; CASTILHO, Ricardo (Coord.). Direito Civil - direito patrimonial, direito existencial - estudos em homenagem à Professora Giselda Maria Fernandes Novaes Hironaka. São Paulo: Método/EPD, 2006. p. 512.

${ }_{555}$ CAVALIERI FILHO, Sérgio. Programa de responsabilidade civil, p. 375.

${ }^{556}$ STJ. $3^{\mathrm{a}}$ T. REsp. 696284/RJ. Rel. Min. Sidnei Beneti. j. 03.12.09. v.u.

${ }^{557}$ Partilha do mesmo entendimento: STJ. $3^{\text {a }}$ T. REsp. 731078/SP. Rel. Min. Castro Filho. j. 13.12.05. v.m.; TJSP. 2 ${ }^{\underline{a}}$ Câmara de Direito Privado. Ap. 990.10.278838-5. Rel. José Carlos Ferreira Alves. j. 26.10.10. v.u.
} 
A aplicação do Código de Defesa do Consumidor também gera efeitos sobre a responsabilidade das pessoas jurídicas formadas por profissionais liberais, inclusive as de direito público.

Pela aplicação do art. 14 do referido Diploma legal ${ }^{558}$, a pessoa jurídica formada por profissionais liberais deve responder objetivamente por danos em relação aos seus credores.

A questão deve, no entanto, ser estudada com cautela no que tange à sociedade de advogados, por se tratar de uma sociedade profissional que não se confunde com as demais sociedades civis ${ }^{559}$, na medida em que a esta é vedada a caracterização mercantil, conforme se observa do art. 16 da Lei n. 8.906/1994 (Estatuto da Advocacia e da Ordem dos Advogados do Brasil - EAOB):

“Art. 16. Não são admitidas a registro, nem podem funcionar, as sociedades de advogados que apresentem forma ou características mercantis, que adotem denominação de fantasia, que realizem atividades estranhas à advocacia, que incluam sócio não inscrito como advogado ou totalmente proibido de advogar".

O registro das sociedades em comento não pode ser feito nas juntas comerciais, e nem mesmo em cartórios de registro civil das pessoas jurídicas, mas tão somente no Conselho Seccional da Ordem dos Advogados em cuja base territorial tiver sede. Depois de efetivado o registro, a sociedade passa a ter personalidade jurídica, mas lhe são impostas diversas restrições, como, por exemplo, a obrigatoriedade de que da razão social conste ao menos o nome do advogado responsável pela sociedade, de forma completa ou resumida, ou ainda seu patronímico ${ }^{560}$.

Silvia Vassilieff, atenta a esse fato e negando a objetivação da responsabilidade das sociedades de advogados, assim se manifesta, ipsis litteris:

"Pela legislação brasileira, as sociedades de advocacia são de pessoas e não se admite que a responsabilidade individual de seus

\footnotetext{
${ }^{558}$ A norma possui a seguinte redação: "Art. 14. O fornecedor de serviços responde, independentemente da existência de culpa, pela reparação dos danos causados aos consumidores por defeitos relativos à prestação de serviços, bem como por informações insuficientes ou inadequadas sobre sua fruição e riscos".

${ }^{559}$ DIAS, Sérgio Novais. Responsabilidade civil do advogado - perda de uma chance, p. 39.

${ }^{560}$ CAVAZZANI, Ricardo Duarte. Responsabilidade civil do advogado. Jus Navigandi. Teresina, ano 13, n. 1.953, 5 nov. 2008. Disponível em: <http://jus.uol.com.br/revista/texto/11927〉. Acesso em: 25 nov. 2010.
} 
sócios seja afastada. Essa peculiaridade das nossas sociedades de advocacia exclui a responsabilidade objetiva e reafirma a subjetividade da responsabilização dos advogados como prestadores de serviços profissionais liberais e não como empresários, mesmo se associados na forma de um grande escritório" ${ }^{, 561}$.

De fato, mesmo que o cliente procure uma sociedade de profissionais, a procuração não será concedida à pessoa jurídica, mas sim a um determinado advogado, ou advogados, o que demonstra a peculiaridade desta espécie de sociedade ${ }^{562}$.

Luiz Carlos de Assis Júnior, ressaltando esse aspecto, assim se posiciona:

“Ademais, duas premissas emergem da análise aqui empreendida: a primeira, de que a sociedade de advogados se confunde com os seus profissionais e os serviços nunca são prestados pela sociedade em si, mas por algum ou alguns dos advogados que a compõem; e a segunda, que o CDC é inaplicável às atividades advocatícias.

A construção deste pensamento silogístico leva à conclusão de que a sociedade de advogados, assim como os advogados em si, está fora do campo de aplicação do $\mathrm{CDC}$ e da forma como ele regulamenta a responsabilidade civil, em função da natureza dos serviços prestados: serviços da espécie advocatícia, os quais possuem regulamentação especialíssima"563.

Não se pode, no entanto, concordar com o doutrinador em todas as suas conclusões, por ser evidente que as sociedades formadas unicamente por advogados também se submetem às normas do Código de Defesa do Consumidor. Ocorre tão somente que a

\footnotetext{
${ }^{561}$ VASSILIEFF, Silvia. Responsabilidade civil do advogado, p. 111.

562 Nesse caso, em regra, todos os advogados que constam da procuração outorgada pelo cliente respondem solidariamente (STJ. 4ํㅡㄹ T. REsp. 596613/RJ. Rel. Min. César Asfor Rocha. j. 19.12.04. v.u.).

${ }^{563}$ ASSIS JÚNIOR, Luiz Carlos de. Responsabilidade civil da sociedade de advogados. Revista Magister de Direito Empresarial, Concorrencial e do Consumidor, v. 29, out./nov. 2009. p. 13-14.
} 
sociedade, por se confundir com seus integrantes, se insere na exceção do art. 14, § $4^{\underline{0}}$, respondendo subjetivamente, ao contrário das outras pessoas jurídicas ${ }^{564}$.

É oportuno salientar, igualmente, que a sociedade de advogados não isenta seus sócios de responsabilidade pessoal, subsidiária e ilimitada, pelos danos causados por ação ou omissão no exercício da advocacia, conforme se depreende do art. 17 do Estatuto em referência. Como não se admite que a procuração ad judicia seja outorgada à pessoa jurídica, mas sim aos membros da sociedade, individualmente considerados, essas pessoas deverão responder pessoal e solidariamente, com observância do disposto no art. 942 do $\mathrm{CC}^{565}$.

Por tudo quanto assinalado, resta cristalino que a sociedade de advogados, em razão do disposto no Estatuto dos Advogados, não possui e não pode possuir natureza empresarial $^{566}$, o que justifica que responda subjetivamente pelos danos provocados ao cliente ${ }^{567}$.

\footnotetext{
${ }^{564}$ DIAS, Sérgio Novais. Responsabilidade civil do advogado - perda de uma chance, p. 42: "É importante salientar que a responsabilidade da sociedade de advogados perante o cliente é também subjetiva e não objetiva. Não prevalece o argumento segundo o qual a sociedade, pessoa jurídica, encontra-se fora da exceção do $\S 4^{0}$ do art. 14 do CDC, por não ser ela propriamente um profissional liberal. É que, como salientado precedentemente, a sociedade de advogados é exclusivamente de pessoas e de finalidades profissionais, de modo que a atividade da sociedade se confunde com a atividade profissional, inclusive em se tratando de dano causado por advogado empregado da sociedade". No mesmo sentido, Ana Paula Pazin Gomes (Da natureza da obrigação assumida pelo advogado e pela sociedade de advogados. Disponível em: <www.direitonet.com.br/artigos/exibir/2364/Da-natureza-da-obrigação-assumida-pelo-advogado-e-pelasociedade-de-advogados>. Acesso em: 25 nov. 2010. Esposa entendimento contrário, Carlos Roberto Gonçalves (Responsabilidade civil, p. 385).

${ }^{565}$ DIAS, Sérgio Novais, op. cit., p. 39.

${ }^{566}$ Nesse sentido, TJSP. 15를 Câmara de Direito Público. Ap. 990.10.073775-9. Rel. Rodrigues de Aguiar. j. 06.05.10. v.u. Desse acórdão, que trata do recolhimento de ISS por sociedades uniprofissionais, consta a seguinte afirmação: "O art. 16 da Lei n⿳o 8.906/94 espanca qualquer dúvida acerca da natureza nãoempresarial das sociedades de advogados. Segundo a previsão normativa, não serão admitidas a registro, nem poderão funcionar, 'as sociedades de advogados que apresentem forma ou características mercantis'. Tranquila a conclusão de que a sociedade civil de advocacia, qualquer que seja o conteúdo de seu contrato social, goza do tratamento tributário diferenciado previsto no art. $9^{\circ}$, $\S \S 1^{\circ}$ e $3^{\circ}$, do Decreto-lei $n^{\circ} 406 / 68$, já que são necessariamente uniprofissionais, não possuem natureza mercantil, sendo pessoal a responsabilidade dos profissionais nele associados ou habilitados". Em sentido contrário, sustentando que a sociedade de advogados, mesmo quando não apresente finalidade mercantilista, enquadra-se no conceito de sociedade

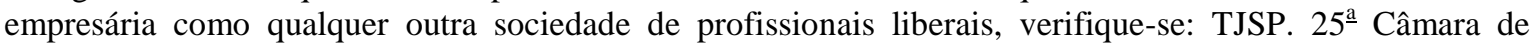
Direito Privado. Ap. 990.10.287520-2. Rel. Ricardo Pessoa de Mello Belli. j. 19.10.10. Nesse julgado, admitiu-se a penhora de quotas sociais da sociedade de advogados.

${ }^{567}$ Apenas para registro, encontrou-se decisão em sentido contrário, estabelecendo que a responsabilidade da sociedade civil composta por advogados é objetiva: TJRJ. 4 Câmara Cível. Ap. 0170775-80.1999.8.19.0001. Rel. Des. Fernando Cabral. j. 25.03.03.v.u. Também manifestando pensamento diverso, Carlos Roberto Gonçalves entende que as prestadoras de serviços advocatícios devam responder objetivamente (Responsabilidade civil, p. 385).
} 
O mesmo não se pode dizer, contudo, acerca dos hospitais e clínicas médicas ${ }^{568}$, no que tange à responsabilidade pelos atos dos médicos que integram seus quadros de empregados. Em verdade, no tocante à responsabilidade dos hospitais, segundo Miguel Kfouri Neto, esta deve ser diferenciada no que concerne a atos extramédicos, atos paramédicos e atos propriamente médicos. Os primeiros se reportam a serviços prestados exclusivamente pelo hospital, não atinentes a atividades médicas, mas sim de hospedagem do doente. Nesse caso, a responsabilidade é indiscutivelmente objetiva, tendo em vista ser aplicável o Código de Defesa do Consumidor no que diz respeito a defeito do produto ${ }^{569}$. Os segundos se referem à atuação de enfermeiros e outros profissionais da saúde, que recebem determinações dos médicos. Nessa esfera também seria aplicável a responsabilidade objetiva. Com relação aos atos exclusivamente médicos, por um lado, o hospital somente responde em caso de comprovação de culpa do médico, não sendo o caso, segundo o autor, de aplicação do Código de Defesa do Consumidor ${ }^{570}$; por outro lado, se o médico apenas loca as dependências do hospital para realização de atos cirúrgicos, não há qualquer responsabilidade do hospital ${ }^{571}$.

Não convém tratar novamente da submissão da prestação de serviços médicos ao Código de Defesa do Consumidor, eis que essa questão já foi tratada aqui, quando houve a oportunidade de exposição do entendimento de que não é possível, em verdade, afastar a aplicação da legislação consumerista à matéria. No que tange à conclusão de Miguel Kfouri Neto, de que os hospitais somente respondem pelos atos dos médicos que ali prestam serviço, esta é confirmada pela jurisprudência ${ }^{572}$. E, de fato, esta é a melhor

\footnotetext{
${ }^{568}$ As sociedades civis formadas exclusivamente por médicos recebem os mesmos benefícios tributários das sociedades de advogados (STJ. 1 ${ }^{\underline{a}}$ T. REsp. 3356/PB. Rel. Min. Humberto Gomes de Barros. j. 18.03.92. v.u.), informação da qual não se deve inferir que também se submetem aos mesmos princípios no que tange à responsabilidade civil. De fato, em razão de tais sociedades não sofrerem as limitações constantes do Estatuto dos Advogados retromencionado, não há que se falar em responsabilização fundada na culpa. Verifique-se, nesse sentido, Sérgio Cavalieri Jr. (Programa de responsabilidade civil, p. 370).

${ }^{569}$ Como será salientado no próximo Capítulo, essa responsabilização direta objetiva do hospital se verifica no caso de infecção hospitalar (STJ. 4- T. REsp. 629212/RJ. Rel. Cesar Asfor Rocha. j. 15.05.07. v.m.). Na mesma esteira, Arnaldo Rizzardo (Responsabilidade civil, p. 319).

${ }^{570}$ KFOURI NETO, Miguel. Responsabilidade civil dos hospitais, p. 136-139.

${ }^{571}$ Ibidem, p. 108. O mesmo entendimento é partilhado por Ruy Rosado de Aguiar Jr. (Responsabilidade civil do médico. Revista dos Tribunais, v. 84, n. 718, p. 42) e Arnaldo Rizzardo (op. cit., p. 314). No mesmo sentido, STJ. $4^{\mathrm{a}}$ T. REsp. 764001/PR. Rel. Min. Aldir Passarinho Junior. j. 04.02.10. v.u.

${ }^{572}$ TJRS. $5^{\text {a }}$ Câmara Cível. Ap. 70037218252. Rel. Jorge Luiz Lopes do Canto. j. 29.09.10. v.u. No acórdão em comento afirma-se que: "Não obstante, para imputar a responsabilidade ao hospital, nos termos da legislação consumeirista, tratando-se de demanda que discute a atuação técnica do médico que atendeu a demandante, cumpre verificar a ocorrência de culpa pelo profissional, ao qual se aplica a responsabilidade civil subjetiva, de acordo com o que preceitua o art. $14, \S 4^{\circ}$, do CDC, de sorte a se aferir o nexo causal". No mesmo sentido, TJRS. 9a Câmara Cível. Ap. 70038994000. Rel. Iris Helena Medeiros Nogueira. j. 20.10.10. v.u.; TJRS. 9ª Câmara Cível. Ap. 700369809879. Rel. Tasso Caubi Soares Delabary. j. 10.11.10. v.u.; TJRJ. 6 ${ }^{\mathrm{a}}$ Câmara Cível. Ap. 0002341-05.2002.8.19.0202. Rel. Nagib Salibi. j. 03.11.10. v.u.; TJRJ. 17 ${ }^{\mathrm{a}}$ Câmara
} 
interpretação da matéria: tratar o assunto como responsabilidade por ato de terceiro, observando a aplicação do duplo estágio de responsabilidade - subjetiva com relação à atuação do terceiro e objetiva no tocante à do responsável, decorrente da conduta culposa do terceiro ${ }^{573}$.

Por fim, no que alude às entidades privadas de seguro e de assistência médica, estas serão abordadas com pormenores no próximo Capítulo. Por ora, cumpre salientar que podem ser responsabilizadas pelos danos sofridos pelo paciente, dependendo de sua atuação. Se, por um lado, a entidade mantém hospitais ou credencia outros estabelecimentos para a prestação dos serviços contratados no plano de saúde, responde solidariamente pela reparação dos danos; se, por outro lado, confere liberdade ao consumidor para que escolha médicos e hospitais, apenas reembolsando suas despesas, ela não responde pelos profissionais assim escolhidos ${ }^{574}$.

Cível. Ap. 0003939 - 72.2005.8.19.0045. Rel. Marcia Alvarenga. j. 10.11.10. v.u.; TJSP. 4 Câmara de Direito Privado. Ap. 990.10.299767-7. Rel. Francisco Loureiro. j. 21.10.10. v.u.; STJ. 3 ${ }^{\mathrm{a}}$ T. REsp. 696284/RJ. Rel. Min. Sidnei Beneti. j. 03.12.09. v.u.; STJ. 3-a T. REsp. 1184128/MS. Rel. Min. Sidnei Beneti. j. 03.06.10. v.u.

${ }_{573}^{5 I Z Z A R D O, ~ A r n a l d o . ~ R e s p o n s a b i l i d a d e ~ c i v i l, ~ p . ~} 317$.

${ }^{574}$ AGUIAR JR., Ruy Rosado de. Responsabilidade civil do médico. Revista dos Tribunais, v. 84, n. 718, p. 48. 


\section{A RESPONSABILIDADE CIVIL DOS MÉDICOS, DENTISTAS, FARMACÊUTICOS E OUTROS PROFISSIONAIS DA ÁREA DA SAÚDE}

Principia-se o estudo da responsabilidade profissional propriamente dita com a atividade dos médicos, por ser a que gera mais questionamento, admite diversas modalidades com espécies de obrigações diferentes e assume a máxima relevância por envolver a vida e a saúde dos contratantes ${ }^{575}$.

A responsabilidade civil decorrente da atividade médica abrange amplo campo de estudo, difícil de ser examinado em sua integralidade, especialmente em um trabalho da natureza deste estudo, no qual os serviços médicos não sejam os únicos abordados. Sendo assim, fez-se necessária a escolha dos assuntos que seriam discutidos, tendo-se como critérios a relevância e o interesse desses. De início, tratar-se-á da responsabilidade contratual e da obrigação de meio do médico e, em seguida, de seus deveres, do erro profissional, de diagnóstico e médico; passando-se às áreas médicas específicas, será estudada a responsabilidade do cirurgião plástico e de outros profissionais cujas obrigações sejam reputadas de resultado, bem como a do anestesista. Por fim, serão tecidos comentários sobre a responsabilidade pelos aparelhos e equipamentos, sobre o ônus da prova - incluindo a importante matéria da perda de uma chance -, a responsabilidade dos hospitais, clínicas psiquiátricas e operadoras de planos de saúde. O Capítulo conclui-se com a análise da responsabilidade de dentistas, farmacêuticos e enfermeiros.

\subsection{Notas introdutórias}

A profissão médica está inserida em uma área cujo erro profissional pode resultar até mesmo no óbito do paciente, motivo pelo qual se exigem diversos requisitos legais para

${ }^{575}$ ITURRASPE, Jorge Mosset. Responsabilidad por daños - responsabilidad de los profesionales. Buenos Aires: Rubinzal-Culzoni, 2004. t. VIII, p. 216-217. 
o exercício da atividade, os quais abrangem a obtenção de um diploma universitário e a inscrição no órgão de classe ${ }^{576}$.

A relação entre médico e paciente costumava ser de confiança, e até mesmo de amizade, uma vez que o profissional cuidava de toda a família, e de todas as enfermidades de seus pacientes. Com o desenvolvimento da sociedade, e a consequente e progressiva crise da prestação de serviços médicos, essa espécie de relação foi se deteriorando e sendo substituída pelo atendimento massificado, em particular no serviço público ${ }^{577}$.

Como preleciona Antônio Jeová Santos:

"[...] a pressa no atendimento, para diminuir a enorme fila daqueles que esperam que a ciência lhes dê uma mínima chance para que continuem vivendo, isentos de algum mal que lhes acometem o corpo ou a mente, torna a Medicina difícil de ser exercitada e seus médicos pouco propensos, diante da dificuldade de material e de outros meios, a fornecer um mínimo de cuidado para que o paciente receba tratamento adequado" 578 .

A massificação, associada com problemas de preparação dos profissionais, fez que começassem a proliferar demandas judiciais em relação à má prestação de serviço médico, não só no País como mundialmente ${ }^{579}$. Esse fato torna ainda mais importante a análise da matéria.

576 CAVAliERI FILHO, Sérgio. Programa de responsabilidade civil, p. 367. Convém salientar que o Decreto n. 20.931, de 11 de jan, 1932, regulamentou diversos cursos universitários das áreas médicas, como a medicina, a odontologia e a veterinária, determinando, quanto ao médico, a habilitação e o registro do título que, atualmente, se faz no Conselho Regional de Medicina, nos termos do Decreto n. 44.045, de 19 de julho de 1958.

577 VENOSA, Silvio de Salvo. Direito Civil - responsabilidade civil, p. 94. Também Miguel Kfouri Neto (Responsabilidade civil do médico, p. 29).

${ }^{578}$ SANTOS, Antônio Jeová. Dano moral indenizável, p. 247.

${ }^{579}$ CAVALIERI FILHO, Sérgio, op. cit., p. 368. O autor tece os seguintes comentários sobre o assunto: "As ações de indenização decorrentes de responsabilidade médica e hospitalar, que antes eram raras em nossa Justiça, estão se tornando cada vez mais freqüentes. Talvez em razão da má qualidade do ensino de um modo geral e dos péssimos serviços prestados, principalmente, pelos hospitais públicos, talvez pelo aumento da procura desses serviços por parte da população em geral, cada vez mais pobre e doente; talvez ainda, por ter hoje o cidadão uma maior consciência dos seus direitos e encontrar mais facilidade de acesso à Justiça. Em uma década o número de processos por negligência ou imperícia encaminhados anualmente ao Conselho Federal de Medicina (CFM) aumentou sete vezes". 


\subsection{A responsabilidade subjetiva contratual e a obrigação de meio do médico}

Conforme salientado neste estudo, a responsabilidade civil do médico é de natureza predominantemente contratual e as obrigações a que se obriga de meio, o que significa que não tem o dever de curar o paciente, mas sim de prestar seus serviços de modo consciente e atento, de acordo com os progressos da medicina ${ }^{580}$.

No que tange ao fato de se tratar de responsabilidade contratual, já houve muita discussão doutrinária, a qual se encontra superada. De fato, atualmente, entende-se que a responsabilidade do médico é de natureza contratual não somente no caso de prestação de serviços remunerados, como também quando o profissional atua por caridade ou cortesia $^{581}$. Poderá, contudo, ser extracontratual nas hipóteses em que o médico fornece atestado falso; consente que pessoa não habilitada pratique medicina ${ }^{582}$; a relação do médico com o paciente é decorrente de uma emergência, ou um acidente que acontece em via pública; bem como no caso de realização de intervenção em favor de incapaz ${ }^{583}$. Ruy Rosado de Aguiar Jr. também entende ser extracontratual a responsabilidade do médico servidor público e do médico contratado para atender aos empregados de uma empresa, tendo em vista que, nas hipóteses mencionadas, não há voluntariedade do paciente na escolha do profissional, e o atendimento é obrigatório ${ }^{584}$.

O contrato médico é intuitu personae, bilateral, oneroso (em regra), de trato contínuo, e de consumo. Por ser fundado na confiança, admite-se a resilição unilateral por qualquer uma das partes, a qualquer tempo, observadas certas restrições no que tange à desistência pelo médico, o que será analisado por ocasião do estudo de seus deveres, no item 4.3. Discute-se, porém, acerca do tipo de contrato firmado pelo profissional com seu cliente, ou seja, qual é o seu nomen juris do pacto, o que se trata de questão tormentosa. Parte da doutrina insiste no fato de que se trata de um contrato de prestação de serviços regular, enquanto outra corrente sustenta que se está diante de um contrato sui generis ${ }^{585}$.

Sérgio Cavalieri Filho, v.g., posiciona-se com a segunda corrente, sob o argumento de que o médico "não se limita a prestar serviços estritamente técnicos, acabando por se

\footnotetext{
${ }^{580}$ DINIZ, Maria Helena. Curso de Direito Civil brasileiro - responsabilidade civil, p. 265.

${ }^{581}$ KÜHN, Maria Leonor de Souza. Responsabilidade civil - a natureza jurídica da relação médico-paciente, p. 62-63.

582 DINIZ, Maria Helena, op. cit., p. 296.

583 AGUIAR JR., Ruy Rosado de. Responsabilidade civil do médico. São Paulo: Revista dos Tribunais, ano 84, v. 718, ago. 1995. p. 35.

${ }^{584}$ Ibidem, p. 35.

${ }^{585}$ AGUIAR DIAS, José de. Da responsabilidade civil, t. II, p. 273.
} 
colocar numa posição de conselheiro, de guarda e protetor do enfermo e de seus familiares", e registra que essa é a orientação adotada pelos Códigos da Suíça e da Alemanha. Maria Leonor de Souza Kühn advoga pela tese do contrato de prestação de serviços comum, acentuando, porém, o fato de, ainda que o médico preste serviço como qualquer outro profissional, deve também contar com a colaboração do paciente, seguindo as prescrições médicas para que o tratamento surta resultados ${ }^{586}$.

A despeito da dissidência doutrinária acerca do tema, em verdade, verifica-se que o nome que se dá ao contrato tem pouca importância para a determinação da responsabilidade do médico. A relevância está em se estabelecer quando a obrigação do profissional da saúde será de meio ou de resultado. Como reiterado ao longo deste estudo, em regra, a obrigação do médico será considerada de meio ${ }^{587}$. Ocorre, porém, que, em alguns casos, como os de cirurgia plástica e exames técnicos laboratoriais ${ }^{588}$, v.g., a doutrina e a jurisprudência firmaram entendimento no sentido de que a obrigação será de resultado. Tratar-se-á dessa matéria em breve.

Por fim, já restou evidenciado que a responsabilidade pessoal do médico é subjetiva, ou seja, depende da prova de culpa na atuação profissional, o que se depreende do disposto no art. 951 do $\mathrm{CC}^{589}$, e também do mencionado $\S 4^{\mathrm{o}}$, do art. 14, do CDC, sendo admitida, em algumas hipóteses, a inversão do ônus da prova, como será discutido no item 4.9 .

\subsection{Os deveres do médico}

Segundo José de Aguiar Dias, os deveres dos médicos são de três espécies: de conselhos, de cuidados e de abstenção de abuso ou desvio de poder ${ }^{590}$. Os conselhos estão relacionados à prestação de instruções sobre condutas essenciais que devem ser tomadas

\footnotetext{
${ }^{586}$ KÜHN, Maria Leonor de Souza. Responsabilidade civil - a natureza jurídica da relação médico-paciente, p. 72.

${ }^{587}$ AGUIAR JR., Ruy Rosado. Responsabilidade civil do médico, v. 718, p. 35: "A obrigação é de meios quando o profissional assume prestar um serviço ao qual dedicará atenção, cuidado e diligência exigidos pelas circunstâncias, de acordo com o seu título, com os recursos de que dispõe e com o desenvolvimento atual da ciência, sem se comprometer com a obtenção de um certo resultado. O médico, normalmente, assume uma obrigação de meios".

${ }_{588}$ VENOSA, Silvio de Salvo. Direito Civil - responsabilidade civil, p. 90-91.

${ }^{589} \mathrm{O}$ dispositivo em referência possui a seguinte redação: "O disposto nos arts. 948, 949 e 950 aplica-se ainda no caso de indenização devida por aquele que, no exercício de atividade profissional, por negligência, imprudência ou imperícia, causar a morte do paciente, agravar-lhe o mal, causar-lhe lesão, ou inabilitá-lo para o trabalho".

${ }_{590}$ AGUIAR DIAS, José de. Da responsabilidade civil, t. I, p. 275.
} 
pelo paciente para que possa melhorar de sua enfermidade, bem como sobre os riscos que os tratamentos ou cirurgias propostos podem oferecer. No que tange ao dever de cuidado, este diz respeito à vigilância e à obtenção de consentimento para os procedimentos a serem realizados. Por fim, a abstenção ao abuso de poder significa que ao médico não é licita a realização de experiências científicas com o paciente, bem como a atuação fora dos limites contratuais $^{591}$. A seguir, tratar-se-á com maiores pormenores desses deveres, apresentando, contudo, uma divisão diferente daquela preconizada pelo doutrinador pré-citado, a qual se entende seja mais condizente com o exercício contemporâneo da medicina. Será, no entanto, possível inferir que as lições desse doutrinador não serão negligenciadas neste estudo.

\subsubsection{Do dever de aconselhar e informar}

O dever de informar, além de ser inerente à prestação de serviços médicos, também decorre da relação de consumo. A informação a ser prestada pelo médico deve ser clara e compreensível pelo leigo, não havendo, contudo, necessidade de relatar pormenores técnicos. Além disso, deve ser prestada não somente ao paciente como também aos seus familiares e acompanhantes. Tem por objeto esclarecer o tratamento e/ou a cirurgia que serão realizados, bem como a conduta que deverá ser adotada pelo paciente para que ele próprio colabore no processo de cura.

A colaboração do paciente é, aliás, de suma importância, eis que este influencia de duas maneiras a atividade do médico: em primeiro lugar, participa da prestação de serviço por meio da reação de seu próprio organismo diante do tratamento que está sendo executado; em segundo lugar, desde que esteja consciente e possa atuar de maneira voluntária, decidirá, por conta própria, se tem confiança ou não nas prescrições do profissional, o que se refletirá de modo decisivo sobre o tratamento ${ }^{592}$. Sendo assim, quanto mais informações receber, melhores serão as condições para se orientar no caminho adequado, e mais confiança terá no médico.

O dever de informação, entretanto, encontra certos limites. Quando, v.g., a comunicação direta da enfermidade, em toda sua extensão, puder ser ainda mais danosa à sua saúde do paciente, este deverá ser poupado de detalhes que lhe causem desnecessário

\footnotetext{
${ }^{591}$ AGUIAR DIAS, José de. Da responsabilidade civil, t. I, p. 281.

${ }^{592}$ KÜHN, Maria Leonor de Souza. Responsabilidade civil - a natureza jurídica da relação médico-paciente, p. 72 .
} 
sofrimento. Nessa hipótese, as informações deverão ser prestadas aos membros da família que estiverem lhe oferecendo apoio ${ }^{593}$, conforme disposto no art. 34 do Código de Ética Médica (Resolução CFM n. 1931, de 17 de setembro de 2009).

O médico, ademais, deve ser sincero com o paciente, não lhe conferindo esperanças muito elevadas quando a situação clínica não o permitir, mas também não sendo tão pessimista a ponto de lhe gerar insegurança. No que tange às cirurgias, deve ser esclarecido, igualmente, se estas deverão ser realizadas em caráter de emergência ou não e quais as consequências advindas de sua postergação.

O dever de indenizar decorrente do descumprimento do dever de informar verificase toda vez que o paciente toma uma decisão que lhe gera danos, por ter sido mal informado $^{594}$. De fato, se os riscos não são informados de maneira correta, o paciente consente com a terapêutica sem saber ao que está, de fato, se submetendo. Nessa hipótese, quem deverá responder pelos riscos será o profissional. Do mesmo modo, se o paciente se submete a uma intervenção cirúrgica por falta de informação, e a cirurgia vem a lhe gerar danos, resta configurada a culpa médica, justamente por falha no dever de informar. Se, contudo, mesmo havendo falha no dever de informar, a cirurgia era essencial para o tratamento ou sobrevivência do paciente, a questão deve ser analisada com mais cuidado, tendo em vista que não realizar a intervenção também agravaria a condição do enfermo ${ }^{595}$.

\subsubsection{Obtenção do consentimento esclarecido do paciente}

A informação e o consentimento do paciente são assuntos entrelaçados e complementares $^{596}$, motivo pelo qual serão estudados em sequência.

Ainda que haja uma relação de confiança especial no contrato de prestação de serviços médicos, há que se reconhecer que o médico não deve dar ordens ao paciente. $\mathrm{O}$ profissional, ao contrário, deve, sempre que possível, buscar obter o consentimento do paciente para a realização de tratamento e intervenção cirúrgica. A menos que se trate de

\footnotetext{
593 CASTRO, João Monteiro de. Responsabilidade civil do médico, p. 100: “O diagnóstico grave, que envolva possibilidade de óbito, pode comportar para o doente outros interesses, quanto a medidas a tomar, referentes à religião, família, fortuna, bem como para dispor, como melhor lhe convier, do tempo que lhe resta. Avisar a família é uma postura ética não reprovável do médico, tanto para dar apoio psicológico ao doente quanto para tomar medidas que entenda pertinentes. O Código de Ética Médica prevê como falta ética do médico deixar de informar o paciente da gravidade dos riscos que pesam sobre ele".

${ }^{594}$ SILVA, Rafael Peteffi da. Responsabilidade civil pela perda de uma chance, p. 164.

${ }^{595}$ CASTRO, João Monteiro de, op. cit., p. 98.

${ }^{596}$ REPRESAS, Félix A. Trigo; MESA, Marcelo J. López. Tratado de la responsabilidad civil, t. II, p. 316.
} 
situação emergencial, caberá ao paciente decidir sobre sua saúde, bem como avaliar o risco ao qual estará se submetendo, e decidir se concorda ou não com a proposta trazida pelo médico $^{597}$. É o que dispõe o inc. XXI, do art. 3ํㅡㄹ do Código de Ética Médica:

“[...]

XXI - No processo de tomada de decisões profissionais, de acordo com seus ditames de consciência e as previsões legais, o médico aceitará as escolhas de seus pacientes, relativas aos procedimentos diagnósticos e terapêuticos por eles expressos, desde que adequadas ao caso e cientificamente reconhecidas".

De fato, de acordo com os termos do art. 15 do $\mathrm{CC}^{598}$, os pacientes não podem ser compelidos a realizar tratamentos aos quais não queiram se submeter. Do mesmo modo, pode haver consentimento no início do tratamento, mas desistência durante o seu prolongamento.

Verifica-se, porém, que o consentimento somente pode ser tomado como autorizador da atividade do médico quando seguido da prestação de todas as informações necessárias para que o paciente tenha o verdadeiro conhecimento de sua doença. Trata-se do consentimento esclarecido ${ }^{599}$.

O consentimento pode ser expresso ou tácito, mas é importante que seja expresso quando o procedimento puder gerar danos graves ao paciente. Ademais, o consentimento não se presume, pura e simplesmente, da ausência de manifestação em sentido contrário; faz-se necessária a análise do caso concreto.

Em algumas hipóteses, entretanto, é possível submeter o doente a tratamento mesmo sem seu consentimento. É o que ocorre em caso de doença contagiosa que requeira, v.g., a ingestão de um medicamento, ou vacina. Nesse caso, o interesse da coletividade há que prevalecer em detrimento do interesse individual. Não obstante, em situação de urgência, em que não tenha sido possível colher o consentimento, como, por exemplo, no meio de um procedimento cirúrgico, também se dispensa a anuência, devendo o médico,

${ }^{597}$ CAVALIERI FILHO, Sérgio. Programa de responsabilidade civil, p. 376.

${ }^{598} \mathrm{O}$ artigo em comento tem a seguinte redação: "Ninguém pode ser constrangido a submeter-se, com risco de vida, a tratamento médico ou a intervenção cirúrgica". Na verdade, desde que a pessoa esteja em plena posse de suas faculdades mentais, pode se opor a qualquer tratamento ou intervenção cirúrgica, mesmo que esta não lhe traga risco de vida.

${ }_{599}^{\text {Art. }} 22$ do Código de Ética Médica. 
contudo, buscar sua obtenção perante os parentes, se existirem e estiverem presentes. Em acréscimo, poderá ser necessária a intervenção à revelia do paciente quando este tiver propósitos suicidas $^{600}$.

No que tange à transfusão de sangue, em particular, a matéria é controversa. Sabese que os adeptos da religião "Testemunhas de Jeová" são orientados a não autorizar a transfusão de sangue. Nesse caso, está-se diante de dois princípios constitucionais: o direito à crença e o direito à vida, o que exige a ponderação. Verifiquem-se, então, algumas alternativas e soluções possíveis para o impasse:

a) A transfusão pode ser substituída por outro método de tratamento, ainda que esse não seja o mais conveniente. Nesse caso, o médico deverá utilizar o tratamento alternativo, respeitando a vontade do doente ${ }^{601}$.

b) O paciente está inconsciente, a transfusão é essencial tendo em vista iminente perigo de vida, mas seus parentes querem impedir o procedimento. Nessa hipótese, prevalece o direito à vida, e o médico deverá fazer a transfusão, mesmo à revelia da família $^{602}$. Se possível, deverá buscar uma autorização judicial ${ }^{603}$.

c) O paciente está consciente, a situação não é emergencial, mas a transfusão é procedimento que se faria necessário, e este se recusa. Aqui, o enfermo deverá assinar termo de responsabilidade perante autoridade policial ou judicial, ou então apresentar um documento de manifestação de vontade registrado em cartório ${ }^{604}$, e o médico deverá respeitar esse posicionamento, mesmo que tenha convicção que isso, em longo prazo, levará à morte do enfermo ${ }^{605}$.

\footnotetext{
${ }^{600}$ AGUIAR DIAS, José de. Da responsabilidade civil, t. I, p. 280.

601 GAGLIANO, Pablo Stolze; PAMPLONA FILHO, Rodolfo. Novo curso de Direito Civil responsabilidade civil, p. 215.

${ }^{602}$ A Resolução CFM n. 1.021/1980, do Conselho Federal de Medicina, adotou os fundamentos do Parecer Proc. CFM n. 21/80, o qual teve como Relator o Dr. Telmo Reis Ferreira, cuja conclusão é a seguinte: "Em caso de haver recusa e permitir a transfusão de sangue, o médico, obedecendo a seu Código de Ética Médica, deverá observar a seguinte conduta: $1^{\circ}$ Se não houver iminente perigo de vida, o médico respeitará a vontade do paciente ou de seus responsáveis. $2^{\underline{o}}$ Se houver iminente perigo de vida, o médico praticará a transfusão de sangue, independentemente de consentimento do paciente ou de seus responsáveis".

${ }^{603}$ O Parecer Proc. CFM n. 21/1980 sugere que, sempre que possível, o médico ingresse com pedido de alvará de autorização judicial.

${ }^{604}$ VASSILIEFF, Silvia. A responsabilidade civil profissional do médico no Direito Civil e no Direito do Consumidor. In: TARTUCE, Flávio; CASTILHO, Ricardo (Coord.). Direito Civil - direito patrimonial, direito existencial - estudos em homenagem à Professora Giselda Maria Fernandes Novaes Hironaka. São Paulo: Método/EPD, 2006. p. 510.

${ }^{605}$ Graciela Lovece ressalta que a jurisprudência e doutrina argentinas têm se inclinado para o entendimento de que deve ser respeitada a decisão do paciente quando este se encontra em pleno gozo de suas faculdades mentais, não sendo o caso de obtenção de autorização judicial para forçar o paciente a fazer algo que ele conscientemente não quer (Responsabilidad del hemoterapeuta. In: GHERSI, Carlos Alberto (Director).
} 
d) O paciente está consciente mas é incapaz - relativa ou absolutamente -, a situação é de emergência, e a família não dá consentimento. Em tal situação, ainda com mais razão deve ser aplicada a mesma solução que consta do item "b". O médico, assim, deverá buscar autorização judicial se a urgência da situação permitir; caso contrário, atuará prontamente, em respeito ao direito à vida do incapaz, que nem sequer tem discernimento necessário para determinar qual religião irá seguir, e muito menos que está disposto a sacrificar sua vida por ela.

Conclui-se, assim, que, havendo iminente perigo de vida, o médico não poderá ser responsabilizado pela realização de transfusão de sangue, mesmo que a terapêutica, ao final, não surta o efeito pretendido, e o paciente venha a falecer.

Por fim, acerca do dever de obter consentimento, cumpre salientar que o ônus de prová-lo cabe ao médico, razão pela qual é salutar que seja conferido por escrito ${ }^{606}$.

\subsubsection{Dever de cuidados com o paciente}

O dever de cuidados, apesar de parecer banal, ocorre em diversas fases.

Em primeiro lugar, o médico deve se inteirar do histórico clínico do paciente, fazendo todas as perguntas que julgar necessárias. Com base nas informações obtidas, começará a desenvolver o diagnóstico, que deve evoluir conforme vai conhecendo em profundidade o enfermo. Estabelecido o quadro clínico, será o momento de prescrever o tratamento, isto é, fazer a indicação terapêutica ${ }^{607}$. É nesse momento que prepondera o dever de cuidado, uma vez que não basta dizer ao paciente para tomar uma ou outra providência: é necessário que o médico o acompanhe e veja a progressão da cura, e se esta caminha de acordo com o esperado. Quando o tratamento médico começou, é necessário que se continue até chegar ao resultado perseguido, desde que o profissional esteja contando com a colaboração do paciente ${ }^{608}$.

Responsabilidad profesional. Buenos Aires: Editorial Astrea de Alfredo y Ricardo Depalma, 1998. v. 5, p. $185)$.

${ }^{606}$ KFOURI NETO, Miguel. Responsabilidade civil do médico, p. 45.

${ }^{607}$ AGUIAR JR., Ruy Rosado de. Responsabilidade civil do médico, p. 36.

${ }^{608}$ ITURRASPE, Jorge Mosset. Responsabilidad por daños - responsabilidad de los profesionales, t. VIII, p. 316. 
Também faz parte do dever de cuidado envidar esforços para que não ocorra a iatrogenia, que se verifica quando a intervenção médica ou os medicamentos ministrados geram uma nova enfermidade no paciente ${ }^{609}$.

É cediço que o dever de acompanhamento do médico é limitado, já que não pode obrigar o paciente a vir até seu consultório; poderá, contudo, fazer a sua parte, estabelecendo o melhor momento para o retorno da consulta, bem como se colocando à disposição para atendê-lo tão logo seja possível. Na hipótese de o paciente não colaborar com o tratamento, causando seu próprio infortúnio, configurar-se-á uma excludente de responsabilidade civil: a culpa exclusiva da vítima. Se houver concorrências de culpas, isto é, negligência do médico e descuido do paciente, aplica-se o disposto no art. 945 do $\mathrm{CC}^{610}$.

O dever de cuidado deve ser estudado em associação com a proibição de abandono do paciente, o que não significa que o médico não poderá deixar de prestar seus serviços, mas sim que não poderá deixar o enfermo sem assistência. Quando o médico decidir, por motivos particulares, que não é mais conveniente prosseguir com seus cuidados pessoais ao paciente, deverá comunicá-lo para que providencie, caso queira, outro profissional para continuar lhe prestando assistência; assegurar-se de que realmente esteja recebendo cuidados; e fornecer as informações necessárias para o médico que o suceder, possibilitando que este tenha uma atuação adequada. $\mathrm{O}$ abandono é, pois, vedado, mas não a renúncia cautelosa ${ }^{611}$.

Convém salientar, todavia, que se a situação do paciente não enseja perigo imediato, o médico pode simplesmente abster-se de atendê-lo; no entanto, havendo urgência no atendimento, não pode negar-se a prestá-lo, sob pena de configuração de omissão de socorro.

\footnotetext{
${ }^{609}$ AGUIAR JR., Ruy Rosado de. Responsabilidade civil do médico, p. 37.

${ }^{610}$ Como esclarecido no Capítulo 1, trata-se do dispositivo que se aplica à concorrência de culpa entre ofensor e vítima. A proporção de concorrência de cada uma das partes na responsabilidade decorrente de prestação de serviços médicos será difícil de ser estabelecida com precisão, mesmo em caso de realização de perícia. Se não for possível chegar a valores concretos, há que se dividir a indenização em $50 \%$ para cada parte.

${ }^{611}$ Art. 36 do Código de Ética Médica, que possui a seguinte redação: "É vedado ao médico: [...] Art. 36. Abandonar paciente sob seus cuidados. $\S 1^{\circ}$. Ocorrendo fatos que, a seu critério, prejudiquem o bom relacionamento com o paciente ou o pleno desempenho profissional, o médico tem o direito de renunciar ao atendimento, desde que comunique previamente ao paciente ou a seu representante legal, assegurando-se da continuidade dos cuidados e fornecendo todas as informações necessárias ao médico que lhe suceder. $\S 2$ 을 Salvo por motivo justo, comunicado ao paciente ou aos seus familiares, o médico não abandonará o paciente por ser este portador de moléstia crônica ou incurável e continuará a assisti-lo ainda que para cuidados paliativos".
} 
Caso tenha de se ausentar, e o doente exija cuidados ou vigilância constantes, como uma gestante, ou, então, um doente acometido de distúrbio psiquiátrico, o médico deverá deixar outro profissional de sua confiança para lhes prestar atendimento. Responderá solidariamente pelos atos do substituto, pois se presume que este seja seu preposto ${ }^{612}$.

\subsubsection{Dever de sigilo}

O médico, em conformidade com o art. $3^{\circ}$, inc. XI, do Código de Ética Médica, bem como com o art. 154 do CP, tem o dever ético e legal de guardar para si as informações obtidas por meio de sua atuação profissional ${ }^{613}$. A matéria é complementada pelo art. 73 do mesmo Código de Ética, que possui a seguinte redação:

"Art. 73. Revelar fato de que tenha conhecimento em virtude do exercício de sua profissão, salvo por motivo justo, dever legal ou consentimento, por escrito, do paciente.

Parágrafo único. Permanece essa proibição:

a) mesmo que o fato seja de conhecimento público ou o paciente tenha falecido;

b) quando de seu depoimento como testemunha. Nessa hipótese, o médico comparecerá perante a autoridade e declarará seu impedimento;

c) na investigação de suspeita de crime, o médico estará impedido de revelar segredo que possa expor o paciente a processo penal".

João Monteiro de Castro ${ }^{614}$ relata que podem ser identificados três tipos de segredo:

- o cometido, que se verifica quando é feito o pedido de sigilo antes que seja revelado o fato;

- o prometido, em que o pedido de sigilo é posterior à narrativa do fato; $\mathrm{e}$

${ }^{612}$ CASTRO, João Monteiro de. Responsabilidade civil do médico, p. 107.

${ }^{613}$ REPRESAS, Félix A. Trigo; MESA, Marcelo J. López. Tratado de la responsabilidad civil, t. II, p. 312313.

${ }^{614}$ CASTRO, João Monteiro de, op. cit., p. 125. 
- o natural, no qual não há um pedido, mas é mantido por razões humanitárias, para não gerar prejuízo à honra da pessoa à qual o segredo se relaciona ${ }^{615}$.

Esse autor sustenta que o sigilo do médico enquadra-se na primeira modalidade. Com relação à atividade médica, no entanto, impõe-se o segredo em qualquer uma dessas hipóteses, e até mesmo quando o paciente nada lhe tenha requisitado. De fato, o próprio doutrinador reconhece que o pedido de segredo não precisa ser expresso, sendo presumido "em função das condições pessoais e posição social e familiar do paciente, conhecidas ou dadas a conhecer ao profissional, mesmo que se refiram a particularidades que correspondam a motivos menores ou que visem fins não engrandecedores"616.

No que tange ao sigilo requisitado por crianças e adolescentes, o art. 74 do Código de Ética Médica dispõe ser vedado ao médico "revelar sigilo profissional referente a paciente menor de idade, inclusive a seus pais ou responsáveis legais, desde que o menor tenha capacidade de discernimento, salvo quando a não revelação possa acarretar dano ao paciente".

Há hipóteses em que o profissional pode ser dispensado do dever em comento, quando se tratar da defesa de um interesse mais relevante, como, por exemplo, salvar a vida do próprio paciente ou de outra pessoa, se diante de uma doença infectocontagiosa ${ }^{617}$, para, v.g., a realização de perícias médico-legais e outras solicitações judiciais ${ }^{618}$. Além disso, o médico pode entender ser necessário compartilhar a informação sigilosa com outros profissionais para obter a cura do paciente. Também não haverá responsabilização do médico quando este contar com o consentimento do próprio paciente.

\subsection{O erro profissional, o erro de diagnóstico e o erro médico}

O erro profissional, ou técnico, consiste no emprego da técnica incorreta para o caso concreto, isto é, entre os procedimentos disponíveis, o médico não escolheu o mais

\footnotetext{
${ }^{615}$ CASTRO, João Monteiro de. Responsabilidade civil do médico, p. 125.

${ }^{616}$ Ibidem, p. 130.

${ }^{617}$ Nesse sentido, não se olvide que o art. 269 do CP tipifica a conduta de omissão da comunicação de doença às autoridades públicas, cuja notificação seja compulsória. Do mesmo modo, o art. 66, inc. II, da Lei de Contravenções Penais estabelece ser contravenção deixar de comunicar crime de ação pública sobre o qual o médico teve conhecimento no exercício de sua atividade, "desde que a ação penal não dependa de representação e a comunicação não exponha o cliente a processo criminal".

${ }^{618}$ CAVALIERI FILHO, Sérgio. Programa de responsabilidade civil, p. 376.
} 
adequado - o que não significa, porém, que o médico atuou culposamente, ou seja, com negligência, imprudência ou imperícia. A culpa exige uma falta de diligência em relação ao que se espera de um bom profissional, ao passo que o erro é a falha do homem comum, a consequência inafastável da atuação humana ${ }^{619}$.

Se, porém, a técnica escolhida foi a correta, mas sua aplicação se deu de maneira deficiente, haverá responsabilidade pelos danos dela decorrentes. No que tange à avaliação da culpabilidade, a conduta do profissional especialista é realizada com mais rigor do que a do profissional clínico geral ${ }^{620}$.

Saliente-se, ademais, que existem certos procedimentos médicos bastante conhecidos e que contam com reconhecimento internacional; assim, quando o médico deles se afasta, o comportamento culposo evidencia-se. Decerto, o profissional será responsabilizado pela utilização de tratamento ou técnica já considerados obsoletos pela comunidade médica $^{621}$. Métodos antigos, entretanto, podem ser usados quando justificáveis no caso concreto, ou se mostrem igualmente eficazes aos mais recentes. A questão se torna mais complexa quando são utilizadas novas técnicas, que geram perplexidade até mesmo perante a classe médica ${ }^{622}$. Nesse caso, haverá maior benevolência na avaliação da culpabilidade do médico, desde que a técnica recém- desenvolvida se mostre manifestamente mais vantajosa do que a clássica.

De qualquer modo, exige-se que o médico esteja sempre atualizando seus conhecimentos, para que possa disponibilizar ao doente as técnicas mais eficazes entre aquelas disponíveis. Em caso de danos, deverá estar preparado para esclarecer por que um procedimento foi escolhido em detrimento de outro e se mostrar apto a conduzir todos aqueles disponíveis em sua área de atuação.

O médico que trabalha em hospitais públicos, contudo, em muitas ocasiões, por falta de recursos, não poderá utilizar a técnica mais atual; nem por isso poderá ser responsabilizado: trata-se de hipótese de responsabilização do próprio Estado, por risco administrativo.

O médico, igualmente, deverá abster-se de realizar intervenções cujos riscos sejam desproporcionais aos benefícios, mesmo que o paciente insista em sua realização. Também

\footnotetext{
${ }^{619}$ AGUIAR JR., Ruy Rosado de. Responsabilidade civil do médico, p. 38.

${ }^{620}$ GONÇALVES, Carlos Roberto. Responsabilidade civil, p. 364.

${ }^{621}$ CASTRO, João Monteiro de. Responsabilidade civil do médico, p. 105.

${ }^{622}$ VENOSA, Silvio de Salvo. Direito Civil - responsabilidade civil, p. 91.
} 
lhe é vedado realizar experiências com o paciente, há menos que haja justificativa para tanto; assim, a experiência deve ter por finalidade exclusivamente combater a doença que acomete a pessoa a que ela se submete.

O erro de diagnóstico se verifica quando o médico falha em identificar a enfermidade do paciente; novamente, não significa que o médico atuou culposamente e não levará, em regra, à condenação em indenização dos danos provocados ao paciente. Na verdade, o erro de diagnóstico faz parte da própria dificuldade inerente à profissão e não gerará dever de reparar se for possível verificar que o engano poderia ter sido cometido por qualquer médico devidamente habilitado.

Nas hipóteses apontadas, para que haja a responsabilização do médico, será necessário avaliar se, conforme o estado da ciência, seria possível, ou não, para o médico, ter evitado o erro, caso atuasse de modo mais diligente ${ }^{623}$. Um padrão importante de referência é a realização de exames adequados ao caso em estudo ${ }^{624}$.

Por fim, passar-se-á à análise do erro médico, que não se confunde com o erro profissional. O primeiro se verifica, segundo João Monteiro de Castro, em caso de "conduta profissional inadequada, associada à inobservância de regra técnica, potencialmente capaz de produzir dano à vida ou agravamento do estado de saúde de outrem, mediante imperícia, imprudência ou negligência"625. O segundo - erro profissional - já foi abordado no início deste item.

No caso do erro médico, então, conforme João Monteiro de Castro ${ }^{626}$, está-se no domínio da culpa, a qual pode se manifestar em uma de suas três modalidades, ou por meio de uma combinação delas. A imprudência se verifica quando o médico não antevê os possíveis resultados do tratamento prescrito ou da intervenção realizada e não toma as medidas necessárias para neutralizá-los. A negligência está relacionada a condutas omissivas, quando o profissional não se empenha para obter a cura ou sobrevivência do paciente, isto é, não faz tudo aquilo que estava ao seu alcance. Constata-se, v.g., no caso do médico deixar de solicitar a realização de um exame que seria importante para a intervenção cirúrgica. Por fim, a imperícia, conforme ressaltado no Capítulo 2, é a falta de conhecimentos técnicos específicos, experiência ou habilidade, para o exercício de determinada profissão. É imperioso assinalar que, na responsabilidade médica, torna-se

\footnotetext{
${ }^{623}$ CAVALIERI FILHO, Sérgio. Programa de responsabilidade civil, p. 373.

${ }^{624}$ GONÇALVES, Carlos Roberto. Responsabilidade civil, p. 366.

${ }^{625}$ CASTRO, João Monteiro de. Responsabilidade civil do médico, p. 141.

${ }^{626}$ Ibidem.
} 
difícil diferenciar as modalidades de culpa, motivo pelo qual o julgador não deverá se prender à nomenclatura dada à conduta culposa, mas tão somente ao seu conteúdo ${ }^{627}$.

\subsection{A responsabilidade civil do cirurgião plástico}

A doutrina majoritária afirma que a obrigação do cirurgião plástico é de resultado $^{628}$, mas a assertiva deve ser analisada com cuidado antes de ser tomada como verdade absoluta.

Observa-se, na verdade, que fatos expostos nos meios de comunicação influenciam essa orientação jurídica. De um lado, veem-se mulheres que superam o padrão de beleza submetendo-se a diversas cirurgias plásticas manifestamente desnecessárias e correndo os graves riscos advindos do procedimento, incluindo o anestésico; e, de outro, os resultados do excesso de intervenções em algumas celebridades, que se tornam, em vez de mais bonitas ou rejuvenescidas, irremediavelmente deformadas, ainda que estas, talvez por desvios psiquiátricos, não se deem conta da terrível situação em que se encontram e continuem se submetendo a sucessivas intervenções.

Diante dessas imagens, o observador, com efeito, pode pensar que os cirurgiões plásticos não atuam eticamente, que se dedicam a procedimentos fúteis e que, por isso, devem ser responsabilizados com rigor por sua atividade, o que motivaria o entendimento, quase uníssono, de que sua obrigação é de resultado.

627 De fato, não é incomum que as três modalidades se verifiquem. Na Apelação n. 994.02.065152-4, proveniente da $8^{\text {a }}$ Câmara de Direito Privado do TJSP, a vítima sofreu lesão no reto causada em procedimento comum de parto normal, ao que se seguiu quadro grave de infecção. No caso em comento, podem ser vislumbradas as três hipóteses de culpa, como se verifica do excerto do acórdão a seguir transcrito: "Depreende-se da narrativa, que o insucesso da cirurgia de sutura da fístula reto-vaginal feita pelos médicos do requerido, teve como causa presumida a demora em se proceder a intervenção, a falta de limpeza correta do intestino e do reto, isto é, sem os cuidados e assepsias necessários, provável inaptidão na realização do procedimento específico de sutura e, quiçá, emprego de material inadequado, vez que não atingido o resultado esperado, haja vista a posterior eliminação de fezes também pela vagina, agravando ainda mais o estado de saúde da apelada" (Rel. Luiz Ambra. j. 01.12.10. v.u.). O hospital foi condenado objetivamente pelos danos causados à paciente.

${ }^{628}$ CASTRO, João Monteiro de. Responsabilidade civil do médico, p. 153: "a cirurgia estética gera obrigação de resultado e não de meio. O paciente do cirurgião estético não é um doente que procura tratamento e o médico não se engaja na sua cura. O médico está empenhado em atingir o resultado pretendido e, se não há como consegui-lo, não deve efetuar o ato cirúrgico". No mesmo sentido, Carlos Roberto Gonçalves assevera que: "A obrigação que assumem é de 'resultado'. Os pacientes, na maioria dos casos de cirurgia estética, não se encontram doentes, mas pretendem corrigir um defeito, um problema estético. Interessa-lhes, propriamente, o resultado. Se o cliente fica com aspecto pior, após a cirurgia, não se alcançando o resultado que constituía a própria razão de ser do contrato, cabe-lhe o direito à pretensão indenizatória. Da cirurgia mal-sucedida surge a obrigação indenizatória pelo resultado não alcançado" (Responsabilidade civil, p. 366). 
O que verifica na televisão, nas revistas, e nos jornais, no entanto, não corresponde à realidade da população. É de conhecimento geral que as celebridades, ou semicelebridades - como há tantas no Brasil, oriundas, principalmente, do infindável número de programas de reality show - têm preocupação obsessiva com a beleza e encontram médicos inescrupulosos, dispostos a lhes atender as vontades. Outra parte da população, muito maior em comparação à retromencionada, no entanto, procura esses profissionais porque de fato não se sente bem consigo mesma, seja em consequência de um nariz desproporcional, que lhe causa desconforto e humilhações desde a adolescência, seja em razão da excessiva flacidez resultante de perda significativa de peso, ou mesmo em decorrência de outra cirurgia, de cunho estético ou não, que lhe deixou cicatrizes.

Conforme resta demonstrado, a atividade do cirurgião plástico não deve ser considerada fútil, mas sim necessária para a sociedade, já que atende a um dos principais objetivos da medicina, que é o bem-estar do paciente.

Tecidas essas considerações, passar-se-á ao estudo da matéria.

Convém apresentar, preliminarmente, a diferenciação, já tradicional na doutrina, entre cirurgia plástica embelezadora e cirurgia corretiva ${ }^{629}$. A primeira modalidade consiste na intervenção cirúrgica que tem finalidade meramente estética, para aperfeiçoamento da aparência do paciente, quando este não padece de qualquer enfermidade. A segunda espécie é realizada com o escopo de corrigir defeitos congênitos ou adquiridos posteriormente, de forma traumática ${ }^{630}$. Não deixa de envolver preocupação estética, mas possui um fim terapêutico relacionado. Também é utilizada para corrigir uma cirurgia plástica embelezadora malsucedida.

De acordo com Sérgio Cavalieri Filho, a responsabilidade do cirurgião plástico somente é de meio em caso de cirurgia corretiva, mas não na cirurgia estética, pois nesta “o objetivo do paciente é melhorar a aparência, corrigir alguma imperfeição física - afinar o nariz, eliminar as rugas do rosto etc. Nesses casos, é indubitável que o médico assume obrigação de resultado, pois se compromete a proporcionar ao paciente o resultado pretendido. Se esse resultado não for possível, deverá desde logo alertá-lo e se negar a

\footnotetext{
${ }^{629}$ SANCHEZ, María Del Carmen García. Responsabilidad del cirujano estético. In: GHERSI, Carlos Alberto (Director). Responsabilidad profesional, v. 5, p. 2-3.

${ }^{630}$ CAVALIERI FILHO, Sérgio. Programa de responsabilidade civil, p. 378.
} 


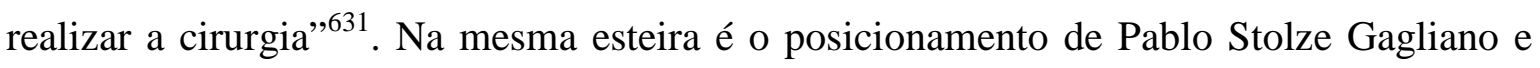
Rodolfo Pamplona Filho ${ }^{632}$ e Carlos Roberto Gonçalves ${ }^{633}$, entre tantos outros.

A diferença entre cirurgia embelezadora e cirurgia corretiva, no entanto, somente denota facilidade de ser apreendida no papel, eis que, diante de casos reais, torna-se difícil distinguir o corretivo do simplesmente embelezador. Em primeiro lugar, qualquer procedimento corretivo também é, necessariamente, embelezador, pois, uma vez corrigida uma deformidade, o resultado final será o embelezamento do paciente. Em segundo lugar, a beleza e a correção dependem do entendimento do observador. Verifique-se, v.g., o usual procedimento de colocação de próteses de silicone nos seios. Em alguns casos, a paciente já possui seios em tamanho adequado, mas deseja aumentá-los para que sejam mais chamativos e sensuais. Nessa hipótese, está claro o intuito meramente estético. O mesmo procedimento de implantação de prótese pode ser desejado por paciente que teve uma das mamas retiradas em consequência de acometimento de câncer e anseia que a extração não fique visível. Aqui, evidencia-se o caráter corretivo. Mais frequentes são, no entanto, as áreas cinzentas, como, v.g., o caso da paciente, perfeitamente saudável e sem deformidades, que queira colocar prótese porque possui seios anormalmente pequenos e desproporcionais com o porte físico. Seria, então, caso de correção ou de embelezamento? De qualquer modo, o procedimento de colocação da prótese será igual em todos os casos; todavia, se diferenciadas as cirurgias corretivas das embelezadoras, cada profissional poderá responder de maneira diferente - com ou sem presunção de culpa -, mesmo realizando procedimento idêntico.

Em razão do exposto, tem-se que a diferenciação ora procedida não é adequada para o estudo da responsabilidade do cirurgião plástico ${ }^{634}$.

O dano advindo da cirurgia pode decorrer de duas situações: frustração das expectativas do paciente, ou, então, agravamento dos defeitos que se pretendia corrigir. Muitas vezes, o médico é demandado pelo paciente porque este tinha expectativas muito elevadas com relação à cirurgia. De fato, não são poucas as pessoas que realizam os procedimentos cirúrgicos com a falsa ilusão de que sairão deles totalmente modificadas, ou até mesmo parecidas com os artistas favoritos; contudo, o profissional não poderá

\footnotetext{
${ }^{631}$ CAVALIERI FILHO, Sérgio. Programa de responsabilidade civil, p. 378.

${ }^{632}$ GAGLIANO, Pablo Stolze; PAMPLONA FILHO, Rodolfo. Novo curso de Direito Civil responsabilidade civil, p. 210.

${ }^{633}$ GONÇALVES, Carlos Roberto. Responsabilidade civil, p. 367.

634 SANCHEZ, María Del Carmen García. Responsabilidad del cirujano estético. In: GHERSI, Carlos Alberto (Director). Responsabilidad profesional, v. 5, p. 5.
} 
responder por expectativas inalcançáveis. Se, por um lado, a cirurgia transcorreu normalmente, e o procedimento utilizado alcançou as finalidades previstas, como, v.g., a redução do nariz, o levantamento da pálpebra etc., o médico não haverá de ser responsabilizado. Se, por outro lado, a cirurgia trouxe o agravamento dos defeitos que a intervenção pretendia superar, a situação se complica, e exige perícia para determinar se o médico é, ou não, responsável pela piora. Também deverá ser responsabilizado se o resultado indesejável era previsível, ou se verifica com grande frequência.

Não há, portanto, necessidade de se considerar que a responsabilidade do cirurgião plástico é de resultado para que as vítimas sejam devidamente indenizadas.

A respeito do assunto, a doutrinadora Giselda Maria Fernandes Novaes Hironaka disserta:

"É bem verdade, no entanto, que muitos julgados e ainda muitos doutrinadores da área do direito enxergam sempre na cirurgia plástica estética uma obrigação de resultado, ou seja, presumem sempre que o médico obrigou-se a atingir o resultado querido pelo paciente. Mas isso decorre, muitas vezes, da reação que surgiu aos desmandos e à absoluta impossibilidade de se provar que o médico fora culpado. A absoluta falta de perícias conclusivas, deixando de indicar a existência de erro mesmo onde ele era grosseiro e visível, o corporativismo que grassava então entre os médicos forçaram os aplicadores do direito a coibir toda sorte de abusos, tornando factível a hipótese de reparação, mesmo quando havia dúvida sobre a culpa do médico ter existido ou não. Recorremos ao conceito de presunção. Presumíamos, amparados pela lei, que o médico agira com culpa e abríamos a possibilidade para que o médico mostrasse a sua não-culpa, ou seja, admitíamos que ele, único conhecedor da técnica aplicada, convencesse-nos de que agira ou se omitira com lisura, segundo o que determinasse a sua ciência e seu saber aplicados ao caso concreto" ${ }^{, 635}$.

${ }^{635}$ HIRONAKA, Giselda Maria Fernandes Novaes. Cirurgia plástica e responsabilidade civil do médico: para uma análise jurídica da culpa do cirurgião plástico. Disponível em: 〈http://www.flaviotartuce.adv.br〉. Acesso em: $1^{\circ}$ fev. 2009. p. 5-6. 
E conclui a doutrinadora:

"Mais recentemente, diante da ampliação do conceito de saúde e da descoberta de que fatores biológicos que escapam ao controle do profissional da saúde eram aptos a interferir no resultado da cirurgia, assiste-se já a um retorno do tratamento unitário dispensado aos médicos em geral, entendendo-se que o vosso labor não se compromete para além daquilo que permite a falibilidade humana e as condições biológicas do paciente" ${ }^{\text {,636. }}$.

Além de tudo quanto exposto, há que se verificar que a álea envolvendo a atividade do cirurgião plástico é a mesma que permeia a atividade dos demais profissionais da medicina, motivo pelo qual também na seara em estudo se justifica a manutenção da obrigação de meio ${ }^{637}$, com algumas particularidades ${ }^{638}$ :

- dever de informação do cirurgião plástico necessita ser avaliado de modo mais rigoroso - é salutar fazer as instruções por escrito e colher a assinatura do paciente sobre os riscos da cirurgia, os cuidados pré e pós-operatórios (como por exemplo, o uso de cinta elástica), entre outras diretivas que sejam essenciais para o sucesso da cirurgia $^{639}$;

- dever de avaliar com rigor a conveniência da realização da cirurgia, em vez de simplesmente atender aos desejos do paciente. Se o profissional entender que os

${ }^{636}$ HIRONAKA, Giselda Maria Fernandes Novaes. Cirurgia plástica e responsabilidade civil do médico: para uma análise jurídica da culpa do cirurgião plástico. Disponível em: <http://www.flaviotartuce.adv.br>. Acesso em: $1^{\circ}$ fev. 2009. p. 5-6.

${ }^{637}$ Também partilhando desse entendimento, Ruy Rosado de Aguiar Jr.: "O acerto está, no entanto, com os que atribuem ao cirurgião estético uma obrigação de meios. Embora se diga que os cirurgiões plásticos prometam corrigir, sem o que ninguém se submeteria, sendo são, a uma intervenção cirúrgica, pelo que assumiriam eles a obrigação de alcançar o resultado prometido, a verdade é que a álea está presente em toda intervenção cirúrgica, e imprevisíveis as reações de cada organismo à agressão do ato cirúrgico. Pode acontecer que algum cirurgião plástico, ou muitos deles assegurem a obtenção de um certo resultado, mas isso não define a natureza da obrigação, não altera a sua categoria jurídica, que continua sendo sempre a obrigação de prestar um serviço que traz consigo o risco. É bem verdade que se pode examinar com maior rigor o elemento culpa, pois mais facilmente se constata a imprudência na conduta do cirurgião que se aventura à prática da cirurgia estética, que tinha chances reais, tanto que ocorrente, de fracasso. A falta de uma informação precisa sobre o risco, e a não obtenção de consentimento plenamente esclarecido, conduzirão eventualmente à responsabilidade do cirurgião, mas por descumprimento culposo da obrigação de meios" (Responsabilidade civil do médico, p. 40).

${ }^{638}$ Trata-se de uma obrigação de meio reforçada, segundo nomenclatura utilizada por Miguel Kfouri Neto (Culpa médica e ônus da prova - presunções, perda de uma chance, cargas probatórias dinâmicas, inversão do ônus probatório e consentimento informado - responsabilidade civil em pediatria e responsabilidade civil em gineco-obstetrícia. São Paulo: Revista dos Tribunais, 2002. p. 250).

${ }^{639}$ Ibidem, p. 248. 
riscos são muito altos, deve abster-se de fazer a intervenção. $\mathrm{O}$ consentimento do paciente, nesse caso, é irrelevante, porque o direito à incolumidade física é inviolável ${ }^{640}$;

- dever de realizar o maior número de exames possíveis a fim de detectar eventuais contraindicações ao procedimento;

- dever de atenção redobrada no pós-operatório, fundamental para evitar ou minimizar cicatrizes;

- dever de sigilo, sendo ainda mais importante, uma vez que a divulgação dos procedimentos realizados pode ser constrangedora para o paciente ${ }^{641}$.

Caso se entenda que sua obrigação é de resultado, como é a orientação predominante dos Tribunais acerca da cirurgia com fins meramente estéticos ${ }^{642}$, uma vez constatado o insucesso da intervenção de maneira objetiva - e não de acordo com as expectativas do paciente -, haverá presunção de culpa do cirurgião plástico.

\subsection{Outras obrigações de resultado relacionadas à atividade médica}

Além da obrigação do cirurgião plástico, a doutrina entende serem de resultado a obrigação referente à vacinação, à transfusão de sangue, à realização de exames biológicos e radiológicos e à realização de consultas ${ }^{643}$.

No que tange à vacinação, de fato, o médico se obriga à sua efetivação, de maneira adequada. Também é responsabilizado pelo devido acondicionamento da vacina e observância da data de validade; no entanto, escapam de sua esfera de atuação vícios do próprio produto, pelos quais responde o fabricante, inclusive por reações adversas imprevistas suportadas pelo vacinado.

No que diz respeito à transfusão de sangue, a responsabilidade recai, em regra, sobre os bancos de sangue e de serviço de hemoterapia, os quais respondem objetivamente

\footnotetext{
${ }^{640}$ GONÇALVES, Carlos Roberto. Responsabilidade civil, p. 369.

${ }^{641}$ SANCHEZ, María Del Carmen García. Responsabilidad del cirujano estético. In: GHERSI, Carlos Alberto (Director). Responsabilidad profesional, v. 5, p. 29.

${ }^{642}$ Como exemplo, verifique-se: STJ. 3. T. REsp 1180815/MG. Rel. Min. Nancy Andrighi. j. 19.08.10. v.u. Há inúmeras decisões no mesmo sentido, motivo pelo qual se torna despiciendo relatá-las.

${ }^{643}$ AGUIAR JR., Ruy Rosado. Responsabilidade civil do médico, p. 39.
} 
pelo produto fornecido ${ }^{644}$. Trata-se de hipótese de difícil caracterização de responsabilidade pessoal do médico. $\mathrm{O}$ mesmo se aplica à realização de exames biológicos e radiológicos, cuja responsabilidade caberá aos laboratórios ${ }^{645}$. De qualquer forma, a obrigação é inegavelmente de resultado ${ }^{646}$, eis que depende apenas da excelência da técnica laboratorial e dos aparelhos empregados. Se, entretanto, mesmo assim houver probabilidade de inexatidão no resultado fornecido, esta deverá ser informada ao paciente.

No tocante às realizações de consulta, assim como o que ocorre com os advogados, a obrigação realmente é de resultado, sem que isso, contudo, signifique que da consulta advirá a cura do paciente.

\subsection{A obrigação do anestesista e a responsabilidade civil da equipe médica}

A anestesia é procedimento cientificamente autônomo com relação à cirurgia ${ }^{647}$, mas aconselha-se que não ofereça riscos maiores do que a própria cirurgia, o que nem sempre é possível de se obter. Em regra, depende do consentimento daquele a que ela se submete, e deve ser realizada na presença de testemunhas ${ }^{648}$; ademais, deve ser seguida do maior número possível de exames, a fim de trazer segurança ao procedimento.

A obrigação do anestesista é de meio, já que sua atividade envolve álea tão grande quanto a dos demais profissionais, motivo pelo qual sua obrigação deve ser realmente de meio. Na mesma esteira, Ruy Rosado de Aguiar Jr.:

"Parece, todavia, que a álea a que estão submetidos o anestesista e seu paciente não é diferente das demais situações enfrentadas pela medicina, razão pela qual não deixa de ser uma obrigação de meios, ainda que se imponha ao profissional alguns cuidados especiais, na preparação do paciente, na escolha do anestésico, etc. Dele se exige acompanhamento permanente, não podendo afastar-

\footnotetext{
644 LOVECE, Graciela. Responsabilidad del hemoterapeuta. In: GHERSI, Carlos Alberto (Director). Responsabilidad profesional, p. 179.

${ }^{645}$ GONÇALVES, Carlos Roberto. Responsabilidade civil, p. 371.

${ }^{646}$ STJ. 3. T. REsp 594962/RJ. Rel. Min. Antônio de Pádua Ribeiro. j. 09.11.04. v.u.

${ }^{647}$ KFOURI NETO, Miguel. Culpa médica e ônus da prova - presunções, perda de uma chance, cargas probatórias dinâmicas, inversão do ônus probatório e consentimento informado - responsabilidade civil em pediatria e responsabilidade civil em gineco-obstetrícia, p. 158.

${ }^{648}$ AGUIAR DIAS, José de. Da responsabilidade civil, t. I, p. 286.
} 
se da cabeceira do paciente durante o ato cirúrgico, até sua recuperação." ${ }^{, 649}$.

Observa-se, hoje, que a atuação do anestesista é muito mais ampla do que foi no passado. Na fase pré-anestésica, o anestesista deve avaliar o paciente às vésperas da cirurgia, a fim de determinar o procedimento a ser adotado no momento da intervenção caso essa não seja de urgência ${ }^{650}$. Na fase seguinte, no momento em que o paciente está sendo sedado, e perdendo a consciência, exige-se a máxima atenção desse profissional, para observar as reações. A terceira fase consiste naquela em que o paciente já está inconsciente, fazendo-se necessário o controle de suas condições ventilatórias e cardiovasculares, exigindo a permanência do anestesista na sala cirúrgica ${ }^{651}$. Por fim, segue-se a etapa de recuperação, na qual a maior parte dos pacientes é acometida de náusea e vômito, o que pode gerar sufocamento, se não houver a devida vigilância. A falha em qualquer uma dessas fases implica a responsabilização do anestesista.

A questão mais importante no tocante a esse profissional é sua atuação em equipe, o que se passa a analisar.

No Capítulo 3, mencionou-se que o médico responsável pela equipe responde solidariamente pelos danos causados pelos membros que a integram, desde que tenham por ele sido escolhidos ${ }^{652}$. Se os outros membros foram contratados diretamente pelo paciente, o que se trata de hipótese remota, seria possível a individualização da responsabilização de cada profissional, sem que se olvide, contudo, que o cirurgião-chefe tem sempre a responsabilidade de vigilância sobre as condutas tomadas no transcorrer da cirurgia.

O cirurgião ocupa o papel principal na sala de cirurgia, esperando-se dele experiência, habilidade e segurança na prática de sua atividade. Os seus auxiliares possuem papel menor, mas não de somenos importância, já que são encarregados da instrumentação, das compressas, da injeção de medicamentos, da colocação do paciente na posição adequada etc. $\mathrm{O}$ anestesista, contudo, exerce função crucial e de maior risco, o que dá origem os entendimentos controversos.

\footnotetext{
${ }^{649}$ AGUIAR JR., Ruy Rosado. Responsabilidade civil do médico, p. 43.

${ }^{650}$ Isso se exige quando a cirurgia é pré-programada. No caso de procedimento de emergência, é evidente que as cautelas tomadas serão menores, em face da rapidez com que deve ser feita a cirurgia.

${ }^{651}$ TJRJ. 5a Câmara Cível. Ap. 0009415-09.1997.8.19.0066 (2006.001.21884). Rel. Des. Antônio Saldanha Palheiro. j. 30.06.09. v.u.

${ }^{652}$ CASTRO, João Monteiro de. Responsabilidade civil do médico, p. 159.
} 
No que tange a esse profissional, verificam-se dois posicionamentos: o primeiro defende que o chefe da equipe responde por todos os profissionais que a integram, incluindo o médico anestesista; o segundo sustenta que o anestesista tem atuação autônoma, sendo possível que os danos por ele provocados sejam individualizados em relação àqueles causados pelo restante da equipe. Na primeira vertente, encontram-se João Monteiro de Castro ${ }^{653}$ e Ruy Rosado de Aguiar Jr. ${ }^{654}$; na segunda, verificam-se Miguel Kfouri Neto ${ }^{655}$ e Sérgio Cavalieri Filho, este último entendendo que o médico somente responde pelo dano causado pelo anestesista se esse lhe prestar serviço diretamente, podendo ser considerado seu preposto ${ }^{656}$. No mesmo diapasão, assegurando a atividade independente do anestesista, Carlos Roberto Gonçalves, o qual admite, porém, que, em algumas hipóteses, pode haver responsabilidade solidária entre o anestesista e o cirurgião $^{657}$.

A jurisprudência se inclina a responsabilizar solidariamente o chefe da equipe pelo dano a que o anestesista der causa quando este tiver sido escolhido por ele ${ }^{658}$ (culpa in eligendo), entendimento esse que se considera acertado. Em verdade, o paciente dificilmente consulta diretamente o anestesista, mas sim o médico chefe da equipe, que contrata alguém de sua confiança; sendo assim, há que se responsabilizar por sua atuação, mesmo que o dano provocado pelo anestesista possa ser individualizado. Saliente-se, ademais, que, em regra, é o próprio cirurgião que estabelece para o cliente os honorários devidos ao anestesista e aos demais membros da equipe. Nada impede, porém, que o chefe da equipe mova ação regressiva contra o anestesista.

\subsection{A responsabilidade médica pelos aparelhos e equipamentos utilizados}

Os médicos e outros profissionais da área da saúde se valem, no desempenho profissional, dos mais variados instrumentos ou aparatos, o que justifica a breve análise da matéria.

\footnotetext{
${ }^{653}$ CASTRO, João Monteiro de. Responsabilidade civil do médico, p. 160.

${ }^{654}$ AGUIAR JR., Ruy Rosado. Responsabilidade civil do médico, p. 43.

655 KFOURI NETO, Miguel. Culpa médica e ônus da prova - presunções, perda de uma chance, cargas probatórias dinâmicas, inversão do ônus probatório e consentimento informado - responsabilidade civil em pediatria e responsabilidade civil em gineco-obstetrícia, p. 159: “A regra é clara: trata-se de profissionais com autonomia científica e técnica, com responsabilidades independentes. Eventualmente, o cirurgião-chefe poderá ser responsabilizado por culpa in vigilando, jamais pela aceitação do anestesista, profissional qualificado e preparado para o seu mister".

${ }^{656}$ CAVALIERI FILHO, Sérgio. Programa de responsabilidade civil, p. 375.

${ }^{657}$ GONÇALVES, Carlos Roberto. Responsabilidade civil, p. 365.

658 STJ. 4. T. REsp 605435/RJ. Rel. Min. João Otávio de Noronha. j. 22.09.09. v.m; STJ. 3. T. REsp 53104/RJ. Rel. Min. Waldemar Zveiter. j. 04.03.97. v.u.
} 
Félix A. Trigo Represas e Marcelo J. López Mesa assinalam que há um dever implícito de segurança ou garantia a cargo de quem utiliza um objeto para o cumprimento de obrigação. Haveria, portanto, uma obrigação de resultado pelas coisas que o profissional possa utilizar no desempenho da profissão, consistente em assegurar que o efeito preciso do emprego delas não trará prejuízos ao paciente. Em decorrência dessa consideração, afirmam os autores que, havendo danos da utilização de instrumentos, a mera infração do dever de segurança permite presumir a responsabilidade do profissional ${ }^{659}$.

A despeito desse entendimento, devem ser feitas algumas distinções.

Quando os aparelhos e equipamentos médicos são utilizados no âmbito hospitalar, o hospital responde objetivamente pelos danos que estes possam vir a provocar; se, no entanto, são utilizados pelos médicos atuando em seus próprios consultórios, estes respondem pela utilização inadequada. O problema surge, porém, quando o próprio equipamento falha e gera danos ao paciente ${ }^{660}$.

Há que se entender, nesse caso, que o médico é fornecedor dos serviços da máquina defeituosa, de modo a se configurar uma obrigação de resultado pelos equipamentos utilizados? A par do entendimento de que defeitos do material ou equipamento são suficientes para atribuir responsabilidade ao profissional, independentemente da prova de culpa $^{661}$, sustenta-se que a responsabilidade do médico continua sendo subjetiva, mesmo porque ele não tem o conhecimento técnico para avaliar se o aparelho está funcionando corretamente antes de sua utilização prolongada ${ }^{662}$. Se houve um teste prévio, e este se

${ }^{659}$ REPRESAS, Félix A. Trigo; MESA, Marcelo J. López. Tratado de la responsabilidad civil, t. II, p. 399.

${ }^{660}$ AGUIAR JR., Ruy Rosado. Responsabilidade civil do médico, p. 44.

${ }^{661}$ CASTRO, João Monteiro de. Responsabilidade civil do médico, p. 180.

${ }^{662}$ TJRJ. 4 ${ }^{\mathrm{a}}$ Câmara Cível. Ap. 0012372-86.2005.8.19.0038. Rel. Des. Sidney Hartung. j. 13.04.10. v.u.: “APELAÇÃO CÍVEL - RESPONSABILIDADE CIVIL - ERRO MÉDICO - AUSÊNCIA DE PROVAS OBRIGAÇÃO DE MEIO E NÃO DE RESULTADO - Cirurgia realizada no estabelecimento hospitalar ( $2^{\underline{0}}$ réu), por médica ( $1^{\mathrm{a}}$ ré) em cirurgia cesárea - Durante a cirurgia o instrumento de cauterização denominado "bisturi elétrico", utilizado para a hemostasia (interrupção do sangramento) apresentou transtornos operacionais, permanecendo ligado sobre os membros inferiores da autora, ocasionando-lhe queimaduras Pretensão de reparação por danos materiais, morais e estéticos - Sentença de procedência parcial do pedido, condenando o segundo réu a pagar a autora $\mathrm{R} \$ 10.000,00$ pelo dano estético, bem como indenização por danos morais, estéticos e honorários advocatícios fixados em $20 \%$ do valor da condenação Responsabilidade pessoal do médico é subjetiva. Não há prova nos autos de que a médica Ré tenha agido de forma culposa - Não configuração de negligência e omissão da apelada (Médica) na prestação dos serviços médicos - Improcedência do pedido em relação da $1^{1}$ ré que se mantém. Evidenciado nexo de causalidade e a lesão, pressupostos para a responsabilidade civil da Associação da Caridade Hospital Iguaçu, tendo em vista uma deficiência no serviço prestado pelo $2^{\underline{0}}$ réu, em face de falha e consequente omissão do $2^{\circ}$ suplicado que não verificou a existência de defeito no aparelho utilizado no ato cirúrgico "bisturi elétrico" - Dano moral e estético comprovados e devidamente fixados - Manutenção do quantum arbitrado em R \$10.000,00 (dez mil reais) pelo dano estético e $\mathrm{R} \$ 23.950,00$ (vinte e três mil, novecentos e cinquenta reais), a título de danos morais - Honorários fixados em consonância com a norma processual vigente - Manutenção da sentença Aplicabilidade do disposto no art. 557, caput, do CPC - Não seguimento do recurso”. 
mostrava funcionando de maneira adequada, não deve haver responsabilização do profissional $^{663}$. Se, contudo, for possível provar que o profissional estava a par dos defeitos do equipamento, e o utilizou mesmo assim, deverá ser responsabilizado pelos danos provocados pelo fato da coisa. Da mesma maneira, em caso de instrumento muito perigoso, poderá haver responsabilização pela negligência na conduta apta a minimizar os riscos ${ }^{664}$.

\subsection{Do ônus da prova}

A própria imprevisibilidade das reações do organismo humano torna difícil a comprovação da atuação culposa do profissional, o que fez que a doutrina, mundialmente, procurasse encontrar estratégias que facilitassem o ônus probatório da vítima ${ }^{665}$. Estudarse-á algumas delas a seguir.

\subsubsection{A inversão do ônus da prova}

Como reiteradamente exposto neste estudo, a obrigação de prestação de serviços médicos é, em regra, de meio, o que significa que o ônus da prova acerca da culpabilidade do profissional é do paciente. O ônus probatório pode ser definido como o encargo de efetivar a prova dos fatos alegados.

Aplica-se, então, o disposto no art. 333 do $\mathrm{CPC}^{666}$ : à vítima demandante caberá o dever de alegar e provar a existência dos fatos que persuadam o julgador das razões que militam a favor de sua pretensão. No que alude ao médico, a ele será incumbida a demonstração da inexistência desses fatos ou a verificação de fatos impeditivos, modificativos ou extintivos da pretensão formulada pelo autor.

Ocorre que, conforme já esclarecido, o Código de Defesa do Consumidor é aplicável aos contratos da seara médica, motivo pelo qual se admite a inversão do ônus da prova, se verificados os requisitos ínsitos no art. 6, inc. VIII ${ }^{667}$. Está-se diante de

${ }_{663}^{663}$ RIZZARDO, Arnaldo. Responsabilidade civil, p. 335.

${ }^{664}$ REPRESAS, Félix A. Trigo; MESA, Marcelo J. López. Tratado de la responsabilidad civil, t. II, p. 404405.

${ }^{665}$ NUNES, Manuel Rosário. O ónus da prova nas acções de responsabilidade civil por actos médicos. 2. ed. Coimbra: Almedina, 2007. p. 26.

${ }^{666} \mathrm{O}$ artigo em comento possui a seguinte redação: "Art. 333. O ônus da prova incumbe:

I - ao autor, quanto ao fato constitutivo do seu direito;

II - ao réu, quanto à existência de fato impeditivo, modificativo ou extintivo do direito do autor".

${ }^{667}$ Miguel Kfouri Neto esposa entendimento contrário, sustentando que a inversão do ônus da prova nesse caso implicaria a objetivação da responsabilidade (Culpa médica e ônus da prova - presunções, perda de 
vulnerabilidade técnica ${ }^{668}$, já que o paciente lesado terá grande dificuldade de provar o nexo de causalidade em razão da falta de documentação que em regra fica em poder do médico, a natureza confidencial da relação, o que faz que não existam testemunhas, bem como a complexidade técnica dos procedimentos médicos.

\subsubsection{Teoria da carga dinâmica do ônus da prova}

As regras que determinam o ônus da prova são, de acordo com o disposto no CPC, imutáveis; no entanto, foi desenvolvida a teoria da carga dinâmica do ônus da prova para que, em determinadas situações, o magistrado possa alterá-las em alguns aspectos ${ }^{669}$.

De acordo com essa teoria, o encargo probatório cabe àquele que, no caso concreto, pelas circunstâncias, encontre-se mais apto a fazê-lo ${ }^{670}$. As partes devem colaborar e agir de boa-fé para trazer ao juiz o maior número de informações para a solução da causa. Para que as questões sejam definitivamente esclarecidas, pode ser determinado, inclusive, que ambas as partes façam prova do mesmo fato. A teoria somente pode ser aplicada quando a distribuição normal se mostrar inadequada ao caso concreto. É medida excepcional.

Em regra, o médico teria uma incumbência maior na produção da prova ${ }^{671}$, já que o paciente, em rigor, somente terá condições de provar que não lhe foram dispensados todos os cuidados possíveis ${ }^{672}$.

Seria uma alternativa menos radical à inversão completa do ônus da prova ${ }^{673}$, devendo o magistrado estabelecer quais são, especificamente, as matérias a serem provadas pelas partes.

\subsubsection{A perda de uma chance}

A teoria da perda de uma chance foi estudada no Capítulo 2. Nesta oportunidade, convém fazer particularizações no que tange à atividade médica.

\footnotetext{
uma chance, cargas probatórias dinâmicas, inversão do ônus probatório e consentimento informado responsabilidade civil em pediatria e responsabilidade civil em gineco-obstetrícia, p. 151). Diverge-se desse entendimento, uma vez que a inversão do ônus da prova continua mantendo a discussão da culpa, que deverá ser afastada pelo médico.

${ }^{668}$ CAVALIERI FILHO, Sérgio. Programa de responsabilidade civil, p. 376.

${ }^{669}$ KFOURI NETO, Miguel. A culpa médica e o ônus da prova, p. 137.

${ }^{670}$ SANCHEZ, María Del Carmen García. Responsabilidad del cirujano estético. In: GHERSI, Carlos Alberto (Director). Responsabilidad profesional, v. 5, p. 49.

${ }^{671}$ REPRESAS, Félix A. Trigo; MESA, Marcelo J. López. Tratado de la responsabilidad civil, t. II, p. 383.

${ }^{672}$ AGUIAR JR., Ruy Rosado. Responsabilidade civil do médico, p. 39.

${ }^{673}$ KFOURI NETO, Miguel, op. cit., p. 145.
} 
Como decorrência da omissão de qualquer dos deveres do médico, pode o paciente perder a possibilidade de se curar de determinada enfermidade, ou obter resultado favorável no tratamento, o que ensejará a indenização por perda da chance. Em situações como essa, a culpa do médico encontra-se em não ter dado todas as oportunidades ao doente $^{674}$.

É de se observar que a perda de uma chance de cura ou sobrevivência - perte d'une chance de guérison ou de survie - tem o condão de conferir determinada conotação de resultado à obrigação do médico, com escopo de facilitar a comprovação do nexo causal pela vítima, conforme exposto anteriormente. De fato, na prestação de serviços médicos é muito difícil determinar a causa mortis específica do paciente, problema que, se não solucionado por mecanismos de ordem jurídica, raramente levará à condenação do profissional $^{675}$.

Já se salientou que a perda de uma chance pode encontrar dois fundamentos: ou a utilização menos ortodoxa do nexo de causalidade, ou o fenômeno de ampliação dos danos reparáveis ${ }^{676}$. Esses dois fundamentos deram origem a três correntes doutrinárias: a primeira defende a utilização da causalidade alternativa ou parcial em qualquer caso; a segunda sustenta que a causalidade alternativa seja utilizada somente para a responsabilidade médica, enquanto, para os demais casos, entenda-se a perda da chance como um dano autônomo ${ }^{677}$; a terceira advoga que a perda da chance constituirá sempre uma espécie autônoma de dano, não sendo necessário flexibilizar o nexo de causalidade. Quando se considera a necessidade de conceder outra concepção ao nexo causal na responsabilidade médica, está se levando em consideração justamente a dificuldade de estabelecer a responsabilidade do profissional, motivo pelo qual se passaria a indenizar de acordo com a probabilidade de a atuação do médico ter gerado dano ao paciente ${ }^{678}$. Ao contrário, na perda de uma chance clássica, o ato ilícito encontra nexo de causalidade certo com a interrupção de um processo do qual não se sabe se adviriam resultados positivos ou negativos. Está-se diante, assim, da apreciação do prejuízo. A perda da chance de cura ou de sobrevivência não pode ser enxergada da mesma perspectiva, já que, em caso de morte ou invalidez do paciente, o processo já teve a sua conclusão, que se sabe que foi negativa e se conhece o prejuízo dele resultante. O que se há de questionar é a participação do médico

\footnotetext{
${ }^{674}$ KFOURI NETO, Miguel. A culpa médica e o ônus da prova, p. 64.

${ }^{675}$ SAVI, Sérgio. Responsabilidade civil por perda de uma chance, p. 24.

${ }^{676}$ SILVA, Rafael Peteffi da. Responsabilidade civil pela perda de uma chance, p.7.

${ }^{677}$ A perda da chance, quando considerada dano autônomo, é chamada de perda da chance clássica.

${ }^{678}$ SILVA, Rafael Peteffi da, op. cit., p. 49.
} 
no evento danoso: houve ato ilícito, ou a doença simplesmente seguiu seu curso natural em razão de os tratamentos realizados não terem surtido efeito ${ }^{679}$ ?

A esse propósito, verifiquem-se, v.g., as predisposições patológicas da vítima, ou seja, aquelas condições que lhe são particulares e indicam uma potencialidade latente para determinada enfermidade. Em alguns casos, é possível diferenciar a atuação do médico de tais predisposições; em outros, contudo, torna-se tarefa muito difícil.

Segundo Miguel Kfouri Neto, a perda de chance de cura constitui uma abstração intelectual destinada a suavizar as dificuldades da prova de certeza, de modo que o paciente possa ser indenizado quando o médico não atuar de maneira correta ${ }^{680}$. Essa avaliação, entretanto, é de extrema complexidade, em razão dos riscos que envolvem a atividade e que abrangem não somente a técnica e o conhecimento científico do médico, mas também os decorrentes das características pessoais do doente e outros fatores imprevisíveis $^{681}$.

É justamente em razão dessa particularidade que a aplicação da teoria da perda da chance no campo da responsabilidade médica constitui-se em alvo de muitas críticas ${ }^{682}$. A generalização da aplicação dessa teoria, de fato, mudaria o entendimento que se tem acerca de muitos assuntos, em especial o de erro de diagnóstico, que, quando não grosseiro, é usualmente considerado não culposo. Isso, contudo, não invalida a utilização da perda de uma chance nesse nível.

A falta de exames pré-operatórios, por sua vez, demonstra negligência na conduta do médico, razão pela qual, se essa ausência implicar erro de diagnóstico, este ensejará indenização. A propósito desse assunto, Miguel Kfouri Neto relata que a jurisprudência francesa condena o médico a reparar parcialmente o prejuízo, mesmo se o nexo de causalidade entre a omissão e o dano não puder ser identificado com absoluta certeza, sob

\footnotetext{
${ }^{679}$ SILVA, Rafael Peteffi da. Responsabilidade civil pela perda de uma chance, p. 87/238: "a aplicação da categoria de perda de uma chance na qual o processo aleatório foi até o final não pode prescindir da noção de causalidade parcial e, portanto, constitui uma exceção ao modelo atual de responsabilidade civil existente no Brasil".

${ }^{680}$ KFOURI NETO, Miguel. Culpa médica e ônus da prova - presunções, perda de uma chance, cargas probatórias dinâmicas, inversão do ônus probatório e consentimento informado - responsabilidade civil em pediatria e responsabilidade civil em gineco-obstetrícia, p. 96.

${ }^{681}$ Ibidem, p. 102-103.

${ }^{682}$ NORONHA, Fernando. Direito das obrigações: fundamentos do direito das obrigações - introdução à responsabilidade civil, p. 678.
} 
o fundamento de que, ao não realizar esses exames, causou ao paciente perda de uma chance de sobreviver $^{683}$.

Acrescente-se, ainda, que a falta de cuidados médicos e qualquer outra falha de diligência podem ocasionar o surgimento da perda de uma chance, que somente irá variar no que concerne à sua indenização ${ }^{684}$.

No tocante a esse assunto, Miguel Kfouri Neto assinala:

“[...] o reconhecimento da 'chance perdida' há que se apoiar em dados fáticos e científicos claramente provados, indicativos de que, caso a enfermidade tivesse sido diagnosticada com antecedência pelos claros sintomas que o paciente apresentava, desconsiderados pelo médico - o percentual de probabilidade de cura, indicado pela ciência médica, aumentaria. $\mathrm{O}$ contrário, todavia, conduziu à perda dessa chance" ${ }^{, 685}$.

Conforme mencionado neste estudo, Fernando Noronha identifica duas espécies de perda da chance: a de obter uma vantagem futura e a de evitar um prejuízo efetivamente ocorrido. Enquanto na primeira espécie determinado fato interrompeu um processo em curso e o possível dano resulta dessa interrupção, na segunda, o dano surge exatamente porque o processo em curso não foi interrompido, quando poderia tê-lo sido. Se, portanto, o processo tivesse sido interrompido, haveria uma possibilidade do prejuízo não ocorrer, mas não se sabe, no presente momento, se ele não teria ocorrido de qualquer maneira ${ }^{686}$. $\mathrm{O}$ primeiro caso é o da perda da chance clássica, enquanto a segunda hipótese, de "evitar um prejuízo ocorrido", é a que se verifica, entre outros casos, na seara médica.

\footnotetext{
${ }^{683}$ KFOURI NETO, Miguel. Culpa médica e ônus da prova - presunções, perda de uma chance, cargas probatórias dinâmicas, inversão do ônus probatório e consentimento informado - responsabilidade civil em pediatria e responsabilidade civil em gineco-obstetrícia, p. 107.

${ }^{684}$ Acerca da perda da chance na responsabilidade do médico, vide a Apelação Cível 137002-3 - Jacarezinho - Juiz Noeval de Quadros - Sétima Câmara Cível do Tribunal de Alçada do Paraná - j. em 18.09.1990, cuja ementa tem a seguinte redação: "Responsabilidade Civil - Erro médico - Anestesia - Ausência de exames pré-anestésicos e do medicamento eficaz contra a crise de hipertermia maligna - Simultaneidade de atendimento a mais de um paciente - Teoria da perda de uma chance - Solidariedade passiva do hospital Recurso provido, por maioria. [...] 3. Ainda que não se pudesse afirmar com absoluta certeza que, de outra forma, a paciente se salvaria, indeniza-se, ainda que de forma minimizada, a perda de chance, por não terem esgotados todos os meios possíveis para o tratamento da doença e que estavam ao alcance dos réus".

${ }^{685}$ KFOURI NETO, Miguel, op. cit., p. 127.

${ }^{686}$ NORONHA, Fernando. Direito das obrigações: fundamentos do direito das obrigações - introdução à responsabilidade civil, p. 677.
} 
A perda da oportunidade de cura é exemplo característico dessa espécie de perda de chance. Fernando Noronha ${ }^{687}$ menciona como exemplo o caso do paciente que está inválido ou faleceu em decorrência do erro de diagnóstico ou tratamento do médico. A despeito do erro, a pessoa poderia ter se tornado inválida ou morrido da mesma forma, no entanto, a conduta do médico fez que as chances de ocorrência dessas situações aumentassem.

Frise-se, assim, que a perda de uma chance na responsabilidade médica atinge o nexo de causalidade, ao passo que nas demais áreas, pode se referir tão somente à extensão do dano indenizável ${ }^{688}$.

No que tange à quantificação dos danos, há que se analisar o estado anterior do paciente, o dano decorrente do ato omissivo que ocasionou a perda da oportunidade e, então, estabelecer a proporcionalidade entre a atuação do médico e o dano em si mesmo considerado. Trata-se de tarefa bastante árdua. Mesmo que se consiga estabelecer que o médico não esgotou todos os meios possíveis para o tratamento da doença e que estes estavam ao seu alcance, é muito difícil estabelecer o quantum indenizatório por meio de critérios objetivos, de modo que, em caso de perícia inconclusiva, a indenização deverá ser concedida em forma de danos morais, a serem arbitrados pelo magistrado.

\subsubsection{Teoria da res ipsa loquitur}

A expressão res ipsa loquitur denota a assertiva de que a coisa fala por si mesma ${ }^{689}$. Essa teoria é de origem norte-americana, tendo origem no caso "Byrne vs. Boadle", de $1863^{690}$. A culpa é procedente das pessoas que se encontrarem em uma situação que lhes permita controlar o processo causal do qual o prejuízo é derivado. A teoria poderá ser

\footnotetext{
${ }^{687}$ NORONHA, Fernando. Direito das obrigações: fundamentos do direito das obrigações - introdução à responsabilidade civil.

${ }^{688}$ KFOURI NETO, Miguel. Culpa médica e ônus da prova - presunções, perda de uma chance, cargas probatórias dinâmicas, inversão do ônus probatório e consentimento informado - responsabilidade civil em pediatria e responsabilidade civil em gineco-obstetrícia, p. 112. No mesmo sentido, João Monteiro de Castro (Responsabilidade civil do médico, p. 198). Rute Teixeira Pedro, no entanto, esposa pensamento contrário, entendendo que não há necessidade de alteração do nexo causal, mas sim a consideração de outra espécie de dano, diferente, por meio do qual podem se constatar todos os pressupostos da responsabilidade civil, incluindo o nexo de causalidade (A responsabilidade civil do médico - reflexões sobre a noção da perda de chance e a tutela do doente lesado. Coimbra: Coimbra, 2008. p. 282). No mesmo sentido, Manuel Rosário Nunes ( $O$ ónus da prova nas acções de responsabilidade civil por actos médicos, p. 42).

${ }^{689}$ REPRESAS, Félix A. Trigo. MESA, Marcelo J. López. Tratado de la responsabilidad civil, t. II, p. 384.

${ }^{690}$ KFOURI NETO, Miguel, op. cit., p. 133.
} 
utilizada na seara médica sempre que houver evidência de que a conduta do profissional da saúde se apresenta de tal modo que será possível inferir ou presumir prontamente a culpa.

Aplica-se a teoria quando verificados quatro pressupostos:

- não há prova conclusiva sobre como e por que ocorreu o dano;

- sabe-se, porém, que não teria acontecido o evento sem a atuação culposa de um dos envolvidos;

- o médico estava atendendo ao paciente pessoalmente ou por meio de assistente pessoal, na condição de preposto ${ }^{691}$;

- a vítima não pode ter contribuído, de maneira alguma, para o dano de que foi acometida $^{692}$.

\subsubsection{Teoria da faute virtuelle}

Quando aplicada a teoria da faute virtuelle, desenvolvida pelos tribunais franceses, o magistrado, diante da constatação de um resultado anormalmente danoso em comparação com o tratamento ministrado, considera não ser possível que uma falta não tenha sido cometida; por consequência, o médico é condenado a indenizar o dano, mesmo sem o firme estabelecimento do nexo causal ${ }^{693}$. A teoria é invocada, portanto, quando o resultado provocado pela intervenção médica é danoso e incompatível com as consequências de uma terapêutica normal ${ }^{694}$.

Na verdade, observa-se que há uma inversão do ônus da prova, mas não somente em relação à culpa, mas também no que diz respeito ao nexo causal.

A teoria pode parecer extremamente rígida para emprego na atuação médica, no entanto, deve-se levar em consideração que, na França, o entendimento atual da matéria é

\footnotetext{
${ }^{691}$ KFOURI NETO, Miguel. Culpa médica e ônus da prova - presunções, perda de uma chance, cargas probatórias dinâmicas, inversão do ônus probatório e consentimento informado - responsabilidade civil em pediatria e responsabilidade civil em gineco-obstetrícia, p. 133.

${ }^{692}$ NUNES, Manuel Rosário. O ónus da prova nas acções de responsabilidade civil por actos médicos, p. 39. ${ }^{693}$ KFOURI NETO, Miguel, op. cit., p. 127: "O juiz presume a existência de culpa quando, pelas circunstâncias em que o dano foi produzido, este não pode ser explicado pelas regras de experiência comum, a não ser que se admita a existência de falta médica. Isto, sem analisar a conduta do facultativo, sem que a culpa resulte certa das provas produzidas".

${ }^{694}$ NUNES, Manuel Rosário, op. cit., p. 43.
} 
que a atividade médica é de risco ${ }^{695}$, e que a ela deve ser aplicada a responsabilidade objetiva $^{696}$. Além do movimento para objetivação da responsabilidade, há também outro para a criação de um regime de indenização do acidente médico independentemente da responsabilidade civil do médico ou do hospital. Nessa segunda tendência, propugna-se pela criação de um fundo de garantia, que seria custeado pelos médicos e pelos beneficiários de seus serviços ${ }^{697}$.

Entende-se que a faute virtuelle é de difícil aplicação no Direito brasileiro e se adapta melhor ao Ordenamento Jurídico francês.

\subsection{A responsabilidade dos hospitais e outros estabelecimentos semelhantes}

Os hospitais e clínicas médicas particulares constituem universalidade de fato, que, segundo Ruy Rosado de Aguiar Jr., é “formada por um conjunto de instalações, aparelhos, e instrumentos médicos e cirúrgicos destinados ao tratamento da saúde, vinculada a uma pessoa jurídica, sua mantenedora, mas que não realiza ato médico"698.

No tocante aos referidos estabelecimentos, é necessário observar, conforme mencionado no Capítulo anterior, três espécies de responsabilidade ${ }^{699}$ :

- A decorrente de atos dos médicos que integram o corpo clínico, com ou sem vínculo empregatício, quando então a falha de prestação de serviço do hospital somente será constatada após a configuração de culpa do profissional ${ }^{700}$. Em um hospital, os médicos que nele prestam serviço podem ocupar posições diferentes: há os médicos diretores, incumbidos de atividades administrativas; os médicos chefes de equipe, que coordenam diversos outros em sua área de atuação; os médicos membros do corpo clínico, que trabalham com regularidade no hospital; os médicos plantonistas, que trabalham ocasionalmente, em regime de plantão de 12 ou 24 horas; e, por fim, os médicos residentes, que compõem as equipes médicas, e ainda estão em fase de aprendizagem. Por todos eles. o hospital deverá responder

\footnotetext{
${ }^{695}$ SARGO, Pierre. Le point de vue d'un magistrat sur l'indemnisation des accidents médicaux. In: VINEY, Geneviève (Coord.). L'indemnisation des accidents médicaux. Paris: LGDJ, 1997. p. 85.

${ }^{696}$ SAURY, Robert. Le point de vue du médecin sur l' indemnisation des accidents médicaux. In: VINEY, Geneviève (Coord.), op. cit., p. 95.

${ }^{697}$ VINEY, Geneviève. Rapport de synthèse. In: (Coord.), op. cit., p. 112.

${ }^{698}$ AGUIAR JR., Ruy Rosado. A responsabilidade civil dos médicos, p.41.

${ }^{699}$ KFOURI NETO, Miguel. Responsabilidade civil dos hospitais, p. 36-38.

${ }^{700}$ CASTRO, João Monteiro de. Responsabilidade civil do médico, p. 78; GONÇALVES, Carlos Roberto. Responsabilidade civil, p. 371.
} 
objetivamente, desde que comprovada a culpa do profissional, em aplicação à responsabilidade em duplo estágio prevista nos arts. 932 e 933 do CC. Pode, ainda, não haver dependência do médico com o hospital, quando o profissional utiliza o estabelecimento apenas para locação do espaço e de equipamentos, hipótese em que a responsabilidade será exclusiva do médico e não do estabelecimento ${ }^{701}$.

- A advinda dos atos de enfermeiros e outros empregados, que conduzem atividade acessória à dos médicos - os chamados atos paramédicos, pelos quais o hospital responde objetivamente ${ }^{702}$.

- A responsabilidade direta do hospital, que se origina de um contrato semelhante ao de hospedagem, relacionado à administração do estabelecimento ${ }^{703}$.

No que tange a essa última modalidade, diz-se que o contrato é semelhante ao de hospedagem porque o hospital se obriga a fornecer acomodação e alimentação ao internado, além dos serviços de natureza médica. Dessa constatação decorre o dever de vigilância do hospital que é agravado, uma vez que a este cabe zelar pela incolumidade física dos pacientes, respondendo sempre que eles venham a sofrer algum dano causado por empregados e por terceiros, ou causem prejuízos uns aos outros.

Do mesmo modo, como ressaltado no Capítulo precedente, há de ser aplicado o Código de Defesa do Consumidor aos contratos por ele firmados, já que os hospitais e estabelecimentos semelhantes são fornecedores de serviços e, de acordo com o art. 14 do Diploma legal em comento, devem responder objetivamente pelos danos gerados às pessoas que neles se encontram em tratamento ${ }^{704}$. Mesmo quando os danos são provocados em terceiros, os quais não firmaram contrato com a prestadora de serviços de cuidados médicos, estes são, igualmente, considerados consumidores por equiparação, por força do art. 17 do mesmo Diploma legal ${ }^{705}$, razão pela qual a responsabilidade objetiva não poderá ser descaracterizada.

Conclui-se, assim, que o hospital responde pelo fato do serviço, isto é, sua responsabilidade advém do serviço defeituoso. Esta, contudo, restringe-se ao período de

\footnotetext{
${ }^{701}$ KFOURI NETO, Miguel. Responsabilidade civil dos hospitais, p. 41.

702 Ibidem, p. 37.

${ }^{703}$ AGUIAR JR., Ruy Rosado. Responsabilidade civil do médico, p. 41.

${ }^{704}$ CAVALIERI FILHO, Sérgio. Programa de responsabilidade civil, p. 380.

705 Para conferência, a norma citada é assim redigida: “Art. 17. Para os efeitos desta Seção, equiparam-se aos consumidores todas as vítimas do evento".
} 
internação e ao espaço físico do estabelecimento. Dentro dessas limitações, responde pelos danos causados por seus pacientes a terceiros, o que pode ocorrer, por exemplo, no caso de fuga ou suicídio de doentes mentais ${ }^{706}$. Com efeito, entende-se que a internação de incapazes em estabelecimentos de saúde desloca a responsabilidade de guarda dos pais e curadores para os hospitais e clínicas psiquiátricas; aliás, é justamente para garantir a segurança desses pacientes que se procede à internação, motivo pelo qual esses não podem se eximir do seu dever de guarda.

Verifica-se, em acréscimo, que a obrigação dessa espécie de estabelecimento é de resultado, isto é, para que se considere adimplida, a prestação de serviço deve ter sido concluída com perfeito êxito, motivo pelo qual a responsabilidade dos hospitais e estabelecimentos semelhantes somente pode ser ilidida em caso de excludentes de nexo de causalidade.

Também é de resultado a obrigação de manter o estabelecimento em condições propícias para o tratamento dos doentes, razão pela qual o hospital é objetivamente responsabilizado por danos oriundos de infecção médico-hospitalar ${ }^{707}$. Esse tipo de infecção é adquirido após a entrada do enfermo no estabelecimento de saúde e se manifesta durante a internação ou após a alta, sempre que puder ser relacionada com o período em que o paciente passou nas dependências do hospital, sendo submetido a procedimentos médicos. Ao hospital cabe zelar pela saúde de seus usuários, atuando de maneira preventiva e exercendo controle por meio de medidas de qualificação da assistência hospitalar, de vigilância sanitária, entre outras. Sendo assim, quando o paciente vem a contrair infecção hospital, configura-se falha na prestação do serviço, respondendo o hospital objetivamente por ato próprio ${ }^{708}$.

\footnotetext{
${ }^{706}$ Há decisões em sentido contrário, com as quais não se concorda. Em caráter exemplificativo, verifique-se: TJSP. 11ª Câmara de Direito Público. Ap. n. 990.10.336704-9. Rel. Francisco Vicente Rossi. j. 22.11.10. v.u.: "RESPONSABILIDADE CIVIL DA ADMINISTRAÇÃO - Doente esquizofrênico que se suicida em hospital - Alegação da dosagem insuficiente de medicamento e ausência de grades na janela - Provas que demonstram rompimento da barreira de alumínio da janela e nenhuma prova sobre os medicamentos, mas técnica médica empregada não se confunde com erro médico - Ausência de nexo causal - Recurso provido".

${ }^{707}$ Miguel Kfouri Neto adverte que, para que haja a responsabilização do hospital, devem ser comprovados: a) que o paciente não portava nenhum agente infeccioso ou apresentava baixa imunidade; b) a infecção não se classifica como endógena, gerada pelo próprio organismo; c) a infecção surgiu quando o paciente já se encontrava nas dependências do hospital; e d) a infecção foi causada por agente infeccioso tipicamente hospitalar (Responsabilidade civil dos hospitais, p. 221). Em que pese o entendimento do doutrinador, não poderá recair tal prova diabólica. Caberá ao hospital afastar o nexo de causalidade para eximir-se do dever de ressarcir.

${ }^{708}$ STJ. 4. T. REsp 629212/RJ. Rel. Min. Cesar Asfor Rocha. j. 15.05.07. v.u.
} 
O hospital responde também pelo fato das coisas, ou seja, pelos danos gerados em razão de aparelhos utilizados na prestação de serviço.

Os hospitais públicos, conforme assinalado no Capítulo anterior, também respondem objetivamente, mas com outro fundamento - o risco administrativo, o que não dispensa a caracterização da culpa do profissional quando o dano decorre de serviços prestados pelo médico, e não diretamente pelo hospital ${ }^{709}$.

O Sistema Único de Saúde (SUS) pode prestar serviços hospitalares por meio de seus próprios hospitais, ou entidades conveniadas, e de médicos credenciados. Há responsabilidade objetiva tanto pelos danos ocorridos nos estabelecimentos próprios quanto pelos estabelecimentos e profissionais credenciados ${ }^{710}$. Com efeito, os hospitais conveniados ao Sistema Único de Saúde (SUS) também prestam serviço público, o que justifica que respondam solidariamente com o Estado.

\subsection{Responsabilidade civil das operadoras de planos de saúde}

A precariedade do serviço médico público brasileiro fez que se proliferassem as empresas mantenedoras de plano de assistência à saúde, as quais são regidas pela Lei n. 9.656, de 3 de junho de 1998. Essas empresas comercializam planos privados de assistência à saúde, que consistem, segundo o inc. $\mathrm{I}^{711}$, do art. $1^{\underline{0}}$, da Lei em referência, na:

“[...] prestação continuada de serviços ou cobertura de custos assistenciais a preço pré ou pós estabelecido, por prazo indeterminado, com a finalidade de garantir, sem limite financeiro, a assistência à saúde, pela faculdade de acesso e atendimento por profissionais ou serviços de saúde, livremente escolhidos, integrantes ou não de rede credenciada, contratada ou referenciada, visando a assistência médica, hospitalar e odontológica, a ser paga integral ou parcialmente às expensas da operadora contratada, mediante reembolso ou pagamento direto ao prestador, por conta e ordem do consumidor".

\footnotetext{
${ }^{709}$ KFOURI NETO, Miguel. Responsabilidade civil dos hospitais, p. 123.

${ }^{710}$ Nesse caso, haverá responsabilização do Município e não da União, em virtude da descentralização das atribuições determinada pela Lei n. 8.080/1990: STJ. 2. T. REsp 1162669/PR. Rel. Min. Herman Benjamin. j. 06.04.10. v.u.

${ }^{711}$ Incluído pela Medida Provisória n. 2.177-44, de 2001.
} 
Da diversidade de planos de saúde pré-descritos, depreende-se que as operadoras podem atuar de diversas maneiras, o que gera efeitos sobre sua responsabilidade. Eles podem, simplesmente, reembolsar as despesas médicas efetuadas pelo segurado, não influindo na escolha dos médicos ou hospitais. Outros, ao contrário, dispõem de hospitais próprios ou credenciados, não cabendo aos pacientes a escolha de quem vai lhes prestar o serviço médico. Por fim, há ainda situações em que o paciente pode até exercitar sua escolha, mas o rol de opções é muito limitado ${ }^{712}$. Nestes últimos dois casos, há responsabilidade solidária entre as operadoras de planos de saúde e os hospitais e médicos credenciados $^{713}$. A jurisprudência caminha no mesmo sentido ${ }^{714}$.

Nessa esteira também se manifesta Sérgio Cavalieri Filho ao salientar que:

“[...] médicos e hospitais credenciados formam uma rede de serviços médicos hospitalares eficiente, atrativa e competitiva para atender à cativa clientela dos planos de saúde. Na verdade, há um pacto proveitoso para ambas as partes; médicos e hospitais aumentam a clientela e a empresa credenciadora, além de tornar os seus serviços mais eficientes, suportará menor encargo financeiro pagando despesas de hospitalização e honorários médicos previamente estabelecidos numa tabela. Por sua vez, segurados ou contratados procuram os médicos e hospitais credenciados (ou referenciados) não só porque nada têm a pagar, mas também porque confiam na indicação, acreditando tratar-se de instituições e profissionais competentes, criteriosamente selecionados pela empresa seguradora ou operadora de serviço" ${ }^{, 715}$.

\footnotetext{
${ }^{712}$ VASSILIEFF, Sílvia. A responsabilidade civil profissional do médico no Direito Civil e no Direito do Consumidor, p. 517.

713 GAGLIANO, Pablo Stolze; PAMPLONA FILHO, Rodolfo. Novo curso de Direito Civil responsabilidade civil, p. 223; AGUIAR JR., Ruy Rosado. Da responsabilidade civil do médico, p. 48.

${ }^{714}$ STJ, 3. T. AgRg no Ag 742453/RJ. Rel. Min. Vasco Della Giustina. j. 18.02.10. v.u; TJRJ. $10^{\mathrm{a}}$ Câmara Cível. Ap. 007394-96.2004.8.19.0001. Rel. Des. Pedro Saraiva Andrade Lemos. j. 03.08.10. v.u. Aplicando a responsabilidade solidária também no que diz respeito à cooperativa de médicos, igualmente considerada operadora de plano de assistência à saúde pelo inc. II, do art. $1^{\underline{0}}$, da Lei n. 9.656/1998, verifique-se: TJRJ. $5^{\text {a }}$ Câmara Cível. Rel. Paulo Gustavo Horta. j. 26.08.03. v.m.: "A cooperativa de médico, como prestadora de serviços, responde solidariamente pela qualidade do serviço prestado por profissional credenciado, pois o credenciamento importa na avaliação da capacidade dos médicos e na restrição da escolha pelo beneficiário".

${ }^{715}$ CAVALIERI FILHO, Sérgio. Programa de responsabilidade civil, p. 382-383.
} 
Esclareça-se, contudo, que se denota exagerada a responsabilização solidária da operadora de plano de saúde quando os hospitais que integram o convênio são bastante variados e permitem que o paciente faça a escolha que entender mais adequada, ou seja, opte pelo atendimento no estabelecimento de confiança de seu médico particular.

\subsection{Responsabilidade civil dos dentistas}

O respeito à dignidade humana exige que a saúde seja protegida em todos os seus aspectos, motivo pelo qual a medicina deve atender à totalidade deste ser indivisível que é o homem, levando em consideração não somente suas facetas morfológicas e funcionais, mas também seu bem-estar e estado psíquico. Isso denota que a odontologia não é uma ciência menor em relação à medicina.

Na verdade, a história da odontologia esteve, durante muito tempo, ligada à da medicina, tendo em vista que ambas possuem bases científico-biológicas comuns. As particularidades da odontologia acabaram, no entanto, por torná-la uma ciência autônoma. É, contudo, uma ciência jovem, já que nos primórdios da análise da matéria, acreditava-se que enfermidades bucais não provocavam mortes. Não obstante, o desenvolvimento do conhecimento médico demonstrou ser falsa tal assertiva, pois elas podem não somente comprometer seriamente a saúde do indivíduo como também levá-lo a óbito, como é o caso do câncer bucal ${ }^{716}$.

Na legislação brasileira, a responsabilidade civil dos dentistas, cuja profissão é regulamentada pela Lei n. 5.081, de 24 de agosto de 1966, era equiparada à do médico pelo art. 1.545 do CC de $1916^{717}$, o que não se manteve no art. 951 do $\mathrm{CC}$ hodierno. Isso, contudo, não afasta as coincidências evidentes que existem entre as obrigações de cada um desses profissionais.

A odontologia tem como objetivos principais a prevenção, a recuperação e a conservação da saúde bucal.

A prevenção é o conjunto de medidas que tendem a diminuir ou prevenir a enfermidade bucal. Os progressos da odontologia preventiva trouxeram ao profissional uma nova orientação que se agrega ao dever de assistência, o critério preventivo, que

\footnotetext{
${ }^{716}$ WEINGARTEN, Celia. Responsabilidad del odontólogo y del técnico en prótesis dentales. In: GHERSI, Carlos Alberto (Director). Responsabilidad profesional, v. 5, p. 53.

${ }^{717} \mathrm{O}$ artigo em comento possui a seguinte redação: "Os médicos, cirurgiões, farmacêuticos, parteiras e dentistas são obrigados a satisfazer o dano, sempre que da imprudência, negligência, ou imperícia, em atos profissionais, resultar morte, inabilitação de servir, ou ferimento".
} 
compreende a aplicação de medidas profiláticas adequadas. A prevenção não se trata, em específico, de uma atividade estritamente curativa, mas contribui para prevenir a enfermidade, adiantando-se a ela, ou, ao menos, retardando o avanço de certas lesões.

A recuperação implica a aplicação dos conhecimentos científicos destinados à cura das afecções ou enfermidades da boca pelo emprego de todas as medidas terapêuticas.

Por fim, a conservação da saúde bucal compreende todos os atos odontológicos que contribuam para o seu funcionamento adequado.

O dentista deve desenvolver sua atividade com diligência e idoneidade, observando as normas consagradas pela prática e de acordo com a evolução científico-tecnológica que ela experimente. Procura-se, com isso, a melhoria das condições de saúde, mas também o bem-estar físico, mental e social do paciente, isto é, elevar a qualidade de vida do indivíduo.

Ainda que muito semelhante à responsabilidade médica, a obrigação do dentista é vista pela maior parte da doutrina como de resultado ${ }^{718}$, já que nessa área a preocupação com a estética seria preponderante.

Essa afirmação, reiteradamente formulada, no entanto, denota ter pouca aplicação, em especial no Brasil, onde a população não tem condições financeiras de fazer qualquer tratamento nos dentes, que dirá de cunho estético. Na verdade, o que se observa é que o paciente procura o dentista quando já sente grande desconforto, e a enfermidade bucal está lhe gerando não somente dores de dente, mas também de ouvido, cefaleia, dificuldade para se alimentar, dormir, e até mesmo para realizar tarefas cotidianas. Em hipóteses semelhantes, a obrigação desse profissional deve ser considerada de meio ${ }^{719}$. Aliás, não somente a ausência de caráter puramente estético afasta a obrigação de resultado, como também a álea inerente ao ofício, muito semelhante à que permeia as obrigações do médico. Como visto no Capítulo anterior, é justamente a aleatoriedade inerente à obrigação

${ }^{718}$ CAVALIERI FILHO, Sérgio. Programa de responsabilidade civil, p. 335; GONÇALVES, Carlos Roberto. Responsabilidade civil, p. 375; AGUIAR DIAS, José de. Da responsabilidade civil, t. I, p. 308; VENOSA, Silvio de Salvo. Direito Civil - responsabilidade civil, p. 108; STOCO, Rui. Tratado de responsabilidade civil, p. 496. No mesmo sentido, TJRJ. 2ª Câmara Cível. Ap. 0073913-52.1996.8.19.0001. Rel. Des. Carlos Eduardo Passos. j. 06.10.10. v.u.

719 GAGLIANO, Pablo Stolze; PAMPLONA FILHO, Rodolfo. Novo curso de Direito Civil responsabilidade civil, p. 224; DINIZ, Maria Helena. Curso de Direito Civil brasileiro - responsabilidade civil, p. 312. Na mesma toada: STJ. 3. T. REsp. 122505/SP. Rel. Min. Carlos Alberto Menezes Direito. j. 04.06.98. v.u.; TJRJ. 17 ${ }^{\text {a }}$ Câmara Cível. Ap. 0005388-96.2005.8.19.0067. Rel. Des. Luisa Bottrel Souza. j. 10.11.10. v.u.; TJRJ. 14 ${ }^{\mathrm{a}}$ Câmara Cível. Ap. 0104569-11.2004.8.19.0001. Rel. Des. Cleber Ghelfenstein. j. 21.09.10. v.u. 
que faz que esta seja considerada de meio: o dentista poderá agir com toda a diligência possível, utilizando as técnicas mais modernas disponíveis, e ainda assim não atingir bons resultados porque as reações do organismo humano são imprevisíveis. Se o profissional não pode garantir o resultado, a obrigação somente pode ser de meio.

Em razão dessas considerações, essa espécie de obrigação prepondera na maior parte das especialidades odontológicas ${ }^{720}$ : na realização de implantes, na endodontia ${ }^{721}$, na ortodontia $^{722}$ e na periodontia ${ }^{723}$, entre outras. Como exemplos de obrigações de resultado, podem-se mencionar o procedimento de clareamento dental, a odontologia preventiva e a radiologia $^{724}$.

O próprio cirurgião-dentista toma a frente dos procedimentos anestésicos, motivo pelo qual somente pode dar início à cirurgia depois de ter feito a investigação necessária sobre a sensibilidade do paciente à medicação. Ademais, enquanto faz a intervenção, deve controlar os sinais vitais do paciente, tal qual se exige do anestesista atuando na área médica $^{725}$. Uma vez tomadas todas as precauções necessárias, não poderá ser responsabilizado pelas consequências imprevisíveis geradas pela anestesia.

Da mesma forma que se verifica com o médico, o erro de diagnóstico é escusável sempre que se originar do estado imperfeito da ciência.

Em síntese, o dentista somente pode ser responsabilizado quando comprovada a atuação culposa, o que pode se verificar, v.g., nas seguintes hipóteses:

- escolhe tratamento impróprio, manifestamente em desuso, ou então não o executa da maneira correta ${ }^{726}$;

- atua com desleixo e não obtém bons resultados em procedimentos quotidianos como tratamento de cáries e canais;

- emprega medicamentos perigosos, em evidente desproporção com o mal que acomete o paciente;

\footnotetext{
${ }^{720}$ TANAKA, Eduardo. Responsabilidade civil do cirurgião-dentista. Obrigação de meio ou de resultado? In: HIRONAKA, Giselda Maria Fernandes Novaes (Coord.). Direito e responsabilidade. Belo Horizonte: Del Rey, 2002. p. 283.

721 A endodontia destina-se ao tratamento de canal e controle das alterações da polpa e dos tecidos periradiculares.

${ }_{722}$ Esta especialidade atua sobre o aparelho mastigatório e visa à correção das estruturas dentofaciais.

${ }^{723}$ A periodontia refere-se ao estudo dos tecidos de suporte e circundantes dos dentes e seus substitutos.

${ }^{724}$ KFOURI NETO, Miguel. Responsabilidade civil do médico, p. 241.

${ }^{725}$ WEINGARTEN, Celia. Responsabilidad del odontólogo y del técnico en prótesis dentales, p. 65.

726 TJRJ. 7ํㅡㄹ Câmara Cível. Ap. 0001603-51.2006.8.19.0210. Rel. Des. Ricardo Couto. j. 11.08.10. v.u.
} 
- interpreta de maneira incorreta radiografias que não geram dúvidas ao profissional bem-instruído;

- atua com omissão, não tomando as cautelas e providências necessárias para o acompanhamento do tratamento;

- subestima a enfermidade do paciente, libera-o com rapidez de qualquer acompanhamento médico, e ele acaba por sofrer desnecessariamente enquanto o dentista não percebe o seu equívoco;

- atende aos pacientes em ambiente em desacordo com as normas de higiene, utilizando aparelho não esterilizado ${ }^{727}$.

Da mesma forma, não se afasta a responsabilidade do dentista pela má utilização de equipamentos necessários para o exercício de sua atividade, cabendo a ele a indenização do paciente sempre que os danos advirem dos aparelhos ${ }^{728}$. No que tange às próteses, responsabiliza-se pela verificação de sua conformidade em relação ao pedido efetuado, bem como por sua colocação. Se, entretanto, o produto apresenta um defeito oculto, que somente se revela depois de um tempo de uso, há de ser responsabilizado o fabricante ${ }^{729}$.

\subsection{Responsabilidade civil dos farmacêuticos}

A obrigação dos farmacêuticos não é semelhante àquelas dos médicos e dos dentistas, somente a elas se relaciona, ou melhor, as complementa. Em razão dessa dependência, apresentar-se-ão alguns comentários a respeito dela.

A obrigação principal do farmacêutico é o cumprimento das prescrições médicas, tendo responsabilidade por infração de normas profissionais, inobservância de regras de prudência, venda de substâncias controladas sem receita médica ${ }^{730}$, bem como pelo cumprimento inexato das prescrições médicas ${ }^{731}$, ou eventual troca de medicamentos entre

727 TANAKA, Eduardo. Responsabilidade civil do cirurgião-dentista. Obrigação de meio ou de resultado?, p. 245.

${ }_{728}$ Ibidem, p. 246. Também Miguel Kfouri Neto (Responsabilidade civil do médico, p. 242).

${ }^{729}$ WEINGARTEN, Celia. Responsabilidad del odontólogo y del técnico en prótesis dentales, p. 78.

${ }^{730}$ TJRJ. 8 ${ }^{\text {a }}$ Câmara Cível. Ap. 0009462-95.2004.8.19.0208. Rel. Des. Letícia Sardas. j. 27.02.07. v.u.

${ }^{731}$ TJRJ. 3 ${ }^{\text {a }}$ Câmara Cível. Ap. 0146177-91.2001.8.19.0001. Rel. Des. Ronaldo Rocha Passos. j. 14.03.06.

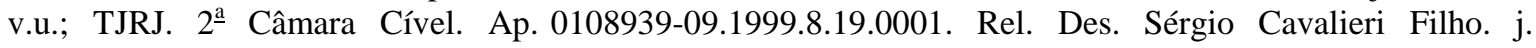
12.11.03. v.u. 
os clientes ${ }^{732}$; também não pode se substituir ao médico, sugerindo medicamentos ou $\operatorname{tratamentos}^{733}$.

A responsabilidade desse profissional é subjetiva ${ }^{734}$; no entanto, como a atividade farmacêutica em geral é realizada por meio de uma pessoa jurídica com fins mercantis, acaba sendo objetiva, por força da aplicação do art. 14 do CDC, tanto por ato próprio (da empresa) quanto pelo ato de seus prepostos e empregados. No que tange a esse último aspecto, saliente-se que esse entendimento já datava da época de vigência do Código Civil de 1916, que, em seu art. 1.546, dispõe: "O farmacêutico responde solidariamente pelos erros e enganos de seu preposto".

A obrigação do farmacêutico é, ademais, de resultado, motivo pelo qual somente é adimplida com o cumprimento exato das prescrições médicas.

Por fim, registre-se a possibilidade de responsabilização solidária do farmacêutico com o médico. Miguel Kfouri Neto relata que, na Bélgica, um farmacêutico, seguindo prescrições de um médico desatencioso, preparou medicação com $10 \mathrm{~g}$ de carbonato de bário, um veneno, ao contrário de sulfato de bário, que é substância inofensiva. $\mathrm{O}$ descuido ocasionou o óbito da paciente e levou à condenação do médico, em razão de negligência, e à do farmacêutico, tendo em vista que este deveria ter observado o equívoco cometido pelo médico, em particular porque a medicação era destinada ao uso interno ${ }^{735}$.

\subsection{Responsabilidade civil dos enfermeiros e demais profissionais com atuação conexa}

A atividade de enfermagem é regulamentada pela Lei n. $7.498 / 1986^{736}$, e pode ser exercida, em graus de responsabilidade diferentes, por quatro tipos de profissionais: o enfermeiro, o técnico de enfermagem, o auxiliar de enfermagem e a parteira. A atividade em referência compreende dois papéis distintos: por um lado, o assistencial, que abarca as

\footnotetext{
${ }^{732}$ DINIZ, Maria Helena. Curso de Direito Civil brasileiro - responsabilidade civil, p. 303-304. No mesmo sentido, José de Aguiar Dias (Da responsabilidade civil, t. I, p. 302).

${ }^{733}$ Há decisão afastando a responsabilidade do farmacêutico por indicação de medicamento, quando a vítima deveria saber, por indicações na caixa do remédio, que este poderia lhe fazer mal (TJRJ. $5^{\mathrm{a}}$ Câmara Cível. Ap. 0019150-20.2004.8.19.0002. Rel. Des. Cristina Tereza Gaulia. j. 25.05.10. v.u.). Trata-se de entendimento que deve ser tomado com cautela, tendo em vista que o farmacêutico deve se abster, em qualquer caso, de indicar medicamentos.

${ }_{734}$ STOCO, Rui. Tratado de responsabilidade civil, p. 522.

${ }^{735}$ KFOURI NETO, Miguel. Culpa médica e ônus da prova - presunções, perda de uma chance, cargas probatórias dinâmicas, inversão do ônus probatório e consentimento informado - responsabilidade civil em pediatria e responsabilidade civil em gineco-obstetrícia, p. 203.

${ }^{736}$ A lei em comento é regulamentada pelo Decreto n. 94.406/1987.
} 
funções de recuperação e reabilitação da saúde, assim como a prevenção de enfermidades; por outro, há o papel reservado exclusivamente para o profissional com título universitário, que é o da docência, pesquisa e assessoramento sobre temas de sua incumbência, bem como administração de serviços ${ }^{737}$.

Esses profissionais, em regra, são empregados ou prepostos de hospitais, de médicos, ou de sociedades ou clínicas médicas, motivo pelo qual sua atuação acaba implicando responsabilidade objetiva ${ }^{738}$; nada impede, porém, que atuem de forma autônoma, quando, então, sua responsabilidade será subjetiva.

De acordo com o art. 11 da Lei retromencionada, algumas atividades são privativas do enfermeiro, v.g., a direção do órgão de enfermagem integrante da estrutura básica da instituição de saúde, pública ou privada, e chefia de serviço e de unidade de enfermagem, e a consultoria na área de enfermagem. O técnico de enfermagem somente pode atuar sob a orientação de um enfermeiro, mediante a participação de uma equipe médica, realizando procedimentos básicos na internação de pacientes em instituições da saúde. Ao auxiliar de enfermagem cabe executar ações de tratamento simples; prestar cuidados de higiene e conforto ao paciente; realizar o controle e registro da pulsação, respiração, pressão arterial, peso, altura e temperatura; informar ao enfermeiro ou ao médico sobre as condições do paciente, entre outras atividades semelhantes ${ }^{739}$. No que tange à parteira, esta atua exclusivamente no auxílio à gestante no momento do parto, podendo atendê-la em sua residência se o parto for normal ${ }^{740}$.

O profissional da enfermagem pode ser responsabilizado quando atua de maneira omissiva, faltando com os deveres inerentes à sua profissão, em particular o dever de cuidado $^{741}$, ou imprudência ${ }^{742}$. De fato, o contato desse profissional com o paciente, na maior parte das vezes idoso ou debilitado, é diário, razão pela qual há de se ter especial

\footnotetext{
${ }^{737}$ HISE, Mónica. Responsabilidad del personal de enfermería. In: GHERSI, Carlos Alberto (Director). Responsabilidad profesional, v. 5, p. 163.

${ }_{738}^{73}$ TJRJ. 11 $1^{\mathrm{a}}$ Câmara Cível. Ap. 0060200-34.2001.8.19.0001. Rel. Des. Valéria Dacheux. j. 12.08.09. v.u.

${ }^{739}$ HISE, Mónica. Responsabilidad del personal de enfermería, p. 166.

${ }^{740}$ Art. 12 do Decreto n. 94.406/1987.

${ }^{741}$ DEODATO, Sérgio. Responsabilidade profissional em enfermagem: valoração da sociedade. Coimbra: Almedina, 2008. p. 37.

${ }^{742}$ Há responsabilização de enfermeiros, v.g., por queimadura na perna de paciente ocasionada na tentativa de realizar uma fenda no gesso (TJRJ. 12 ${ }^{\underline{a}}$ Câmara Cível. Ap. 0001703-90.1998.8.19.0014. Rel. Des. Helena Belc Klausner. j. 02.09.03. v.u.), bem como pela coleta de sangue tão imperita que gera a perda da mobilidade do dedo polegar do paciente (TJRJ. 9 ${ }^{a}$ Câmara Cível. Ap. 0086998-71.1997.8.19.0001. Rel. Des. Jorge Magalhães. j. 07.08.01. v.u.).
} 
cuidado com a maneira como lhes dispensa tratamento. Exige-se do enfermeiro e auxiliares extremo respeito à dignidade.

Com relação aos enfermeiros, estes devem ser responsabilizados pelas decisões tomadas e pelos atos que praticam ou delegam. Quando, v.g., observa que um medicamento está gerando consequências inusuais tem o poder de decisão de suspendê-lo até que se verifique que não há engano na prescrição médica ${ }^{743}$.

A recusa na prestação de cuidados lhes é, ademais, facultada quando:

- a terapia é manifestamente inútil ou gera risco de infecção;

- não há condições mínimas de prática segura do tratamento;

- entende que sua dignidade está sendo violada, ou por objeção de consciência;

- o paciente deseja que lhe seja fornecido medicamento sem prescrição médica ${ }^{744}$.

Por fim, saliente-se que o enfermeiro e seus auxiliares, assim como o médico, têm o dever de prestar informações na esfera da sua área de conhecimento, bem como o dever de sigilo, com os limites que lhe são pertinentes, mencionados no item 4.3.4 ${ }^{745}$.

\footnotetext{
${ }^{743}$ AGUIAR DIAS, José de. Da responsabilidade civil, t. I, p. 307.

${ }^{744}$ DEODATO, Sérgio. Responsabilidade profissional em enfermagem: valoração da sociedade, p. 123.

${ }^{745}$ Ibidem, p. 156-157.
} 


\section{RESPONSABILIDADE CIVIL DOS ADVOGADOS, TABELIÃES E PROFISSIONAIS CONEXOS}

A atividade do advogado é essencial na esfera jurídica, sendo reconhecida como tal pela própria Constituição Federal que, em seu art. 133, preceitua que esse profissional é indispensável para a administração da justiça. A despeito da dignidade inerente ao papel do advogado, nos últimos tempos, observou-se uma mercantilização da atividade, e a proliferação de profissionais, muitos deles sem qualificação. Esses fatores resultaram no aumento do número de demandas pleiteando a responsabilização civil dos causídicos, que se tornou frequente e demonstra a importância do estudo aqui desenvolvido.

No presente Capítulo, tratar-se-á da responsabilidade contratual, subjetiva e de meios desse profissional, dos atos de desídia no patrocínio da causa do cliente - omissão de providências necessárias, omissão de informações e perda de prazo processual -, da perda de uma chance especificamente aplicada à matéria, além da responsabilidade sobre as ofensas irrogadas em juízo e pela litigância de má-fé e por violação do dever de sigilo. Em acréscimo, será abordada a responsabilidade dos mandatários, e dos tabeliães, notários e registradores.

\subsection{A responsabilidade contratual e subjetiva do advogado}

A obrigação do advogado, em relação ao seu cliente, é contratual, salvo quando esse profissional atua como defensor público ou procurador de entidades públicas. De fato, o defensor dativo, indicado pela entidade a que pertence ou pelo juiz do processo, não tem vínculo contratual com a pessoa que irá representar. Do mesmo modo, quando o hipossuficiente é defendido em juízo pela Defensoria Pública, Procuradoria de Assistência Judiciária ou Procuradoria do Estado também não se configura o liame contratual; o mesmo se aplica aos procuradores de entidades da administração direta ou indireta do Estado e aos advogados da União ${ }^{746}$. O vínculo contratual ou extracontratual não altera,

${ }^{746}$ STOCO, Rui. Tratado de responsabilidade civil, p. 479. 
entretanto, os deveres pertinentes à atividade advocatícia, conforme se observa do $\S 1^{\underline{o}}$, do art. $3^{\circ}$, da Lei n. 8.906/1994 (EAOAB $)^{747}$.

A obrigação contratual do advogado, a qual é regra geral fora das hipóteses ora declinadas, decorre especificamente do contrato de mandato - ainda que associado a um contrato de prestação de serviço ${ }^{748}$-, o qual se trata, em sua essência, de contrato intuitu personae $^{749}$. Na condição de mandatário, deve o advogado empregar sua diligência habitual na execução do mandato, ficando obrigado a indenizar qualquer prejuízo decorrente de sua culpa, ou daquele a quem substabeleceu poderes sem autorização. Tem também o dever de prestar contas ao mandante ${ }^{750}$.

A principal obrigação profissional do causídico é a devida representação do seu cliente, judicial ou extrajudicialmente, com a promoção adequada do andamento de suas causas, sempre no interesse deste, bem como o fornecimento de orientações jurídicas com o maior número de informações possível ${ }^{751}$. Sua responsabilidade civil, por expressa disposição do art. 14, $\S 4^{\mathrm{o}}$, do $\mathrm{CDC}^{752}$, e do art. 32 do $\mathrm{EAOAB}^{753}$, verifica-se por meio da avaliação de culpa, sendo admitida, como já mencionado no Capítulo 3, a inversão do ônus da prova prevista no art. $6^{\circ}$, inc. VIII, do CDC, por se tratar de relação de consumo, nas hipóteses de constatação de verossimilhança da alegação ou de hipossuficiência da outra parte $^{754}$.

A responsabilidade será sempre subjetiva mesmo que a relação entre o advogado e seu cliente não seja contratual, de modo que o causídico somente poderá ser

\footnotetext{
${ }^{747} \mathrm{Na}$ dicção do dispositivo legal em comento: "§ $1^{\circ}$. Exercem atividade de advocacia, sujeitando-se ao regime desta lei, além do regime próprio a que se subordinem, os integrantes da Advocacia-Geral da União, da Procuradoria da Fazenda Nacional, da Defensoria Pública e das Procuradorias e Consultorias Jurídicas dos Estados, do Distrito Federal, dos Municípios e das respectivas entidades da administração indireta e funcional" (sem grifo no original).

${ }^{748}$ Como já esclarecido no Capítulo 3, o contrato firmado com o advogado não é exclusivamente de mandato. $\mathrm{O}$ mandato se encontra associado a um contrato de prestação de serviço, o qual prepondera (VASSILIEFF, Silvia. Responsabilidade civil do advogado, p. 39). No que tange ao caráter personalíssimo da obrigação, este é característica adquirida do contrato de mandato, e não do de prestação de serviço.

${ }^{749}$ É de se ressaltar, entretanto, que o contrato de honorários pode ser realizado com uma sociedade de advogados, hipótese em que, obviamente, atenua-se o caráter personalíssimo da obrigação, mas não a responsabilidade objetiva, pelos motivos esclarecidos no Capítulo 3.

${ }^{750}$ VENOSA, Silvio de Salvo. Direito Civil - responsabilidade civil, p. 272-273.

${ }^{751}$ CAVALIERI FILHO, Sérgio. Programa de responsabilidade civil, p. 86.

752 A aludida norma tem a seguinte redação: "A responsabilidade pessoal dos profissionais liberais será apurada mediante a verificação de culpa".

${ }^{753} \mathrm{O}$ artigo em referência dispõe: "O advogado é responsável pelos atos que, no exercício profissional, praticar com dolo ou culpa". No tocante ao cliente, determina o art. 34, inc. IX, do mesmo Estatuto que: "Constitui infração disciplinar: [...] IX - prejudicar, por culpa grave, interesse confiado ao seu patrocínio".

${ }^{754}$ DIAS, Sérgio Novais. Responsabilidade civil do advogado - perda de uma chance, p. 26.
} 
responsabilizado se causar dano ao cliente com dolo ou culpa manifesta ${ }^{755}$, atuando de maneira absolutamente inaceitável para a sua qualificação e dignidade profissional. A responsabilidade da sociedade de advogados também é subjetiva, em virtude de sua natureza não mercantilizada, com a peculiaridade de que os membros dela integrantes respondem subsidiaria e ilimitadamente pelos danos provocados no exercício da atividade advocatícia, conforme disposto no art. 17 do $\mathrm{EAOAB}^{756}$.

Não há que se falar, portanto, em presunção de culpa do advogado por resultado insatisfatório na demanda ${ }^{757}$, mesmo porque sua responsabilidade, no âmbito contencioso, é somente de meio e não de resultado, como ocorre com outros profissionais liberais, como o médico. Tratar-se-á dessa questão no item seguinte.

\subsection{A obrigação de meio do advogado}

A diferenciação entre obrigações de meio e obrigações de resultado já foi analisada no Capítulo 3, motivo pelo qual neste momento apenas serão examinadas as características peculiares às obrigações dos advogados.

Afirma-se, tradicionalmente, que a responsabilidade do advogado é de meio, comprometendo-se ele, ante seu cliente, a estudar com profundidade a causa, a examinar documentos $^{758}$, a aconselhá-lo, com pertinência, acerca da melhor atitude a adotar e a demandar de modo adequado. Não tem, entretanto, a obrigação de ser vitorioso no processo $^{759}$. Isto quer dizer que deve apresentar as manifestações, defesas e recursos dentro

\footnotetext{
755 A culpa manifesta diz respeito ao erro inescusável, isto é, aquele grosseiro e imperdoável quando cometido por um profissional. Ao longo do trabalho, serão esclarecidas as hipóteses em que o erro do advogado é considerado inescusável, gerando o dever de indenizar.

756 DINIZ, Maria Helena. Curso de Direito Civil brasileiro - responsabilidade civil, p. 283; DIAS, Sérgio Novais. Responsabilidade civil do advogado - perda de uma chance, p. 42: "É importante salientar que a responsabilidade da sociedade de advogados perante o cliente é também subjetiva e não objetiva. Não prevalece o argumento segundo o qual a sociedade, pessoa jurídica, encontra-se fora da exceção do $\S 4^{\circ}$ do artigo 14 do CDC, por não ser ela propriamente um profissional liberal. É que, como salientado precedentemente, a sociedade de advogados é exclusivamente de pessoas e de finalidades profissionais, de modo que a atividade da sociedade se confunde com a atividade do profissional, inclusive em se tratando de dano causado por advogado empregado da sociedade de advogados". A matéria em comento é tratada com maior cautela no Capítulo 3 do presente trabalho. Por ora, apenas a título de menção, esclareça-se que os advogados podem agregar-se em sociedade civil de prestação de serviços de advocacia, que deverá ser registrada no Conselho Seccional em cuja base territorial tiver sede. A referida sociedade somente poderá prestar serviços advocatícios e apenas poderá abrigar profissionais com formação jurídica.

${ }_{757}^{75}$ STOCO, Rui. Tratado de responsabilidade civil, p. 481.

${ }^{758}$ STJ. 3. T. REsp 807925/DF. Rel. Min. Ari Pargendler. j. 12.08.08. v.u.

759 GOMES, Luiz Roldão de Freitas. Elementos de responsabilidade civil, p. 349: "O advogado se compromete perante seu cliente a estudar a causa a fundo, a aconselhá-lo com pertinência a atitude a adotar e a demandar de modo convincente, mas não a ser vitorioso no processo (a obrigação, contudo, de praticar atos
} 
dos prazos estabelecidos pela lei, comparecer às audiências designadas e procurar resguardar os interesses de seu cliente de acordo com a melhor técnica. O advogado não tem, todavia, responsabilidade sobre o desfecho da causa ${ }^{760}$.

Não se pode olvidar, contudo, que sua atuação não é somente contenciosa. No âmbito extrajudicial e consultivo, o causídico deve efetivamente apresentar o trabalho ao qual se propôs a realizar. É o caso, v.g., da elaboração de um contrato, um parecer ou de uma escritura, nos quais o advogado deverá, necessariamente, ultimar o trabalho, sob pena de inadimplemento contratual ${ }^{761}$. No que tange ao conteúdo de parecer ou consulta, o profissional somente poderá ter responsabilidade se emitir seu entendimento em clara contrariedade à doutrina, à lei, ou à jurisprudência, e o cliente, seguindo o aconselhamento absurdo, vem a sofrer prejuízos ${ }^{762}$.

O que se conclui de todo o exposto neste item é que o advogado não pode, em sua atuação contenciosa, sem a comprovação de manifesta culpabilidade, ser condenado a indenizar seu cliente em razão da improcedência do feito. Isto vai gerar, sem sombra de dúvida, dificuldade no campo probatório, o que torna interessante o estudo da perda de uma chance na seara da responsabilidade do advogado.

\subsection{A responsabilidade por atos de desídia no patrocínio da causa do cliente}

O advogado, sendo responsabilizado apenas subjetivamente, responde pelos atos realizados de modo culposo. Ocorre que esse tipo de culpa é difícil de ser aferido de forma meramente abstrata, o que torna a análise jurisprudencial essencial para este estudo.

Para responsabilização do causídico, faz-se necessária a constatação de erro inescusável de conduta, que consiste no erro grosseiro ou inadmissível, como, por exemplo, o de ingressar com ação inexistente ou absolutamente inadequada para a

processuais nas formas e prazos requeridos, como de interpor um recurso, deve ser considerada como obrigação de resultado)".

${ }^{760}$ FERRASSINI, Antônio Alexandre. A responsabilidade do advogado por litigância de má fé. Disponível em: <http://www.datavenia.net/opiniao/2001/Aresponsabilidadecivildoadvogadoporlitiganciademafe>. Acesso em: 11 jul. 2005.

761 VENOSA, Silvio de Salvo. Direito Civil - responsabilidade civil, p. 175-176. Ver também Rui Stoco (Tratado de responsabilidade civil, p. 480).

${ }^{762}$ AGUIAR DIAS, José de. Da responsabilidade civil, t. II, p. 321. O STJ já firmou entendimento que o consultor jurídico ou parecerista pode ser enquadrado como sujeito passivo em uma ação de improbidade administrativa, quando ficar evidenciada sua má-fé (STJ. 2. T. REsp 1183504/DF. Rel. Min. Humberto Martins. j. 17.06.10. v.u.). 
hipótese, deixar de repassar os valores devidos ao cliente no momento oportuno ${ }^{763}$, alegar fatos que nunca ocorreram, perder prazos peremptórios não controvertidos ${ }^{764}$, entre outros $^{765}$. O advogado sempre responde pelos erros de fato, mas nem sempre pelos de direito, quando far-se-á uma comparação de sua conduta com a do profissional médio. Félix A. Trigo Represas e Marcelo J. López Mesa assinalam que a rigidez alusiva aos fatos se deve à obrigação do advogado de fazer a verificação do que lhe é relatado pelo cliente, procurando observar se há verossimilhança na situação fática retratada. O profissional não pode, contudo, ser responsabilizado por todas as inexatidões oriundas das informações fornecidas pelo cliente, uma vez que não é um investigador. No que tange aos erros de direito, segundo os autores pré-citados, estes podem não ter consequências tão relevantes porque podem ser sanados pela aplicação do princípio iura curit novit, pelo qual o magistrado pode eleger livremente a norma que se aplica ao caso submetido à sua decisão, prescindindo da designação técnica que tenha fornecido o litigante ${ }^{766}$.

Nos casos controvertidos ou duvidosos, o erro profissional não pode ser considerado imperícia, imprudência ou negligência, de modo que não ensejará reparação ${ }^{767}$. Sérgio Cavalieri Filho, corroborando essa assertiva, ressalta que a responsabilização do advogado somente pode advir de desvio de conduta grave, decorrente de erros grosseiros, de fato ou de direito, cometidos no desempenho do contrato, entre os quais são enumerados o ajuizamento de ação inviável, desconhecimento de texto expresso de lei ou de jurisprudência dominante, bem como perda de prazo para contestar, recorrer, fazer o preparo do recurso ou requerer a realização de alguma diligência importante ${ }^{768}$.

Vê-se, portanto, que o estudo da matéria se dá por meio da análise dos casos concretos que representam o cotidiano da advocacia. Analisar-se-á, em seguida, as hipóteses mais importantes.

\footnotetext{
${ }^{763}$ TJRJ. 2 $2^{\text {a }}$ Câmara Cível. Ap. 0041659-43.2008.8.19.0021. Rel. Des. Jessé Torres. j. 27.10.10. v.u.

${ }^{764}$ TJSP. 30를 Câmara de Direito Privado. Ap. 992060525516. Rel. Edgard Rosa. j. 15.09.10. v.u.

${ }^{765}$ STOCO, Rui. Tratado de responsabilidade civil, p. 481. O CPC não determinou um critério especial para identificar quais os prazos legais peremptórios e quais os meramente dilatórios, o que acabou sendo determinado pela jurisprudência. Alguns casos já se encontram estabelecidos por um consenso da doutrina processual: os prazos para oferecimento de defesa, bem como os de recorrer, são tidos como peremptórios, enquanto os de juntar documentos, arrolar testemunhas e realizar diligências determinadas pelo juiz são dilatórios. O prazo peremptório, de acordo com o que se infere dos exemplos de casos concretos, é aquele cujo termo cria uma situação que condiciona a própria função jurisdicional, tal como se dá com a revelia, a coisa julgada e a preclusão (THEODORO JÚNIOR, Humberto. Curso de Direito Processual Civil. 33. ed. Rio de Janeiro: Forense, 2000. v. 1, p. 214-215).

${ }^{766}$ REPRESAS, Félix A. Trigo. MESA, Marcelo J. López. Tratado de la responsabilidad civil, t. II, p. 533534.

${ }^{767}$ STOCO, Rui, op. cit., p. 478

${ }^{768}$ CAVALIERI FILHO, Sérgio. Programa de responsabilidade civil, p. 387.
} 


\subsubsection{Omissão de providências necessárias}

O advogado responde pela omissão de providências necessárias para o resguardo do direito de seu cliente, como, por exemplo, a propositura de habilitação em falência, e a feitura de acordo em causa cujo resultado tende a ser negativo ${ }^{769}$, e a propositura de medida cautelar para salvaguarda de direitos ${ }^{770}$. Nessa hipótese de indenização, insere-se a omissão que implica prescrição ao direito do cliente ${ }^{771}$. Rui Stoco inclui entre os erros inescusáveis o ingresso de ação intempestiva, quando já decorrido o prazo decadencial ou de prescrição $^{772}$.

Está-se, nessa hipótese, diante de situação em que a perda da chance ou oportunidade é evidente, já que o cliente não mais poderá ver sua pretensão examinada pelo Judiciário. Não se pode, entretanto, determinar qual seria o resultado do julgamento do feito, de modo que não será possível conceder a pretensão final pleiteada pelo cliente em seu processo. Em casos como esse, os tribunais têm, com frequência, condenado o advogado a indenizar a vítima com aplicação da perda da chance ${ }^{773}$.

A omissão de providências também pode estar relacionada às hipóteses que constam do art. 267 do $\mathrm{CPC}^{774}$. O referido dispositivo legal enumera diversas ocasiões em

${ }^{769}$ DINIZ, Maria Helena. Curso de Direito Civil brasileiro - responsabilidade civil, p. 251. Também Carlos Roberto Gonçalves (Responsabilidade civil, p. 383); e José de Aguiar Dias (Da responsabilidade civil, t. II, p. 324).

${ }_{770}$ ITURRASPE, Jorge Mosset. Responsabilidad por daños - responsabilidad de los profesionales, t. VIII, p. 513.

${ }^{771}$ DINIZ, Maria Helena, op. cit., p. 251-252.

${ }^{772}$ STOCO, Rui. Responsabilidade civil, p. 487-488.

773 Sobre o assunto, verifiquem-se os seguintes acórdãos: $2^{\underline{o}}$ Tribunal de Alçada Civil de São Paulo. 5 Câmara de Direito Privado. Ap. c/ Rev. 606.170-00/5. Rel. Juiz Luís de Carvalho. j. 31.10.01: "Indenização Dano moral - Não ajuizamento tempestivo de demanda trabalhista para a qual o mandatário havia sido contratado - Hipótese de perda da chance para o cliente - Desídia profissional - Caracterização Admissibilidade. A conduta desidiosa do advogado que, por deixar de promover a ação judicial para a qual foi contratado, permite que prescreva o direito do cliente, caracteriza a figura da 'perda de uma chance'

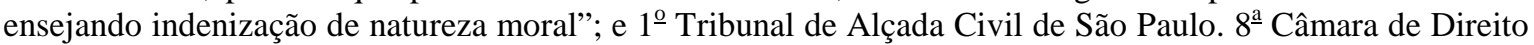
Privado. Ap. 0680655-1. Rel. Juiz Costa Telles. j. 23.10.96: "Contrato - rescisão - honorários de advogado excessiva demora da mandatária na propositura da demanda trabalhista para a qual foi contratada, não obstante a fluência do prazo prescricional - arquivamento determinado - negligência da ré configurada artigo 87, XVIII, da Lei 4.215/63 - indenização devida pela perda da chance do autor de ver seu pleito analisado - rescisão do contrato determinada, condenando-se a vencida ao pagamento de 50 salários mínimos mais despesas processuais e honorários de advogado arbitrados em $15 \%$ sobre o valor atualizado da condenação - recurso parcialmente provido".

${ }^{774} \mathrm{O}$ referido artigo tem a seguinte redação: "Extingue-se o processo, sem resolução do mérito:

I - quando o juiz indeferir a petição inicial;

II - quando ficar parado durante mais de 1 (um) ano por negligência das partes;

III - quando, por não promover os atos e diligências que lhe competir, o autor abandonar a causa por mais de 30 (trinta) dias;

IV - quando se verificar a ausência de pressupostos de constituição e de desenvolvimento válido e regular do processo;

V - quando o juiz acolher a alegação de perempção, litispendência ou de coisa julgada; 
que o processo é extinto sem julgamento do mérito, algumas delas podendo ser ocasionadas pela desídia do advogado da causa.

Poderá ensejar responsabilidade, dentro dessas hipóteses, o comportamento omissivo do causídico que, por desídia, mantém o processo no qual foi constituído patrono paralisado por mais de um ano, ou então, quando, por mais de trinta dias, deixa de praticar os atos e diligências a seu cargo, abandonando a causa sem motivação e sem prévio aviso do cliente contratante ${ }^{775}$.

Cumpre salientar, todavia, que, nesse caso, não se configura a perda da chance porque a ação poderá ser proposta de novo, conforme determinação do art. 268 do $\mathrm{CPC}^{776}$. Se, no entanto, o autor do feito tiver, por mais de três vezes, abandonado o processo, não poderá propor a ação novamente, possibilitando-se a configuração de uma eventual perda da chance. Mesmo não sendo o caso de perda da chance, evidencia-se dano - dano emergente ou lucros cessantes -, em razão do atraso no desenvolvimento do processo da vítima.

\subsubsection{A omissão de informações}

O primeiro e mais importante dever do advogado é trazer ao cliente a informação adequada sobre a questão que lhe foi proposta e também sobre sua própria formação. Aliás, no que tange a esse último aspecto, o profissional pode vir a ser responsabilizado no caso

VI - quando não concorrer qualquer das condições da ação, como a possibilidade jurídica, a legitimidade das partes e o interesse processual;

VII - pela convenção de arbitragem;

VIII - quando o autor desistir da ação;

IX - quando a ação for considerada intransmissível por disposição legal;

$\mathrm{X}$ - quando ocorrer confusão entre autor e réu;

$\mathrm{XI}$ - nos demais casos prescritos neste Código.

$\S 1^{o} \mathrm{O}$ juiz ordenará, nos casos dos nos $\mathrm{II}$ e III, o arquivamento dos autos, declarando a extinção do processo, se a parte, intimada pessoalmente, não suprir a falta em 48 (quarenta e oito) horas.

$\S 2^{\underline{0}}$ No caso do parágrafo anterior, quanto ao $\mathrm{n}^{\mathrm{o}}$ II, as partes pagarão proporcionalmente as custas e, quanto ao n⿳⼈ㅡㄴ III, o autor será condenado ao pagamento das despesas e honorários de advogado (art. 28).

$\S 3^{\circ} \mathrm{O}$ juiz conhecerá de ofício, em qualquer tempo e grau de jurisdição, enquanto não proferida a sentença de mérito, da matéria constante dos nos $\mathrm{IV}, \mathrm{V}$ e VI; todavia, o réu que a não alegar, na primeira oportunidade em que lhe caiba falar nos autos, responderá pelas custas de retardamento.

$\S 4^{0}$ Depois de decorrido o prazo para a resposta, o autor não poderá, sem o consentimento do réu, desistir da ação".

${ }_{775}$ Art. 267, incs. II e III, do CPC - vide nota anterior.

${ }^{776} \mathrm{O}$ art. 268 determina, in verbis: "Salvo o disposto no art. 267, V, a extinção do processo não obsta a que o autor intente de novo a ação. A petição inicial, todavia, não será despachada sem a prova do pagamento ou do depósito das custas e dos honorários de advogado.

Parágrafo único. Se o autor der causa, por 3 (três) vezes, à extinção do processo pelo fundamento no n. III do artigo anterior, não poderá intentar nova ação contra o réu com o mesmo objeto, ficando-lhe ressalvada, entretanto, a possibilidade de alegar em defesa o seu direito". 
de se nomear, em desconformidade com a verdade, especialista ou detentor de conhecimentos específicos em determinada área ${ }^{777}$.

O profissional também responde pela omissão de informação sobre vantagens e desvantagens da medida judicial já proposta e de outras a serem eventualmente tomadas ${ }^{778}$.

Não somente em razão do contrato de mandato assumido, mas também pelo disposto no CDC, art. $6^{\circ}$, inc. III $^{779}$, o advogado tem o dever de informar seu cliente acerca de todos os percalços e possibilidades que a causa possa trazer, bem como das conveniências e inconveniências de quaisquer outras demandas que poderiam ter sido ingressadas. Aplica-se, ademais, ao contrato o princípio da boa-fé objetiva, insculpido no art. 422 do $\mathrm{CC}^{780}$.

A referida informação deve, ainda, ser atualizada à medida que a demanda se desenvolve. Isto significa que, em cada nova situação, deve o profissional fornecer noções básicas das nuance que envolvam o direito do cliente e as mudanças de rumo que a causa sugere $^{781}$. Não se deve inferir dessa assertiva que será facultado ao cliente atuar com abuso de direito, contatando diariamente o advogado, para efetuar perguntas repetitivas. É necessário que o cliente espere o tempo razoável para o desenrolar do processo, conforme indicado pelo advogado, o que faz parte do dever de informação deste último ${ }^{782}$.

\subsubsection{A perda de prazo processual}

A perda de prazo para cumprimento de determinação judicial, como o oferecimento de defesa ou interposição de recurso, é causa clássica de responsabilização do advogado ${ }^{783}$. Trata-se, novamente, de hipótese de perda da chance do cliente, desta vez, de submeter seu

\footnotetext{
777 BARBIER, Eduardo. A.; VERGARA, Leandro. Responsabilidad del abogado. In: GHERSI, Carlos Alberto (Director). Responsabilidad profesional. Buenos Aires: Editorial Astrea de Alfredo y Ricardo Depalma, 1995. v. 2, p. 12.

${ }_{778}^{7}$ DINIZ, Maria Helena. Curso de Direito Civil brasileiro - responsabilidade civil, p. 253.

779 “Art. 6‥ São direitos básicos do consumidor: [...]

III - a informação adequada e clara sobre os diferentes produtos e serviços, com especificação correta de quantidade, características, composição, qualidade e preço, bem como sobre os riscos que apresentem”.

${ }^{780} \mathrm{O}$ artigo em comento rege que: "Os contratantes são obrigados a guardar, assim na conclusão do contrato, como em sua execução, os princípios de probidade e boa-fé”.

${ }^{781}$ VENOSA, Silvio de Salvo. Direito Civil - responsabilidade civil, p. 177.

${ }^{782}$ Não se perca de vista, entretanto, que o advogado faz mera estimativa do lapso temporal levado por um procedimento no Judiciário, não podendo garantir a conclusão do processo dentro de um prazo determinado.

${ }^{783}$ STJ. 4 ${ }^{\mathrm{a}}$ T. REsp 596613/RJ. Rel. Min. César Asfor Rocha. j. 19.02.04. v.u. TJRJ. 10 ${ }^{\mathrm{a}}$ Câmara Cível. Embargos Infringentes n. 0073070-77.2002.8.19.0001. Rel. Des. Marília de Castro Neves. J. 03.06.09. v.u.; TJRJ. 1a Câmara Cível. Ap. 0070341-39.2006.8.19.0001. Rel. Des. Myriam Medeiros. j. 01.04.08. v.u.; TJRJ. 14를 Câmara Cível. Ap. 0001124-42.1994.8.19.0028. Rel. Des. Ferdinaldo do Nascimento. J. 07.10.03. v.u.
} 
processo ao duplo grau de jurisdição, conseguir o acolhimento de uma preliminar ou o julgamento de improcedência do feito, ou, até mesmo, obter a produção de prova necessária para comprovar suas alegações ${ }^{784}$.

Conforme já havia sido ressaltado, o advogado tem o dever de cumprir os prazos processuais, constitui sua perda erro grave e, portanto, inescusável. De fato, o mínimo que se espera do profissional do direito é o conhecimento dos prazos processuais ${ }^{785}$, pois estes constam da lei. Da mesma forma, deve ser diligente e atento, não deixando perecer o direito do cliente por falta de medidas ou omissão de providências ${ }^{786}$.

Rui Stoco pondera, por sua vez, que somente a perda de prazo fatal, peremptório e induvidoso com relação ao seu início e fim enseja a reparação, uma vez que não é tão simples a administração dos prazos. Discorda-se do autor no que tange a esse aspecto, tendo em vista que, em regra, os prazos são de fácil cômputo; no entanto, algumas vezes, dependem da conjugação de diversos dispositivos legais e ainda podem ser interrompidos ou suspensos, como na hipótese de férias forenses, período no qual nem todas as ações deixam de ter curso ${ }^{787}$. Não se afaste, do mesmo modo, possível dissidência jurisprudencial no que tange à data de início da contagem do prazo processual. Trata-se, contudo, de ocorrência rara e não corriqueira.

De qualquer modo, a culpabilidade do profissional deve ser evidente para que haja sua responsabilização, como se infere da decisão transcrita a seguir:

"Revelia - Justificativa tardia - Responsabilidade do advogado por
negligência comprovada no desempenho do mandato judicial.
Tardia alegação de doença de filho, feita só no apelo, não justifica
devolução de prazo para contestar, mormente quando já houvera
anterior devolução concedida em primeiro grau, fundada em
doença de outro parente, e faz a advogada, em causa própria, carga
dos autos, em meio ao prazo devolvido de 15 dias de que dispunha
para contestar, retendo-os indevidamente por mais de quatro meses,

\footnotetext{
${ }^{784}$ STJ. 3. T. REsp 1079185/MG. Rel. Min. Nancy Andrighi. j. 11.11.08. v.u.

${ }^{785}$ A constatação em referência vem sendo confirmada de modo reiterado pela jurisprudência, da qual extraise o seguinte acórdão: "Mandato. Reparação de danos. Perda de prazos processuais. Culpa grave. Indenização devida. Do exercício da advocacia exige-se, ao mínimo, o conhecimento de prazos processuais, a fim de que o profissional possa realizar a correta defesa dos interesses do constituinte, nos moldes admitidos pelas regras legais" (2 $2^{\circ}$ Tribunal de Alçada de São Paulo. 10ª Câmara. Apelação 521.964. Rel. Juiz Marcos Martins. j. 24.03.99).

${ }^{786}$ GONÇALVES, Carlos Roberto. Responsabilidade civil, p. 383.

${ }^{787}$ STOCO, Rui. Tratado de responsabilidade civil, p. 485/487-488.
} 
só os devolvendo mediante mandado de busca e apreensão, sem nenhuma justificativa. Negligência comprovada da advogada constituída, deixando fluir em branco prazo assinado para falar nos autos, e com isso ocasionando o deferimento de pedido de imissão de posse da parte contrária no imóvel residencial ocupado pela constituinte, gera, de acordo com o art. 159, do CC, a responsabilidade civil do profissional, já penalizada administrativamente pelo Tribunal de Ética e Disciplina do órgão de classe, sujeitando-a a indenizar as perdas e danos causados. Apelo a que se nega provimento" ${ }^{, 788}$.

Note-se que, no referido acórdão, o Egrégio Tribunal, a fim de caracterizar a culpa da advogada, teve de adentrar na análise concreta de sua conduta, ressaltando, v.g., que ela reteve os autos durante meses sem qualquer tipo de justificativa e se utilizou, por duas vezes, da alegação de doença de parentes para obter a devolução do prazo.

No que concerne à interposição de recurso, a eventual omissão do advogado é questão mais delicada, pois não se trata apenas de atendimento de prazo, mas também de questões de conveniência e admissibilidade ${ }^{789}$. Sérgio Cavalieri Filho sustenta que cabe ao advogado determinar a conveniência da medida, em particular no caso de recurso especial ou recurso extraordinário, sujeitos a requisitos rigorosos e específicos. O advogado, com mais razão quando zeloso do seu bom nome profissional, não pode ser obrigado a interpor um recurso manifestamente incabível. Não deve, entretanto, deixar de recorrer no caso de indiscutível necessidade, ou contrariando a vontade do cliente. Neste último caso, se tem convicção jurídica contrária, o procedimento correto a ser adotado é a renúncia do mandato $^{790}$.

Rui Stoco, esposando entendimento contrário, entende que o advogado deve sempre recorrer, em especial no caso de recurso ordinário ou ação rescisória. O mesmo não se aplicaria aos agravos, cuja interposição, pela demora no processo, pode até ser mais

\footnotetext{
${ }^{788}$ TJDF. 4 ${ }^{\mathrm{a}}$ Turma Cível. Apelação Cível nํㅜ 4696897. Rel. Mário Machado. j. 18.3.98. v.u.

${ }^{789}$ Quando há grandes chances de provimento do recurso, não se questiona a responsabilidade do advogado, mas sim a verba a ser paga a título de indenização. Na maior parte das vezes, é concedida indenização de danos morais, como, v.g., em: TRT. 3를 Região. RO 00258.2006.016.03.00.9. Rel. Juíza Conv. Adriana Goulart de Sena. j. 30.10.06. v.m. (Demandante ingressou com ação em face de Sindicato, em razão de o advogado que lhe foi por ele encaminhado não ter interposto recurso de revista.)

${ }^{790}$ CAVALIERI FILHO, Sérgio. Programa de responsabilidade civil, p. 387.
} 
prejudicial ao cliente do que benéfica ${ }^{791}$. Sustenta-se aqui que a questão do agravo de instrumento é mais complexa, pois esse recurso pode ser essencial para assegurar diversos direitos do cliente, como, por exemplo, concessão dos benefícios da justiça gratuita, antecipação dos efeitos da tutela, produção de determinada prova, entre outros. A questão deve, portanto, ser estudada em cada caso específico, podendo, sim, o advogado ser responsabilizado pela não interposição do agravo ${ }^{792}$.

Rui Stoco assevera que, se a orientação do cliente é incisiva e expressa no sentido de que o advogado deveria recorrer e este não o faz, incorre em responsabilidade já que, havendo divergência entre o seu ponto de vista e o do cliente, deveria ter renunciado ao mandato $^{793}$.

De todo modo, a interposição de recurso deve ser vista com muita cautela, com mais razão pelo fato de a Lei n⿳ำ 9.756, de 17 de dezembro de 1998 , que dá nova redação ao art. 557 do $\mathrm{CPC}^{794}$, prever a cominação de multa para o caso de recursos inadmissíveis e/ou infundados contra algumas decisões do relator. Acrescente-se, ainda, que o art. 17,

\footnotetext{
${ }^{791}$ STOCO, Rui. Tratado de responsabilidade civil, p. 484.

${ }^{792}$ Nesse sentido, TJRS. $1^{\mathrm{a}}$ Turma Recursal Cível. Ap. 71002711653. Rel. Des. Ricardo Torres Hermann. j. 14.10.10. v.u.: "RESPONSABILIDADE CIVIL. ADVOGADO. PERDA DA CHANCE. NÃO INTERPOSIÇÃO DE RECURSO DE AGRAVO DE INSTRUMENTO PARA AGREGAR EFEITO SUSPENSIVO A APELAÇÃO CONTRA SENTENÇA QUE EXONEROU O PAGAMENTO DE PENSÃO ALIMENTÍCIA. SUSPENSÃO DO PAGAMENTO DA PENSÃO. JURISPRUDÊNCIA A INDICAR A GRANDE PROBABILIDADE DE SUCESSO NO ACOLHIMENTO DO AGRAVO CASO HOUVESSE SIDO INTERPOSTO. 1. O fato de não ter o advogado apresentado recurso de agravo de instrumento, visando conferir efeito suspensivo à apelação contra a sentença que exonerou o ex-marido da autora de pagar pensão alimentícia, revela atuação desidiosa e, portanto, culposa sob a modalidade da negligência. 2. Como a verificação do dano envolve a teoria da perda da chance, já que há de se apurar a expectativa de benefício incerto ou de prejuízo que poderia ser evitado, há de se avaliar a responsabilidade civil do causídico, não só mercê da investigação da conduta culposa, mas também a partir da realidade e seriedade da possibilidade de interferir na decisão judicial do órgão recursal, ou seja, na probabilidade de que a decisão fosse diversa daquela tomada no julgamento em que houve a negligente atuação. 3. Considerando tal critério, resta claro que deixou a autora de perceber durante dois meses a pensão alimentícia que the vinha sendo paga. 4 . Contudo, como foi restabelecida metade dos alimentos, quando do julgamento da apelação, apenas a metade faltante há de lhe ser alcançada como indenização pelo prejuízo sofrido em razão da perda da chance. Recurso parcialmente provido".

${ }^{793}$ STOCO, Rui, op. cit., p. 485.

${ }^{794} \mathrm{O}$ artigo em comento tem a seguinte redação: "O relator negará seguimento a recurso manifestamente inadmissível, improcedente, prejudicado ou em confronto com súmula ou com jurisprudência dominante do respectivo tribunal, do Supremo Tribunal Federal, ou de Tribunal Superior.

$\S 1^{\circ}-\mathrm{A}$ Se a decisão recorrida estiver em manifesto confronto com súmula ou com jurisprudência dominante do Supremo Tribunal Federal, ou de Tribunal Superior, o relator poderá dar provimento ao recurso.

$\S 1^{\underline{o}}-$ Da decisão caberá agravo, no prazo de 5 (cinco) dias, ao órgão competente para o julgamento do recurso, e, se não houver retratação, o relator apresentará o processo em mesa, proferindo voto; provido o agravo, o recurso terá seguimento.

$\S 2^{\mathrm{o}}$ - Quando manifestamente inadmissível ou infundado o agravo, o tribunal condenará o agravante a pagar ao agravado multa entre $1 \%$ (um por cento) e $10 \%$ (dez por cento) do valor corrigido da causa, ficando a interposição de qualquer outro recurso condicionada ao depósito do respectivo valor".
} 
inc. VII ${ }^{795}$, do mesmo Diploma legal determina que a interposição de recurso com intuito manifestamente protelatório configura litigância de má-fé. Nesse sentido vem se orientando a jurisprudência, na qual abundam decisões dispensando o advogado de dever de interposição de recurso ${ }^{796}$. De fato, em casos semelhantes, atua com mais diligência o profissional que se empenha na transação com a parte contrária do que aquele que interpõe o recurso, que poderá gerar mais despesas ao cliente.

\subsection{A perda de uma chance na responsabilidade do advogado}

Conforme esclarecido anteriormente ${ }^{797}$, não há limites determinados para a aplicação da teoria da perda da chance. Ela pode ser utilizada tanto se a chance perdida era de obter um ganho quanto se era de evitar uma perda e se aplica a uma série de situações, como, por exemplo, a perda de oportunidade profissional ou acadêmica, a de chance de cura ou de sobrevivência a uma doença.

A mais tradicional espécie de perda da chance é a perda da oportunidade relacionada a um direito. A responsabilidade do advogado se insere nesse campo. Rafael Peteffi da Silva assinala que essa é a matéria em que mais se aplica a teoria em comento, em particular pelo fato de que o magistrado se sente seguro ao fazê-lo, já que tem condições técnicas e conhecimentos suficientes para avaliar o trabalho do advogado e estabelecer as possibilidades de acolhimento da demanda frustrada. O magistrado julga, desse modo, virtualmente o mérito da demanda ${ }^{798}$.

Suponha-se que um advogado tarde na propositura de uma demanda para a qual ele foi contratado e deixe prescrever a ação por meio da qual o cliente poderia ser beneficiado:

\footnotetext{
795 O referido art. 17 dispõe que: "Reputa-se litigante de má-fé aquele que: [...] VII - interpuser recurso com intuito manifestamente protelatório".

${ }^{796}$ Verifiquem-se os seguintes acórdãos: 2o Tribunal de Alçada Civil de São Paulo. 2ª Câmara Cível. Ap. c/ Rev. 520.828. rel. Juiz Felipe Ferreira. j. 22.06.98: "Mandato - Responsabilidade civil - Advogado (artigos 159 e 1.300, do Código Civil [1916], artigo 32 da Lei nº 8.906/94) - Prova - Ausência - Descabimento. Não há culpa por negligência do advogado que não recorre de sentença desfavorável, se foi induzido por informações incorretas do cliente a promover ação temerária, cujo direito prova irrefutável comprova inexistir. Inteligência do artigo 17, do Código de Processo Civil combinado com o artigo 31 e parágrafo único do artigo 32, da Lei no 8.906/94. Sentença reformada"; e $2^{\underline{o}}$ Tribunal de Alçada Civil de São Paulo. $2^{\text {a }}$ Câmara Cível. Ap. 567.552-00/7. Rel. Juiz Felipe Ferreira. j. 10.04.00: "Mandato. Responsabilidade civil do advogado. Opção por não recorrer de sentença desfavorável. Admissibilidade. - Se o recurso se apresentava como temerário e protelatório, caracterizador de litigância de má-fé, tem o advogado o dever profissional de não recorrer, conforme inteligência do art. 17, VII do CPC, c/c o art. 31, § 1 1ํ, da Lei nº 8.906/94 (Estatuto do Advogado). Sentença de procedência reformada. Recurso referente à reconvenção não conhecido. Recurso da ação principal provido".

${ }^{797}$ Trata-se de matéria examinada no Capítulo 2.

${ }^{798}$ SILVA, Rafael Peteffi. Responsabilidade civil pela perda de uma chance, p. 165-166.
} 
ainda que não haja certeza de que essa ação pudesse prosperar, é certo, porém, que ela não poderá mais lhe gerar proveito.

O mesmo pode acontecer se o advogado não oferece a defesa de seu cliente dentro do prazo legal, ou no momento oportuno, deixa de dar andamento à ação e o processo é extinto com julgamento do mérito ${ }^{799}$, ou, ainda, quando deixa de se manifestar sobre erro grosseiro em laudo pericial ${ }^{800}$, entre outras hipóteses. Nesses casos, o magistrado admitirá uma reparação se ele considerar que a vítima poderia ter obtido satisfação, razão pela qual deverá, necessariamente, avaliar a matéria objeto da ação que não foi proposta, bem como dos meios de defesa que não foram oferecidos no prazo. Ele a rejeitará se entender que a vítima não teria, de qualquer maneira, chance razoável de ver prosperar seu pleito ${ }^{801}$.

Com esse entendimento, o Egrégio Tribunal de Justiça do Estado do Paraná condenou um advogado a indenizar seu cliente por lhe ter privado de ver apreciado em instância superior o mérito de seu processo, conforme se transcreve a seguir:

"Responsabilidade civil do advogado - Embargos de declaração e
apelações interpostas fora do prazo legal - Descumprimento do
dever de diligência - Perda de prazos - Não conhecimento dos
recursos - Dano - Existência - Forma de liquidação - Ação
procedente. O advogado tem o dever de manifestar recurso
ordinário oportuno tempore, respondendo por sua interposição
intempestiva. A perda de prazo, como ensina José Aguiar Dias,
'constitui erro grave, a respeito do qual não é possível escusa, uma
vez que os prazos são de direito expresso e não se tolera que o
advogado o ignore' (Da responsabilidade civil, v. 1, p. 348,
Forense - 1987 - 8ª edição). O prejuizo da parte consiste na perda
da possibilidade de ver apreciado o mérito da causa na instância
superior. Não se configurando qualquer causa de exclusão de
responsabilidade civil do advogado, impõe-se a procedência do
pedido indenizatório, com fixação da indenização através de
arbitramento em liquidação de sentença, levando-se em conta que o

\footnotetext{
${ }^{799}$ TJRJ. 20 $0^{\mathrm{a}}$ Câmara Cível. Ap. 0004220-62.2006.8.19.0087. Rel. Des. Teresa Castro Neves. j. 04.08.10. v.u. ${ }^{800}$ STJ. $3^{\mathrm{a}}$ T. REsp. 402182/RS. Rel. Min. Humberto Gomes de Barros. j. 18.05.06. v.u.

${ }^{801}$ STJ. $4^{\mathrm{a}}$ T. REsp 1190180/RS. Rel. Min. Luis Felipe Salomão. j. 16.11.10.v.u.
} 
dano corresponde apenas a perda de uma chance" ${ }^{\wedge 02}$. (sem grifo no original)

Sidnei Agostinho Beneti Filho distingue a perda do direito de análise da matéria em juízo, da perda da oportunidade de vitória, esclarecendo que, no primeiro caso, a vítima perde o direito de ver analisado judicialmente seu pleito, por meio da distribuição de uma ação ou revisão de decisão desfavorável. Já o segundo decorre da oportunidade de análise e é a chance de que seu direito prevaleça sobre o da parte contrária, pela atuação do advogado $^{803}$. Segundo entendimento do doutrinador, a perda da oportunidade de análise se resolve em danos morais, ao passo que a perda da oportunidade de vitória pode ensejar reparação de danos patrimoniais, em especial quando o resultado do processo é esperado, seja pela sua comparação com outros análogos, seja pela evidência do direito em discussão ${ }^{804}$.

A divisão estabelecida pelo autor pré-citado ${ }^{805}$, apesar de inovadora, não é relevante do ponto de vista prático. Em muitas hipóteses, ambas as oportunidades são fulminadas ao mesmo tempo, o que ocorre, v.g., quando o advogado perde o prazo para interposição de recurso; em outras, talvez nem seja possível determinar qual das duas espécies de chance foi frustrada. Entende-se, assim, que a questão pode ser analisada de maneira mais adequada por meio de casos concretos que possam dar ensejo à perda da chance, o que se fará em seguida.

Sérgio Novais Dias arrola as seguintes hipóteses de perda de chance decorrentes de má atuação do advogado: falta de propositura de ação judicial, pedido não formulado, ausência de interposição de recurso, omissão na produção de prova necessária, extravio de autos, falta de interposição de recursos de natureza extraordinária, ausência de contrarrazões ao recurso, não realização de sustentação oral do recurso, e ação rescisória não proposta ${ }^{806}$.

A falta de propositura de ação judicial, já mencionada neste estudo, somente ensejará reparação quando a omissão resultar na prescrição do direito do cliente. Trata-se

${ }^{802}$ TJPR. 5a Câmara Cível. Apelação Cível n. 0045988-1 (Acórdão n. 833) Rel. Des. Carlos Hoffmann. j. 22.4.96. v.u.

${ }^{803}$ BENETI FILHO, Sidnei Agostinho. A atividade advocatícia e a responsabilidade civil decorrente. 2002.

Dissertação (Mestrado) - Faculdade de Direito da Universidade de São Paulo, 2002. p. 281.

804 Ibidem, loc. cit.

805 Ibidem.

${ }^{806}$ DIAS, Sérgio Novais. Responsabilidade civil do advogado - perda de uma chance, p. 72-86. 
de caso em que a perda da chance é evidente, uma vez que a vítima não mais poderá ver sua pretensão examinada pelo Poder Judiciário. A materialização do prejuízo é patente, porém não se pode determinar qual seria o resultado do julgamento do feito, a não ser em casos extremos para os quais existam súmulas dos tribunais superiores.

Em casos como este, os advogados em rigor são condenados a indenizar seu cliente sob o argumento da perda da chance ${ }^{807}$.

Deve-se mencionar que o ato culposo do advogado pode acarretar não somente danos de ordem patrimonial ao seu cliente, mas também de ordem moral. Quando a vítima tem frustrada sua pretensão de obter direito de resposta, v.g., ela perdeu o direito de ser indenizada. A reparação mencionada é tão somente moral ${ }^{808}$, o que, contudo, não deve representar qualquer impedimento para a concessão de indenização.

Essas considerações se aplicam, do mesmo modo, à ausência de formulação de um pedido, que não deixa de ser a falta de propositura de parte de determinada ação.

No que tange ao descumprimento dos prazos processuais, comentou-se que se trata de hipótese apta a ensejar indenização. O problema é a quantificação da chance perdida, quando o caso concreto não se situa em um dos extremos retromencionados - chance próxima a $100 \%$ ou de $0 \%$ de provimento do pleito, se cumprido regularmente o prazo processual pelo causídico.

Em hipóteses como as levantadas, far-se-á necessário o estudo probabilístico de sucessos de demandas semelhantes no tribunal competente para análise do recurso que não foi interposto.

Conforme relata Sérgio Novais Dias, essa ideia começou a ser desenvolvida por Piero Calamandrei ${ }^{809}$, ao propor que o cálculo estatístico do acolhimento dos recursos se baseasse somente em dois parâmetros: o período de tempo (determinado ano) e o tribunal

\footnotetext{
${ }^{807}$ Vide Ap. c/Rev. 606.170-00/5. $5^{\text {a }}$ Câmara do Extinto Segundo Tribunal de Alçada Civil de São Paulo. Rel. Juiz Luís de Carvalho. j. 31.10.01; Ap. 680.655-1. 8 $8^{\mathrm{a}}$ Câmara do Extinto Primeiro Tribunal de Alçada Civil de São Paulo. Rel. Juiz Costa Telles. j. 23.10.96; Ap. 70005473061. 9ª Câmara Cível do Tribunal de Justiça do Rio Grande do Sul. Rel. Adão Sérgio do Nascimento Cassiano. j. 10.12.03; Ap. 70006227599. 9a Câmara Cível do Tribunal de Justiça do Rio Grande do Sul. Rel. Adão Sérgio do Nascimento Cassiano. j. 29.09.04.

${ }^{808}$ ANDRADE, Fábio Siebeneichler de. Responsabilidade civil do advogado. Revista dos Tribunais, São Paulo, ano 82, n. 697, nov. 1993. p. 27.

${ }^{809}$ CALAMANDREI, Piero. Opere Giuridiche. In: DIAS, Sérgio Novais. Responsabilidade civil do advogado - perda de uma chance, p. 59.
} 
para o qual seria enviado o recurso; assim, não se faria uma avaliação da matéria discutida $^{810}$.

Entende-se, no entanto, que o raciocínio em análise padece de erro grave, pois nivela em condição de igualdade matérias mais ou menos controvertidas e que possuem chances diferentes de sucesso perante determinado tribunal.

Sustenta-se, igualmente, que o período da pesquisa deverá variar de acordo com as alterações legislativas que regem a matéria objeto de discussão e não ser estabelecida arbitrariamente. No caso das matérias que sofreram alteração pelo CC de 2002, há que se analisar somente a jurisprudência posterior a esse período, o mesmo se aplicando para quaisquer outros assuntos.

O advogado não há de ser responsabilizado, nos termos da teoria da perda de uma chance, se comprovar que o cliente não teria sua pretensão acolhida mesmo se tivesse praticado a tempo o ato que lhe competia, seja o ajuizamento de uma ação antes do prazo prescricional, seja a interposição do recurso cabível antes de findo o prazo preclusivo ${ }^{811}$; no entanto, há de ser responsabilizado por não ter atuado no momento oportuno, o que possibilita a aplicação das normas pertinentes à mora e ao inadimplemento contratual, como, por exemplo, a constante do art. 399 do CC, que já foi objeto de comentários no Capítulo 3. O mesmo raciocínio deve ser aplicado ao recurso não recebido por deserção ${ }^{812}$.

Sérgio Novais Dias assinala que, ainda que o cliente tenha poucas chances, pode o profissional ser condenado a indenizá-lo a título de danos morais, desde que aquele não visasse com o recurso procrastinar, mas se encontrasse sinceramente inconformado com a decisão prolatada. De acordo com o autor, esse inconformismo é a razão pela qual foi concebido o duplo grau de jurisdição ${ }^{813}$.

Fábio Siebeneichler de Andrade acrescenta, por sua vez, especificamente com relação aos recursos, que sempre há possibilidade de reforma da sentença ${ }^{814}$. Yves Avril esposa o mesmo entendimento, afirmando que "aucune décision de justice ne saurait être

\footnotetext{
${ }^{810}$ DIAS, Sérgio Novais. Responsabilidade civil do advogado - perda de uma chance, p. 59.

${ }^{811}$ AGUIAR DIAS, José de. Da responsabilidade civil, t. II, p. 324.

${ }^{812}$ TJSP. 28 $8^{\mathrm{a}}$ Câmara de Direito Privado. Ap. 992070537851. Rel. Cesar Lacerda. j. 09.11.2010. v.u.

${ }^{813}$ DIAS, Sérgio Novais, op. cit., p. 52.

${ }^{814}$ ANDRADE, Fábio Siebeneichler de. Responsabilidade civil do advogado. Revista dos Tribunais, ano 82, n. 697 , p. 27.
} 
considerée comme échappant à toute possibilité de réformation", ou seja, nenhuma decisão judicial deve ser considerada impossível de sofrer algum tipo de modificação ${ }^{815}$.

A despeito do pensamento dos referidos autores, entende-se que, se as chances de provimento do recurso se aproximavam de zero por cento, não será o caso de se conceder indenização, seja a título de danos tanto patrimoniais como morais, pois o recurso será procrastinatório $^{816}$. A interposição de recurso pelo simples desejo de ver a matéria ser apreciada de novo é interesse manifestamente contrário à manutenção da justiça e não deve ser incentivado.

O causídico não será responsabilizado pela falta de interposição do recurso quando esta foi ocasionada por culpa exclusiva do cliente, que pode derivar, v.g., da falta de um documento, ou do não pagamento do preparo do recurso.

Já no que concerne à omissão de produção de prova, torna-se mais difícil responsabilizar o causídico, uma vez que, enquanto os prazos de prescrição, decadência e preclusão estão todos dispostos na lei, as provas necessárias ao prosseguimento da lide variam de acordo com o caso concreto ${ }^{817}$.

É importante ressaltar que a chance ou oportunidade não se confundem com a atuação diligente do profissional em todos os níveis. Muitas vezes, a falta de produção de determinada prova pode decorrer do comportamento negligente do patrono da causa, mas este somente será responsabilizado se o erro for de fato inescusável ou prejudicar efetivamente a demanda ${ }^{818}$. O cliente deverá demonstrar, ainda, que a falta de produção da mencionada prova ocasionou a perda do processo ou do pedido formulado ${ }^{819}$.

O extravio dos autos do processo, por sua vez, constitui erro grave, sendo muito difícil de ser ilidido pelo advogado, exceto se este possa comprovar a ocorrência de força maior, caso fortuito e outras excludentes de responsabilidade civil. Nesse caso, portanto, não bastaria provar que a ação frustrada não teria futuro, uma vez que essa alegação

\footnotetext{
${ }^{815}$ AVRIL, Yves. La responsabilité de l'avocat. Paris: Dalloz, 1981. p. 45.

${ }^{816}$ Comunga do mesmo entendimento, Rafael Peteffi da Silva (Responsabilidade civil pela perda de uma chance, p. 215).

${ }^{817}$ O Tribunal de Justiça de São Paulo considerou um advogado negligente por não ter informado o perito sobre o local de realização da perícia (TJSP. 35 ${ }^{\mathrm{a}}$ Câmara de Direito Privado, Ap. 992070267943. j. 18.10.10. v.u.).

${ }^{818}$ BENETI FILHO, Sidnei Agostinho. A atividade advocatícia e a responsabilidade civil decorrente, p. 296. $\mathrm{O}$ advogado pode ser responsabilizado por não arrolar testemunhas, quando se julgar que estas eram essenciais para o provimento da demanda (TJRJ. 4" Câmara Cível. Ap. 0000700-27.2007.8.19.0001. Rel. Des. Horacio S. Ribeiro Neto. j. 02.06.09. v.u.).

${ }^{819}$ Ibidem, p. 296.
} 
deporia contra sua própria atuação profissional. Com efeito, se entendia que a demanda não tinha chance de ser julgada procedente, não deveria nem sequer ter aceitado propô$\mathrm{la}^{820}$. Atenua-se a responsabilidade, entretanto, se for demonstrada a possibilidade de mudança jurisprudencial sobre o assunto, o que não raro se observa.

A ausência de apresentação de contrarrazões de recurso, outra das hipóteses aventadas por Sérgio Novais Dias, é menos relevante, e muito raramente implicaria a perda da chance do cliente, uma vez que toda a matéria já foi deduzida em primeira instância. Configura, no mais das vezes, somente negligência do profissional, e não perda da chance.

De fato, é indubitável que compete ao advogado a apresentação de contrarrazões (ou contraminuta de agravo), se foi contratado para o acompanhamento de determinada lide em todas as instâncias; no entanto, tal falta não há que ser penalizada por meio da imposição de uma indenização, mas, no máximo, pela perda de parte de seus honorários advocatícios em razão do inadimplemento contratual.

A ausência de contrarrazões pode, excepcionalmente, configurar perda de uma chance. Sérgio Novais Dias oferece como exemplo dessa situação o recebimento de documentos novos, posteriores ao julgamento de primeira instância da causa, os quais seriam úteis para combater os argumentos da apelação ${ }^{821}$.

No que tange à análise da ausência de sustentação oral de recurso, sustenta-se que esta não é apta a gerar indenização por falta profissional; aliás, na prática, a mencionada sustentação é exceção, e não regra, sendo em geral exercida por advogados contratados para esse fim específico, em razão de notório conhecimento e influência intelectual em relação aos desembargadores do tribunal.

Se o advogado, no entanto, foi expressamente contratado para a apresentação de sustentação oral e não o fez, a questão se resolve na condenação de devolução de seus honorários, bem como do pagamento de custas e despesas processuais. Observe-se, porém, no que diz respeito, em específico, à apresentação de sustentação, que esta se trata de obrigação de resultado, e não de meio ${ }^{822}$. Isso não significa, contudo, que o advogado se obriga a obter o resultado favorável da demanda do cliente com a sustentação, mas tão somente que deve realizá-la de maneira adequada, em conformidade com o que se espera de um profissional de sua especialidade.

\footnotetext{
${ }^{820}$ DIAS, Sérgio Novais. Responsabilidade civil do advogado - perda de uma chance, p. 77.

${ }^{821}$ Ibidem, p. 79-80.

${ }^{822}$ BENETI FILHO, Sidnei Agostinho. A atividade advocatícia e a responsabilidade civil decorrente, p. 298.
} 
Acerca da ação rescisória, que tem por objetivo rescindir a sentença como ato jurídico viciado ${ }^{823}$, Sérgio Novais Dias entende que sua propositura é obrigatória pelo advogado, desde que esteja enquadrada nas hipóteses legalmente previstas ${ }^{824}$.

Em que pese o respeitável posicionamento do doutrinador - e levando-se em consideração que, para a propositura de ação rescisória, há que se depositar uma multa de $5 \%$ sobre o valor da causa, prevista no art. 488, inc. II, do CPC -, caberá ao advogado somente o dever de informar o cliente sobre a possibilidade de propositura da referida ação, a qual ficará condicionada ao pagamento de custas pelo próprio cliente ${ }^{825}$.

Por fim, no que concerne à indenização dos danos ora elencados, é possível adotar uma de três soluções: considerar a perda da chance como dano moral e conceder indenização a esse título, em montante que será estimado pelo próprio juiz; proceder ao balanço estatístico das probabilidades e reparar a perda da chance com uma porcentagem da pretensão da demanda ${ }^{826}$; ou, então, simplesmente condenar o advogado à devolução dos valores recebidos a título de honorários, despesas e custas judiciais ${ }^{827}$.

Clara está, portanto, a necessidade de reconhecimento da reparação da perda da chance para que algumas espécies de prejuízo sejam reparadas, o que ocorre com frequência no âmbito da responsabilidade civil do advogado. De fato, no caso de omissão e desídia do patrono, a única maneira de se indenizar a vítima com coerência é considerar a oportunidade perdida e conceder indenização proporcional à probabilidade de concretização da chance perdida.

\footnotetext{
${ }^{823}$ THEODORO JUNIOR, Humberto. Curso de Direito Processual Civil, p. 573.

${ }^{824}$ DIAS, Sérgio Novais. Responsabilidade civil do advogado - perda de uma chance, p. 84-87.

825 O artigo em comento possui a seguinte redação: "A petição inicial será elaborada com observância dos requisitos essenciais do Art. 282, devendo o autor:

I - cumular ao pedido de rescisão, se for o caso, o de novo julgamento da causa;

II - depositar a importância de 5\% (cinco por cento) sobre o valor da causa, a título de multa, caso a ação seja, por unanimidade de votos, declarada inadmissível, ou improcedente".

${ }^{826}$ Sobre essa hipótese de indenização, esclarece Sílvia Vassilieff que: "Como a grande dificuldade é valorar a perda de uma chance, uma solução seria, com fundamentos estatísticos baseados na jurisprudência dos tribunais superiores, estabelecer as probabilidades de lograr êxito em uma determinada causa e obrigar o advogado a pagar, não o valor da causa, mas o valor da probabilidade estatística de ganhar a causa. Tal solução, contudo, esbarra numa questão de ordem técnica e estatística, de como estabelecer probabilidades em situação tão imprevisível como o resultado de uma demanda judicial" (Responsabilidade civil do advogado, p. 71).

${ }^{827}$ Sobre esse assunto, Sérgio Novais Dias adverte que, se o advogado for condenado a pagar indenização, fará jus aos honorários; estes deverão ser compensados, "de sorte que o cliente pagará apenas a quantia remanescente, se o valor do dano for inferior ao dos honorários, ou o advogado pagará ao cliente a quantia que sobejar, se a indenização superar o quantum dos honorários pactuados” (op. cit., p. 89).
} 


\subsection{A responsabilidade sobre as ofensas irrogadas em juízo e pela litigância de má-fé}

Conforme mencionado no início deste Capítulo, o art. 133 da CF consagrou a indispensabilidade da figura do advogado para a administração da justiça, da qual decorre a inviolabilidade desse profissional e sua imunidade judiciária. A inviolabilidade, do ponto de vista positivo, abrange a imunidade profissional por suas manifestações e palavras, a garantia do sigilo profissional, bem como a proteção dos meios de trabalho, incluindo as instalações e os documentos do causídico. Do ponto de vista negativo, ressalte-se o poder exclusivo da Ordem dos Advogados do Brasil (OAB) em punir disciplinarmente os profissionais que atuarem com abuso de direito.

A imunidade profissional, em seus dois aspectos, consta do art. $7^{\underline{o}}, \S 2^{\underline{o}}$, do EAOAB, que assim dispõe:

\section{“[...]}

$\S 2^{\underline{o}}$. O advogado tem imunidade profissional, não constituindo injúria ou difamação puníveis qualquer manifestação de sua parte, no exercício de sua atividade, em juízo ou fora dele, sem prejuízo das sanções disciplinares perante a $\mathrm{OAB}$, pelos excessos que cometer".

No mesmo sentido, dispõe o CP, no art. 142, inc. I, que não constitui injúria ou difamação punível, a ofensa irrogada em juízo, na discussão da causa, pela parte ou por seu procurador.

Isso não significa que seja permitido ao advogado ofender as partes, o magistrado ou o membro do Ministério Público (MP). Sempre que sua atuação configurar violação do direito à honra ou outro direito da personalidade, deverá ser responsabilizado ${ }^{828}$. A esse propósito, verifique-se recente decisão do TJRJ:

“Apelação cível. Ação de responsabilidade civil. Indenização por danos morais. Atuação do advogado. Ofensas à honra da advogadaautora em petição protocolizada nos autos da ação de reintegração de posse movida em face dos clientes do réu, patrocinados pela

828 GAGliANO, Pablo Stolze; PAMPLONA FILHO, Rodolfo. Novo curso de Direito Civil responsabilidade civil, p. 229. Também: STJ. 4ª T. REsp 988380/MG. Rel. Min. Luis Felipe Salomão. j. 20.11.08. v.u. 
autora. Responsabilidade subjetiva extracontratual. Inteligência dos artigos 186 c.c. 927 caput do CC. STJ que firmou o entendimento de que a imunidade profissional do advogado, prevista no art. 133 da $\mathrm{CF} / 88$ e nos [sic] Estatuto da Advocacia e da OAB não alberga eventuais excessos cometidos pelo causídico em afronta à honra de quaisquer das pessoas envolvidas no processo. Dano moral configurado. Quantum indenizatório que merece redução para melhor se adequar aos parâmetros desta Corte. Provimento parcial do recurso para reduzir a indenização ao patamar de $\mathrm{R} \$ 5.000,00$ (cinco mil reais). Sentença mantida quanto ao mais" ${ }^{, 829}$.

De fato, como ressalta Sérgio Cavalieri Filho, à imunidade do advogado se contrapõe a inviolabilidade da honra do ofendido ${ }^{830}$. Não lhe é vedado, contudo, criticar decisões judiciais, desde que sejam atacados os argumentos jurídicos e não a pessoa do juiz $^{831}$. Da mesma forma, também se admite que o advogado seja combativo no tocante às decisões que prejudicam seu cliente, não sendo lícita, entretanto, a imputação leviana de crime às outras partes e ao julgador ${ }^{832}$.

Frise-se, ainda, no que tange à responsabilidade por ofensas irrogadas em juízo, que o advogado, mesmo quando empregado, responde pessoalmente, não sendo o caso de responsabilização do empregador ${ }^{833}$.

No que tange à condenação por litigância de má-fé, entretanto, somente a parte litigante pode ser penalizada com as multas previstas no art. 18 do $\mathrm{CPC}^{834}$, mas não seu

${ }^{829}$ TJRJ. 5a Câmara Cível. Ap. 0007934-52.2006.8.19.0209. Rel. Des. Cristina Tereza Gaulia. j. 10.08.10. v.u.

${ }^{830}$ CAVALIERI FILHO, Sérgio. Programa de responsabilidade civil, p. 388.

${ }^{831}$ STJ. $3^{\underline{a}}$ T. REsp 531335/MT. Rel. Min. Nancy Andrighi. j. 02.09.08. v.u.

${ }^{832}$ STJ. $3^{\mathrm{a}}$ T. REsp 854452/RS. Rel. Min Humberto Gomes de Barros. j. 22.08.08. v.u.

${ }^{833}$ STJ. 4. T. REsp 983430/ES. Rel. Min. Fernando Gonçalves. j. 01.12.09. v.m.

${ }^{834}$ A litigância de má-fé consta do art. 17 do CPC que possui a seguinte redação:

"Art. 17 - Reputa-se litigante de má-fé aquele que:

I - deduzir pretensão ou defesa contra texto expresso de lei ou fato incontroverso;

II - alterar a verdade dos fatos;

III - usar do processo para conseguir objetivo ilegal;

IV - opuser resistência injustificada ao andamento do processo;

$\mathbf{V}$ - proceder de modo temerário em qualquer incidente ou ato do processo;

VI - provocar incidentes manifestamente infundados;

VII - interpuser recurso com intuito manifestamente protelatório".

$\mathrm{O}$ art. 18 estabelece a penalidade cabível: "O juiz ou tribunal, de ofício ou a requerimento, condenará o litigante de má-fé a pagar multa não excedente a um por cento sobre o valor da causa e a indenizar a parte contrária dos prejuízos que esta sofreu, mais honorários advocatícios e todas as despesas que efetuou. 
advogado, cuja atuação deve ser objeto de processo autônomo ${ }^{835}$. Rossana Teresa Curioni diverge desse entendimento. ${ }^{836}$ A doutrinadora defende que os advogados (e procuradores das Fazendas e suas autarquias) também podem ser condenados nas penas decorrentes da litigância de má-fé, sendo o caso, inclusive, de encaminhamento de comunicado à OAB sempre que a infração se verificar em determinado processo. A autora conclui sua exposição afirmando que a parte prejudicada poderia ingressar com ação diretamente em face do advogado do outro litigante, havendo solidariedade entre o profissional e o cliente em caso de configuração de litigância de má-fé e $^{837}$.

No que tange à condenação do advogado por litigância de má-fé, entende-se que esta é afastada pela própria sistemática processual, eis que os arts. 17 e 18 do CPC se encontram inseridos na seção intitulada "Da responsabilidade das partes por dano processual", o que denota a vontade do legislador que o causídico não respondesse pela atuação judiciária nos próprios autos. No tocante ao ingresso de ação direta em face do advogado da parte contrária fundamentada nas hipóteses constantes do art. 17 do CPC, admite-se que essa é possível, porém de difícil manejo, em face da necessidade de se comprovar que o advogado extrapolou os limites normais de defesa de seu cliente e tinha intenções escusas de prejudicar diretamente a parte contrária. A responsabilidade solidária do advogado somente pode advir de sua atuação dolosa ${ }^{838}$. Não se pode perder de vista que, a despeito da atuação do advogado, o proveito da lide, mesmo que temerária, é, em princípio, de seu patrocinado. Justifica-se, assim, que a responsabilidade pese sobre aquele que obtém os maiores proveitos.

\subsection{A responsabilidade por violação do dever de sigilo}

O dever de sigilo, de acordo com Jorge Mosset Iturraspe, é "la obligación de alcance jurídico y no sólo ético, de mantener la reserva de cualquier hecho cuya

\footnotetext{
$\S 1^{0}$ - Quando forem dois ou mais os litigantes de má-fé, o juiz condenará cada um na proporção do seu respectivo interesse na causa, ou solidariamente aqueles que se coligaram para lesar a parte contrária. $\$ \mathbf{2}^{\mathbf{o}}$ - O valor da indenização será desde logo fixado pelo juiz, em quantia não superior a $20 \%$ (vinte por cento) sobre o valor da causa, ou liquidado por arbitramento".

${ }^{835}$ STJ. $3^{\mathrm{a}}$ T. AgRg no REsp 696102/RN. Rel. Min. Paulo de Tarso Sanseverino. j. 06.10.10. v.u.; STJ. $4^{\mathrm{a}}$ T. REsp 140578/SP. Rel. Min. Luis Felipe Salomão. j. 15.12.08. v.u.

${ }^{836}$ CURIONI, Rossana Teresa. Responsabilidade civil por dano processual decorrente de litigância de má fé. In: HIRONAKA, Giselda Maria Fernandes Novaes (Coord.). Direito e Responsabilidade, p. 490-494.

837 Ibidem, loc. cit.

${ }^{838}$ RIZZARDO, Arnaldo. Responsabilidade civil, p. 309.
} 
divulgación o revelación tenga la aptitud de ocasionar un daño patrimonial o moral, sea a la persona que confió ese secreto, sea a un tercero" ${ }^{\text {"839. }}$.

O advogado, assim como o médico, tem obrigação de não divulgar as informações que lhe tenham sido confidenciadas no exercício de seu ofício ${ }^{840}$, sob pena de infração disciplinar, conforme disposto no art. 32, inc. VII, do EAOAB, e responsabilização penal, nos termos do art. 154 do $\mathrm{CP}^{841}$.

Em verdade, a obrigação de confidencialidade existe em todas as hipóteses em que um profissional seja detentor de informação estritamente pessoal e íntima, e cuja revelação possa trazer prejuízo para o cliente ${ }^{842}$. É evidente, portanto, que tal obrigação ganha especial relevo na atividade advocatícia.

São excludentes do dever de sigilo, v.g., a intenção do cliente de cometer crime ${ }^{843}$, a defesa dos direitos do advogado - inclusive para propositura de cobrança de honorários advocatícios -, o consentimento do cliente para a divulgação da informação, ou a notoriedade do fato, provado em juízo ou constante de registro público.

A atividade do advogado faz que seus prepostos e empregados possam ter informações sobre os dados sigilosos; nesse caso, também têm o dever de sigilo ${ }^{844}$.

\subsection{A responsabilidade civil dos mandatários}

A obrigação dos mandatários, assim como a dos advogados, é de meio, devendo esses, portanto, diligenciar para obtenção dos atos ou negócios jurídicos pretendidos pelo mandante. Da mesma forma, é intuitu personae, eis que o contrato de mandato é de confiança, extinguindo-se com a morte ou a incapacidade superveniente do mandatário ou do mandante, nos termos do art. 682 do CC. Também em decorrência do caráter de confiança, pode ser revogado a qualquer tempo, ad nutum.

${ }^{839}$ ITURRASPE, Jorge Mosset. Responsabilidad por daños - el incumplimiento contractual, t. II, p. 297. Tradução livre: "a obrigação de alcance jurídico e não apenas ético, de manter o sigilo de qualquer fato cuja divulgação ou revelação tenha aptidão para ocasionar um dano patrimonial ou moral, seja à pessoa que lhe confiou o segredo, seja a um terceiro".

${ }^{840}$ VASSILIEFF, Sílvia. Responsabilidade civil do advogado, p. 51.

${ }^{841} \mathrm{O}$ tipo penal em comento é assim redigido: “Art. 154 - Revelar alguém, sem justa causa, segredo, de que tem ciência em razão de função, ministério, ofício ou profissão, e cuja revelação possa produzir dano a outrem".

${ }^{842}$ REPRESAS, Félix A Trigo. MESA, Marcelo J. López. Tratado de la responsabilidad civil, t. II, p. 513.

${ }^{843} \mathrm{O}$ advogado deve manter o sigilo sobre fatos referentes a um crime já cometido, quando relacionado com sua atuação judicial; no entanto, se o cliente relata que pretende cometer um delito, o profissional deve comunicar às autoridades a intenção que lhe foi manifestada.

${ }^{844}$ VASSILIEFF, Sílvia, op. cit., p. 53. 
A diferenciação que pode ser feita entre a obrigação do mandatário e do advogado é que, no primeiro caso, forma-se apenas um contrato de mandato, que não é para realização de atos em juízo, enquanto, com relação ao segundo, predomina um contrato de prestação de serviço em detrimento da mera representação.

De fato, por meio do contrato de mandato, o mandatário se obriga a realizar, por conta e encargo do mandante, atos e negócios jurídicos ${ }^{845}$. A atuação do advogado, como se infere do que foi exposto anteriormente, é mais extensa do que a mera representação. Todo mandato tem um encargo e instruções ou direções, mais ou menos precisas, sobre a maneira de cumpri-lo. O advogado atua no interesse do cliente, mas decide por conta própria os procedimentos que deverão ser tomados. O CC, antevendo essa diferença de atuação, dispôs, no art. 692, que o mandato judicial fica subordinado às normas que lhe dizem respeito, sendo apenas supletivamente regido pelo Diploma Civil.

O mandato pode ser com ou sem representação. Quando ocorre a representação, opera-se um fenômeno semelhante ao desdobramento da personalidade ou sua multiplicação; é como se o mandante adquirisse um dom de ubiquidade que lhe permitisse estar em vários lugares ao mesmo tempo ${ }^{846}$. Na hipótese do mandato sem representação, o mandatário atua no interesse do mandante, mas utiliza seu próprio nome. Caso não se valha do nome do mandante, responderá pelos próprios danos em relação a terceiros ${ }^{847}$. É o que dispõe o art. 663 do CC:

\footnotetext{
“Art. 663. Sempre que o mandatário estipular negócios expressamente em nome do mandante, será este o único responsável; ficará, porém, o mandatário pessoalmente obrigado, se agir no seu próprio nome, ainda que o negócio seja de conta do mandante".
}

O mandato pode ser gratuito ou oneroso. Presume-se, porém, que seja oneroso quando consista em trabalhos próprios da profissão lucrativa ou de seu modo de vida.

\footnotetext{
${ }^{845} \mathrm{O}$ contrato em comento se encontra definido no art. 653 do CC: "Art. 653. Opera-se o mandato quando alguém recebe de outrem poderes para, em seu nome, praticar atos ou administrar interesses. A procuração é o instrumento do mandato".

${ }^{846}$ ITURRASPE, Jorge Mosset. Responsabilidad por daños - el incumplimiento contractual, t. II, p. $432-$ 433.

${ }^{847}$ Ibidem, p. 428.
} 
Quando não se tiver convencionado que o mandatário perceba uma retribuição por seu trabalho, presume-se que o contrato é gratuito ${ }^{848}$.

As principais obrigações do mandatário são a execução do encargo, a atuação com diligência e a realização da prestação de $\operatorname{contas}^{849}$, ao passo que, ao mandante, cabe facilitar a execução das tarefas do mandatário, a retribuição e o ressarcimento dos danos sofridos como consequência da interposição. O mandatário será responsabilizado quando não cumprir com seus deveres, bem como quando substabelecer mandato sem autorização, e empregar verbas do mandante em proveito próprio.

O mandante responde pelos atos do mandatário objetivamente, uma vez que este se insere na função de preposto constante do art. 932, inc. III, do CC, mas tem direito de regresso em face deste ${ }^{850}$.

\subsection{A responsabilidade civil dos tabeliães, notários e registradores}

O tabelionato, também chamado de cartório não oficializado, é uma instituição muito antiga, cuja existência está vinculada à necessidade de segurança jurídica que deve existir em toda sociedade politicamente organizada ${ }^{851}$. Essa segurança exige que determinados atos sejam revestidos do caráter de certeza. Para isso, o Estado delega a fé pública aos tabeliães, notários e registradores, de modo que os atos por estes autorizados sejam considerados autênticos ${ }^{852}$.

Os tabeliães ${ }^{853}$ desenvolvem atividade conexa à dos advogados, contudo, tal atividade diferencia-se da dos causídicos em virtude de seu caráter público. De fato, os tabeliães exercem suas atividades como particulares em colaboração com o Poder Público, desenvolvendo função pública mediante delegação, sendo considerados servidores

\footnotetext{
${ }^{848}$ Em conformidade com o disposto no art. 658 do CC: "O mandato presume-se gratuito quando não houver sido estipulada retribuição, exceto se seu objeto corresponder ao daquele que o mandatário trata por ofício ou profissão lucrativa". Esclarecendo o disposto no artigo, verifique-se: José Fernando Simão (Direito Civil contratos. 4. ed. São Paulo: Atlas, 2010. p. 295).

${ }_{850}^{849}$ DINIZ, Maria Helena. Curso de Direito Civil brasileiro - responsabilidade civil, p. 285.

${ }^{850}$ Ibidem, p. 287.

${ }^{851}$ STOCO, Rui. Tratado de responsabilidade civil, p. 569.

${ }^{852}$ DI PROSPERO, Mariana. Responsabilidad del escribano. In: GHERSI, Carlos Alberto (Director). Responsabilidad profesional, v. 2, p. 33.

${ }^{853}$ No presente trabalho, em toda a oportunidade que se fizer referência ao termo "tabelião", pode-se entender estarem abrangidos igualmente os notários e os registradores.
} 
públicos em sentido amplo ${ }^{854}$, de acordo com o disposto pelo art. 236 da CF, a seguir transcrito:

“Art. 236. Os serviços notariais e de registro são exercidos em caráter privado, por delegação do Poder Público.

$\S 1^{\underline{0}}$ - Lei regulará as atividades, disciplinará a responsabilidade civil e criminal dos notários, dos oficiais de registro e de seus prepostos, e definirá a fiscalização de seus atos pelo Poder Judiciário.

$\S 2^{\underline{o}}$ - Lei federal estabelecerá normas gerais para fixação de emolumentos relativos aos atos praticados pelos serviços notariais e de registro.

$\S 3^{0}-\mathrm{O}$ ingresso na atividade notarial e de registro depende de concurso público de provas e títulos, não se permitindo que qualquer serventia fique vaga, sem abertura de concurso de provimento ou de remoção, por mais de seis meses".

A propósito desse assunto, Carlos Roberto Gonçalves salienta:

"Parece-nos que se justifica plenamente a inserção dos serventuários da justiça no rol dos servidores públicos, dos funcionários públicos em sentido lato, a despeito do 'caráter privado' como são exercidos os serviços que lhes são pertinentes, pois ocupam cargos criados por lei, com denominação própria e em número certo, são nomeados pelo Poder Público, mediante concurso público, gozam do direito a férias e licenças, estão sujeitos a regime disciplinar, contribuem para o instituto de Previdência do estado, fazem jus à aposentadoria nos termos do Estatuto dos Funcionários Públicos. E, embora não remunerados diretamente pelos cofres públicos, o preço de seus serviços, pagos

\footnotetext{
${ }^{854}$ DI PIETRO, Maria Sylvia Zanella. Direito administrativo, p. 482; MELLO, Celso Antônio Bandeira de. Curso de Direito Administrativo. 17. ed. São Paulo: Malheiros, 2004. p. 232; ARAUJO, Edmir Netto de. Curso de Direito Administrativo, p. 256. A mesma natureza jurídica de delegação é observada na Argentina, segundo Mariana Di Prospero (Responsabilidad del escribano. In: GHERSI, Carlos Alberto (Director). Responsabilidad profesional, v. 2, p. 35).
} 
pelos usuários, decorre de tabelas também aprovadas pelo Poder Público" 855 .

A despeito da função pública, esses profissionais são pessoas físicas que prestam serviços ao Estado sem vínculo empregatício, recebendo remuneração pelos terceiros usuários do serviço, e não pelo ente público, conforme observado por Carlos Roberto Gonçalves ${ }^{856}$. Isso, contudo, não afasta a responsabilidade estatal, como bem assinala Clayton Reis:

\begin{abstract}
"Portanto, é absolutamente cristalina a conclusão de que ao delegar poderes, o Estado reserva para si o direito de controlar, fiscalizar e ditar normas, a fim de que o interesse público sobreleve sobre o particular. A delegação difere assim, da iniciativa privada, cujo nascimento decorre da affectio societatis e é comandada por obrigações contratuais firmadas pelo acordo de vontades individuais. O Estado, nesse caso, apenas observa se os objetivos e as cláusulas dos estatutos constitutivos obedeceram aos conceitos de moralidade e legalidade" 857 .
\end{abstract}

O tabelião é, portanto, operador do direito encarregado de uma função pública, que consiste em receber, interpretar e dar forma legal à vontade das partes, redigindo instrumentos adequados para esse fim, e, em conformidade com o art. $1^{\underline{o}}$ da Lei n. 8.935, de 18 de novembro de 1994, que regulamenta o art. 236 da CF, destinado "a garantir a publicidade, autenticidade, segurança e eficácia dos atos jurídicos".

O tabelião, o notário ${ }^{858}$, ou o registrador, conforme estabelece o art. $5^{0}$ da legislação retromencionada, podem exercer seu ofício nas seguintes modalidades:

- tabelião de notas;

- tabelião e oficial de registro de contratos marítimos;

\footnotetext{
${ }^{855}$ GONÇALVES, Carlos Roberto. Responsabilidade civil, p. 470-471.

${ }^{856}$ Ibidem.

${ }^{857}$ REIS, Clayton. A responsabilidade civil do notário e do registrador. Revista dos Tribunais, São Paulo, v. 83, n. 703, maio 1994. p. 19.

${ }^{858} \mathrm{O}$ art. $3^{\mathrm{o}}$ da Lei n. 8.935/1994 iguala os dois termos (tabelião e notário), mas em regra se associa o termo "notário" ao tabelião de notas.
} 
- tabelião de protesto de títulos;

- oficial de registro de imóveis;

- oficial de registro de título e documentos e civis das pessoas jurídicas;

- oficial de registro civil das pessoas naturais e de interdições e tutela;

- oficial de registro de distribuição.

Em qualquer caso, o profissional é encarregado da lavratura de atos para lhe conferir autenticidade e fé. De acordo com o art. $7^{\circ}$ do mesmo Diploma legal, o tabelião de notas tem algumas funções privativas, como lavrar escrituras e procurações públicas, lavrar testamentos públicos ${ }^{859}$ e aprovar os cerrados, reconhecer firmas e autenticar cópias.

\subsubsection{Responsabilidade contratual e extracontratual dos tabeliães, notários e registradores}

Os tabeliães são chamados em juízo, com mais frequência, em virtude de sua atuação em cartórios de notas. As demandas giram em torno do reconhecimento de firma falsa, irregularidade em testamento ou escritura ${ }^{860}$, bem como de negócios jurídicos invalidados em razão da falsidade de mandato lavrado em cartório. De qualquer modo, em qualquer cartório não oficializado, a atuação dos tabeliães pode gerar dano para o requerente do serviço ou para terceiros. Sendo assim, sua responsabilidade poderá ser contratual ou extracontratual, de acordo com a posição da pessoa prejudicada.

\footnotetext{
${ }^{859} \mathrm{O}$ art. $20, \S 4^{\mathrm{o}}$, da Lei n. $8.935 / 1994$ determina que somente o próprio tabelião pode lavrar testamento, sendo vedada a atuação de assistente nessa esfera. O art. 1.864, inc. I, do CC, no entanto, define o testamento público como aquele que é elaborado pelo tabelião ou por seu substituto legal em seu livro de notas. Flávio Tartuce e José Fernando Simão observam a incongruência e assim se manifestam: "A Lei 8.935/1994, em seu art. $20, \S 4^{\circ}$, proibia aos substitutos que lavrassem testamentos. O dispositivo considera-se tacitamente revogado com a vigência do Código Civil de 2002 em razão da incompatibilidade das normas, já que o art. 1.864, I, prevê a possibilidade de atuação do substituto. Curioso notar que a Lei estadual paulista 12.227, de 12 de janeiro de 2006, reproduz a orientação da Lei Federal 8.935/1994, em seu art. 13, § 2º , contrariando expressamente o texto do Código Civil de 2002. Não há dúvidas de que deve-se considerar que essa lei estadual não tem mais aplicação, pois a lei codificada prevalece tendo em vista o critério hierárquico (norma superior prevalece sobre inferior)" (Direito Civil - direitos das sucessões. 2. ed. São Paulo: Método, 2008. v. 6, p. 289-290).

${ }^{860}$ AGUIAR DIAS, José de. Da responsabilidade civil, t. II, p. 334-335.
} 
Se a vítima for aquele que contratou seus serviços, os tabeliães responderão na modalidade contratual ${ }^{861}$. No que tange a terceiros, responderão pelos erros graves que cometerem no exercício da função, com fundamento na responsabilidade aquiliana ${ }^{862}$; caso, contudo, o terceiro prejudicado seja parte no instrumento viciado, poderá invocar os princípios da responsabilidade contratual em seu favor.

\subsubsection{Da obrigação assumida pelo tabelião, notário e registrador}

A responsabilidade dos tabeliães decorre do inadimplemento de obrigação de resultado ${ }^{863}$, perante as pessoas que contratam o correto exercício de suas funções. Sendo assim, o objetivo pretendido pelo cliente deve ser obtido, sob pena de inadimplemento. Isto significa que não basta ao tabelião demonstrar que atuou da melhor maneira possível, devendo comprovar, ao contrário, a conclusão perfeita do trabalho que se propôs a desenvolver.

Sua responsabilidade emergirá, portanto, sempre que causar dano ao cliente ou a terceiro, quando o fim pretendido pelo serviço não for devidamente atingido ou quando houver vício ou falha em sua realização ${ }^{864}$.

\subsubsection{Deveres do tabelião, notário e registrador}

O tabelião tem diversos deveres, como a conservação dos documentos que lhe foram entregues, a expedição de cópias das escrituras, a observância das normas estabelecidas pelo juízo competente, o tratamento das partes com respeito e presteza, entre $\operatorname{outros}^{865}$. Desses deveres, sobrelevam-se três: a prestação de assessoria à parte, os deveres registrais e o segredo profissional.

${ }^{861}$ DI PROSPERO, Mariana. Responsabilidad del escribano. In: GHERSI, Carlos Alberto (Director). Responsabilidad profesional, v. 2, p. 40-41.

${ }^{862}$ AGUIAR DIAS, José de. Da responsabilidade civil, t. II, p. 333.

${ }^{863}$ DI PROSPERO, Mariana, op. cit., p. 49; DINIZ, Maria Helena. Curso de Direito Civil brasileiro responsabilidade civil, p. 288. AGUIAR DIAS, José de, op. cit., p. 136: "A responsabilidade civil dos notários, tabeliães e oficiais de registro difere da responsabilidade profissional em geral. Porque, ao contrário dos médicos, advogados, etc., assumem obrigação de resultado. Daí a consequência: o erro profissional não lhes serve de escusa".

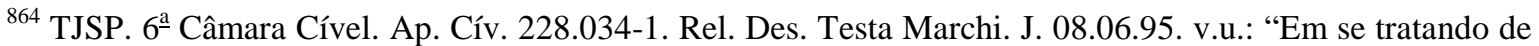
ação de responsabilidade civil, resultante de ato notarial, a mais ligeira culpa produz a obrigação de indenizar, respondendo o Tabelião perante aquele que perdeu o imóvel adquirido".

${ }^{865}$ Os deveres em referência constam do art. 30 da Lei n. 8.935/1994. 
No que tange ao primeiro dever, pode denotar não ser este cabível entre as obrigações do tabelião, eis que este desenvolve atividade meramente técnica; no entanto, não é o que se verifica na realidade. O tabelião deve apreciar a vontade dos requerentes de seus serviços, interpretá-la, enquadrá-la juridicamente e explicar o conteúdo do ato que querem instrumentalizar ${ }^{866}$. Tome-se como exemplo a redação do testamento público, que, de acordo com o disposto no art. 1.864, inc. I, do CC, deve ser escrito pelo tabelião, de acordo com as declarações do testador. Nesse caso, é evidente que o testador, se não foi previamente auxiliado por advogado, fará suas declarações de maneira pouco formal, cabendo ao tabelião organizá-las em termos jurídicos e esclarecer o que pode e o que não pode constar do testamento, sob pena de nulidade.

O tabelião tem, assim, a obrigação de fornecer informações corretas e orientar o requerente de seus serviços da melhor maneira possível. Quando, porém, observar-se que uma mesma matéria recebe orientações doutrinárias distintas, o profissional deverá optar por uma delas e esclarecer a dissidência ao cliente, para que este fique ciente, desde logo, da possibilidade de impugnação judicial do ato.

Com relação à segunda espécie de deveres, aos quais se chamou de registrais, o tabelião deve cumprir a legislação registrária que lhe impõe obrigações anteriores ou posteriores à celebração do ato jurídico. Conforme esclarecido no item anterior, tais deveres traduzem-se em obrigação de resultado; assim, v.g., tendo sido requisitado o registro de determinado documento, este deve ser feito tão logo quanto possível. Se o atraso no desempenho do dever do tabelião implicar dano ao requerente, aquele será responsabilizado civilmente.

Por fim, assim como o advogado, o tabelião também tem o dever de manter o segredo profissional a respeito de toda a informação à qual teve acesso por meio do exercício de sua profissão, conforme disposto no inc. VI, do art. 30, da Lei n. 8.935/1994. O segredo compreende todos os atos, circunstâncias, antecedentes e dados que o profissional tenha conhecido em virtude de sua profissão.

A documentação lavrada em cartório, por sua vez, somente poderá ser acessada por terceiros nos limites da lei. De fato, nem sempre o documento lavrado em cartório pode ser verificado por qualquer pessoa. É o caso, v.g., dos testamentos públicos. Apesar de públicos, sua existência não é comunicada ao público em geral em qualquer hipótese. $\mathrm{O}$

866 DI PROSPERO, Mariana. Responsabilidad del escribano. In: GHERSI, Carlos Alberto (Director). Responsabilidad profesional, v. 2, p. 43. 
item 26 das Normas de Serviço da Corregedoria Geral da Justiça de São Paulo determina que a informação acerca da existência de testamento somente possa ser fornecida depois que o testador tiver falecido, o que deverá ser comprovado mediante apresentação de certidão de óbito. Além disso, a informação somente será fornecida caso seja obtida autorização judicial ou o pedido seja deferido pelo juiz corregedor permanente da Comarca $^{867}$.

O profissional estará liberado da manutenção do segredo quando houver necessidade de que este seja revelado para sua própria defesa, ou houver dispensa do próprio interessado, desde que a revelação não gere prejuízos para terceiros. Se chamado em juízo, deverá comparecer, mas poderá se furtar a responder às questões que atinjam a esfera do segredo.

\subsubsection{Responsabilidade objetiva do Estado pelos atos dos tabeliães}

Conforme salientado, a atividade dos tabeliães é de natureza pública, razão pela qual esses profissionais são considerados agentes públicos lato sensu. Em razão dessa consideração, a eles se aplica o disposto no $§ 6^{\circ}$, do art. 37, da CF, in verbis:

“[...]

$\S 6^{0}-$ As pessoas jurídicas de direito público e as de direito privado prestadoras de serviços públicos responderão pelos danos que seus agentes, nessa qualidade, causarem a terceiros, assegurado o direito de regresso contra o responsável nos casos de dolo ou culpa”.

A despeito do mencionado dispositivo não fazer referência expressa às pessoas físicas delegatárias de serviço, a tese que sempre predominou na doutrina e na jurisprudência é a de que o Estado responde objetiva e solidariamente pelos danos que titulares das serventias extrajudiciais ou seus prepostos causarem a terceiros ${ }^{868}$. Será, no

${ }^{867}$ TARTUCE, Flávio; SIMÃO, José Fernando. Direito Civil - direito das sucessões, p. 293. Os autores assinalam, igualmente, que, a despeito de não haver norma sobre o assunto no CC, o Projeto de Lei 276/2007 propõe o acréscimo de um parágrafo no art. 1.864, para que dele conste: "A certidão do testamento público, enquanto vivo o testador, só poderá ser fornecida a requerimento deste ou por ordem judicial".

${ }^{868}$ STF. 2. T. RE 209354/PR. Rel. Min. Carlos Velloso. j. 02.03.1999. v.u.; STJ. 2. T. REsp 439465/MS. Rel. Min. Paulo Medina. j. 15.10.02. v.u.; STJ. 1. T. REsp 481939/GO. Rel. Min. Teori Albino Zavascki. J. 03.03.05. v.u.; TJSP. 13 ${ }^{\mathrm{a}}$ Câmara de Direito Público. Ap. 990.10.264825-7. Rel. Des. Borelli Thomaz. J. 27.10.10. v.m. 
entanto, facultado ao Poder Público se ressarcir em ação regressiva contra o causador do dano, desde que comprove a atuação culposa ou dolosa deste último ${ }^{869}$.

A esse propósito, Arnaldo Rizzardo enfatiza que:

"Verificada a responsabilidade dos funcionários públicos [...], indiscutível, também, a imputação da responsabilidade ao Estado, a teor do disposto no art. $37, \S 6^{\circ}$, da Constituição Federal, eis que os atos do Tabelionato e de Registro de Imóveis são de controle e responsabilidade do Poder Público. Qualquer ofensa e irregularidades na prática desses atos ocasiona a responsabilização do ente público responsável pelo serviço. [...]

Se a responsabilidade é solidária, transparece evidente a possibilidade de serem, Estado, Notário e Oficial de Registro acionados judicialmente em conjunto, respondendo pelos danos acarretados pelo ato estatal, consoante assegura o preceito contido no artigo 37, parágrafo $6^{\circ}$, da Constituição Federal”870.

É, no entanto, possível observar uma alteração da orientação jurisprudencial em decisão recente do STJ, na qual o tabelião foi responsabilizado objetivamente, ao passo que se sustentou que a responsabilidade do Estado é apenas subsidiária. Em razão da importância do julgado, transcreve-se a seguir um pequeno excerto:

"PROCESSUAL CIVIL E ADMINISTRATIVO. OFENSA AO ART. 535 DO CPC NÃO CONFIGURADA. CARTÓRIO NÃO OFICIALIZADO. ATIVIDADE DELEGADA. ART. 22 DA LEI 8.935/1994. RESPONSABILIDADE OBJETIVA DO TABELIÃO E SUBSIDIÁRIA DO ESTADO. DESNECES-SIDADE DE DENUNCIAÇÃO À LIDE. DANO MORAL. SÚMULA 7/STJ. DIVERGÊNCIA JURISPRUDENCIAL. SÚMULA 83/STJ.

\footnotetext{
${ }^{869}$ REIS, Clayton. A responsabilidade civil do notário e do registrador. Revista dos Tribunais, v. 83, n. 703, p. 20/22: "O tabelião ou registrador, embora não percebam dos cofres públicos, é funcionário público para efeito de responsabilidade civil, sendo indiscutível que ao Estado incumbe ressarcir os danos que tal funcionário causar a terceiros". No mesmo sentido, Rui Stoco (Tratado de Direito Civil, p. 573); Maria Helena Diniz (Curso de Direito Civil brasileiro - responsabilidade civil, p. 289) e Carlos Roberto Gonçalves (Responsabilidade civil, p. 468).

${ }^{870}$ RIZZARDO, Arnaldo. Responsabilidade civil, p. 392-394.
} 
$[\ldots]$

3. O exercício de atividade notarial delegada (art. 236, § $1^{\stackrel{0}{ }}$, da Constituição) deve se dar por conta e risco do delegatário, nos moldes do regime das concessões e permissões de serviço público.

4. Conforme decidido pela Segunda Turma no julgamento do Recurso Especial 1.087.862/AM, em caso de danos resultantes de atividade estatal delegada pelo Poder Público, há responsabilidade objetiva do notário, nos termos do art. 22 da Lei 8.935/1994, e apenas subsidiária do ente estatal. Precedentes do STJ.

5. O Código de Defesa do Consumidor aplica-se à atividade notarial.

6. Em se tratando de atividade notarial e de registro exercida por delegação, tal como in casu, a responsabilidade por danos é do notário, diferentemente do que ocorre quando se tratar de cartório ainda oficializado. Precedente do STF. [...]" $]^{\prime 871}$.

A decisão em comento deverá exercer influência sobre os tribunais inferiores ${ }^{872}$, contudo, entende-se ser mais acertado o posicionamento de responsabilidade solidária do Estado, que facilita o ressarcimento da vítima, na medida em que esta pode dirigir a ação em face do Estado ou do servidor ${ }^{873}$. Ademais, é a única interpretação que admite o art. 37, $\S 6^{\circ}$, da $\mathrm{CF}$, o qual está sendo diretamente contrariado pela tese da responsabilidade subsidiária do Estado pelos atos do tabelião.

\subsubsection{A responsabilidade individual dos tabeliães}

A responsabilidade dos tabeliães, tradicionalmente, era vista como subjetiva, o que se alterou após a vigência da Lei n. 8.935/1994, cujo art. 22 tem a seguinte redação: "os notários e os oficiais de registro responderão pelos danos que eles e seus prepostos causem a terceiros, na prática de atos próprios da serventia, assegurado aos primeiros direito de regresso no caso de dolo ou culpa dos prepostos".

${ }^{871}$ STJ. 2. T. REsp 1163652/PE. Rel. Min. Herman Benjamin. j. 01.06.10. v.u.

${ }^{872}$ TJRJ. 8 ${ }^{a}$ Câmara Cível. Ap. 0025616-57.2009.8.19.0001. Rel. Des. Katya Monnerat. j. 20.07.10. v.u.

${ }^{873}$ GONÇALVES, Carlos Roberto. Responsabilidade civil, p. 471. 
O dispositivo em comento, assim, permitiu duas interpretações: a primeira foi a de que a responsabilidade do tabelião remanescia subjetiva, ao passo que a do Estado, por atos desse profissional, seria objetiva. Desse modo, se o ofendido demandasse diretamente o Estado, o faria com fundamento na responsabilidade objetiva administrativa, livrando-se do ônus da comprovação de culpa ou dolo. Caso, entretanto, optasse por ingressar com ação em face da pessoa física do tabelião, deveria comprovar que o causador do dano agiu dolosa ou culposamente ${ }^{874}$. Esse entendimento é corroborado pelo disposto no art. 28 da Lei n. 6.015/1973 (Lei de Registros Públicos), que possui a seguinte redação: "Além de casos expressamente consignados, os oficiais são civilmente responsáveis por todos os prejuízos que, pessoalmente ou pelos seus prepostos ou substitutos que indicarem, causarem, por culpa ou dolo, aos interessados no registro"; e pela Lei n. 9.492/1997, cujo art. 38 determina que: "Os Tabeliães de Protesto de Títulos são civilmente responsáveis por todos os prejuízos que causarem por culpa ou dolo, pessoalmente, pelos substitutos que designarem ou Escreventes que autorizarem, assegurado o direito de regresso".

A despeito dos dispositivos legais pré-citados, uma segunda corrente doutrinária entende que o art. 22 retromencionado denota a responsabilidade objetiva dos tabeliães, o que seria corroborado pela regra do $\S 6^{0}$ do art. 37 , mediante a qual a pessoa de direito privado prestadora de serviço público se equipara àquela pessoa jurídica de direito público $^{875}$. Ocorre que, por um lado, o art. 22 não determina, de modo algum, que os tabeliães respondam objetivamente por ato próprio, mas sim por seus prepostos e empregados; por outro, a pessoa física não se enquadra na parte inicial do dispositivo legal em comento, já que este faz referência expressa a pessoas jurídicas de direito privado ${ }^{876}$. A despeito da interpretação dessa vertente ser evidentemente contra legem, a jurisprudência tem se orientado no sentido da objetivação da responsabilidade do tabelião ${ }^{877}$,

\footnotetext{
${ }^{874}$ TJSP. 4- Câmara de Direito Privado. Ap. Civ. 161.802-4/0. Rel. Des Ênio Zuliani. J. 08.09.05. v.u. ${ }^{875}$ DINIZ, Maria Helena. Curso de Direito Civil brasileiro - responsabilidade civil, p. 289.

876 DUARTE, Flávio Henrique. A responsabilidade civil do tabelião e do registrador. Jus Navigandi, Teresina, ano 14, n. 2.230, 9. ago. 2009. Disponível em: 〈http://jus.uol.com.br/revista/texto/13299>. Acesso em: 12 dez. 2010. No mesmo sentido, Juliana Hörlle Pereira (Responsabilidade civil dos notários e registradores. Revista CEJ, Brasília, n. 30, p. 92, jul./set. 2005. p. 92).

${ }^{877}$ STF. 2. T. RE 201595/SP. Rel. Min. Marco Aurélio. j. 28.11.2000. v.u. O julgado possui a seguinte ementa: "RESPONSABILIDADE OBJETIVA - ESTADO - RECONHECIMENTO DE FIRMA CARTÓRIO OFICIALIZADO. Responde o Estado pelos danos causados em razão de reconhecimento de firma considerada assinatura falsa. Em se tratando de atividade cartorária exercida à luz do artigo 236 da Constituição Federal, a responsabilidade objetiva é do notário, no que assume posição semelhante à das pessoas jurídicas de direito privado prestadoras de serviços públicos $-\S 6^{\circ}$ do artigo 37 também da Carta da República". No mesmo sentido, TJSP. 4aㅡ Câmara de Direito Privado. Ap. Civ. 459.728.4/0-00. Rel. Des. Francisco Loureiro. J. 3.09.09. v.m., cuja ementa segue transcrita: "RESPONSABILIDADE CIVIL Lavratura e uso de procuração falsa para venda de ações - Responsabilidade das co-rés que utilizaram em
} 
entendimento que tende a prevalecer. Se, de fato, for consolidada a orientação de que o Estado somente responde subsidiariamente - com a qual não se concorda, conforme salientado em item posterior -, é, com efeito, mais adequado que a responsabilidade do profissional seja objetivada, a despeito de ser assim considerada em face da má exegese dos dispositivos legais. Está-se diante do desempenho de função pública e, portanto, na seara do risco administrativo, o que significa que alguém deve ser responsabilizado objetivamente. Seria melhor que fosse o Estado, mas, alternativamente, admite-se que seja o próprio profissional.

Responde, também de forma objetiva, o tabelião, pelos atos de seus servidores não concursados, os quais, de acordo com os arts. 20 e 21 da Lei n. 8.935/1994, têm o contrato que os vincula regido pela legislação do trabalho. Trata-se, nesse caso, de mera aplicação do art. 932, inc. III, do CC, motivo pelo qual o profissional tem, em face dos prepostos e empregados, direito de regresso ${ }^{878}$, nos limites expostos no item 3.4.

Acrescente-se, igualmente, que a responsabilidade do oficial é pessoal, não sendo transferida para seus sucessores no cartório $^{879}$, a menos que os sucessores tenham participado, de alguma maneira, do ato danoso. Em caso de falecimento do tabelião responsável pelo dano, caberá à vítima demandar seus herdeiros ${ }^{880}$.

Por fim, cumpre mencionar a antiga controvérsia existente sobre a legitimidade passiva dos cartórios em ação de indenização. A matéria já não é tão discutida, mas, durante muito tempo, conviveram entendimentos em sentidos opostos. O posicionamento do STJ era, inicialmente, no sentido da responsabilização do Cartório de Notas ou Tabelionato, por estes serem considerados pessoas jurídicas formais ${ }^{881}$, o que se explica pelo fato de as serventias extrajudiciais serem, originalmente, pertencentes ao patrimônio dos tabeliães, podendo, inclusive, serem transferidas por herança. Hoje, afirma-se que a

negócio da bolsa de procuração falsa outorgada em nome do autor, para alienar a terceiros sua participação acionária - Responsabilidade objetiva, também do Tabelião, causador maior e primário do dano - Perdas e danos - Indenização pelo valor máximo de cotação das ações na data em que foram alienadas, corrigidas a contar de então, nos termos do pedido, mais lucros cessantes - Recurso do autor provido - Recurso dos réus não provido". No mesmo sentido, TJSC. $3^{\underline{a}}$ Câmara de Direito Civil. Ap. 2007.008413-1. Rel. Des. Fernando Carioni. j. 19.06.07. v.u.

${ }^{878}$ TJSP. $3^{\text {a }}$ Câmara de Direito Privado. AgIn 185.843-4. Rel. Des. Carlos Roberto Gonçalves. j. 06.02.01. v.u.

${ }^{879}$ STJ. 3. T. REsp 443.467/PR. Rel. Min. Castro Filho. j. 05.05.05. v.u; STJ. 4. T. REsp 545613/MG. Rel. Min. Cesar Asfor Rocha. j. 08.05.07. v.m.; STJ. 2. T. REsp 852770/SP. Rel. Min. Humberto Martins. J. 03.05.07. v.u.

${ }^{880}$ AGUIAR DIAS, José de. Da responsabilidade civil, t. II, p. 341.

${ }^{881}$ STJ. 4. T. REsp 476.532/RJ. Rel. Min. Ruy Rosado de Aguiar Jr. j. 20.05.03. v.u. 
titularidade destas é do Estado $^{882}$, consistindo a serventia em apenas uma divisão administrativa, dizendo respeito a delegação somente à função, que é pessoal do tabelião. A alteração mencionada teve como decorrência a mudança da orientação jurisprudencial nesse Superior Tribunal, que passou a professar que o Tabelionato não detém personalidade jurídica ou judiciária, motivo pelo qual a responsabilidade é pessoal, no caso, do titular da serventia ${ }^{883}$. Os tribunais estaduais seguiram na mesma esteira ${ }^{884}$.

Infere-se, assim, que, em caso de dano decorrente de má prestação de serviços de tabelionato, somente o tabelião titular do Cartório à época dos fatos e o Estado, solidária ou subsidiariamente - dependendo da corrente doutrinária que se adote -, possuem legitimidade passiva para a demanda indenizatória.

${ }^{882} \mathrm{O}$ fato de o Estado ser considerado o verdadeiro titular do cartório denota a incongruência do posicionamento de que a responsabilidade estatal é subsidiária à do tabelião.

${ }^{883}$ STJ. 4. T. REsp 545.613/MG. Rel. Min. Cesar Asfor Rocha. j. 08.05.07. v.m.

${ }^{884}$ TJSP. 2- Câmara de Direito Privado. Ap. Civ. com revisão 404.899-4/1-00. Rel. Des. Ariovaldo Santini Teodoro. j. 02.12.08. v.u., cuja ementa transcreve-se: "Responsabilidade civil. Indenização. Danos morais. Autenticação de assinatura falsificada. Ajuizamento contra o Cartório do Oitavo Tabelião de Notas da Comarca de Santos. Ilegitimidade passiva ad causam caracterizada. Tabelionato. Ausência de personalidade jurídica. Responsabilidade do Estado ou do titular da delegação por prejuízos causados ao particular. Precedentes. Carência decretada. Matéria de ordem pública. Extinção de ofício. Recurso prejudicado". No mesmo sentido, TJSP. 9ạ Câmara de Direito Privado. Apelação Cível 548.212.4/9-00. Rel. Des. Graciella Salzman. J. 27.11.08. v.u; TJSP. 12a Câmara de Direito Privado. Ap. Civel 7203925-5. Rel. Des. José Reynaldo. J. 11.02.09. v.u.; TJSP. 1a Câmara de Direito Público. AgI 994.09.390067-0. Rel. Des. Regina Capistrano. J. 23.11.10. v.u.; TJSP. 15ª Câmara de Direito Privado. Ap. Cível 991.09.052372-6. Rel. Des. Adherbal Acquati. J. 20.07.10. v.u. 


\section{RESPONSABILIDADE CIVIL DE ENGENHEIROS,} ARQUITETOS E EMPREITEIROS

Este Capítulo analisa a responsabilidade civil de engenheiros, arquitetos e empreiteiros, a qual se diferencia, de certo modo, da responsabilidade dos demais profissionais em razão das consequências dos danos causados por essas pessoas. De fato, está-se diante de situação em que um erro no desempenho da atividade pode gerar danos a um número muito grande de indivíduos - verifique-se, v.g., o caso de desabamento de um edifício -, ao passo que o erro profissional do médico ou do advogado tende a gerar prejuízo para uma ou poucas vítimas.

Pablo Stolze Gagliano e Rodolfo Pamplona Filho, ao tratar do assunto, defendem que os construtores desempenham atividade perigosa, ainda que sua responsabilidade seja subjetiva, em razão do disposto no art. 14, § 4ํㅜㄹ do CDC:

“[...] a atividade dessas pessoas, por sua própria natureza, exigiria disciplina legal diferenciada, não apenas pela singularidade dos conhecimentos técnicos exigidos para a atuação no setor, mas, principalmente, pela possibilidade de os danos porventura ocorrentes gerarem um espectro de atuação muito maior do que o observado na atividade de outros profissionais, a exemplo de médicos e advogados.

Imagine-se, por exemplo, a queda de uma laje em um grande shopping, por força da imperícia do engenheiro responsável. Quantas pessoas poderiam, no caso, ser potencialmente atingidas?

Por tais razões, já cuidamos de ressaltar que, em nosso entendimento, a atividade desses profissionais pode e deve ser considerada de natureza perigosa, embora a sua responsabilidade não seja objetiva, por força do art. $14, \S 4^{\circ}$, do $\mathrm{CDC}$, norma especial, que admite, como regra, apenas a responsabilidade subjetiva para os profissionais liberais" ${ }^{\prime 85}$.

885 GAGliANO, Pablo Stolze; PAMPLONA FILHO, Rodolfo. Novo Curso de Direito Civil responsabilidade civil, p. 307. Nesse mesmo sentido posiciona-se Sérgio Cavalieri Filho, tecendo 
Nada há que se discutir acerca do fato de ser a responsabilidade desses profissionais subjetiva, conforme já exposto; no entanto, no que tange à afirmação de que se trata de atividade essencialmente perigosa, ainda que se concorde com os autores no que tange à potencialidade ofensiva do trabalho desempenhado por engenheiros e profissionais congêneres, não se pode assentir com tal assertiva. De fato, sustenta-se aqui, como se infere do esclarecido no item 1.2.4, que o parágrafo único do art. 927 do $\mathrm{CC}$, ao tratar de atividade que em geral "implicar, por sua natureza, risco para os direitos de outrem", não se refere à prestação de um serviço que, se realizado com zelo habitual, não gera dano a pessoa alguma.

Em verdade, se bem considerada a questão, a construção civil não é atividade perigosa de per se; ademais, se a atividade efetivamente fosse perigosa, haveria de ser aplicada a responsabilidade objetiva, e não a subjetiva, por força do disposto no Código Civil, motivo pelo qual se detecta certa incoerência no pensamento dos autores.

De qualquer modo, a consideração acerca da amplitude dos danos que podem ser gerados pelos construtores permeará todo o Capítulo, e fará que a responsabilidade desse grupo seja analisada com mais rigor.

O Capítulo trata da responsabilidade civil de engenheiros e arquitetos que atuam na área da construção civil, motivo pelo qual o termo "empreiteiros" foi acrescido ao título do Capítulo; no entanto, o estudo se limita aos profissionais diplomados em curso superior, aos quais os demais profissionais encarregados de obras devem se subordinar. Pautado nesse mister, serão discutidos: o contrato de construção, em suas diversas modalidades; a incorporação imobiliária; o contrato de projeto e de fiscalização; as obrigações e responsabilidades do empreiteiro e do dono da obra; a aplicabilidade da teoria dos vícios redibitórios; o polêmico prazo constante do art. 618 do $\mathrm{CC}$; e a responsabilidade extracontratual do construtor.

\subsection{O contrato de construção}

A responsabilidade civil de engenheiros e arquitetos não se resume somente ao contrato de construção ${ }^{886}$, tendo em vista que esses profissionais podem ser contratados

\footnotetext{
comentários sobre o célebre caso do edifício Palace II, o qual desmoronou em decorrência do material de má qualidade utilizado na construção (Programa de responsabilidade civil, p. 340).

${ }^{886}$ É a responsabilidade do empreiteiro ou construtor que está diretamente relacionada com a obrigação de construir.
} 
para outras finalidades além da promoção de uma obra, como, por exemplo, a elaboração de um projeto $^{887}$. O fato de a maioria das hipóteses que geram indenização estar relacionada com a edificação propriamente dita justifica, no entanto, que se principie o estudo pelo contrato de construção.

De acordo com Hely Lopes Meirelles, o contrato de construção consubstancia-se em:

\begin{abstract}
"[...] todo ajuste para execução de obra certa e determinada, sob direção e responsabilidade do construtor, pessoa física ou jurídica legalmente habilitada a construir que se incumbe dos trabalhos especificados no projeto, mediante as condições avençadas com o proprietário ou comitente.
\end{abstract}

Esse conceito abarca, na sua generalidade, as duas modalidades de contrato de construção de obra particular, conhecidas e praticadas entre nós - a empreitada e a administração - as quais se diversificam nas condições econômicas da realização da obra, mas guardam as características da espécie que assinalamos" ${ }^{\text {} 888}$.

O referido contrato de construção é celebrado entre o empreiteiro ou construtor, aquele que realiza uma obra ou executa um serviço, e o dono da obra ou comitente, isto é, o contratante que determina o trabalho a ser realizado e paga o preço da construção. Como construção, designa-se toda obra realizada com o escopo de transformar determinado imóvel $^{889}$; assim, tanto pode consistir na edificação em um terreno, como também na reforma de uma obra já construída.

No que tange à posição de empreiteiro ou construtor, esta é ocupada pelo engenheiro, pelo arquiteto e pelo construtor legalmente habilitado, que assumem os encargos técnicos da construção e usufruem dos benefícios econômicos advindos da execução da obra, juntamente com o dono ${ }^{890}$. O contrato firmado com esses profissionais,

\footnotetext{
${ }^{887}$ O próprio contrato de empreitada admite uma grande diversidade de objetos, que não apenas a construção, como será salientado em seguida.

${ }^{888}$ MEIRELLES, Hely Lopes. Direito de construir. 4. ed. São Paulo: Revista dos Tribunais, 1983. p. 186.

889 ZULIANI, Ênio Santarelli. Responsabilidade civil nos contratos de construção, empreitadas e incorporações. In: SILVA, Regina Beatriz Tavares da (Org.). Responsabilidade civil e sua repercussão nos tribunais. São Paulo: Saraiva, 2008. p. 225.

${ }^{890}$ GONÇALVES, Carlos Roberto. Responsabilidade civil, p. 417.
} 
para a mera elaboração de um projeto de obra, não compreende a obrigação de construção ou de fiscalização da obra, conforme disposto pelo art. $610, \S 2^{\circ}$, do $\mathrm{CC}^{891}$.

O contrato tem caráter pessoal, mas não personalíssimo; isso autoriza que a obra seja realizada por terceiros que lavorem sob a fiscalização do profissional contratado. $\mathrm{O}$ construtor, portanto, poderá firmar contratos de subempreitada com especialistas em determinados assuntos, independentemente de autorização do contratante, desde que se responsabilize pela atuação de todos eles ${ }^{892}$. No que tange ao projeto, contudo, há que se admitir que este possui, em regra, caráter artístico, em conjunção com o técnico, motivo pelo qual espera-se que seja realizado pelo próprio contratado.

A obrigação do construtor e demais profissionais semelhantes é, em qualquer caso, de resultado ${ }^{893}$, fazendo que a obra deva ser executada conforme a encomenda para que seja considerada totalmente adimplida ${ }^{894}$. De fato, conforme estudado anteriormente, na obrigação de resultado somente ocorre o adimplemento com a consecução do fim, ao contrário do que se dá na obrigação de meio, em que o contratado se compromete a reunir esforços para determinado objetivo sem, no entanto, a ele estar vinculado.

A referida obrigação de resultado, nessa modalidade de contrato, não abrange somente a solidez da obra, mas também a capacidade desta para servir aos propósitos para os quais foi encomendada ${ }^{895}$.

Sendo assim, o construtor tem um dever de garantia que somente se ilide em caso de força maior ou caso fortuito, fato exclusivo da vítima ou de terceiro, com as variações pertinentes ao tipo de contrato de construção que estiver sendo tratada.

No tocante à alegação da excludente de fato exclusivo da vítima, cumpre salientar que, em particular no que alude a questões técnicas, o profissional não pode alegar que seguiu instruções do proprietário para ilidir sua responsabilidade ${ }^{896}$. Em verdade, não cumpre ao profissional acatar ordens que possam levar ao insucesso da obra. Também irá

\footnotetext{
${ }^{891}$ O referido artigo tem a seguinte redação: "§ $2^{\circ}$. O contrato para elaboração de um projeto não implica a obrigação de executá-lo, ou de fiscalizar-lhe a execução".

${ }^{892}$ MEIRELLES, Hely Lopes. Direito de construir, p. 189.

${ }^{893}$ GONÇALVES, Carlos Roberto. Responsabilidade civil, p. 407. No mesmo sentido, Jorge Mosset Iturraspe (Responsabilidad por daños - el incumplimiento contractual, t. II, p. 293) e Maria Helena Diniz (Curso de Direito Civil brasileiro - responsabilidade civil, p. 315).

${ }^{894}$ ZULIANI, Ênio Santarelli. Responsabilidade civil nos contratos de construção, empreitadas $e$ incorporações, p. 225. O referido autor enfatiza que a obrigação de construir, além de ser de resultado, não consiste na entrega de "edificação irregular, insegura e com risco de desabamento"; portanto, deve se prestar ao fim para o qual foi construída.

${ }^{895}$ AGUIAR DIAS, José de. Da responsabilidade civil, t. I, p. 342.

896 Ibidem, p. 348.
} 
responder o construtor se os danos se devem à inadequação do terreno, tendo em vista que cabia a ele avaliar se o local da obra era próprio para os fins que se pretendia ${ }^{897}$; em caso negativo, não podia sequer ter iniciado a construção ${ }^{898}$.

O contrato de construção pode ser de duas espécies: construção por empreitada e construção por administração ${ }^{899}$.

A empreitada admite diversos objetos, inclusive de ordem intelectual, como a realização de um trabalho artístico ${ }^{900}$. Nesse momento, tratar-se-á apenas da empreitada de construção, que pode ser somente de lavor, ou então, de trabalho e de materiais. Serão tecidos apenas breves comentários sobre cada um deles, e também sobre o contrato de incorporação imobiliária, uma vez que o interesse do trabalho recai sobre a responsabilidade profissional e não sobre os tipos contratuais.

Convém mencionar, antes de serem abordadas as espécies contratuais, a possibilidade da ocorrência de responsabilidade pré-contratual do construtor, quando este, v.g., abandona imotivada e abruptamente projeto de obra em fase de tratativas. Da mesma forma, o profissional que, depois de procurado pelo cliente, inicia estudos com a finalidade de elaborar um anteprojeto de obras necessárias para a conclusão do contrato final e procede à sondagem do terreno, terá direito a indenização pelo trabalho já realizado se o dono da obra não quiser prosseguir com a execução desta ${ }^{901}$.

\subsubsection{O contrato de empreitada}

A construção por empreitada é realizada pelo construtor com caráter de autonomia, caracterizando-se pelo fato do profissional assumir os riscos econômicos da obra, ao contrário do que se verifica na construção por administração, contrato no qual o construtor depende do aporte financeiro progressivo do dono da obra, conforme será analisado no próximo item ${ }^{902}$.

\footnotetext{
${ }^{897}$ AGUIAR DIAS, José de. Da responsabilidade civil, t. I, p. 354.

${ }^{898}$ MEIRELLES, Hely Lopes. Direito de construir, p. 191.

${ }^{899}$ GONÇALVES, Carlos Roberto. Responsabilidade civil, p. 407.

900 BDINE JUNIOR, Hamid Charaf. Da empreitada. Revista dos Tribunais, São Paulo, v. 96, n. 858, abr. 2007. p. 83. José Fernando Simão distingue a empreitada, quanto ao seu objeto, em empreitada de execução e empreitada de projeto. Neste último caso, o profissional se compromete a entregar plantas e cálculos para que qualquer profissional habilitado possa fazer a obra (Direito Civil - contratos, p. 262). Optou-se, neste trabalho, a tratar dessa hipótese, no item 6.2, como contrato de projeto e de fiscalização.

901 AGUIAR DIAS, José de, op. cit., loc. cit.

902 MEIRELLES, Hely Lopes. Direito de construir, p. 190.
} 
O contrato de empreitada é o negócio jurídico no qual o empreiteiro assume, mediante devida remuneração, a obrigação de efetuar uma construção no interesse do dono da obra, utilizando materiais próprios ou somente sua mão de obra ${ }^{903}$.

\subsubsection{A empreitada por preço global e por medição}

No que tange ao modo de pagamento, a empreitada pode ser por preço global ou por medição. Na primeira hipótese, o valor do trabalho é estabelecido antecipadamente para a sua totalidade, ao passo que, na segunda, o pagamento é feito após a conclusão de etapas e sua devida medição. Nada impede que a empreitada por preço global seja paga em prestações, a diferença jaz na prévia estipulação do montante devido ao construtor.

A empreitada remunerada por medição é bastante comum em obras públicas, constituindo fonte de inúmeras irregularidades que podem implicar a responsabilização do profissional responsável pelos relatórios e medidas. Para demonstrar essa assertiva, tomase por modelo a construção do Fórum Trabalhista da Cidade de São Paulo, que ensejou a responsabilização do engenheiro contratado para executar os serviços de supervisão e fiscalização da obra.

O Tribunal de Contas da União (TCU) decidiu pela responsabilidade solidária do engenheiro pela totalidade do dano imposto ao Erário, no parecer cujo excerto segue transcrito:

“278. Na prática, o seu trabalho [do engenheiro] consistia na emissão de relatórios periódicos, contendo tabelas às quais se referia como cronogramas físico-financeiros, mas que apenas apresentavam os percentuais de execução de serviços e a correspondente parcela financeira a liberar. Comumente chamados de planilhas de medições, tais relatórios nada mais eram que atestados utilizados pelo TRT-2 ${ }^{\mathrm{a}}$ Região, para efetuar pagamentos antecipados, defesos pela Lei $\mathrm{n}^{\mathrm{o}} 4.320 / 64$, artigos 62 e 63 e Decreto n⿳0 93.782/86, art. 38 .

279. Este é o ponto, advirta-se, que motivou sua inserção como responsável nesses autos: os relatórios e pareceres por ele

\footnotetext{
${ }^{903}$ Trata-se da divisão trazida pelo art. 610, o qual dispõe que: "O empreiteiro de uma obra pode contribuir para ela só com seu trabalho ou com ele e os materiais".
} 
produzidos não guardavam correspondência com a realidade, e mais, contribuíram para um grandioso esquema de repasse espúrio de verbas públicas.

280. Note-se que o engenheiro não procedia a uma medição efetiva do estágio físico da obra, na forma estabelecida na Lei $\mathrm{n}^{\circ}$ 8.666/93, qual seja, contando com orçamentos detalhados em planilhas, fundamentados em quantitativos de serviços e fornecimentos que expressassem a composição de todos os custos unitários, elementos esses que deveriam constar de um projeto básico, consoante art. $6^{\underline{0}}$, inciso IX, alínea 'f', c/c o art. $7^{7}$, $\S 2^{\underline{o}}$, da citada Lei.

$[\ldots]$

284. Com supedâneo nesse esquema, o engenheiro $[\mathrm{G}]^{904}$ incluía em seus relatórios medições superestimadas, incompatíveis com o estágio de desenvolvimento da obra nos períodos avaliados, e pior, medições de serviços inexistentes.

$[\ldots]$

288. Diante dessas graves irregularidades destacadas pela SECEX/SP, quando da prolação do Acórdão n. 045/99, o eminente Ministro-Relator Adhemar Paladini Ghisi arrolou o engenheiro como responsável. A propósito, é oportuno transcrever trechos do v. Voto, verbis:

'Também não pode ser afastada a responsabilidade do engenheiro A. C. G. S., contratado pelo TRT $-2^{2}$ Região com a atribuição específica de acompanhar a obra mediante a emissão de relatórios gerenciais, demonstrando sua evolução física, e de pareceres técnicos, visando ao exame da correspondência entre os recursos financeiros alocados e o avanço da implantação do empreendimento. As inconsistências constantes de seus relatórios, devidamente demonstradas pela equipe de auditoria, não podem ser tidas como meros equívocos, constituindo, na melhor das hipóteses,

904 Optou-se por não revelar o nome do engenheiro neste trabalho, uma vez que essa informação é desnecessária para os fins pretendidos com a transcrição do parecer. 
negligência, e, quiçá, má-fé. Assim, faz-se necessária sua responsabilização solidária. Mais ainda, considerando que os atos por ele cometidos decorrem de incúria no exercício de sua atividade profissional, entendo que sua responsabilidade deva ser apurada também no âmbito do CREA/SP'.

$[\ldots]$

295. Observa-se, em suma, que, por intermédio de seus relatórios, propiciou a liberação indevida de vultosa quantia à Contratada. As medições por ele apresentadas não se mostraram em nenhum momento condizentes com o real andamento da obra, ao contrário, ficou patente que se prestavam ao cumprimento de mera formalidade, com vistas ao favorecimento ilícito da Incal Incorporações S/A., ensejando, de consequência, o desvio de verbas registrado pela CPI do Judiciário, e objeto de investigação nas esferas competentes.

296. Em conclusão, entendo como caracterizada a responsabilidade solidária do Sr. A. C. G. S. pela totalidade do dano imposto ao Erário, haja vista que, citado, manteve-se silente, a despeito das graves irregularidades acima enumeradas, as quais, portanto, permanecem na íntegra" ${ }^{905}$.

A Tomada de Contas retrotranscrita demonstra com acuidade como a atuação desse profissional pode trazer graves danos não somente a particulares, mas também à sociedade, justificando que sua responsabilidade, ainda que fundada na culpa, seja avaliada com rigor.

\subsubsection{A empreitada de lavor ou de material}

No tocante à prestação do empreiteiro, a empreitada pode ser de lavor ou de material.

905 Tomada de Contas Especial. Grupo II - Classe IV - Plenário. TC-001.025/1998-8, com 6 apensos: TC001.838/1998-9, TC-005.005/1998-1, TC-700.214/1998-4, TC - 003.858/1999-5, TC-007.506/1999-6 e TC 08.817/2000-8. Ministro-Relator Lincoln Magalhães da Rocha e Ministro-Redator Walton Alencar Rodrigues. Data da sessão: 11/07/01 (Auditorias do TCU, Brasília, ano 4, n. 15, 2001). 
A empreitada de lavor ou de mão-de-obra é uma obrigação de fazer do empreiteiro, relacionada ao encaminhamento e à fiscalização dos trabalhos de construção. Nesse caso, o profissional não responderá pela oscilação do valor dos materiais empregados e todos os demais riscos correm por conta do dono da obra, o que se depreende do art. 612 do CC.

A empreitada mista, por sua vez, envolve a obrigação de dar, que consiste no fornecimento de materiais, e a de fazer, referente à construção propriamente dita. Cumpre salientar que a obrigação de fornecer materiais não se presume, conforme disposto no art. $610, \S 1^{0}$, do CC, devendo, portanto, constar por escrito do contrato. Nessa hipótese, o empreiteiro assume o risco de variação do preço do material, a menos que a empreitada tenha sido contratada com reajustamento.

Com efeito, tratando-se de empreitada a preço fixo, dispõe o art. 619 do referido Diploma que o empreiteiro não terá direito a exigir acréscimo no preço, mesmo que sejam introduzidas modificações no projeto, exceto se estas tiverem sido feitas por escrito ou se o dono tiver acompanhado, mediante reiteradas visitas, sua realização, nos termos do parágrafo único do mesmo dispositivo em comento.

Saliente-se que, quando fornece material, o construtor responde pelos riscos por caso fortuito até a entrega da obra, em clara aplicação do brocardo res perit domino, isto é, a coisa perece para o dono ${ }^{906}$. Se, entretanto, o dono estiver em mora injustificada no recebimento da obra, isto é, sem explicação se recusou a aceitá-la, responderá pelos eventuais danos advindos. Por certo, pode ele - e, em verdade, deve - recusar o recebimento sempre que observar a ocorrência de imperfeições ou vícios.

Quando não fornece os materiais de construção, isto é, a empreitada é somente de lavor, o construtor será responsável pela perda ou deterioração dos materiais empregados se tiver atuado culposamente, sendo essa responsabilidade, portanto, subjetiva, a senso do disposto no art. 617 do CC.

\subsubsection{O contrato de construção por administração}

No contrato de construção por administração, ou a preço de custo, o construtor apenas se encarrega da edificação da obra ${ }^{907}$, ao passo que os riscos econômicos desta

\footnotetext{
${ }^{906}$ Os materiais são de propriedade do empreiteiro até o momento de entrega da obra ao comitente. O simples contrato não transfere a propriedade, conforme exposto no art. 1.267 do CC (SIMÃO, José Fernando. Direito Civil - contratos, p. 261).

${ }^{907}$ GONÇALVES, Carlos Roberto. Responsabilidade civil, p. 410.
} 
ficam a cargo do proprietário que, igualmente, assume os custos do empreendimento ${ }^{908}$. O construtor se responsabiliza tão somente pela execução técnica do projeto, tendo menos liberdade e, por consequência, menos responsabilidade, pois depende da liberação de verba pelo dono da obra.

O construtor é remunerado, em geral, com uma porcentagem sobre o preço total da obra.

Esse contrato não se confunde com o da construção por empreitada. De fato, neste último, o construtor assume os encargos técnicos da obra e os riscos econômicos da construção, custeando-a, com preço fixado de início, mesmo no caso da empreitada por medição. No contrato de administração, ao contrário, o construtor responde tão somente pela execução da obra, custeada paulatinamente pelo dono-contratante, conforme as necessidades. Nesse caso, o dono-contratante apenas conhecerá o preço total do empreendimento ao término da obra ${ }^{909}$. Os materiais podem ser adquiridos pelo próprio dono da obra, ou então, sob o seu comando, pelo construtor que, nesse caso, atua como preposto ou mandatário ${ }^{910}$.

O contrato de construção por administração, a despeito de sua importância na seara em estudo, não foi regulamentado pelo Código Civil. Sendo assim, remanesce o quanto disciplinado pela Lei de Condomínio e Incorporações (Lei n. 4.591/1964), em seus arts. 58 a 62, os quais, no entanto, não trazem muitos elementos para a devida caracterização do contrato.

Em qualquer hipótese, o empreiteiro construtor, por força do art. 624 do CC, responde por perdas e danos em caso de suspensão da obra, que pode advir de resilição sem justa causa ou então do adiamento da obra. Verifique-se, contudo, que em caso de inadimplemento ou negativa de fornecimento de material pelo dono da obra, justifica-se a sua paralisação, o que, aliás, ocorre com frequência na construção de edifícios condominiais. De fato, se os condôminos não efetivarem o pagamento das prestações

\footnotetext{
${ }^{908}$ MEIRELLES, Hely Lopes. Direito de construir, p. 204. É o que dispõe o art. 58 da Lei n. 4.591/1964.

909 Ibidem, loc. cit.: "Não há também confusão possível entre o construtor-administrador e o construtorempreiteiro. O primeiro se responsabiliza unicamente pela execução técnica do projeto; o segundo assume os encargos técnicos da obra e mais os riscos econômicos da construção até a sua conclusão e entrega a quem encomendou. Na construção por administração o proprietário é quem custeia a obra e só a final conhece o seu preço; na empreitada, a construção é custeada pelo empreiteiro e o preço é fixado de início. O empreiteiro é executor autônomo dos trabalhos ajustados; o administrador é executor dependente das deliberações do dono da obra, no que concerne ao andamento dos serviços, ressalvada sempre a parte técnica que é de inteira responsabilidade dos profissionais, qualquer que seja a modalidade de contrato de construção".

${ }^{910}$ GONÇALVES, Carlos Roberto. Responsabilidade civil, p. 410.
} 
devidas, não é possível prosseguir com a obra, o que os impedirá, futuramente, de pleitear indenização em razão do atraso desta.

\subsubsection{O contrato de incorporação imobiliária}

O contrato de incorporação imobiliária é o instrumento pelo qual o incorporador assume a obrigação de construir, ele mesmo ou por meio de terceiros, imóveis que serão repassados ao adquirente tão logo seja pago o preço convencionado. A obrigação do incorporador implica a transferência da propriedade horizontal de unidades autônomas de um mesmo edifício de vários pavimentos, bem como a parte ideal do terreno e das áreas de uso comum ${ }^{911}$. O incorporador, que nem sempre é um construtor, atua como intermediário entre este e os adquirentes de edifício de apartamentos residenciais ou conjuntos comerciais. Além de atuar como mediador, pode também estar encarregado do financiamento do empreendimento, bem como da aquisição de unidades para a revenda futura, a fim de impulsar a criação do condomínio.

O contrato é disciplinado pela Lei n. 4.591/1964, a qual define, no art. 29, o incorporador como "a pessoa física ou jurídica, comerciante ou não, que embora não efetuando a construção, compromisse ou efetive a venda de frações ideais de terreno, objetivando a vinculação de tais frações a unidades autônomas".

De acordo com o artigo subsequente, também são considerados incorporadores os proprietários que contratem a construção de edifícios com o escopo de constituir condomínio, sempre que iniciarem a venda das unidades antes da conclusão final das obras.

Importante ressaltar que a lei em comento, no art. 31, faz restrições à figura do incorporador, que somente pode ser:

- o proprietário, o promitente comprador, cessionário ou promitente cessionário do terreno; ou

- o construtor ou o corretor de imóveis ${ }^{912}$.

${ }_{911}$ MEIRELLES, Hely Lopes. Direito de construir, p. 223.

912 Caio Mário da Silva Pereira assinala que há três modalidades de incorporador: o que faz em seu nome a compra do terreno e realiza também em seu nome a construção; o que funciona como mero coordenador do condomínio, realizando-se a compra do terreno diretamente pelos condôminos, que se tornam em comum donos do solo e promovem a edificação; e o que obtém a opção de compra do terreno, trata da constituição do condomínio, promove a escritura de alienação do terreno diretamente do proprietário aos condôminos e 
O mencionado contrato enseja obrigações que se formam em etapas sucessivas, permeadas pelo pagamento de prestações pelos adquirentes, culminando na conclusão do edifício condominial ${ }^{913}$.

O incorporador se obriga pela conclusão da obra perante os adquirentes, devendo proceder ao prévio registro do empreendimento no Cartório de Registro de Imóveis, mediante apresentação da documentação estabelecida no art. 32 da Lei n. 4.591/1964. Depois de realizada a construção, cada unidade autônoma deverá receber um número específico e ser averbada no Registro de Imóveis, conforme disposto no art. 44 do Diploma legal em comento.

O incorporador deve obedecer a uma série de normas no momento da redação do contrato de venda das unidades imobiliárias, especificando, v.g., o valor devido para a aquisição da fração ideal do terreno, e o montante pertinente ao pagamento da construção da unidade, conforme disposto pelo art. 41 da mesma Lei retromencionada.

O contrato de incorporação, todavia, não se confunde com o contrato de construção do edifício. O primeiro é firmado entre o incorporador e os interessados na aquisição das unidades condominiais, enquanto o segundo se estabelece entre o incorporador e o construtor para erigir-se a obra ${ }^{914}$. A despeito da mencionada distinção, encontram-se com certa freqüência casos de um único contrato ser firmado entre o construtor, a incorporadora e o adquirente, mesmo porque a responsabilidade da incorporadora por vícios do imóvel é solidária com a da construtora, conforme será elucidado no item 6.8 .

\subsection{Contratos de projeto e fiscalização de obra}

Conforme salientado no início do estudo, a atividade dos engenheiros e arquitetos, mesmo na seara da construção civil, não se restringe propriamente à construção. Existem ajustes conexos à construção, como os contratos de projeto e fiscalização de obra, sobre os quais serão tecidos alguns comentários.

Sabe-se que a construção de um prédio ou edifício é precedida de um projeto regularmente aprovado pelo Poder Público. Para o desempenho dessa função, pode ser

dirige a construção do edifício como procurador dos proprietários (Condomínio e incorporações. 5. ed. Forense: Revista dos Tribunais, 1985. p. 110).

${ }^{913}$ RIZZARDO, Arnaldo. Responsabilidade civil, p. 540.

914 POSSI, Luciana. Contrato de incorporação imobiliária - notas à Lei 4.591/64. In: HIRONAKA, Giselda Maria Fernandes Novaes; TARTUCE, Flávio. Direito contratual - temas atuais. São Paulo: Método, 2008. p. $642-643$. 
firmado o contrato de projeto $^{915}$, ou seja, um pacto em que o profissional se compromete a desenvolver o projeto técnico de uma obra e a fornecer todos os elementos essenciais para a construção, e o contratante a pagar os honorários convencionados ${ }^{916}$. Nesse trabalho, prepondera o caráter intelectual, eis que o projetista deverá conceber a obra e traduzi-la em elementos gráficos e descritivos. Daí advém o caráter personalíssimo da obrigação.

Esse contrato abrange os estudos preliminares, a elaboração do projeto, todas as modificações que se fizerem necessárias e sua aprovação pelo Poder Público, já que essa formalidade é essencial para que o projeto possa ser executado.

O comitente não pode modificar o projeto aprovado sem anuência do profissional que o elaborou, a menos que, nos termos do art. 621 do CC, "por motivos supervenientes ou razões de ordem técnica, fique comprovada a inconveniência ou a excessiva onerosidade de execução do projeto em sua forma originária”. Também se admite a alteração se estas forem de pequena monta ${ }^{917}$. A proibição se deve a dois fatores: a responsabilidade técnica do profissional, que não pode responder por alterações que não lhe foram cientificadas, e a eventual violação de direito de autor, conforme se observa do art. 5º , inc. XXVII, da CF, e do art. 7º̣ , da Lei n. 9.610/1998.

De acordo com o art. 622 do CC, mesmo que não se encarregue da construção ou fiscalização da obra, será responsável pela solidez e segurança do trabalho, previstas no art. 618 do CC, objeto de estudo do item 6.5, responsabilidade essa, contudo, subjetiva ${ }^{918}$, ainda que se admita a inversão do ônus da prova.

Em qualquer contrato, é importante diferenciar a responsabilidade do empreiteiro e a do engenheiro projetista. Caso ocorram defeitos na construção e estes se referirem a erro de projeto e não puderem ser detectados pelo empreiteiro, quem responde pelos danos é o engenheiro; se, contudo, for constatado que as irregularidades deveriam ter sido notadas pelo empreiteiro, este irá responder por elas, pois tem o dever apontá-las no transcorrer da obra. Na hipótese de o empreiteiro ter sido indicado pelo engenheiro ou arquiteto e trabalhar sob sua supervisão, haverá responsabilidade solidária dos profissionais, uma vez verificada a culpa, na modalidade in eligendo. Evidente que, havendo relação de emprego

\footnotetext{
${ }^{915} \mathrm{O}$ contrato, aqui tratado como autônomo, pode também ser entendido como de empreitada (SIMÃO, José Fernando. Direito Civil - contratos, p. 269).

${ }^{916}$ MEIRELLES, Hely Lopes. Direito de construir, p. 218.

${ }^{917}$ BDINE JUNIOR, Hamid Charaf. Da empreitada. Revista dos Tribunais, v. 96, n. 858, p. 86.

${ }^{918}$ SIMÃO, José Fernando, op. cit., p. 270.
} 
ou preposição entre eles, há de se aplicar os preceitos pertinentes à responsabilidade por fato de terceiro, tema abordado no Capítulo 3 deste estudo.

O contrato de fiscalização de obra verifica-se quando o profissional se encarrega de acompanhar a execução de uma construção, em estrita observância ao projeto - próprio ou de outro profissional -, mediante remuneração fixa ou percentual, paga pelo contratante ${ }^{919}$.

O responsável pela fiscalização da obra, assim como o projetista, não suporta os encargos econômicos da construção e nem assume responsabilidade perante terceiros, desde que o construtor da obra seja um profissional habilitado. Deve-se fazer essa distinção por ser muito comum que pessoas sem habilitação, ainda que com conhecimento do trabalho - isto é, os pedreiros, erroneamente chamados de empreiteiros -, encarreguem-se da construção da obra, sob a fiscalização de um engenheiro ou arquiteto. Ocorre que, nesse caso, não se trata de mera fiscalização, mas sim de responsabilização por toda a parte técnica do trabalho. Se, contudo, o construtor for uma empresa ou profissional diplomado, as obrigações do fiscal relacionam-se somente com o contrato firmado com o proprietário.

A obrigação do profissional, nesse caso, encerra-se, em regra, com o recebimento da obra pelo proprietário, remanescendo, entretanto, a responsabilidade pela solidez e segurança da construção, a senso do disposto no art. 622 do CC.

Mencione-se, por fim, que o contrato de elaboração de projeto pode estar associado com o de fiscalização da obra, quando, então, haverá acúmulo de obrigações e de responsabilidades.

\subsection{Obrigações e responsabilidades do empreiteiro e do dono da obra}

Conforme preceitua o art. 615 do $\mathrm{CC}^{920}$, a principal obrigação do empreiteiro é entregar a obra de acordo com os termos do ajuste. No caso de mora ou defeito aparente na construção, o dono pode optar pelo recebimento com abatimento do preço, ou então pela resolução do contrato com a devida indenização; nada impede, porém, que opte pela correção dos vícios, apesar de não previsto no art. 616 do CC.

\footnotetext{
${ }^{919}$ MEIRELLES, Hely Lopes. Direito de construir, p. 218.

${ }^{920}$ A norma em comento possui a seguinte redação: "Concluída a obra de acordo com o ajuste, ou o costume do lugar, o dono é obrigado a recebê-la. Poderá, porém, rejeitá-la, se o empreiteiro se afastou das instruções recebidas e dos planos dados, ou das regras técnicas em trabalhos de tal natureza”.
} 
Se a obra for dividida em partes, deve ser observado o cronograma de entrega de cada uma delas, presumindo-se que tudo que foi pago foi devidamente verificado pelo dono da obra, excepcionando-se os eventuais defeitos ocultos, discutidos no próximo item deste estudo.

A obrigação mais importante do dono da obra é o pagamento da construção, o qual está diretamente vinculado com sua aprovação. Caso tarde no cumprimento dessa obrigação, o empreiteiro tem o direito, com fundamento no art. 625, inc. I, do CC, de suspender a realização dos trabalhos. Do mesmo modo, tendo se comprometido a fornecer os materiais, deve deixá-los à disposição do empreiteiro conforme transcorra a obra.

A obrigação que decorre do pagamento refere-se ao recebimento da construção, cuja mora, conforme analisado anteriormente, enseja o deslocamento da responsabilidade do empreiteiro para o dono da obra, o qual não terá, contudo, obrigação de aceitá-la se nela constatar erros de execução, além de outros vícios ou defeitos.

Em qualquer caso, o empreiteiro não pode pleitear a resolução do negócio, tendo em vista que este se aperfeiçoou com o término da obra, abrindo-se, tão somente, a via da indenização no tocante aos gastos da manutenção e conservação da coisa durante o período em que o dono não a recebeu.

\subsection{Aplicação da teoria dos vícios redibitórios aos contratos de construção}

Consoante abordado no item anterior, se o vício constante da obra for aparente, a construção deve ser rejeitada de imediato, ou então recebida com abatimento do preço. Vícios perceptíveis, portanto, não são indenizáveis após o recebimento da obra ${ }^{921}$; mas nada impede que existam vícios ocultos na construção, os quais não puderam ser identificados no momento da entrega. Nesse caso, entende-se que há de ser aplicada a doutrina dos vícios redibitórios, prevista nos arts. 441 e seguintes do $\mathrm{CC}^{922}$.

921 GONÇALVES, Carlos Roberto. Responsabilidade civil, p. 414; ITURRASPE, Jorge Mosset. Responsabilidad por daños - el incumplimiento contractual, t. II, p. 326.

${ }_{922}$ Comunga desse entendimento Carlos Roberto Gonçalves (Responsabilidade civil, p. 416), que assim se manifesta: "Aduza-se que os pequenos defeitos, que não afetam a segurança e a solidez da obra, são considerados vícios redibitórios, que devem ser alegados no prazo decadencial de um ano, contado da entrega efetiva. Se o lesado já estava na posse do imóvel, o prazo é reduzido à metade. Quando o vício, por sua natureza, só puder ser conhecido mais tarde, o prazo contar-se-á do momento em que dele se tiver ciência, até o prazo máximo de um ano (CC, art. 445 e $\S 1^{\circ}$ ). 
Ao ser constatado o vício oculto, ao dono da obra abrem-se duas opções: a ação quanti minoris, para abatimento do preço da construção (art. 442 do $\mathrm{CC}^{923}$ ), ou então a rejeição da obra, nos termos do art. 441 do mesmo Diploma legal ${ }^{924}$, a qual confere ao dono o direito a indenização, se a obra já foi integralmente paga.

Se o empreiteiro conhecia o vício ou defeito do trabalho executado, deverá restituir o preço recebido com acréscimo de perdas e danos; se, no entanto, dele não tinha conhecimento, restituirá somente a quantia recebida, com as despesas do contrato, de acordo com o previsto no art. 443 do CC.

De acordo com a aplicação das normas gerais, o prazo para a redibição ou abatimento do preço é de um ano, contado da entrega efetiva da construção (art. 445 do CC). O $\S 1^{\underline{o}}$ do art. 445, entretanto, apresenta a seguinte ressalva, de extrema importância para o contrato em comento: "Quando o vício, por sua natureza, só puder ser conhecido mais tarde, o prazo contar-se-á do momento em que dele tiver ciência, até o prazo máximo de 180 (cento e oitenta) dias, em se tratando de bens móveis; e de 1 (um) ano, para os imóveis". Portanto, não sendo ostentativos os defeitos, mas tendo decorrido do uso ou pequeno desgaste, passa a correr o prazo a partir de seu efetivo aparecimento.

Ainda no que tange a esse assunto, tratando-se de hipótese de relação de consumo $^{925}$, não se olvide a eventual aplicação do art. 18 do CDC, a ser aplicado em caso de vícios de qualidade dos materiais utilizados na construção. De acordo com esse dispositivo legal, os fornecedores dos produtos respondem solidariamente, facultando-se ao consumidor, se o vício não for sanado no prazo de trinta dias, exigir:

- a substituição do material por outro de igual espécie, em boa condição de uso;

- a restituição imediata da quantia paga corrigida monetariamente, sem prejuízo de eventual indenização; ou

- o abatimento proporcional do preço.

\footnotetext{
${ }^{923}$ O dispositivo reza que: "Em vez de rejeitar a coisa, redibindo o contrato (art. 441), pode o adquirente reclamar abatimento no preço".

${ }^{924} \mathrm{O}$ artigo em comento dispõe: "A coisa recebida em virtude de contrato comutativo pode ser enjeitada por vícios ou defeitos ocultos, que a tornem imprópria ao uso a que é destinada, ou lhe diminuam o valor".

${ }^{925}$ A aplicação do Código de Defesa do Consumidor aos contratos de construção é cristalina e decorre da própria lei, já que, ao definir fornecedor, o art. $3^{\circ}$ incluiu expressamente o construtor, que é de novo mencionado no art. 12 do Diploma legal em comento. Configura-se a relação de consumo sempre que a construção for realizada para o destinatário final, mas não quando a construção decorrer de encomenda de empresas que comercializarão os imóveis, de modo habitual e profissionalmente.
} 
Também não se afasta a aplicação do art. 20, do mesmo Código, cuja redação é a seguinte:

\author{
“Art. 20. O fornecedor de serviços responde pelos vícios de \\ qualidade que os tornem impróprios ao consumo ou lhes diminuam \\ o valor, assim como por aqueles decorrentes da disparidade com as \\ indicações constantes da oferta ou mensagem publicitária, podendo \\ o consumidor exigir, alternativamente e à sua escolha: \\ I - a reexecução dos serviços, sem custo adicional e quando \\ cabível; \\ II - a restituição imediata da quantia paga, monetariamente \\ atualizada, sem prejuízo de eventuais perdas e danos; \\ III - o abatimento proporcional do preço".
}

O item a seguir abordará a responsabilidade dos construtores ínsita no art. 618 do $\mathrm{CC}$ vigente.

\title{
6.5. A responsabilidade dos construtores prevista no art. 618 do CC
}

Por força do art. 618 do $\mathrm{CC}^{926}$, o empreiteiro de materiais e execução responde pela solidez e segurança de seu trabalho, seja no que tange aos materiais, seja pela edificação como um todo, dentro do prazo irredutível de cinco anos, somente no que se refere à empreitada de edifícios ou outras construções consideráveis. Trata-se de responsabilidade objetiva $^{927}$, de natureza legal e de ordem pública.

No Código de 1916, esse prazo também era de cinco anos, sendo este considerado somente prazo de garantia de solidez da obra ${ }^{928}$. A ação pertinente a defeitos da obra

\footnotetext{
${ }^{926}$ O referido artigo, caput, tem a seguinte redação: "Nos contratos de empreitada de edifícios ou outras construções consideráveis, o empreiteiro de materiais e execução responderá, durante o prazo irredutível de 5 (cinco) anos, pela solidez e segurança do trabalho, assim em razão dos materiais, como do solo".

${ }^{927}$ Conforme salientado, a responsabilidade do profissional em estudo é, em regra, subjetiva. No entanto, quanto se trata de responsabilidade por solidez e segurança, esta é objetivada (TJRJ. 18 ${ }^{\mathrm{a}}$ Câmara Cível. Ap. 0006225-84.2003.8.19.0209. Rel. Roberto Felinto. j. 03.08.10. v.u.).

${ }^{928}$ PORTO, Mário Moacyr. Responsabilidade civil do construtor - o art. 1.245 do Código Civil. Revista dos Tribunais, São Paulo, v. 76, n. 623, set. 1987. p. 8. O art. 1.245 do CC de 1916 possuía o seguinte teor: "Nos contratos de empreitada de edifícios ou outras construções duráveis, o empreiteiro de materiais e de execução responderá, durante 5 (cinco) anos, pela solidez e segurança do trabalho, assim em razão dos materiais, como do solo, exceto, quanto a este, se não o achando firme, preveniu em tempo o dono da obra". A jurisprudência
} 
prescrevia somente no prazo comum de $20 \operatorname{anos}^{929}$. O entendimento em comento foi consolidado na Súmula 194 do Superior Tribunal de Justiça ${ }^{930}$. Ocorre que, após a mudança do Código Civil, esse prazo não é mais aplicável e o posicionamento deve ser especialmente repensado em razão do disposto pelo parágrafo único do art. 618, que estabelece que o dono da obra decairá do direito de reclamação sobre a solidez da construção se não propuser ação contra o empreiteiro no prazo de 180 dias seguintes ao aparecimento do vício ou defeito.

A exiguidade desse prazo gerou críticas da doutrina; ademais, o prazo do parágrafo único é decadencial, e não prescricional. Muitos são os pensamentos esposados, sendo certo que nem todos são muito coerentes.

Pablo Stolze Gagliano e Rodolfo Pamplona Filho entendem que o prazo retromencionado é alusivo apenas a eventuais vícios de qualidade que prejudiquem a economicidade ou a utilização da obra realizada, tratando-se de norma específica e, portanto, prevalecendo em relação àquela geral disposta pelo art. 445 do CC. O dono da obra teria, assim, prazo decadencial de 180 dias para desfazer o contrato, rejeitando a construção, ou, então, pedir abatimento do preço. Sustentam, ainda, os autores que, tratando-se de dano proveniente de falha na estrutura da obra, por defeito de segurança ou solidez, o direito de pleitear a reparação por perdas e danos poderá ser postulado no prazo prescricional geral de três ou cinco anos - respectivamente, art. 206, $\S 3^{\circ}$, inc. V, do CC e art. 27 do CDC -, caso se cuide ou não de relação de consumo ${ }^{931}$.

Não se partilha aqui, contudo, do mesmo entendimento, tendo em vista que o prazo do parágrafo único denota com clareza se aplicar aos vícios relacionados com solidez e segurança, e não com meros vícios redibitórios. Sustenta-se que se trata de hipóteses diferentes, sendo certo que o prazo concedido pela norma em comento - art. 618, parágrafo único - é menor do que o prazo que se aplica aos demais vícios, pois os defeitos

majoritária caminha no mesmo sentido, STJ. 4.T. REsp 215832/PR. Rel. Min. Sálvio de Figueiredo Teixeira. j.06.03.03. v.u.; TJRJ. Ap. 0128646-16.2006.8.19.001. Rel. Des. Ferdinaldo do Nascimento. j. 16.06.09. v.u.

${ }_{929}$ MEIRELLES, Hely Lopes. Do direito de construir, p. 240: "O prazo quinquenal dessa responsabilidade é de garantia e não de prescrição, como erroneamente têm entendido alguns julgados. Desde que a falta de solidez ou de segurança da obra apresente-se dentro de cinco anos de seu recebimento, a ação contra o construtor e demais participantes do empreendimento subsiste pelo prazo prescricional comum de 20 anos, a contar do dia em que surgiu o defeito". Na mesma esteira: TJSP. 4- Câmara de Direito Privado. Ap. 990101922576. Rel. Natan Zelinschi de Arruda. j. 25.11.10. v.u.

${ }^{930}$ A referida Súmula possui a seguinte redação: "Prescreve em vinte anos a ação para obter, do construtor, indenização por defeitos da obra".

931 GAGLIANO, Pablo Stolze; PAMPLONA FILHO, Rodolfo. Novo curso de Direito Civil responsabilidade civil, p. 317. 
pertinentes a solidez e segurança são mais evidentes e devem ser sanados com maior prontidão.

O fato de o prazo ser decadencial, no entanto, gera perplexidade. José Fernando Simão salienta que, para a reparação civil, a tutela pleiteada tem natureza condenatória e não poderia estar sujeita a prazo decadencial, afirmação com a qual não se pode deixar de concordar. O autor sustenta que o prazo de 180 dias é aplicável somente à desconstituição do contrato, e não à demanda indenizatória, cujo prazo será prescricional de cinco anos, se aplicável o Código Civil, ou de três anos, caso se trate de relação de consumo ${ }^{932}$.

Com efeito, a despeito de faltar clareza ao parágrafo em comento, a única explicação coerente que se pode dar ao prazo decadencial alude à demanda indenizatória. Se esse é o caso, surge uma segunda dúvida: o prazo de seis meses é aplicável às relação de consumo, tendo em vista que o art. $26, \S 3^{\circ}$, do CDC, estabelece que o prazo para reclamar de vícios ocultos é de 90 dias? José Fernando Simão sustenta que deve ser aplicado o menor prazo, mesmo em prejuízo do consumidor ${ }^{933}$. Hamid Charaf Bdine Junior $^{934}$ e Rodrigo Toscano de Brito ${ }^{935}$ esposam entendimento em contrário, propugnando pela aplicação do prazo de 180 dias para as relações de consumo, eis que a interpretação da lei deve ser sempre a mais propícia ao vulnerável. Partilha-se aqui do entendimento de José Fernando Simão, tendo em vista que, uma vez decidido o estatuto jurídico a ser aplicado, este deverá ser mantido para todas as situações.

A terceira dificuldade se encontra em conciliar o prazo de cinco anos do caput do dispositivo pré-citado com o prazo de 180 dias do parágrafo único, e definir a natureza do prazo previsto no caput.

Sobre o assunto, a maior parte da doutrina sustenta que o prazo de 180 dias não se relaciona com os cinco anos previstos no caput, que continua sendo um prazo de

\footnotetext{
${ }^{932}$ SIMÃO, José Fernando. Aspectos controvertidos da prescrição e decadência na teoria geral dos contratos e contratos em espécie. In: DELGADO, Mário Luiz; ALVES, Jones Figueiredo (Coord.) Questões controvertidas no direito das obrigações e dos contratos. São Paulo: Método, 2005. v. 4, p. 378. No mesmo sentido, Hamid Charaf Bdine Junior (Da empreitada. Revista dos Tribunais, v. 96, n. 858); Teresa Ancona Lopez (Comentários ao Código Civil. São Paulo: Saraiva, 2003. v. 7, p. 298); Nelson Nery Junior e Rosa Maria de Andrade Nery (Código Civil anotado e legislação extravagante. 2. ed. São Paulo: Revista dos Tribunais, 2003. p. 494); Ênio Santarelli Zuliani (Responsabilidade civil nos contratos de construção, empreitadas e incorporações, p. 234).

${ }^{933}$ SIMÃO, José Fernando, op. cit., p. 381.

${ }^{934}$ BDINE JUNIOR, Hamid Charaf, op. cit., p. 98.

${ }^{935}$ BRITO, Rodrigo Toscano de. Responsabilidade civil do construtor pela solidez e segurança da obra no sistema do Código Civil de 2002 e no Código de Defesa do Consumidor. In: DELGADO, Mário Luiz. ALVES, Jones Figueiredo. Questões controvertidas. São Paulo: Método, 2006. v. I, p. 188.
} 
garantia ${ }^{936}$; assim, o parágrafo primeiro seria alusivo somente ao exercício do direito de ação concernente aos defeitos que podem surgir dentro do período de cinco anos. Para cada novo defeito, portanto, abre-se novo prazo decadencial de 180 dias.

A esse propósito, transcrevem-se as conclusões de Sérgio Cavalieri Filho, essenciais para o presente estudo:

“1) O prazo de cinco anos estabelecido no caput nada tem a ver com este prazo decadencial. É, como visto, prazo de garantia, de ordem pública, irredutível.

2) O prazo de decadência estabelecido neste parágrafo único, como não poderia deixar de ser, é apenas para o exercício do direito de ação em relação aos vícios e defeitos que a obra apresentar no período de cinco anos. Se nesse prazo a obra apresentar defeitos em diferentes momentos, para cada novo defeito haverá o prazo de 180 dias para a propositura da respectiva ação, sempre a contar do aparecimento do vício ou defeito, mesmo em relação àqueles defeitos que, por ironia, só se manifestaram no último dia dos cinco anos.

3) Esse prazo decadencial só se aplica ao dono da obra em relação ao empreiteiro/construtor, conforme expresso no texto legal, não afetando a ação de terceiros contra o construtor, sujeitos apenas à prescrição, no prazo estabelecido no novo Código Civil”.

Na mesma toada segue o Enunciado n. 181, do Conselho da Justiça Federal, aprovado na III Jornada de Direito Civil, cujo teor é o que se segue:

“O prazo referido no art. 618, parágrafo único, do $\mathrm{CC}$, refere-se unicamente à garantia prevista no caput, sem prejuízo de poder o

\footnotetext{
${ }^{936}$ Ênio Santarelli Zuliani afirma que, quando ocorrerem danos dentro desse prazo de 5 anos, "será preciso identificar se são eles decorrentes da falta de solidez e segurança ou se eventualmente decorrem de vícios construtivos (rachaduras, infiltrações). No caso de se caracterizar falha estrutural (decorrente de falta de solidez e segurança), o dono da obra deverá reclamar indenização, sendo que, em se constatando defeitos construtivos, deverá reclamar abatimento, indenização ou devolução (rescisão)" (Responsabilidade civil nos contratos de construção, empreitadas e incorporações, p. 230).
} 
dono da obra, com base no mau cumprimento do contrato de empreitada, demandar perdas e danos".

Comunga-se desse entendimento, desde que se considere que o prazo decadencial não se aplica a demandas indenizatórias ${ }^{937}$. A ideia de contagem do prazo prescricional, contudo, é a mesma: o prazo de três ou cinco anos passa a transcorrer a partir do conhecimento do dano, que deverá se dar dentro do prazo de garantia dos cinco anos.

A propósito do tema, mencione-se, ainda, que o Tribunal de Justiça de São Paulo tem seguido uma vertente diferente no que tange ao prazo prescricional: este somente começaria a correr após o término do prazo de garantia ${ }^{938}$. Trata-se de uma tentativa de compensar a redução drástica do prazo prescricional em comento, a qual, entretanto, não encontra embasamento legal.

A doutrina majoritária sustenta que os termos "solidez" e "segurança do trabalho" devem ser interpretados com flexibilidade para abranger defeitos de menor monta, como rachaduras, vazamentos, entre outros; assim, todo defeito que comprometa a destinação normal da construção, ou mesmo do solo, deveria ser incluído na garantia dos cinco $\operatorname{anos}^{939}$. Carlos Roberto Gonçalves é um dos que expressam tal posicionamento, conforme manifestação reproduzida a seguir:

"O que a jurisprudência, na realidade, tem feito é alargar o conceito de solidez e segurança, para considerar uma e outra ameaçadas com o aparecimento de defeitos que, por sua natureza e numa interpretação estrita do art. 618, não teriam tal alcance. O que se justifica perfeitamente pelo progresso e desenvolvimento da

\footnotetext{
937 Esposam entendimento contrário, sustentando que o prazo de 180 dias se aplica a demandas indenizatórias: Arnaldo Rizzardo (Responsabilidade civil, p. 530; Álvaro Villaça Azevedo (Responsabilidade civil do empreiteiro - natureza normativa do art. 618 do Código Civil - prazo de garantia. Revista Magister de Direito Civil e Processual Civil, n. 4, jan./fev. 2005. Disponível em: 〈www.magisteronline.com.br〉. Acesso em: $10 \mathrm{dez}$. 2010).

${ }^{938}$ TJSP. 25 $5^{\text {a }}$ Câmara de Direito Privado. Ap. 992050596305. Rel. Ricardo Pessoa de Mello Belli. j. 11.08.10. v.u.; TJSP. 6 ${ }^{\mathrm{a}}$ Câmara de Direito Privado. Ap. 994020327718. Rel. Paulo Alcides. j. 12.08.10. v.u.

939 Nessa direção tem se posicionado a jurisprudência, conforme se observa da seguinte ementa: "REGIMENTAL. CIVIL. REPARAÇÃO DE DANOS. RESPONSABILIDADE CIVIL. EMPREITEIRO. SOLIDEZ E SEGURANÇA. INTERPRETAÇÃO EXTENSIVA. ART. 1.245 CC/1916. SÚMULA 7. - A solidez e a segurança a que se refere o art. 1.245 do Código Civil não retratam simplesmente o perigo de desmoronamento do prédio, respondendo, também, a construtora, por defeitos que possam comprometer, futuramente, o empreendimento, tais como rachaduras e infiltrações. Precedentes. - A construtora é quem detém o conhecimento técnico, cabendo a ela dizer a viabilidade ou não do material a ser utilizado, ainda que a escolha do material coubesse ao proprietário. - Em recurso especial não se reexamina provas. Súmula 07" (STJ. 3. T. AgRg no REsp 399.701-PR. Rel. Min. Humberto Gomes de Barros. j. 12.04.05. v.u).
} 
indústria da construção civil e pela necessidade de preservar a incolumidade física e patrimonial das pessoas que possam ser afetadas pelos mencionados vícios e defeitos" $" 940$.

A despeito de concordar com o alargamento da abrangência da norma, entende-se que esta não deve compreender os vícios de pequena monta, aos quais deve ser aplicado o esquema geral dos vícios redibitórios, mencionados no item anterior. O construtor tem duas espécies de responsabilidade distintas: a responsabilidade pela perfeição da obra e a responsabilidade pela solidez e segurança da obra. A perfeição da obra está relacionada com o seu acabamento, ao passo que a solidez diz respeito a vícios mais graves como rachaduras e vazamentos ${ }^{941}$. Desse modo, há que se ter prudência para distinguir os defeitos que, de fato, comprometem a utilização da construção, dos pequenos vícios, os quais recebem tratamento diferenciado.

Depreende-se do texto legal que a regra em comento refere-se tão somente à empreitada de materiais e lavor, o que não gera grandes questionamentos da doutrina ${ }^{942}$; no entanto, tal afirmação há de ser estudada com cuidado, já que a responsabilidade do construtor diplomado deve ser tomada com mais rigor do que a do empreiteiro sem habilitação (pedreiro). O Código Civil de 1916 igualava a responsabilidade dos profissionais com diploma universitário e dos demais, mesmo porque a profissão de engenheiros e arquitetos ainda não era regulamentada no Brasil na época de promulgação do Código ${ }^{943}$. Hoje, no entanto, não se justifica mais desconhecer os encargos técnicos que pesam sobre tais profissionais e manter a divisão entre empreitada de lavor e de material para fins de garantia da solidez e segurança da obra; ademais, o próprio Código hodierno estabelece, no art. 622, que o projetista tem responsabilidade pelos defeitos ínsitos no art. 618 do CC vigente. Se é esse o caso, por que excluir da responsabilização o empreiteiro de lavor?

Sustenta-se aqui, portanto, que tanto o projetista quanto o empreiteiro de lavor deverão ser responsabilizados pelo eventual abalo da construção ou danos relacionados à

\footnotetext{
${ }^{940}$ GONÇALVES, Carlos Roberto. Responsabilidade civil, p. 414.

${ }^{941}$ MEIRELLES, Hely Lopes. Do direito de construir, p. 238.

${ }^{942}$ Em sentido contrário, verifique-se: Sérgio Cavalieri Junior (Programa de responsabilidade civil, p. 345).

943 MEIRELLES, Hely Lopes, op. cit., p. 233.
} 
solidez e segurança desta, a menos que o dano esteja dissociado do trabalho desempenhado. Verifica-se, nesse caso, uma responsabilidade de natureza subjetiva ${ }^{944}$.

A indenização insculpida no art. 618 do CC variará de acordo com o ocorrido no caso concreto. Na hipótese de desabamento, v.g., deverá ser ressarcido o valor da construção, além de outros danos gerados pela queda do edifício; tratando-se, porém, de ameaça de desabamento, será necessário o custeio da demolição, se esta se fizer essencial, além do valor da construção e de outros danos. Se não for necessária a demolição, deverão ser indenizados os custos requeridos para que o prédio se mantenha de pé, com segurança. Também nesse caso não se afasta a indenização por outros danos, tendo em vista que, mesmo depois do conserto da obra, o prédio pode sofrer uma desvalorização em razão de sua gênese tormentosa ${ }^{945}$.

\subsection{A responsabilidade extracontratual do construtor}

No que se refere à responsabilidade extracontratual do construtor ou empreiteiro, abordar-se-á a responsabilidade decorrente dos danos provocados a vizinhos e a transeuntes.

Sustenta-se aqui que, independentemente do tipo de contrato de construção objeto de discussão, no que tange aos danos provocados aos vizinhos, há que se estabelecer responsabilidade solidária entre o proprietário do imóvel - que pode ou não ser o dono da obra - e o construtor ${ }^{946}$.

Saliente-se que a responsabilidade aludida é objetiva, pois decorre de encargo de

\footnotetext{
${ }^{944}$ AGUIAR DIAS, José de. Da responsabilidade civil, t. I, p. 356. Na jurisprudência, também se encontra consideração nesse sentido, STJ. 3. T. REsp 650603/MG. Rel. Min. Nancy Andrighi. j. 03.04.07. v.u.; STJ. 4. T. REsp 8410/SP. Rel. Min. Athos Carneiro. j. 23.10.91. v.u.: "Empreitada de lavor. Responsabilidade do engenheiro. Desabamento de prédio em construção. Embora somente concorrendo com o serviço, e recebendo do dono da obra os materiais a serem empregados, o engenheiro contratado para elaborar o projeto e fiscalizar a construção é civilmente responsável pelo evento danoso, pois era de se dever examinar os materiais empregados, tais como os tijolos, e recusá-los se frágeis ou defeituosos. Artigos 159 do Código Civil, invocado na inicial, e 1.245 do mesmo Código. A ocorrência de chuvas excessivas, máxime na região da serra do mar, não constitui fato da natureza imprevisível aos construtores de edifícios. Divergência pretoriana não caracterizada. Recurso especial não conhecido".

${ }_{945}$ AGUIAR DIAS, José de, op. cit., p. 349.

946 ZULIANI, Ênio Santarelli. Responsabilidade civil nos contratos de construção, empreitadas $e$ incorporações, p. 239; GONÇALVES, Carlos Roberto. Responsabilidade civil, p. 416; REPRESAS, Félix A. Trigo. MESA, Marcelo J. López. Tratado de la responsabilidad civil, t. II, p. 619.
} 
vizinhança $^{947}$, somente sendo ilidida pelo fortuito externo, ou seja, o evento imprevisível e inevitável cuja causa seja inteiramente estranha à construção ${ }^{948}$.

A responsabilidade do proprietário se justifica em razão da necessidade de assegurar ao vizinho prejudicado a reparação de um dano provocado em decorrência de atividade que é de interesse do proprietário ${ }^{949}$. Trata-se, na verdade, de simples aplicação da teoria da responsabilidade objetiva na sua modalidade risco-proveito, ou seja, quem aufere uma vantagem, arca também com o ônus ${ }^{950}$. Nada impede, porém, que o vizinho demande diretamente o construtor ou empreiteiro, ou então que o demande em conjunto com o proprietário ${ }^{951}$.

Considerações similares são aplicáveis aos danos gerados a terceiros, isto é, aqueles transeuntes que, mesmo não sendo vizinhos do imóvel em construção ou reforma, sofrem danos em razão de objetos lançados da propriedade. A despeito de não serem aplicáveis as normas de vizinhança nesse caso, entende-se que o proprietário não pode se eximir da responsabilidade, mesmo porque, a vítima, muitas vezes, não tem acesso ao construtor, não sabendo quem foi o responsável pela edificação. Aquele que a vítima vislumbra como causador do dano que lhe foi impingido é o proprietário dono da obra, motivo pelo qual este não pode se eximir de sua responsabilidade.

Há quem entenda, entretanto, que somente haverá solidariedade entre proprietário e construtor em caso de prejuízo provocado a vizinhos, e não a terceiros, quando então teria

\footnotetext{
${ }^{947}$ Nesse sentido, verifique-se: “Art. 1.299. O proprietário pode levantar em seu terreno as construções que lhe aprouver, salvo o direito dos vizinhos e os regulamentos administrativos".

${ }_{948}$ CAVALIERI FILHO, Sérgio. Programa de responsabilidade civil, p. 352.

${ }^{949}$ RIZZARDO, Arnaldo. Responsabilidade civil, p. 534.

950 “Confesso não possuir argumento para defender a exclusão do proprietário, embora possa parecer injusto responsabilizá-lo pela culpa da construtora que selecionou para executar trabalho em seu terreno. Contudo, é mera aparência, porque, no fundo, o proprietário será sempre beneficiado pelo serviço mal executado em relação a outrem. Afirma-se que quem constrói executa regular direito, o que não é verdadeiro em ocorrendo lesão ao patrimônio do vizinho. Quando o dano se concretiza, não existe exercício normal, mas, sim, irregular, de modo que não teria sentido estabelecer relação entre o vizinho e a construtora, quando o litígio decorre do direito de vizinhança, o que se aplica, em determinadas situações, a um terceiro (caso do pedestre atingido por destroços). Resulta ser muito mais injusto obrigar a vítima, vizinho ou estranho, a reclamar reparação da construtora, quando, no cume da cadeia de vantagens, figura o dono da obra. Evidente que se faculta ao dono exercer o direito de regresso contra a construtora, reclamando dela a restituição, princípio que justificaria até a denunciação da lide, nos termos do art. 70, III, do CPC” (ZULIANI, Ênio Santarelli. Responsabilidade civil nos contratos de construção, empreitadas e incorporações, p. 240).

${ }^{951}$ Verifique, nessa esteira, o acórdão proveniente do TJSP, 9a Câmara de Direito Público, Apelação Cível com Revisão n. 293.275-5/6-00- São José do Rio Preto, rel. João Carlos Garcia, j. em 16 de abril de 2008, v. m., no qual o município de São José do Rio Preto ingressou com demanda indenizatória em face de Condomínio de edifício que desmoronou, da Construtora responsável pela obra e dos condôminos proprietários de unidades autônomas, em razão dos gastos gerados pelo desmoronamento à municipalidade. Os réus foram condenados em primeira e segunda instâncias. O relator do voto vencido, Des. Antonio Rulli, sustentou a exclusão dos condôminos do polo passivo da lide.
} 
responsabilidade apenas o construtor ${ }^{952}$. O dono da obra somente teria responsabilidade em caso de contratação de pessoa inabilitada para realizar o trabalho. Nesse sentido, verifiquese o posicionamento de Maria Helena Diniz, in verbis:

"Haverá responsabilidade exclusiva do arquiteto, havendo erro de projeção ou de cálculo, e do empreiteiro ou construtor, no caso de defeito de construção. $\mathrm{O}$ arquiteto ou empreiteiro será o responsável, a não ser que o dono da obra os tenha escolhido mal, hipótese em que a responsabilidade abrangeria o comitente por presunção jure et de jure de culpa in eligendo [...], como preferem alguns autores, mas pelos arts. 932, III, e 933 responderá ele pelos atos praticados por terceiro, mesmo que não haja culpa de sua parte, pois a responsabilidade é objetiva"953.

José de Aguiar Dias esposa um terceiro entendimento, advogando que o proprietário não possui responsabilidade em hipótese alguma, já que este, ao contratar o construtor para empreender obra em seu terreno, encontra-se em seu exercício regular de direito, sendo responsável tão somente o profissional ou a construtora por terem agido com imperícia e imprudência e, por consequência, gerado dano a outrem. O doutrinador afirma, ainda, que não há solidariedade entre o dono da obra e o empreiteiro, eis que este não é preposto do primeiro e guarda autonomia no domínio de sua técnica ${ }^{954}$.

De qualquer maneira, na hipótese de prevalecimento de pensamento aqui perfilhado, qual seja, o da existência da solidariedade, e sendo demandado apenas o dono da obra, este poderá ingressar com ação regressiva contra o construtor, apontando sua atuação em desconformidade com o pactuado ou então a imperícia para execução das tarefas contratadas, isto é, a atuação com culpa ${ }^{955}$.

Saliente-se que a responsabilidade do proprietário acerca dos danos gerados pela

952 GONÇALVES, Carlos Roberto. Responsabilidade civil, p. 417; PORTO, Mário Moacyr. Responsabilidade civil do construtor - o art. 1.245 do Código Civil. Revista dos Tribunais, v. 76, n. 623, p. 11.

953 DINIZ, Maria Helena. Curso de Direito Civil brasileiro - responsabilidade civil, p. 319. No mesmo sentido, Hely Lopes Meirelles (Direito de construir, p. 245).

${ }^{954}$ AGUIAR DIAS, José de. Da responsabilidade civil, t. I, p. 351-353: "E não é possível vislumbrar culpa por parte do proprietário cuja obra, mal executada, vem a causar dano a terceiros. Com efeito, essa culpa só poderia ser in eligendo ou in vigilando. Quanto à primeira, está afastada, porque a construção é entregue, por lei, a um técnico; quanto à segunda, igualmente improvável, porque o proprietário é quase sempre um leigo". 955 ZULIANI, Ênio Santarelli. Responsabilidade civil nos contratos de construção, empreitadas e incorporações, p. 239; GONÇALVES, Carlos Roberto. Responsabilidade civil, p. 417. 
construção não se confunde com a responsabilidade objetiva prevista no art. 937 do CC $^{956}$, referente aos danos, sofridos por terceiros, resultantes da falta de reparos no imóvel. Nesse último caso, há abandono negligente da conservação do imóvel, não havendo qualquer construção no local, motivo que justifica somente responsabilizar o proprietário.

O construtor permanece responsável mesmo com a alteração de titularidade da propriedade. O novo adquirente do imóvel pode demandar judicialmente o construtor e o vendedor, mesmo em caso de problemas com solidez e segurança da obra ${ }^{957}$.

\subsection{A responsabilidade do incorporador imobiliário}

No início do Capítulo mencionou-se que o incorporador imobiliário é o intermediário entre o construtor e o adquirente da construção, assumindo obrigação de resultado e de fazer que consiste na entrega de prédio de acordo com as disposições constantes do projeto.

Faz-se necessário, preliminarmente à venda das unidades, que se proceda ao registro imobiliário do título da constituição da incorporação, conforme se depreende do art. 32 da Lei n. 4.591/1964. No caso de o incorporador não proceder ao registro supramencionado, torna-se responsável pelo reembolso dos valores pagos pelos adquirentes, além de eventuais danos que possam ter sofrido. A responsabilidade aludida é solidária com o proprietário do terreno sobre o qual iria se estabelecer o empreendimento, pois este último permitiu o surgimento da incorporação antes da regularização.

A inadimplência com relação às providências determinadas pela lei enseja, ainda, o pagamento, por parte do incorporador, mas não do proprietário do terreno, de uma multa no valor de $50 \%$ do montante recebido, a qual será revertida em favor do adquirente ou candidato à aquisição, conforme disposto no art. $35, \S 5^{\circ}$, da referida Lei n. 4.591.

O incorporador tem diversas obrigações, entre elas a de manutenção do projeto e do plano de construção originais, salvo quando houver autorização unânime dos interessados ou exigência legal (art. 43, inc. IV); a de não modificação das condições do pagamento ou

\footnotetext{
${ }^{956} \mathrm{O}$ artigo em comento possui a seguinte redação: "O dono de edifício ou construção responde pelos danos que resultarem de sua ruína, se esta provier de falta de reparos, cuja necessidade fosse manifesta".

${ }_{957}$ GONÇALVES, Carlos Roberto. Responsabilidade civil, p. 418-419: "Não resta dúvida de que o alienante deve assegurar ao adquirente o uso da coisa. Este o princípio acolhido pelo nosso Direito, bem expresso no capítulo dos vícios redibitórios e da evicção. Assim, deve indenizar não só os prejuízos decorrentes de pequenos defeitos da obra como também, e com mais razão, os mais graves, provocados pela falta de solidez e segurança".
} 
alteração do preço, a menos que essa faculdade conste do contrato (art. 43, inc. V); e a escolha e supervisão da execução das obras. Desses deveres origina-se a responsabilização pela construção, devendo indenizar os adquirentes em caso de interrupção das atividades ou atraso injustificado. Como principal direito, menciona-se o recebimento das parcelas,

cujo atraso no adimplemento pode gerar o direito de retenção da obra até o cumprimento de todas as obrigações assumidas (art. $52^{958}$ ).

O incorporador imobiliário também será responsável por todo o prejuízo que possa advir da inexecução ou da execução imperfeita do contrato, em particular, falhas ou construção defeituosa e inadimplemento total.

Em qualquer caso, o incorporador terá responsabilidade solidária com o construtor, na medida em que é o verdadeiro contratante perante os adquirentes da unidade. Já o construtor responde em razão da garantia legal imposta em decorrência da ordem pública e por ser o substituto do incorporador na execução do contrato; ademais, este último é o verdadeiro causador do dano ${ }^{959}$.

Os prejudicados, isto é, os adquirentes das unidades autônomas, podem demandar diretamente o construtor, o incorporador ou os dois ao mesmo tempo. Se somente for proposta ação em face do incorporador, este terá direito de regresso em face do construtor.

Como, na maior parte das vezes, as unidades são vendidas para consumidores finais, é perfeitamente aplicável o Código de Defesa do Consumidor, nos termos já explicitados.

\subsubsection{O patrimônio de afetação}

A Lei n. 10.931, de 2 de agosto de 2004, incluiu no art. 31 da Lei n. 4.594/1964, disposições sobre o patrimônio de afetação nas incorporações imobiliárias.

\footnotetext{
${ }^{958}$ O mencionado dispositivo assim preceitua: "Cada contratante da construção só será imitido na posse de sua unidade se estiver em dia com as obrigações assumidas, inclusive as relativas à construção exercendo o construtor e o condomínio até então, o direito de retenção sobre a respectiva unidade; no caso do art. 43, esse, este direito será exercido pelo incorporador".

${ }^{959}$ Conforme Sérgio Cavalieri Filho: "Em nada altera esta conclusão o fato de ter sido a construção cometida ao construtor. O incorporador continua responsável porque é o contratante. Responde também o construtor, porque é o causador direto do dano, e tem responsabilidade legal, de ordem publica, de garantir a solidez e segurança da obra em benefício do seu dono e da incolumidade coletiva, conforme já demonstrado" (Programa de responsabilidade civil, p. 355). No mesmo sentido, Arnaldo Rizzardo (Responsabilidade civil, p. 550); Rodrigo Toscano de Brito (Responsabilidade civil do construtor pela solidez e segurança da obra no sistema do CC de 2002 e no CDC, p. 105).
} 
A alteração tem por finalidade estabelecer regras e critérios que disciplinam as relações imobiliárias para aumentar a transparência das incorporações, a credibilidade dos empreendimentos e a segurança jurídica. Teve origem na experiência catastrófica oriunda da falência da construtora Encol, que gerou prejuízos para mais de 42 mil famílias, em decorrência de mais de 700 empreendimentos fracassados.

O caso em comento não é isolado, uma vez que era procedimento comum das construtoras direcionar verbas levantadas em um empreendimento para destiná-las a outro, que estivesse em atraso ou se encontrasse deficitário; contudo, o efeito "bicicleta" não poderia se prolongar ad infinitum, motivo pelo qual, quando a empresa tornava-se definitivamente insolvente, os consumidores perdiam o patrimônio investido na aquisição da propriedade.

O termo "afetar" significa destinar determinado patrimônio a um objetivo. Sendo assim, por regime de afetação entende-se o regime de incorporação mediante o qual o objeto do empreendimento fica segregado do patrimônio geral da empresa ${ }^{960}$. Será feita a afetação de patrimônio específico e separado para cada empreendimento, evitando o desvio de recursos - o significa que, havendo mais de um empreendimento afetado, um não se comunicará com o outro ${ }^{961}$.

A afetação, que é facultativa, e não obrigatória como teria sido salutar, poderá ser requerida no memorial de incorporação ou em momento posterior, mas somente até a conclusão da obra, o que se verifica com a emissão do habite-se. Caso tenha havido alguma alienação em período anterior, será necessário obter a anuência dos futuros proprietários da unidade.

O memorial de incorporação traz as características do patrimônio que será objeto de afetação, e também compõem o projeto de construção, a descrição e caracterização das unidades autônomas, a discriminação das frações ideais, além das peças enumeradas no art. 32 da Lei n. 4.591/1964.

\footnotetext{
${ }^{960}$ Nesse sentido, verifique-se o teor do art. 31-A e seu $\S 11^{\mathrm{o}}$ : "Art. 31-A. A critério do incorporador, a incorporação poderá ser submetida ao regime da afetação, pelo qual o terreno e as acessões objeto de incorporação imobiliária, bem como os demais bens e direitos a ela vinculados, manter-se-ão apartados do patrimônio do incorporador e constituirão patrimônio de afetação, destinado a consecução da incorporação correspondente e à entrega das unidades imobiliárias aos respectivos adquirentes.

$\S 1$. O patrimônio de afetação não se comunica com os demais bens, direitos e obrigações do patrimônio geral do incorporador ou de outros patrimônios de afetação por ele constituídos e só responde por dívidas e obrigações vinculadas à incorporação respectiva".

${ }^{961}$ POSSI, Luciana. Contrato de incorporação imobiliária - notas à Lei 4.591/64, p. 651.
} 
Com a afetação, que deverá ser averbada no Registro de Imóveis, o terreno objeto de incorporação imobiliária e os demais bens e direitos a ela vinculados manter-se-ão apartados da seara patrimonial do incorporador, não se comunicando. Com isso, há a constituição de um patrimônio separado e, portanto, independente, destinado à efetiva consecução da obra e entrega das unidades aos respectivos adquirentes. A independência patrimonial, todavia, não exclui o acervo da incorporação do patrimônio do incorporador, nem limita sua responsabilidade pela incorporação, motivo pelo qual continuará cabendo a este a obtenção de recursos para a conclusão da obra ${ }^{962}$.

O patrimônio de afetação extingue-se com a conclusão da obra, ou seja, com a averbação da construção pelos registros dos títulos de domínio ou de direito de aquisição em nome dos correspondentes compradores e, quando for o caso, pela extinção das obrigações do incorporador perante a instituição financeira do empreendimento. Também é hipótese de extinção a desistência do empreendimento, no prazo de carência previsto em lei, quando, então, deverão ser restituídas as quantias já pagas pelos compradores.

Em caso de falência ou insolvência do incorporador, os efeitos da quebra não atingem o patrimônio da afetação, o que possibilita a continuidade da incorporação. De acordo com o art. 31-F, $\S 1^{0}$, nos sessenta dias que se seguirem à decretação da falência ou insolvência civil do incorporador, o condomínio dos adquirentes, por convocação da Comissão de Representantes, ou, na sua falta, de um sexto dos adquirentes, ou, ainda, por determinação do juiz prolator da decisão, realizará assembleia geral para:

- ratificar o mandado da Comissão ou eleger novos membros, por maioria simples;

- instituir o condomínio da construção, por dois terços dos adquirentes em primeira convocação, ou por maioria absoluta em segunda;

- deliberar pela continuidade da obra ou pela liquidação do patrimônio, também pelo mesmo quorum.

A Comissão de Representantes do Condomínio está investida de mandato legal para adotar todas as providências necessárias para continuidade da obra ou liquidação do patrimônio; no entanto, o produto do leilão não será totalmente destinado aos proprietários. Em primeiro lugar, serão pagos os créditos trabalhistas, previdenciários e fiscais

${ }^{962}$ CHALHUB, Melhim Namem. A afetação das incorporações imobiliárias - Lei n⿳ํㅗ 10.931/2004. Jus Navigandi, Teresina, ano 10, n. 866, 16 nov. 2005. Disponível em: <http://jus2.uol.com.br/doutrina/ texto.asp?id=7595>. Acesso em: 6 abr. 2010. 
vinculados ao empreendimento; somente depois o valor remanescente será revertido em prol dos proprietários, sendo pago à Comissão de Representantes. O montante em discussão permanece afetado até o limite necessário à conclusão da obra.

Por fim, saliente-se que a mesma lei instituiu o Regime Especial Tributário de Afetação aplicável às incorporações imobiliárias, que é um regime opcional, porém irretratável, enquanto houver direitos de créditos ou obrigações do incorporador perante os compradores de imóveis que compõem a incorporação. É possível adotar o regime de afetação e subordiná-la ao regime do lucro real, ou, então, adotar o regime aqui examinado $^{963}$.

De acordo com o regime especial, o incorporador pagará a alíquota unificada de $7 \%$ da receita mensal recebida, para o custeio do Imposto de Renda das Pessoas Jurídicas (IRPJ), da Contribuição Social sobre o Lucro Líquido (CSLL), da Contribuição para o Financiamento da Seguridade Social (Cofins) e da Contribuição para os Programas de Integração Social e de Formação do Patrimônio do Servidor Público (PIS/Pasep) ${ }^{964}$.

963 CHALHUB, Melhim Namem. A afetação das incorporações imobiliárias - Lei $\mathrm{n}^{\mathbf{0}}$ 10.931/2004. Jus Navigandi, Teresina, ano 10, n. 866, 16 nov. 2005. Disponível em: <http://jus2.uol.com.br/doutrina/ texto.asp?id=7595>. Acesso em: 6 abr. 2010.

${ }^{964}$ Art. $4^{\circ}$ da Lei n. 10.931/2004. 


\section{CONCLUSÃO}

As considerações formuladas ao longo do trabalho corroboraram a importância da análise cuidadosa da responsabilidade dos profissionais e da indenização dos danos dela decorrentes. Conforme salientado, a despeito de se tratar de tema clássico, remanesce o interesse em seu estudo, a fim de dissipar diversas incongruências e entendimentos equivocados, ainda que consolidados pela doutrina e pela jurisprudência. Reproduzem-se, a seguir, as principais conclusões alcançadas neste estudo:

1. A caracterização da conduta que gera responsabilidade deve afastar-se da consideração da antijuridicidade ou ilicitude, uma vez que se admite responsabilidade decorrente de conduta lícita.

2. A culpa caracteriza-se por dois traços constitutivos: a voluntariedade e a evitabilidade da conduta. Pode ser aferida in abstracto ou in concreto, predominando na jurisprudência a análise da culpa de acordo com a primeira modalidade, ou seja, mediante a comparação da conduta do ofensor com a do bonus pater familias.

3. A classificação da culpa de acordo com a gravidade (lata, leve e levíssima) passou a ter importância para efeitos de responsabilidade civil a partir da vigência do Código Civil hodierno, e a introdução no ordenamento jurídico do parágrafo único do art. 944, que autoriza a diminuição da indenização em caso de excessiva desproporção entre a gravidade da culpa e o dano. Diverge-se do disposto pela norma, mas há que se reconhecer a alteração de posicionamento legislativo introduzida por ela deverá influenciar os tribunais.

4. O parágrafo único do art. 927 do CC consagrou a adoção da teoria do risco criado pelo Código vigente. A atividade de risco mencionada no dispositivo legal é aquela que, mesmo quando exercida de maneira regular, seja potencialmente nociva ou danosa. A atividade de médicos, advogados e engenheiros não é essencialmente de risco, motivo pelo qual sua responsabilidade não se enquadra no disposto no referido parágrafo único, a despeito de entendimentos em contrário.

5. A teoria de causalidade direta ou imediata, adotada pelo art. 403 do CC de 2002 e pelo art. 1.060 do CC de 1916, consiste na identificação da causa somente como o 
evento necessário para a consecução do dano. A expressão "direto e imediato", portanto, deve ser interpretada como a necessidade de verificação do nexo causal necessário.

6. O art. 393 do CC igualou as excludentes de caso fortuito e força maior para fins de eximir o devedor da obrigação de indenizar em decorrência do inadimplemento da obrigação; ademais, ambas dependem de dois elementos fundamentais: a ausência de culpa e a inevitabilidade do evento. A distinção, no entanto, ainda permanece viva na doutrina, configurando-se o caso fortuito como o impedimento proveniente de atos humanos, ao passo que a força maior é o acontecimento externo à figura humana.

7. Dano é toda lesão, sofrida pelo ofendido, de interesses tutelados pela ordem jurídica, quer sejam de caráter patrimonial, quer de caráter moral. O dano material consiste na lesão que afeta um interesse relativo ao patrimônio econômico da vítima e divide-se em dano emergente e lucro cessante. $\mathrm{O}$ dano emergente é um dano positivo, representado pela concreta diminuição do patrimônio. O lucro cessante é um dano negativo, decorrente do fato da vítima ter deixado de auferir um benefício em função do incidente danoso.

8. Lucros cessantes não se confundem com a teoria da perda de uma chance. No primeiro caso, as probabilidades de ocorrência da expectativa frustrada se encontram em grau máximo, não havendo que se falar em incerteza. Na perda de uma chance, não se sabe qual o resultado que a concretização da chance traria; ademais, trata-se de espécie de dano emergente, já que não implica o ressarcimento de um lucro que eventualmente poderia se verificar, mas sim o dano atual e certo decorrente da frustração da oportunidade.

9. Dano moral é lesão de direitos da personalidade ou direitos fundamentais, ou seja, direitos da personalidade erigidos à condição de constitucionais. Não se trata, nesse caso, de dano homogêneo, admitindo diversas espécies, tantas quantas puderem decorrer da cláusula geral de tutela da pessoa humana. A dor não constitui elemento de identificação do dano moral, mas tão somente seu reflexo; ademais, a verificação do abalo emocional não é imprescindível para a indenização do dano extrapatrimonial.

10. Pessoa jurídica não sofre dano moral, pois não possui direitos da personalidade, que são inerentes exclusivamente à pessoa humana. 
11. A despeito de posicionamento majoritário em sentido divergente, entende-se que o fundamento para a reparação dos danos morais é somente o compensatório. Não há qualquer justificativa para a importação dos danos punitivos ao Direito brasileiro. Pode-se admitir, excepcionalmente, um caráter punitivo à indenização quando decorrente de danos causados a um grande número de pessoas; contudo, os valores excedentes à reparação do dano devem ser destinados a um fundo de amparo às vítimas, e não ao litigante.

12. Os critérios de avaliação do dano moral decorrem do fundamento que lhe seja concedido. São compatíveis com a função exclusivamente compensatória os critérios da extensão do dano e das condições pessoais da vítima.

13. O dano estético é uma espécie de dano moral considerado em sentido amplo, eis que decorre da lesão a um direito da personalidade: o direito à integridade física. Resulta da lesão à forma física externa do indivíduo, de modo a ocorrer uma alteração morfológica desfavorável à sua aparência, em maior ou menor extensão. Não se confunde com o dano moral em sentido estrito, que decorre da lesão ao direito à integridade moral. A alteração da aparência não precisa gerar abalo moral para que seja indenizado, portanto, sendo verificado o desequilíbrio do aspecto estético do indivíduo e, concomitantemente, abalo psíquico deverão ser concedidas duas verbas indenizatórias distintas.

14. A possibilidade de cumulação de verbas a título de dano moral e dano estético já está consolidada na Súmula 387 do STJ, tratando-se de entendimento acertado e embasado em firme posicionamento doutrinário.

15. A perda de uma chance consiste no desaparecimento de um evento favorável que não se tem certeza se efetivamente aconteceria, de modo que a indenização pela frustração da oportunidade não é do ganho que se deixou de ter ou do prejuízo que se deixou de evitar, mas da oportunidade perdida pela vítima. A aplicação da teoria depende da seriedade da chance perdida, o que deve ser avaliado caso a caso. A perda de uma chance pode ser tomada como um dano autônomo - na modalidade de dano material emergente -, ou então como autorizadora da flexibilização do nexo de causalidade, em especial na seara da atividade médica.

16. O dano decorrente da perda de uma chance deve ser apurado de acordo com as probabilidades de concretização da oportunidade perdida. Somente configura-se correta a indenização a título de danos morais quando não for possível estabelecer o valor do dano pelos meios de prova previstos em direito, em particular o pericial. 
17. A divisão das obrigações em meio e resultado tem por escopo determinar a quem caberá o ônus da prova da culpa pelo inadimplemento. A obrigação de meio decorre de situações em que a álea inerente ao negócio jurídico não permite que o devedor garanta o resultado objetivado pelo credor. A obrigação de resultado não é imbuída dessa característica e depende basicamente da atuação do próprio devedor. Ao credor de uma obrigação de resultado cumpre tão somente provar que o resultado não foi atingido, enquanto ao credor de uma obrigação de meio compete provar que o dano que lhe foi impingido advém da atuação negligente do profissional, o que decerto será mais difícil.

18. O profissional responde por ato próprio e ato de terceiro - preposto, empregado e serviçal. No que tange ao direito de regresso, somente faz jus a esse ressarcimento em relação a empregados e prepostos que atuaram com dolo ou culpa grave, em

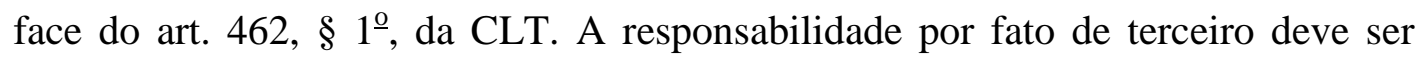
observada em duas fases: na primeira, formada entre o terceiro causador do dano e a vítima, deve haver culpa ${ }^{965}$; na segunda, estabelecida entre o ofensor e o responsável, a responsabilidade é objetiva, por força do disposto no art. 933 do CC.

19. O profissional que atua como servidor público exerce função pública, portanto, seria o caso de aplicação do disposto no art. $37, \S 6^{\circ}$, da $\mathrm{CF}$, de modo a responder o Estado objetivamente pelos danos provocados pelo servidor, independentemente, também, de culpa desse; no entanto, o entendimento majoritário, e com o qual se concorda, é de que somente haverá responsabilidade das pessoas jurídicas de direito público quando se verificar erro profissional.

20. O Código de Defesa do Consumidor é aplicável à atividade dos profissionais liberais, ainda que sua responsabilidade seja subjetiva, conforme consta do art. 14,§ $4^{\underline{0}}$. Em decorrência disso, é possível a inversão do ônus da prova, prevista no inc. VIII do art. $6^{0}$, quando for constatada a verossimilhança da alegação, ou a hipossuficiência do contratante. Da mesma maneira, é aplicável a prescrição de cinco anos, insculpida no art. 27.

21. A pessoa jurídica formada por profissionais liberais deve responder objetivamente, com exceção da sociedade formada pelos advogados, em razão das peculiaridades constantes do Estatuto da Advocacia e da Ordem dos Advogados do Brasil

\footnotetext{
${ }^{965}$ Nada impede que a primeira fase seja formada por situação que enseja responsabilidade objetiva, quando, então, não se avaliará a culpa em hipótese alguma. Não é o que ocorre no caso em tela, já que se analisa a responsabilidade do profissional, em regra, subjetiva.
} 
(EAOAB) e da ausência de caráter mercantil. Os sócios advogados respondem pessoal, subsidiária e ilimitadamente com a sociedade pelos danos causados por ação ou omissão no exercício da advocacia.

22. No que tange a hospitais e clínicas médicas, estes respondem direta e objetivamente pelos danos decorrentes da hospedagem do paciente e de atos paramédicos. Com relação aos médicos que integram seu corpo clínico, só haverá responsabilização da pessoa jurídica se o profissional tiver atuado com culpa. A responsabilidade das operadoras de plano de saúde somente será solidária se mantiver ou credenciar hospitais para a prestação dos serviços; quando a escolha do profissional cabe ao cliente, não haverá responsabilidade.

23. O médico tem o dever de: aconselhar e informar o paciente, seguindo os preceitos do Código de Ética Médica; obter o consentimento esclarecido do paciente, obtido após a devida informação sobre os principais aspectos do tratamento ou intervenção; cuidar do paciente até o término do tratamento, sendo vedado o abandono deste; manter sigilo sobre as informações obtidas no exercício da profissão.

24. A transfusão de sangue, quando negada por pacientes da religião "Testemunhas de Jeová", não deve ser realizada pelo médico, exceto em caso de urgência, quando, então, o profisssional deverá obter, se possível, autorização judicial para a intervenção. Em caso de impossibilidade de obter a referida autorização, deverá proceder à transfusão assim mesmo. Isso se aplica também aos pacientes incapazes, que não possuem o discernimento necessário para determinar se colocarão sua vida em risco em virtude de princípios religiosos.

25. O erro profissional ou técnico, que se refere ao emprego da técnica incorreta para o caso concreto, e o erro de diagnóstico não necessariamente implicam culpa do profissional. É o erro médico que sempre enseja indenização, uma vez que imbuído de negligência, imprudência, imperícia, ou uma combinação das modalidades de culpa.

26. A obrigação do cirurgião plástico mesmo em caso de cirurgia meramente embelezadora, a despeito de entendimento doutrinário e jurisprudencial divergente, não é de resultado, mas somente de meio agravada, já que o profissional está submetido à mesma aleatoriedade das outras especialidades médicas.

27. São obrigações de resultado: a vacinação, a transfusão de sangue, a realização de exames biológicos e radiológicos, bem como de consultas. 
28. O chefe da equipe médica, quando escolhe os membros que irão integrá-la, responde solidariamente pelos danos por ele provocados, inclusive com relação ao médico anestesista, a despeito da autonomia científica da anestesiologia. No caso deste último ser indicado pelo hospital, a responsabilidade do cirurgião-chefe é afastada. Da mesma forma, na remota hipótese de o anestesista ter sido escolhido pelo próprio enfermo, também não haverá responsabilidade do cirurgião.

29. O médico responde pelos danos oriundos dos vícios dos aparelhos e aparatos tecnológicos utilizados, exceto se puder comprovar que o instrumento já havia sido pré-testado e funcionava perfeitamente.

30. A questão do ônus da prova se torna mais relevante na atividade médica, pois para o doente é difícil demonstrar que o médico atuou com culpa. Sendo assim, desenvolveram-se diversos artifícios com a finalidade de facilitar a responsabilização do profissional: a inversão do ônus da prova, a teoria da carga dinâmica do ônus da prova, em que cada uma das partes colabora para a fase probatória do processo com os elementos que puder fornecer; a perda de uma chance; a teoria da res ipsa loquitur - a expressão significa "a coisa fala por si mesma" e denota a hipótese em que o ocorrido, por si próprio, demonstra que a culpabilidade somente pode ser do profissional -; e a teoria da faute virtuelle, segundo a qual diante da constatação de um resultado anormalmente danoso em comparação com o tratamento ministrado, considera-se impossível que uma falta não tenha sido cometida pelo médico.

31. A teoria da perda de uma chance, na responsabilidade médica, implica, em regra, a flexibilização do nexo causal. O dano advindo da perda da chance de cura ou sobrevivência surge porque determinado processo em curso não foi interrompido, diferenciando-se da perda de uma chance clássica, que se relaciona à obtenção de vantagem futura e constitui dano autônomo passível de indenização.

32. O hospital, conforme salientado, responde objetivamente por ato próprio, decorrente do contrato firmado com o paciente, o qual se assemelha ao de hospedagem. Em razão disso, responde objetivamente por danos decorrentes de infecção hospital. Também responde objetivamente por atos paramédicos, isto é, por atos perpetrados por enfermeiros, técnicos de enfermagem e profissionais semelhantes. Por fim, no que tange aos médicos, responde somente em caso de comprovação de culpa em sua atuação. Não haverá responsabilidade solidária com os médicos que apenas locam as instalações do hospital. 
33. Há responsabilidade solidária entre as operadoras de plano de saúde e os hospitais e clínicas quando estes últimos são credenciados e não resta escolha ao adquirente do plano acerca dos estabelecimentos que quer frequentar. Se a escolha do paciente for livre, sendo suas despesas médicas simplesmente reembolsadas, não haverá responsabilidade da operadora.

34. Com relação a outras modalidades de atividade da área da saúde, a obrigação dos dentistas é, em regra, de meio, em decorrência da álea inerente à atividade, assim como sua responsabilidade é subjetiva. A obrigação dos farmacêuticos, no entanto, é de resultado, uma vez que consiste na manipulação correta das fórmulas, atividade que não contém caráter de aleatoriedade, dependendo tão somente de sua própria atuação. A obrigação dos enfermeiros é de meio, e a sua responsabilidade subjetiva.

35. A responsabilidade do advogado, na maior parte das vezes, tem natureza contratual e subjetiva. Sua obrigação na área contenciosa é de meio, ao passo que na área consultiva é de resultado. O profissional será responsabilizado pelos erros inescusáveis, o que se verifica nos atos de desídia no patrocínio da causa, como a omissão de providências necessárias e omissão de informações.

36. A perda de prazo processual é hipótese inafastável de responsabilização do profissional, gerando questionamentos no que tange à sua indenização. Sustentouse que há de ser aplicada a teoria da perda de uma chance, calculando-se o valor indenizatório de acordo com a probabilidade de deferimento da pretensão do cliente prejudicado. No que tange a recursos especiais e extraordinários, cabe ao advogado estudar a conveniência de sua interposição.

37. A responsabilidade do advogado é a área de aplicação por excelência da teoria da perda de uma chance. Encaixa-se com perfeição na falta de propositura judicial, implicando a prescrição da demanda; no pedido não formulado, na ausência de interposição de recurso, conforme mencionado no item anterior, na omissão na produção de prova necessária, além de outras hipóteses.

38. O advogado responde, por um lado, pelas ofensas irrogadas em juízo, não sendo a violação da honra das partes, magistrados e promotores autorizada pela imunidade do causídico; por outro, não pode ser condenado diretamente por litigância de máfé.

39. O advogado será igualmente responsabilizado em caso de violação do dever de sigilo profissional. 
40. O contrato puramente de mandato diferencia-se do contrato firmado pelo advogado, no qual preponderam os elementos do contrato de prestação de serviço. $O$ advogado, ao contrário do mandatário, atua no interesse do cliente, mas decide por conta própria os procedimentos que deverão ser tomados. O próprio Código Civil estabelece a diferença entre o mandatário e o advogado, determinando, no art. 692, que o mandato judicial fica subordinado às normas que lhe dizem respeito, sendo apenas supletivamente regido pelo Diploma Civil.

41. Os tabeliães, notários e registradores exercem suas atividades como particulares em colaboração com o Poder Público, desenvolvendo função pública mediante delegação e sendo considerados servidores públicos. Sua responsabilidade é contratual em relação ao requerente dos serviços e extracontratual em relação a terceiros que sejam prejudicados em face de sua atuação. A obrigação desses profissionais é de resultado, devendo comprovar a conclusão perfeita dos trabalhos que se propuseram a realizar.

42. O Estado responde objetiva e solidariamente pelos danos que titulares dos cartórios extrajudiciais causarem a terceiros, facultando-se ao Poder Público o ressarcimento em ação regressiva contra o causador do dano, desde que se comprove sua atuação culposa ou dolosa. Não se acolhe a orientação jurisprudencial do STJ no sentido de que o tabelião deve ser direta e objetivamente responsabilizado, ao passo que a responsabilidade do Estado é tão somente subsidiária.

43. A confluência de normas sobre o assunto deixa dúvidas no que tange à responsabilidade do tabelião ser subjetiva ou objetiva. Em face de já se desenhar um cenário de responsabilidade meramente subsidiária do Estado, sustentou-se que a melhor interpretação para a matéria é a de que a responsabilidade desse profissional é objetiva, já que ele atua como prestador de serviço público, sendo equiparado às pessoas jurídicas de direito público.

44. A responsabilidade é da pessoa física do tabelião e não do cartório extrajudicial, pois este não possui responsabilidade judiciária; da mesma forma, essa responsabilidade não se transfere para o novo titular do cartório. Esses profissionais somente respondem, assim, pelos atos próprios e pelos atos cometidos por seus prepostos e empregados.

45. A atuação dos engenheiros, arquitetos e empreiteiros, quando mal-executada, é potencialmente mais danosa do que a de advogados e médicos, o que não significa que se trata de hipótese abrangida pelo parágrafo único do art. 927 do CC. Sua 
responsabilidade continua, na maior parte dos casos, sendo subjetiva, desde que não se associem para formação de uma pessoa jurídica. Suas obrigações, contudo, são de resultado.

46. O contrato de construção admite duas modalidades: a construção por empreitada e a construção por administração. As duas espécies de contrato não se confundem porque o construtor por empreitada assume os encargos técnicos da obra e os riscos econômicos da construção, custeando-a, com preço fixado de início, mesmo no caso de empreitada por medição. No contrato de administração, ao contrário, o construtor responde somente pela execução técnica da obra, custeada paulatinamente pelo dono-contratante, conforme as necessidades. Nessa última modalidade, o contratante apenas conhecerá o preço total do empreendimento ao término da construção.

47. Na esfera do contrato de empreitada, analisou-se o art. 618 do CC, que determina que o empreiteiro de material e de lavor tem dever de garantia pela segurança e solidez da obra, e chegou-se ao entendimento que o prazo de cinco anos do caput é de garantia, e o prazo decadencial de 180 dias refere-se somente à pretensão de desconstituição do contrato. O prazo prescricional aplicável é o comum, de três anos, que se conta a partir da descoberta do defeito, o que deve se verificar dentro do prazo de garantia de cinco anos. Se a relação configurar-se como de consumo, aplica-se o prazo prescricional de cinco anos (art. 27 do CDC), e o prazo decadencial de 90 dias (art. 26, § $3^{\circ}$, do CDC).

48. $\mathrm{O}$ artigo 618 do $\mathrm{CC}$ admite interpretação mais ampla para abranger todos os danos que comprometam o bom uso da propriedade, sem, contudo, confundir-se com os vícios de pequena monta, aos quais deve ser aplicado o esquema geral dos vícios redibitórios.

49. O dispositivo em exame restringe a garantia da solidez para a empreitada de material e lavor, mas a matéria deve ser analisada com cautela, já que não se justifica manter a divisão entre empreitada de lavor e de material para os fins em comento, desconhecendo os encargos técnicos que pesam sobre esses profissionais; ademais, o próprio art. 622 do CC estabelece que o projetista tem responsabilidade pelos defeitos inseridos no art. 618 do CC. Se este é o caso, não convém excluir da responsabilização o empreiteiro de lavor. 
50. O construtor também tem responsabilidade extracontratual com relação a vizinhos do dono da obra e terceiros. Em ambos os casos, a responsabilidade é solidária com o comitente.

51. O incorporador tem responsabilidade solidária com o construtor pelos danos sofridos pelos adquirentes, que podem promover a ação somente em face do incorporador, somente em face do construtor, ou contra os dois, em litisconsórcio facultativo. Se somente o incorporador for demandado, poderá ingressar com ação regressiva em face do construtor.

52. Por tudo quanto salientado, fica claro que a responsabilidade profissional ainda é a área em que a culpa se encontra melhor acolhida, a despeito da tendência demonstrada pelo direito francês de objetivar a responsabilidade por acidentes médicos, o que se entende ser conveniente somente para a realidade francesa e não para a brasileira. Da mesma forma, advoga-se aqui pela generalização da obrigação de meio nessa seara, sempre que os resultados do trabalho não dependerem apenas do profissional. 


\section{REFERÊNCIAS}

AGUIAR DIAS, José de. Dano psíquico e dano estético - uma decisão memorável. Ajuris, v. 29, n. 66, p. 64-76, nov. 1983.

Cláusula de não-indenizar: chamada cláusula de irresponsabilidade. 3. ed. Rio de Janeiro: Forense, 1976.

Da responsabilidade civil. 3. ed. Rio de Janeiro: Forense, 1954. v. I/II.

AGUIAR JR., Ruy Rosado de. Responsabilidade civil do médico. Revista dos Tribunais, São Paulo, ano 84, v. 718, p. 32-53, ago. 1995.

ALLETTO, F. et alli. La responsabilita extracontrattuale - le nuove figure di rissarcimento del danno nella giurisprudenza. Milano: Giuffrè, [s.d.]

ALPA, Guido. Il danno biologico - percorso di un'idea. Padova: Cedam, 1987.

ALVIM, Agostinho. Da inexecução das obrigações e suas conseqüências. 5. ed. São Paulo: Saraiva. 1980.

3. ed. Rio de Janeiro/São Paulo: Jurídica e Universitária, 1965.

AMARAL, Francisco. Direito civil: introdução. 3. ed. Rio de Janeiro: Renovar, 2000.

ANDRADE, Fábio Siebeneichler de. Responsabilidade civil do advogado. Revista dos Tribunais, São Paulo, ano 82, n. 697, p. 22-33, nov. 1993.

ARAÚJO, Edmir Netto de. Curso de Direito Administrativo. 3. ed. São Paulo: Saraiva, 2007.

ASSIS JÚNIOR, Luiz Carlos de. Responsabilidade civil da sociedade de advogados. Revista Magister de Direito Empresarial, Concorrencial e do Consumidor, v. 29, out./nov. 2009.

ASSUNÇÃO, Alexandre Guedes A. et al. Código Civil comentado. 6. ed. São Paulo: Saraiva, 2008.

Auditorias do TCU, Brasília, ano 4, n. 15, 2001.

AVRIL, Yves. La responsabilité de l'avocat. Paris: Dalloz, 1981. 
AZEVEDO, Álvaro Villaça. Responsabilidade civil do empreiteiro - natureza normativa do art. 618 do Código Civil - prazo de garantia. Revista Magister de Direito Civil e Processual Civil, n. 4, jan./fev. 2005. Disponível em: 〈www.magisteronline.com.br>. Acesso em: 10 dez. 2010.

Teoria geral das obrigações - responsabilidade civil. 10. ed. São Paulo: Atlas, 2004.

AZEVEDO, Antônio Junqueira de. Por uma nova categoria de dano na responsabilidade civil: o dano social. In: Novos estudos e pareceres de direito privado. São Paulo: Saraiva, 2009. p. 377-384.

BAPTISTA, Sílvio Neves. Teoria geral do dano de acordo com o Novo Código Civil brasileiro. São Paulo: Atlas, 2003.

BARBIER, Eduardo. A.; VERGARA, Leandro. Responsabilidad del abogado. In: GHERSI, Carlos Alberto (Director). Responsabilidad profesional. Buenos Aires: Editorial Astrea de Alfredo y Ricardo Depalma, 1995. v. 2, p. 1-31.

BARROS MONTEIRO, Washington de. Curso de Direito Civil - Direito das Obrigações. 19. ed. São Paulo: Saraiva. 1984. v. 4-5.

BDINE JUNIOR, Hamid Charaf. Da empreitada. Revista dos Tribunais, São Paulo, v. 96, n. 858, p. 82-102, abr. 2007.

BÉNABENT, Alain. Droit civil - les obligations. 9. ed. Paris: Montchrestien, 2003. La chance et le droit. Paris: Librairie Générale de Droit et de Jurisprudence, 1973.

BENETI FILHO, Sidnei Agostinho. A atividade advocatícia e a responsabilidade civil decorrente. 2002. Dissertação (Mestrado) - Faculdade de Direito da Universidade de São Paulo, 2002.

BITTAR, Carlos Alberto. Os direitos da personalidade. 5. ed. Rio de Janeiro: Forense, 2001. Responsabilidade civil - teoria e prática. Rio de Janeiro: Forense, 1989. . Responsabilidade civil nas atividades nucleares. São Paulo: Revista dos Tribunais, 1985 . 
BORGES, Roxana Cardoso Brasileiro. Direitos de personalidade e dignidade: da responsabilidade civil para a responsabilidade constitucional. In: DELGADO, Mário Luiz; ALVES, Jones Figueiredo (Coord.). Questões controvertidas - responsabilidade civil. São Paulo: Método, 2006. v. I, p. 557-582.

BOTTALLO, Marcelo de Carvalho. Os direitos da personalidade e a Constituição de 1988. Direitos da Personalidade e Responsabilidade Civil. Revista do Advogado, n. 38, p. 45-48, dez. 1992.

BRASIL, Avio. O dano moral no direito brasileiro. Rio de Janeiro: [s.e.] 1943.

BREBBIA, Roberto H. El daño moral - doctrina, legislación, jurisprudencia, precedida de una teoría jurídica del daño. 2. ed. Buenos Aires: Orbir, 1967.

BRITO, Rodrigo Toscano de. Responsabilidade civil do construtor pela solidez e segurança da obra no sistema do Código Civil de 2002 e no Código de Defesa do Consumidor. In: DELGADO, Mário Luiz; ALVES, Jones Figueiredo (Coord.). Questões controvertidas - responsabilidade civil. São Paulo: Método, 2006. v. I, p. 103-123.

BRIZ, Jaime Santos. La responsabilidad civil - derecho sustantivo y derecho procesal. 3. ed. Madrid: Montecorvo, 1981.

CAHALI, Yussef Said. Dano moral. 2. ed. São Paulo: Revista dos Tribunais, 2000.

CALAMANDREI, Piero. Opere Giuridiche. In: DIAS, Sérgio Novais. Responsabilidade civil do advogado - perda de uma chance. São Paulo: LTr, 1999.

CARDOSO, Alaércio. Responsabilidade civil e penal dos médicos nos casos de transplantes. Belo Horizonte: Del Rey, 2002.

CARVAL, Suzanne. La construction de la responsabilité civile. Paris: Presses Universitaires de France, 2001.

CASTRO, José Monteiro. Responsabilidade civil do médico. São Paulo: Método, 2005.

CAVAlIERI FILHO, Sérgio. Programa de responsabilidade civil. 4. ed. São Paulo: Malheiros, 2003.

CAVAZZANI, Ricardo Duarte. Responsabilidade civil do advogado. Jus Navigandi. Teresina, ano 13, n. 1.953, 5 nov. 2008. Disponível em: <http://jus.uol.com.br/ revista/texto/11927>. Acesso em: 25 nov. 2010. 
CHALHUB, Melhim Namem. A afetação das incorporações imobiliárias - Lei $\mathrm{n}^{0}$ 10.931/2004. Jus Navigandi, Teresina, ano 10, n. 866, 16 nov. 2005. Disponível em: <http://jus2.uol.com.br/doutrina/texto.asp?id=7595>. Acesso em: 6 abr. 2010.

CHARTIER, Yves. La réparation du préjudice. Paris: Dalloz, 1996.

La responsabilité de l'avocat. Paris: Dalloz, 1981.

CHAVES, Antonio. Responsabilidade pré-contratual. 2. ed. São Paulo: Lejus, 1996.

CHINDEMI, Domenico. Il danno da perdita di chance. Milano: Giuffrè, 2007.

CHINELATO, Silmara Juny. Tendências da responsabilidade civil no direito contemporâneo: reflexos no Código de 2002. In: DELGADO, Mário Luiz; ALVES, Jones Figueiredo (Coord.). Questões controvertidas - responsabilidade civil. São Paulo: Método, 2006. v. I, p. 583-606.

CIANCI, Mirna. O valor da reparação moral. São Paulo: Saraiva. 2003.

COSTA, Carlos Celso Orcesi da. Código Civil na visão do advogado - responsabilidade civil. São Paulo: Revista dos Tribunais, 2005. v. 3.

CRUZ, Gisela Sampaio da. O problema do nexo causal na responsabilidade civil. Rio de Janeiro: Renovar, 2005.

CURIONI, Rossana Teresa. Responsabilidade civil por dano processual decorrente de litigância de má fé. In: HIRONAKA, Giselda Maria Fernandes Novaes (Coord). Direito e responsabilidade. Belo Horizonte: Del Rey, 2002. p. 479-505.

DANTAS, Francisco Clementino de San Tiago. Problemas de direito positivo: estudos e pareceres. Rio de Janeiro: Forense, 1953.

DE CUPIS, Adriano. Il danno - teoria génerale della responsabilitá civile. Milano: Giuffrè, 1946.

DELGADO, Mário Luiz; ALVES, Jones Figueiredo (Coord.). Questões controvertidas responsabilidade civil. São Paulo: Método, 2006. v. I.

Questões controvertidas no direito das obrigações e dos contratos. São Paulo: Método, 2005. v. 4.

DEMOGUE, René. Traité des obligations en général. Paris: Librairie Arthur Rousseau, 1925. t. V. 
DEODATO, Sérgio. Responsabilidade profissional em enfermagem: valoração da sociedade. Coimbra: Almedina, 2008.

DI PROSPERO, Mariana. Responsabilidad del escribano. In: GHERSI, Carlos Alberto (Director). Responsabilidad profesional. Buenos Aires: Editorial Astrea de Alfredo y Ricardo Depalma, 1995. v. 2, p. 33-84.

DIAS, João Antônio Álvaro. Dano corporal - quadro epistemológico e aspectos ressarcitórios. Coimbra: Almedina, 2004.

DIAS, Maria Berenice. Manual de direito das famílias. 3. ed. São Paulo: Revista dos Tribunais, 2006.

DIAS, Sérgio Novais. Responsabilidade civil do advogado - perda de uma chance. São Paulo: LTr, 1999.

DICOPLUS. Disponível em: <www.dicoplus.org/definition/faute>. Acesso em: 15 abr. 2010.

DINIZ, Maria Helena. Curso de direito civil brasileiro: responsabilidade civil. 17. ed. São Paulo: Saraiva, 2003. v. 7.

DRAY, Guilherme Machado. Direitos de personalidade - anotações ao Código Civil e ao Código do Trabalho. Coimbra: Almedina, 2006.

DUARTE, Flávio Henrique. A responsabilidade civil do tabelião e do registrador. Jus Navigandi, Teresina, ano 14, n. 2.230, 9 ago. 2009. Disponível em: <http://jus.uol.com.br/revista/texto/13299>. Acesso em: 12 dez. 2010.

DUARTE, Ronnie. Responsabilidade civil e o novo código: contributo para uma revisitação conceitual. Revista dos Tribunais, São Paulo, ano 95, v. 850, ago. 2006.

FALAVIGNA, Maria Clara Osuna Diaz (Coord.). Ensaios sobre responsabilidade civil na pós-modernidade. Porto Alegre: Magister, 2007. p. 13-32.

FERRASSINI, Antônio Alexandre. A responsabilidade do advogado por litigância de má fé. Disponível em: <http://www.datavenia.net/opiniao/2001/Aresponsabilidadecivildo advogado porlitiganciademafe>. Acesso em: 11 jul. 2005.

FILOMENO, José Geraldo Brito. Código Brasileiro de Defesa do Consumidor comentado pelos autores do anteprojeto. 7. ed. Rio de Janeiro: Forense, 2001. 
FISCHER, Hans Albrecht. Der Schaden Nach den Bürgerlichen Gesetzbuche. Trad. Ferrer Correia. A reparação dos danos no direito civil. São Paulo: Acadêmica. 1938.

FORMICA, G. Dizionario pratico del diritto privato, de Scialoja, v. II. Milano. In: SILVA, Wilson Melo da. O dano moral e sua reparação. 3. ed. Rio de Janeiro: Forense, 1999.

GAGLIANO, Pablo Stolze; PAMPLONA FILHO, Rodolfo. Novo curso de direito civil responsabilidade civil. 4. ed. São Paulo: Saraiva, 2006. v. III.

GOMES, Ana Paula Pazin. Da natureza da obrigação assumida pelo advogado e pela sociedade de advogados. Disponível em: <www.direitonet.com.br/artigos/exibir/2364/Danatureza-da-obrigação-assumida-pelo-advogado-e-pela-sociedade-de-advogados >. Acesso em: 25 nov. 2010.

GOMES, José Jairo. Responsabilidade civil e eticidade. Belo Horizonte: Del Rey, 2005.

GOMES, Luiz Roldão de Freitas. Elementos de responsabilidade civil. Rio de Janeiro/São Paulo: Renovar, 2000.

GOMES, Orlando. Contratos. 21. ed. Rio de Janeiro: Forense, 2000a. . Obrigações. Rio de Janeiro: Forense, 2000b.

GONÇALVES, Carlos Roberto. Comentários ao Código Civil - parte especial do Direito das Obrigações (arts. 927 a 965). São Paulo: Saraiva, 2003. v. 11.

Responsabilidade civil. 7. ed. São Paulo: Saraiva, 2002.

GRAMSTRUP, Erik Frederico. Responsabilidade objetiva na cláusula geral codificada e nos microssistemas. In: DELGADO, Mário Luiz; ALVES, Jones Figueiredo (Coord.). Questões controvertidas - responsabilidade civil. São Paulo: Método, 2006. v. I, p. 125140.

GRINOVER, Ada Pellegrini et al. Código Brasileiro de Defesa do Consumidor comentado pelos autores do anteprojeto. 7. ed. Rio de Janeiro: Forense, 2001.

HIRONAKA, Giselda Maria Fernandes Novaes. Cirurgia plástica e responsabilidade civil do médico: para uma análise jurídica da culpa do cirurgião plástico. Disponível em: <http://www.flaviotartuce.adv.br>. Acesso em: $1^{\underline{0}}$ fev. 2009.

Direito civil: estudos. Belo Horizonte: Del Rey, 2000. . Peixes e afeto: um devaneio sobre a ética no direito de família. Disponível em: 
<http://www.flaviotartuce.adv.br>. Acesso em: $1^{\circ}$ fev. 2009.

HIRONAKA, Giselda Maria Fernandes Novaes. Responsabilidade pressuposta. Evolução de fundamentos e de paradigmas da responsabilidade civil na contemporaneidade. In: DELGADO, Mário Luiz; ALVES, Jones Figueiredo (Coord.). Questões controvertidas responsabilidade civil. São Paulo: Método, 2006. v. I, p. 197-222.

. Responsabilidade civil e contemporaneidade: retrato e moldura. Revista EPD Escola Paulista de Direito, São Paulo, ano I, n. I, p. 203-216, maio/ago. 2005a.

Responsabilidade pressuposta. Belo Horizonte: Del Rey, 2005b.

et al. Direito e responsabilidade. Belo Horizonte: Del Rey, 2002.

; MORAES, Renato Duarte Franco de. Direito das obrigações. São Paulo:

Revista dos Tribunais, 2008. v. 2.

HISE, Mónica. Responsabilidad del personal de enfermería. In: GHERSI, Carlos Alberto (Director). Responsabilidad profesional. Buenos Aires: Editorial Astrea de Alfredo y Ricardo Depalma, 1998. v. 5, p. 163-176.

IGLESIAS, Sérgio. Responsabilidade civil por danos à personalidade. Barueri: Manole, 2003.

ITURRASPE, Jorge Mosset. Responsabilidad por daños. Responsabilidad de los profesionales. Buenos Aires: Rubinzal-Culzoni, 2004. t. VIII.

Responsabilidad por daños - parte general. Buenos Aires: Rubinzal-Culzoni, 1998a. t. I.

Responsabilidad por daños - el incumplimiento contractual. Buenos Aires:

Rubinzal-Culzoni, 1998b. t. II.

KFOURI NETO, Miguel. Responsabilidade civil do médico. 7. ed. São Paulo: Revista dos Tribunais, 2010.

Responsabilidade civil do médico. 5. ed. São Paulo: Revista dos Tribunais, 2003.

Culpa médica e ônus da prova - presunções, perda de uma chance, cargas probatórias dinâmicas, inversão do ônus probatório e consentimento informado responsabilidade civil em pediatria e responsabilidade civil em gineco-obstetrícia. São Paulo: Revista dos Tribunais, 2002. 
KÜHN, Maria Leonor de Souza. Responsabilidade civil - a natureza jurídica da relação médico-paciente. Barueri: Manole, 2002.

LALOU, Henri. La responsabilité civile: principes élémentaires et applications pratiques. 2. ed. Paris: Dalloz, 1932.

LE TOURNEAU, Philippe. La responsabilité civile. 2. ed. Paris: Dalloz, 1976.

LEVADA, Cláudio Antônio Soares. Responsabilidade civil do notário público. Revista de Direito Privado, n. 8, p. 40-3, out.-dez. 2001.

LIMA, Alvino. Culpa e risco. 2. ed. São Paulo: Revista dos Tribunais, 1998. . A responsabilidade civil pelo fato de outrem. Rio de Janeiro: Forense, 1973.

LIMONGI FRANÇA, Rubens. Direitos da personalidade - coordenadas fundamentais. Direitos da Personalidade e Responsabilidade Civil. Revista do Advogado, n. 38, dez. 1992. p. 5-13.

LÔBO, Paulo Luiz Netto. Responsabilidade civil do advogado. Revista de Direito Privado, São Paulo, n. 10, abr.-jun. 2002.

LOPEZ, Teresa Ancona. Princípio da precaução e evolução da responsabilidade civil. São Paulo: Quartier Latin, 2010. . Comentários ao Código Civil. São Paulo: Saraiva. 2003. v. 7. O dano estético - responsabilidade civil. 2. ed. São Paulo: Revista dos Tribunais, 1999.

LOVECE, Graciela. Responsabilidad del hemoterapeuta. In: GHERSI, Carlos Alberto (Director). Responsabilidad profesional. Buenos Aires: Editorial Astrea de Alfredo y Ricardo Depalma, 1998. v. 5, p. 177-191.

LUNA, Ana Cláudia Vergamini; ARCAS, Rita de Cássia Gimenes. Responsabilidade civil do Estado e a atividade médica. In: HIRONAKA, Giselda Maria Fernandes Novaes;

MAJO, Adolfo di. La responsabilità contrattuale. Torino: G. Giappichelli, 2007.

MALUF, Carlos Alberto Dabus. Do caso fortuito e da força maior excludentes de culpabilidade no Código Civil de 2002. In: DELGADO, Mário Luiz; ALVES, Jones Figueiredo (Coord.). Questões controvertidas - responsabilidade civil. São Paulo: Método. 2006. v. I, p. 41-64. 
MALUFE, Guilherme Martins. Responsabilidade civil dos médicos. Disponível em: <www.neofito.com.br>. Acesso em: 14 out. 2005.

MARIN, Rubens Leonardo. Dos sentidos da responsabilidade civil no Código Civil de 2002, e sua correlação aos tipos. In: TARTUCE, Flávio; CASTILHO, Ricardo (Coord.). Direito Civil - Direito Patrimonial - Direito Existencial - Estudos em homenagem à Professora Giselda Maria Fernandes Novaes Hironaka. São Paulo: Método/EPD, 2006.

MARTINS-COSTA, Judith. Os danos à pessoa no direito brasileiro e a sua reparação. A reconstrução do direito privado. São Paulo: Revista dos Tribunais. 2002.

MAZEAUD, Henri; MAZEAUD, Léon. Traité théorique et pratique de la responsabilité civile delictuelle et contractuelle. 3. ed. Paris: Librarie du Recueil Sirey, 1938a. t. I. ; ; MAZEAUD, Jean. Leçons de droit civil - obligations - théorie générale. Atualizada por François Chabas. 9. ed. Paris: Montchrestien, 1998b. t. II, v. I.

MEIRELLES, Hely Lopes. Direito de construir. 4. ed. São Paulo: Revista dos Tribunais, 1983.

MELLO, Celso Antônio Bandeira de. Curso de Direito Administrativo. 17. ed. São Paulo: Malheiros, 2004.

MELO, Diogo L. Machado de. A função punitiva da reparação dos danos morais (e a destinação de parte da indenização para entidades de fins sociais - artigo 883, parágrafo único, do Código Civil). In: DELGADO, Mário Luiz; ALVES, Jones Figueiredo (Coord.). Questões controvertidas - responsabilidade civil. São Paulo: Método, 2006. v. I, p. 85-124. MELO, Nehemias Domingos de. Excludentes de responsabilidade em face do Código de Defesa do Consumidor. Revista Magister de Direito Empresarial, Concorrencial e do Consumidor, n. 23, out./nov. 2008.

MINOZZI, Alfredo. Studio sul danno non patrimoniale. 3. ed. Milano: Societá Editrice Libraria, 1917.

MONTEIRO, Washington de Barros. Curso de direito civil - direito das obrigações. 19. ed. São Paulo: Saraiva. 1984. v. 4.

MORAES, Maria Celina Bodin de. Danos à pessoa humana - uma leitura civilconstitucional dos danos morais. Rio de Janeiro/São Paulo: Renovar, 2003. 
MORWOOD, James (Ed.). Oxford Latin Minidictionary. Oxford: Oxford University Press, 1995.

NERY JUNIOR, Nelson; NERY, Rosa Maria de Andrade. Código Civil anotado e legislação extravagante. 2. ed. São Paulo: Revista dos Tribunais, 2003.

NICOLAU, Gustavo René. Efetiva aplicação da teoria do risco no Código Civil de 2002. In: DELGADO, Mário Luiz; ALVES, Jones Figueiredo (Coord.). Questões controvertidas - responsabilidade civil. São Paulo: Método, 2006. v. I, p. 223-242.

NORONHA, Fernando. Responsabilidade por perda de chances. Revista de Direito Privado, São Paulo, n. 23, jul.-set. 2005.

Direito das obrigações: fundamentos do direito das obrigações - introdução à responsabilidade civil. São Paulo: Saraiva, 2003. v. 1.

O nexo de causalidade na responsabilidade civil. Revista dos Tribunais, São Paulo, v. 92, n. 816, p. 733-752, out. 2003.

Desenvolvimentos contemporâneos da responsabilidade civil. Revista dos Tribunais, ano 88, v. 761, p. 31-44, mar. 1999.

NUNES, Luiz Antônio Rizzato; CALDEIRA, Mirella D’Angelo. $O$ dano moral e sua interpretação jurisprudencial. São Paulo: Saraiva, 1999.

NUNES, Manuel Rosário. O ónus da prova nas acções de responsabilidade civil por actos médicos. 2. ed. Coimbra: Almedina, 2007.

PEREIRA, Caio Mário da Silva. Instituições de direito civil - contratos, declaração unilateral de vontade, responsabilidade civil. 11. ed. Rio de Janeiro: Forense, 2003. v. III. . Responsabilidade civil. 9. ed. Rio de Janeiro: Forense, 1999.

. Condomínio e incorporações. 5. ed. Revista dos Tribunais: Forense, 1985.

PEREIRA, Juliana Hörlle. Responsabilidade civil dos notários e registradores. Revista CEJ, Brasília, n. 30, p. 87-93, jul./set. 2005.

PERLINGIERI, Pietro. Perfis do Direito Civil: introdução ao Direito Civil Constitucional. 3. ed. Renovar: Rio de Janeiro, 2007.

PETRONE, Aldo. Responsabilidad del obstreta. In: GHERSI, Carlos Alberto (Director). Responsabilidade profesional. Buenos Aires: Editorial Astrea de Alfredo y Ricardo Depalma, 1998. v. 5, p. 97-117. 
PIETRO, Maria Sylvia Zanella Di. Direito Administrativo. 21. ed. São Paulo: Atlas, 2008. PODESTÁ, Fábio Henrique. Apontamentos sobre o contrato de prestação de serviços. Revista EPD, São Paulo, ano I, n. I, p. 115-140, maio/ago. 2005.

PONTES DE MIRANDA, Francisco Cavalcanti. Tratado de Direito Privado - parte especial. 3. ed. Rio de Janeiro: Borsoi, 1972. t. LIII.

POPP, Carlyle. Responsabilidade civil pré-negocial: o rompimento das tratativas. Curitiba: Juruá, 2006.

PORTO, Mário Moacyr. Responsabilidade civil do construtor - o art. 1.245 do Código Civil. Revista dos Tribunais, São Paulo, v. 76, n. 623, p. 7-12, set. 1987.

POSSI, Luciana. Contrato de incorporação imobiliária - notas à lei 4.591/64. In: HIRONAKA, Giselda Maria Fernandes Novaes; TARTUCE, Flávio. Direito contratual temas atuais. São Paulo: Método, 2008. p. 627-656.

POTHIER, Robert Joseph. Oeuvres completes de Pothier: traité des obligations. Paris: Langlois, 1844. v. 2.

QUEIROZ, O. A. Pereira de. Dicionário Latim-Português. 5. ed. São Paulo: Lep, 1958.

REALE, Miguel. Temas de direito positivo. São Paulo: Revista dos Tribunais, 1992.

REIS, Clayton. Dano moral. 4. ed. Rio de Janeiro: Forense, 1997. A responsabilidade civil do notário e do registrador. Revista dos Tribunais, São Paulo, v. 83, n. 703, p. 15-22, maio 1994.

REPRESAS, Félix A. Trigo. Responsabilidad civil del abogado. Buenos Aires: Hammurabi, 1991.

; MESA, Marcelo J. López. Tratado de la responsabilidad civil. Buenos Aires: La Ley, 2005. t. I.

—. Responsabilidade civil: circunstâncias naturalmente, legalmente e convencionalmente escusativas do dever de indenizar o dano. In: . Atualidades jurídicas. São Paulo: Saraiva, 1999.

RIPERT, Georges. A regra moral nas obrigações civis. Campinas: Bookseller, 2002. RIZZARDO, Arnaldo. Responsabilidade civil. Rio de Janeiro: Forense, 2005. RODRIGUES, Sílvio. Direito Civil - parte geral. 33. ed. São Paulo: Saraiva, 2003. v. 1. 
RODRIGUES, Sílvio. Direito Civil - responsabilidade civil. 19. ed. São Paulo: Saraiva, 2002. v. 4.

Direito Civil - parte geral: das obrigações. 28. ed. São Paulo: Saraiva, 2000. v. 2 .

Direito Civil - dos contratos e das declarações unilaterais de vontade. 26. ed. São Paulo: Saraiva, 1999. v. 3.

SALAZAR, Alcino de Paula. Reparação do dano moral. Rio de Janeiro: Borsoi, 1943.

SANCHEZ, María Del Carmen García. Responsabilidad del cirujano estético. In: GHERSI, Carlos Alberto (Director). Responsabilidad profesional. Buenos Aires: Editorial Astrea de Alfredo y Ricardo Depalma, 1998. v. 5, p. 1-49.

SANTOS, Antônio Jeová. Dano moral indenizável. 4. ed. São Paulo: Revista dos Tribunais, 2003.

SARGO, Pierre. Le point de vue d'un magistrat sur l'indemnisation des accidents médicaux. In: VINEY, Geneviève (Coord.). L'indemnisation des accidents médicaux. Paris: LGDJ, 1997. p. 81-86.

SAURY, Robert. Le point de vue du médecin sur l' indemnisation des accidents médicaux. In: VINEY, Geneviève (Coord.). L’indemnisation des accidents médicaux. Paris: LGDJ, 1997. p. 91-98.

SAVATIER, René. Traité de la responsabilité civile en Droit français. Paris, 1939. t. II.

SAVI, Sérgio. Responsabilidade civil por perda de uma chance. São Paulo: Atlas, 2006.

SCAVONE JUNIOR, Luiz Antônio. Causas e cláusulas de exclusão de responsabilidade civil. Revista de Direito Privado, São Paulo. v. 2, n. 8, p. 53-119, out/dez. 2001.

SCHREIBER, Anderson. Novos paradigmas da responsabilidade civil - da erosão dos filtros da reparação à diluição dos danos. 2. ed. São Paulo: Atlas, 2009.

SCOGNAMIGLIO, Renato. El daño moral. Trad. esp. de Fernando Hinestrosa. Bogotá: Universidad Externado de Colómbia, 1962.

SERGE, Damião; CASTRO, Ludovico M. Gomes de; MULLER, Reinaldo. Ars Latina Curso prático da língua latina. 32. ed. Petrópolis: Vozes, 1999.

SEVERO, Sérgio. Os danos extrapatrimoniais. São Paulo: Saraiva, 1996. 
SILVA, Américo Luis Martins da. O dano moral e sua reparação. São Paulo: Revista dos Tribunais, 1999.

SILVA, Rafael Peteffi da. Responsabilidade civil pela perda de uma chance. 2. ed. São Paulo: Atlas, 2009.

A responsabilidade pela perda de uma chance e as condições para a sua aplicação. In: DELGADO, Mário Luiz; ALVES, Jones Figueiredo (Coord.). Questões controvertidas - responsabilidade civil. São Paulo: Método, 2006. p. 443-462.

SILVA, Regina Beatriz Tavares da. Perda de uma chance. Disponível em: <www.flaviotartuce.adv.br>. Acesso em: 15 set. 2005.

SILVA, Wilson de Melo da. O dano moral e sua reparação. 3. ed. Rio de Janeiro: Forense, 1999.

Da responsabilidade civil automobilística. São Paulo: Saraiva, 1974.

Responsabilidade sem culpa e socialização do risco. Belo Horizonte: Bernando Alvares, 1962.

SIMÃO, José Fernando. Direito civil - contratos. 4. ed. São Paulo: Atlas, 2010.

Responsabilidade civil do incapaz. São Paulo: Atlas, 2008.

Aspectos controvertidos da prescrição e decadência na teoria geral dos contratos e contratos em espécie. In: DELGADO, Mário Luiz; ALVES, Jones Figueiredo (Coord.). Questões controvertidas no direito das obrigações e dos contratos. São Paulo: Método, 2005. v. 4, p. 343-384.

Vícios do produto no novo Código Civil e no Código de Defesa do Consumidor. São Paulo: Atlas, 2003.

SOARES, Orlando. Responsabilidade civil no Direito brasileiro - teoria, prática forense e jurisprudência. Rio de Janeiro: Forense, 1996.

STOCO, Rui. Tratado de responsabilidade civil. 6. ed. São Paulo: Revista dos Tribunais, 2004.

TANAKA, Eduardo. Responsabilidade civil do cirurgião-dentista. Obrigação de meio ou de resultado? In: HIRONAKA, Giselda Maria Fernandes Novaes (Coord.). Direito e responsabilidade. Belo Horizonte: Del Rey, 2002. 
TARTUCE, Flávio. Direito civil - Direito das Obrigações e responsabilidade civil. 5. ed. São Paulo: Método, 2010. v. 2.

- Questões controvertidas quanto à reparação por danos morais. Aspectos doutrinários e visão jurisprudencial. Disponível em: <www.flaviotartuce.adv.br>. Acesso em: 15 set. 2005.

; CASTILHO, Ricardo (Coord.). Direito civil - direito patrimonial, direito existencial - estudos em homenagem à Professora Giselda Maria Fernandes Novaes Hironaka. São Paulo: Método/EPD, 2006.

; GROENINGA, Giselle Câmara. $O$ dano à integridade psíquica. Uma análise interdisciplinar. In: DELGADO, Mário; ALVES, Luiz Jones Figueiredo (Coord.). Questões controvertidas - responsabilidade civil. São Paulo: Método, 2006. p. 141-166.

; SIMÃO, José Fernando. Direito civil - direitos das sucessões. 2. ed. São Paulo: Método, 2008. v. 6.

TEPEDINO, Gustavo. A tutela da personalidade no ordenamento civil-constitucional brasileiro. In: . Temas de Direito Civil. 3. ed. Rio de Janeiro: Renovar, 2004. p. 23-58.

; BARBOSA, Heloisa Helena; MORAES, Maria Celina Bodin de. Código Civil interpretado conforme a Constituição da República. 2. ed. Rio de Janeiro/São Paulo/Recife: Renovar, 2007. v. 1.

TERRÉ, François. Droit Civil - les obligations. 8. ed. Paris: Dalloz, 2002.

; SIMLER, Philippe; LEQUETTE, Yves. Droit civil - les obligations. 8. ed. Paris: Dalloz, 2002.

THEODORO JÚNIOR, Humberto. Curso de Direito Processual Civil. 33. ed. Rio de Janeiro: Forense, 2000. v. 1.

TUNC, André. La responsabilité civile. 2. ed. Paris: Economica, 1989.

VARGAS, Glaci de Oliveira Pinto. Reparação do dano moral - controvérsias e perspectivas. 4. ed. Porto Alegre: Síntese, 2001.

VASSILIEFF, Sílvia. Responsabilidade civil do advogado. Belo Horizonte: Del Rey, 2006. 
VASSILIEFF, Sílvia. A responsabilidade civil profissional do médico no direito civil e no direito do consumidor. In: TARTUCE, Flávio; CASTILHO, Ricardo (Coord.). Direito civil - direito patrimonial, direito existencial - estudos em homenagem à Professora Giselda Maria Fernandes Novaes Hironaka. São Paulo: Método/EPD, 2006.

VENOSA, Silvio de Salvo. Direito Civil - responsabilidade civil. 3. ed. São Paulo: Atlas, 2003a. t. IV.

Direito Civil - contratos em espécie. São Paulo: Atlas, 2003b.

Responsabilidade civil. 3. ed. São Paulo: Atlas, 2003c. v. 4.

Direito Civil - teoria geral das obrigações e teoria geral dos contratos. São Paulo: Atlas, 2001. t. II.

VINEY, Geneviève. Rapport de synthèse. In: VINEY, Geneviève. L'indemnisation des accidents médicaux. Paris: L.G.D.J., 1997. p. 103-116.

. Traité de droit civil - introduction à la responsabilité. 2. ed. Paris: LGDJ, 1995.

; JOURDAIN, Patrice. Traité de Droit Civil - les effets de la responsabilité. 2. ed. Paris: Librairie Générale de Droit et de Jurisprudence, 2001.

; MARKESINIS, Basil. La réparation du dommage corporel - essai de comparaison des droits anglais et français. Paris: Economica, 1985.

VISINTINI, Giovanna. La responsabilitá contrattuale. Napoli: Eugenio Jovene, 1979.

WEINGARTEN, Celia. Responsabilidad del odontólogo y del técnico en prótesis dentales. In: GHERSI, Carlos Alberto (Director). Responsabilidad profesional. Buenos Aires: Editorial Astrea de Alfredo y Ricardo Depalma, 1998. v. 5, p. 51-95.

ZENUN, Augusto. Dano moral e sua reparação. 5. ed. Rio de Janeiro: Forense, 1997.

ZULIANI, Ênio Santarelli. Responsabilidade civil nos contratos de construção, empreitadas e incorporações. In: SILVA, Regina Beatriz Tavares da (Org.). Responsabilidade civil e sua repercussão nos tribunais. São Paulo: Saraiva, 2008.

Responsabilidade civil nos contratos de construção, empreitadas e incorporações. In: SILVA, Regina Beatriz Tavares da (Coord.). Responsabilidade civil e sua repercussão nos tribunais. São Paulo: Saraiva, 2008. 
ZULIANI, Ênio Santarelli. Responsabilidade civil e reparação de danos; raízes históricas; função e objetivo. Revista Magister de Direito Civil e Processual Civil, n. 9, nov./dez. 2005. Disponível em: <www.magisteronline.com.br/mgstrnet/lpext.dll/Dout〉. Acesso em: 12 ago. 2009. 